\title{
Nederlands adelsrecht : Wettelijke adeldom als historisch gegroeid instituut
}

\author{
Citation for published version (APA):
}

Wolleswinkel, E. J. (2012). Nederlands adelsrecht : Wettelijke adeldom als historisch gegroeid instituut. [Doctoral Thesis, Maastricht University]. Stichting De Nederlandse Leeuw.

https://doi.org/10.26481/dis.20121205ew

Document status and date:

Published: 01/01/2012

DOI:

10.26481/dis.20121205ew

Document Version:

Publisher's PDF, also known as Version of record

\section{Please check the document version of this publication:}

- A submitted manuscript is the version of the article upon submission and before peer-review. There can be important differences between the submitted version and the official published version of record.

People interested in the research are advised to contact the author for the final version of the publication, or visit the DOI to the publisher's website.

- The final author version and the galley proof are versions of the publication after peer review.

- The final published version features the final layout of the paper including the volume, issue and page numbers.

Link to publication

\footnotetext{
General rights rights.

- You may freely distribute the URL identifying the publication in the public portal. please follow below link for the End User Agreement:

www.umlib.nl/taverne-license

Take down policy

If you believe that this document breaches copyright please contact us at:

repository@maastrichtuniversity.nl

providing details and we will investigate your claim.
}

Copyright and moral rights for the publications made accessible in the public portal are retained by the authors and/or other copyright owners and it is a condition of accessing publications that users recognise and abide by the legal requirements associated with these

- Users may download and print one copy of any publication from the public portal for the purpose of private study or research.

- You may not further distribute the material or use it for any profit-making activity or commercial gain

If the publication is distributed under the terms of Article $25 \mathrm{fa}$ of the Dutch Copyright Act, indicated by the "Taverne" license above, 
NEDERLANDS ADELSRECHT 



\section{NEDERLANDS ADELSRECHT}

\section{WETTELIJKE ADELDOM ALS HISTORISCH GEGROEID INSTITUUT}

\section{PROEFSCHRIFT}

ter verkrijging van de graad van doctor aan de Universiteit Maastricht op gezag van de Rector Magnificus, Prof. dr. L.L.G. Soete, volgens het besluit van het College van Decanen

in het openbaar te verdedigen

op woensdag 5 december 2012 om 16.00 uur

door

Egbert Jan Wolleswinkel

Stichting De Nederlandse Leeuw

's-Gravenhage

2012 


\section{Promotor}

Prof. dr. G.R. de Groot

\section{Beoordelingscommissie}

Prof. dr. A.M.J.A. Berkvens (voorzitter)

Prof. dr. A.W. Heringa

Prof. dr. J.S.L.A.W.B. Roes (Radboud Universiteit Nijmegen) 
'Edelboortig zijn die gekomen zijn van een Vader, wiens geslagt van outs voor Edel was bekent, ofte door de Landt-overheyt Edel was gemaeckt. Want eenige Geslagten hebben haer Adel van alle oude tijden gehadt, soo bekent zijnde dat deselve geen bewijs en behoeft. Andere eerlike Geslagten zijn door verdiensten ofte gunsten daer naer daer by gevoegt.'

Hugo de Groot, Inleidinge tot de Hollandsche Regts-Geleertheyt, boek 1, deel 14, p. 43. 


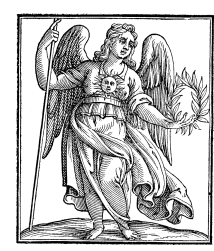

\section{WERKEN UITGEGEVEN DOOR HET KONINKLIJK NEDERLANDSCH GENOOTSCHAP VOOR GESLACHT- EN WAPENKUNDE XIX}

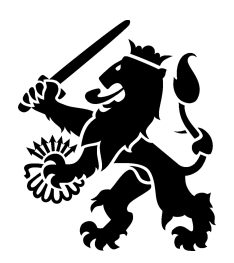

(C) 2012 E.J. Wolleswinkel / Hoge Raad van Adel

DRUK Drukkerij Wilco, Amersfoort

Alle rechten voorbehouden. Niets uit deze uitgave mag worden verveelvoudigd, opgeslagen in een geautomatiseerd gegevensbestand of openbaar gemaakt, in enige vorm of op enige wijze, hetzij digitaal, electronisch, mechanisch, door fotokopieen, opnamen of op enige andere manier, zonder voorafgaande schriftelijke toestemming van de uitgever.

ISBN 978-90-805689-6-9 


\section{Inhoud}

$\begin{array}{ll}\text { Inleiding } & 11\end{array}$

Erfelijke adeldom

Probleemstelling 14

Wettelijke adeldom 15

Onderzoeksmethode 17

Geraadpleegde archieven 23

Indeling $\quad 25$

Hoofdstuk I. De adel van het Koninkrijk Holland 27

1. Bataafse staatsregelingen $\quad 27$

2. Grondwet op de constitutionele adel van het Koninkrijk Holland 32

3. Inlijving bij het Keizerrijk Frankrijk 39

Hoofdstuk II. Nederlandse adel onder de Soevereine Vorst der Verenigde Nederlanden 43

1. Soevereine Vorst der Verenigde Nederlanden 43

2. Vereniging met België in een Koninkrijk der Nederlanden 49

Hoofdstuk III. Adelsrecht in het Koninkrijk der Nederlanden 61

1. 1815-1839: met België 61

$\begin{array}{ll}\text { Proprio motu } & 62\end{array}$

Oude adel $\quad 64$

Zuid-Nederlandse adel $\quad 68$

Wijziging van nationaliteit $\quad 69$

Het Oostenrijkse archief $\quad 71$

2. 1839-1848: zonder België 72

Strafrechtelijke ministeriële verantwoordelijkheid 72

De held van Waterloo als koning der Nederlanden 73

Raad van Adel van het Koninkrijk België 75

3. 1848-1937: adeldom in plaats van adelstand 77

$\begin{array}{ll}\text { Afschaffing van de standenmaatschappij } & 77\end{array}$

Reciprociteitsbeginsel $\quad 83$

De Hoge Raad van Adel als adviseur van de minister van Justitie 84 
$\begin{array}{lr}\text { Koninklijk grootzegel } & 88\end{array}$

Erfopvolging in vrouwelijke lijn binnen het koninklijk huis 91

Rijkswapen 93

$\begin{array}{ll}\text { Staatsbelang } & 94\end{array}$

Wettige afstamming 96

4. 1937-1947: einde klassenmaatschappij 99

De Hoge Raad van Adel als adviseur van de minister van Algemene Zaken 99

Tweede Wereldoorlog 100

Zuivering van de Nederlandse adel 101

5. 1947-1983: geen creatie van adeldom 102

Adelsbeleid van de minister van Binnenlandse Zaken Beel 105

Adelsbeleid van het Kabinet Drees 106

Een Nederlandse adellijke titel voeren zonder daartoe gerechtigd te zijn (435 Sr.) 107

Voorstellen van de Hoge Raad van Adel voor een nieuw adelsbeleid 109

Aanschrijf-en aanspreekvormen 111

Bestuursrechtspraak voor afgewezen adelsverzoeken 113

Erfopvolging binnen het koninklijk huis 114

Adeldom uit de grondwet 116

Royement uit de Nederlandse adel 119

6. 1983-1994: Wet op de adeldom 121

$\begin{array}{ll}\text { Naamrecht } & 121\end{array}$

'Adellijke geslachtsnamen' 122

Sluimerende adeldom 125

$\begin{array}{ll}\text { Opheffing externe adviescolleges } & 127\end{array}$

Wet op de adeldom $\quad 130$

Behandeling in de Tweede Kamer 132

Controversiële amendementen 133

Behandeling in de Eerste Kamer 133

Aanpassing tekst koninklijke besluiten en adelsdiploma's 139

7. 1994-2002: Wet lidmaatschap koninklijk huis 142

$\begin{array}{ll}\text { Overgang van adeldom } & 142\end{array}$

Javaanse adel $\quad 143$

Overerfbaarheid van adellijke titels $\quad 144$

Onrechtvaardigheden $\quad 150$

Onevenwichtigheden 151

Middel erger dan de kwaal? 154

Adeldom geen 'civil right' in de zin van het EVRM 158

Wet lidmaatschap koninklijk huis 160

Vrouwen als 'decoratieve aanhangsels van hun echtgenoot' 169

$\begin{array}{ll}\text { Toestemmingswet voor het huwelijk van prins Constantijn } & 170\end{array}$

Toestemmingswet voor het huwelijk van de prins van Oranje $\quad 172$

Titulatuur en geslachtsnaam voor prins Friso 174

Inlijvingen volgens artikel 8 van de Wet op de adeldom 176 
De Bourbon de Parme $\quad 178$

Meerdere koninklijke families? 179

$\begin{array}{lr}\text { Persoonlijke adeldom } & 181\end{array}$

Pieter van Vollenhoven $\quad 181$

Supra-nationale vorstelijke titels 183

Koninklijke erfopvolging en adellijke afstamming 184

8. 2002-heden: eerbiedigende werking 186

$\begin{array}{lr}\text { Geen terugwerkende kracht } & 187\end{array}$

Brieven van wettiging 188

De mythe van het blauwe bloed 189

Gerechtelijke vaststelling van het vaderschap 190

Discriminatie ten aanzien van 'adellijke geslachtsnamen' 191

Overgangsrecht inzake geslachtsnaamswijziging 191

Eerst naamswijziging, dan adeldom? 192

Biologische en maatschappelijke werkelijkheid 195

Volgorde primogenituur na geslachtsverandering 195

Hoofdstuk IV. Het vigerende adelsrecht belicht aan de hand van actuele vraagstukken

1. Inleiding 197

2. Institutionele consequenties 198

$\begin{array}{ll}\text { Een stand buiten de staat } & 198\end{array}$

Onbezoldigde ereambten 199

Hoge colleges van staat $\quad 201$

De Hoge Raad van Adel als hoog college van staat 203

3. Adelsrecht in beweging 204

Het Europese Hof voor de Rechten van de Mens heeft gesproken 207

4. Adelsrecht en naamrecht 209

Afstamming als gemeenschappelijke noemer van adelsrecht en naamrecht 209

Discriminatie in het Nederlandse naamrecht 210

Sluimerende adeldom als consequentie van het naamrecht en in
vergelijking met adoptie

Traditioneel gewoonterecht? 214

Gecodificeerde aanschrijf-en aanspreekvormen 215

De jonkvrouw gezien als freule $\quad 217$

'Verlies van het predikaat als straf verbonden aan het huwen met
$\quad$ een niet-adellijk heer'

5. Constitutioneel recht 224

Nederlands naamrecht in Caribisch perspectief 224

De (on)mogelijkheid van creatie van adeldom via de Caribische route 226 
Nederlands naamrecht in Europees perspectief 228

Nederlands adelsrecht en Duits naamrecht 229

Hoofdstuk V. Conclusies en aanbevelingen 233

1. Conclusies 233

2. Aanbevelingen 236

Onderscheid tussen authentieke gegevens en aanschrijfgegevens 236 Aanschrijf-en aanspreeknamen vormen geen overheidsbelang 238 Adelsrecht als aangelegenheid van het koninkrijk 240 Buitenlandse adellijke titulatuur in strijd met de Nederlandse openbare orde 241

$\begin{array}{ll}\text { Bijlagen } & 245\end{array}$

1. Briefwisseling minister Thorbecke met koning Willem III over de Hoge Raad van Adel, 1852

2. Briefwisseling minister Colijn met de Hoge Raad van Adel, 1937

3. Nota adelsbeleid van minister Beel, $1953 \quad 253$

4. Lijst van voorzitters, leden en secretarissen van de Raad, 1814-heden 256

$\begin{array}{ll}\text { Geraadpleegde literatuur } & 259\end{array}$

$\begin{array}{ll}\text { Summaries } & 271\end{array}$

1. Nederlandse samenvatting $\quad 271$

2. English summary 274

3. Deutsche Zusammenfassung 277

$\begin{array}{ll}\text { Nawoord } & 281\end{array}$

$\begin{array}{ll}\text { Schema's } & 285\end{array}$

1. Geslachten in aantallen 285

2. Wetten, besluiten, circulaires, disposities en officiële mededelingen 285

3. Jurisprudentie 290

$\begin{array}{ll}\text { Wetgeving in druk } 1809 \text { en } 1814 & 297\end{array}$

1. Grondwet constitutionele adel Koninkrijk Holland, 22 april 1809

2. Statuten constitutionele adel Koninkrijk Holland, 1 oktober 1809302

3. Besluit tot wijziging art. 29 van de Statuten, 21 november 1809

4. Instructie Hoge Raad van Adel, 24 juni 1814

$\begin{array}{ll}\text { Register } & 313\end{array}$ 


\section{Inleiding}

\section{Erfelijke adeldom}

De Nederlandse rechtsstaat kent aan de vooravond van de viering '200 jaar Koninkrijk der Nederlanden' twee bij wet beschermde instituten die op afstamming zijn gebaseerd. In de eerste plaats is dit het op basis van de grondwet regerende vorstenhuis. Daarnaast bestaat de Nederlandse adel, die zijn creatie aan de koninklijke soevereiniteit heeft te danken. De basis van deze erfelijke Nederlandse adel was aanvankelijk een grondwetsartikel, maar na de grondwetsherziening van 1983 kwam daarvoor de ruim tien jaar later tot stand gekomen Wet op de adeldom in de plaats. ${ }^{1}$

Beide instituten vormen de grondslag van de constitutionele monarchie. Hun publieke macht is door inperking van bevoegdheden geen bedreiging (meer) voor algemeen aanvaarde democratische beginselen. Vorstendom en adelstand zijn grootheden die tot de middeleeuwen teruggaan en onlosmakelijk met elkaar zijn verbonden. De vorst kwam vanouds zelf voort uit de hoogste adel en verbond medestanders aan zich door adeldom te verlenen, waaruit vervolgens hiërarchisch lagere adel ontstond.

Onder de historische koningschapsvisies zijn twee hoofdtheorieën gangbaar: de theocratische staatsleer en de leer van de door natuur- en gewoonterecht begrensde macht van de vorst. Volgens de eerste theorie ontleende de koning zijn macht aan de gratie Gods, terwijl de tweede theorie de begrenzingen van zijn gezag vond in een feodaal contract tussen de verschillende standen. ${ }^{2}$

Uitgaande van dit onderscheid lijkt de Nederlandse adel, die formeel in 1814 werd ingesteld, een exponent van de door God aan de soevereine vorst gegeven macht. ${ }^{3}$ De adel uit het ancien regime, die opgeroepen werd zich voor erkenning door de koning te melden, was daarentegen het product van een feodale standenmaatschappij. Tijdens de Republiek der Verenigde Nederlanden had deze zich soeverein gewaand en zich zonder vorst staande gehouden. De oude adel was georganiseerd gebleven in ridderschappen, die over zaken van algemeen bestuur gingen. Bij het aantreden van de soevereine vorst in 1814 betekende benoeming in een ridderschap aanvankelijk automatisch verwerving van adeldom, maar vanaf 1815 eiste de koning een akte van bewijs of adelsdiploma. Daarna kon adeldom nog uitsluitend door middel van een koninklijk besluit worden verleend, waarmee toegang tot de ridderschap en indirect tot het bestuur van een provincie werd verkre-

\footnotetext{
${ }^{1}$ De Ridderlijke Duitsche Orde, Balije van Utrecht, een van oorsprong twaalfde-eeuwse militaire en godsdienstige orde, die tot de oudste charitatieve particuliere organisaties in Europa behoort, wordt hier buiten beschouwing gelaten. De protestantse Nederlandse afdeling van deze exclusief adellijke orde werd hersteld bij Wet van 8 augustus 1815, nr. 55 (Stb. 43). Vgl. De Bruin, Bedreigd door Napoleon, passim.

${ }^{2}$ Vermeulen, Krijnen en Roos (red.), De Koning in het Nederlandse staatsrecht, 1-8.

${ }^{3}$ De Grondwet van den Staat der Vereenigde Nederlanden (Amsterdam 29 maart 1814), art. 42.
} 
gen. Niet alle oude adellijke geslachten waren even enthousiast geweest om zich te conformeren aan het nieuw opgerichte instituut Nederlandse adel. Binnen tien jaar volgde echter erkenning van de hun vanouds toekomende adellijke titulatuur op allen, waarmee de hiërarchie ten opzichte van doorgaans zonder titel verheven en ingelijfde geslachten enigszins werd hersteld.

Hoe was het mogelijk dat van een internationaal bewonderde en nagevolgde staatsvorm als de Republiek der Verenigde Nederlanden afstand werd gedaan ten gunste van een koninkrijk? Het vorstendom was toch de staatsvorm die al in 1581 werd afgezworen en na tachtig jaar strijd definitief was verlaten?

Aan het einde van de achttiende eeuw had de Republiek echter bij lange na niet meer de mondiale uitstraling die de daaraan voorafgaande Gouden Eeuw had bewerkstelligd. De hoogste ambtenaar van de Staten-Generaal, de stadhouder uit het huis Oranje-Nassau, besliste over alle benoemingen bij uit te geven ambten. Deze gesloten regentenmaatschappij, waarin een door coöptatie afgeschermd bestuur van voornamelijk Hollandse steden de dienst uitmaakte, luidde het einde van de idealen van de Republiek in. ${ }^{4}$ Hierdoor was een voedingsbodem ontstaan voor een Bataafse revolutie, die het adagium 'vrijheid, gelijkheid en broederschap' verkondigde en iedere inwoner van het land, zonder aanziens des persoons, 'Burger' noemde.

Met de inval van de Fransen was de complete revolutie een feit, maar al spoedig bleek deze op een totalitair regime gebaseerd te zijn. Gedurende een vijandelijke overheersing van achttien jaar was met niet onverdeeld succes geëxperimenteerd met achtereenvolgens een Bataafse Republiek, het Koninkrijk Holland en ten slotte het Keizerrijk Frankrijk. De Bataafse omwenteling had te abrupt plaatsgevonden en bleek uiteindelijk gekaapt door een buitenlandse dictator. Het tijdelijke bewind van de broer van de keizer, Lodewijk Napoleon als koning van Holland, kweekte niet alleen de basis voor de eenheidstaat, maar stelde zelfs een Hoog Heraldiek Collegie in, dat een grondwet voor de adel moest uitvoeren. ${ }^{5}$ Deze fase uit de Nederlandse geschiedenis, waarin op het gebied van wetgeving, maar ook van kunsten en wetenschappen, veel tot stand kwam of werd voorbereid, liet uiteindelijk toch een overwegend positieve indruk achter. ${ }^{6}$

Nadat de keizer in 1813 was verslagen, werd zelfs de ingetrokken adelsgrondwet weer tevoorschijn gehaald. De vraag kan gesteld worden in hoeverre deze een voorbeeld voor het adelsstatuut van het nieuwe Koninkrijk der Nederlanden is geweest.

\footnotetext{
${ }^{4}$ Gabriëls, De heren als dienaren en de dienaar als heer, 13-88.

${ }^{5}$ Grondwet op den constitutionelen adel van het Koningrijk Holland ('s-Hertogenbosch 22 april 1809); ingetrokken Parijs 18 februari 1810. Hoge Raad van Adel, 's-Gravenhage (HRvA), Raadsarchief (RA), inv. nr. 889.

${ }^{6}$ Recente themastudies over de juridische en bestuurlijke gevolgen van de Franse overheersing zijn: Moorman van Kappen en Coppens (red.), De Staatsregeling voor het Bataafsche volk van 1798, passim; Hallebeek en Sirks, Nederland in Franse schaduw, passim; Berkvens, Hallebeek en Sirks, Het Franse Nederland: de inlijving 1810-1813, passim. Het adelsrecht is daarin (nog) niet behandeld.
} 
Met de bekomst van de idealen van de revolutie, die in de praktijk de willekeur van de macht van de Franse keizer openbaarde, was na diens val de situatie van vóór 1795 in zoverre teruggekeerd, dat de (zoon van de) erfelijke stadhouder uit de Republiek was gevraagd als soeverein vorst op te treden. Hij aanvaardde het hoogste staatsambt met een eed van trouw op de grondwet, afgelegd ten overstaan van de volksvertegenwoordiging. ${ }^{7}$

Onder invloed van democratische bewegingen in heel Europa maakte het Koninkrijk der Nederlanden in 1848 een fluwelen revolutie door. De liberaal Thorbecke maakte een einde aan de in vele opzichten onbegrensde macht van de koning en de ministeriële verantwoordelijkheid werd ingevoerd. De standenmaatschappij werd afgeschaft en adelstand werd adeldom. In het provinciebestuur waren de ridderschappen, volgens de nieuwe grondwet, niet meer vertegenwoordigd en zij verloren daarmee hun staatsrechtelijke positie. Op een lange weg naar algemene verkiezingen bepaalde nog zo'n zestig jaar de aanslag in de directe belastingen of men kiesgerechtigd was en/of gekozen kon worden. Daardoor zou het nog wel een eeuw duren voordat ook de klassenmaatschappij was verdwenen. ${ }^{8}$

Deze omwenteling betekende een ingrijpende verandering voor het nog betrekkelijk jonge instituut dat de Nederlandse adel was. De Hoge Raad van Adel, die van 1814 tot 1848 een goed betaald adviescollege van de koning was geweest, werd ontbonden terwijl één deskundig lid als referendaris in dienst trad van het Ministerie van Binnenlandse Zaken om adelszaken af te handelen. Hij werd tevens toegevoegd als secretaris aan een nieuwe Hoge Raad van Adel, die onbezoldigd teruggekeerde. 9

De Raad had zijn voortbestaan te danken aan de bestendiging van het koninkrijk, dat een revolutie zoals elders in Europa overleefde. Secretaris baron D'Ablaing van Giessenburg hield zich nuttig bezig met een historische beschrijving van de ridderschappen, waarbij hij zich openlijk afvroeg of deze eigenlijk nog wel bestonden of dat ze formeel moesten worden opgeheven. ${ }^{10}$ In deze sfeer kabbelde het Nederlandse adelsbeleid voort en kwamen op den duur weer meer aanvragen binnen van belangstellenden voor een adelsverlening. $\mathrm{Nu}$ adeldom geen staatsrechtelijke betekenis meer had en aan de status niet langer privileges waren verbonden, had de distributie van eerbewijzen door eigenzinnig optreden van de koning weinig maatschappelijke gevolgen. Een aanwijzing voor het stempel dat de koning op het adelsbeleid bleef drukken, zou in de loop van de negentiende eeuw het relatief grote aantal adelsverleningen aan vertrouwelingen van de koning kunnen zijn, dikwijls zichtbaar aan hun functies in dienst van het Hof. ${ }^{11}$ Soms leidde adelsverlening tot dienstbaarheid aan de koning en vloeiden hoffuncties juist voort uit de

\footnotetext{
${ }^{7}$ Fasseur, De gekroonde republiek, 7-25; Vermeulen, Krijnen en Roos (red.), De Koning in het Nederlandse staatsrecht, 19-24; Hirsch Ballin, De Koning, 17-21.

${ }^{8}$ Moes, Onder aristocraten, 60-66.

${ }^{9}$ Kort en Wolleswinkel, Het archief van de Hoge Raad van Adel, 5-16.

${ }^{10}$ D’Ablaing van Giessenburg, De Ridderschappen in het Koninkrijk der Nederlanden (Inleiding).

${ }^{11}$ Koning Willem III greep bijv. zijn 25-jarig regeringsjubileum in 1874 aan om leden van de hofhouding te nobiliteren. Vgl. Van Valkenburg, 'Adelbeleid sedert 1813', 66.
} 
begunstiging. ${ }^{12}$ Het adelsstatuut, in Nederland aanvankelijk slechts bestaande uit een verzameling soevereine en koninklijke besluiten, gaf nog steeds vorm aan een persoonlijk beloningsstelsel, dat kenmerkend is voor een vorstendom. ${ }^{13}$

In 1890 stierf met het overlijden van koning Willem III het huis Oranje-Nassau in mannelijke lijn uit. De Grondwet van 1887 voorzag in opvolging van het koningschap in vrouwelijke lijn en de benoeming van koningin Emma als regentes voor de tijd dat prinses Wilhelmina minderjarig was. ${ }^{14}$ Eerst in 1962 stierf het geslacht Van Oranje-Nassau ook in vrouwelijke lijn uit. De Grondwet van 1922 had de troonopvolging intussen beperkt tot afstammelingen van koningin Wilhelmina, zodat koningin Juliana haar moeder in 1948 kon opvolgen.

Was dit het cruciale moment waarop de regelgeving betreffende het regerende vorstenhuis ging afwijken van het vigerende adelsrecht, dat immers bepaalt dat erfelijke adeldom niet langs vrouwelijke lijn kan worden doorgegeven? De vraag kan gesteld worden of adeldom - achteraf gezien - op dat moment tot historisch instituut is verklaard. Ontleend aan de koninklijke soevereiniteit leek het aloude uitgangspunt van vererving langs mannelijke lijn in een dynamisch adelsrecht immers moeilijk staande te kunnen blijven daar waar binnen het vorstenhuis zelf nieuwe regels waren gaan gelden.

De behandeling van de desbetreffende grondwetsherziening in het parlement vond plaats kort na de invoering van het algemeen kiesrecht, zowel passief als actief, waardoor de democratisering van het Nederlandse staatsrecht in 1919 voltooid leek te zijn. Toch was er nog een Tweede Wereldoorlog nodig om het gelijkheidsbeginsel 'iedereen is voor de wet gelijk' in grondwet en samenleving te doen verankeren. Het Kabinet Drees anticipeerde op de naoorlogse ontwikkelingen met het aanvankelijk nog geheime kabinetsbesluit van 1953, waardoor adelsverheffingen in feite onmogelijk werden, met uitzondering van leden van het koninklijk huis. ${ }^{15}$ Ook hier ontstond dus een discrepantie tussen de regelgeving met betrekking tot koningshuis en adel, die achtereenvolgens in 1985 (2002) en 1994 werd gecodificeerd.

\section{Probleemstelling}

Een aantal belangrijke vragen rond het instituut adeldom, die uit dit beknopte historische overzicht naar voren komen, vragen om beantwoording.

In de eerste plaats rijst de vraag hoe en waarom in 1809 tijdens het Koninkrijk Holland een constitutionele adel werd gevestigd na een periode van relatieve vrijheid en gelijkheid tijdens de Bataafse Republiek. Daaraan wordt de vraag gekoppeld waarom deze adel binnen een jaar al weer werd afgeschaft alsof deze nooit

\footnotetext{
${ }^{12}$ HRvA, RA, inv. nr. 281 (extracten notulen 1814-1878).

${ }^{13}$ [Beelaerts van Blokland e.a.] De Hoge Raad van Adel, bijlagen.

${ }^{14}$ De personele unie met Luxemburg werd op grond van een familiecontract verbroken omdat de staatsregeling van het groothertogdom vererving in mannelijke lijn voorschreef.

${ }^{15}$ Coenraad, 'Het Nederlandse adelsrecht', 138 en 153.
} 
had bestaan. Tijdens de periode van inlijving bij het Keizerrijk Frankrijk golden hier te lande vervolgens de Franse regels betreffende titulatuur.

Een tweede belangrijke vraag is, hoe de soevereine vorst der Verenigde Nederlanden al een half jaar na zijn aankomst in Scheveningen over een gedegen adelsstatuut kon beschikken, dat tot de dag van vandaag bestendig is gebleken en afscheidingen, revoluties en oorlogen heeft doorstaan. Wie waren zijn adviseurs en waaraan ontleenden deze hun inspiratie?

De derde hoofdvraag waarop antwoord moet worden gegeven, is die betreffende het in de loop van de twee eeuwen van zijn bestaan steeds verder uiteengroeien van de wetgeving betreffende het koninklijk huis en die betreffende de adeldom. Uitgaande van een gemeenschappelijk oorsprong kan verwacht worden dat hiërarchisch gezien het ene instituut uit het andere is voortgekomen. Des te opmerkelijker is de constatering dat de regeling betreffende het koninklijk huis regelmatig blijkt te zijn aangepast aan emancipatoire en democratische wensen.

Een vierde hoofdvraag betreft actuele vraagstukken met betrekking tot het geldende Nederlandse adelsrecht. Centraal staat daarbij de vraag hoe de ongelijkheid, die adeldom in wezen inhoudt, zich verhoudt tot in de grondwet en internationale verdragen beschermde burgerlijke vrijheden. Wettelijke adeldom, die vanouds alleen via wettige afstamming in mannelijke lijn vererft, wordt daarom getoetst aan recente regelgeving inzake gelijke behandeling zowel van binnen en buiten het huwelijk geboren kinderen als van mannen en vrouwen. Het is in dit kader ook nodig om aandacht te besteden aan de relatie van het adelsrecht met het naamrecht, die diverse rechtsvragen oproept. Aandacht vragen ook de praktische consequenties voor de overheid van de verplichte vermelding van adellijke titulatuur op officiële documenten.

Binnen het Koninkrijk der Nederlanden bestaat een discrepantie tussen adelsrecht en naamrecht in de diverse jurisdicties. Internationaal blijkt voorts spanning te bestaan tussen het Nederlandse adelsrecht en buitenlands naamrecht, dat voor Nederland via internationaal privaatrechtelijke conflictregels of zelfs Europees recht relevant is.

\section{Wettelijke adeldom}

In de afgelopen decennia heeft in universitair verband het sociaal-historisch onderzoek naar de Nederlandse aristocratie een grote vlucht genomen. Dit zogenaamde eliteonderzoek had vaak een prosopografisch uitgangspunt en beperkte zich aanvankelijk tot het ancien regime. ${ }^{16}$ Patriciaat speelde hierbij een hoofdrol, maar daarnaast werd ook aandacht besteed aan de historische adel. In de oorspronkelijke betekenis worden met het begrip patriciaat regeringsgeslachten aangeduid, die tijdens de Republiek der Verenigde Nederlanden in het bestuur van stemhebbende steden zaten. De meeste publicaties worden gekenmerkt door een historischsociologische benadering van de machtspositie die beide groepen gezamenlijk of

\footnotetext{
${ }^{16}$ Overzichten zijn te vinden in het Tijdschrift voor geschiedenis 93 (1980), 339-512; en Bijdragen en Mededelingen betreffende de geschiedenis der Nederlanden 123 (2008), 481-654.
} 
afzonderlijk in de samenleving speelden. ${ }^{17}$ Moes maakt in zijn onlangs verschenen dissertatie over hegemonie, welstand en aanzien van adel, patriciaat en andere notabelen in Nederland in de periode 1848 tot 1914 een onderscheid tussen de sociaal-culturele en de politiek-institutionele benadering. Hij geeft een actueel overzicht van de belangrijkste dissertaties, wetenschappelijke monografieën en bundels waarin deze beide invalshoeken naar voren komen. ${ }^{18}$

Deze studie zal zich daarentegen bepalen tot een juridische benadering van de constitutionele adel, zoals deze in het Koninkrijk Holland voor het eerst vorm kreeg, tijdens het Keizerrijk Frankrijk weer verviel, maar onder het Koninkrijk der Nederlanden herleefde en thans nog bestaat.

De basis van het onderzoek betreft de wettelijke adel, die in de Nederlandse eenheidsstaat aanvankelijk een staatsrechtelijke, maar na enkele decennia nog een louter symbolische en aan het privaatrecht verwante betekenis heeft. Daartoe dient in de eerste plaats een definitie van het begrip adel te worden gegeven. Politieke erkenning en bescherming door een soevereine vorst zijn essentiële voorwaarden om adel van andere groepen te onderscheiden en af te schermen. Erfelijke adel is in juridische zin meer dan een historische groep waarin exclusieve geboorte, bezit van privileges en sociaal-economische verheffing vanouds samenkomen. Anders dan we ons nu kunnen voorstellen, was rechtsongelijkheid in die tijd de normaalste zaak van de wereld. Tijdens het ancien regime had de adel in de Republiek bijvoorbeeld niet het alleenrecht op een bevoorrechte positie, aangezien deze ook voor andere instituten en colleges gold.

Het ontbreken van een soevereine vorst tijdens de Republiek maakte de adel (in die tijd) tot een 'onttroonde adel', die dankzij de standenmaatschappij in stand bleef en zichzelf noodgedwongen aanvulde. ${ }^{19}$ In deze coöptatie van bestaande ridderschappen kan een vorm van erkenning van adeldom door gelijken worden gezien. Anders dan in de Zuidelijke Nederlanden, waar de adel onder Spaanse en later Oostenrijkse heerschappij werd uitgebreid en verder geïnstitutionaliseerd, kon in de Noordelijke Nederlanden geen vernieuwing meer plaatsvinden. Door uitgevaardigde adelsedicten monopoliseerden de achtereenvolgende vorsten in de Zuidelijke Nederlanden de toekenning van adeldom en werd verwerving ervan door sociale assimilatie (usurpatie) onmogelijk. Verbodsbepalingen moesten de exclusiviteit vervolgens waarborgen. $^{20}$

De samenbundeling van deze twee groepen adel in het nieuwe Koninkrijk der Nederlanden werd door de uiteenlopende achtergronden van de Nederlandse en Belgische adel geen groot succes. Deze verschillen in de hoogste stand binnen het

\footnotetext{
${ }^{17}$ Zie o.a.: Aalbers en Prak (red.), De bloem der natie; Van Nierop, Van ridders tot regenten; Kuiper, Adel in Friesland; Dronkers, 'De maatschappelijke relevantie van hedendaagse Nederlandse adel'; Schijf, Dronkers en Van den Broek-George, 'De overdracht van eliteposities binnen adellijke en patricische families in de twintigste eeuw'.

${ }^{18}$ Moes, Onder aristocraten, 26-34 en 298-304.

${ }^{19}$ Vergelijk o.a. Feenstra, De bloeitijd en het verval van de Ommelander adel; Gietman, Republiek van adel; Wolleswinkel, 'Willem Flessiers, wapenheraut in de Republiek'.

${ }^{20}$ Janssens, De evolutie van de Belgische adel sinds de late Middeleeuwen, 103-107 (definitie), 331-346 (adelsedicten van Philips II, 1595; Albrecht en Isabella, 1616; Karel II, 1700; Maria Theresia, 1754).
} 
Verenigde Koninkrijk droegen bij aan de ontbinding van dit koninkrijk, die nog geen 25 jaar later plaatsvond. ${ }^{21}$

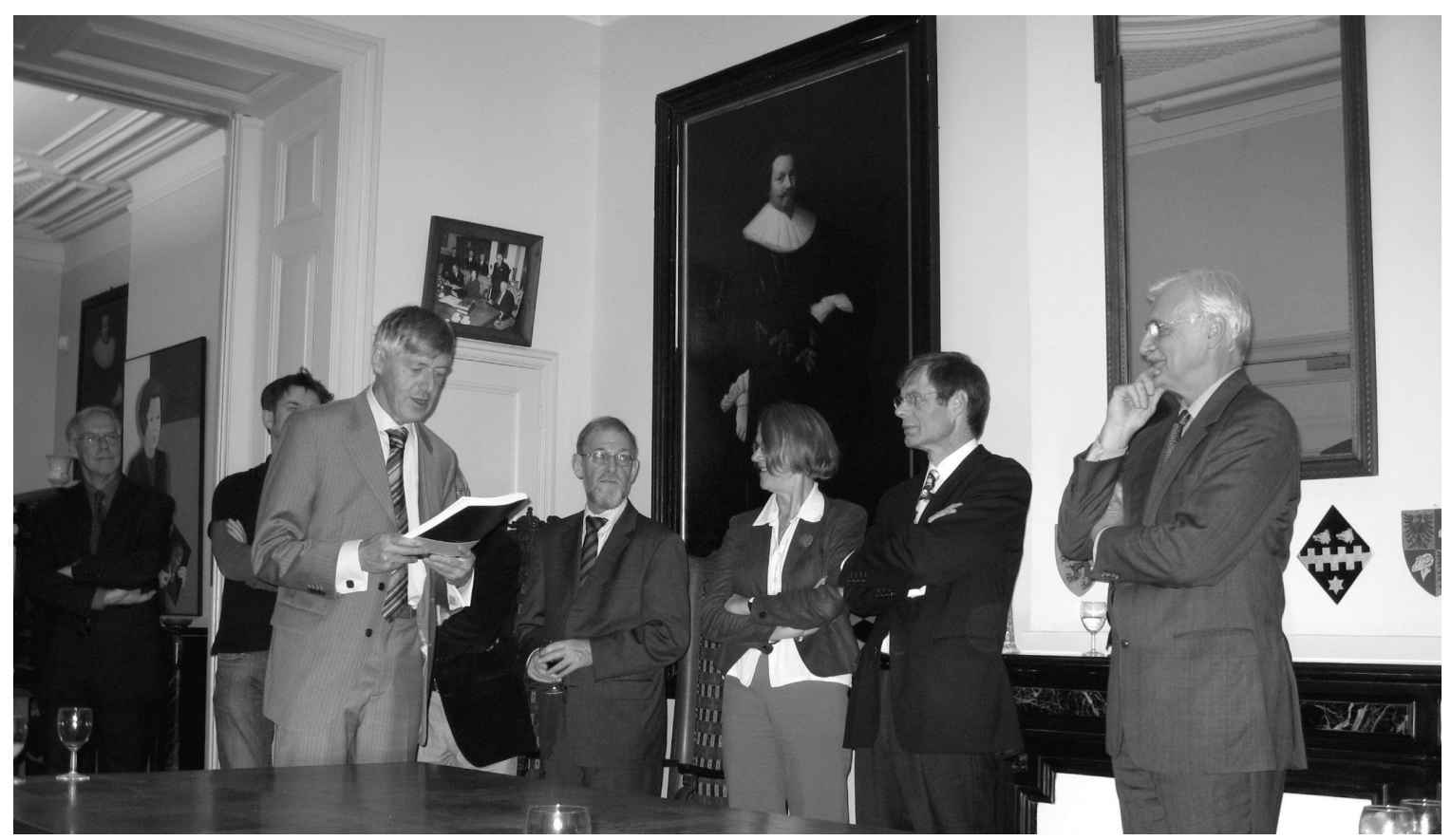

Presentatie van de archiefinventaris van de Hoge Raad van Adel op 25 oktober 2006 in de Raadzaal, Nassaulaan 2B, 's-Gravenhage. V.r.n.l. C.O.A. baron Schimmelpenninck van der Oije (voorzitter), jonkheer F.K.M. van Nispen tot Pannerden (lid), Z. Plomp-Kamphuis (medewerker Nederland's Adelsboek), N. Plomp, J.C. Kort, C.A.M. Gietman en E.J. Wolleswinkel (secretaris). Foto jonkvrouw J. de Roy van Zuydewijn, 's-Gravenhage.

\section{Onderzoeksmethode}

De literatuur over het Nederlandse adelsrecht wordt tot op heden gekenmerkt door thematische studies, die zowel de regelgeving als het adviescollege tot onderwerp hebben. De chronologie en vragen betreffende oorzaak en gevolg kunnen bij deze methode uit het oog worden verloren. Van deze publicaties, die zich doorgaans tot een bepaalde periode beperken, zal ik de belangrijkste hierna kort analyseren.

De inventarisatie van de archieven van de Chambre Héraldique en van de Hoge Raad van Adel, die het afgelopen decennium is gerealiseerd, heeft het Raadsarchief integraal toegankelijk gemaakt en een schat aan nieuwe gegevens opgeleverd. ${ }^{22}$ Mijn stelling is dat door politieke factoren de ontwikkeling van het Nederlandse adelsrecht nader kan worden verklaard en dat dit tot nieuwe inzichten leidt. Om deze reden heb ik in deze studie gekozen voor een chronologische opzet, waarbij de Bataafse staatsregeling uit 1798 als uitgangspunt is genomen.

\footnotetext{
${ }^{21}$ Colenbrander, De afscheiding van België, 11-42.

${ }^{22}$ Kort en Wolleswinkel, Het archief van de Hoge Raad van Adel, passim; idem, Het archief van de Chambre Héraldique, passim.
} 
De belangrijkste publicatie over de ontwikkeling van het adelsrecht achtereenvolgens tijdens het Koninkrijk Holland en het Keizerrijk Frankrijk is van de hand van de toenmalige voorzitter van de Hoge Raad van Adel, jonkheer M.A. Beelaerts van Blokland. ${ }^{23}$ Hij baseerde zich daarbij op de uitgegeven briefwisseling tussen de keizer en zijn broer, de koning van Holland, waaruit zeer persoonlijke opvattingen over adeldom zijn op te maken. Zijn uitgebreide notenapparaat verwijst niet expliciet naar het archief van het Hoog Heraldiek Collegie, dat als gedeponeerd archief in het Raadsarchief is bewaard gebleven, maar naar de Archives Nationales in Parijs, waar het kabinetsarchief van de ex-koning van Holland berust. Een vergelijking van de - overigens gepubliceerde - grondwet en statuten van de constitutionele adel van het Koninkrijk Holland met het Nederlandse adelsstatuut uit 1814 vindt niet plaats, maar zal in deze studie uitgebreid aan de orde komen.

De oud-secretaris van de Raad, O. Schutte, heeft in een tweetal artikelen de periode van de inlijving bij het keizerrijk beschreven en een cumulatieve lijst opgesteld van de Nederlanders die Napoleontische titels hebben ontvangen. ${ }^{24}$ Hij kwam tot de conclusie dat de jure geen sprake was van adeldom, maar van persoonlijke titelverlening, zich baserend op een advies van de Hoge Raad van Adel aan de koning om deze groep niet voor inlijving in de Nederlandse adel in aanmerking te laten komen. ${ }^{25}$ Om deze reden heb ik deze periode niet specifiek beschreven, evenmin trouwens als die andere periode van vijandelijke overheersing, gedurende de Tweede Wereldoorlog, toen de Nederlandse koningin in ballingschap in Londen verbleef en geen adelsbeleid werd ontwikkeld.

Naar aanleiding van het 150-jarig jubileum van de Hoge Raad van Adel in 1964 verscheen twee jaar later op initiatief van de toenmalige Raad een jubileumboek, waarin naast het hierboven vermelde artikel van zijn voorzitter, drie artikelen van leden van de Raad zijn gepubliceerd, die nog altijd gezaghebbend zijn. Jonkheer Van Valkenburg beschreef aan de hand van concrete voorbeelden het adelsbeleid van na $1813 .^{26}$ Hij gaf als eerste een getalsmatige opsomming van het aantal Noord-Nederlandse adellijke geslachten dat vanaf 1814 tot 1964 heeft bestaan. Zijn uitgangspunt was het aantal verschillende adellijke geslachtsnamen over die hele periode, inclusief de uitgestorven geslachten, maar zonder de ZuidNederlandse geslachten die na de afscheiding voor België opteerden. Deze telling is geactualiseerd in de inleiding van het jubileumboek, dat in 1989 ter gelegenheid van het 175 -jarig bestaan van de Raad verscheen. Deze uitgave is een systematisch overzicht van alle adels- en wapenverleningen met indices op familienaam en wa-

\footnotetext{
${ }^{23}$ Beelaerts van Blokland, 'Adelsbeleid en adelsrecht vóór 1813', 1-54.

${ }^{24}$ Schutte, 'Les titres du Premier Empire Français', 323-358; Schutte, 'Het beleid tijdens het Koninkrijk der Nederlanden', 310-322. Ook van zijn monografie De Orde van de Unie, die strikt genomen niet over adeldom gaat, maar het bijzondere beloningsstelsel van koning Lodewijk Napoleon behandelt, heb ik dankbaar gebruik gemaakt. Keizer Napoleon Bonaparte verklaarde - analoog aan de constitutionele adel van het Koninkrijk Holland - ook deze orde ongeldig, waarna hij de Orde van de Reunie instelde.

${ }^{25}$ Ibidem, 312 (HRvA, RA, inv. nr. 47, not. 1822-409, verzoekschrift van Pieter Jacob de Bye).

${ }^{26}$ Van Valkenburg, 'Adelsbeleid sedert 1813', 69-71.
} 
penfiguur. ${ }^{27}$ Hoewel het werk geen aanvulling of verbetering van het jubileumboek uit 1966 pretendeerde te zijn, geeft de inleiding een actuele neerslag van het vigerende adelsrecht. In een schema (nr. 1) heb ik de telling van deze twee overzichten gecombineerd en aan de hand van de laatst gepubliceerde adelslijst met recent uitgevaardigde koninklijke besluiten aangevuld. ${ }^{28}$

De andere twee artikelen uit het jubileumboek van 1966 zijn een artikel van jonkheer Van Meeuwen over het vigerende adelsrecht en een bijdrage over de geschiedenis van de Raad door jonkheer Ruijs de Beerenbrouck. ${ }^{29}$ Kenmerkend voor deze naoorlogse jaren is dat de Raad zelf verslag doet van zijn adelsbeleid sinds zijn bestaan en nog geen buitenstaanders toelaat tot het archief. ${ }^{30}$ Inherent aan deze opvatting is, in het bijzonder bij het artikel van Ruijs, het ontbreken van bronvermelding waarin de argumentatie en de verblijfplaats van aangehaalde stukken worden verantwoord. Zo vermeldde hij als eerste de heftige briefwisseling tussen minister Thorbecke en de een paar jaar eerder aangetreden koning Willem III, vertegenwoordigd door de directeur van het Kabinet des Konings, over het al of niet voortbestaan van de Hoge Raad van Adel na de grondwetsherziening van 1848. Deze correspondentie is nadien niet meer geciteerd en kennelijk niet teruggevonden ten behoeve van de intussen gepubliceerde briefwisseling van de staatsman over die periode. $^{31}$ De als gedeponeerd archief in het Raadsarchief aangetroffen correspondentie, bestaande uit door Thorbecke persoonlijk verbeterde en ondertekende minuten van uitgegane brieven, wordt als bijlage (nr. 1) in deze studie gepubliceerd. Over het geheime besluit van het Kabinet Drees om voortaan van verheffing in de Nederlandse adel af te zien, zweeg jonkheer Van Valkenburg (nog) in zijn hierboven aangehaalde artikel, terwijl de nota Beel over het wenselijke adelsbeleid toch al in 's Raads notulendossier uit 1962 werd aangetroffen. Baron Van Lynden beschreef als lid in 1984 het beleid van de Raad in de periode dat jonkheer Van Valkenburg voorzitter was met vermelding van alle genobiliteerde geslachten op naam; overigens ook de namen van diegenen, die in die tijd tevergeefs procedeerden. ${ }^{32}$ Hij ontkwam niet aan openbaarmaking van het naoorlogse regeringsbeleid ten aanzien van adelsverleningen aangezien dat intussen onderwerp van bespreking bij de grondwetswijziging van 1972 was geworden. Ook de nota van minister van Binnenlandse Zaken Beel, die een nadere nota inzake toepassing van artikel 74 van de grondwet was, is in deze studie integraal als bijlage (nr. 3) opgenomen. Overigens werd eerst bij de grondwetsherziening van 1983 de knoop doorgehakt om dit artikel ('De Koning verleent adeldom') uit de grondwet te schrappen en adeldom in een gewone wet te regelen.

\footnotetext{
${ }^{27}$ [Nijkamp en Schutte], De Nederlandse adel, 9-13, gebaseerd op de adelslijst, die bij KB van 4 mei 1982 (Stb. 410) werd vastgesteld.

${ }^{28}$ Vastgesteld bij KB van 9 juni 2004 (Stb. 307).

${ }^{29}$ Van Meeuwen, 'Een en ander over het Nederlandse adelsrecht', 74-90; Ruijs de Beerenbrouck, 'Uit de geschiedenis van de Hoge Raad van Adel', 91-104.

${ }^{30}$ De jubileumboeken van de Raad uit 1966 en 1989 waren niet of nauwelijks in de handel en zijn alleen nog antiquarisch te verkrijgen.

${ }^{31}$ Hooykaas en Santegoets, De briefwisseling van J.R. Thorbecke, V (1845-1853), passim. Het foutieve jaartal (1851 in plaats van 1852), dat Ruijs opgaf (103), kan de vindbaarheid extra hebben bemoeilijkt.

${ }^{32}$ Van Lynden, 'Enkele notities over het adelsrecht', 200-206.
} 
Bij de totstandkoming van de in het vooruitzicht gestelde Wet op de adeldom ontstond vanuit genealogische hoek belangstelling voor het adelsrecht. Dit resulteerde in 1992 in een door het Koninklijk Nederlandsch Genootschap voor Geslacht- en Wapenkunde georganiseerd symposium met een themanummer van De Nederlandsche Leeuw, waarvoor ook een in het privaatrecht gespecialiseerde jurist een bijdrage leverde. ${ }^{33}$ Naamrechtdeskundige Loeb behandelde als een van de eersten de relatie tussen naam- en adelsrecht met opgave van relevante literatuur. ${ }^{34}$ In de onderhavige studie zullen de recente ontwikkelingen binnen het naamrecht uitvoerig aan de orde worden gesteld voor zover deze van invloed zijn (geweest) op het adelsrecht.

Een bijdrage van Keesom - die in 1978 als gemachtigde was opgetreden in de juridische procedure Von Hertzberg (inlijvingsverzoek) - over de hoofdlijnen van het Nederlandse adelsrecht geeft een vluchtig overzicht met weinig regelgeving en veel adellijke geslachtsnamen. Doordat hij een vergelijking maakte met buitenlandse adelsstatuten, die dikwijls niet of onvolledig bekend zijn, kunnen in dit artikel 'Wahrheit und Dichtung' moeilijk worden ontrafeld. Ten aanzien van het wetsontwerp nam hij het uitzonderlijke standpunt in dat adeldom als onderscheiding voor iedere Nederlander open zou moeten staan, dus als variant op ridderorden. ${ }^{35}$ Hoewel ik met hem van mening ben dat zowel adeldom als ridderorden aangelegenheden van het koninkrijk zijn, zal ik de verschillen - ook in historisch perspectief - trachten aan te tonen. Een vroeg artikel van de hand van Keesom, dat een aantal foutieve jurisprudentieverwijzingen geeft, zal in deze studie in een schema (nr. 3) met jurisprudentie over adelszaken vanaf 1899 worden gecorrigeerd. $^{36}$

Tien jaar later vatte De Groot in een overzichtsartikel in hetzelfde tijdschrift zijn grieven over de intussen uitgevaardigde wet samen in de vorm van een drama in zes bedrijven. ${ }^{37}$ De tragedie bleek uiteindelijk minder groot te zijn dan werd opgevoerd omdat de uitspraak van het Europese Hof voor de Rechten van de Mens (EHRM), dat adellijke privileges geen 'civil rights' zijn, hierin (nog) niet was verwerkt. De discussie hierover, die tot op heden wordt gevoerd, komt in alle facetten in deze studie aan de orde.

Onder begeleiding van wijlen prof. mr. A.K. Koekkoek schreef Coenraad een - later in bewerkte vorm gepubliceerde - doctoraalscriptie staats- en bestuursrecht met de pretentieuze titel 'Het Nederlandse adelsrecht; een staatsrechtelijk overzicht van

\footnotetext{
${ }^{33}$ Hofman Kolk, 'Het symposium "Ontwikkelingen in het Nederlandse adelsrecht, van Koning Willem I tot een Wet op de Adeldom”,, 225-227, 271-286 (met beknopte bibliografie).

${ }^{34}$ Loeb, 'De relatie tussen het naamrecht het adelsrecht', 254-268.

${ }^{35}$ Keesom, 'Hoofdlijnen van het Nederlandse adelsrecht', 237-253.

${ }^{36}$ Idem, 'Notities over Nederlands adelsrecht', 89-94.

${ }^{37}$ De Groot, 'Adelsrecht op de drempel van de 21 ${ }^{\text {ste }}$ eeuw', 118 (2001), 501-509 en 663-664 (reactie van mr. G.N. Westerouen van Meeteren); 119 (2002), 63-64 (antwoord van De Groot).
} 


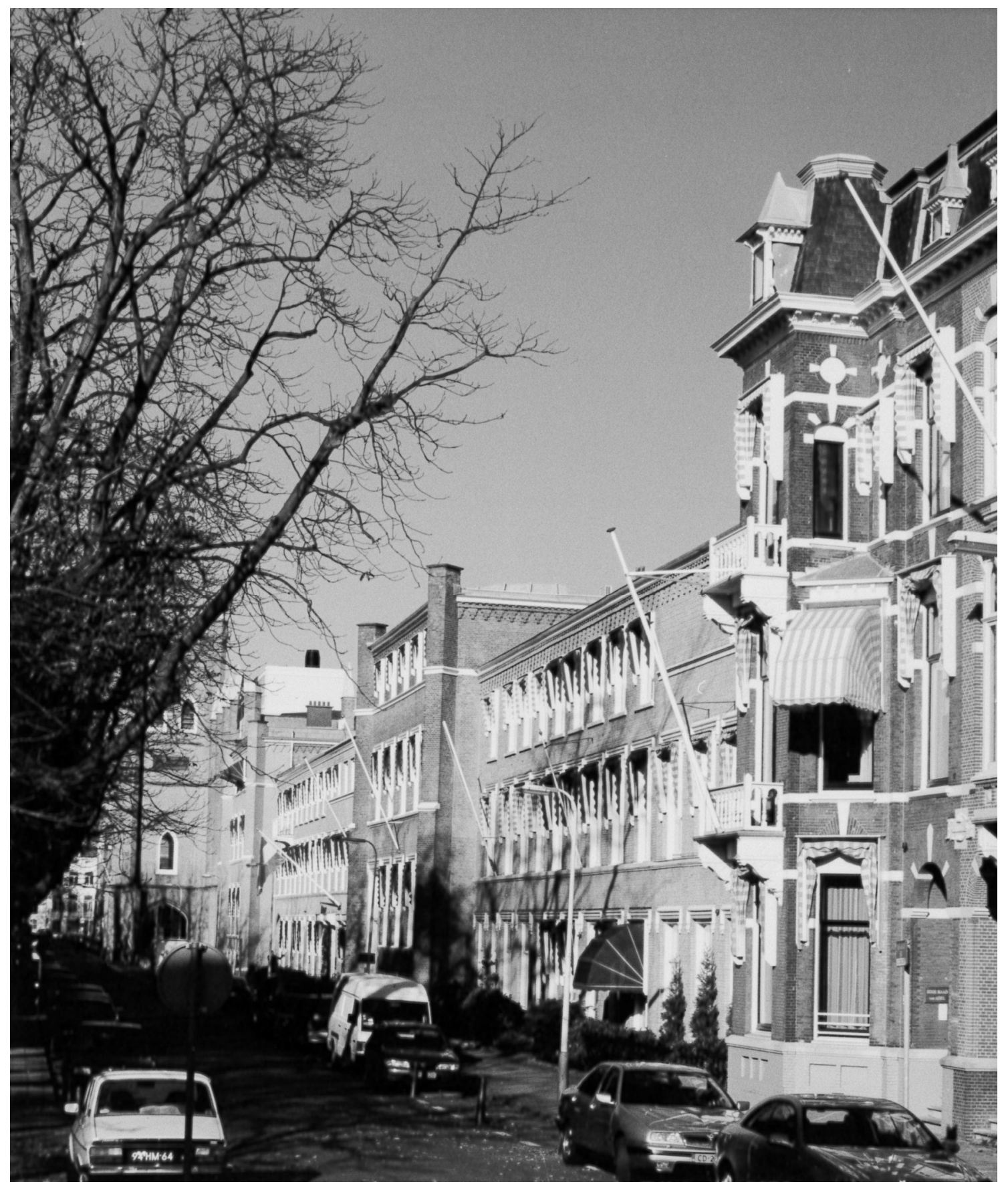

Het gebouw van de Hoge Raad van Adel aan de Haagse Nassaulaan (geheel rechts). Foto E.J. Wolleswinkel, 2003.

het vigerende adelsrecht ${ }^{38}$ De publicatie geeft in eerste instantie de indruk van een chronologische benadering, maar na een kort historisch overzicht worden alleen actuele thema's als de status en rol van het adviescollege en de Wet op de adeldom behandeld. Het artikel sluit af met een hoofdstuk over het verband tussen

\footnotetext{
${ }^{38}$ R.P.N. Coenraad, Het Nederlandse adelsrecht. Een staatsrechtelijk overzicht van het vigerende adelsrecht en een commentaar op de Wet op de adeldom met betrekking tot het gelijkheidsbeginsel (Princenhage 2003), Universiteit Tilburg, ANR 93.52.47.
} 
adeldom en naamrecht. ${ }^{39}$ Coenraad concludeerde dat het Nederlandse adelsrecht anders dan in Duitsland geen naamrecht is, maar ook niet los daarvan kan worden gezien. De modernisering van het adelsrecht die in de Wet op de adeldom is gecodificeerd om adeldom ook buiten het huwelijk om te laten overgaan, achtte hij ingrijpender dan een door hem voorgestane aanpassing van de wet, die vererving van adeldom langs vrouwelijke lijn mogelijk zou maken. Als belangrijkste argument voerde hij het belang van de bloedband aan, die bij adoptiefkinderen geheel ontbreekt in tegenstelling tot die van kinderen van adellijke moeders. Mijns inziens gaat hij in deze stelling voorbij aan het karakter van het instituut vanaf zijn oprichting in 1814. Ik zal trachten aan te tonen dat de soevereine vorst steeds een wettelijke adelstand voor ogen heeft gehad en de bloedband de jure niet van belang was.

Het meest recente adelsrechtelijke overzicht dateert uit 2009 en geeft een vergelijking tussen het Nederlandse adelsrecht en het Duitse naamrecht. De auteur besprak uitvoerig de verschillen in benadering, maar kwam slechts tot de kwalificatie dat in beide gevallen sprake is van een bijzonder identiteitsrecht. ${ }^{40}$

Ik zal me in deze studie overigens beperken tot het onderzoek naar het Nederlandse adelsstatuut en zijn voorloper. De diversiteit van al of niet bestaande buitenlandse adelsstatuten is te groot om in dit kader te behandelen en komt in aanmerking voor één of meer vervolgstudies. Wel zal de implementatie van het in 1919 afgeschafte Duitse adelsstatuut in het vigerende Duitse naamrecht aan de orde worden gesteld voor zover dit consequenties heeft voor het Nederlandse adels- en naamrecht.

Bovenstaande publicaties besteden geen of onvoldoende aandacht aan de bijzondere positie van het adelsrecht als constitutioneel recht, dat vanouds tot de prerogatieven van de koning behoorde. Nadat de Nederlandse adel zijn staatsrechtelijke positie volgens de Grondwet van 1848 was kwijtgeraakt, bleef de aard van het gehandhaafde adelsstatuut onduidelijk. Bij menige begrotingsbehandeling laaide de discussie in het parlement, vooral vanwege de financiële consequenties, over het voortbestaan van de Hoge Raad van Adel op. Westerbeek heeft de juridische en financiële geschiedenis van het instituut in opdracht van het Ministerie van Binnenlandse Zaken beschreven in het kader van de destijds op handen zijnde grondwetsherziening van 1972. ${ }^{41}$ De conclusie van de samenstellers van de proeve voor een nieuwe grondwet, dat er geen behoefte was aan een grondwettelijke bepaling omdat adelsrecht positiefrechtelijk niet meer is dan het toestaan van een bijzonder soort naamsverandering, staat haaks op de intussen algemeen aanvaarde overtuiging dat adelsrecht geen naamrecht is. Nader onderzocht zal worden waarom bij de grondwetsherziening van 1983 een onderscheid is gemaakt tussen adeldom en ridderorden, waar beide vanouds aangelegenheden van het koninkrijk zijn. Ten aanzien van ridderorden wordt in de Grondwet van 1983 expliciet bepaald dat deze bij

\footnotetext{
${ }^{39}$ Coenraad, 'Het Nederlandse adelsrecht', 118-171.

${ }^{40}$ Van Rijn, 'What's in a name? - Adel in de $21^{\mathrm{e}}$ eeuw', 171-181.

${ }^{41}$ Westerbeek, De Hoge Raad van Adel, 19-22.
} 
wet moeten worden ingesteld (art. 111), terwijl adeldom er zonder verwijzing uit is verdwenen. Heringa en Zwart doen voorkomen alsof voor adeldom ook in de wet terzake voor de ridderorden een voorziening zou worden getroffen. ${ }^{42}$

\section{Geraadpleegde archieven}

Het omvangrijke archief van de Hoge Raad van Adel, dat vanaf zijn oprichting in 1814 is bewaard gebleven, berust bij uitzondering niet in het Nationaal Archief, maar om redenen van efficiency ter secretarie van de Raad. De ambtelijke staf raadpleegt bij zijn werkzaamheden het archief vrijwel dagelijks wanneer voor lopende zaken geput moet worden uit dossiers uit afwisselende perioden van het koninkrijk. Weinig overheidscolleges zullen bij het uitbrengen van hun adviezen en in hun verdere expertise zo afhankelijk zijn van hun archieven als de Hoge Raad van Adel. Een korte beschrijving van de geschiedenis en inhoud van het archief is op deze plaats noodzakelijk.

Nadat onder invloed van de staatsrechtelijke hervorming van 1848 Raad en secretarie werden gesplitst, vond nog slechts archiefvorming plaats bij het departement waaronder adelszaken ging ressorteren, respectievelijk het Departement van Binnenlandse Zaken (1853-1859) en dat van Justitie (1860-1937). Toen de werkzaamheden in 1937 overgingen van het Ministerie van Justitie naar het nieuw opgerichte Ministerie van Algemene Zaken en de Hoge Raad van Adel zijn zelfstandige positie van vóór 1853 grotendeels terugkreeg, werd het archief van de Raad over de periode 1814-1937 en het ambtelijke archief over de periode 1876-1937 aan de Raad overgedragen ten behoeve van zijn werkzaamheden. Het ambtelijke archief over de periode die daaraan voorafging, is toen al overgedragen aan het Algemeen Rijksarchief. Ditzelfde gebeurde in 1984 met het ambtelijke archief over de periode 1876-1937, dat archieftechnisch onderdeel uitmaakte van de respectievelijke departementsarchieven. $^{43}$

Sinds 1937 vindt de archiefvorming van Raad en secretarie weer in hetzelfde gebouw plaats. Dit neemt niet weg dat het archief van de afdeling adelszaken van het Ministerie van Binnenlandse Zaken (en Koninkrijksrelaties), die de adviesaanvragen van de minister voorbereidt en afhandelt, in het archief van het ministerie teruggevonden kan worden, de overbrengingstermijn van twintig jaar naar het Nationaal Archief in aanmerking genomen.

Het ambtelijk archief van de Departementen van Binnenlandse Zaken, Justitie en Algemene Zaken (tot 1945) en het archief van het Ministerie van Binnenlandse Zaken (vanaf 1945) is ten behoeve van dit onderzoek nauwelijks geraadpleegd. ${ }^{44}$ De conclusie kon worden getrokken, dat de ontwikkeling van adelsbeleid en adelsrecht niet op een ambtelijke afdeling van een departement of ministerie plaatsvond,

\footnotetext{
${ }^{42}$ Heringa en Zwart, Grondwet 1983, 146-147.

${ }^{43}$ Kort en Wolleswinkel, Het archief van de Hoge Raad van Adel, 10-11.

${ }^{44}$ De inventaris van dit archief, die in 1985 door H.A.J. van Schie voor het Algemeen Rijksarchief (thans Nationaal Archief) werd samengesteld, is als bijlage opgenomen in: Kort en Wolleswinkel, Het archief van de Hoge Raad van Adel, 47-52, met vermelding van actuele toegangscodes en inventarisnummers.
} 
maar op het niveau van de adelsverzoeken aan de koning, waarover via de verantwoordelijke minister advies aan de Hoge Raad van Adel werd gevraagd. In de departementsarchieven berust bijvoorbeeld informatie over adelsverzoeken die op grond van de bestaande regelgeving al op ambtelijk niveau konden worden afgewezen en dus niet het stadium van een adviesaanvraag aan de Raad bereikten. In menige patriciërsfamilie doet nog een verhaal de ronde over een ooit afgewezen adelsverlening, waarvoor uit de familieoverlevering de meest uiteenlopende redenen worden opgegeven. Als hiervan in het archief van de Raad geen schriftelijk teken is te vinden, kan hiervan in theorie een afgewezen verzoekschrift met een kantlijnbeslissing in het departementsarchief aanwezig zijn. Anders dan bij ridderorden, die - een enkele uitzondering zoals voorheen de Militaire Willemsorde daargelaten - alleen op voordracht van anderen dan de begunstigde worden verleend, ging aan een adelsverzoek doorgaans een eigen verzoek vooraf, soms zelfs met opgave van de gewenste titulatuur...

Een onderzoek naar bij voorbaat afgewezen adelsverzoeken valt buiten het onderwerp van deze studie, maar kan als thema voor de adelsgeschiedenis het bestuderen waard blijken te zijn. In het bijzonder zou de aandacht dan uit kunnen gaan naar het selectiecriterium.

Naast het Raadsarchief beheert de Hoge Raad van Adel een aantal gedeponeerde archieven, die tamelijk onbekend, maar voor dit onderzoek van cruciaal belang zijn geweest. Voor de periode van het Koninkrijk Holland is het archief van het Hoog Heraldiek Collegie, het adviescollege van koning Lodewijk Napoleon over de periode $1809-1810$, aanwezig. ${ }^{45}$ Hierin zijn de stukken bewaard van de voorbereiding en de besluitvorming betreffende de oprichting van een constitutionele adel, zoals deze vanuit het koninklijk paleis in Amsterdam gestalte kreeg. In samenhang met het familiearchief Van Spaen, waarin veel persoonlijke en ambtelijke stukken van 's konings belangrijkste adviseur W.A. van Spaen van Hardestein zijn te vinden, krijgt de onderzoeker hieruit een goed beeld van de wijze waarop adeldom weer op de staatsrechtelijke agenda kwam te staan. ${ }^{46}$ Eén van de eersten die voor zijn publicaties op uitgebreide schaal gebruik maakte van deze rijke archieven was de historicus Aalbers. ${ }^{47}$ Maar ook Beelaerts van Blokland en Schutte, hierboven genoemd, kenden het bestaan van deze archieven.

Van de geraadpleegde gedeponeerde archieven dienen hier nog enkele in het bijzonder te worden genoemd. Allereerst zijn er de archieven van verscheidene voorzitters, leden en secretarissen van de Hoge Raad van Adel. Hun persoonlijke archieven werden dikwijls eerst na overlijden door hun erfgenamen geschonken en in een enkel geval, wanneer het ambtelijke stukken bleken te zijn, teruggegeven. ${ }^{48}$ Een klein archief, afkomstig van het Departement van Justitie, waarin besluiten,

\footnotetext{
${ }^{45}$ Kort en Wolleswinkel, Het archief van de Hoge Raad van Adel, 41 (inv. nr. 889).

${ }^{46}$ Van Zanten Jut, Inventaris van het familiearchief Van Spaen, inv. nrs. 312 e.v.

47 Aalbers, 'Willem Anne van Spaen van Hardestein', 104-128; idem, 'Van riddermatige naar koninklijke adel', 49-69.

${ }^{48}$ Kort en Wolleswinkel, Het archief van de Hoge Raad van Adel, $42-44$ (inv. nrs. 892-937).
} 
reglementen en documentatie betreffende adelszaken over de jaren 1815-1936 zijn samengebracht, berust mogelijk ten onrechte in het Raadsarchief. Archieftechnisch gezien, had ook dit archief, als behorende tot het departementsarchief in 1984 overgedragen moeten zijn aan het Algemeen Rijksarchief, maar is waarschijnlijk vanwege de praktische relevantie achtergehouden. ${ }^{49}$ Ten slotte zijn door de Raad ook adellijke familiearchieven verzameld, bijvoorbeeld van het geslacht Melvill van Carnbee, die fragmentarisch zijn geraadpleegd. ${ }^{50}$

Sporadisch is geciteerd uit het archief van de Chambre Héraldique, dat was gevormd door wapenkoningen in de Oostenrijkse Nederlanden en dat kort vóór de inval van de Fransen in Wenen in veiligheid was gebracht. Dit archief was van belang voor het functioneren van de Hoge Raad van Adel van het Verenigde Koninkrijk der Nederlanden en is van 1827 tot 1843 in Den Haag ondergebracht. Als uitvloeisel van het scheidingsverdrag met België werd het grootste deel weer afgestaan ten behoeve van de Raad van Adel van het nieuwe Koninkrijk België, echter niet nadat het was gekopieerd. Het archief wordt thans beschouwd als één van de handschriftcollecties die aan de Raad zijn toevertrouwd. ${ }^{51}$

\section{Indeling}

De indeling van de hoofdstukken en paragrafen in deze studie is zodanig opgezet, dat allereerst de herkomst van de teruggekeerde adelstand tijdens het Koninkrijk Holland zal worden beschreven. Vervolgens zal de vorming van een Nederlandse adelstand onder de soevereine vorst daarmee worden vergeleken.

Het leeuwendeel van het boek gaat over de juridische betekenis van de Nederlandse adel in het Koninkrijk der Nederlanden. Daarbij worden de hoofdstukken chronologisch afgebakend aan de hand van politieke gebeurtenissen, die belangrijke veranderingen voor het instituut adel tot gevolg hebben gehad. Enkele bijlagen, waarvan de belangrijkste - de correspondentie van Thorbecke (1) en de nota adelsbeleid van Beel (3) - hierboven al zijn genoemd, illustreren de staatsrechtelijke consequenties. Maar ook de geschiedenis van het adviescollege, dat in 1937 zijn positie van vóór 1853 grotendeels terugkreeg (bijlage 2), komt op meerdere plaatsen aan de orde. In bijlage 4 is een lijst opgenomen van de voorzitters, leden en secretarissen van de Hoge Raad van Adel van 1814 tot heden. Het in deze studie beschreven en becommentarieerde adelsbeleid kan hiermee vertaald worden naar de personele samenstelling van de Raad in de desbetreffende perioden.

Schema 1 vermeldt, zoals hiervoor is aangekondigd, getalsmatig het aantal NoordNederlandse adellijke geslachten, dat - uitgaande van de verschillende geslachtsnamen - over de volledige periode van de oprichting van het instituut Nederlandse adel in 1814 heeft bestaan. Van deze 566 geslachten is in de loop van de tijd een aanzienlijk deel uitgestorven, terwijl de aanwas van nieuwe geslachten geleidelijk minder werd. Thans leven in Nederland of daarbuiten nog ruim 300 verschillende

\footnotetext{
${ }^{49}$ Ibidem, 44-45 (inv. nrs. 946-956).

${ }^{50}$ Ibidem, 53 e.v.

${ }^{51}$ Idem, Het archief van de Chambre Héraldique, 5-13 (inleiding).
} 
adellijke geslachten voort. ${ }^{52}$ Hierbij kan eenzelfde aantal Belgische adellijke geslachten opgeteld worden, dat zijn erfelijke Nederlandse adeldom tussen 18151839 verwierf. Deze Zuid-Nederlandse geslachten werden door koning Willem I genobiliteerd, opteerden na de afscheiding voor het Koninkrijk België, maar worden geacht hun Nederlandse adeldom te hebben behouden. ${ }^{53}$ Het aantal gehonoreerde verzoeken tot verheffing, inlijving of erkenning is overigens veel groter dan het aantal geslachten, aangezien de verzoekschriften individueel werden gedaan (en behandeld) en dikwijls door telgen van dezelfde geslachten. Een overzicht op persoons- en geslachtsnaam is te vinden in het hierboven geciteerde jubileumboek van de Raad uit 1989. De lijst met familienamen is ook via de website van de Raad raadpleegbaar. ${ }^{54}$

Het vigerende adelsrecht tijdens het Koninkrijk der Nederlanden wordt beschreven, zoals dat nog is terug te vinden in vele soevereine en koninklijke besluiten, die vaak onbekend zijn maar hun gelding op grond van de Wet op de adeldom hebben behouden. In een overzichtslijst (schema 2) zijn de belangrijkste wetten, besluiten en richtlijnen opgenomen. Een selectie hieruit is als illustratie afgebeeld. Een lijst van relevante jurisprudentie (schema 3 ), zoals deze in de loop van vooral de twintigste eeuw is gevormd - met een belangrijke toename rond de laatste eeuwwisseling - is opgenomen met een korte aanduiding van de inhoud en de publicaties waarin de zaak uitvoeriger wordt besproken. Wanneer in deze publicaties eigennamen van de partijen zijn vermeld, worden deze als bekend verondersteld en zijn deze hier overgenomen.

Het slothoofdstuk bevat conclusies en aanbevelingen voor aanpassing van de wetgeving inzake adelsrecht en naamrecht, waarmee onevenwichtigheden binnen het koninkrijk worden gecorrigeerd. Door het Nederlandse adelsrecht te beschouwen als deel van de constitutionele orde van het Koninkrijk der Nederlanden, kan de doorwerking van eventuele onwenselijke aspecten van het buitenlands naamrecht ten aanzien van voormalige adellijke titulatuur worden voorkomen.

\footnotetext{
${ }^{52}$ Nederland's Adelsboek, passim.

${ }^{53}$ État présent de la noblesse de Belge, passim.

${ }^{54}$ www.hogeraadvanadel. $n l$ (adeldom $>$ filiatieregister $>$ familienamen).
} 


\section{De adel van het Koninkrijk Holland}

\section{Bataafse staatsregelingen ${ }^{55}$}

De besluiten van de Assemblée Nationale in Parijs van 4, 6, 7, 8 en 11 augustus 1789 , waarin afscheid werd genomen van het ancien regime door alle feodale rechten af te schaffen, hadden grote internationale gevolgen. De daaropvolgende decreten van 19-23 juni 1790 en 27 september-16 oktober 1791 schaften de adelstand en de titels af. ${ }^{56} \mathrm{Al}$ bij voorbaat werden vervolgens decreten uitgevaardigd, die afschaffing van rechten en privileges regelden in de landen welke door de Franse legers bezet zouden worden. Zo regelde het 'Decreet van den tweeden maart', dat formeel op 7 maart 1793 werd vastgesteld, de toepassing in Nederland. Dit decreet werd in gewijzigde vorm op 20 januari 1795, nadat de feitelijke inval had plaatsgevonden, te Amsterdam geproclameerd. ${ }^{57}$ In tegenstelling tot diverse andere Europese landen werd Nederland niet door Frankrijk ingelijfd, maar daarmee verenigd via een vergaande vorm van zelfbestuur. De voedingsbodem hiervoor was al in de nadagen van de Republiek der Verenigde Nederlanden gelegd door een onder invloed van de Verlichting sterk opgekomen patriottenbeweging. Mede door het pamflet van de Gelderse edelman Joan Derk van der Capellen tot den Poll, getiteld Aan het volk van Nederland, was een intellectuele bovenlaag van de bevolking wakker geschud. Deze om democratie en vrijheid roepende minderheid was vervolgens een ernstige bedreiging voor het stadhouderlijke bewind gaan vormen, maar werd in 1787 met harde hand door de koning van Pruisen, zwager van prins Willem V, ontmanteld. De belangrijkste patriotten namen de wijk naar NoordFrankrijk en bereidden vanuit St. Quentin, gelegen ongeveer halverwege de lijn Parijs-Brussel, de 'Franse bevrijding' voor. ${ }^{58}$ Een felle patriot als Herman Willem Daendels maakte op de Fransen indruk door zijn oproep aan zijn Gelderse en Overijsselse landgenoten om het land te zuiveren van 'adellijk ongedierte' en om de heerlijke rechten af te schaffen. ${ }^{59} \mathrm{Na}$ de inval van de Fransen in januari 1795 werd een publicatie verspreid 'behelsende de erkentenis en verklaring der rechten van de mensch en van de burger', waarin ondubbelzinnig staat: 'dat wij ons ook terstond ontwaar geworden zijn, dat alle erfelijke waardigheden als van erfstadhouder, kapitein-generaal en admiraal dezer provinciën en van ridderschap, mitsgaders alle erfelijke adeldom met de rechten van de mensch waren strijdende en

\footnotetext{
55 Voor de volledige inhoud, zie: De Gou, De Staatsregeling van 1798; De Gou, De Staatsregeling van 1801; De Gou, De Staatsregeling van 1805 en de Constitutie van 1806.

${ }^{56}$ Van Damme, Adel, 19-21.

${ }^{57}$ Ketelaar, Oude zakelijke rechten, 16-23 (met uitgebreide literatuuropgave en vindplaatsen van de pamfletten).

${ }^{58}$ Rosendaal, Bataven! Nederlandse vluchtelingen in Frankrijk 1787-1795, 57-136.

${ }^{59}$ Pamflet d.d. 's-Hertogenbosch 21 okt. 1794. Vgl. Rogge, Tafereel van de geschiedenis der jongste omwenteling, 159-162.
} 
dat dus alle dezelve voor vervallen moesten worden gehouden en verklaard, zoals dezelven vervallen verklaard worden bij dezen. ${ }^{, 60}$

Aan deze initiatieven was de betrekkelijke vrijheid te danken waarin de gewestelijke vergaderingen van volksrepresentanten, die spoedig een meerderheid in de Staten-Generaal hadden verworven, de kans kregen om het erfelijke stadhouderschap af te schaffen en de volkssoevereiniteit te erkennen. Gelderland liep daarbij voorop met een publicatie van 25 maart 1795 waarin met felle bewoordingen het leenstelsel werd afgeschaft, dat in strijd was met 'verschillende artikels der staatelijk afgekondigde verklaring der rechten van den mensch en burger., ${ }^{61}$

Naar Frans voorbeeld werd tot tweemaal toe een Nationale Vergadering bijeengeroepen, getrapt gekozen door alle mannelijke burgers van twintig jaar en ouder. ${ }^{62}$ Deze slaagden er toen niet in tot het vaststellen van een constitutie te komen. Breekpunt was steeds de botsing tussen de bescherming van het eigendomsrecht en de afschaffing van het feodale stelsel. De tegenstelling tussen behoudende federalisten en radicale unitarissen resulteerde drie jaar na de inval van de Fransen in een nieuwe staatsgreep, waarbij een constitutie werd opgelegd. Deze Staatsregeling van 1798, die in grote lijnen de Franse constitutie volgde, werd wel aanvaard omdat de belangrijkste federalisten waren gevangengenomen en de stemgerechtigden een verklaring moesten ondertekenen van 'onveranderlijke afkeer van het Stadhouderlijk bestuur, het Foederalismus, de Aristocratie en de Regeeringloosheid'. ${ }^{3}$ Ondanks deze gedwongen totstandkoming kan in historisch verband gezien de Staatsregeling van 23 april 1798 als de meest verlichte grondwet worden gekenschetst die Nederland ooit heeft gekend. ${ }^{64}$ De leer van de volkssoevereiniteit, op grond waarvan de Amerikaanse onafhankelijkheidsstrijd werd gevoerd, was de basis voor de Franse revolutie en lag ook ten grondslag aan deze staatsregeling. Uitgangspunt is de natuurlijke gelijkheid van de mens, die de overheid volmacht geeft om gezag uit te oefenen. Historische privileges als erfelijke adeldom en daaruit voortvloeiende overheidsmacht in particuliere handen (feodale rechten) zijn in de regeling afgeschaft, waardoor iedereen - modern omschreven - gelijk was voor de wet. ${ }^{65}$ Uitgaande van de beginselen van vrijheid, gelijkheid en broederschap werden de belangrijkste grondrechten voor de mens nader omschreven. Ook de staatskerk werd als zodanig afgeschaft. ${ }^{66}$ Het Vertegenwoordigend Lichaam was als democratische vertegenwoordiging het belangrijkste orgaan, dat als geheel werd gekozen en zichzelf daarna in twee kamers opdeelde. Een tweekamerstelsel naar het

\footnotetext{
${ }^{60}$ Pamflet van 31 jan. 1795. Vgl. Van Meeuwen, 'Een en ander over het Nederlandse adelsrecht', 75.

${ }^{61}$ Ketelaar, Oude zakelijke rechten, 21-22.

${ }^{62}$ Brood, Nieuwland en Zoodsma (red.), Homines novi, 9-27.

${ }^{63}$ Van Haersolte, Inleiding tot het Nederlandse staatsrecht, 18.

${ }^{64}$ [Berendse en Brood], In 21 stappen vrij onverveerd, nr. 8 (Nationaal Archief, 's-Gravenhage (NA), Bibliotheek, cat. nr. 8 A 10).

${ }^{65}$ Staatsregeling des Bataafschen Volks (Den Haag 1798), artt. 24 (afschaffing van 'Alle eigenlyk gezegde heerlyke regten en tituls (...)') en 25 (afschaffing van 'Alle tiend-, chyns- of thyns, nakoops-, afstervingsen naastingsregten van welken aard, mitsgaders alle andere regten of verpligtingen, hoe ook genoemd uit het leenstelsel of leenregt afkomstig (...)').

${ }^{66}$ Ketelaar, Oude zakelijke rechten, 24-30; Vermeulen, Krijnen en Roos (red.), De Koning in het Nederlandse staatsrecht, 15.
} 
Engelse model, waarbij de ene, vanouds een 'adelskamer', de andere controleerde, werd afgewezen als in strijd met het Bataafse vertegenwoordigingsbeginsel. Het grondbeginsel van de gelijkheid stond in de verklaring van 1795 boven dat van de vrijheid. Het kenmerkte zich enerzijds door gelijkstelling van andere godsdiensten (protestanten, katholieken en joden) met de bevoorrechte gereformeerde staatskerk, anderzijds door afschaffing van het erfelijke ambtenstelsel. ${ }^{67}$ Een nieuwe staatsgreep later in het jaar, nu op initiatief van eerdergenoemde generaal Daendels, waarborgde nieuwe verkiezingen op grond van de aanvaarde staatsregeling, waarmee niet de pioniers automatisch als Uitvoerend Bewind konden gaan optreden. $^{68}$

Toch werd de staatsregeling van 1798 geen succes, want in de praktijk werkte deze te centralistisch. Doordat de provincies waren afgeschaft en vervangen door departementen met een willekeurige indeling, was het uitvoerend bewind oppermachtig maar grotendeels onervaren in de nieuwe opzet. In Frankrijk bleek de staatkundige ontwikkeling evenmin stil te staan. Een staatsgreep in 1799 bracht daar een nieuwe constitutie (1801), die een eerste consul als hoofd van het uitvoerend bewind veel macht gaf. Als primeur werd de goedkeuring van deze constitutie geregeld bij volksstemming (plebisciet of referendum), die in 1802 ook de persoon achter deze nieuwe functie aanwees: de in 1801 benoemde eerste consul Napoleon Bonaparte. Twee jaar later riep deze zichzelf tot keizer uit. ${ }^{69}$

Ook de nieuwe 'Staatsregeling des Bataafschen Volks' (1801) werd bij volksstemming aanvaard. Deze herstelde de oude provinciale indeling en realiseerde daarmee weer een zekere mate van decentralisatie. Een teken aan de wand was dat onder de grondrechten het recht van vereniging en vergadering was verdwenen. Vier jaar later werd deze staatsregeling op aandrang van keizer Napoleon in die zin gewijzigd dat het uitvoerend bewind werd vervangen door een eenhoofdige leiding in de functie van raadpensionaris. Rutger Jan Schimmelpenninck bleef als raadpensionaris maar een jaar in functie, want bij Frans-Bataafs verdrag van 24 mei 1806 werd de Bataafse Republiek omgezet in een Koninkrijk Holland. ${ }^{70}$ De Constitutie van het Koningrijk Holland bracht de veranderingen die van een centralistisch bewind onder leiding van een vorst verwacht konden worden. De autonomie van de departementen, die de voormalige gewesten vervingen, werd ongedaan gemaakt, maar deze behielden het benoemingsrecht van het Wetgevend Lichaam ('Hun Hoog Mogende'). De constitutie is een lofzang op de absolute macht van de koning, maar het instituut adel ontbreekt daarin (nog) geheel. De constitutie begint met de aankondiging: 'De Regering van Holland is Monarchaal gewijzigd en geregeld bij constitutie (art. 1). Het groot beginzel der Maatschappelijke Vrijheid bestaat daarin, dat de Wet gelijke Regten verzekere en gelijke pligten oplegge aan alle Burgers, zonder onderscheid van rang of geboorte' (art. 2). Bij uitzondering

\footnotetext{
${ }^{67}$ De Meij, 'Hoe belangrijk is de Bataafse Staatsregeling van 1798 geweest?', 309-319.

${ }^{68}$ Elias en Schölvinck, Volksrepresentanten en wetgevers, 9-16 en 265-276 (naamlijsten).

${ }^{69}$ Van der Pot/Donner, Handboek van het Nederlandse staatsrecht, 87-92.

${ }^{70}$ Van Haersolte, Inleiding tot het Nederlandse staatsrecht, 14-18.
} 


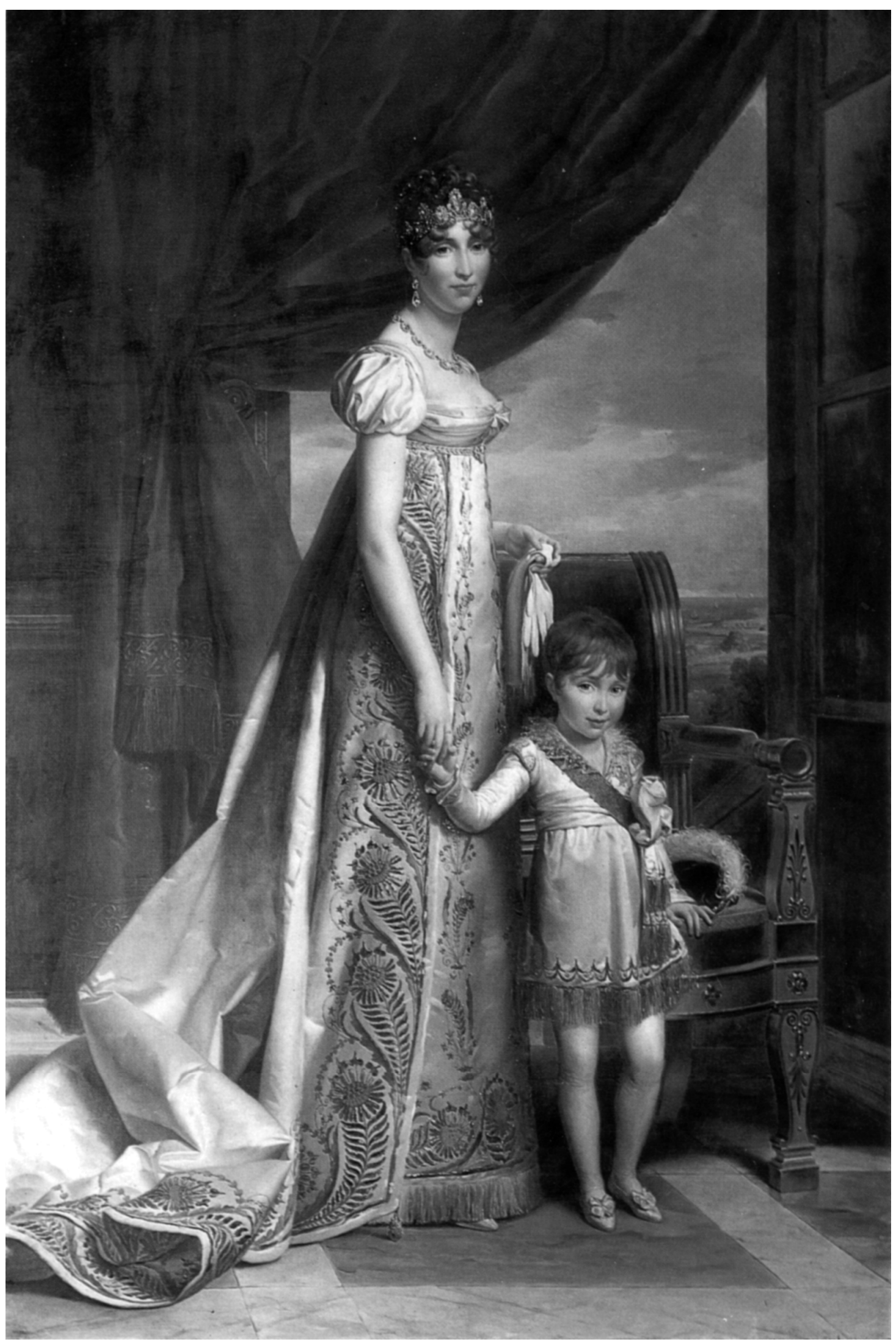

Hortense Eugénie de Beauharnais (1783-1837), koningin-regentes van Holland (1810) met haar zoontje Napoleon Louis Bonaparte (1804-1831), prins van Holland (1807) en koning van Holland van 1-9 juli 1810.

Doek, $216 \times 145$ cm, door François P.S. baron Gérard, 1808. Veiling Monaco 4 dec. 1976, nr. 4. Foto RKD/IB, 's-Gravenhage. 


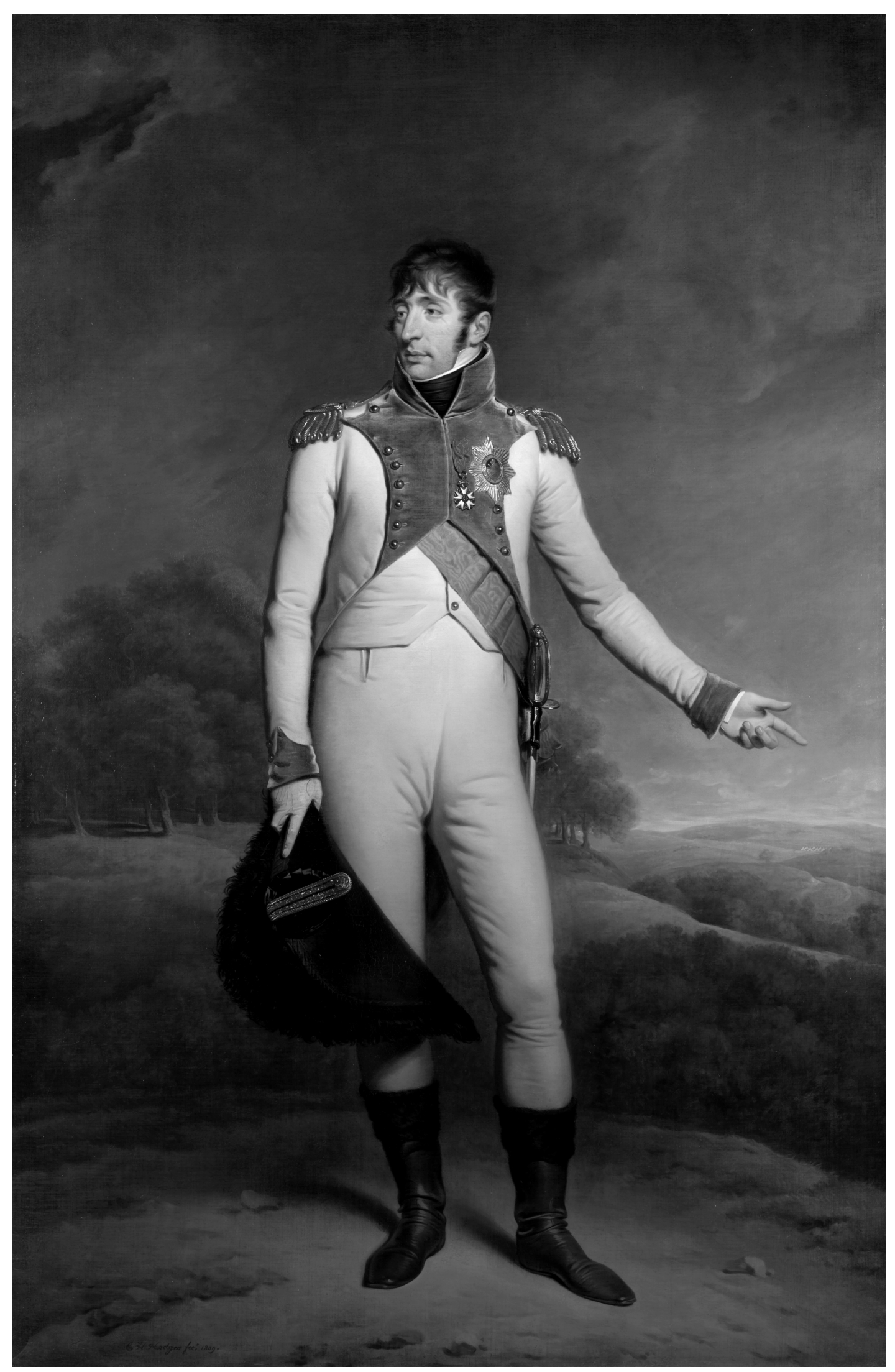

Lodewijk Napoleon Bonaparte (1778-1846), koning van Holland 1806-1810. Doek, $223 \times 147$ cm, door Charles H. Hodges, 1809. Collectie en foto: Rijksmuseum Amsterdam. 
wordt voor het koninklijk huis de erfopvolging, langs mannelijke lijn bij eerstgeboorte, constitutioneel vastgelegd (art. 19). ${ }^{71}$

\section{Grondwet op de constitutionele adel van het Koninkrijk Holland}

De machtsgreep bij volksreferendum in Frankrijk door het hoofd van het uitvoerend bewind, de eerste consul Napoleon Bonaparte, had niet alleen daar ingrijpende staatsrechtelijke veranderingen tot gevolg, maar uiteindelijk ook in Nederland. Napoleon veroverde belangrijke delen van Europa, die hij politiek opnieuw indeelde en waar hij familieleden aan het hoofd stelde. In dit kader benoemde hij op 5 juni 1806 zijn jongere broer Lodewijk Napoleon tot koning van het nieuwe Koninkrijk Holland, dat - anders dan de naam doet veronderstellen - de oude zeven provincies omvatte met het voormalige generaliteitsland Brabant als achtste. ${ }^{72}$ De verhouding tussen de broers zou overigens niet ideaal blijken te zijn, omdat de keizer de koning als zijn stiefkind - hij had hem ook werkelijk opgevoed - bleef behandelen. Initiatieven van laatstgenoemde, die zijn nieuwe rol in vertwijfeling was begonnen, werden dikwijls kritisch door zijn broer bekeken en vervolgens afgekeurd. Onder meer hun uiteenlopende ideeën over adeldom veroorzaakten uiteindelijk een breuk, die na vier jaar een einde aan het Koninkrijk Holland maakte.

Al kort na zijn aantreden als eerste consul had Napoleon Bonaparte in Frankrijk een Legioen van Eer ingesteld, dat hoofdofficieren een jaargeld verleende dat gefinancierd werd uit schattingen (belastingen) die aan nieuw opgerichte koninkrijken als Italië en Napels werden opgelegd. De begunstiging door toelating tot deze ridderorde, waarvoor de eed aan vorst en vaderland moest worden afgelegd en waaraan titels als 'chevalier' en 'commandeur' waren verbonden, werd gezien als een vorm van persoonlijke adeldom. Na Napoleons kroning tot keizer, op 2 december 1804, werd de behoefte groter om een keizerlijk hof in te stellen, waarvoor een organisatie en financiering moest worden bedacht. Gaandeweg werd een systeem ontwikkeld dat gebaseerd was op de toekenning van zogenaamde majoraten. Dit waren veroverde gebieden, waaruit de inkomsten werden toegekend aan door de keizer benoemde machthebbers, die behalve uit familieleden ook uit trouwe wapenbroeders werden gerecruteerd. Ze ontvingen titels die op het ancien regime teruggingen, maar steeds in samenhang met de naam van het majoraat. Toen daar vervolgens een vorm van belening en vererving voor werd bedacht die opvallend veel gelijkenis vertoonde met het afgeschafte leenstelsel, moesten zelfs de revolutionaire erfrechtbepalingen van de Code Civil worden aangepast. ${ }^{73}$

\footnotetext{
${ }^{71}$ Constitutie voor het Koningrijk Holland, d.d. Me(n)tz 7 aug. 1806 (Den Haag, Kon. Staats Drukkerij 1806) (HRvA, RA, inv. nr. 889).

${ }^{72}$ Van Haersolte, Inleiding tot het Nederlandse staatsrecht, 14-18.

${ }^{73}$ Beelaerts van Blokland, 'Adelsbeleid en adelsrecht vóór 1813', 21-23: bij wet van 14 nov. 1792 waren de majoraten afgeschaft en bij wet van 3 sept. 1807 werd artikel 896 van de Code Civil (verbod van substitutie) uitgebreid met de bevoegdheid om majoraten in te stellen.
} 
Gezien het voorgaande was het begrijpelijk dat een van de eerste maatregelen die de nieuwe koning van Holland nam, het instellen van een ridderorde was. Op 12 december 1806 stelde hij de Orde van de Unie in, die met een koninklijke beloningsorde voor verdienstelijke oorlogsveteranen in een wet van 14 februari 1807 werd verenigd. ${ }^{74}$ In navolging van het keizerrijk volgde aan het einde van dat jaar de benoeming van zogenaamde grootofficieren van het koninkrijk, hetgeen echter bij de keizer niet in goede aarde viel. Deze was er namelijk achter gekomen dat zijn broer toestond dat op officiële uitnodigingen adellijke titulatuur werd gebezigd. De keizer nam dit hoog op en zag het zelfs als landverraad. Hij was toen waarschijnlijk nog niet op de hoogte van de opdracht van zijn broer, eerder dat jaar, aan de historicus Van Spaen van Hardestein. Deze was verzocht een memorandum op te stellen over het al of niet bestaan van oude adel in Nederland, waarover onduidelijkheid binnen het uitvoerend gezag was ontstaan. Zonder de uitslag daarvan af te wachten, bleef de koning adellijke titulatuur in uitnodigingen van het Hof en geloofsbrieven van ambassadeurs bezigen. ${ }^{75}$ Dit leverde kritiek van de keizer op: 'Welk voordeel is er in gelegen den ouden adel en de Patriciërs hun uitsluitende voorrechten terug te geven? Talenten vindt men onder alle klassen, de ware adel zoekt men bij U bij de rijken., ${ }^{76}$

Onder invloed van goede berichten over het koningschap van zijn broer werd het oordeel van de keizer milder. Hij kondigde op 1 maart 1808 zelfs een regeling af ten aanzien van de adel in Frankrijk die de vererving van de aan bovengenoemde majoraten verbonden titels regelde. ${ }^{77}$ Daarmee was de weg vrij om ook in Holland adelszaken te gaan regelen. Anders dan het heimelijke onderzoek van een jaar eerder, stelde de koning op 5 juli 1808 een officiële 'Commission spéciale des titres' in, waarvan behalve W.A. van Spaen van Hardestein ook maarschalk Ph.J. van Zuylen van Nijevelt, grootkanselier van de Orde van de Unie M. van der Goes, directeur-generaal Kunsten en Wetenschappen J. Meerman, en landsarchivaris H. van Wijn deel uitmaakten. In zijn ruime opdracht kwam de commissie tot andere voorstellen dan de koning voor ogen had. Het historisch onderzoek is in het familiearchief Van Spaen bewaard gebleven en zou uiteindelijk nog in verschillende fasen van het te ontwikkelen adelsbeleid een rol gaan spelen. Vooral op het overzicht van de ridderschappen met hun verschillende reglementen die onder het ancien regime in de voormalige gewesten een rol hadden gespeeld, werd nogal eens teruggegrepen tijdens het juridische vacuüm dat ontstond toen de Fransen in 1813 waren verdreven. ${ }^{78}$ De koning dacht echter veeleer in de lijn van zijn broer, die een adeldom voorstond waarbij de titulatuur verbonden was aan majoraten, welke tevens voor de financiering zorgden. Deze domeinen zouden na overlijden terugval-

\footnotetext{
${ }^{74}$ Schutte, De Orde van de Unie.

${ }^{75}$ Beelaerts van Blokland, 'Adelsbeleid en adelsrecht vóór 1813', 4-5.

${ }^{76}$ Wichers, De regeering van koning Lodewijk Napoleon, 273-277 (bijlage 14: verslag van een felicitatiebezoek van een Nederlandse delegatie onder leiding van Jan van Styrum, lid van het Wetgevend Lichaam, d.d. 24 mei 1807 aan de keizer op kasteel Finckenstein te Polen na behaald succes op de Pruisen bij Jena), 274.

${ }^{77}$ [Beelaerts van Blokland e.a.], De Hoge Raad van Adel, 166-167 (bijlage II).

${ }^{78}$ HRvA, Archief van de familie (FA) Van Spaen, inv. nr. 312.
} 


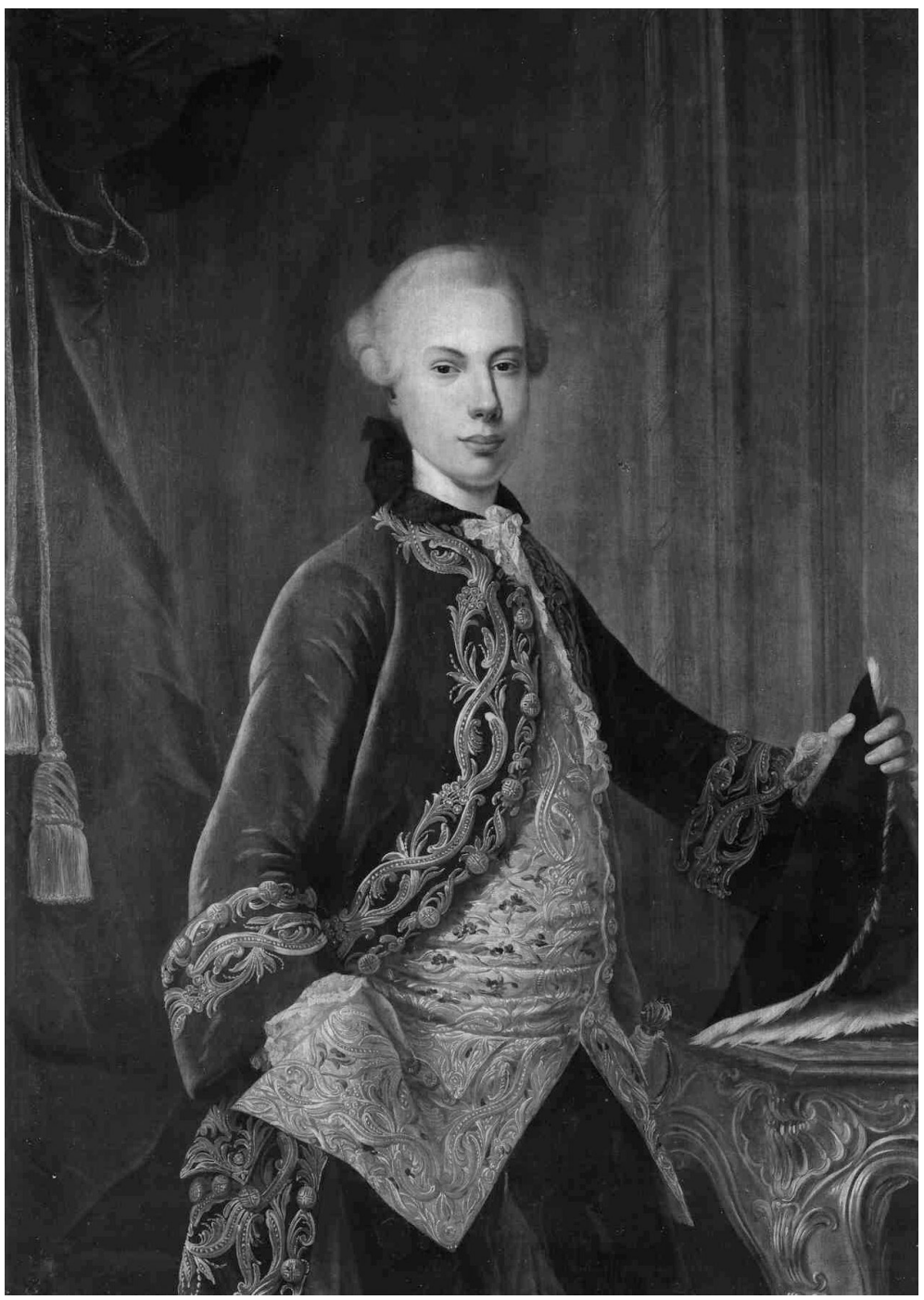

Willem-Anne van Spaen van Hardestein (1750-1817), grootmeester der wapenen van het Koninkrijk Holland en lid van het Hoog Heraldiek Collegie (1809).

Doek, 124,5 x $94 \mathrm{~cm}$, toegeschreven aan Guillaume de Spinny, 1768. Collectie Brantsen van de Zypstichting (Stichting Geldersche Kasteelen), Arnhem, foto RKD/IB, 's-Gravenhage.

len aan de Kroon, die een nieuwe gunst aan een zoon zou kunnen doen. In feite propageerde hij het uitsterven van oude adel en zag hij nieuwe (persoonlijke) adeldom louter als beloning voor bijzondere (overwegend militaire) verdiensten. Van Spaen probeerde, nog voor de commissie bijeenkwam, de koning te overtuigen van het belang van vererving van adellijke titulatuur bij eerstgeboorte en de relatieve zegen van majoraten voor de Nederlandse situatie. ${ }^{79}$ Er zou in Nederland te weinig fortuin aanwezig zijn om de instelling daarvan tot een succes te maken. Wanneer vermogen het enige criterium zou zijn, zou dit de moraliteit (beginselen van eer en toewijding als basis voor de eenheidstaat) niet ten goede komen en het evenwicht tussen adel en kroon verstoren. Binnen de commissie, die op 1 augustus 1808 voor het eerst bijeenkwam, heerste grote verdeeldheid, maar de discussie leidde wel tot een belangrijke aanbeveling. Erkenning van oude adel zou van wezenlijk belang zijn omdat de groep anders op afstand van de Kroon zou komen te staan, met het gevaar van vijandigheid. De erfelijke adel zou echter geen voorrechten mogen ge-

\footnotetext{
${ }^{79}$ Beelaerts van Blokland, 'Adelsbeleid en adelsrecht vóór 1813', 1-10.
} 
nieten die ten nadele van andere klassen van medeburgers zouden zijn. In meerderheid zag men erfelijke vertegenwoordiging in het landsbestuur als in strijd met de constitutie. In de loop van de maand werd met de koning overeenstemming bereikt over erfelijke adeldom met titels bij eerstgeboorte, een afgezwakte vorm van toekenning van majoraten uit 's konings eigen middelen, en enkele privileges. $\mathrm{Na}$ een kritisch advies van de Raad van State, door Van Spaen aan de koning aanbevolen om in te roepen, werd bij de koninklijke besluiten van 26 en 28 september het rapport met memories en conceptreglementen vastgesteld. Er was naast een reglement voor de constitutionele adel ook een reglement ontworpen voor een Hooge Raad van den Adel, een naam die hier voor het eerst in de annalen opduikt. ${ }^{80}$ Op 1 januari 1809 leverden echter de ministers W.F. Röell en F.A. van Leyden (en daarna zijn opvolger A.P. Twent), die met de uitvoering waren belast, ongezouten kritiek op de hen ter hand gestelde stukken. Hun bezwaren waren vooral van praktische aard: erkenning en bloc zou in individuele benoeming moeten worden omgezet, de in Nederland voorkomende titel van markies ontbrak, de ongewenstheid van majoraten, en de onduidelijkheid in titulatuur ten opzichte van die van de Orde van de Unie. Ten slotte waren er nog financiële en juridische onevenwichtigheden. ${ }^{81}$ Uit de hofalmanak van dat jaar blijkt al dat de koning zijn zinnen doorzette ondanks de bezwaren van zijn ministers, die hem mogelijk met de beste bedoelingen hadden willen waarschuwen voor de - hem uiteindelijk fatale - reactie van zijn broer. ${ }^{82}$ Op 2 april 1809 benoemde de koning een staatscommissie met als secretaris A.C. Snouckaert van Schauburg, intendant der paleizen. Deze commissie ontzag de oude adel, maar bestond dan ook uit vier staatsraden (leden van het Wetgevend Lichaam) die op één na tot de voormalige adel behoorden: F.S. van Bylandt van Halt, E.M. von Inn- und Knipphausen, A. van Pallandt van Eerde en J.F.R. van Hooff. ${ }^{83}$ Nog geen week later, bij decreet van 7 april 1809, wees de koning uit hun midden Andries van Pallandt van Eerde aan om het wetsontwerp op de constitutionele adel van het koninkrijk voor te dragen. In de vergadering van het Wetgevend Lichaam van 8 april 1809 werd een adviescommissie benoemd, bestaande uit J.F.W. van Spaen van Biljoen, L[amoraal] Rengers, Cremers, Van Westreenen van Themaat, Van Bleiswijk en Von Wedel tot Gödens, die al op 13 april reageerde. J.F.W. van Spaen bracht namens de commissie een zeer lovend advies uit, alsof zijn familie niet bij de voorbereiding betrokken was geweest. ${ }^{84}$ Hij memoreerde dat het buiten kijf stond dat in een 'monarchiek' bestuur, zoals het

\footnotetext{
${ }^{80}$ Van Schie, Inventaris van het archief van Hendrik van Wijn, inv. nr. 41: 'Project-Reglement voor den Adel en voor eenen Raad van Adel in het Koningrijk Holland, van den jare 1809, in een pakketje' (NA, maar verblijfplaats van dit inventarisnummer onbekend). Duplicaten, gedateerd 26 sept. 1808 en 1 jan. 1809, zijn aanwezig in de Archives Nationales te Parijs. In het 'Fonds de la sécretarie d'Etat, consulat et empire, affaires étrangères' bevinden zich de 'Archives du cabinet de l'ex-roi de Hollande Louis Bonaparte', inv. nr. A F IV 1818 (collège héraldique). Fotokopieën van deze stukken zijn aanwezig in: HRvA, hs.coll. (oud nr. 'paars') 889.

${ }^{81}$ Beelaerts van Blokland, 'Adelsbeleid en adelsrecht vóór 1813', 6-16.

${ }^{82}$ Almanach de la Cour pour l'année 1809 (Amsterdam 1808), waarin de vanouds gevoerde titulatuur staat vermeld. Keizer Napoleon zelf had vanwege zijn Europese veroveringen de Almanach de Gotha voor 1808 herschreven.

${ }^{83}$ Aalbers, 'Willem Anne van Spaen', 117-122.

${ }^{84}$ HRvA, RA, inv. nr. 889. W.A. van Spaen stamde uit een jongere tak van dit geslacht.
} 
gevestigde, het verheffen tot de adel van de koning afhing. Voorts dat dit verschijnsel 'in de (Lage) Landen niet vreemd was, aangezien de vermaardheid van de Nederlandse adel sedert de dertiende en veertiende eeuw in de annalen was opgetekend en dit zelfs een (Hollandse graaf als) Roomsch koning in het Duitsche Rijk had opgeleverd.' Ten slotte bracht hij in herinnering 'dat de adel tijdens de Republiek een aanmerkelijk aandeel aan 's Lands regering had gehad.' In het algemeen constateerde hij 'dat in alle beschaafde monarchieën de adel tot luister en vastigheid van de troon bijdroeg en als een nuttige middelstand tussen het overige deel van de natie en de soeverein fungeerde.' In het bijzonder kwam hij tot de positieve overweging dat 'er voldoende oude eerbiedwaardige vaderlandse geslachten, wier oorsprong zich, evenals die van de adel, in de nacht der oudheid verloor, aanwezig waren om een constitutionele adel uit samen te stellen.' Bij een globale artikelsgewijze behandeling kwam hij tot de conclusie dat aan alle bezwaren, zoals deze bij de voorbehandeling waren gerezen, was tegemoetgekomen.

In de preambule van de op 22 april 1809 vastgestelde Grondwet op den constitutionelen adel van het Koningrijk Holland is nog een algemene motivatie voor de totstandkoming opgenomen: 'Overwegende, dat de constitutie van het rijk ons de verpligting oplegt voor de bevestiging der Monarchie te waken, en dat een monarchiek bestuur niet kan bestaan zonder lieden rondom zich te hebben, die het verdedigen en onderschragen, en door de onverbrekelijke banden van eer en eed aan hetzelve gehecht zijn.' Deze wordt gevolgd door de bijzondere overweging 'dat het volstrekt noodig is den staat en de voorregten van den constitutionelen adel des rijks te regelen, en denzelven met de staatsregeling en het welzijn des volks overeen te brengen, ${ }^{85}$ Een aantal bepalingen van de uit 34 artikelen bestaande wet stelden vervolgacties in het vooruitzicht. Volgens artikel 3 zou de koning een heraldiek collegie benoemen ten behoeve van de uitvoering van de wet, terwijl hij volgens artikel 34 aan zichzelf voorbehield om statuten en verdere bepalingen betreffende de adel te maken. Was de adelswet nog te 's-Hertogenbosch uitgevaardigd, de vaststelling van de adelsstatuten, de oprichting van het Hoog Heraldiek Collegie (HHC) en de benoeming van twee grootofficieren vond plaats vanuit het koninklijk paleis in Amsterdam, dat de koning eind april had betrokken. Het op 1 oktober 1809 in de zaal der ambassadeurs ingestelde Hoog Heraldiek Collegie bestond uit zes grootofficieren. In de eerste plaats de vier grootofficieren van de kroon: de grootkamerheer $\mathrm{Ph} . J$. van Zuylen van Nijevelt (als provisioneel president), de opperjagermeester L. van Heeckeren tot de Cloese, de opperstalmeester A. Bruno, en de grootmaarschalk van het paleis A.M.J.J. Roest van Alkemade. En voorts de twee specialisten, de op die datum benoemde grootofficeren W.A. van Spaen van Hardestein als grootmeester der wapenen en J.H. Mollerus als grootkanselier der titels. ${ }^{86}$ De uitgevaardigde Statuten betrekkelijk den adel van het Ko-

\footnotetext{
${ }^{85}$ Archivaris Van Wijn verving in een aan hem voorgelegd concept het begrip 'Landadel' door 'Constitutionele adel' omdat het belang van een door de koning ingestelde adel in de titel tot uitdrukking moest worden gebracht (HRvA, FA Van Spaen, inv. nr. 312).

${ }^{86}$ HRvA, RA, inv. nr. 889, KB van 1 okt. 1809, nrs. 2-5 (regl. van orde HHC, art. 1; not. HHC d.d. 4 okt. 1809). De zaal van de ambassadeurs (vóór 1808 de kamer van de commissarissen in kleine zaken) lag naast
} 
ningrijk Holland bleken een zeer gedetailleerde codificatie van het geschreven en ongeschreven adelsrecht uit het ancien regime te zijn. ${ }^{87}$ Het leidt geen twijfel dat de resultaten van het historisch onderzoek van W.A. van Spaen, die een jaar eerder aan de koning waren uitgebracht, ten behoeve van deze uit 36 artikelen bestaande statuten zijn gebruikt.

De in de loop van 1809 ontwikkelde 'feodale' grondslag voor de nieuwe adel wekte de toorn op van de keizer, waardoor de onderlinge verstandhouding tussen de broers onherstelbare schade opliep. Een kleine correctie van artikel 29 van de statuten, waardoor de voorrang van edelen bij de verdeling van gelijke posten of ambten werd beperkt tot die edelen die een door anciënniteit hogere rang hadden verworven, mocht niet meer baten. ${ }^{88}$ Nadat de keizer had gedreigd met opheffing van het Koninkrijk Holland, deed de koning tot tweemaal toe een toezegging om het Hollandse adelsrecht in overeenstemming met de vigerende Franse wetgeving te brengen. Op 4 februari 1810 ontbood de keizer zijn broer in het Palais des Tuileries in Parijs en ventileerde scherpe kritiek op de instelling van een constitutionele adel en de benoeming van maarschalken. ${ }^{89}$ In een brief aan zijn broer, d.d. 4 april 1807, vatte de keizer zijn mening nog eens kort samen: 'Gij moet geen maarschalken, baronnen en graven maken, maar soldaten!' ${ }^{90}$ Meer dan eens had hij hem geraden de conscriptie in te voeren. De maarschalken van Holland waren in feite militaire territoriale bevelhebbers om de handelsblokkade tegen Engeland te bewaken. Bij geheim besluit van 7 februari schafte de keizer de titel van maarschalk af, met behoud overigens van het tractement. ${ }^{91}$ Uiteindelijk greep de keizer op 18 februari in met het - in naam van zijn broer - in Parijs uitgevaardigde besluit dat de adel van het Koninkrijk Holland buiten werking was gesteld alsof deze nimmer had bestaan. ${ }^{92}$ Bij identiek besluit, d.d. Parijs 1 maart 1810, ondergingen de statuten van 1 oktober, inclusief het nadere besluit van 21 november, hetzelfde lot. 'Ons Heraldiek Collegie' bleef bestaan en kreeg de opdracht zo spoedig mogelijk te adviseren hoe het stuk van de adel in overeenstemming kon worden gebracht met hetgeen in Frankrijk was vastgesteld. Daarvoor werd autorisatie verleend om met de ambassadeur in Parijs te corresponderen. Met de uitvoering van het besluit werden de minister van Justitie en Politie en het Heraldiek Collegie tezamen belast. Opvallend is dat in dit door de keizer geredigeerde besluit de kwalificatie 'Hoog'

\footnotetext{
de troonzaal (vóór 1808 de schepenzaal). Vgl. Van der Zwaag (red.), Koning Lodewijk Napoleon \& zijn Paleis op de Dam, 69 (afb.).

${ }^{87}$ Ibidem, KB van 1 okt. 1809, nr. 1.

${ }^{88}$ Ibidem, KB van 21 nov. 1809.

${ }^{89}$ Wichers, De regeering van koning Lodewijk Napoleon, 61 en 165.

${ }^{90}$ Beelaerts van Blokland, 'Adelsbeleid en adelsrecht vóór 1813', 41 (noot 40): 'Ce ne sont pas des marchéaux, des chevaliers et des comtes qu'il faut faire, ce sont des soldats.'

${ }^{91}$ Ibidem, 165 (noot). De maarschalken van Holland (VerHuell, Dumonceau, De Winter, Van Kinsbergen, Daendels en Van Zuylen van Nijevelt) kregen begin 1811 alsnog de graventitel van het keizerrijk verleend, met uitzondering van generaal Daendels, die op 16 nov. 1810 tot gouverneur-generaal van Ned. Oost-Indië werd benoemd (Schutte, De Orde van de Unie, 61; idem, 'Het beleid tijdens het Koninkrijk der Nederlanden', 320-321).

${ }^{92}$ KB van 18 febr. 1810, afgegeven te Parijs, in: HRvA, RA, inv. nr. 889 (drukwerk).
} 


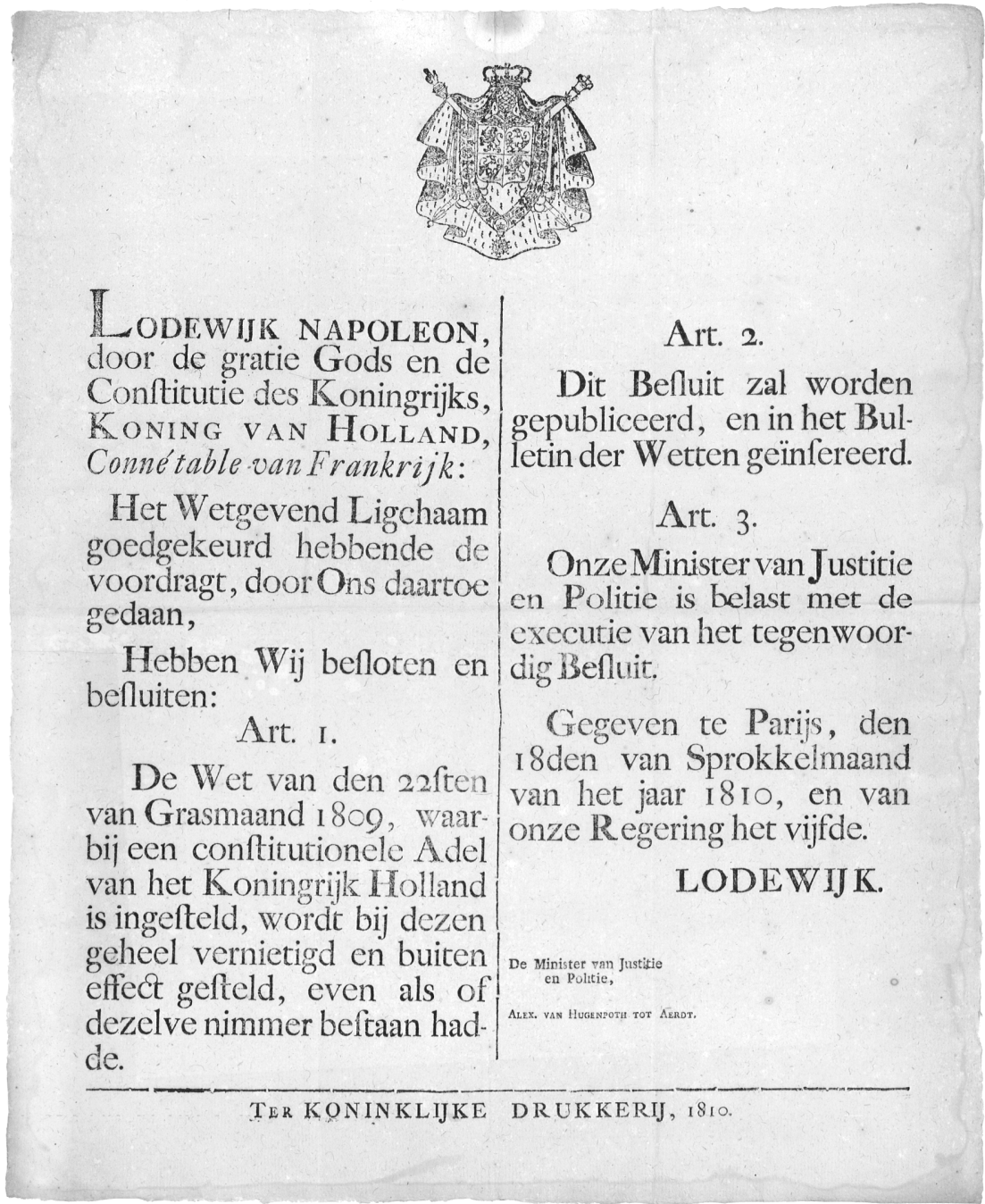

KB van 18 februari 1810, uitgevaardigd te Parijs, tot opheffing van de constitutionele adel van het Koninkrijk Holland. HRvA, RA, inv. $n r$. 889.

als nadere aanduiding voor het college was weggelaten. ${ }^{93}$ In de vergadering van het college van 25 mei 1810 werd zelfs nog een secretaris aangesteld, die in de volgende vergadering de eed aflegde. ${ }^{94}$ De koning was toen feitelijk al van het toneel verdwenen, maar deed eerst op 1 juli 1810 afstand van de troon, formeel ten behoeve van zijn minderjarige zoon. Op 2 juli werd een Provisionele Raad van Regentschap benoemd die tot de komst van de koningin-regentes zou functioneren. De Raad ging op audiëntie bij de nieuwe koning Napoleon Louis te Haarlem, die als kleuter hen daarvoor in het Frans bedankte. ${ }^{95}$ Op 9 juli lijfde Napoleon het voormalige koninkrijk in bij het Keizerrijk Frankrijk, waarmee een nieuwe episode aanbrak. $^{96}$

\footnotetext{
${ }^{93}$ HRvA, RA, inv. nr. 889 (afschrift KB van 1 maart 1810); Beelaerts van Blokland, 'Adelsbeleid en adelsrecht vóór 1813', 17-18.

${ }^{94}$ HRvA, RA, inv. nr. 889 (not. HHC d.d. 25 en 28 mei 1810). Dit was E.J.R. Mollerus, de vierde zoon van de grootkanselier der titels, die sous-chef de Bureau bij het Ministerie van de Waterstaat was en aangesteld werd in de rang van secretaris-generaal. Vgl. Nederland's Adelsboek 88 (1999), 417-419 en 441-442.

${ }^{95}$ Wichers, De regeering van koning Lodewijk Napoleon, 225-230.

${ }^{96}$ Uitterhoeve, Koning, keizer, admiraal, die de persoonlijke, politieke en militaire oorzaken van de ondergang van het Koninkrijk Holland beschrijft, maar de kwestie van de adeldom maar twee keer zijdelings noemt (p. 18 en 133).
} 
Op 24 augustus werd het archief van het Collegie, op last van de architrésorier, de hertog De Plaisance, aan hem overgeleverd met een inventaris der stukken, die door de secretaris was opgesteld. ${ }^{97}$ Kennelijk moesten deze in het Frans vertaald worden, want (concept)notulen en besluiten in beide talen zijn uit de periode dat het Hoog Heraldiek Collegie functioneerde, bewaard gebleven. Ook een Franse inventaris, althans een genummerd overzicht van alle stukken, is aanwezig. Het archief geeft een goed overzicht van de uitvoerige discussies over en het beperkte resultaat van het tussen 22 april 1809 en 1 juli 1810 gevoerde adelsbeleid. ${ }^{98}$ Wonderlijk genoeg zijn alle adelsgunsten van het Koninkrijk Holland verleend nadat wet en statuten al buiten werking waren gesteld. Zonder wetgeving kon echter geen nieuwe adel, maar eventueel slechts oude adeldom, tezamen met titulatuur, erkend worden. De koning gaf daarom het adviescollege op 6 juni 1810 de opdracht een reglement te ontwerpen om voormalige edellieden aan te kunnen schrijven en de taak de door hen in te dienen bewijzen te beoordelen. Deze actie heeft echter geen resultaat meer gehad, aangezien het einde van het koningschap nabij was. ${ }^{99}$

Tussen 13 april en 10 juni 1810 kregen niettemin drie admiraals, een generaal en een minister de graventitel en een generaal-majoor de baronnentitel, na overigens eerst in de adelstand verheven te zijn. Deze titels waren verbonden met en werden doorgaans gevoerd in samenhang met territoria, waardoor een jaargeld was verzekerd. ${ }^{100}$ De gebieden waren kort daarvóór aan het grondgebied van het koninkrijk toegevoegd, zoals Huissen en Zevenaar en het land van Jever (Oost-Friesland). ${ }^{101}$ Op de dag van abdicatie ( 1 juli) werden nog zes baronnentitels uitgedeeld. ${ }^{102}$

\section{Inlijving bij het Keizerrijk Frankrijk}

De opdracht die het heraldisch college op 1 maart 1810 bij gelegenheid van de ontmanteling van de adel van het Koninkrijk Holland kreeg, had als direct resultaat dat vanuit Frankrijk werd verzocht een lijst op te maken van de door de voormalige koning verleende adeldom. Nu immers door de inlijving per 9 juli 1810 de wetten en besluiten inzake de adel van het Keizerrijk in Nederland van kracht waren geworden, leek het nieuwe bewind aan te koersen op bevestiging van de verleende titulatuur en de aan vaste goederen (territoria) verbonden jaargelden. ${ }^{103}$

\footnotetext{
${ }^{97}$ De Bruyn, 'Hoge Raad van Adel', 15-26.

${ }^{98}$ HRvA, RA, inv. nr. 889.

${ }^{99}$ Aalbers, 'Willem Anne van Spaen', 123-124.

${ }^{100}$ Dit waren in chronologische volgorde generaal J.B. Dumonceau, graaf van Bergerduin; admiraal C.H. VerHuell, graaf van Sevenaer; admiraal J.W. de Winter, graaf van Huessen; admiraal J.H. van Kinsbergen, graaf van Doggersbank; minister A.P. Twent van Raaphorst, graaf van Rozenburg; en generaal-majoor E.J. Travers, baron van Jever (HRvA, RA, inv. nr. 889; FA. Van Spaen, inv. nr. 312).

${ }^{101}$ Met opzet wordt hier niet over majoraten gesproken om verwarring met het systeem van het Keizerrijk te voorkomen.

${ }^{102}$ Beelaerts van Blokland, 'Adelsbeleid en adelsrecht vóór 1813', 19-20.

${ }^{103}$ HRvA, RA, inv. nr. 889 (briefwisseling).
} 


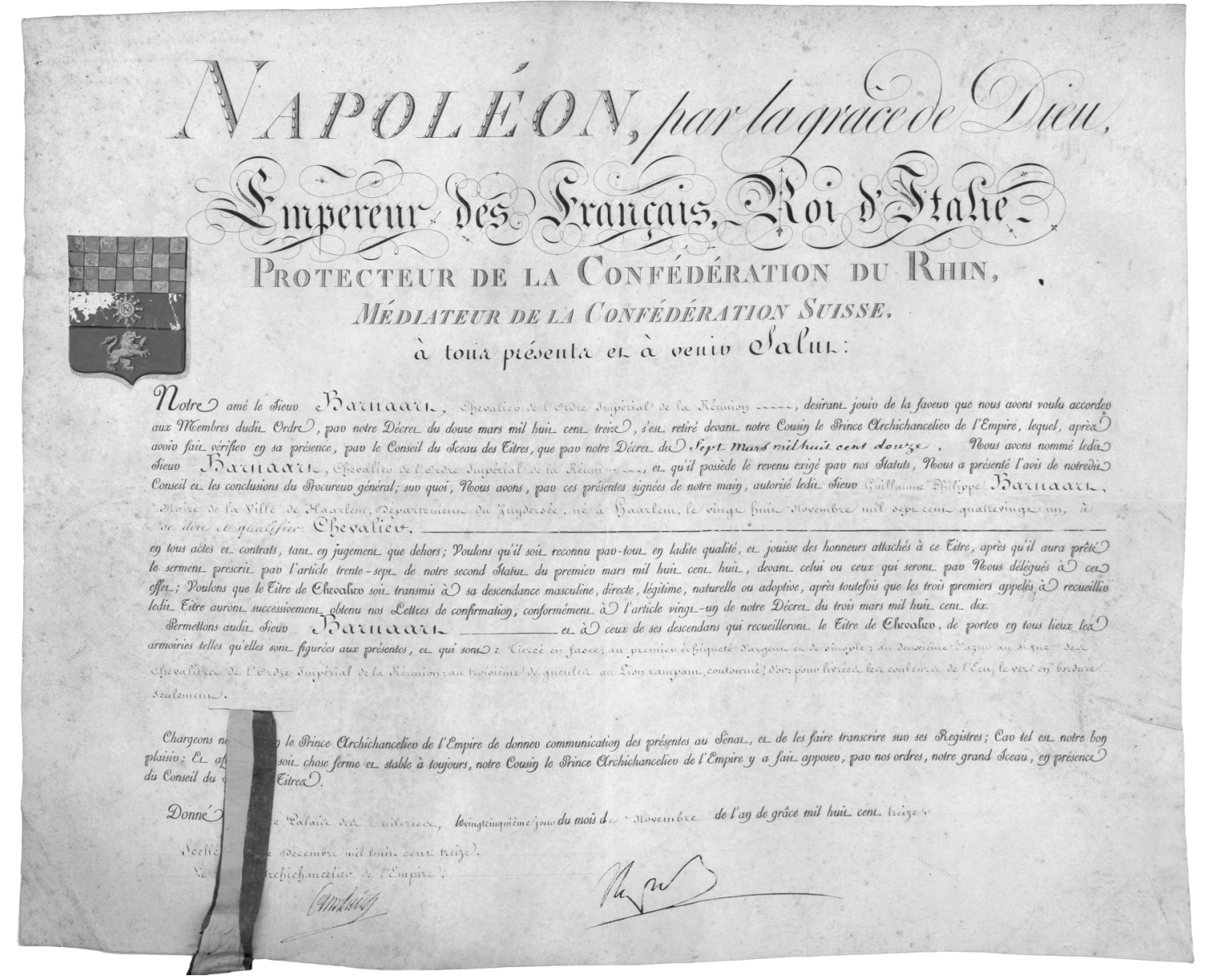

Adelsdiploma van keizer Napoleon voor Willem Philip Barnaart, Parijs 25 november 1813. HRvA, RA, hs. coll., adels- en wapendiploma's, inv. nr. 24.

Hierboven is al aangegeven hoe ver de keizer met zijn broer was meegegaan in het uitvaardigen op 1 maart 1808 van het 'Premier statut impérial portant création et transmission des titres'. In het Franse systeem was essentieel dat op grond van verdiensten een titel werd verleend aan personen van een bepaalde, doorgaans militaire rang, en dat daar vervolgens een materiële beloning aan vast zat. Een adequate financiële positie was de basisvoorwaarde om een vooraanstaande plaats in de samenleving te kunnen innemen, veeleer dan een illustere afstamming zonder meer. De verleende titels, die hiërarchisch aan bepaalde ambten en majoraten waren verbonden, werden voor het leven uitgevaardigd. Alleen de titel van ridder in het Legioen van Eer kon bij eerstgeboorte vererven als pretendenten konden aantonen een bepaald jaarinkomen te genieten. Het toekennen van titels en wapens gebeurde uitsluitend bij diploma en was aan de keizer voorbehouden. Krachtens artikel 10 van het Keizerlijk Decreet van 3 maart 1810 werd de mogelijkheid geschapen tot het verlenen van de titel van chevalier aan de jongere zonen van een houder van een majoraat. Naam en wapen zouden overgaan op alle kinderen van de getitelde eigenaar van een majoraat. Napoleon erkende geen andere adel dan die hijzelf had verleend en die door de af te leggen eed voor volk en vaderland gebonden was aan het Franse onderdaanschap. Dit maakte het voor andere soevereine vorsten onmogelijk om op den duur verzoeken tot erkenning of inlijving te honore- 
ren. Beelaerts en Schutte komen tot de conclusie dat het Napoleontische systeem 'titres de l'Empire' kende die geen adeldom inhielden. Niettemin heeft het systeem invloed gehad op latere adelsstatuten, zonder dat het als gelijkwaardig werd gezien. $^{104}$

Op 26 augustus 1811 - met nadere bepalingen op 23 september - werd bij keizerlijk decreet een oproep gedaan aan inwoners van de ingelijfde departementen met 'feodale' titulatuur, die zij volgens de wetten van de staat niet (meer) mochten behouden, om een verzoekschrift in te dienen bij de prins kanselier van het Keizerrijk. Tot 1 januari 1813 konden zij hun bewijzen inleveren, waarbij nieuwe (persoonlijke) titels, familiewapens en livreien in het vooruitzicht werden gesteld. Ook nu weer werd advies van W.A. van Spaen ingewonnen, die in oktober 1811 te Amsterdam werd ontboden door de daar residerende Franse minister De Montalivet. Van Spaen herhaalde in zijn memorie van 4 oktober dat van oude erfelijke adeldom moeilijk bewijzen waren te leveren, in het bijzonder waar het titulatuur betrof. Voorts was het voorgestane primogenituurstelsel (vererving bij recht van eerstgeboorte) van Engelse en/of Franse herkomst en daardoor in de Noordelijke Nederlanden zeldzaam. Hij vreesde daardoor achterstelling van 'oeradel' ten opzichte van 'briefadel'. Ook de hierboven reeds beschreven stichting van majoraten stuitte nog immer op praktische problemen. Volgens De Montalivet zou de Franse Raad van de Titels oplossingen kunnen aandragen bij voorkomende problemen. Toen Van Spaen aangaf daarin zitting te willen nemen, haastte de minister zich mee te delen dat de werkzaamheden van deze raad werden verricht door lieden die een lage rang in de maatschappij hadden. ${ }^{105}$

Vanwege de boven vermelde bezwaren, die het voor oude adel weinig aantrekkelijk maakte op de geboden gelegenheid in te gaan, kwamen nauwelijks verzoeken binnen. Ook het onderscheid tussen adeldom en titels bleek een breekpunt van belang te zijn gebleven. Vanzelfsprekend komen wel de vijf graven en de ene baron van het Koninkrijk Holland, en zelfs baron D.H. Chassé, wiens door Lodewijk Napoleon verleende titel nietig was verklaard, voor onder de comtes en barons de l'Empire van 1811 (1813). Op deze lijst staan voorts een aantal NoordNederlanders dat zich in de voorafgaande periode had onderscheiden, waaronder de afgezette raadpensionaris Rutger Jan Schimmelpenninck, maar ook leden van de adviescommissies betreffende adeldom. Een negental bestuurders werd in 1813 nog chevalier de l'Empire, een titel aanvankelijk slechts weggelegd voor leden van het Légion d'Honneur maar na een algemeen decreet van 12 maart 1813 ook opengesteld voor leden van de Orde van Réunie. ${ }^{106}$

\footnotetext{
${ }^{104}$ Beelaerts van Blokland, 'Adelsbeleid en adelsrecht vóór 1813', 21-34; Schutte, 'Les titres du premier Empire français en relation avec les Pays Bas', De Nederlandsche Leeuw 97 (1980), 323-358 (met literatuuropgave).

105 Aalbers, 'Willem Anne van Spaen', 122-127.

${ }^{106}$ Schutte, 'Het beleid tijdens het Koninkrijk der Nederlanden ten aanzien van de door Napoleon verleende titels', 310-313 en 319-322. Van de in dit decreet benoemde Nederlanders, ontvingen als laatsten Pieter Jacob de Bye en Willem Philip Barnaart hun door de keizer ondertekende en bezegelde diploma's te Parijs op 25 november 1813, vijf dagen ná de Nederlandse onafhankelijksverklaring en vijf dagen vóór de aankomst van de prins van Oranje in Scheveningen (HRvA, RA, hs. coll., adels- en wapendiploma's, inv. nr. 24: Barnaart).
} 


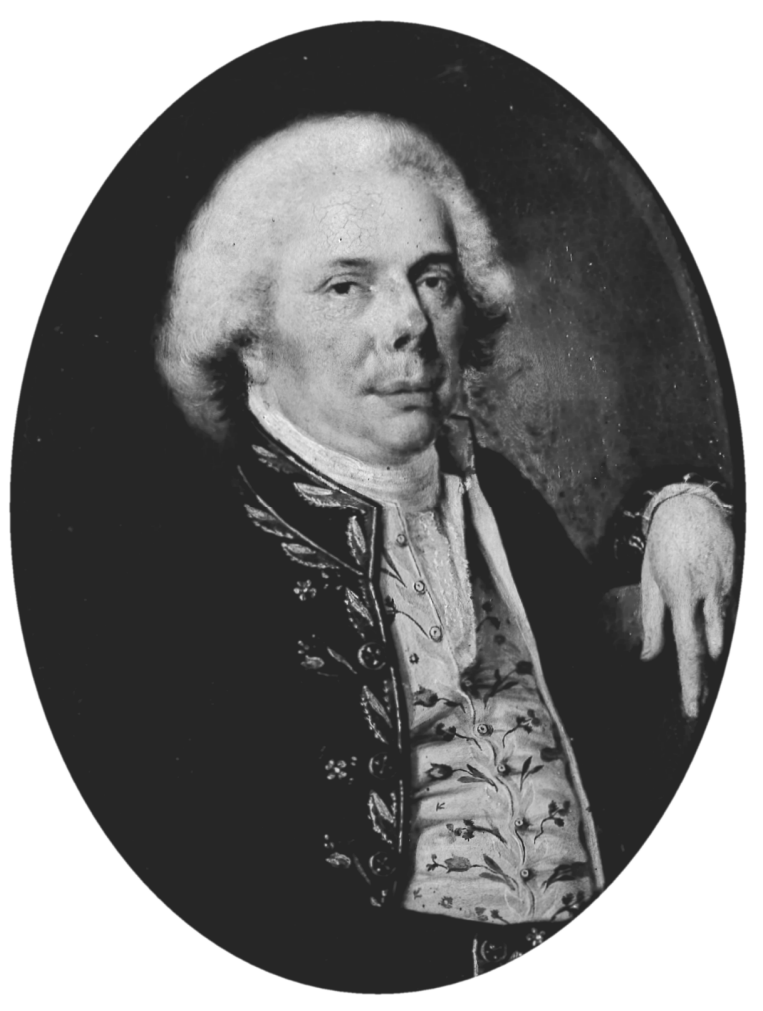

Willem-Anne baron van Spaen la Lecq (1750-1817), president van de Hoge Raad van Adel.

Miniatuur (metaal), 19,3 $\times 15 \mathrm{~cm}$, anoniem. Particuliere collectie. Foto RKD/IB, 's-Gravenhage.

SB van 24 juni 1814, waarin Willem Anne van Spaen la Lecq wordt benoemd tot 'President van den Hoogen Raad van Adel' (met vermelding van de eedsaflegging op $25 \mathrm{ju}$ ni). HRvA, FA Van Spaen, inv. nr. 314.

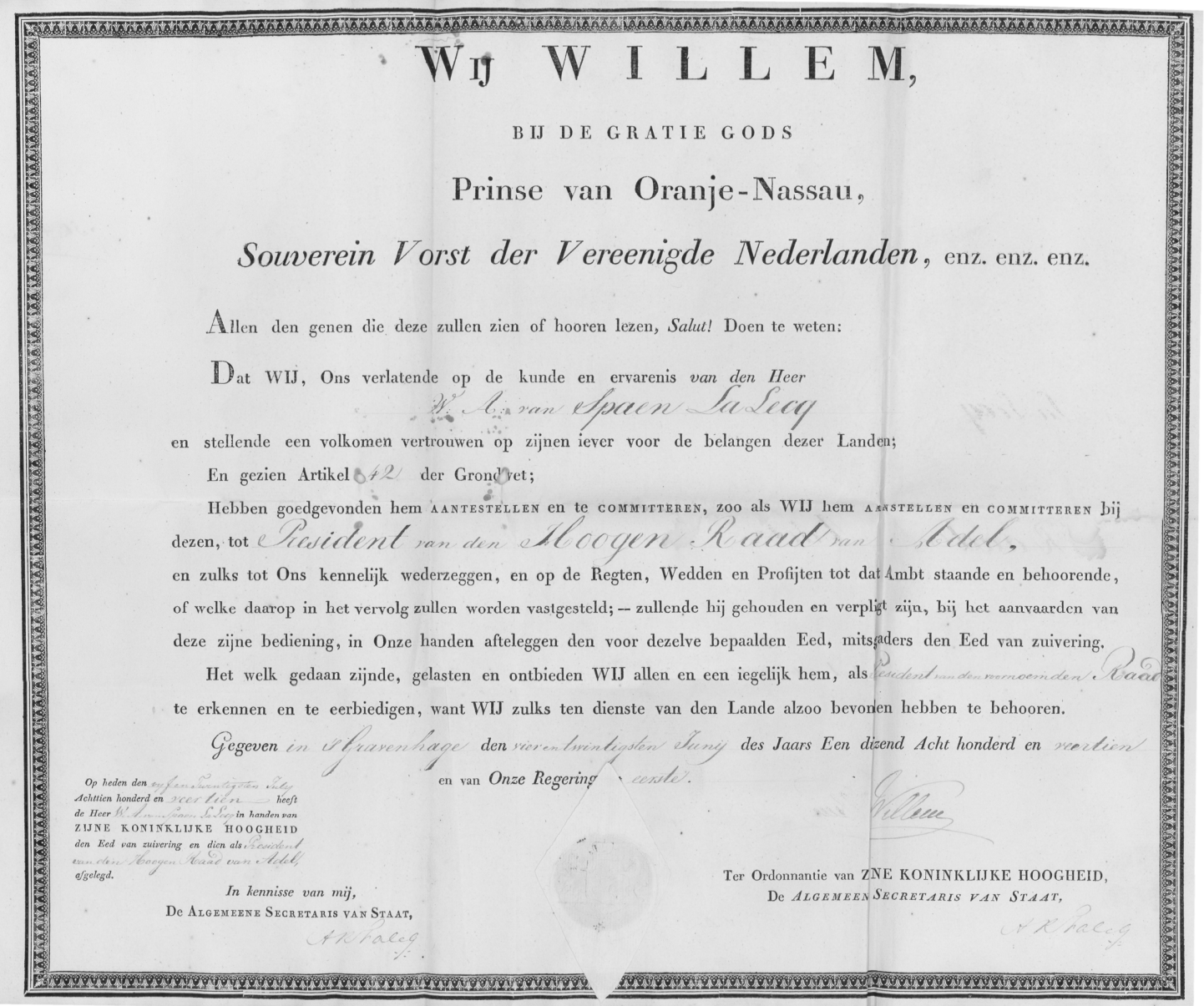




\section{Nederlandse adel onder de Soevereine Vorst der Verenigde Nederlanden}

\section{Soevereine Vorst der Verenigde Nederlanden}

Nadat de Fransen in het najaar van 1813 waren verdreven, trad de voormalige Rotterdamse regent Gijsbert Karel van Hogendorp op de voorgrond om in het ontstane machtsvacuüm te voorzien. Als een van de weinige bestuurders was hij van politiek onbesproken gedrag aangezien hij gedurende de gehele Franse overheersing ambteloos was geweest en geen ander regime had willen aanvaarden dan een door Oranje geleide staatsvorm. Aan de zijlijn had hij op verschillende momenten zijn zienswijze gepubliceerd. Deze evolueerde van een door een stadhouder voorgezeten Staten-Generaal met een vijftal uitvoerende departementen, maar met een centraal hoogste gerechtshof ('Memorie', 1795), naar een onschendbare erfstadhouder met beslissende stem als voorzitter van de Staten-Generaal ('De Unie van Utregt herzien', 1799-1801), tot een soeverein vorst van een eenheidsstaat ('Schets van eene Grondwet voor de Vereenigde Nederlanden', 1812). ${ }^{107}$ De grondwet zag hij als een gesloten verbond tussen de vorst, als de beschermer van het volk, en de aristocratie, waarin de oude gedachte van een feodaal contract tussen vorst en adel is terug te vinden. ${ }^{108}$

In zijn 'Schets', waarvan verscheidene versies bekend zijn, opteerde hij voor herstel van de decentrale instellingen van vóór 1795, maar dan centraal geleid door een erfelijk staatshoofd in de persoon van de prins van Oranje. De constitutie van provinciale staten, ridderschappen, steden en plattelandsbesturen zou haar plaats terugkrijgen binnen een nationale grondwet. Het platteland had, volgens Van Hogendorp, geleden onder de Republiek der Verenigde Nederlanden, toen veel heerlijkheden door koop in handen van stedelingen waren gekomen, die veraf woonden, zodat 'de landman zijn hoofd miste. De weinige familiën, in de ridderschappen zittende, konden de belangen van het platteland onmogelijk naar behoren voorstaan. $\mathrm{Nu}$ kan de Souvereine Vorst wederom, onder de aanzienlijkste ingezetenen, edellieden maken en de gestoorde evenredigheid herstellen. De edelen, willen zij in de Ridderschappen beschreven zijn, moeten een Heerlijkheid bezitten; zij zullen er een, die in hun familie is, op hun naam krijgen, of er een koopen, en zoodoende zal het platteland allengskens vanzelf wederom zijn natuurlijke hoofden krijgen, die het voor zullen staan in de Statenvergaderingen.' ${ }^{109}$ Als criterium

\footnotetext{
107 Van Hogendorp, Brieven en gedenkschriften. Van der Pot/Donner, Handboek van het Nederlandse staatsrecht, 134-135; Colenbrander, Ontstaan der Grondwet 1, 43-56 (derde redactie van de 'Schets').

${ }^{108}$ Van Nifterik, 'De vorst in evenwicht', 182-190.

${ }^{109} \mathrm{Vgl}$. De Monté ver Loren, Hoofdlijnen uit de ontwikkeling der rechterlijke organisatie, 172-181 (het ontstaan van heerlijkheden).
} 


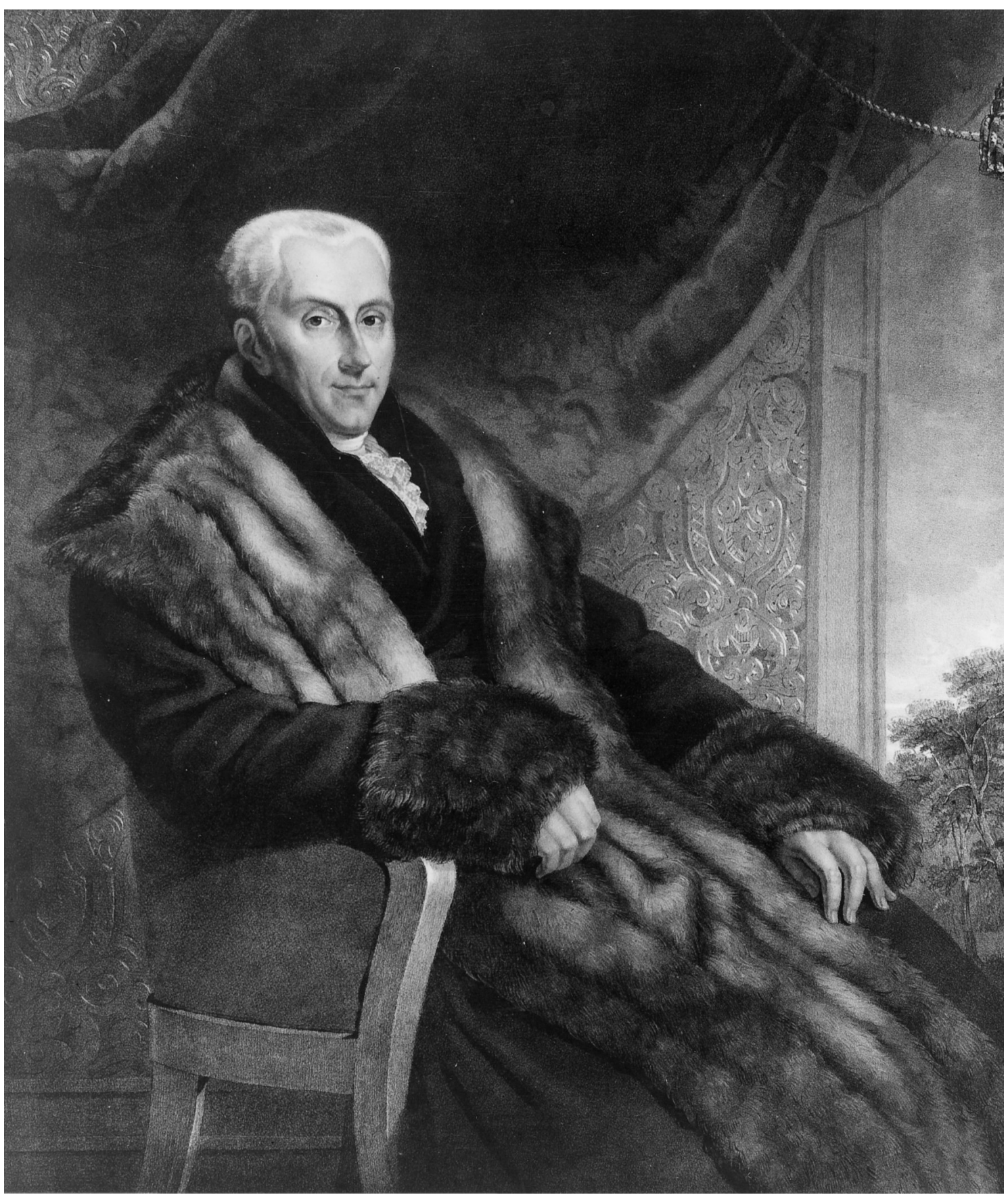

Gijsbert Karel graaf van Hogendorp (1762-1834), lid van het provisioneel algemeen bestuur der Verenigde Nederlanden (1813), minister van Staat.

Litho door J.C. Hamburger naar het schilderij door C. Cels. Collectie en foto RKD/IB, 's-Gravenhage.

voor de adelsverheffing van deze aanzienlijken werd uitgegaan van mannelijke afstammelingen uit geslachten die gedurende ten minste drie generaties zitting hadden in de regering van stemhebbende steden.

Van Hogendorp bezag adeldom en ridderorden in elkaars verlengde en behandelde ze in zijn schets in één bepaling. Omdat de soevereine vorst de onderlinge samen- 
hang volgens zijn commentaar niet begreep, werden beide instituten in de Grondwet van 1814 in afzonderlijke, elkaar opvolgende, artikelen behandeld. ${ }^{110}$ Met betrekking tot de adel voerde Van Hogendorp de in latere grondwetten overgenomen zinsnede op dat de koning in de adelstand verheft. Het onderscheid tussen oude en nieuwe adel vond hij in de titel bij eerstgeboorte (baron) voor de laatste categorie. Een gewaagd plan om naar Engels voorbeeld in elke provincie per honderdduizend inwoners een graaf als pair te verheffen, die automatisch zitting had in de volksvertegenwoordiging, haalde het in latere redacties niet. Van Hogendorp beschreef in zijn geheime gedenkstukken een onderhoud met de vorst waarin hij het voorstel had gedaan om twaalf erfelijke Rijksgraven in de Staten-Generaal te brengen. De vorst had toen duidelijk gemaakt dat hij 'geenen zin in zoo groote heeren' had. ${ }^{111}$ Voorts zou de 'geest der natie' tegen erfelijke ambten zijn, hetgeen duidelijk werd in sommige 'verlichte' commentaren uit onverdachte hoek: 'als een vader een verdienstelijk man is, kan de zoon een gek zijn' (W.K.H. van Lynden van Blitterswijk, vertegenwoordiger in de grondwetscommissie voor Gelderland); en: 'erfelijke titels mogen dienen tot opluistering van een monarchie, maar erfelijke waardigheden kunnen deze ondermijnen' (W.F. Röell). ${ }^{112}$ De regentengeslachten, die met hun nepotisme indirect de revolutie hadden bevorderd, zouden hun invloed in het stedelijk bestuur moeten opgeven ten gunste van de burgerij, die deze was kwijtgeraakt. Ter compensatie zou uit hun gelederen de door uitsterven bedreigde oude adel kunnen worden aangevuld. ${ }^{113}$

Een door Van Hogendorp en een aantal oud-regenten op 18 november 1813 bijeengeroepen overgangsbewind had niet voldoende daadkracht. Twee dagen later richtte hij tezamen met A.F.J.A. van der Duyn van Maasdam een 'Algemeen Bestuur der Vereenigde Nederlanden' op, dat - in afwachting van de komst van de tot overheidsgezag uitgenodigde prins van Oranje - een aantal proclamaties uitvaardigde. Ze benoemden Leopold graaf van Limburg Stirum tot provisioneel gouverneur van Den Haag met het doel een nationale krijgsmacht bijeen te brengen, en J.M. Kemper en C.A. Fannius Scholten tot commissarissen-generaal om de Amsterdamse notabelen tot actie te mobiliseren. In de hoofdstad immers moesten de democratische controle en de bevestiging van de nieuwe staatsvorm hun beslag krijgen. $^{114}$

De prins van Oranje vaardigde bij zijn terugkeer uit Engeland - in Scheveningen op 30 november 1813 - een proclamatie uit die mede ondertekend was door zijn secretaris Hendrik Fagel. Na een afwezigheid van negentien jaar wist hij zich met de verzekering van zijn bondgenoten, van wie hij de koning van Groot-Brittannië expliciet noemde, eenstemmig teruggeroepen om het volk 'in het genot van Uwe

\footnotetext{
${ }^{110}$ Van Zelm van Eldik, Ons grondwetsartikel regelende de instelling van ridderorden, 5-20.

${ }^{111}$ Van Hogendorp, Brieven en gedenkschriften 3, 82.

${ }^{112}$ Van Meeuwen, 'Een en ander over het Nederlandse adelsrecht', 74 (76)-90.

${ }^{113}$ Van Haersolte, Inleiding tot het Nederlandse staatsrecht, 18-23; Van Nifterik, 'De vorst in evenwicht', 190-195.

${ }^{114}$ Van Haersolte, Inleiding tot het Nederlandse staatsrecht, 23.
} 
voorige Onafhankelijkheid en Welvaart te helpen herstellen'. ${ }^{115}$ Bij deze gelegenheid werd hem ook de iets aangepaste 'Schets' van Van Hogendorp aangeboden. De prins ging hiermee, na enkele correcties, akkoord, waarna de ontwikkelingen elkaar in snel tempo opvolgden.

Bij proclamatie d.d. Amsterdam 2 december 1813 aanvaardde prins Willem I - een dag eerder hadden Kemper en Scholten uitdrukkelijk verklaard dat het geen Willem VI zou worden - als vorstelijk staatshoofd met enige schroom het soevereine gezag over de Verenigde Nederlanden, maar alleen onder voorwaarde van een grondwet als waarborg voor de vrijheid van het volk. ${ }^{116}$ Vier dagen later ontbond de vooralsnog absolute monarch het voorlopige bestuur onder dankzegging en decharge, waarna hij zelf het overheidsgezag op zich nam.

Op 21 december 1813 benoemde hij een grondwetscommissie, bestaande uit veertien leden met Van Hogendorp als voorzitter, om de vaststelling van een grondwet op basis van de gemaakte schets voor te bereiden. $\mathrm{Na}$ veel discussie tussen de leden, die verschillende stromingen vertegenwoordigden, ontstond een compromis dat gekenmerkt werd door een aanzienlijke versterking van het centrale gezag: in feite een constitutionele monarchie. Vervolgens moest deze, bij gebrek aan een gekozen volksvertegenwoordiging, democratische legitimiteit krijgen. Aangezien afscheid was genomen van de revolutionaire grondvergaderingen, werd de toevlucht genomen tot een zogenaamde volksvergadering. Deze werd gevormd door het opstellen van een lijst met de min of meer willekeurige namen van zeshonderd 'aanzienlijken'. De aanwezigen op deze 'grote vergadering van notabelen' werden - na tervisielegging, waartegen geen oppositie was gekomen - als representanten van het gehele volk gezien. ${ }^{117} \mathrm{Zij}$ werden door de soevereine vorst op 29 maart 1814 in de Nieuwe kerk te Amsterdam bijeengeroepen en keurden de 'Grondwet voor de Verenigde Nederlanden van 1814' met grote meerderheid goed, waarna deze terstond werd afgekondigd. ${ }^{118}$ In artikel 42 was voor het eerst sprake van doelbewust adelsbeleid: 'De Souvereine Vorst verheft in den adelstand. Al, wie door den Souvereinen Vorst in den adelstand verheven wordt, brengt het bewijs daarvan ter kennis van de Staten zijner Provincie of Landschap en deelt aanstonds in alle de voorregten daaraan verbonden, bijzonderlijk in de bevoegdheid van beschreven te worden in de ridderschap, mits voldoende aan de vereischten voor dezelve bepaald'. Artikel 45, tweede zin, bepaalde voorts: 'Het is geen Nederlander geoorloofd in het vervolg vreemden adeldom aan te nemen'. Artikel 58 garandeerde, dat een kwart van de (55) leden van de Staten-Generaal (één Kamer), uit vertegenwoordigers van de adel zou bestaan. Vanouds was het provinciale bestuur als kiescollege voor een derde deel samengesteld uit leden van de ridderschap, maar

\footnotetext{
115 [Berendse en Brood], In 21 stappen vrij onverveerd, nr. 9 (NA, Archief Staatssecretarie en Kabinet des Konings (AS en KdK) 1813-1840, 2.02.01, inv. nr. 6085).

${ }^{116}$ Vermeulen, Krijnen en Roos, De Koning in het Nederlandse staatsrecht, 19-24.

${ }^{117}$ Van Ette, 'Onze Volksvertegenwoordigers', 81-118 (met naamlijsten).

${ }^{118}$ Van der Pot/Donner, Handboek van het Nederlandse staatsrecht, 135-136; [Berendse en Brood], In 21 stappen vrij onverveerd, nr. 10 (NA, AS en KdK, inv. nr. 6056).
} 
op dat moment waren de ridderschappen nog niet overal op de daarvoor benodigde sterkte gekomen, als ze al niet (her)opgericht moesten worden. ${ }^{119}$

Omdat een adviserende instantie gecreëerd diende te worden die de bewijzen van adeldom op waarde zou kunnen schatten en ook de uitvoering van het adelsbeleid ter hand zou kunnen nemen, benoemde de vorst op 4 mei een commissie. Voorzitter W.A. van Spaen la Lecq rapporteerde al op 19 mei met een concept-instructie voor een in te stellen Collegie van Heraldie. ${ }^{120}$ Bij soeverein besluit van 24 juni 1814, nr. 10, werd dit college onder de titel Hoge Raad van Adel opgericht (art. 1) en een uit dertig artikelen bestaande instructie gearresteerd (art. 2). Wat de samenstelling betreft, werd bepaald dat de Raad zou bestaan uit een president, vier raadsleden en een secretaris (art. I); dat minimaal de president en twee raadsleden tot de Nederlandse adel zouden moeten behoren (art. II); en dat van de gehele Raad, inclusief president, tenminste twee gegradueerde juristen deel zouden moeten uitmaken (art. III). Allen dienden 'inboorlingen der Vereenigde Nederlanden' te zijn en de secretaris tevens aldaar geboren. ${ }^{121}$ Voorwaarden waren daarnaast een minimumleeftijd van 25 jaar en geen nadere onderlinge bloedverwantschap dan in de vierde graad (artt. IV en V). Bij hetzelfde besluit vonden concrete benoemingen alsmede vaststelling van het jaarsalaris plaats. Voorzitter van de adviescommissie W.A. van Spaen la Lecq werd benoemd als president met een jaarwedde van vijfduizend gulden. Als leden werden M.L. d'Yvoy, A.C. Snouckaert van Schauburg en mr. R. Metelerkamp benoemd met een jaarwedde van het halve bedrag van de voorzitter, dat ook aan mr. J. van der Lely van Oudewater als secretaris werd vergund. ${ }^{122}$ Twee weken later werd nog mr. H. van Wijn, 'archivarius van het Rijk', als honorair lid aan de Raad toegevoegd. ${ }^{123}$

Naast de beschrijving van alle zaken, adelsaangelegenheden betreffende, zijn in de instructie ook een aantal bepalingen opgenomen betreffende hofceremonieën. In artikel XXVII werd de Raad belast met de vaststelling van de orde die bij alle publieke ceremonieën in acht moest worden genomen en kreeg hij tevens opdracht deze, op aanschrijven van de vorst, te regelen. Ook de ontwerpen voor het grootzegel zouden door de Raad, vanuit diens heraldische opdracht, moeten worden voorgedragen (art. XV). De dubbelfunctie die enkele leden van de Raad hadden als hofdignitaris, bleek een goede aanzet voor het opzetten van een hofcultuur, die de constitutionele monarchie zou moeten gaan ondersteunen. ${ }^{124}$ Nadat een maand la-

\footnotetext{
${ }^{119}$ In Zeeland bij KB van 25 juni 1816, nr. 70, en in Friesland bij KB van 23 dec. 1825, nr. 122.

${ }^{120}$ Willem Anne baron van Spaen (1750-1817), heer van Ringenberg (bij Wesel) en Harde(n)stein (Dortmund) noemde zich na zijn nobilitatie, ter onderscheiding van andere takken, Van Spaen la Lecq (zijn moeder was een gravin Van Nassau la Lecq, afstammelinge van prins Maurits). Vgl. Nederland's Adelsboek 93 (2008), 445-462.

${ }^{121}$ In de Grondwet van 1815, art. 8, lid 2, werden de kinderen van geboren Nederlanders of inboorlingen, die in het buitenland waren geboren, met inboorlingen gelijkgesteld. Vgl. Heijs, Van vreemdeling tot Nederlander, 15-20.

${ }^{122}$ HRvA, RA, inv. nr. 1 (not. 1814-1). [Beelaerts van Blokland e.a.], De Hoge Raad van Adel, 171-175 (bijlage IIIB).

${ }^{123}$ Bij Soeverein Besluit (SB) van 8 juli 1814, nr.197 (HRvA, RA, inv. nr. 1, not. 1814-2).

${ }^{124}$ HRvA, RA, inv. nr. 890 (commissies tot samenstelling van een etiquette voor het paleis, 1814-1815). Dit betrof met name het lid A.C. Snouckaert van Schauburg, die hoge betrekkingen aan het hof vervulde, maar ook de secretaris J. van der Lely van Oudewater, die regelmatig op voordracht van Snouckaert als koning
} 
ter de beëdiging ten overstaan van de vorst volgens artikel XXIX had plaatsgevonden, kon de Raad aan zijn taak beginnen. De maand augustus werd gevuld met het inventariseren van de nog in leven zijnde edelen die vóór 1795 namens de ridderschappen op de landdagen zitting hadden. Daartoe werden de gouverneurs van de provincies aangeschreven, maar ook eigen lijsten opgesteld, waarbij ook buiten een ridderschap gebleven (veelal rooms-katholieke) geslachten werden betrokken. Uiteindelijk tekende de soevereine vorst op 28 augustus 1814 een verzamelbesluit waarbij de leden van de ridderschappen van Gelderland, Holland, Utrecht, Overijssel, Groningen, Brabant en Drenthe werden benoemd. ${ }^{125}$ Omdat in Zeeland en Friesland (nog) geen ridderschappen bestonden, werden daar edelen benoemd om hun stand in het provinciaal bestuur te kunnen vertegenwoordigen.

Behalve bovengenoemde ridderschapsbenoemingen is uit 1814 maar één adelsbesluit bekend. Dit betreft de bevestiging bij Soeverein Besluit van 5 september 1814 van de titel baron op verzoek van J.F.W. van Spaen van Biljoen voor alle leden van diens geslacht, onder wie de eerste president van de Hoge Raad van Adel, W.A. van Spaen la Lecq, die uit een jongere tak van de familie was gesproten. ${ }^{126}$ Verscheidene leden van het adellijke geslacht Van Spaen waren zowel onder Lodewijk Napoleon als onder Willem I het eerste aanspreekpunt voor adelszaken; de titelhomologatie (bevestiging van buitenlandse titulatuur) kan niet los gezien worden van deze bijzondere relatie. ${ }^{127}$

Op 'voordragt van president Van Spaen' deed de Hoge Raad van Adel op 12 oktober 1814 een uitvoerig pleidooi bij de soevereine vorst, voor toewijzing van alle voorrechten die de adel krachtens art. 42 van de nieuwe grondwet zou toekomen. Allereerst zag de Raad ter onderscheiding van de burgerstand de adel als 's lands eerste stand, die vanouds voorrechten kende. Daarbij werd de kanttekening gemaakt dat de oprichting van de nieuwe adelstand, waarvoor erkenning door de vorst noodzakelijk was, niet betekende dat de adellijke afkomst niet bestaan had of verloren was gegaan. Daarna werden de drie vormen van verlening aangegeven: erkenning, inlijving en creatie. Vervolgens gaf de Raad een opsomming van maar liefst tien voorrechten die voor bescherming in aanmerking zouden komen. Het advies werd afgesloten met een vijftiental punten waaraan de reglementen van de ridderschappen zouden moeten voldoen. ${ }^{128}$

Bij Soeverein Besluit van 13 februari 1815, nr. 60 (Stb. 15), kwam een regeling tot stand waarin de voorwaarden en voorrechten van de adelstand werden opgesomd. Lang niet alle voorrechten die de Raad had aanbevolen, stonden daarin vermeld,

\footnotetext{
van wapenen optrad (HRvA, RA, inv. nr. 892). De officiële opdracht aan de HRvA om een etiquette voor het paleis te ontwerpen en de aanstelling van een ceremoniemeester vond plaats bij Kon. Disp. van 15 nov. 1814, nr. 40 (HRvA, RA, inv. nr. 1 (not. 1814-145). Anders dan bij KB was voor het afgeven van een koninklijke dispositie geen contraseign van een minister noodzakelijk.

${ }^{125}$ SB van 28 aug. 1814, nr. 14 (HRvA, RA, inv. nr. 1, not. 1814-36).

${ }^{126}$ Van Valkenburg, 'Adelsbeleid sedert 1813', 55-57; HRvA, RA inv. nr. 1 (not. 1814-29).

127 Aalbers, 'Willem Anne van Spaen', 104-128. Als koning Lodewijk Napoleon niet binnen een jaar was teruggeroepen, had hij volgens een bewaard gebleven concept-besluit W.A. van Spaen de titel 'Graaf van Nijkerk' verleend (HRvA, FA. Van Spaen, inv. nrs. 312 en 325).

${ }^{128}$ HRvA, RA, inv. nr. 2 (not. 1814-49).
} 
maar wel de belangrijkste. Artikel 1 bepaalde dat tot de adel zouden worden gerekend zij die tot het inwerkingtreden van de reglementen op de ridderschappen door de soevereine vorst daarin waren of zouden worden benoemd, alsmede allen die door de soevereine vorst werden erkend, ingelijfd of verheven in de adel; adeldom ging over op wettige afstammelingen. Artikel 2 behandelde het (voor)recht, dat in alle publieke en particuliere documenten voor de adel het predikaat Jonkheer zou worden gebezigd, voorzover geen titel was toegekend. Dit werd gevolgd door artikel 3, waarin de bevoegdheid tot het openlijk mogen voeren en gebruiken van een erkend adellijk wapen werd beschreven. Ten slotte stond in artikel 4 het recht van jacht beschreven, waartoe een edelman in zijn provincie onvoorwaardelijk was gekwalificeerd. ${ }^{129}$ Niet gehonoreerd werden voorstellen om uitsluitend voor een gerechtshof terecht te hoeven staan en om in landstorm of burgerwachten exclusief de officiersrang te bekleden. Ook de adellijke eed ('Ik zweer op adellijk woord en trouw dat ik, etc.') en de aanschrijftitel voor een adellijke advocaat ('Heer en meester') sneuvelden.

Voor het eerst werd in een algemeen geldende regeling het onderscheid tussen erkende (oude inheemse), ingelijfde (Nederlanders met buitenlanders adeldom) en verheven (inclusief benoemde) adel opgenomen. Ten aanzien van de laatste groep was in de haast waarmee het adelsbeleid vorm had gekregen een onvolkomenheid ingeslopen, die bij soeverein besluit van dezelfde datum, nr. 61, werd gecorrigeerd. Aan de ridderschappen werd hierbij opgedragen om hun reglementen zodanig aan te passen, dat uitdrukkelijk zou worden vermeld dat niemand in een ridderschap of verband van provinciale edelen beschreven kon worden, aan wie niet tevoren door de vorst adeldom was verleend. ${ }^{130}$ Een enkele keer was de praktijk andersom geweest, waarbij zelfs titulatuur was verleend, die de benoemde nimmer had gevoerd. Laatstgenoemde onregelmatigheid werd later bij koninklijk besluit hersteld, waarbij deze titels als persoonlijk en dus niet erfelijk werden verklaard. ${ }^{131}$ Overigens kregen alle voordien benoemden nog een zogenaamde akte van bewijs uitgereikt om de registratie op orde te brengen. Hiermee werd tevens discussie voorkomen welke vorm van adeldom door deze benoeming in een ridderschap was gecreeerd. Edelen die afstamming uit riddermatige geslachten, dat wilde zeggen adeldom van vóór 1579, konden bewijzen werden (voorlopig) vrijgesteld van het in ontvangst nemen ('lichten') van een adelsdiploma. ${ }^{132}$

\section{Vereniging met België in een Koninkrijk der Nederlanden}

De Grondwet van 1814, die voorzag in één nationale volksvertegenwoordiging van 55, door de Staten der provinciën volgens hun oude juridische samenstelling be-

\footnotetext{
${ }^{129}$ HRvA, RA, inv. nr. 3 (not. 1815-63); [Beelaerts van Blokland e.a.], De Hoge Raad van Adel, 185-186 (bijlage IIIC); www.overheid.nl (wetten, besluiten, etc.).

${ }^{130}$ HRvA, RA, inv. nr. 3 (not. 1815-66).

${ }^{131} \mathrm{~KB}$ van 21 maart 1823, nr. 95 (HRvA, RA, inv. nr. 447 en 449).

${ }^{132} \mathrm{SB}$ van 4 maart 1815, nr. 85 (HRvA,RA, inv. nrs. 3 (not. 1815-154), 281 (f. 7) en 447).
} 
noemde, leden, is ruim een jaar van kracht gebleven. De internationale politieke ontwikkelingen - Napoleon was na zijn ontsnapping vanaf Elba opnieuw tot keizer der Fransen uitgeroepen - noopten de geallieerden een sterke staat aan de noordzijde van Frankrijk te vormen. Hierdoor kwam een vereniging van de Noordelijke Nederlanden met de voormalige Oostenrijkse Zuidelijke Nederlanden ('Provinces belgiques') tot stand in een nieuw Koninkrijk der Nederlanden met de prins van Oranje-Nassau als soeverein. Het Congres van Wenen zou laatstgenoemde als schadevergoeding voor het verlies van zijn Duitse vorstendommen ook Luxemburg toewijzen. Dit betrof louter een personele unie, want in militair opzicht bleef het groothertogdom deel uitmaken van de Duitse Bond. ${ }^{133}$

Bij decreet d.d. 's-Gravenhage 4 maart 1815, vaardigde de soevereine vorst organisatorische maatregelen uit 'voornemens zijnde om eerlang, ten gevolge der Vereeniging van al de Nederlanden onder Ons Souverein Gezag, de Koninklijke waardigheid en tijtel aan te nemen'. Zo diende een plechtige vergadering van de StatenGeneraal te worden belegd waarin de aanvaarding van het gezag met de nieuwe titels (inclusief die van de kroonprins) geproclameerd zouden moeten worden (artt. 1-3). De afkondiging van het gevestigde koningschap op de belangrijkste pleinen van de residentie zou geschieden door een wapenkoning en twee herauten, die onder een cavalerie-escorte van het paleis zouden afrijden (art. 4). De commissarisgeneraal van oorlog kon reeds dadelijk orders doen uitgaan om herwaarts te komen (art. 5). Op oorlogsschepen zouden de officieren hun eed van trouw dienen te vernieuwen, waarna de onderofficieren en minderen driemaal 'Leve de Koning!' zouden uitroepen, waarvan het proces-verbaal aan het Departement van Marine moest worden gezonden (art. 6). Tijdens de optocht zou van de torens gevlagd dienen te worden en de klokken regelmatig geluid. Wapenkoning en herauten moesten een dag later de afkondiging in de hoofdstad op dezelfde wijze vormgeven (art. 7). ${ }^{134}$

Nog vóór het Wener Congres der Europese mogendheden was afgerond, aanvaardde bij proclamatie van 16 maart 1815, nr. 1 (Stb. 27), (vanaf dat moment: Koning) Willem I tijdens een plechtige bijeenkomst in de Ridderzaal de soevereiniteit over België in een verenigd Koninkrijk der Nederlanden. ${ }^{135}$ Bij dezelfde gelegenheid stelde de koning de aan zijn geslacht verbonden erfelijke titel prins van Oranje veilig door deze voortaan aan de kroonprins toe te kennen. ${ }^{136}$ De bij koninklijk besluit gedane proclamatie van de titulatuur van hemzelf en zijn oudste zoon werd twee maanden later nog bij koninklijke dispositie aangevuld met de titel groothertog van Luxemburg, eveneens - zoals hiervoor aangegeven - op basis van afspraken tijdens het Congres te Wenen. ${ }^{137}$

\footnotetext{
${ }^{133}$ In 1866 werd deze band verbroken, terwijl Luxemburg na het overlijden van koning Willem III in 1890 langs mannelijke lijn vererfde naar de tak Nassau-Weilburg.

${ }^{134}$ HRvA, RA, inv. nr. 3 (not. 1815-82); [Beelaerts van Blokland e.a.], De Hoge Raad van Adel, 175-177 (bijlage IIIB).

${ }^{135}$ De Wet van 23 maart 1815 (Stb. 29), gearresteerd bij KB van 23 maart 1815, nr. 167, is een verklaring van de noodzakelijkheid om na de aanvaarding van de koninklijke waardigheid de grondwet aan te passen. De gewijzigde soevereiniteit werd bevestigd bij akte van het Weense Congres van 9 juni 1815, art. 65 (geciteerd in: Hirsch Ballin, De Koning, 17-20).

${ }^{136}$ HRvA, RA, inv. nr. 3 (not. 1815-112); Van Haersolte, Inleiding tot het Nederlandse staatsrecht, 26.

${ }^{137}$ Kon. Disp. van 12 mei 1815, nr. 701 (HRvA, RA, inv. nr. 4, not. 1815-201).
} 
In zijn 'Schets' had Van Hogendorp al een voorschot genomen op de aanspreektitulatuur voor de leden van het huis van de soevereine vorst uit het geslacht Van Oranje-Nassau. In artikel 11 werd de optie genoemd om voor hen het predikaat doorluchtige hoogheid te regelen bij wet, maar de grondwetscommissie van 1813 vond dit toen niet gewenst. Naar aanleiding van het gearrangeerde huwelijk van de erfprins met prinses Charlotte van Groot-Brittannië had de soevereine vorst in de grondwet van 1814 toch weten te bewerkstelligen dat zijn zoon het predikaat koninklijke hoogheid zou krijgen (art. 17). Deze kon immers geen mindere titel voeren dan de hem toegedachte echtgenote. ${ }^{138}$ Inmiddels was door de stichting van het koninkrijk de opneming van dit predikaat overbodig geworden. ${ }^{139}$

Opnieuw werd een grondwetcommissie, per 22 april onder voorzitterschap van Gijsbert Karel van Hogendorp en bestaande uit een even grote Belgische vertegenwoordiging, ingesteld om de Grondwet van 1814 aan te passen aan de nieuwe situatie. Nadat de koning als Zuid-Nederlandse ministers de graaf De Thiennes en de hertog Van Ursel in zijn kabinet had opgenomen, ontstond enige discussie binnen de grondwetcommissie over adellijke titelverlening. Van Hogendorp was voorstander van titulatuur bij eerstgeboorte in navolging van het edict van aartshertog Albrecht (1616), dat door keizerin Maria Theresia was vernieuwd (1754). ${ }^{140}$ De Hoge Raad van Adel dacht in de nieuwe constellatie voornamelijk aan het inlijven van zogenaamde briefadel, dat wil zeggen op grond van buitenlandse adelsdiploma's. De koning daarentegen wilde naast de oude inheemse adel als tegenwicht voor de Zuid-Nederlandse adel patricische families 'verheffen' en gelastte dit laatste woord in de conceptgrondwet op te nemen. Van Hogendorp werd door hem gevraagd een lijst met oude families samen te stellen, die voor verheffing in aanmerking zouden komen. Uiteindelijk slaagde hij erin een veertigtal (hoofden) van families te benaderen, die soms met enige tegenzin instemden met verheffing in de Nederlandse adel. ${ }^{141}$

$\mathrm{Na}$ een kleine drie maanden vergaderen werd de 'Grondwet voor het Koninkrijk der Nederlanden van 1815' door de in 1814 ingestelde Staten-Generaal met algemene stemmen aangenomen. In België, waar nog geen volksvertegenwoordiging bestond, werd naar Nederlands voorbeeld de toevlucht genomen tot de benoeming van 1604 notabelen. België telde meer inwoners dan Nederland en opteerde voor samenroepen per arrondissement. De stemming verliep minder vlekkeloos dan een jaar eerder in het noorden, mogelijk mede onder invloed van de verminderde dreiging nu Napoleon op 18 juni definitief bij Waterloo was verslagen. Een zesde van de opgeroepenen was niet verschenen, een deel van de uitgebrachte stemmen was ongeldig, en ... een beduidende meerderheid had tegen gestemd. Vooral de gelijke

\footnotetext{
${ }^{138}$ Van Ditzhuyzen, Oranje-Nassau. Een biografisch woordenboek, 242-244 (met literatuuropgave).

${ }^{139}$ Beelaerts van Blokland, 'Titulatuur, standaarden en wapens van het Koninklijk Huis', 108-111. Hij toont aan dat de stadhouders doorgaans met excellentie werden aangesproken, maar dat prins Frederik Hendrik op (politiek) initiatief van koning Lodewijk XIII van Frankrijk op 3 jan. 1637 de titel hoogheid door de Staten-Generaal bevestigd kreeg.

${ }^{140}$ In feite had Philips II, koning van Spanje, in 1595 het eerste groot adelsedict uitgevaardigd, waarop de latere aangepast waren gebaseerd (Janssens, De evolutie van de Belgische adel, 123-125 en 331).

${ }^{141}$ Van Hogendorp, Brieven en gedenkschriften 3, 130-131.
} 


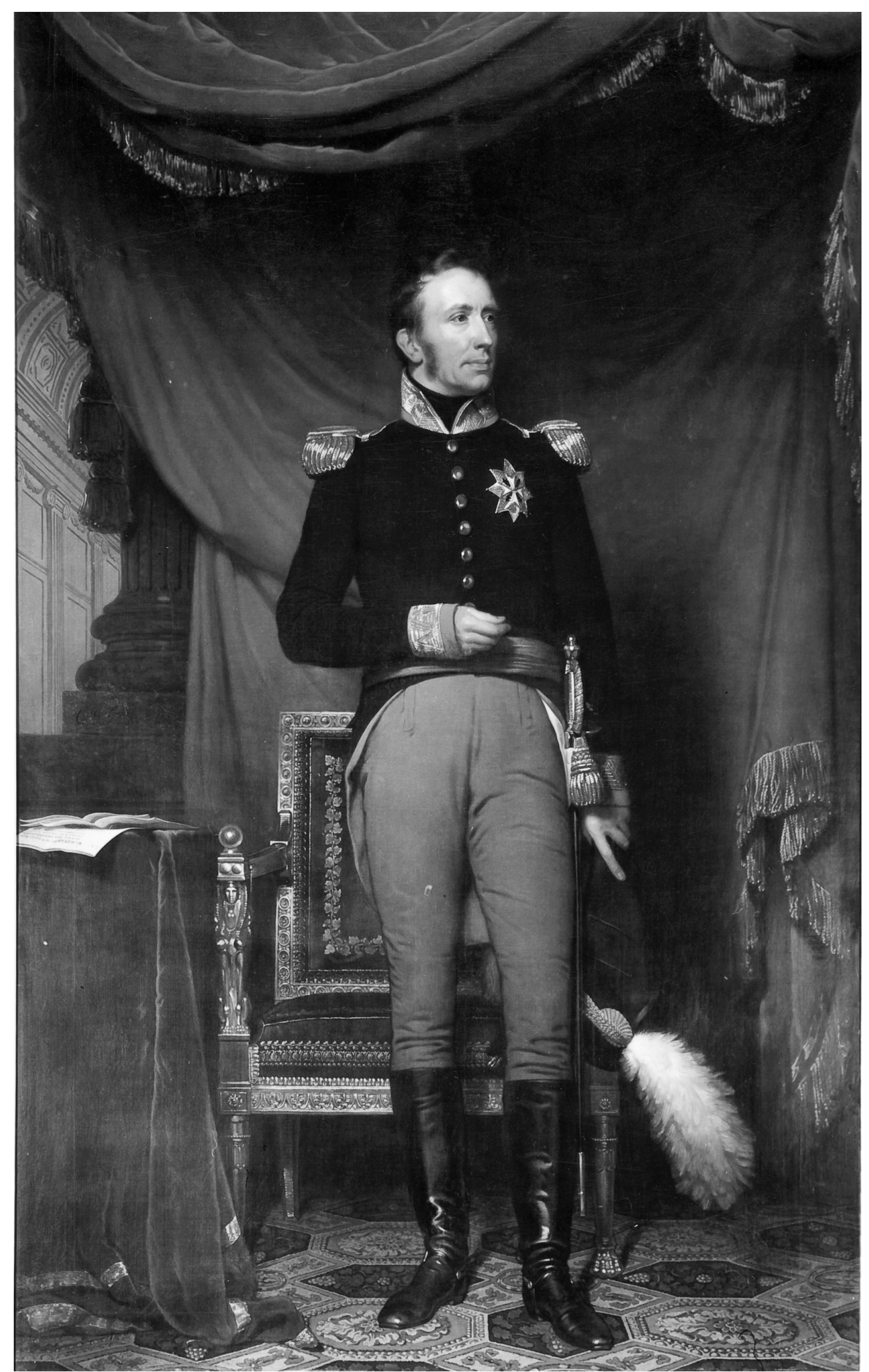

Willem I (1772-1843), soeverein vorst der Verenigde Nederlanden (1813), koning der Nederlanden 1815-1840, groothertog van Luxemburg 1815-1840.

Doek, 230 x $146 \mathrm{~cm}$, door Charles H. Hodges, 1816. Collectie Amsterdam Museum (Tweede Kamer der Staten-Generaal, 's-Gravenhage). Foto RKD/IB, 's-Gravenhage. 

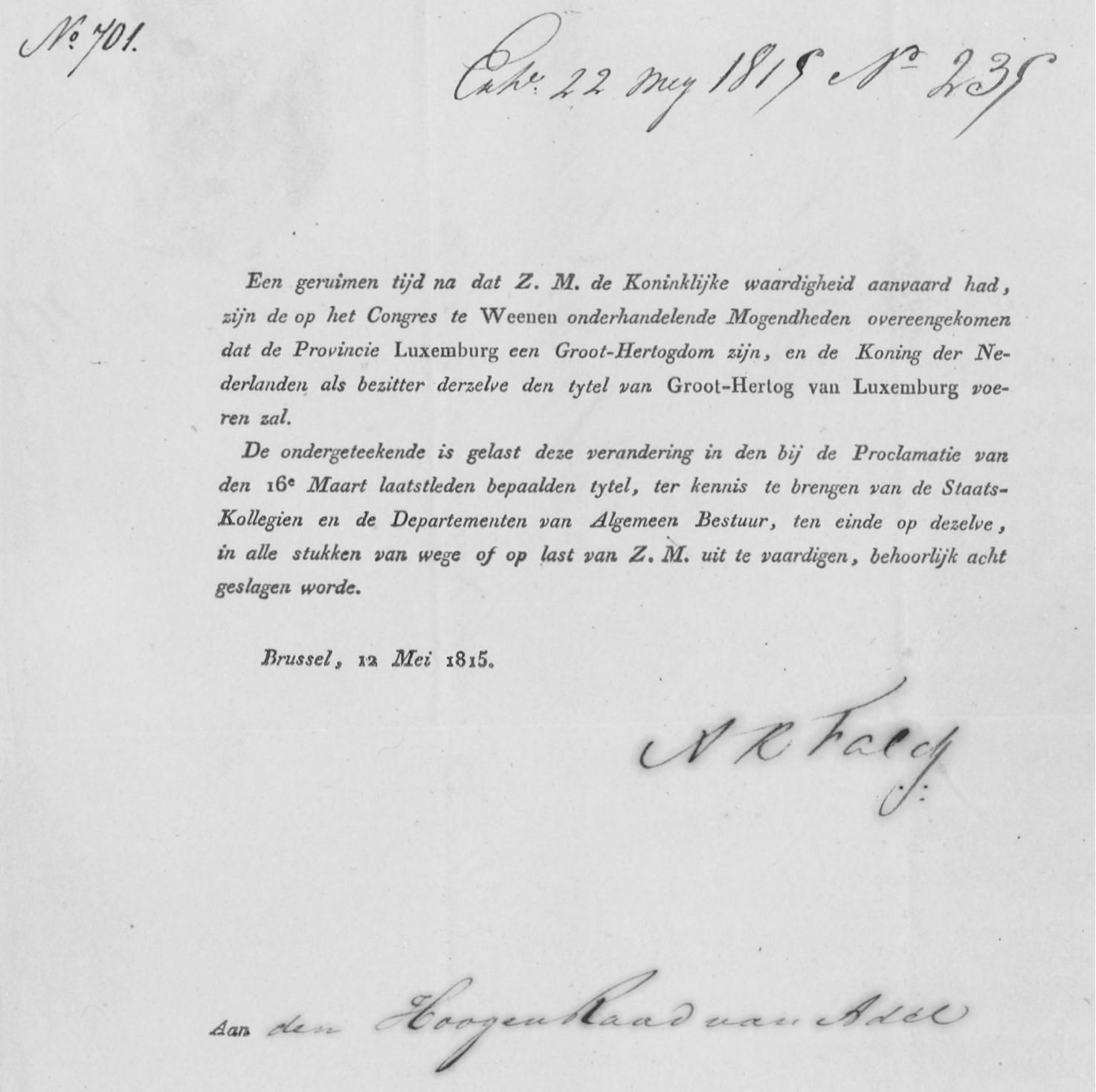

Aankondiging van de Koninklijke Dispositie van 12 mei 1815, inhoudende proclamatie van de titel groothertog van Luxemburg.

HRvA, RA, inv. nr. 4 (1815-201).

rechten voor alle godsdiensten, een van de acht door de geallieerden voorgeschreven algemene beginselen voor vereniging van beide landen, was een belangrijke reden voor afkeuring geweest. Aangezien de nieuwe constellatie weinig keuzemogelijkheden overliet, werd tot een manipulatie van stemmen besloten: de afwezigen (een zesde deel) en de 126 tegenstemmers om geloofsredenen werden geacht vóór gestemd te hebben. ${ }^{142}$ Tezamen met de unanieme aanvaarding door het noorden werd de nieuwe grondwet op 24 augustus 1815 verklaard te zijn aangenomen overeenkomstig 'de gevoelens van de grote meerderheid der gezamenlijke onder-

\footnotetext{
${ }^{142}$ Van der Pot/Donner, Handboek van het Nederlandse staatsrecht, $8^{\mathrm{e}}$ druk (1968), 120-126, uitvoeriger dan de $15^{\mathrm{e}}$ druk (2006).
} 
danen', reeds uitgaande van de nieuwe situatie waarover juist beslist werd. ${ }^{143}$ Hier werd, achteraf gezien, al de kiem gelegd voor de mislukte fusie die vijftien jaar later weer tot ontbinding zou komen. De Zuid-Nederlandse onvrede werd nog versterkt doordat de koning in volgende jaren algemene reglementen voor protestantse kerken ging vaststellen alsof hij de oude staatskerk nieuw leven in wilde blazen. Dit dreef de rooms-katholieken automatisch in de oppositie. Op 21 september 1815 vond op de Place Royale te Brussel de inhuldiging van de nieuwe koning plaats.

De Grondwet van 1815 kende voor het eerst een volksvertegenwoordiging die uit twee afzonderlijke Kamers bestond: een Eerste Kamer van aanzienlijken, die voor het leven door de koning werden benoemd, en een Tweede Kamer, gelijk aan die uit 1814 maar dan met het dubbele aantal leden. De nieuwe grondwet was uitvoeriger in zijn formuleringen, zodat hierin uitdrukkelijk werd bepaald dat de Staten der provinciën zouden gekozen worden door de drie standen: edelen of ridderschappen, steden en de landelijke stand. Het aantal provincies werd verdubbeld tot achttien, evenveel uit beide delen, ondanks een verschillende bevolkingsdichtheid. Op instigatie van België zou de Eerste Kamer, naar voorbeeld van het Britse Hogerhuis, samengesteld moeten worden uit hoge erfelijke adel, maar daarvoor was in het noorden de sociale basis niet in voldoende mate aanwezig. Uiteindelijk werd besloten, dat de koning 40 à 60 niet-erfelijke leden zou benoemen. ${ }^{144}$

De erfelijke adel was in het koninkrijk dus alleen via de ridderschappen verzekerd van een belangrijke plaats in het provinciaal bestuur en daarmee indirect in de Tweede Kamer. Niettemin was de koning vrij ook leden van de Nederlandse adel onder de aanzienlijken in de Eerste Kamer te benoemen zonder dat zij een erfelijk recht op deze zetels hadden. De ridderschappen maakten, anders dan vóór 1795, geen deel meer uit van een soevereine standenvergadering, maar fungeerden staatsrechtelijk nog alleen als kiescolleges voor provinciale staten. De bevoorrechte positie van de adel gold niet meer ten aanzien van de directe verkiesbaarheid, zoals deze in het ancien regime bestond voor het gewestelijk bestuur. Bij het opstellen van hun reglementen mochten ridderschappen geen zaken van algemeen bestuur meer tot onderwerp van hun vergadering maken. ${ }^{145}$ Over het toelatingsbeleid van de afzonderlijke ridderschappen, die hun eigen reglementen bleven houden maar hun geschillen aan de Hoge Raad van Adel moesten voorleggen, ontstond nog een uitvoerige discussie tussen de vorst en laatstgenoemd college. De conclusie werd dat de grondwetsartikelen, zowel in 1814 als in 1815, toestonden dat in de adelstand opgenomen personen in beginsel recht hadden op zitting in de ridderschappen. In de meeste reglementen waren echter uitsluitingsgronden, zoals curatele of vreemde (krijgs)dienst opgenomen en konden eisen worden gesteld aan de mate van gegoedheid. Richtinggevend bleef het SB van 13 februari 1815, nr.

\footnotetext{
${ }^{143}$ [Berendse en Brood], In 21 stappen vrij onverveerd, nr. 11 (NA, AS en KdK, inv. nr. 134).

${ }^{144}$ Van Haersolte, Inleiding tot het Nederlandse staatsrecht, 26-28.

${ }^{145}$ Aalbers, 'Van riddermatige naar koninklijke adel', 49-69.
} 
61, waarin onder meer werd bepaald dat bloedverwantschap geen belemmering voor lidmaatschap mocht zijn. ${ }^{146}$

Het adelsbeleid van de nieuwe koning ving officieel aan met de beloning van diegenen die zich hadden onderscheiden bij gelegenheid van de herwonnen onafhankelijkheid, te beginnen met de leden van het driemanschap. Zowel Van Hogendorp als Van der Duyn van Maasdam, die beiden reeds eerder in de Ridderschap van Holland waren benoemd, ontvingen de titel van graaf bij eerstgeboorte. ${ }^{147}$ Graaf Van Limburg Stirum werd bij zijn benoeming in de ridderschap al erkend met de vanouds aan dit geslacht competerende graventitel op allen.

In de periode tussen de afkondiging van het koningschap in Den Haag en Amsterdam en de inhuldiging in Brussel verleende de koning al twee bijzondere titels, die in navolging van het Napoleontische adelsrecht verbonden waren aan territoria of majoraten, waaraan jaarinkomens waren verbonden. Het betrof twee helden van de Slag bij Waterloo, die als veldheer en diplomaat mede de basis hadden gelegd voor de hereniging van de Nederlanden. Aan generaal Arthur Wellesley, duke of Wellington, enz., enz., verleende de koning de titel prins van Waterlo(o) bij recht van eerstgeboorte met het predikaat doorluchtigheid. Hieraan werd een schenking van vast goed verbonden met een jaarlijkse opbrengst van 20.000 gulden. De Engelse ambassadeur in Den Haag Richard Le Poer Trench, earl of Clancarty, enz., enz., kreeg op dezelfde datum de titel van markies (Marquis) van Heusden bij eerstgeboorte verleend met het predikaat hooggeboren. Het er met goedkeuring van de Staten-Generaal aan verbonden vast goed zou jaarlijks 10.000 gulden moeten opbrengen. ${ }^{148}$ Deze adelsverleningen waren uitzonderlijk vanwege vorm, ranghoogte en financiële ondersteuning. Ze lijken een experiment van de jonge koning naar voorbeeld van adelsverleningen tijdens het Koninkrijk Holland te zijn geweest. Adelsverleningen in deze orde van grootte hebben daarna niet meer plaatsgevonden. Door Napoleon verheven Nederlanders, die in het gunstigste geval erfelijke titulatuur hadden verkregen, werden onder de soevereine vorst niet erkend en konden evenmin ingelijfd worden, omdat het Franse adelsstatuut te zeer afweek van het voor Nederland ontworpen stelsel. Zo erkende Napoleon alleen titels die door hemzelf waren verleend, waarmee het reciprociteitsbeginsel, het door Nederland onderschreven stelsel van wederkerigheid, in het gedrang kwam.

\footnotetext{
${ }^{146}$ HRvA, RA, inv. nr. 3 (not. 1815-66). Ruijs de Beerenbrouck, 'Uit de geschiedenis van de Hoge Raad van Adel', 98-103.

${ }^{147} \mathrm{~KB}$ van 16 sept. 1815, nr. 66 (HRvA, RA, inv. nr. 6, not. 1815-390): met anderen 'wegens verdiensten aan het vaderland bewezen' t.g.v. de vestiging van het Koninklijk gezag en de inhuldiging.

${ }^{148}$ HRvA, RA, inv. nr. 5 (not. 1815, nrs. 284 en 300): KB's van 8 juli 1815, nrs. 13 (Wellington) en 14 (Clancarty). Vgl. De Hoge Raad van Adel, 57-58. De aan de titel prins van Waterloo verbonden dotatie, bestaande uit drie partijen domaniale bossen ter grootte van in totaal 1083 hectare of 1270 morgen, gelegen tussen Nivelles (Nijvel) en de Quatre Bras aan beide zijden van de weg van Nivelles naar Namen, werd bij Wet van 29 sept. 1815, nr. 50 (Stb. 48) vastgesteld. De dotatie of het majoraat behorende bij de titel markies van Heusden werd volgens het koninklijk besluit eveneens voorgedragen om bij wet door de StatenGeneraal vast te stellen, maar deze wet is nooit uitgevaardigd. De Franse adellijke titel markies is zeldzaam in het koninkrijk en is synoniem met de Duitse adellijke titel markgraaf. De stadhouders prins Willem IV en $\mathrm{V}$ werden ingehuldigd als markgraaf van Veere, terwijl de titel markiezin van Veere thans nog valt onder het 'enz. enz. enz.' van koningin Beatrix. Vgl. ook Schutte, 'Hoge Raad van Adel 1968-2003', 206.
} 
Het adelsbeleid tijdens het koninkrijk zou echter openbaren dat in specifieke gevallen titelhomologatie analoog aan Napoleontische titelverlening had plaatsgevonden zonder overtuigende juridische argumentatie. De koning kon immers volgens de grondwet verheffen in de adelstand en bij vermeerdering overeenkomstig de ranghiërarchie de laagste daaropvolgende titel verlenen, maar het was ongebruikelijk daarbij tussenliggende titelrangen over te slaan. Schutte geeft een cumulatieve lijst van verzoeken op grond van een Napoleontische titel die resulteerden in verheffing en verlening van een overeenkomstige titel. ${ }^{149}$

Bij de grondwetsherziening van 1815 werd een door een meerderheid ondersteund voorstel van een van de Belgische commissieleden om in navolging van het leenrecht 'majoraten' in te stellen die de luister der adellijke geslachten zouden kunnen waarborgen, uiteindelijk niet overgenomen. C.F. van Maanen bestreed het idee succesvol met als argument dat de lenen van de adel de laatste twee eeuwen de facto als allodiaal werden behandeld. ${ }^{150}$

In de eerste jaren van het koningschap van Willem I kreeg het adelsbeleid nader vorm door het uitvaardigen van specifieke koninklijke besluiten waarin allerlei zaken nader werden geregeld. Dit betrof onder andere de vorm en inhoud van de diploma's, de te betalen taxa en leges gespecificeerd naar titel, de termijn en wijze van 'lichten', reciprociteit (wederkerigheid) ten opzichte van het adelbeleid van het Verenigd Koninkrijk (Groot-Brittannië), de hiërarchie in rangkronen, de overgang van titels, te publiceren adelslijsten en titulatuur op officiële documenten. ${ }^{151}$

Bij KB van 26 maart 1815, nr. 24, vroeg de koning aan de Hoge Raad van Adel advies over het instellen van een militaire en een civiele ridderorde. ${ }^{152}$ In het bijzonder kweet voorzitter W.A. baron van Spaen la Lecq zich van deze taak, die hij ook onder koning Lodewijk Napoleon had vervuld. Adviezen, al of niet naar de zin van de vorst, werden uitgebracht en resulteerden betrekkelijk snel in de instelling van een Militaire Willems-Orde en later in het jaar van de (civiele) Orde van de Nederlandsche Leeuw. ${ }^{153}$ Van Zelm van Eldik heeft aangetoond dat Van Spaen voor de statuten van de Militaire Willems-Orde vooral de Maria Theresia-Orde (1758) als voorbeeld gebruikte en in mindere mate de statuten van de 'Ordre Militaire de Louis' (Militaire Lodewijks-Orde), waaraan hij in 1809 had bijgedragen. $^{154}$

\footnotetext{
${ }^{149}$ Schutte, 'Het beleid tijdens het Koninkrijk der Nederlanden ten aanzien van de door Napoleon verleende titels', 310-322. Eén van de meest in het oog springende verheffingen met hoge titelverlening is die van Gerrit graaf Schimmelpenninck in 1834, zoon van de Napoleontische raadpensionaris graaf (1808) Rutger Jan. Zij stamden uit een bastaardtak van het oude adellijke geslacht Schimmelpenninck van der Oije, dat in 1820 de titel baron op allen kreeg erkend en zo door deze uit zijn familie voortgekomen onwettige tak in adellijke hiërarchie werd gepasseerd. Vgl. [Nijkamp en Schutte], De Nederlandse Adel, 194-195.

${ }^{150}$ Van Meeuwen, 'Een en ander over het Nederlandse adelsrecht', 77.

${ }^{151}$ Zie de bijlage Wetten, Besluiten, etc. [Beelaerts van Blokland e.a.], De Hoge Raad van Adel, 185-196 (bijlagen IIIC). Vgl. Van Meeuwen, 'Een en ander over het Nederlandse adelsrecht, 78-82.

${ }^{152}$ HRvA, RA, inv. nrs. 3 (not. 1815-122, 128, 135 en 141) en 6 (not. 1815-411, 421 en 438).

${ }^{153} \mathrm{~KB}$ van 30 april 1815, nr. 5 (Stb. 33*) en KB van 29 sept. 1815 , nr. 49 (Stb. 47).

${ }^{154}$ Van Zelm van Eldik, Moed en Deugd. Ridderorden in Nederland, 163-206 (172-173).
} 
Deze vergelijking is interessant omdat voor het adelsstatuut dat Van Spaen in opdracht van de soevereine vorst ontwierp, de grondwet en de statuten van de constitutionele adel van het Koninkrijk Holland nu juist het voorbeeld waren. Zonder de neerslag van deze organisatie, die grotendeels aan Van Spaen was te danken maar korter dan een jaar functioneerde, zou het opzetten van een nieuwe adel voor het Koninkrijk der Nederlanden niet zo snel tot stand zijn gekomen als in 1814 het geval was. Er zijn althans geen aanwijzingen dat buitenlandse adelsstatuten, zoals het adelsedict van Maria Theresia (1754), voor de Noordelijke Nederlanden een grote rol hebben gespeeld. ${ }^{155}$

Ook het koninklijke wapen werd met advies van de Hoge Raad van Adel vastgesteld. Het wapen van de soevereine vorst, dat vastgesteld was bij SB van 14 jan. 1814, nr. 133 (Stb. 9), werd in de loop van 1815 gewijzigd. ${ }^{156}$ Bij KB van 24 aug. 1815, nr. 71 (Stb. 46) werd het nieuwe koninklijke wapen, tevens rijkswapen, vastgesteld. De bijbehorende gravure bleek echter een aantal heraldische fouten te bevatten, die bij ordonnantie van de Hoge Raad van Adel van 2 juli 1816 werden gecorrigeerd. Dit had als consequentie dat alle in koper gesneden zegelstempels en cachetten moesten worden teruggenomen voor revisie. ${ }^{157}$ Als uitvloeisel hiervan liep ook de vervaardiging van het nieuwe grootzegel van de koning vertraging op. Volgens zijn instructie 'voorziet de Raad Ons van een groot en een klein zegel, waarvan dezelve aan Ons de teekeningen zullen worden voorgedragen' (art. 15). Het ruiterzegel van de soevereine vorst moest ten behoeve van de aangetreden koning een ander contrazegel met het nieuwe rijkswapen krijgen. De adelsdiploma's van de prins van Waterloo en de markies van Heusden zijn echter nog bezegeld met het grootzegel van de soevereine vorst. In 1819 werd bij 's Rijks Munt te Utrecht een tweede grootzegel, te weten een troonzegel, vervaardigd, dat dienst kon doen bij de departementen van Buitenlandse Zaken en Kolonieën. Het ruiterzegel werd in het bijzonder gebruikt voor de bezegeling van adelsdiploma's. ${ }^{158}$

De historicus Johan Huizinga liet zich als mediëvist in een rede voor de Maatschappij der Nederlandse Letterkunde verleiden tot een heldere terugblik op de betekenis van de onafhankelijkheid in 1813 voor 'Nederland's geestelijke beschaving'. Hij verbaasde zich achteraf over het gemak en de onverschilligheid waarmee de bevolking zich bij de stichting van het nieuwe koninkrijk in slaap had laten sussen. Het nationale besef, dat altijd half monarchaal, half republikeins was geweest, werd nog in november 1813 in Amsterdam gesymboliseerd door het uitsteken van de rood-wit-blauwe 'Statenvlag', waarmee ooit de vlootvoogden op de wereldzeeën zich identificeerden, tezamen met de Oranje wimpel. De 'Schets' voor een grondwet van G.K. van Hogendorp was nog hoopvol geweest, maar al in de Grondwet van 1814 had de Nederlandse bevolking, inclusief de adel, zijn oude

\footnotetext{
${ }^{155} \mathrm{Vgl}$. Janssens, De evolutie van de Belgische adel sinds de late Middeleeuwen, 331-346.

${ }^{156}$ Missive van de algemeen secretaris van de koning aan de HRvA, d.d. 2 juni 1815, nr. 766 (HRvA, RA, inv. nr. 4, nrs. 233 en 269).

${ }^{157}$ HRvA, RA, inv. nrs. 10, nr. 326; 11, nr. 359; 12, nr. 378; 295, nr. 359/105.

${ }^{158}$ Karper, 'De geschiedenis van het Rijkswapen en het Koninklijk grootzegel', 119-120.
} 
rechten verkwanseld. 'Stel u echter eens een ogenblik voor, dat de constitutie van de nieuwe staat onder Oranje eens wat meer in de geest van Hogendorps oorspronkelijke denkbeelden was verwezenlijkt. Wij zouden een antieker en aristocratischer staat hebben gehad, maar niet de schijnmoderniteit van 1814. Minder centralisatie, meer federalisme. Een echte organische adel met majoraten en heerlijkheden, die werkelijk inbreuk maakte op het beginsel der gelijkheid, en niet de schijnadel, die eigenlijk voor het overgrote deel bleef wat hij in zijn vroegere verschijningsvorm als regentenstand geweest was: een burgerlijk patriciaat, maar nu georiënteerd naar de kroon in plaats van naar de stad en het platteland. Als men eens die nieuwe houding had kunnen ontgaan, die weldaden en beschikkingen afwachtte van de vorst! (...) In Hogendorps staat zouden de oude heren zich meer thuis zijn blijven voelen en het volk had wat meer te haten gehad, in plaats van enkel te bedelen. ${ }^{159}$ Niet dat Huizinga een aanhanger was van de oude regentenmaatschappij; integendeel, een krachtiger reactie op staatkundig gebied zou volgens hem het democratiseringsproces in vergelijking met andere West-Europese (buur)landen waarschijnlijk sneller en beter hebben doen verlopen.

De oude adel is dit verwijt in ieder geval niet te maken, want die had destijds de grootste moeite met de oprichting in 1814 van de nieuwe adel, die aan de exclusieve oligarchische ridderschappen uit de achttiende eeuw definitief een einde maakte. De feodale adel zag zichzelf als een autonome stand, die door geen enkele macht van zijn aangeboren soevereiniteit kon worden beroofd. In de verminderde betekenis van de ridderschappen in de nieuwe constellatie en de vele adelsverleningen herkende de oude adel zich in het geheel niet. ${ }^{160}$ Door het verlichte uitgangspunt dat een ieder zonder onderscheid van rang en geboorte tot alle ambten en bedieningen benoembaar zou zijn, had evenwel niet aan een vernieuwing, uitbreiding en verjonging van de adel ontkomen kunnen worden.

In de loop van de negentiende eeuw laaide de discussie (weer) op of er naast de door de soevereine vorst ingestelde adel nog oude inheemse adel bestond, die niet tot de Nederlandse adel behoorde en waarvan titulatuur in officiële akten zou moeten worden vermeld. Aanleiding hiervoor was onder meer het KB van 26 januari 1822 , waarin cumulatieve lijsten werden aangekondigd en met een strafoplegging werd gedreigd bij incorrecte of onvolledige vermelding. Baron Van Breugel Douglas verdedigde de stelling dat de adel in 1795 niet was afgeschaft, maar slechts had opgehouden te bestaan. Edellieden, die zich niet voor erkenning in de Nederlandse adel hadden aangemeld, zouden hun recht op het gebruik van adellijke titulatuur hebben behouden. ${ }^{161}$

Een kleine eeuw later bestreed Prins deze gedachtegang met de simpele redenering dat de grondwet over geen andere Nederlandse adel sprak dan de Nederlandse adel die uitsluitend bij koninklijk besluit 'verheven' kon worden. Dit betekende dat oude adel, die zich niet voor erkenning had aangemeld, in het koninkrijk niet als

\footnotetext{
${ }^{159}$ Huizinga, 'De beteekenis van 1813', 528-542 (537-538).

${ }^{160}$ Aalbers, 'Van ridderschap naar koninklijke adel', 49-69.

${ }^{161}$ Van Breugel Douglas, Over het adelsregt in de Nederlanden, 25 e.v.
} 
adellijk gold en de jure op gelijke voet stond met vreemde adel. Zijn conclusie was dat deze staatsrechtelijk gezien irrelevant was. ${ }^{162}$ Hij voerde daarbij een recente uitspraak van de rechter op, die dezelfde argumentatie gebruikte en de ambtenaar van de burgerlijke stand opdracht gaf tot het schrappen van enkele adellijke predikaten die ten onrechte in geboorteakten waren opgenomen. ${ }^{163}$

Voor vreemde adeldom gold hetzelfde en het was volgens de grondwet geen $\mathrm{Ne}$ derlander toegestaan deze aan te nemen zonder bijzonder verlof van de vorst. Anderzijds was de voorwaarde van Nederlanderschap voor de verlening van adeldom in een tijd dat de begrippen ingezetenen en onderdanen nog niet exact waren gedefinieerd, kennelijk geen beletsel om in 1815 de hiervoor vermelde buitenlanders te verheffen tot prins van Waterloo en markies van Heusden. ${ }^{164}$ Deze Engelse onderdanen behoren met hun nakomelingen tot de Nederlandse adel zonder ooit de Nederlandse (of Belgische) nationaliteit te hebben gehad.

De dotatie naar het voorbeeld van het Napoleontische majoraat, die de prins van Waterloo in 1815 van koning Willem I had ontvangen, ervoeren de Zuidelijke Nederlanders als het wegschenken van Belgische grondgebied. De exploitatie als wingewest kreeg verder vorm, toen de koning toestemming gaf om de 1380 hectare bos te laten rooien en de grond in cultuur te brengen. ${ }^{165}$ De houtopbrengst werd betaald door een vordering op het Grootboek Nationale Schuld, die in het scheidingsverdrag met België in 1839 aan België toeviel en eerst in 1989 werd afgelost in de vorm van nog eens 25 hectare grond bij Houtain le Mont. ${ }^{166}$

Toch zijn er enkele voorbeelden bekend van verwerving van adellijke functies, onder voorwaarde van benoeming bij Nederlands koninklijk besluit, zonder dat daar verlening van Nederlandse adeldom aan vooraf was gegaan. In de tweede helft van de negentiende eeuw kwamen naar verhouding veel toelatingsbesluiten af voor de Ridderlijke Duitsche Orde, Balije van Utrecht, van buitenlandse, voornamelijk Duitse, edellieden die aan het vereiste van minimaal vier oude adellijke kwartieren voldeden, maar niet waren ingelijfd in de Nederlandse adel. ${ }^{167}$

Eén zeldzaam voorbeeld betrof in 1849 een Nederlander, de Gelderse landbouwkundige Frederik Louis Willem van Brakell van den Eng (1788-1865), die als uitzondering op zijn familieleden in 1814 niet in de Ridderschap van Gelderland was benoemd. Hij was dus officieel niet erkend te behoren tot de Nederlandse adel. ${ }^{168}$ Verklaringen van de Ridderschap van Gelderland, waarvan hij nooit deel had uit-

\footnotetext{
${ }^{162}$ Prins, 'Titels en praedicaten', 17-18.

${ }^{163}$ AR (Rotterdam) 14 sept. 1953, rolnr. 270/51 (Van Sasse van Ysselt).

${ }^{164}$ Sloet tot Everlo, Beschouwingen naar aanleiding van de artt. 63 en 65 der Grondwet, 66-67; Heijs, Van vreemdeling tot Nederlander, 15-20.

${ }^{165} \mathrm{~KB}$ van 3 juni 1817 , nr. 59.

${ }^{166}$ Boddaert, 'De Prins van Waterloo', 6-9.

${ }^{167}$ HRvA, RA, inv. nr. 595, fol. 105, 117 en 120 (Zu Sayn-Wittgenstein,1857, 1867, 1870), 109 (Von Romberg, 1863), 115 (Zu Münster-Langelage, 1866), 119 (Von Dönhoff, 1868), 121 en 141 (Von Bernstorff, 1870, 1879), 123 en 160 (Von Künsberg, 1871, 1892), 127 (Von Schwerin-Wolfshagen), 130 en 154 (Von Alvensleben, 1877, 1887), 135 (Von Hessen-Philippsthal, 1877), 146 (Von BodelschwinghPlettenberg, 1881).

${ }_{168}$ [Nijkamp en Schutte], De Nederlandse Adel, 57. Vriendelijke mededeling van drs. C.O.A. baron Schimmelpenninck van der Oije, die mij op deze uitzondering wees.
} 
gemaakt of zou uitmaken; van de Staten van Gelderland, waarin hij nooit een stem had uitgebracht; en van de Hoge Raad van Adel, die nooit om een advies inzake zijn adeldom was gevraagd, waren voldoende voor toelating tot ridder van de Duitsche Orde, maar niet voor het voeren van de titel baron, die hem formeel niet toekwam. De Raad gaf op grond van art. 22 van zijn instructie uit 1814 een verklaring af dat zijn adellijke kwartieren 'niet besmet waren met bastaardij en dat de geslachten geadmitteerd waren geweest in de voormalige Ridderschap van Gelderland' ${ }^{169}$ Van Brakell makte snel carrière binnen de Duitsche Orde, werd in 1850 commandeur en in 1863 zelfs landcommandeur. ${ }^{170}$ Hoewel hij naar Nederlands recht geen baron was, wordt deze titel onder het ridderportret in de portretreeks van de landcommandeurs van de Duitsche Orde wel bij zijn naam vermeld. ${ }^{171}$ Slechts weinig buitenlandse ridders brachten het tot landcommandeur. Aangezien de voorkeur voor de hoogste functie kennelijk naar een Nederlander bleef uitgaan, maar inheemse adel in de tweede helft van de negentiende eeuw onder de voorwaarde van vier riddermatige kwartieren schaars was geworden, zal dit de opklimming van Van Brakell binnen de Orde hebben bevorderd. ${ }^{172}$

\footnotetext{
${ }^{169}$ HRvA, RA, inv. nr. 595, fol. 89-90, nr. 57 (een uitzondering werd gemaakt voor het kwartier van de Van Borsseles, die ambtsjonkers te Geldermalsen waren geweest).

${ }^{170}$ Nederland's Adelsboek 89 (2000-2001), 85-86.

${ }^{171}$ Meuwissen, Gekoesterde traditie, nr. 60.

${ }^{172}$ Ibidem, nr. 57: Carl Freiherr von Bodelschwingh-Plettenberg was van 1841-1850 landcommandeur.
} 


\section{Adelsrecht in het Koninkrijk der Nederlanden}

\section{1815-1839: met België}

In de beginjaren van het Koninkrijk der Nederlanden kenmerkte het adelsbeleid van de nieuwe vorst zich door een streven om de gewenste adel als groep zoveel mogelijk identiek te laten zijn aan de heersende elite in de onder zijn bewind verenigde landen. ${ }^{173}$ De door hem, nog als soevereine vorst, ingestelde Hoge Raad van Adel speelde als adviescollege een volgzame rol en liet veel aan het oordeel van de koning over. President Van Spaen la Lecq, die het onderzoek van de Raad - nadat meestal één van de leden als rapporteur verslag had uitgebracht - coördineerde, stond borg voor een continuering van het beleid zoals dat al tijdens het Koninkrijk Holland door hemzelf met succes was ontwikkeld. Rezen er vraagpunten of was het initiatief van de koning uitgegaan, dan werd de beslissing aan 'de welwillendheid van Zijne Majesteit' overgelaten. Adelsverlening werd letterlijk, in navolging van artikel 63 van de Grondwet ('De Koning verheft in den adelstand'), als een prerogatief van de vorst beschouwd. De opvallende meegaandheid van de Raad kan ook een gevolg zijn geweest van het in dit opzicht rommelig begonnen soevereine bestuur, waaronder benoeming in een ridderschap aanvankelijk automatisch adeldom betekende. In 1814 en 1815 hebben op deze wijze een aantal nietgekwalificeerde geslachten adeldom verkregen, in enkele gevallen zelfs tezamen met hun niet toekomende titulatuur. ${ }^{174}$ Nadat de koning deze bevoegdheid door middel van koninklijke besluiten in 1815 en 1823 weer geheel aan zichzelf had getrokken, werd vervolgens een stringent beleid gevoerd. Hieronder was het KB van 13 februari 1815, nr. 60, zonder meer het belangrijkste, omdat hierin voor het eerst de verschillende vormen van adelsverlening werden aangeduid: benoeming, erkenning, inlijving en verheffing. ${ }^{175}$ Uitdrukkelijk werd hierin ook over vererving van adeldom op wettige afstammelingen gesproken, maar niet expliciet over de mannelijke lijn. De uitgereikte acten van bewijs en adelsdiploma's, waarvan authentieke kopieën bij de Raad bleven berusten, laten hier echter geen misverstand over bestaan, waar deze vermelden dat de persoonlijke verlening tevens betrekking heeft 'op zijn wettige thans bestaande en toekomende kinderen, zo mannelijke als vrouwelijke, mitsgaders alle volgende afstammelingen van zijn geslacht en naam'. ${ }^{176}$

\footnotetext{
${ }^{173}$ Bruin, 'Een verloren zaak', 141-164.

${ }^{174}$ Van Valkenburg, 'Adelsbeleid sedert 1813', 55-57; Duerloo en Janssens, Wapenboek van de Belgische adel, 1, 57-58.

${ }^{175}$ HRvA, RA, inv. nrs. 3 (not. 1815-63) en 877.

${ }^{176} \mathrm{~KB}$ van 18 dec. 1815, nr. 46, bijlage (tekst akte van bewijs) (HRvA, RA, inv. nrs. 7 (not. 1815-581), 447 en 449); Van Meeuwen, 'Een en ander over het Nederlandse adelsrecht', 80; Smissaert, 'Acten van bewijs', 61-68.
} 
Bij SB van 13 februari 1815, nr. 61, kwam een einde aan de autonome benoemingen in de heropgerichte ridderschappen. ${ }^{177}$ Bij SB van 4 maart 1815, nr. 85, werd voorts bepaald dat met terugwerkende kracht alsnog voor alle benoemden een diploma zou moeten worden uitgevaardigd. ${ }^{178} \mathrm{Bij}$ hetzelfde besluit werd gedefinieerd wat in theorie onder oude adel moest worden verstaan, namelijk adeldom terug te voeren tot vóór 1579, en voorts dat individueel en niet als groep erkenning moest worden verzocht. ${ }^{179}$

De gebruikelijke gang van zaken werd dat de potentiële kandidaat zelf een verzoekschrift bij de koning indiende, die vervolgens de Hoge Raad van Adel om advies vroeg. Alleen bij verheffingen kon de koning zelf het initiatief nemen. Maar ook ten aanzien van erkenningen en inlijvingen, die door de Raad altijd serieus werden onderzocht, gold het eindoordeel van de koning als bepalend. Soms werd door de secretaris van Staat (minister) in geval van een negatief advies van de Raad geadviseerd om een verzoek tot verheffing in te dienen. Was de verzoeker niet al te zeer in zijn familietrots gekrenkt, dan bood deze uitweg in tweede instantie uitzicht op een positieve beslissing. ${ }^{180}$ Indien er nog enig zicht op toekomstig bewijs was, bood een in het koninklijk besluit opgenomen 'clausule van erkenning of inlijving', indien het bewijs alsnog geleverd mocht worden, uitkomst. ${ }^{181}$

\section{Proprio motu}

De koning begon zijn adelsbeleid met de verheffing uit eigen beweging ('proprio motu') van een groep vaderlanders 'om verdiensten aan den staat bewezen'. Afstamming speelde hierbij geen rol, maar er zijn geen voorbeelden bekend van verheven burgers die uit onaanzienlijke families stammen. Bij verzamel-KB van 16

\footnotetext{
${ }^{177}$ HRvA, RA, inv. nrs. 3 (not. 1815-66) en 447. Een (te) late benoeming bij KB van 28 maart 1815, nr. 65, van G.Th.A. Snouckaert van Schauburg in de Ridderschap van Holland, werd niettemin gevolgd door een titelerkenning bij KB van 8 juli 1816, nr. 60, voor hemzelf en zijn twee broers. Het verzoek van zijn broer baron Albert Carel om met terugwerkende kracht vanaf 27 aug. 1814 (een dag vóór het verzamelbesluit van 28 aug.!) erkend te worden, dat bij KB van 6 juli 1817, nr. 44, werd gehonoreerd, lijkt een geforceerde correctie achteraf te zijn van een lid van de HRvA, die toch als eerste werd geacht de gestelde regels te kennen. Vgl. [Nijkamp en Schutte], De Nederlandse adel, 205-206.

${ }^{178}$ HRvA, RA, inv. nrs. 3 (not. 1815-154) en 447. Oproepen aan benoemden om zich te melden op straffe van verlies van adeldom werden gedaan bij KB's van 28 dec. 1816, nr. 45 (drukwerk, tweetalig), 3 aug. 1818, nr. 19, en 20 april 1819, nr. 2 (HRvA, RA, inv. nr. 29, not. 1819-192). Ten slotte werd nog een oproep op naam geplaatst in de Staatscourant van 1 mei 1819, nr. 103 (bijvoegsel) met als sluitingsdatum 15 juli 1819 (HRvA, RA, inv. nr. 931A). De koning betuigde bij brief, d.d. Brussel 3 mei 1819, zijn ongenoegen aan de HRvA over de gepubliceerde namenlijst 'omdat de aard der zaak de bemoeying van het publiek met dezelve geheel noodeloos, zoo niet onraadzaam maakte'. Afgesproken zou zijn om belanghebbenden mondeling te benaderen (HRvA, RA, inv. nr. 29, not. 1819-213). De publicatie had overigens effect, want van de Noord-Nederlanders werden alleen leden van geslacht Van Asbeck van hun adeldom vervallen verklaard (HRvA, RA, inv. nr. 35, not. 1820-154). Bij Kon. Disp. van 3 okt. 1820, nr. 207/V, werd G.F. van Asbeck echter alsnog vergund zijn acte van bewijs te lichten (HRvA, RA, inv. nr. 38, not. 1820-418/422).

${ }^{179}$ De eis van oude adeldom van vóór 1579 stond al in de instructie voor de HRvA, d.d. 24 juni 1814, nr. 10 (art. 2, art. XVII) en was herhaald in het advies van de HRvA van 12 oktober 1814 (HRvA, RA, inv. nr. 2 (not. 1814-49). In de praktijk was aan deze strenge eis niet gemakkelijk te voldoen.

${ }^{180}$ HRvA, RA, inv. nr. 281 (extracten notulen 1814-1878).

${ }^{181}$ [Nijkamp en Schutte], De Nederlandse Adel, 12.
} 


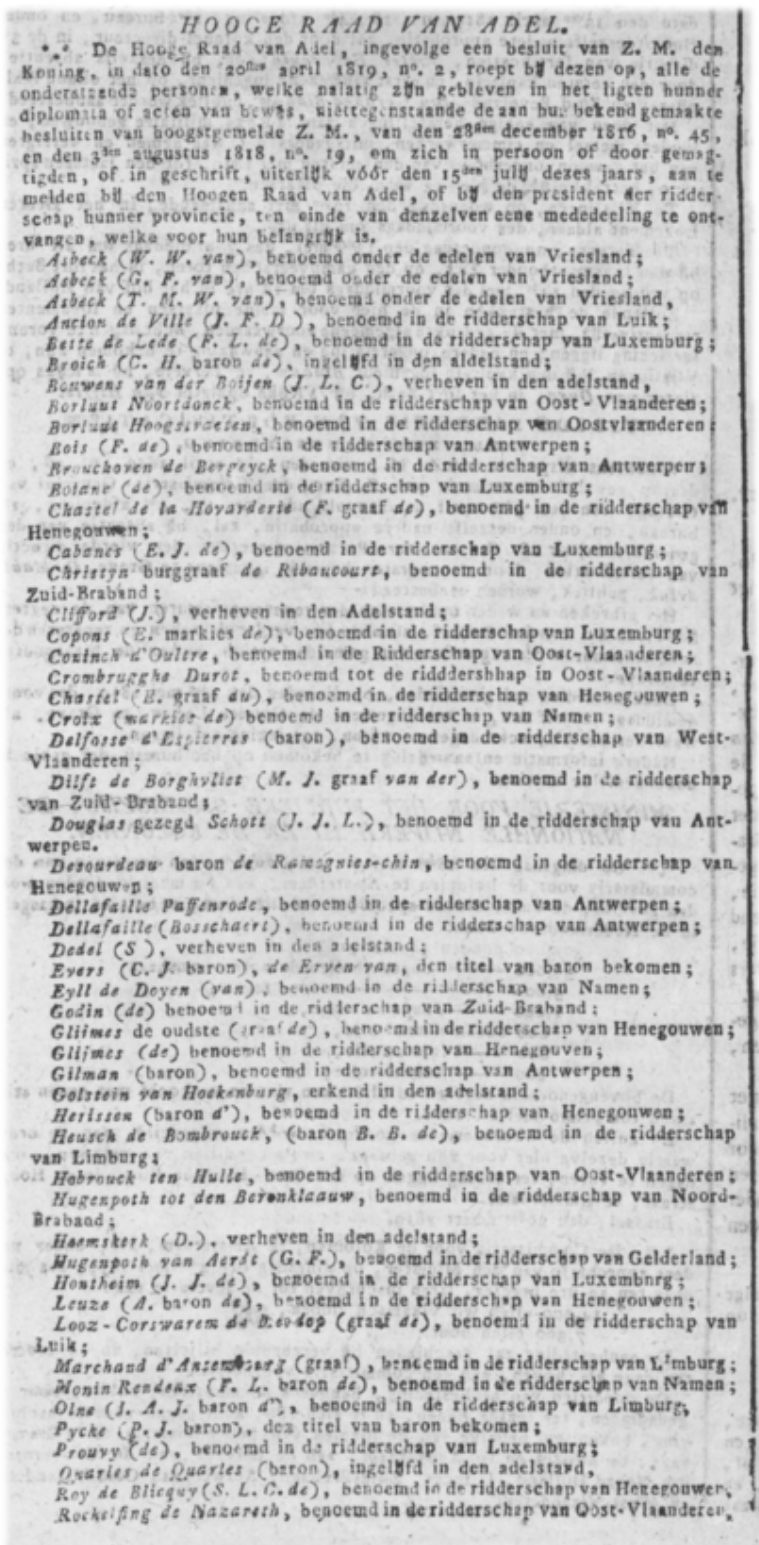

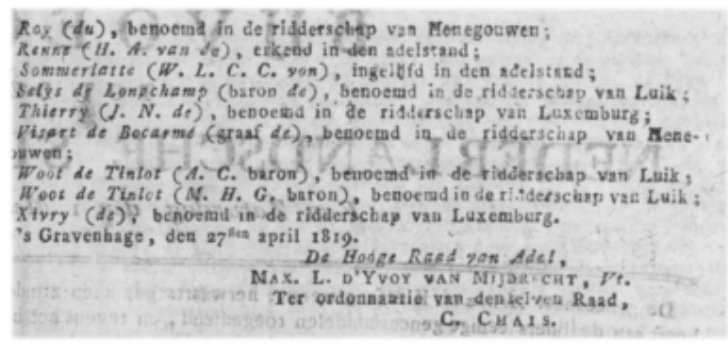

Staatscourant d.d. 1 mei 1819, nr. 103 (bijvoegsel) met de laatste oproep aan benoemden in de Nederlandse adel om zich te melden op straffe van verlies van adeldom. HRvA, RA, inv. nr. 931A.

september 1815 nam de koning op eigen initiatief vervolgens een groot aantal leden van regentengeslachten in de adelstand op, waaronder betrekkelijk veel Amsterdammers. ${ }^{182}$ In het algemeen waren koning en Raad het erover eens dat bij de vernieuwing, uitbreiding en verjonging van de Nederlandse adel alleen vooraanstaande, vermogende en invloedrijke personen in aanmerking zouden komen. Deze gedachte lag reeds ten grondslag aan de Napoleontische adel, waarbij inkomsten uit majoraten een voorwaarde voor verheffing waren. In de beoordeling betrok de Raad dan ook steevast de levensomstandigheden, positie, welstand en reputatie van een genomineerde. Men ging er daarbij van uit dat een bekende familieachtergrond een garantie kon zijn voor adellijke continuïteit op niveau. ${ }^{183}$

\footnotetext{
${ }^{182}$ KB van 16 sept. 1815, nrs. 66, 69 en ongenummerd (HRvA, RA, inv. nr. 6, not. 1815-390 en 392). Van Valkenburg, 'Adelsbeleid sedert 1813', 59-65; Wolleswinkel, 'Verheffing om verdiensten aan den staat bewezen', 252-261.

${ }^{183}$ Ibidem, 70-71; Bruin, 'Een verloren zaak', 146-150.
} 
In de loop van de tijd werd bij verheffing afkomst uit een belangrijke patricische familie steeds belangrijker. Als criterium ontwikkelde zich de voorwaarde van afstamming uit een regentengeslacht dat vóór 1795 meerdere generaties in de vroedschap van een stemhebbende stad of in een landelijk regeringscollege zitting had. Van Spaen van Biljoen adviseerde in 1809 de toenmalige koning al positief over voldoende oude eerbiedwaardige vaderlandse geslachten die in aanmerking zouden komen om een constitutionele adel uit samen te stellen. Hiervan was in de grondwet en de statuten van de adel van het Koninkrijk Holland overigens nog niets terug te vinden. ${ }^{184}$ Als eerste zag Van Hogendorp in zijn 'Schets voor een Grondwet' (1812) in de verheffing van deze groep een genoegdoening voor de verloren positie van de stedelijke regenten. ${ }^{185}$ Een argument om deze categorie voor verheffing in aanmerking te laten komen zou ook de nieuwe staatsrechtelijke positie van de ridderschappen als kiescolleges voor de provinciale staten zijn geweest. In het bijzonder in die provincies waar weinig adel van vóór 1795 voor benoeming beschikbaar was, voorzag het patriciaat in de ontstane leemte. ${ }^{186}$

Rooms-katholieke en afwijkend protestantse geslachten, die wegens hun geloofsovertuiging in de Republiek geen openbare ambten konden bekleden, maar qua positie en levenswijze met de inheemse adel of regentengeslachten waren gelijk te stellen, kregen in het verenigde koninkrijk ook een kans. De eerste categorie bleef bescheiden vertegenwoordigd, maar protestante dissenters zonder regeringservaring rukten daarentegen op. ${ }^{187}$

\section{Oude adel}

Daar waar door de benoemingen in de ridderschappen in 1814-1815 betrekkelijk gemakkelijk adeldom kon worden verworven met zelfs hier en daar nieuwe titulatuur, raakten de rechten van de oude inheemse adel enigszins in het gedrang. ${ }^{188}$ Was deze al niet erg geneigd aan de voorschriften voor de opgerichte adel te voldoen, thans was het toch zaak zich met een genealogie en familiewapen te melden ten behoeve van het register van de Nederlandse adel. In de instructie voor de Hoge Raad van Adel, d.d. 24 juni 1814, staat letterlijk dat 'de Raad zal doen houden een pertinent algemeen register van den Nederlandschen Adel', maar het heeft nog tenminste een jaar geduurd voordat daartoe feitelijk was overgegaan. ${ }^{189} \mathrm{Zo}$ valt in de notulen van de Raadsvergadering van 19 april 1815 te lezen, dat 'is besloten een register van Nederlandschen adel aan te leggen en in hetzelve alle de tegenwoordige van de Ridderschappen en de verder door Zijne Majesteit in den adelstand erkende, ingelijfde en verhevene personen te plaatsen' ${ }^{190}$ Maar in augustus

\footnotetext{
${ }^{184}$ HRvA, RA, inv. nr. 889.

${ }^{185}$ Van Haersolte, Inleiding tot het Nederlandse staatsrecht, 21.

${ }^{186}$ [Nijkamp en Schutte], De Nederlandse Adel, 12.

${ }^{187}$ Van Valkenburg, 'Adelsbeleid sedert 1813', 63-65.

${ }^{188}$ Bij KB van 21 maart 1823, nr. 95, werd deze nieuwe titulatuur echter persoonlijk verklaard (HRvA, RA, inv. nrs. 447 en 449 ).

${ }^{189}$ SB van 24 juni 1814 , nr. 10, art. 2, art. XVI.

${ }^{190}$ HRvA, RA, inv. nr. 3 (not. 1815-155).
} 
1815 blijkt het nog niet te zijn aangelegd, getuige een beschikking van de koning. ${ }^{191}$ Mogelijk heeft de aanvankelijk geringe respons vanuit de oude adel, waarmee een dergelijk register toch minstens zou moeten aanvangen, parten gespeeld. $^{192}$

In 1818 verspreidde de secretaris van de Hoge Raad van Adel een oproep in drukwerk waarin aan stamoudsten van oude adellijke geslachten werd gevraagd hun familiegenealogie in tabelvorm met familiewapen in te leveren (verwijzende naar 's Raads instructie, artikelen 16 tot en met 22), zodat deze als bewijzen van (oude) adeldom in het archief van de Raad bewaard konden blijven. ${ }^{193}$ Vrijstelling van de voorwaarde om een acte van bewijs of adelsdiploma te lichten, was in het vooruitzicht gesteld wanneer de ingeleverde bewijsstukken in orde bevonden waren. ${ }^{194}$

In deze ministeriële circulaire - het was een afschrift van een door de algemene secretaris van Staat A.R. Falck ondertekende beschikking - werd overeenkomstig artikel XVII van de instructie voor de Hoge Raad van Adel opnieuw verwezen naar de eis van adeldom vóór of sedert het jaar 1579. De circulaire was tweetalig, terwijl zowel een vermaarde Noord-Nederlandse (Ferwerda), als Zuid-Nederlandse genealoog (Butkens) als voorbeeld werd gesteld voor de opstelling van stambomen in kolom- of tabelvorm. ${ }^{195}$ Merkwaardig genoeg werd niet expliciet gerefereerd aan de in 1817 vastgestelde bijzondere eis van ouderdom voor Zuid-Nederlandse adellijke geslachten. Bij KB van 23 mei 1817, nr. 2, kreeg officieel ook de ZuidNederlandse oude adel vrijstelling voor een acte van bewijs of adelsdiploma, mits aangetoond kon worden dat de adeldom vóór of sedert 1555 bestond. ${ }^{196}$ Dit onderscheid in jaartal hield verband met de uiteenlopende staatsrechtelijke geschiedenis van de Noordelijke en Zuidelijke Nederlanden. De Unie van Utrecht (1579) was destijds niet door de Spaanse koning erkend, terwijl omgekeerd koning Philips II door de Noordelijke Nederlanden werd afgezworen. De eis van adeldom van vóór 1555 moest dus teruggrijpen op diens vader, keizer Karel V, wiens soevereiniteit onomstreden was. ${ }^{197}$

De circulaire van 1818, die als termijn een jaar na dato noemde - ook deze termijn bleek rekbaar - en geen aanvullende bewijzen verlangde als de genealogie aan de gestelde eisen voldeed, had het effect dat werd beoogd. De meeste titelerkenningen vonden namelijk plaats tussen dit jaar en 1822, toen ervoor betaald moest gaan worden. In strijd met het KB van 4 maart 1815, nr. 85, waarin bewijs van adeldom van vóór of sedert 1579 werd geëist en een individueel verzoek om verlening werd

\footnotetext{
${ }^{191}$ HRvA, RA, inv. nrs. 281, f. 8, en 282, nr. 346 (Kon. Disp. van 21 aug. 1815, nr. 78).

192 Met het in de instructie uit 1814 voorgeschreven 'pertinent algemeen register van den Nederlandschen Adel' (art XVI) wordt zowel het 'Wapenregister' (art. XVII; HRvA, RA, inv. nrs. 501-511) als het 'Filiatieregister' (art. XX; HRvA, RA, inv. nrs. 512-543) aangeduid.

${ }^{193}$ HRvA, RA, inv. nrs. 489-500 (genealogieën) en 877 (circulaire van 30 sept. 1818, nr. 158).

${ }^{194}$ Bij KB van 18 dec. 1815, nr. 46, en nogmaals bij KB van 26 jan. 1822 (Stb. 1), art. 3 (met sluitingstermijn van zes maanden)

${ }_{195}$ A. Ferwerda, Adelijk en Aanzienelijk Wapenboek van de Zeven Provincien (...), 2 dln. (Leeuwarden 1760-1781); Chr. Butkens, Trophées, tant sacrés et prophanes du Duché de Brabant (Antwerpen 1614).

${ }^{196}$ HRvA, inv. 447 en 449.

${ }^{197}$ [Nijkamp en Schutte], De Nederlandse Adel, 15-16, die vanuit de Spaanse (1556-1713) en Oostenrijks/Habsburgse (1714-1792) adeldom de doorgaans erkende titels bij eerstgeboorte verklaren.
} 


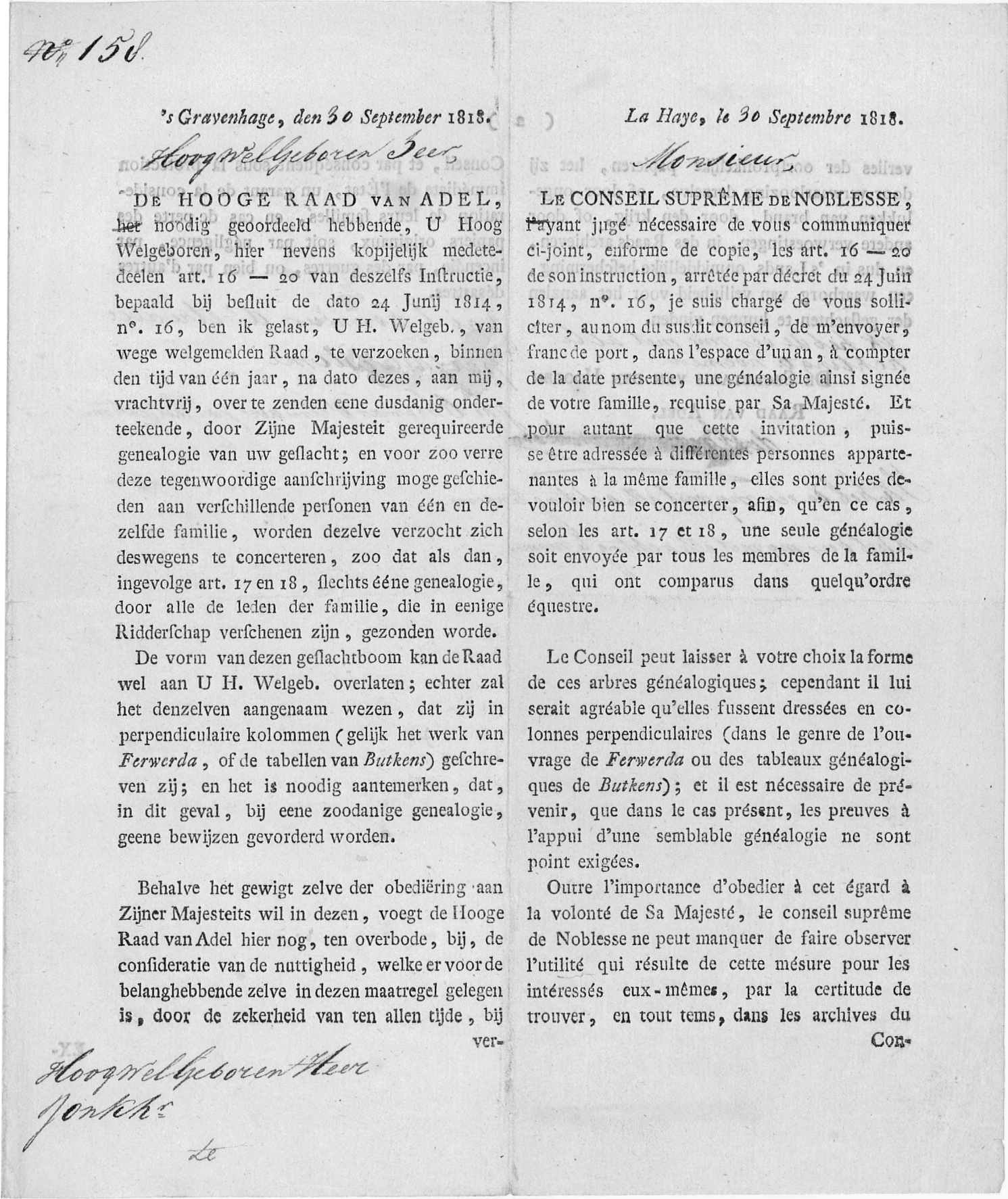

Eerste bladzijde van een circulaire van de Hoge Raad van Adel, d.d. 's-Gravenhage 30 september 1818, nr. 158, gericht aan stamoudsten van inheemse adellijke geslachten om hun bewijzen in te leveren met vrijstelling van taxa. HRvA, RA, inv. $n r .877$.

voorgeschreven, is in rap tempo titelerkenning verleend zonder dat nog over adeldom sec was beslist. Voorbeelden van titelerkenning voor het gehele geslacht zijn Van Balveren, Van der Borch, Van Hoëvell, Schimmelpenninck van der Oije, Du Tour, Van Voorst tot Voorst en Van Westerholt; deze geslachten waren in het al- 
gemeen omvangrijk. ${ }^{198}$ Bij Van der Borch en Du Tour kan bovendien getwijfeld worden aan de mate van inheemse adeldom; ${ }^{199}$ inzake Van Boetzelaer lijkt de titelverlening, die het complete geslacht in 1819 ten deel viel door homologatie van de titel baron, meer correct geformuleerd. ${ }^{200}$

De geste van vrijstelling was slechts tijdelijk, want bij KB van 24 sept. 1822, nr. 22 , werd bij titelerkenning van leden van oude adellijke geslachten die 'den titel van Baron in de Maatschappij voerde[n] van nu voortaan', een diploma uitgereikt waarvoor 100 gulden taxa en 50 gulden leges zou moeten worden betaald. ${ }^{201}$

Oude inheemse adel, die in de Noordelijke Nederlanden doorgaans de titel van baron op allen erkend verkreeg, van ná deze datum, beschikt dus wel over een - uiteindelijk al of niet gelicht - diploma. Eén van de oudste adellijke geslachten uit de Noordelijke Nederlanden is het geslacht Van Coeverden, dat na de benoeming van een drietal stamoudsten in de Ridderschap van Overijssel geen haast maakte met een verzoek om erkenning van de vanouds gevoerde titel van baron. Bij KB van 28 april 1826, nr. 15, werd, op zijn verzoek, voor jonkheer Johannes Wolter van Coeverden de erfelijke titel van baron op allen erkend. ${ }^{202}$ Het adelsdiploma is echter nooit 'gelicht' (lees: betaald), waarna de titelerkenning weer verviel en zijn nageslacht als jonkheer/jonkvrouw door het leven bleef gaan. ${ }^{203}$ De reden hiervoor is niet bekend en zou varieren van minachting voor het jonge koninkrijk tot verval in armoede. Overigens stierf deze tak van de familie weldra uit en zou het ruim anderhalve eeuw duren alvorens leden van het geslacht opnieuw titelerkenning verzochten. De Hoge Raad van Adel adviseerde de minister dezen alsnog voor titelerkenning in aanmerking te laten komen aangezien hun afstamming nog altijd voldeed aan de voorwaarden die aan oude adeldom werden gesteld en de termijn van indiening van het verzoek al in 1822 en ook daarna verschillende keren was opgerekt. De kroon honoreerde de aanvraag en sedert de jaren negentig van de twintigste eeuw zijn diverse leden van deze inmiddels uitgebreide familie voor titelerkenning in aanmerking gekomen. ${ }^{204}$

Soms ontstond onduidelijkheid of de titel bij eerstgeboorte of op allen was verleend. De oplossing is dan vaak te vinden in de zogenaamde adelslijsten, die vanaf 1825 werden gepubliceerd. Bij KB van 24 mei 1827 (Stb. 28), waarin de tweede adelslijst werd gepubliceerd, wordt nog uitdrukkelijk de mogelijkheid vermeld, dat naast het diploma als bewijsstuk ook een gespecificeerde verklaring van de Hoge Raad van Adel voldoende bewijs kan leveren. Deze moest dan wel getekend zijn

\footnotetext{
${ }^{198}$ Bij resp. de KB's van 26 febr. 1822, nr. 83; 8 jan. 1820, nr. 24; 18 juli 1819, nr. 4; 22 aug. 1820, nr. 62; 10 mei 1820 , nr. $23 ; 24$ juli 1820 , nr. 80,19 febr. 1820 , nr. 38 ;

${ }^{199}$ Nederland's Adelsboek 80 (1989), 185-190; 95 (2010), 281-287.

${ }^{200} \mathrm{~KB}$ van 18 juli 1819 , nr. 4.

${ }^{201}$ HRvA, RA, inv. nrs. 449 en 915.

${ }^{202}$ HRvA, RA, inv. nr. 86 (not. 1816-349).

${ }^{203}$ Het desbetreffende diploma is in het archief van de Hoge Raad van Adel bewaard gebleven en afgebeeld bij Coenraad, 'Het Nederlandse adelsrecht', 126 (aldaar met het foutieve jaartal 1816).

${ }^{204} \mathrm{Zie}$ de veertiende adelslijst, vastgesteld bij KB van 9 juni 2004 (Stb. 307).
} 


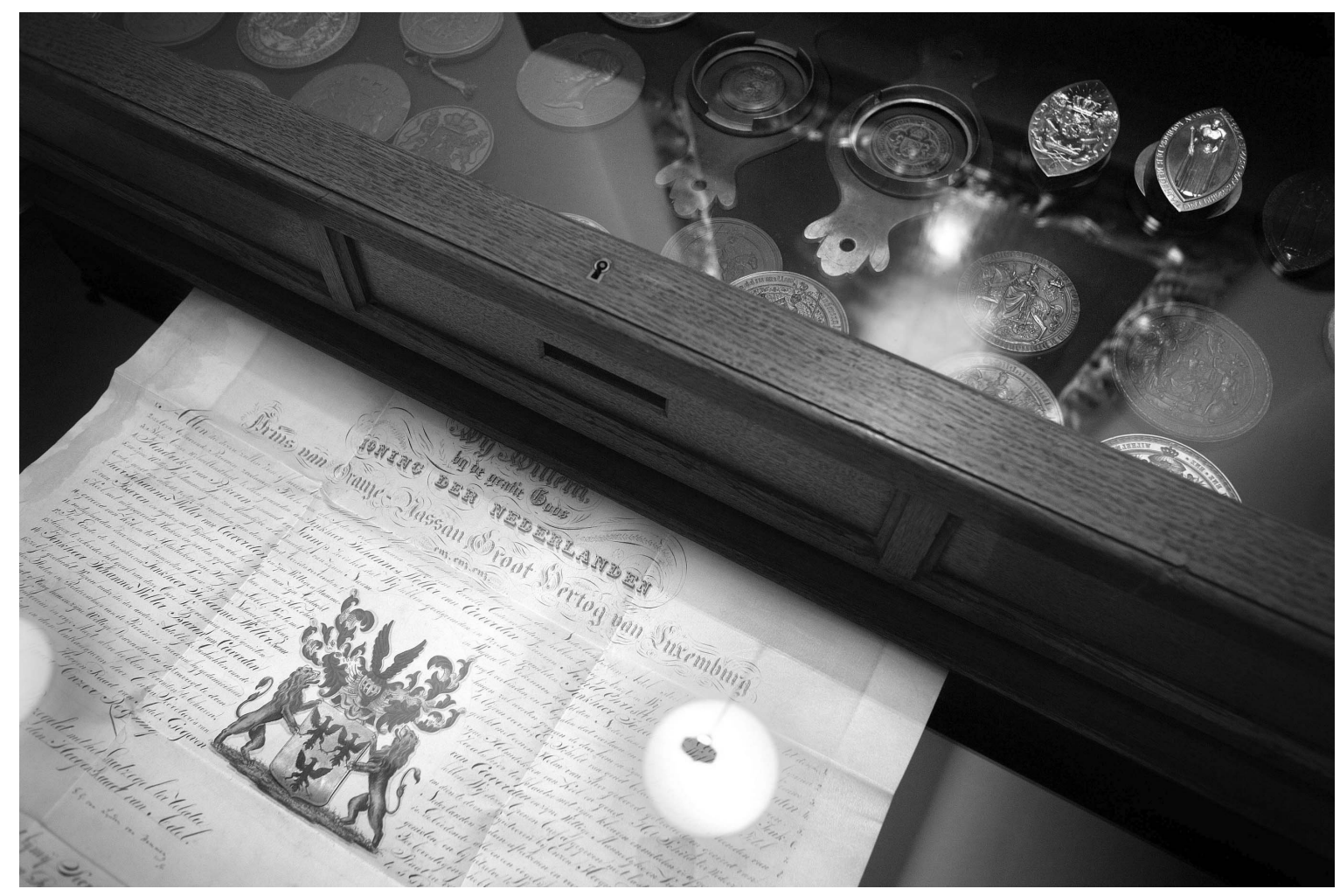

Het niet gelichte adelsdiploma uit 1826 voor jonkheer Johan Wolter van Coeverden, waarin zijn inheemse erfelijke titel van baron op allen werd erkend, wordt ter secretarie van de Hoge Raad van Adel bewaard in de kast met de grootzegelstempels van de soevereine vorsten van het koninkrijk. Foto Roger Dohmen, 's-Gravenhage 2004.

door de voorzitter met contraseign van de secretaris en voorzien van het zegel van de Raad. ${ }^{205}$

\section{Zuid-Nederlandse adel}

In 1830 brak om meerdere redenen de Belgische Opstand uit, die al spoedig tot een feitelijke afscheiding van de Zuidelijke Nederlanden leidde. ${ }^{206}$ De Belgische leden in de Staten-Generaal verschenen niet meer in Den Haag, zodat op grond van noodrecht de volksvertegenwoordiging op halve kracht besluiten moest nemen. Onder meer de godsdienstige verschillen bleken een onderschatte tijdbom te zijn onder het verenigde koninkrijk. Op 4 oktober 1830 werd in Brussel de onafhankelijkheid van de Zuidelijke Nederlanden uitgeroepen. Op 20 december erkenden de grote mogendheden de nieuwe staat België en op 7 februari 1831 vond afkondiging van de grondwet plaats. Hierin werd een constitutionele monarchie gevestigd op grond waarvan de in Engeland verblijvende hertog van Saksen, Leopold prins van Saksen-Coburg-Gotha op 4 juni 1831 tot koning der Belgen werd gekozen. ${ }^{207}$ In het democratiseringsproces was België hiermee Nederland ineens een slag voor.

\footnotetext{
${ }^{205}$ [Nijkamp en Schutte], De Nederlandse Adel, 18.

${ }^{206}$ Colenbrander, De afscheiding van België, 11-42.

${ }^{207}$ Ibidem, 72-112.
} 
In de eerste plaats werd onmiddellijk het beginsel van de ministeriële verantwoordelijkheid ingevoerd, hetgeen de speelruimte van de Kroon (koning en ministers) in menig opzicht vergrootte ten opzichte van de bijna absolute macht van de koning, zoals deze in Nederland nog bijna twee decennia bleef gelden. ${ }^{208}$ Verder gaf de gevestigde parlementaire democratie de koning in artikel 51 van de grondwet nog wel het prerogatief van adelsverlening, maar 'zonder ooit enig voorrecht daaraan te mogen verbinden'. Dit betekende het einde van de standenmaatschappij: geen staatsrechtelijke rol meer voor ridderschappen en geen adellijke bevoorrechting in het kiesstelsel. Om misverstanden te voorkomen werd in 1831 bij amendement aan de Belgische grondwet een artikel toegevoegd dat voorzag in de gelijkheid voor de wet. Artikel 6 bepaalt sindsdien: 'De Belgen zijn gelijk voor de wet. Er is in de Staat geen onderscheid van standen. ${ }^{209}$

De staatscommissie die koning Willem I op 23 oktober 1830 had ingesteld om de staatsinrichting van Nederland te herzien, stelde op 4 december onder andere de opheffing voor van het Departement van de Jacht en van de Hoge Raad van Adel. Het aanhouden van de registers van de adel en het bestuur over de jacht zouden dan tot de verantwoordelijkheden van de minister van Binnenlandse Zaken gerekend kunnen worden. Voorts zouden 'alle expeditiën van verheffingen en verleeningen van titels van adeldom, als bijzondere gunstbewijzen van den Koning, tot het kabinet kunnen worden overgebragt'. De koning gaf echter slechts in enkele opzichten gevolg aan het advies van de staatscommissie, waarin onder meer W.B. Donker Curtius en L.C. Luzac zitting hadden. ${ }^{210}$

\section{Wijziging van nationaliteit}

Hoewel koning Willem I de afscheiding niet erkende, voerde België op 22 september 1835 een wet in die het voor de Zuid-Nederlandse adel mogelijk maakte om te opteren (kiezen) voor de Belgische nationaliteit en daarmee voor de nieuw opgerichte Belgische adel. ${ }^{211}$ De door koning Willem I tussen 1815-1830 (voor Limburg en Luxemburg tot 1839) verleende adellijke titels behielden in België hun gelding van rechtswege. ${ }^{212}$ Meer dan vijfhonderd geslachten gingen over tot de Belgische adel, maar worden thans nog tevens tot de Nederlandse adel gerekend, omdat wijziging van nationaliteit geen verlies van adeldom inhield. Als juridisch argument wordt wel gegeven dat in de (grond)wet geen bepaling voorkomt, dat bij verlies van Nederlanderschap ook Nederlandse adeldom verloren gaat. ${ }^{213}$ De Ne-

\footnotetext{
${ }^{208}$ Van der Burg, 'De toestemming voor prinselijke huwelijken', 21-24.

${ }^{209}$ Janssens, De evolutie van de Belgische adel, 312-313.

${ }^{210}$ Westerbeek, De Hoge Raad van Adel, 8.

${ }^{211}$ Fox, 'Zuidnederlandse edelen', 129-130: leden van Nederlandse adel, die vóór 7 febr. 1831 (afkondiging grondwet) in België woonden en daar waren blijven wonen, kregen in de (Belgische) wet van 22 sept. 1835, art. 1, lid 2e, toestemming om binnen zes maanden een verklaring van verwerving van de Belgische nationaliteit af te leggen. Voor spijtoptanten of laatkomers bestond er nog een tweede (wet van 1 april 1879, artt. 3 en 4) en derde (wet van 25 maart 1894, artt. 3 en 4) mogelijkheid om deze toestemming te verkrijgen (Schutte, 'Boekbespreking Nederland's Adelsboek', 286).

${ }_{212}$ Van Damme, Adel, 21-24; Duerloo en Janssens, Wapenboek van de Belgische adel, 1, 57-58.

${ }^{213}$ Prins, 'Nederlandse namenrecht', 158; [Nijkamp en Schutte], De Nederlandse Adel, 26.
} 
derlandse rechter creëerde in 1963 een gekunstelde en overbodige vorm van sluimerende adeldom door te overwegen dat bij verlies van het Nederlanderschap in 1839 het adelsrecht was afgestorven om bij herkrijging van het Nederlanderschap weer te herleven zonder dat een inlijvingsprocedure noodzakelijk was. ${ }^{214}$

Een ministeriële uitspraak over deze principiële kwestie kwam er eerst na 1870, toen behoefte bestond aan een nieuwe cumulatieve adelslijst waarin ook de Belgische adellijke geslachten van vóór 1830 zouden worden opgenomen. De gedachten hierover werden in een briefwisseling tussen minister en Hoge Raad van Adel gevoerd ter gelegenheid van een verzoek van ene Maurits Taets van Amerongen, officier in Oostenrijkse krijgsdienst, die inschrijving en publicatie verzocht van de buitenlandse geboorte van zijn twee jaar oude zoontje. De vraag kwam daarbij aan de orde of deze afstammeling van de in de eerste adelslijst vermelde voorvader Gerard Godart baron Taets van Amerongen nog wel tot de Nederlandse adel behoorde. Maurits was met toestemming van de koning in Nassause krijgsdienst gegaan, maar had daarna verzuimd toestemming te vragen om in Oostenrijkse dienst te treden, waardoor hij zijn Nederlanderschap was kwijtgeraakt. Op advies van de Raad besliste minister van Justitie Jolles, dat Maurits zijn Nederlandse adeldom niet was kwijtgeraakt 'zolang hij geen onderdaan van een vreemd Rijk was geworden' ${ }^{215}$ Hij moest overigens zijn afstamming nog wel bewijzen en de ministeriële beslissing betekende niet dat hij in een adelslijst zou worden vermeld, omdat daarin alleen de stamvaders werden vermeld.

In dit verband werd na enkele jaren discussie uiteindelijk besloten dat slechts aanvullingslijsten op oudere lijsten zouden worden gepubliceerd. De Belgische geslachten behoefden dus niet opnieuw te worden vermeld, hetgeen trouwens ook om praktische redenen nauwelijks uitvoerbaar was. De minister deelde deze beslissing op 5 juli 1873 aan de Raad mee onder vermelding van de algemene regel, dat 'verlies van nationaliteit geen verlies van adeldom ten gevolge zal hebben'. ${ }^{216}$ Een nieuwe nationaliteit werd - mede met het oog op de Belgen - blijkbaar niet meer als een beletsel gezien. In de beginperiode van het verenigde koninkrijk was vreemde krijgsdienst in samenhang met zonder toestemming van de koning aanvaarde buitenlandse adellijke titulatuur overigens wel reden tot royement uit de Nederlandse adel geweest. ${ }^{217}$

$\mathrm{Na}$ de totstandkoming van een scheidingsverdrag met België bij het Verdrag van Londen van 19 april 1839 (Stb. 26) ${ }^{218}$ brak ook op het gebied van het adelsrecht een nieuwe episode aan. De Zuid-Nederlandse adel, die voor een belangrijk deel uit rooms-katholieke Franssprekende geslachten bestond, had al in overgrote

\footnotetext{
214 AR ('s-Hertogenbosch) 19 okt. 1962 (Calf de Noidans), Nederlandse Jurisprudentie (NJ) 1963, 190. Van Meeuwen, 'Een en ander over het Nederlandse adelsrecht', 87 en 90 (noot 39).

${ }^{215}$ HRvA, RA, inv. nr. 155 (not. 1871-4).

${ }^{216}$ HRvA, RA, inv. nrs. 155 (not. 1873-7) en 878.

${ }^{217} \mathrm{~KB}$ van 31 maart 1816, nr. 69: royement tezamen met intrekking van pensioen voor jonkheer A.B.G. van Dedem, heer van de Gelder, wegens het in strijd met de grondwet aanvaarden van de titel burggraaf en honorair luitenant-generaal, verleend door de koning van Frankrijk (HRvA, RA, inv. nr. 281, f. 73v.).

${ }^{218}$ [Berendse en Brood], In 21 stappen vrij onverveerd, nr. 12 (NA, Archief Ministerie van BuZa, ratificaties 1813-1940, 2.05.02, inv. nr. $110 \mathrm{G}$ ).
} 
meerderheid geopteerd voor België. ${ }^{219}$ De laatste Zuid-Nederlandse orangisten, soms pas in de overgangstijd genobiliteerd en van wie enkelen zich in Nederland hadden gevestigd, kozen na de definitieve afscheiding uiteindelijk toch voor de Belgische nationaliteit. ${ }^{220}$ De volharding in trouw aan de Nederlandse koning zal niet louter uit persoonlijke sympathieën kunnen worden verklaard, maar ook uit politieke motieven aangezien de Noord-Nederlandse adel zijn bevoorrechte positie in het kiesstelsel (voorlopig) behield.

\section{Het Oostenrijkse archief}

Door België werd een claim gelegd op het archief van de voormalige Chambre Héraldique, dat vooral relevant was voor de bewijsvoering ten aanzien van erkenning van Zuid-Nederlandse adel. Sinds 1827 berustte dit archief, dat in de zeventiende en achttiende eeuw in Brussel was gevormd, ter secretarie van de Hoge Raad van Adel in Den Haag. ${ }^{221}$ Het bevatte onder meer door Zuid-Nederlandse wapenherauten verzamelde en overgeschreven genealogieën, die als referentiekader dienden voor adelsverzoeken aldaar tijdens het Habsburgse bewind. Om deze reden wordt het ook wel aangeduid als Oostenrijks Archief of, meer naar de inhoud, Archief van de Belgische Heraldieke Kamer. ${ }^{222}$

Deze overdracht naar Den Haag had destijds al veel voeten in de aarde gehad, omdat het archief in 1794 wegens internationale spanningen van Brussel naar het Oostenrijks Gouvernement in Wenen was overgebracht en het daar nog steeds verbleef. Twaalf jaar onderhandelen resulteerde in een feitelijke overdracht, die werd begeleid door de Nederlandse gezant te Wenen Gerrit Carel baron van Spaen (1756-1841), broer van J.F.W. van Spaen van Biljoen, lid van het Wetgevend Lichaam 1807-1810. De tien kisten archief werden half december 1826 vanuit Wenen eerst per rijtuig vervoerd, vervolgens verscheept naar Frankfurt en vandaar naar Keulen en Rotterdam. Het transport kwam een maand later in Den Haag aan, maar had in Duitsland enige vertraging opgelopen omdat abusievelijk Brussel als eindbestemming was opgegeven. Alle declaraties van de vervoerders en de (concept-)bedankbrief van de Raad aan de minister van Buitenlandse Zaken baron Verstolk van Soelen voor zijn goede zorgen zijn nog aanwezig. ${ }^{223}$ Deze vreugde was dus van korte duur, want als uitvloeisel van het scheidingsverdrag met België werd bepaald dat alle stukken die op de Zuidelijke Nederlanden betrekking hadden, moesten worden afgestaan. In 1843 tekenden de twee commissarissen, W.H.J. baron van Westreenen van Tiellandt, thesaurier-chartermeester van de Hoge Raad van Adel, namens Nederland en F.C.L. Donny namens België de overeenkomst

\footnotetext{
${ }^{219}$ Voor Nederland is de keuze voor een van beide nationaliteiten nader uitgewerkt bij KB van 24 aug. 1839 (Stb. 39).

${ }^{220}$ Fox, 'Zuidnederlandse adel', 122-147; Schutte, 'Nederlandse adel met een vraagteken', 285-310.

${ }^{221}$ Kort en Wolleswinkel, Het archief van de Chambre Héraldique.

${ }^{222}$ De Win, 'De Raad van Adel', 78, noemt het teruggekeerde archief 'Heraldisch Fonds / Fonds Beydals' naar de Zuid-Nederlandse wapenkoning Beydals, die het archief bij het binnenvallen van de Franse troepen in veiligheid bracht door het naar Wenen te verplaatsen. Vergelijk voor de inhoud: Wolleswinkel, 'Een wapenboek uit 1560 van Jan Jansz. Potter', 23-27.

${ }^{223}$ HRvA, RA, inv. nr. 90 (1827-31).
} 
waarbij het archief van de Chambre Héraldique volgens een opgemaakte inventaris werd gesplitst. ${ }^{224}$ Kort daarna heeft R.A. baron van Hoëvell van Nijenhuis, secretaris van de Hoge Raad van Adel, (ook) een inventaris gemaakt van het Nederlandse deel. ${ }^{225}$

\section{1839-1848: zonder België}

De nieuwe indeling van het grondgebied betekende voor Nederland een terugkeer van de zuidgrens naar de tijd van de Republiek. Bij de opdeling van de provincie Limburg werd een geografische aansluiting gecreëerd met de voormalige generaliteitslanden voor Maastricht en delen van Opper-Gelder en Over-Maze. Van de gelegenheid werd gebruik gemaakt om de provincie Holland te splitsen in Noord- en Zuid-Holland, die feitelijk een eigen bestuur hadden. Op deze wijze werd het aantal van negen noordelijke provincies uitgebreid tot elf. Het aantal leden van de Eerste Kamer werd in de aangepaste Grondwet van 1840 gehalveerd, terwijl het gehalveerde ledental van de Tweede Kamer met drie vertegenwoordigers uit Limburg werd uitgebreid. ${ }^{226}$ De beraadslagingen over de herziening van de grondwet begonnen in de loop van 1839 , toen twee ministers hun verantwoordelijkheid hadden genomen en aftraden nadat de Tweede Kamer de tienjaarlijkse begrotingswet had verworpen.

\section{Strafrechtelijke ministeriële verantwoordelijkheid}

Mede onder invloed van de bilaterale ontwikkelingen was ook Gijsbert Karel graaf van Hogendorp (1762-1834), die zich in 1825 'om gezondheidsredenen' uit de politiek had teruggetrokken, met vergaande ideeën voor staatskundige hervormingen gekomen. Nadat de soevereine vorst hem in 1814 zowel tot vice-president van de Raad van State als voorzitter van het parlement, dat toen nog uit één kamer bestond, had benoemd, was de verhouding tussen beiden snel bekoeld. Graaf Van Hogendorp bleef ook in zijn gezaghebbende functies kritisch ten opzichte van de autocratische macht van de vorst. Vooral op financieel terrein probeerde hij daaraan paal en perk te stellen, maar de koning onttrok zich hieraan door veel bij koninklijk besluit te regelen, zodat geen parlementaire goedkeuring vereist was. In 1816 had hij zijn functie bij de Raad van State neergelegd, nadat Johan Hendrik Mollerus, een minder principiële vertrouweling van de koning, in zijn plaats was benoemd. Mollerus had onder koning Lodewijk Napoleon de invloedrijke post van minister van Binnenlandse Zaken bekleed en was door de Engelse gezant Le Poer

\footnotetext{
${ }^{224}$ HRvA, RA, inv. nr. 972.

${ }^{225}$ Het afgesplitste gedeelte van het archief berust thans nog bij de Raad van Adel van het Koninkrijk België, Federale OverheidsDienst (FOD) Buitenlandse Zaken in Brussel. In 1967 werd nog een viertal stukken overgedragen aan het Nationaal Archief van Luxemburg (HRvA, RA, inv. nr. 376).

${ }^{226}$ Van Haersolte, Inleiding tot het Nederlandse staatsrecht, 29; Van der Pot/Donner, Handboek van het Nederlandse staatsrecht, 8 druk (1968), 204 (met vermelding van alle grenswijzigingstractaten), uitvoeriger dan de $15^{\mathrm{e}}$ druk (2006).
} 
Trench, earl of Clancarty, gekarakteriseerd als een opportunistische carrièreambtenaar met een regentenmentaliteit. ${ }^{227}$ Deze typering was voor de koning kennelijk geen reden om van de benoeming van Mollerus, die zijn kwaliteiten als lid van de tweede grondwetscommissie had bewezen, af te zien.

Pogingen van de koning om de graaf Van Hogendorp ook als lid van de Tweede Kamer te lozen door hem in de Eerste Kamer te benoemen, mislukten, waardoor hij nog tot november 1824 kritisch kamerlid bleef. ${ }^{228}$ Graaf Van Hogendorp pleitte al in 1830-1831 voor het invoeren van (strafrechtelijke) ministeriële verantwoordelijkheid en het recht van Kamerontbinding, maar maakte niet meer mee dat deze in respectievelijk 1840 en 1848 werden gerealiseerd. Hij dacht in grondwettelijke evenwichten en opperde de mogelijkheid om de invoering van rechtstreekse verkiezingen gepaard te laten gaan met gelijktijdige versterking van de Eerste Kamer, die volgens het aristocratische beginsel (benoeming door de koning) was samengesteld. Hij was voorstander van een verkiezing van de leden van de Eerste Kamer door de ridderschappen. De adel zou er, in zijn optiek, voor kunnen waken dat de vrijheid van volk en vorst niet wederzijds zou kunnen worden aangetast. Hij zag vorst en volk nog altijd in elkaars verlengde en tegenover de aristocratie. ${ }^{229}$

In de nieuwe grondwet was de neerslag hiervan terug te vinden in de bepaling dat koninklijke besluiten voortaan mede-ondertekend dienden te worden door de verantwoordelijke minister. Met deze strafrechtelijke verantwoordelijkheid kon slechts de rechtmatigheid en (nog) niet de doelmatigheid van de handelingen worden getoetst. ${ }^{230}$

\section{De held van Waterloo als koning der Nederlanden}

De macht van de koning bereikte tussen 1829 en 1840 een hoogtepunt met de benoeming van de prins van Oranje tot vice-president van de Raad van State. Hij was Johan Hendrik (vanaf 1822: baron) Mollerus in deze gezaghebbende functie opgevolgd op dezelfde dag dat deze pragmatische bestuurder werd bedankt voor diens inzet 'ten nutte van den Staat'. Anders dan zijn jongere broer prins Frederik was hij aanvankelijk zelden aanwezig bij zittingen van de Raad van State, maar vanaf 1838 frequenter toen de koning hem installeerde als waarnemend voorzitter. Als een van de vroege wapenfeiten van de prins van Oranje gold de herziening van het strafrecht, waarbij hij voorstelde het duel niet strafbaar te stellen.

De 'held van Waterloo', zoals de prins sinds de definitieve val van Napoleon naar de gelijknamige veldslag werd genoemd, had zijn draai binnen het koninkrijk nog niet kunnen vinden. Zijn militaire opleiding aan het Engelse front tegen Napoleon

\footnotetext{
${ }^{227}$ Slijkerman, In dienst van de kroon, 56-66. Clancarty was in 1815 ambassadeur in Den Haag en kreeg van de nieuwe koning de titel van markies van Heusden bij recht van eerstgeboorte verleend omdat hij een belangrijk adviseur was geweest 'bij het verlossen van het vaderland van de vreemde overheerser', waarbij hij 'door veelvuldige daden zijn verknochtheid aan Ons' had doen blijken. Zie het vorige hoofdstuk.

${ }^{228}$ Slijkerman, In dienst van de kroon, 30-55.

${ }^{229}$ Slijkerman, In dienst van de kroon, 46 e.v.; Van Nifterik, 'De vorst in evenwicht', 196-202.

${ }^{230}$ Colenbrander, De afscheiding van Belgie, 153-195; Oud, Honderd jaren, 1-15
} 


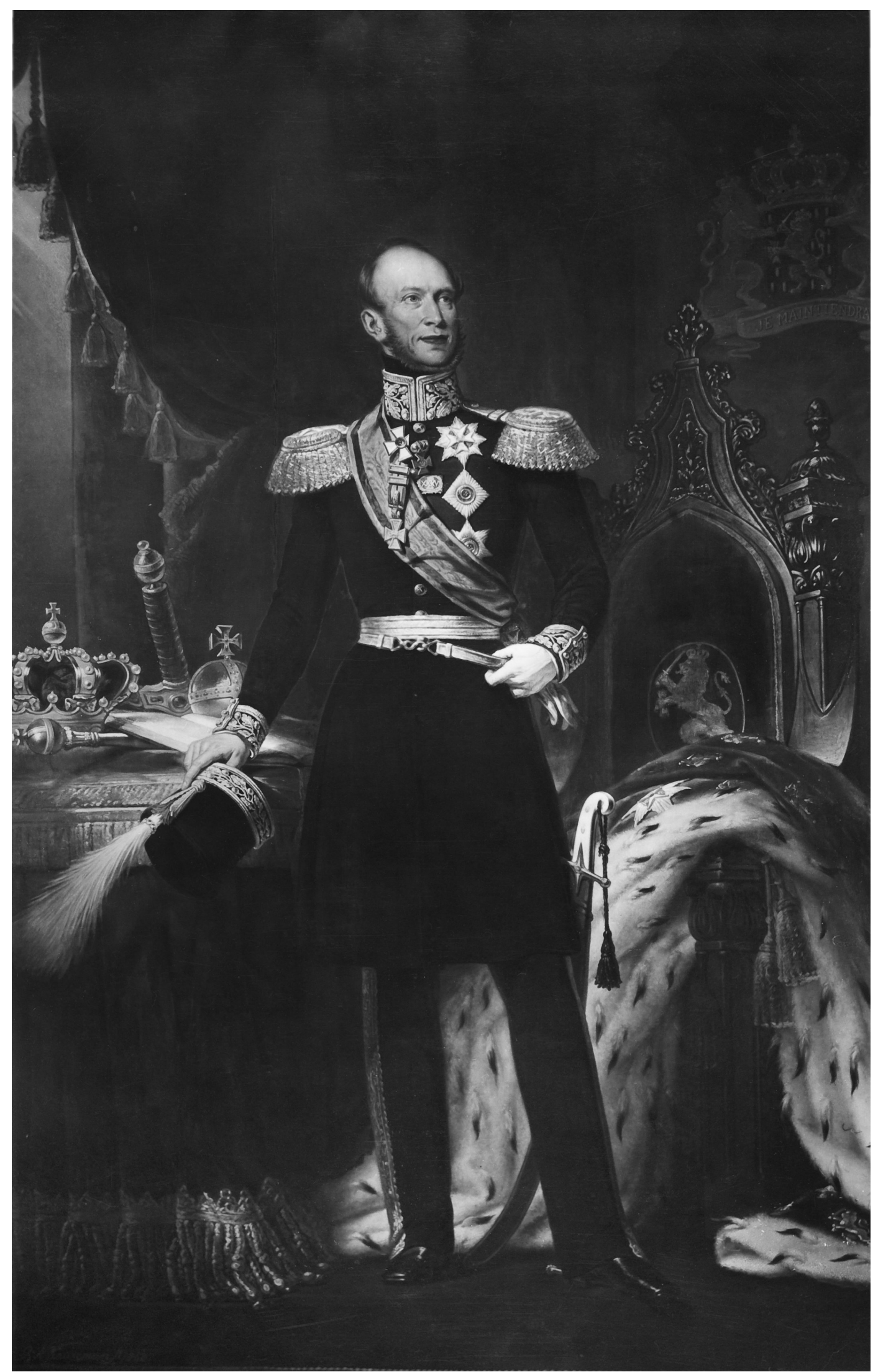

Willem II (1792-1849), koning der Nederlanden 1840-1849, groothertog van Luxemburg 1840-1849.

Doek, $275 \times 172 \mathrm{~cm}$, door Jan Adam Kruseman, 1848. Collectie Rijksdienst Cultureel Erfgoed (Eerste Kamer der Staten-Generaal, 's-Gravenhage). Foto RKD/IB, 's-Gravenhage. 
in Spanje onder leiding van generaal Wellington en de verbroken verloving met de dochter van de Engelse koning hadden hem geen succes gebracht. De duke of Wellington had de jonge prins eens gekarakteriseerd met 'too much is not to be expected from him'. Hij had hem voorts alle eer van de Slag bij Waterloo gegund, hoewel de prins bij Quatre Bras een schotwond in zijn schouder opliep en afgevoerd moest worden. Wellington had de grote nederlaag die de volgende dag aan de Fransen was toegebracht, echter laten uitstralen op het manmoedig optreden van de prins van Oranje. Daarvoor werd hij later door de koning bedankt met de adellijke titel prins van Waterloo, hem verleend bij eerstgeboorte. ${ }^{231}$ De verhouding tussen vader en zoon kwam onder druk te staan toen de prins van Oranje zich met de internationale politiek ging bemoeien en een mislukte poging deed koning van een verenigd België en Frankrijk te worden, waarbij de Bourbons van de troon zouden worden gestoten. Dit convenieerde niet met de plannen van de grote mogendheden en opnieuw redde Wellington de prins uit een penibele situatie. ${ }^{232}$

Op 7 oktober 1840 deed koning Willem I afstand van de troon en werd zijn oudste zoon ingehuldigd als koning Willem II. ${ }^{233}$

\section{Raad van Adel van het Koninkrijk België}

In België werd naar het voorbeeld van de (inmiddels Nederlandse) Hoge Raad van Adel op 26 september 1843 een Commission consultative pour la vérification des titres et l'examen des demandes de reconnaissance de noblesse (Adviescommissie voor het onderzoek van de aanspraken op en de aanvragen tot erkenning van adeldom) opgericht. Maar deze bood niet genoeg tegenwicht in het koninklijke adelsbeleid, zodat zij al bij KB van 6 februari 1844 werd vervangen door een Conseil héraldique met nauwkeuriger omschreven bevoegdheden, die vanaf het einde van de negentiende eeuw officieel in het Nederlands werd aangeduid als Raad van Adel. ${ }^{234}$ Inmiddels draaide de Belgische adelsmachine al op volle toeren, want tussen 1835 en 1844 verleende de koning maar liefst 166 adelsgunsten. ${ }^{235}$

Een zeldzame Luxemburgse adelsverlening uit 1843, die twee jaar later door koning Leopold I in België werd erkend met de titel baron op alle mannelijke afstammelingen, gaf een bijzondere inkijk op het adelsbeleid van koning Willem II als groothertog van Luxemburg. ${ }^{236}$ Luxemburgse adelsverleningen zijn op een hand te tellen en hadden geen rechtskracht in België en Nederland, waardoor zoals in 1845 een inlijvingsprocedure noodzakelijk was. ${ }^{237}$

\footnotetext{
${ }^{231}$ Zie het vorige hoofdstuk.

${ }^{232}$ Slijkerman, In dienst van de kroon, 68-75.

${ }^{233}$ Colenbrander, De afscheiding van België, 196-222.

${ }^{234}$ De Win, 'De Raad van Adel', 77-81.

235 [D'Udekem d'Acoz, Hoogstoel-Fabri en De Win], Le Droit nobilitaire et le Conseil héraldique / Het Adelsrecht en de Raad van Adel (1844-1994), 6.

${ }^{236}$ Duerloo en Janssens, Wapenboek van de Belgische adel, 693: KB van 22 juli 1843 te 's-Gravenhage en $\mathrm{KB}$ van 15 mei 1845 te Laken voor Ferdinand Ch.J. baron del Marmol, oud-hoofdinspecteur van waters en bossen.

${ }^{237}$ Kamerstukken II, 1991-1992, 22 485, nr. 5 (memorie van antwoord ontwerpwet op de adeldom), bijlage.
} 
Er is geen afdoende verklaring te geven voor het feit dat de Raad van Adel (Conseil de Noblesse) vanaf zijn ontstaan tot heden toe ressorteerde onder het Departement van Buitenlandse Zaken van het Koninkrijk België. De griffier van de Raad vermoedt dat het beperkte aantal departementen in de begintijd (slechts vijf), waarvan Buitenlandse Zaken naast een adellijke minister (graaf) en secretarisgeneraal (baron, later graaf) vele edellieden tot zijn diplomatieke corps kon rekenen, daaraan debet is geweest. ${ }^{238}$ Ook het beheer van de Belgische Nationale Orden is hieraan toegevoegd. In 1978 werd op basis van de Belgische grondwet een Consultatieve Commissie voor het toekennen van adellijke gunsten en voor het verlenen van eretekens van hoge graad (Commission d'avis sur les concessions de faveurs nobilitaires et sur l'octroi de distinctions honorifiques de grade élevé) opgericht, die jaarlijks voordrachten doet voor een adellijke gunst of een hoge onderscheiding. ${ }^{239}$

Dit betekent dat de Raad van Adel sinds 1978 uitsluitend adviseert over erkenning van adeldom, hetgeen in België wordt gedefinieerd als afstamming van oude adel of adel van vreemde origine, terwijl de Consultatieve Commissie persoonlijke adeldom en koninklijke onderscheidingen voor haar rekening neemt. De griffier van de Raad van Adel is vervolgens belast met de procedure betreffende alle adelsdiploma's, waarbij de heraldiek vanouds een belangrijke plaats inneemt. De Dienst van Adel (Service de la Noblesse) is de administratieve dienst van de FOD Buitenlandse Zaken en voert het secretariaat van beide adviesorganen. ${ }^{240}$

In de loop van het bestaan van de Raad van Adel schreed de federalisering van België voort en werd deze niet meer bevoegd geacht voor adviezen over gemeenteen provinciewapens. Deze werden overgeheveld naar de vier gewesten of gemeenschappen. Kort na het 150-jarig bestaan van de Raad werd besloten tot een hervorming van de samenstelling, bevoegdheden en taak. Bij KB van 27 februari 1996 werd het aantal leden vastgesteld op acht bij koninklijk besluit benoemde personen, het onbeperkte mandaat omgezet in een benoeming voor vier jaar (met optie tot herbenoeming) en zijn taak verengd tot adelszaken en de daarmee samenhangende heraldiek. ${ }^{241}$ Een in 1997 in werking getreden Belgische wet ter bevordering van de evenwichtige aanwezigheid van mannen en vrouwen in organen met adviserende bevoegdheid maakte een nieuwe aanpassing in de samenstelling van de Raad van Adel noodzakelijk. Bij KB van 16 december 1999 werd het aantal onafhankelijke deskundigen op het gebied van adelsrecht en heraldiek verruimd van acht tot maximaal twaalf. ${ }^{242}$ Deze plaatsen worden, gezien de communautaire evenwichten, door zes Nederlandstaligen en zes Franstaligen bezet. De griffier is een toegevoegd ambtenaar van de FOD Buitenlandse Zaken, Buitenlandse Handel en Ontwikkelingssamenwerking, met een licentiaat of doctoraat in de rechten of in

\footnotetext{
${ }^{238}$ De Win, 'De Raad van Adel', 78.

${ }^{239} \mathrm{~KB}$ van 31 jan. 1978 (Belgisch Staatsblad van 26 mei 1978), met uitbreiding/wijziging van bevoegdheden in 2003 en 2004.

${ }^{240}$ De Win, 'De Raad van Adel', 80-81.

${ }^{241}$ Belgisch Staatsblad van 9 maart 1996.

${ }^{242}$ Belgisch Staatsblad van 29 febr. 2000.
} 
de geschiedenis, die eveneens wordt benoemd door de koning op voordracht van de minister van Buitenlandse Zaken. ${ }^{243}$

\section{1848-1937: adeldom in plaats van adelstand}

Het eerste concrete initiatief voor een algehele grondwetsherziening kwam van de zijde van de liberale hoogleraar Johan Rudolf Thorbecke, die in 1844 door de Staten van Zuid-Holland tot lid van de Tweede Kamer was gekozen. Acht Kamerleden sloten zich bij hem aan en als 'commissie van negenmannen' kwamen zij met ingrijpende voorstellen. In eerste instantie wees de Kamer het initiatief in meerderheid af, omdat dit bij de soeverein zou berusten, en dit kostte Thorbecke zijn Kamerzetel. Landelijke onrust door toenemende werkloosheid en stijgende prijzen van levensmiddelen bracht de regering er in 1847 toe in de troonrede voorstellen voor een grondwetsherziening aan te kondigen. Eerst in 1848, toen in omliggende landen - maar niet in het nog jonge Koninkrijk België - volksrevoluties ontstonden en tronen omver werden geworpen, zag ook koning Willem II de ernst van de situatie in. Nadat hij buiten zijn ministers om de oppositie in de Tweede Kamer was gaan aanhangen om een ruimere grondwetsherziening tot stand te brengen, nam zijn kabinet onmiddellijk ontslag. De koning weigerde ondanks adviezen van de Kamer om Thorbecke te vragen een nieuwe regering te vormen, maar riep daarvoor zijn vertrouweling, de gezant Gerrit graaf Schimmelpenninck, zoon van de Napoleontische raadpensionaris Rutger Jan, uit Londen terug. Thorbecke werd evenwel voorzitter van de weldra benoemde grondwetscommissie, terwijl de liberaal van het eerste uur Dirk Donker Curtius als minister van Justitie aantrad. Het rapport van de grondwetscommissie, waarin algemene ministeriële verantwoordelijkheid, het recht tot kamerontbinding, éénjaarlijkse begrotingen en rechtstreekse verkiezingen werden bepleit, deed het Kabinet Schimmelpenninck splijten, maar voorkwam de grondwet niet. ${ }^{244}$

\section{Afschaffing van de standenmaatschappij}

De nieuwe grondwet, die op 3 november 1848 plechtig werd afgekondigd, introduceerde de belangrijke zinsnede die ook in de huidige grondwet nog is terug te vinden: 'De Koning is onschendbaar; de ministers zijn verantwoordelijk.' ${ }^{245}$ Koning Willem II zou de nieuwe politieke situatie niet lang meer meemaken; hij overleed op 17 maart 1849 aan zijn hartkwaal. ${ }^{246}$

\footnotetext{
${ }^{243}$ Thans Dr. Paul de Win, benoemd bij KB van 11 april 1996. De Win, 'De Raad van Adel', 77-81.

${ }^{244}$ Hooykaas en Santegoets, De briefwisseling van J.R. Thorbecke, 5, VII-XII.

245 [Berendse en Brood], In 21 stappen vrij onverveerd, nr. 13 (NA, Archief KdK, 2.02.02, inv. nr. 514). Grond van 3 nov. 1848 (Stb. 63), art. 53; Grondwet van 19 jan. 1983 (Stb. 19), art. 42, lid 2.

${ }^{246}$ Oud, Honderd jaren, 15-24.
} 


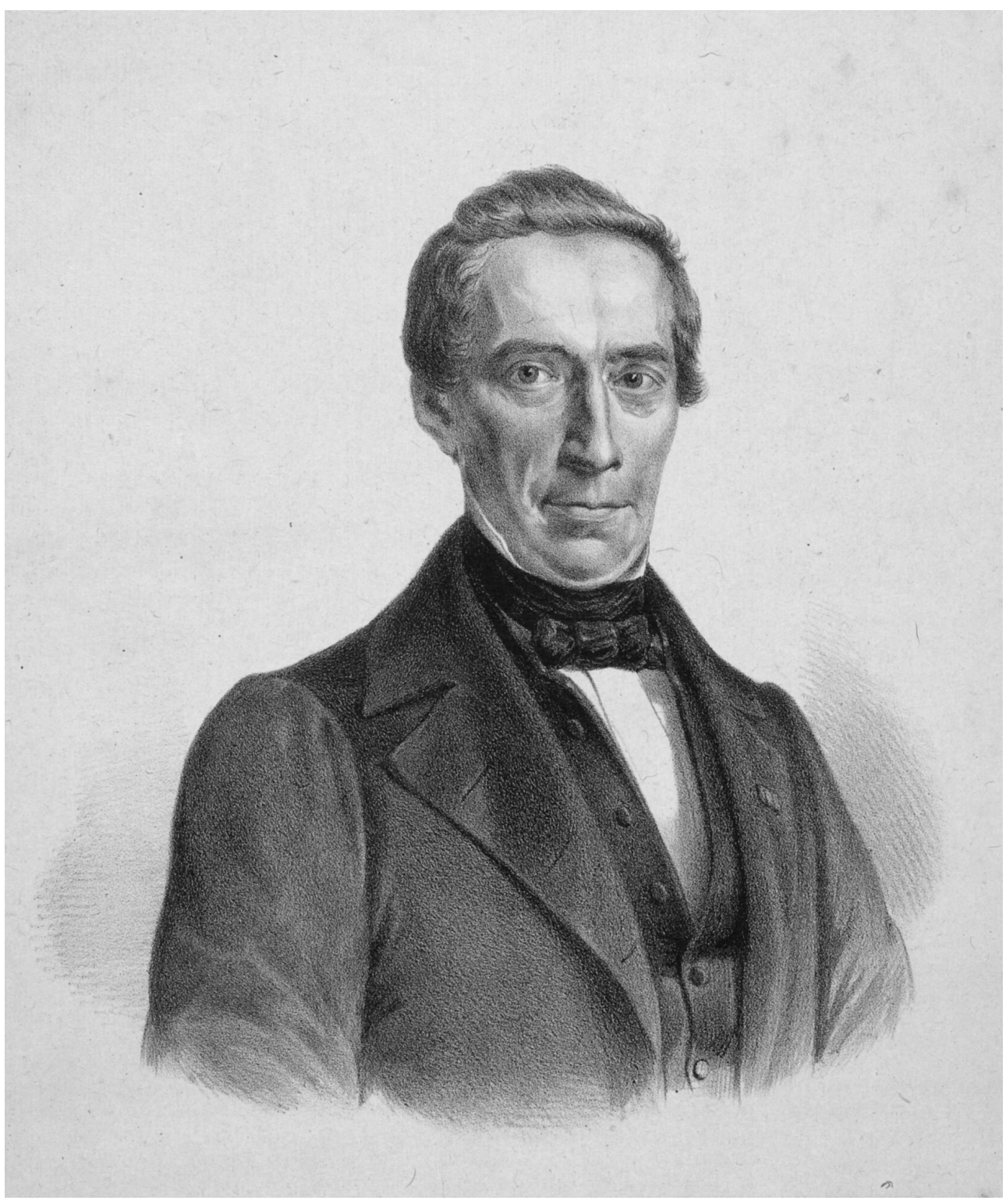

Johan Rudolf Thorbecke (1798-1872), voorzitter van de grondwetscommissie 1848 en minister van Binnenlandse Zaken van 1849-1853, 1862-1866 en 1871-1872.

Litho door P.W.M. Trap naar het schilderij door J.H. Neuman, 1852. Collectie en foto RKD/IB, 's-Gravenhage.

Het woord adelstand werd in de grondwet vervangen door adeldom, waarmee de bijzondere stand met eigen rechten in staatsrechtelijke zin verdween. Artikel 62 van de grondwet van 1840 ('De Koning verheft in den adelstand') werd vervangen door artikel 63 in de grondwet van 1848 ('De Koning verleent adeldom'). ${ }^{247}$

Na een voor de liberalen zeer gunstige verkiezingsuitslag trad op 1 november 1849 het eerste Kabinet Thorbecke aan, dat voortvarend aan de slag ging. Belangrijke wapenfeiten werden de uitvaardiging van de door de grondwet gevorderde kies-

\footnotetext{
${ }^{247}$ Van Meeuwen, 'Een en ander over het Nederlandse adelsrecht', 84.
} 
wet, provinciale wet en gemeentewet. ${ }^{248}$ De Wet op de samenstelling en de macht van de Provinciale Staten van 6 juli 1850 (Stb. 39) concretiseerde de door de grondwet aangekondigde belangrijke wijziging in de positie van de adel. Door de afschaffing van de standenmaatschappij werd de verkiezing van de leden van Provinciale Staten, die voordien door de drie standen (adel, steden en platteland) plaatsvond, opgedragen aan alle ingezetenen die kiesrecht hadden. Het organisch kiesrecht van 1814 werd omgezet in het individueel kiesrecht van 1848. Dit betekende evenwel nog lang geen algemeen kiesrecht, maar slechts censuskiesrecht, gebaseerd op de aanslag in de directe belastingen, die toen niet meer inhield dan een grondbelasting. Een vermogens- of inkomstenbelasting bestond nog niet en zou eerst aan het einde van de negentiende eeuw haar intrede doen. Het heffen van accijnzen, een belasting toegevoegde waarden, zorgde voor het grootste deel van de belastingopbrengst. Daarnaast was er nog de personele en successiebelasting, maar de vererving in rechte lijn was vrij van belasting. Inkomen en roerend goed werden niet belast, hetgeen betekende dat groepen gezeten burgers, zoals leden van hoge colleges van staat en doctoren aan universiteiten, vaak geen kiesrecht hadden. De grondgebonden adel behield doorgaans zijn positie van stemgerechtigde.

De gekozen leden van Provinciale Staten kozen op hun beurt de leden van de Eerste Kamer uit de hoogstaangeslagenen in de directe belastingen. De lijsten van hoogstaangeslagenen werden gespecificeerd in de Staatscourant gepubliceerd. De leden van de Tweede Kamer werden wel direct gekozen, maar ook volgens het censuskiesrecht. $^{249}$

Twee koninklijke besluiten uit 1850 geven in zakelijke bewoordingen de nieuwe situatie betreffende de adel weer. Op 20 juli 1850 ondertekende de minister van Binnenlandse Zaken Thorbecke, als tijdelijk voorzitter van de Raad van Ministers, het koninklijke besluit waarin werd bepaald dat met ingang van 1851 de betrekkingen van de voorzitter en de leden van de Hoge Raad van Adel onbezoldigde ereambten werden. Op 9 november 1850 werden de drie afgetreden leden, die eervol ontslag met pensioenvoorziening hadden gekregen, opnieuw met ingang van 1851 benoemd volgens het nieuwe regiem.

Bij de behandeling van de staatsbegroting voor 1851 rezen in het parlement voor het eerst vragen over de kosten van een instituut waarvan de reden van bestaan niet geheel duidelijk meer was. De minister liet berekenen waaruit deze kosten nog bestonden, nu de voorzitter en de leden een onbezoldigd ereambt bekleedden: salariskosten $f 6259$,- voor zes ambtenaren en $f$ 1385,- voor locatie- en bureaukosten. Gezien de verandering van de taak verschilden de koning, geadviseerd door de Hoge Raad van Adel, en de minister van mening over de aanpassing van de bestaande regelgeving. Koning en Raad wilden het KB van 1822 (opstellen van

\footnotetext{
${ }^{248}$ Hooykaas en Santegoets, De briefwisseling van J.R. Thorbecke, 5, VII-XII.

${ }^{249}$ Van der Pot/Donner, Handboek van het Nederlandse staatsrecht, 327-329; Oud, Honderd jaren, 25-35. Vgl. Moes, Onder aristocraten, passim.
} 


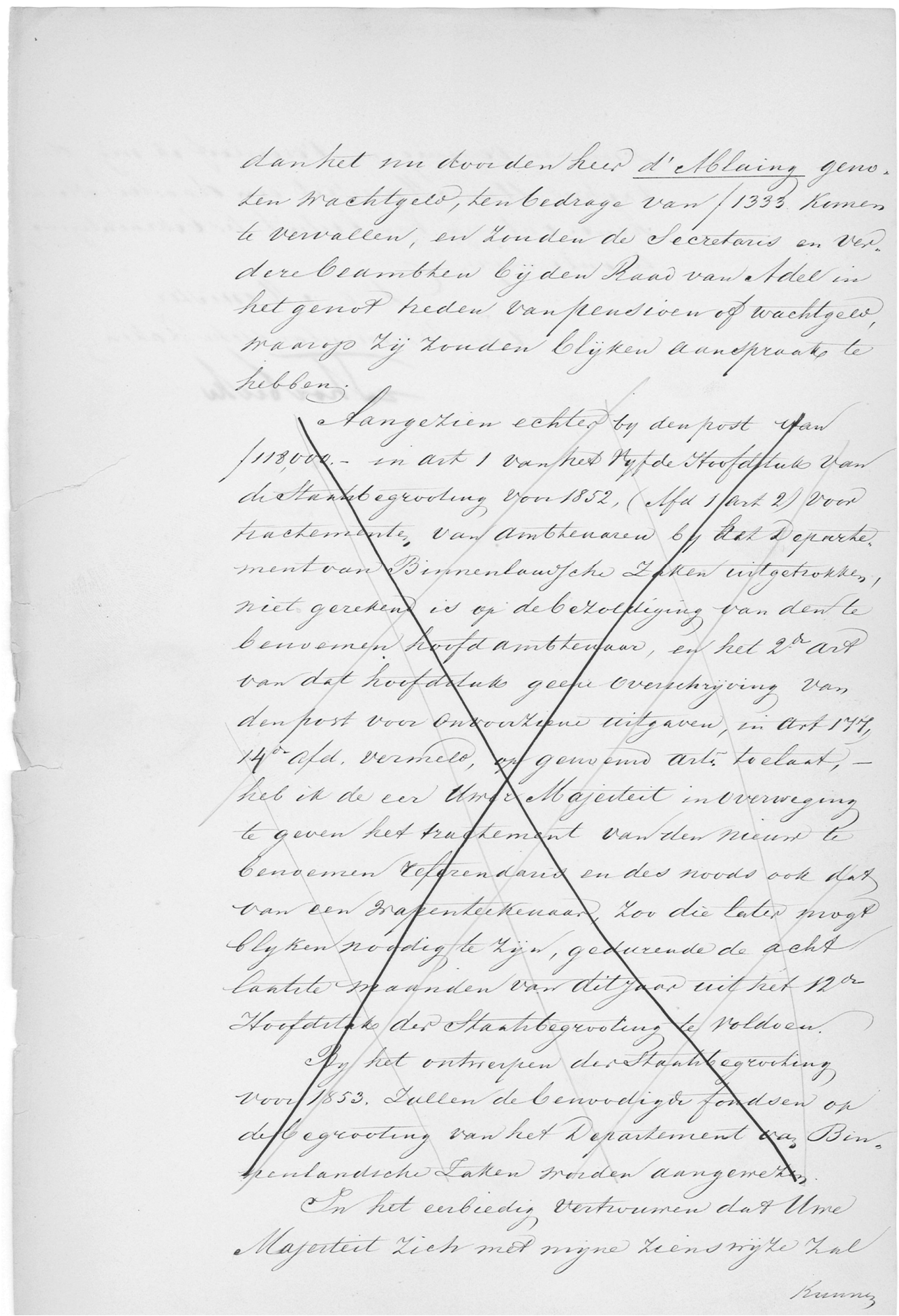

Minuutbrief van J.R. Thorbecke, d.d. 5 jan. 1852. HRvA, RA, inv.nr. 948.

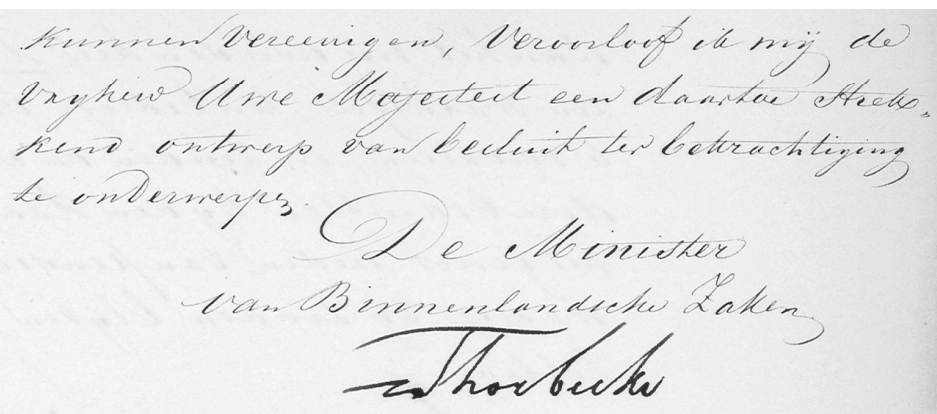


adelslijsten ná de Afscheiding, titulatuur bij eerstgeboorte, Nederlands filiatieregister) aanpassen, terwijl de minister het SB van 1814 (instructie, opdracht en samenstelling van de Raad) ingrijpend wilde wijzigen. ${ }^{250}$ Daarbij werd een vergelijking gemaakt met de Raad van Adel in België, die geen onafhankelijke positie had en onderdeel uitmaakte van het Ministerie van Buitenlandse Zaken. De parlementaire behandeling van de begrotingen voor 1852 en 1853 resulteerde in een scherpe briefwisseling tussen minister Thorbecke en A.G.A. ridder van Rappard, directeur van het Kabinet des Konings. Thorbecke dreigde op 5 januari 1852 de Raad om redenen van bezuiniging en vereenvoudiging op te heffen. ${ }^{251}$ De koning wilde hier niet in meegaan en stelde uiteindelijk voor de Raad buiten de rijksbegroting om te financieren uit het zogenaamde Adelsfonds, dat was gevormd uit taxa-inkomsten en belegd in het Grootboek der Nationale Schuld. ${ }^{252}$ De minister ging akkoord, maar de discussie over de bestemming van de renten duurde voort tot 1856 , toen een wetsontwerp werd ingediend houdende een regeling ter bestemming van het fonds. ${ }^{253}$ Het is echter nooit tot wet geworden en het bevroren kapitaal wordt tot op de dag van vandaag door het Ministerie van Financiën beheerd, terwijl de rente wordt afgedragen aan het Ministerie van Binnenlandse Zaken. ${ }^{254}$

Voor de realisatie van het compromis vaardigden koning en minister een nieuw koninklijk besluit uit, waarin de taak van de Hoge Raad van Adel werd beperkt tot 'het geven van advies over aangelegenheden den adelstand [sic] betreffende' en uitsluitend in het geval de minister daarover aan de koning zou moeten rapporteren. Bij hetzelfde $\mathrm{KB}$ van 17 september 1852, nr. 44, werden alle overige werkzaamheden van de Raad met ingang van 1853 door het Departement van Binnenlandse Zaken uitgeoefend. Baron D'Ablaing van Giessenburg trad terug als lid van de Raad en werd referendaris van het departement, waarbij zijn wachtgeld in een salaris werd omgezet. Hij zou voorts in zijn functie van hoofdambtenaar ('raadsadviseur van de minister') steeds als secretaris van de Raad optreden. De vacature in de Raad werd bij dezelfde gelegenheid ingevuld, waarmee deze (voorlopig) bleef bestaan uit een voorzitter en twee leden. ${ }^{255}$ Deze kleine samenstelling had direct te maken met het verlies door de nieuwe regeling van de eigen ruimte op het Binnenhof, waar het Hoog College van Staat tot 1852 zetelde. Een serieus voorstel van minister Thorbecke om de naam van het uitgeklede adviescollege bij deze gelegenheid te veranderen in Raad van Adel, stuitte op directe weerstand van de koning, met wie de minister via de directeur van het Kabinet des Konings correspondeerde. Het schrappen van de Raad uit hoofdstuk II van de Rijksbegroting leidde

\footnotetext{
${ }^{250}$ HRvA, RA, inv. nr. 147 (not. 1850-76).

${ }^{251}$ HRvA, RA, inv. nr. 948, briefwisseling 1850/1851 (Kabinet, nr. 112) en 1852 (Kab., nr. 204), zie: Bijlage 1. Deze briefwisseling ontbreekt in Hooykaas en Santegoets, De briefwisseling van J.R. Thorbecke, 5 (1845-1853).

${ }^{252}$ Ruijs de Beerenbrouck, 'Uit de geschiedenis van de Hoge Raad van Adel', 103-104 (het daar genoemde jaartal 1851 moet zijn 1852).

${ }^{253}$ Van Randwijck, 'De lijdensgeschiedenis van een Adelfonds', 18-36.

${ }^{254}$ [Nijkamp en Schutte], De Nederlandse Adel, 21-22.

255 [Beelaerts van Blokland e.a.], De Hoge Raad van Adel, 177-179 (bijlagen IIIb).
} 


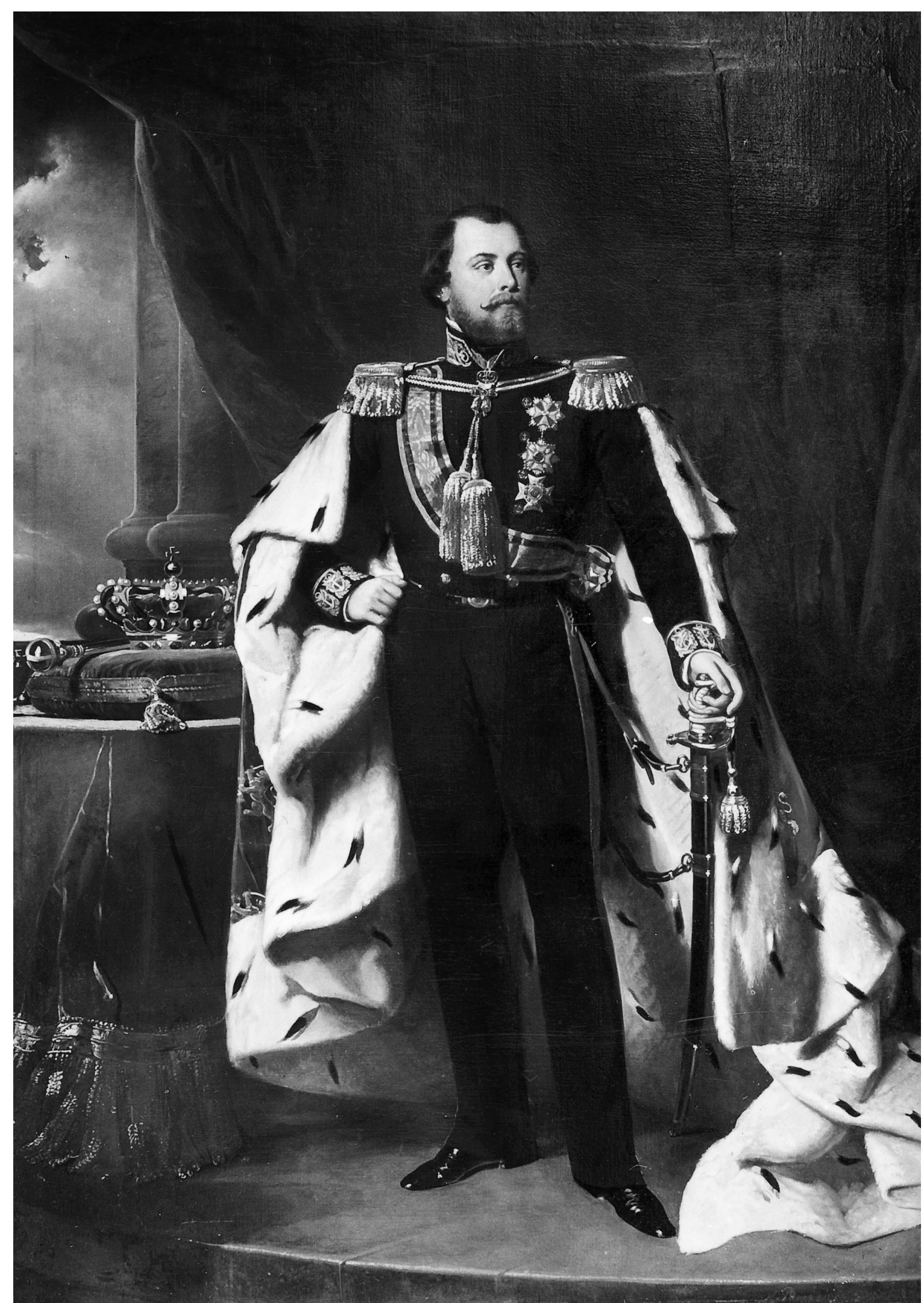

Willem III (1817-1890), koning der Nederlanden 1849-1890, groothertog van Luxemburg 18491890.

Doek, afmeting onbekend, door N. Pieneman. Collectie Rijksdienst Cultureel Erfgoed (verblijfplaats onbekend, destijds in Nederlands Oost-Indië). Foto RKD/IB, 's-Gravenhage. 
wel tot het vervroegd terugtreden per ultimo december 1852 van jonkheer De Witte van Citters, die geen eervolle taak meer voor zichzelf als voorzitter zag weggelegd. De door de koning, na een snelle voordracht van de minister, op de valreep aan hem verleende adellijke titel van ridder bij recht van eerstgeboorte, werd niet geaccepteerd. Jonkheer Van Citters heeft het diploma althans niet gelicht, waardoor de titelverlening een half jaar later was vervallen. ${ }^{256}$

Hoe doortastend het Kabinet Thorbecke op staatsrechtelijk gebied ook opereerde, de eveneens in de grondwet gewaarborgde vrijheid voor kerkgenootschappen om hun inwendige organisatie te regelen, werd het kabinet op 19 april 1853 noodlottig. Het herstel van de rooms-katholieke bisschoppelijke hiërarchie met de vestiging van de aartsbisschop in het calvinistische Utrecht gaf in het land zoveel commotie, dat ook koning Willem III erin betrokken raakte. Opnieuw ontstond een tweespalt tussen vorst en regering, waarna de koning zijn ministers ontsloeg. Bij de daaropvolgende Tweede Kamerverkiezingen veroverde Thorbecke nog net een kamerzetel dankzij het katholieke Maastricht. ${ }^{257}$ Het zou vervolgens negen jaar en vijf kabinetten duren voor in 1862 een tweede Kabinet Thorbecke aantrad, terwijl in 1871 zelfs een derde werd gevormd, maar dit was van korte duur. Eén dag voor de installatie van het opvolgend kabinet overleed hij op 4 juli 1872, na een ziekbed van een half jaar. $^{258}$

\section{Reciprociteitsbeginsel}

Bij KB van 22 maart 1856, nr. 60, stelde de nieuwe minister van Binnenlandse Zaken jonkheer Van Reenen, met het oog op de gewijzigde taak van de Raad, een nieuw formulier voor de eedsaflegging vast. Aangezien de Raad tussen 1853 en 1857 niet bijeenkwam, lijkt dit koninklijk besluit een nogal academisch karakter te hebben. In juli 1858 kwam de Raad voor het eerst weer bijeen in de kamer op het Binnenhof waar hij in december 1852 voor het laatst had vergaderd. ${ }^{259}$ Eén van de redenen waarom de minister de Raad weer wilde consulteren, was mogelijk onvoldoende ambtelijke interesse voor en deskundigheid in adelszaken. Het laatste kan althans opgemaakt worden uit de titelverlening Mackay in maart 1858 zonder advies van de Raad en met onjuiste juridische argumentatie. Leden van dit Schotse geslacht, dat tot de oude adel van Groot-Brittannië behoorde, konden in 1815 wegens het ontbreken van reciprociteit (wederkerigheid) met de continentale adel niet ingelijfd worden in de Nederlandse adel. ${ }^{260}$ Om die reden werden twee leden van geslacht Mackay in 1815-1816 verheven en werd hun in 1822 als bijzondere gunst de titel van baron bij eerstgeboorte verleend. In 1858 echter werd in strijd met het reciprociteitsbeginsel voor anti-revolutionair Aeneas baron Mackay, lid van de

\footnotetext{
${ }^{256}$ HRvA, RA, inv. nr. 948.

${ }^{257}$ Oud, Honderd jaren, 38-45.

${ }^{258}$ Ibidem, 46-98.

${ }^{259}$ HRvA, RA, inv. nr. 150 (not. 1858).

${ }^{260}$ KB's van 21 aug. 1815, nr. 79, en 16 sept. 1815, nr. 70 (geen inlijving, maar verheffing van leden van de geslachten Quarles, Melvill van Carnbee, Mackay en Clifford).
} 
Tweede Kamer en kamerheer in buitengewone dienst van de koning, tezamen met de kinderen van zijn overleden broer, de titel baron op allen gehomologeerd 'wegens het hier te lande gedurende anderhalve eeuw voeren van deze titel', met vrijstelling van taxa. ${ }^{261}$ Hier zijn twee basisregels door elkaar gehaald. Voor het toekennen van de titel baron op allen is bewijs van oude inheemse adeldom noodzakelijk alsmede het gedurende langere tijd tijdens het ancien regime voeren van de titel. Titelhomologatie daarentegen heeft altijd betrekking op buitenlandse titels, dient tezamen met inlijving plaats te vinden, en betekent zelden titelverlening op allen. ${ }^{262}$ Het officiersgeslacht Mackay woonde weliswaar al meer dan honderdvijftig jaar in Tiel en omgeving, waar het in de achttiende eeuw door huwelijk de heerlijkheid Ophemert verkreeg, maar het afwijkende statuut dat Engelse adeldom kenmerkt, had op grond van de wetgeving (1815) nooit inlijving al of niet tezamen met titelhomologatie in de Nederlandse adel tot gevolg kunnen hebben. ${ }^{263}$ Nog in 1839 en 1841 had de Raad aanhoudende verzoeken vanuit de familie Mackay beoordeeld, maar 'wegens verschil van gevoelen' niet afgedaan. Voorzitter baron Van Lijnden van Hemmen had nog wel oren gehad naar een bijzondere gunst en was verantwoordelijk voor de getelde jaren 'oude adeldom', maar baron Snouckaert was om bovenstaande principiële redenen pertinent tegen geweest. In 1858 werd vanuit het departement als ondersteunende argumentatie gegeven 'dat de wederkerigheid, sedert de adel hier geen politieke stand meer uitmaakt, bezwaarlijk [is] vol te houden' en geen bezwaar bestaat 'om zonder bepaalde inlijving deze uitzondering bij gunst te verleenen' ${ }^{264}$ En aldus was geschied, maar nadat vanaf dat jaar de Raad (toch) weer om advies werd gevraagd, hebben geen Britse inlijvingen, laat staan titelerkenningen, meer plaatsgevonden.

\section{De Hoge Raad van Adel als adviseur van de minister van Justitie}

Per 1 januari 1860 trad opnieuw een wijziging in en werd de secretarie van de Hoge Raad van Adel een afdeling van het Departement van Justitie. ${ }^{265}$ De dienstdoende hoofdambtenaar, de referendaris baron D'Ablaing, ging bij KB van 6 juli

\footnotetext{
${ }^{261}$ Bij KB van 17 maart 1858, nr. 131 (met argumentatie op het adelsdiploma). Zie voor een beknopte biografie: Slijkerman, In dienst van de kroon, 96-105.

${ }^{262}$ [Nijkamp en Schutte], De Nederlandse Adel, 16 en 144-145.

${ }^{263}$ Nederland's Adelsboek 88 (1999), 16-55.

${ }^{264}$ HRvA, RA, inv. nr. 281, f. 158 en 181.

${ }^{265}$ HRvA, RA, inv. nr. 949. Bij beschikking van de minister van Justitie Godefroi van 5 januari 1860, nr. 101, ging de Afdeeling Adel van het Departement van Binnenlandse Zaken over naar dat van Justitie, waar deze deel ging uitmaken van de Zesde Afdeeling. Bij beschikking van de minister van Justitie Pické van 12 mei 1866, nr. 123, werd de Afd. Adel weer opgeheven wegens de opheffing van de betrekking van raadadviseur voor de zaken van den Adel (bedacht voor en uitgeoefend door baron d'Ablaing). De behandeling van adelszaken werd toegevoegd aan de Tweede Afdeling (benoeming adj.-commies mr. H.A. Piepers). Bij beschikking van de minister van Justitie Jolles van 11 jan. 1871, nr. 153, werd de Tweede Afd. gesplitst in de onderafdelingen A, B en C. Bij beschikking van de minister van Justitie graaf Van Lynden van Sandenburg van 19 juli 1876, nr. 146, werd de Tweede Afd. samengesteld uit de referendaris jonkheer P.J. van Beijma (chef), de hoofdcommies jonkheer P.A. van den Velden, de commies A. Teixeira de Mattos en de adj. commies G.A.N.T. Jansen. Toegevoegd werd de refendaris A.J.L.M. Lux. De heer Hartman (Eerste Afd.) zorgde voor de bibliotheek.
} 
Willem Jan baron d'Ablaing van Giessenburg (1812-1892), lid (1848-1852) en secretaris (1852-1861) van de Hoge Raad van Adel, raadsadviseur van de minister van Justitie inzake adelszaken 1861-1866. Doek, $81 \times 66 \mathrm{~cm}$, door J.H. Neuman, 1864/ 1865.

Collectie en foto Museum van de Kanselarij der Nederlandse Orden (Nationaal Museum Paleis Het Loo), Apeldoorn.

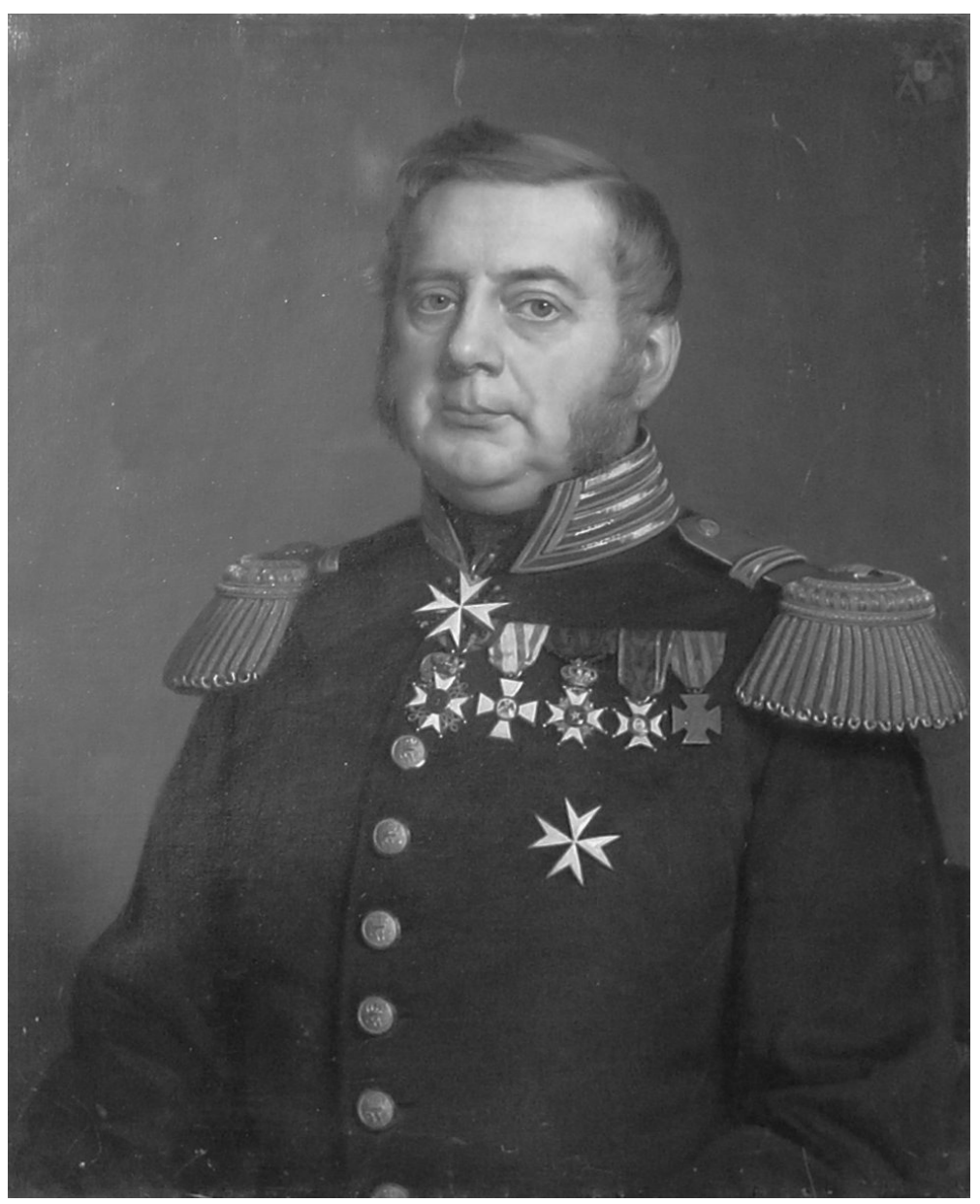

1859, nr. 46, onder dezelfde voorwaarden van het ene naar het andere departement over. Belangrijk was verder dat de uitgaven met betrekking tot adelszaken met ingang van die datum weer onder de Rijksbegroting werden gebracht. Dit zou kunnen duiden op een zekere professionalisering van de werkzaamheden, maar eerst bij KB van 12 mei 1866, nr. 48, kwam de Raad weer op zijn oude sterkte: een voorzitter en vier leden. Ook kreeg hij zijn initiatiefrecht terug om adelszaken aan de minister voor te leggen. ${ }^{266}$ Het reglement van orde uit 1858 zou vervangen worden, hetgeen medio 1867 plaatsvond. Toen in de departementsgebouwen aan het Binnenhof ruimtegebrek ontstond, werd 'het archief en de bibliotheek van den Adel' in 1871 naar een lokaal aan de Nobelstraat in Den Haag overgebracht. ${ }^{267}$ Deze situatie duurde tot einde 1883, toen het nieuwe Departement van Justitie aan het Plein werd opgeleverd. Daar kreeg de Raad een representatieve vergaderzaal op de verdieping exact boven de zaal waar de ministerraad vergaderde, maar met nog steeds beperkte toegang tot archief en bibliotheek. ${ }^{268}$ Uit de reglementen van orde van de Hoge Raad van Adel van 1867-1893 blijkt deze beschikbaarheid een strijdpunt tussen departement en Raad te zijn geworden. De mogelijkheid tot inza-

\footnotetext{
266 [Beelaerts van Blokland e.a.], De Hoge Raad van Adel, 180-182 (bijlagen IIIB).

${ }^{267}$ HRvA, RA, inv. nr. 154 (not. 1871-1).

${ }^{268}$ Kort en Wolleswinkel, Het archief van de Hoge Raad van Adel, 6-7.
} 
ge was voor voorzitter en leden van de Raad in 1867 en 1883 zeer beperkt, maar werd in 1893 versoepeld omdat zo kennelijk niet te werken viel. ${ }^{269}$

Bij KB van 25 dec. 1881, nr. 10, was de waarnemend-secretaris ten slotte weer een bij koninklijk besluit benoemde secretaris geworden. Al na het terugtreden in 1861 van baron D'Ablaing was de kamerheer des konings jonkheer E.W. van Weede aangesteld tot honorair-secretaris, terwijl vanaf 1866 de hoofdcommies bij het departement, jonkheer P.A. van den Velden, het secretariaat waarnam. ${ }^{270}$ Laatstgenoemde werd in 1881 tot secretaris benoemd, maar verbleef vanaf 1884 regelmatig in het buitenland. ${ }^{271}$ Gedurende die tijd trad de commies G.A.N.T. Jansen van Afferden als plaatsvervanger op. ${ }^{272}$ Nadat jonkheer Van den Velden op 7 januari 1892 te Cannes (Fr.) was overleden, nam Jansen ook nog periodiek waar onder de opvolgend secretaris jonkheer Rutgers van Rozenburg, laatstelijk in 1901.

Kenmerkend voor deze periode is het afnemende aantal adelsverleningen. In de eerste plaats was dit een direct gevolg van de afschaffing van de adelstand, maar daarnaast ook vanwege het feit dat zo goed als alle inheemse adel inmiddels in de Nederlandse adel was erkend. Daar waar nog verheffing aan de orde kwam, lag een sterke nadruk op persoonlijke verdienste in tegenstelling tot afstamming uit regentengeslachten. Een bijzondere reden voor adelsverlening was het zilveren regeringsjubileum van de koning op 12 mei 1874. In een verzamelbesluit werden aan zes hoge hoffunctionarissen wegens trouwe dienst (hogere) titels verleend en werd de secretaris van het Kabinet des Konings Berckmans de Weert verheven; de minister van Buitenlandse Zaken en twee commissarissen des Konings kregen (hogere) titels, terwijl de burgemeester van Amsterdam Den Tex werd verheven. ${ }^{273}$ Bij de titelverlening wegens bijzondere persoonlijke verdienste schroomde de koning niet deze in een tiental gevallen op alle afstammelingen toe te passen. ${ }^{274}$ Dit laatste was in strijd met de regel dat titelverlening op allen in feite titelerkenning van oude adeldom betekende. Zelfs de graventitel, die door inheemse adel slechts bij uitzondering was gevoerd, werd in een aantal gevallen op allen verleend. ${ }^{275}$ Ook enkele zeldzame voorbeelden van persoonlijke adeldom, bijvoorbeeld de verheffing met titelverlening van de grootmeesteres van koningin Sophie tot barones Van Wickevoort Crommelin (1877), dateren uit deze periode. ${ }^{276}$

Deze gang van zaken had het Drentse Tweede Kamerlid Oldenhuis Gratama aanleiding gegeven om tijdens de begrotingsbehandeling van Justitie voor het jaar

\footnotetext{
${ }^{269}$ Ruijs de Beerenbrouck, 'Uit de geschiedenis van de Hoge Raad van Adel', 104.

${ }^{270}$ Ibidem, 95-96.

${ }^{271} \mathrm{~KB}$ van 28 dec. 1881, nr. 99 (HRvA, RA, inv. nr. 449).

${ }^{272}$ NA, Archief Departement van Justitie (toegang 2.09.22), inv. nr. 15993, missive van de minister d.d. 2 juli 1884, $2^{\mathrm{e}}$ Afd., nr. 69. Zijn naamstoevoeging werd vastgesteld bij KB van 19 okt. 1876, nr. 23.

${ }^{273} \mathrm{~KB}$ van 12 mei 1874, nr. 12; bij KB van 3 juni 1874, nr. 33 werd aan alle elf genobiliteerden vrijstelling van taxa verleend (HRvA, RA, inv. nr. 155 (not. 1874-9/6).

${ }^{274}$ [Nijkamp en Schutte], De Nederlandse Adel, 17.

275 Van Valkenburg, 'Adelsbeleid sedert 1813', 66-69;

${ }^{276}$ De facto betrof het hier een verheffing, die anders dan bij mannelijke genobiliteerden niet op nakomelingen kon vererven, al werd expliciet vermeld dat de verlening 'uitsluitend haar persoon' betrof (KB van 7 aug. 1877, nr. 52).
} 
1875 kritische vragen te stellen over het adelsbeleid en de financiering van het bureau van de Hoge Raad van Adel op het departement. De verantwoordelijk minister graaf Van Lynden van Sandenburg gaf toe 'dat vroeger streng toegezien [is] dat bij de creatie van nieuwen adel de titel slechts bij regt van eerstgeboorte overgaat, en zijn de afwijkingen daarvan, eenmaal in 1868 en nu laatstelijk in Mei, als uitzonderingen te beschouwen aan bijzondere omstandigheden ontleend. In hoever de werkzaamheden van den Raad van Adel [sic!] op andere wijze kunnen worden geregeld, kan een onderwerp van nadere overweging uitmaken.' Gratama liet zich tijdens de openbare beraadslaging op 27 november 1874 niet door de minister overtuigen, maar stond kennelijk alleen. De minister deelde nog mee dat de Raad door het adelsfonds niet (meer) op de staatsbegroting drukte, maar dat er integendeel meer inkomsten dan uitgaven waren. Gratama benadrukte dat het fonds, zijnde geen rijksmiddel, aan de rechthebbende moest worden teruggegeven en vond het belachelijk dat de kosten voor het vervaardigen van genealogische tabellen als bureaukosten op de rijksbegroting voorkwamen. ${ }^{277}$

De regelmatige vervanging bij afwezigheid van de secretaris van de Hoge Raad van Adel door een ambtenaar van het departement is in die jaren illustratief voor de gang van zaken. Er zijn verschillende voorbeelden te geven van een competentiestrijd, die hier en daar een afbreuk van het vigerende adelsrecht tot gevolgd had. Zo spitste de zaak zich toe op het inlijvingsverzoek Van der Feltz, dat bij gebrek aan bewijs van adeldom, in 1867 conform een advies van de Raad tot verheffing had geleid. ${ }^{278}$ Toen de familie in 1880-1881 opnieuw verzoeken tot inlijving (met bijbehorende titulatuur) deed, was het advies van de Raad niet anders dan in 1867 , aangezien het bewijs evenmin als toen kon worden geleverd. Tot zijn grote verbazing kreeg de Raad bij missive van minister van Justitie A.E.J. Modderman bericht, dat verzoekers bij $\mathrm{KB}$ van 21 jan. 1882, nr. 15, waren ingelijfd in de Nederlandse adel met de titel van baron op allen! ${ }^{279}$ De Raad vroeg de minister in een uitvoerige brief van 17 april 1882 om 'mededeeling der motieven, die tot afwijking van 's Raads advies hebben geleid om daar dan alsnog op te kunnen adviseren'. ${ }^{280}$ Beantwoording heeft echter nooit plaatsgevonden en argumenten konden, zoals later is gebleken, ook niet worden geleverd. ${ }^{281}$ Vanwege precedentwerking werden in 1893 en 1901 nog twee verzoeken van leden van dezelfde familie gehonoreerd, maar ook toen bleef de Raad om goede redenen persisteren in een negatief advies. De minister van Justitie deelde echter al binnen een maand zonder argumentatie mee, dat 'het Hare Majesteit de Koningin-Weduwe, Regentes had behaagd hen bij KB van 27 juni 1893, nr. 36, in te lijven in de Nederlandse adel met de titel van baron overgaande op al hun wettige, zowel mannelijke als vrouwelijke afstammelingen'. Uit dit voorbeeld blijkt overigens eerder een eigenzinnig optreden van de

\footnotetext{
${ }^{277}$ [Rietstap], 'De adelbrieven en de Hooge Raad van Adel', 268-273; Vorsterman van Oyen, De Hooge Raad van Adel, 5-19.

${ }^{278}$ HRvA, RA, inv. nrs. 150 (not. 1858-4, 24 en 61) -153.

${ }^{279}$ HRvA, RA, inv. nr. 158 (not. 1882-7).

${ }^{280}$ NA, Archief Departement van Justitie (toegangsnr. 2.09.22), inv. nr. 15991.

${ }^{281}$ Wijnaendts, 'De laatste schakels in de afstamming Van der Feltz', 107-125.
} 
dienstdoende ambtenaar dan van de politiek verantwoordelijke minister. Dit valt althans op te maken uit het standpunt van baron Du Tour van Bellinchave, lid van de Raad, die van 1883-1888 was teruggetreden om voor de tweede keer minister van Justitie (!) te worden, maar zich in 1893 aan de zijde van de meerderheid schaarde. ${ }^{282}$ In 1901 was er echter een minderheidstandpunt, dat aangaf dat weliswaar ieder bewijs nog altijd ontbrak maar dat er wel van kon worden uitgegaan dat wanneer de vader van de verzoekers in 1882 nog in leven was geweest, hem ook de toen verleende adelsgunst te beurt zou zijn gevallen. ${ }^{283}$

Baron Du Tour trad nog in 1903 als rapporteur op binnen de Raad, toen de secretaris-generaal van het Permanent Hof van Arbitrage Ruyssenaers (opnieuw) een verzoek om verheffing had gedaan. Niet diens afstamming, maar het belang van een adellijk predikaat voor deze functie was de reden voor een positief advies van de Raad, naast diens verdiensten als diplomaat. ${ }^{284}$ Deze verheffing was de laatste die om dergelijke redenen plaatshad. Nadien was afstamming (weer) bepalend. ${ }^{285}$

\section{Koninklijk grootzegel}

Een andere aanwijzing voor toegenomen macht van de ambtenarij is de vervanging van het koninklijke grootzegel, kort na het aantreden van koningin Emma als regentes, op initiatief van het Departement van Justitie, zonder daarbij de voorzitter van de Hoge Raad van Adel, volgens zijn instructie van 1814 (art. 15) grootzegelbewaarder, te raadplegen. Vóór 1890 waren onder de drie koningen gedurende langere tijd meerdere grootzegels in gebruik: een ruiterzegel, een troonzegel en een portretzegel. Vanaf 1860 berustte het ruiterzegel, dat speciaal voor adelsdiploma's werd gebruikt, bij het Ministerie van Justitie (afdeling Adel). Toen in 1891 een nieuw ruiterzegel voor koningin Wilhelmina moest worden vervaardigd, werd het ontwerp door de minister van Justitie rechtstreeks voorgelegd aan koningin Emma zonder de Raad om advies te vragen. Bij die gelegenheid werd ook het randschrift van het contrazegel (met het Rijkswapen) van HOOGE RAAD VAN ADEL gewijzigd in DEPARTEMENT VAN JUSTITIE. Officieel was de Raad daarvan niet in kennis gesteld, maar naar aanleiding van een vraag van M.A. van Rhede van der Kloot, hoofdcommies bij het Departement van Koloniën, vroeg de minister van Justitie advies aan de Raad over door deze gesignaleerde onvolkomenheden (Rijkswapen tezamen met het grootkruis van de Militaire Willemsorde en een regerend vorst met een ruitwapen). In zijn advies van 17 mei 1893 gaf de Raad onderbouwd aan dat er geen reden was om het Rijkswapen met welke orde dan ook te omhangen, maar dat dit slechts misverstanden in de hand werkte, en voorts dat voor wapens van regerende vorstinnen, zowel gehuwde als ongehuwde, traditioneel de gewone schildvorm werd gebruikt. De dienstdoende ambtenaar Jansen van Afferden, die op verzoek van de minister op 26 oktober 1897 rapport uitbracht over de geschie-

\footnotetext{
${ }^{282}$ HRvA, RA, inv. nr. 163.

${ }^{283}$ HRvA, RA, inv. nrs. 172-173.

${ }^{284}$ HRvA, RA, inv. nrs. 167 (not. 1897-46a) en 175 (not. 1903-81, 131).

${ }^{285}$ Bruin, 'Een verloren zaak', 143-146.
} 
denis van het grootzegel voor adelsdiploma's, kon deze zienswijze vervolgens moeilijk in zijn overzicht weglaten. Hij liet daarin los dat de Raad na het overlijden van koning Willem III was geïnformeerd over het aanvankelijke plan om alleen de naam in het randschrift van het ruiterzegel te wijzigen, een traditie die ook onder de voorgaande koningen bestond. De Raad zou daartegen geen bezwaar hebben gehad, maar hijzelf was toen al van mening dat de koningin niet een zegel kon gebruiken, waarop een ridder (de koning) stond afgebeeld. Binnen een week in juni 1891 was vervolgens de machtiging van koningin Emma verkregen om een nieuw ruiterzegel te laten vervaardigen, waarvan Jansen in zijn rapport een uitvoerige beschrijving gaf. De overweging aan het slot van zijn rapportage komt gezien het voorgaande enigszins hypocriet over: 'Zonderling mag het heeten dat de Hooge Raad van Adel, die kort te voren wel was gehoord op het voornemen om eenvoudig het randschrift van het Grootzegel, gelijk het onder koning Willem III in gebruik was, te wijzigen, niet werd geraadpleegd op dat om een geheel nieuw Grootzegel te doen aanmaken, geheel afwijkende van het voorheen gebruikelijke. ${ }^{286} \mathrm{Na}$ de inhuldiging van koningin Wilhelmina in 1898 werd één nieuw grootzegel (een troonzegel) ontworpen, dat sindsdien hoofdzakelijk werd gebruikt voor adelsdiploma's en voor de abdicatieakte. ${ }^{287}$

Iets van de onvrede over zijn positie aan het einde van de negentiende eeuw is zichtbaar in het lidmaatschap van verscheidene leden en opvolgende (oud-)secretarissen van de Hoge Raad van Adel van de in 1880 opgerichte 'Nederlandsche Heraut', een in Den Haag opgerichte exclusieve genealogische vereniging, die zich onder meer tot doel had gesteld een bijdrage te leveren aan een herbezie-ling van de adel in het koninkrijk. Zij zou zich gaan wijden aan een 'ernstige beoefening' van de genealogie als hulpwetenschap van de geschiedenis als tegenwicht voor misbruiken, die op dit gebied uit 'speculatiezucht' de kop opstaken. Baron D'Ablaing van Giessenburg bracht het zelfs tot erevoorzitter van het gezelschap en wist vanuit die functie ook veel ondoordachte plannen te bezweren. Een enkele keer richtte de vereniging zich namelijk rechtstreeks tot de minister van Justitie, hetgeen de (schaarse) contacten van de Raad in die periode kon doorkruisen. Vele principiële adelskwesties werden uitvoerig besproken in de vereniging, maar dit resulteerde door meningsverschillen zelden in publicatie in het gelijknamige orgaan van de vereniging. De zeer besloten vereniging, waarvan door de strenge cooptatie-eisen nooit meer dan 24 'welgeboren mannen' deel uit gemaakt hebben, was gedoemd tot opheffing. ${ }^{288}$ In 1903 werd met algemene stemmen tot ontbinding besloten, terwijl het archief bij de Hoge Raad van Adel werd ondergebracht. ${ }^{289}$

\footnotetext{
${ }^{286}$ HRvA, RA, inv. nr. 955.

${ }^{287}$ Toen in 1899 onduidelijkheid ontstond of het nog bestaande ruiterzegel in gebruik zou blijven voor adelsdiploma's, gaf de directeur van het Kabinet der Koningin te kennen dat volgens het verlangen van de Koningin deze eveneens door het laatst vervaardigde grootzegel (lees: troonzegel) bezegeld zouden worden. ${ }^{288}$ Gietman, 'Genealogie, waarheid en statusangst in de late negentiende eeuw', 178-208.

${ }^{289}$ HRvA, RA, inv. nrs. 958-967.
} 


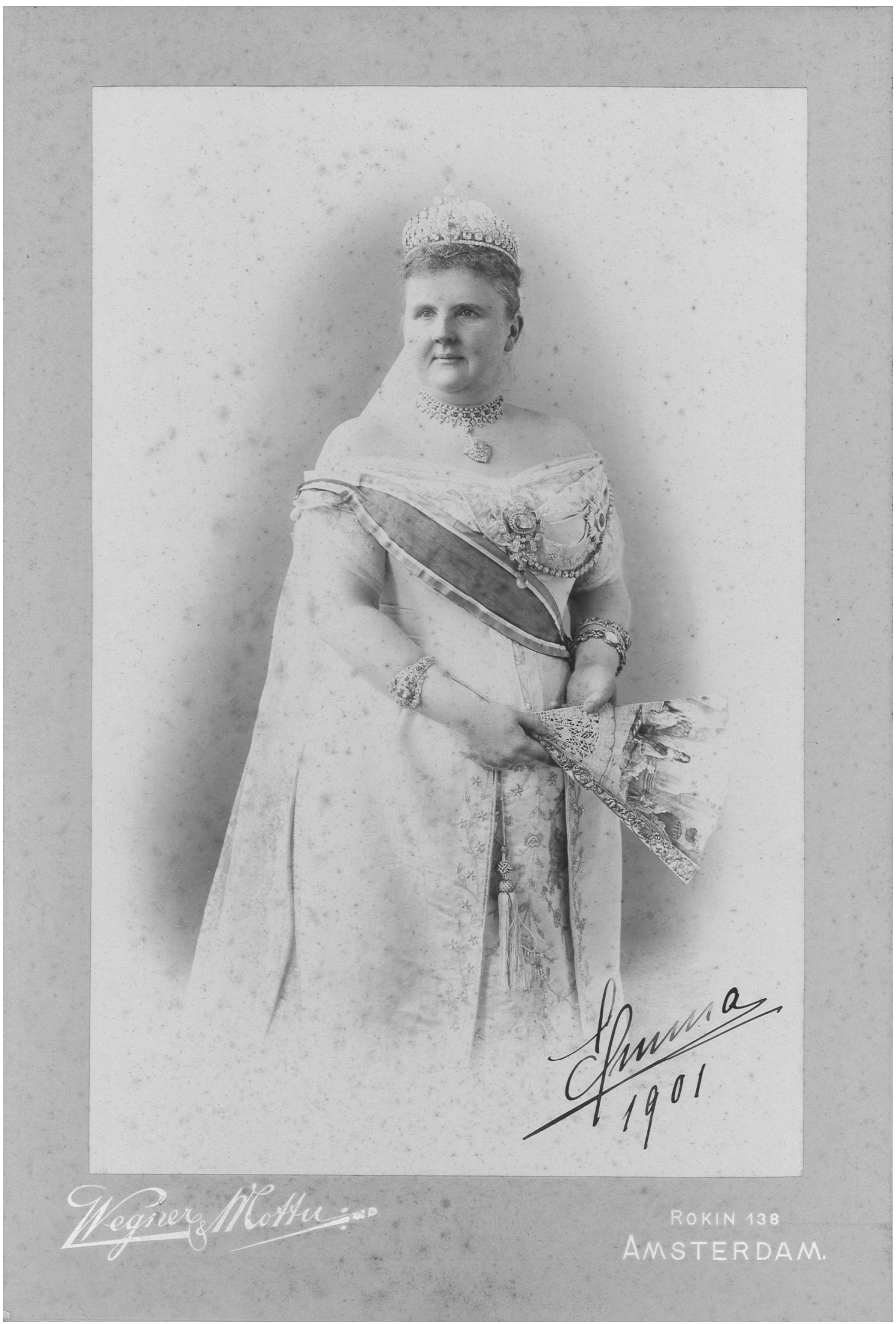

Emma prinses van Waldeck en Pyrmont (1858-1934), koningin-regentes der Nederlanden 18901898.

Foto Wegner \& Mottu, Amsterdam 1901. Collectie en foto HRvA, hs. coll. W.A. Beelaerts van Blokland, inv. $n r .21$. 


\section{Erfopvolging in vrouwelijke lijn binnen het koninklijk huis}

Ook ten aanzien van de erfopvolging binnen het koninklijk huis bleek het standpunt van de minister van Justitie aanvankelijk niet gebaseerd op een advies van de Hoge Raad van Adel, maar van een kort na het overlijden van koning Willem III ingestelde hofcommissie, waarin de Raad overigens wel was vertegenwoordigd. Toen de koningin-regentes Emma haar dochter Wilhelmina proclameerde als koningin der Nederlanden, werd deze tevens prinses van Oranje-Nassau genoemd, een titelcombinatie die de nodige vragen opriep. ${ }^{290}$ Minister van Binnenlandse Zaken jonkheer De Savornin Lohman won hierover begin 1891 advies in van twee deskundigen: de Leidse hoogleraar vaderlandse geschiedenis Fruin en de algemene rijksarchivaris jonkheer Van Riemsdijk, die nog in datzelfde jaar tot lid van de Hoge Raad van Adel werd benoemd. De nota's, die naast uitvoerige historische inleidingen vooral consoliderende conclusies bevatten, werden vervolgens aan de koningin-regentes toegezonden, maar kwamen eerst eind 1900 retour; kennelijk met het oog op het aangekondigde koninklijke huwelijk. ${ }^{291}$

Aan de vooravond van het huwelijk van koningin Wilhelmina in 1901 deed de hiervoor genoemde hofcommissie, waarvan zowel het lid van de Raad A.C. baron Snouckaert van Schauburg, tevens directeur van het Koninklijk Huisarchief, als de secretaris van de Raad jonkheer D. Rutgers van Rozenburg deel uitmaakten, nog naarstig onderzoek naar de betekenis van oude familieverdragen binnen het huis Nassau. ${ }^{292}$ In deze ad hoc adviezen en de op grond daarvan door de minister van Justitie genomen besluiten, is het in de inleiding gesignaleerde uiteengroeien van de regels betreffende erfelijke adeldom en erfopvolging binnen het regerende koningshuis zichtbaar. Minister van Justitie Loeff volgde de oude familieverdragen, volgens welke hij de noodzakelijke toestemming van andere vorstenhuizen vroeg en kreeg, en legde de erfopvolging in vrouwelijke lijn vast in bepalingen die meer met naamrecht dan met adelsrecht van doen hadden. ${ }^{293}$ Belangrijk was in dit verband vooral het familieverdrag van 1736 (vernieuwd in juni 1783), waarin alle nog bloeiende takken van het geslacht Nassau (Dillenburg tot 1739, Dietz, vanaf 1732 Oranje-Nassau, en Weilburg) afspraken dat bij uitsterven in mannelijke lijn van één der takken de erfdochter naam, titel en wapen op haar echtgenoot zou overbrengen. ${ }^{294}$ Toen deze situatie zich in 1901 in Nederland aankondigde, gaf de groothertog van Luxemburg uit het huis Nassau toestemming om de erfelijke titel als naam in combinatie met Oranje voort te zetten door de eventuele kinderen van

\footnotetext{
${ }^{290} \mathrm{~KB}$ van 24 nov. 1890 (Stb. 177).

${ }^{291}$ Verburg, 'Twee nota's uit 1891 over de titel prinses van Oranje-Nassau', 121-139.

292 Deze hofcommissie werd voorgezeten door mr. G.J.P. graaf Schimmelpenninck van Nijenhuis (18511929), terwijl de militair-historicus F. de Bas, kolonel b.d., was toegevoegd (De Ned. Leeuw 97 (1980), 101, noot 11).

${ }^{293}$ Van Valkenburg, 'Titulatuur, wapens en vlaggen van leden van het Koninklijk Huis', 99-107.

${ }^{294}$ Nassauischer Erbverein van 23 en 30 mei 1736; Des fürstlichen Gesamthauses Nassau im Jahre 1783 erneuerter Erbverein (drukwerk uit 1786, in: HRvA, bibliotheek, inv. nr. (rood) 89). Deze afspraken zijn de basis geweest voor de artt. 2-5 e.v. van de Grondwet van 1814 inzake de troonopvolging.
} 


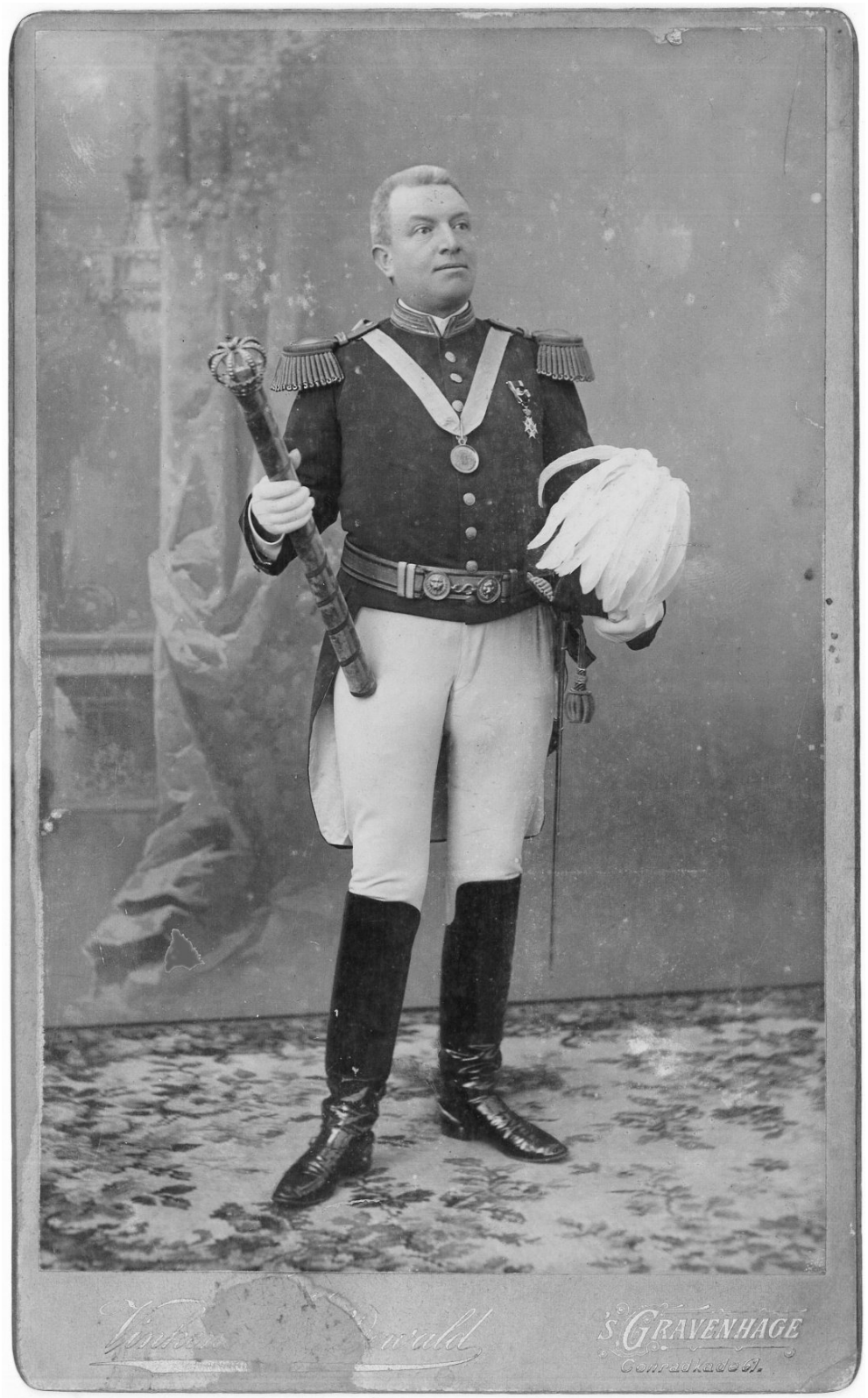

Jonkheer David Rutgers van Rozenburg (1854-1929), secretaris van de Hoge Raad van Adel als koning van wapenen bij de inhuldiging van koningin Wilhelmina.

Foto Vinkenbos \& Dewald, 's-Gravenhage 1898. Collectie en foto HRvA.

koningin Wilhelmina. Sedert 1901 wordt behalve over erfelijke titulatuur in de desbetreffende koninklijke besluiten ook over de naam Oranje-Nassau gesproken. Bij deze gelegenheid werd geen toestemming gevraagd aan de chef-de-famille van het huis Hohenzollern om de ook door hem gevoerde titel prins van Oranje als onderdeel van een familienaam te mogen gebruiken, omdat op grond van een overeenkomst van 1732 ervan kon worden uitgegaan dat het Nederlandse vorstenhuis hier evenveel zeggenschap over had gekregen. ${ }^{295}$ Deze stap van de minister van Justitie werkt tot op de huidige dag in de Nederlandse wetgeving door, in het bijzonder omdat het koninklijk huis daarna opnieuw in vrouwelijke lijn werd voortgezet. De zinsnede in de memorie van toelichting op de Wet lidmaatschap ko-

\footnotetext{
${ }^{295}$ Tractaat van 14 mei en 16 juni 1732 (zie voorgaande noten). Prins Willem IV deed daarin t.b.v. de Franse koning afstand van zijn soevereine rechten op het Prinsdom Orange, zoals de Pruisische koning al in 1713 deed.
} 
ninklijk huis van 30 mei 2002 (Stb. 275) wordt hiermee verklaard: 'Ten aanzien van de historische geslachtsnaam "van Oranje-Nassau" zal de sedert het begin van de vorige eeuw (KB van 8 februari 1901, Stb. 1908, nr. 425) gevolgde lijn worden aangehouden waardoor deze geslachtsnaam in drie opvolgende generaties is behouden voor leden van het koninklijk huis en niet is overgegaan op personen die geen lid zijn van het koninklijk huis. ${ }^{296}$ In dezelfde wet zijn - in samenhang met de Wet op de adeldom - bepalingen opgenomen betreffende de verlening van adellijke titulatuur, die bij leden van het koninklijk huis een sterk persoonlijk karakter hebben.

\section{Rijkswapen}

Naar aanleiding van het huwelijk van koningin Wilhelmina met Hendrik hertog van Mecklenburg moesten in 1901 diverse zaken bij koninklijk besluit worden geregeld, waarbij de Raad zijdelings werd betrokken. Naast zijn naturalisatie, naamgeving, titelverlening en lidmaatschap van het koninklijk huis, was het vooral het gevierendeelde wapen van de nieuwe prins der Nederlanden waarop commentaar van de Raad werd verzocht. Door bemiddeling van de directeur van het Kabinet der Koningin werden meningen uitgewisseld over in het bijzonder de schildhouders. De koningin vond dat de gouden ongekroonde Mecklenburgse griffioen in profiel moeilijk als schildhouder gecombineerd kon worden met de gouden rood getongde en genagelde, maar bovendien gekroonde en aanziende Nederlandse leeuw. Als tussenoplossing werd een vrije keuze gemaakt, die een zestal jaren later tot een aanpassing van het rijkswapen zou leiden. De tijdelijke oplossing voorzag in de Nederlandse leeuw in profiel, maar met een gravenkroon in plaats van de koninklijke kroon en zonder nagels van keel (rood). ${ }^{297}$ In 1907 werd de behoefte gevoeld het in 1815 vastgestelde rijkswapen, tevens wapen van de regerende koning, nauwkeuriger te beschrijven en enkele onvolkomenheden aan te passen. Zo waren als schildhouders slechts twee gekroonde leeuwen vermeld, een jaar later aangevuld met 'van natuurlijke kleur', maar nergens was bepaald dat dit koninklijke kronen zouden zijn. De in 1816 aangepaste tekening was bij twijfel het ijkpunt, maar een argumentatie ontbrak veelal. ${ }^{298} \mathrm{Na}$ een schriftelijke discussie tussen dezelfde actoren als in 1901, die een groot deel van het jaar in beslag nam, werd in overleg de beslissing genomen dat de Nassause leeuw in het schild in plaats van de koninklijke kroon zoals vanouds weer de gravenkroon zou dragen en dat de schildhouders, nota bene in navolging van Mecklenburg, in profiel en van goud zouden zijn, maar ongekroond. Tevens werd bij die gelegenheid de kleur van de baldakijn (een mantel van purper in plaats van azuur) en het correcte helmteken voor de mannelijke opvolgers bepaald (het Ottoonse in plaats van het Walramse, dat ten onrechte was opgevoerd). Nadat overeenstemming was bereikt, werden

\footnotetext{
${ }^{296}$ Kamerstukken II, 2001-2002, 28223, nr. 3, p. 6.

${ }^{297}$ KB van 30 sept. 1901 (Stb. 214a). HRvA, RA, inv. nr. 173 (not. 1901-63).

${ }^{298} \mathrm{~KB}$ van 24 aug. 1815, nr. 71 (Stb. 46), met correctie bij Kon. Disp. van 5 juni 1816 en bij Kon. Disp. van 24 juni 1816 goedgekeurde kleurentekening (brochure Hoge Raad van Adel van 2 juli 1816).
} 
twee koninklijke besluiten uitgevaardigd: één betreffende het rijkswapen en één betreffende een kleine aanpassing van het wapen van prins Hendrik (ongekroonde Nederlandse leeuw als schildhouder, maar met nagels van keel). ${ }^{299}$

\section{Staatsbelang}

Tijdens de Eerste Wereldoorlog werden bij de jaarlijks terugkerende begrotingsbehandelingen regelmatig Kamervragen gesteld over verlening van adeldom en de positie van de Hoge Raad van Adel. De toenmalige secretaris van de Raad, jonkheer W.A. Beelaerts van Blokland, schreef op verzoek van de minister van Justitie Ort notities, waarvan de inhoud in de memories van toelichting op hoofstuk IV van de Staatsbegroting is terug te vinden. Bij de algemene beschouwingen voor het dienstjaar 1918 werd de beantwoording van vragen over het adelsbeleid ('naar verdienste of naar afkomst van oude regentenfamiliën?') vooruitgeschoven, totdat de normale omstandigheden zouden zijn teruggekeerd. ${ }^{300}$ In dat jaar was vanuit rooms-katholieke hoek veel kritiek op het verheffingenbeleid geuit door het Kamerlid Juten, die een achterstelling constateerde van deze godsdienstige groep, die tijdens de Republiek geen regeringsambten kon vervullen en om die reden nog steeds uitgesloten was van adeldom. ${ }^{301}$ In het kader van de voorstellen voor een grondwetsherziening dienden de Kamerleden Troelstra, Schaper, Sannes, jonkheer De Jonge, Kleerekooper, K. ter Laan en Van den Tempel amendementen in om de artikelen 65-67 in de Grondwet van 1917 te laten vervallen. Minister van Binnenlandse Zaken, jonkheer Ruijs de Beerenbrouck, ontraadde als voorzitter van de Ministerraad deze amendementen omdat 'de regering niet kon inzien dat een evident staatsbelang de afschaffing van ridderorden en adeldom zou vorderen. Financiële overwegingen waren hierbij in zeer geringe mate betrokken.' Bij de stemming in de Tweede Kamer werden alle drie de amendementen met ruime meerderheid verworpen. ${ }^{302}$

De eerste decennia van de twintigste eeuw vonden in de samenstelling van de Hoge Raad van Adel relatief weinig mutaties plaats. In het interbellum werd het voorzitterschap (vanaf 1908) tot 1934 bekleed door baron Van Asbeck en daarna tot 1939 door jonkheer Van Sasse van Ysselt, beiden al lang, respectievelijk sedert 1902 en 1903, lid van de Raad. Twee leeftijdgenoten, W.L. baron de Vos van Steenwijk en baron Van der Capellen (vanaf 1919) hadden als gewoon lid zitting, maar weldra vond enige verjonging van de Raad plaats. Jonkheer Van Riemsdijk was in 1924 vanwege het bereiken van de 75-jarige leeftijd opgevolgd door jonk-

\footnotetext{
${ }^{299} \mathrm{~KB}$ van 10 juli 1907 (Stb. 181), met bijbehorende tekening door J.E. van Leeuwen, wapentekenaar van de Hoge Raad van Adel; KB van 10 juli 1907 (Stb. 182), betreffende het wapen van prins Hendrik.

${ }^{300}$ Kamerstukken II 1917-1918, okt./nov. 1917, nrs. 13 en 14 (HRvA, RA, inv. nr. 931A).

${ }^{301}$ Handelingen II 1916-1917, 1100-1101. Vgl ook de kritische verhandeling van Van Ketwich Verschuur, 'Verleening van adeldom', 297-316 (HRvA, RA, inv. nr. 931).

${ }^{302}$ Handelingen II 1921-1922, 511-517 (HRvA, RA, inv. nr. 931A).
} 


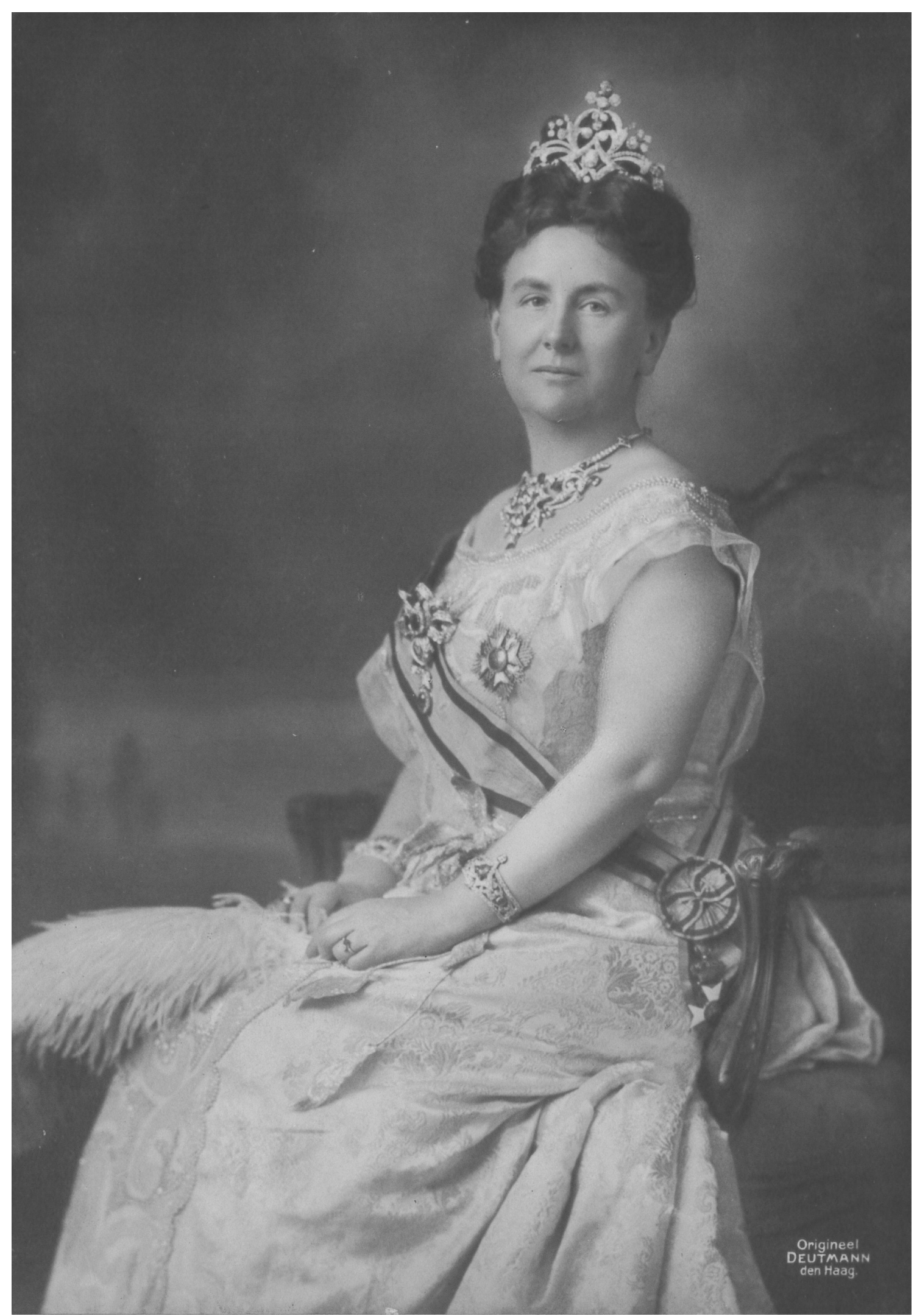

Wilhelmina (1880-1962), koningin der Nederlanden 1890-1948. Foto H. Deutmann, 's-Gravenhage, ca. 1915

Collectie en foto HRvA, hs. coll. W.A. Beelaerts van Blokland, inv. nr. 21. 
heer W.A. Beelaerts van Blokland en tien jaar later nam baron De Smeth de plaats in van de teruggetreden voorzitter Van Asbeck. ${ }^{303}$ Vooral onder invloed van het wetenschappelijke onderzoek van jonkheer Beelaerts, die menige genealogische fabel door publicatie in het ooit met De Nederlandsche Heraut concurrerende tijdschrift (van het gelijknamige Genootschap) De Nederlandsche Leeuw had doorgeprikt, maakte de Raad een verlichte periode door. ${ }^{304}$ Des te triester was Beelaerts' plotselinge overlijden in 1935, waardoor de inhoudelijke kennis van de Raad in kwaliteit inleverde. Dit gemis werd inmiddels ruimschoots ondervangen door de jongbenoemde secretaris De Monté ver Loren, specialist op het gebied van het oud-vaderlandse recht. ${ }^{305}$ In 1935 traden opnieuw twee leden tot de Raad toe: jonkheer F. Beelaerts van Blokland in de plaats van zijn overleden jongere broer en J.A.G. baron de Vos van Steenwijk in de plaats van zijn vader, die vanwege zijn leeftijd was teruggetreden. Eerstgenoemde moest zijn tijd verdelen met zijn functie van vice-president van de Raad van State, waarin hij twee jaar daarvoor was benoemd. ${ }^{306}$ Met zijn aantreden haalde de Hoge Raad van Adel een belangrijk lid binnen, die ook tijdens en na de oorlog als voorzitter zijn diplomatieke invloed zou laten gelden om de (ideeën binnen de) Raad niet te laten ontsporen.

\section{Wettige afstamming}

In bovengenoemde samenstelling behandelde de Raad verzoeken om verheffing van leden van geslachten als Van Rijckevorsel en De Beaufort, die geen adeldom en slechts met moeite regentendom konden bewijzen, maar waarvan takken in de negentiende eeuw waren verheven. De Raad kwam tot de conclusie dat van precedentwerking nauwelijks sprake kon zijn, maar zocht toch naar mogelijkheden om positief advies te kunnen uitbrengen. Tijdens de behandeling van het verzoek in 1936 om verheffing van vier broers De Beaufort ontspon zich op initiatief van de 81-jarige baron Van der Capellen, die deze kwestie kennelijk nog tijdens zijn leven geregeld wilde zien, een theoretische discussie binnen de Raad over wettige afstamming. Hij pleitte ervoor om een tweehonderddagenclausule te gaan hanteren in het geval van wettiging van 'voorkinderen' door opvolgend huwelijk, zodat kinderen die biologisch niet van de wettige (lees: adellijke) vader afstamden, van adeldom uitgesloten zouden blijven. Andere leden, waaronder de voorzitter, wilden de discussie doorschuiven naar een volgende vergadering, omdat deze niets van doen had met het onderhavige verzoek. Toch werd in dezelfde brief, waarin een kort positief advies aan de minister werd uitgebracht inzake De Beaufort, ook deze kwestie in een lang advies met vele voorbeelden aan de minister voorgelegd. ${ }^{307}$ Deze voorbeelden waren alle afkomstig uit het commentaar van baron Van

\footnotetext{
${ }^{303}$ Kort en Wolleswinkel, Het archief van de Hoge Raad van Adel, 15-16.

${ }^{304}$ Kort en Wolleswinkel, Het archief van de Chambre Héraldique, 45-46, 203-218.

${ }^{305}$ Doeleman, 'Johan Philip de Monté verLoren'.

${ }^{306}$ Slijkerman, In dienst van de kroon, 192-202.

${ }^{307}$ HRvA, RA, inv. nr. 204 (not. 1936-17). Met dank aan drs. R.R.J. Melchers, die bij zijn onderzoek naar het geslacht De Beaufort op dit enigszins verstopte Raadsadvies stuitte en mij hier als eerste op attent maakte.
} 
Jonkheer Willem Adriaan Beelaerts van Blokland (1883-1935), griffier van de Eerste Kamer der StaenGeneraal, secretaris (19091924) en lid (1924-1935) van de Hoge Raad van Adel. Foto H. Berssenbrugge, 'sGravenhage. Collectie en foto HRvA, hs. coll. W.A. Beelaerts van Blokland, inv. nr. 45.

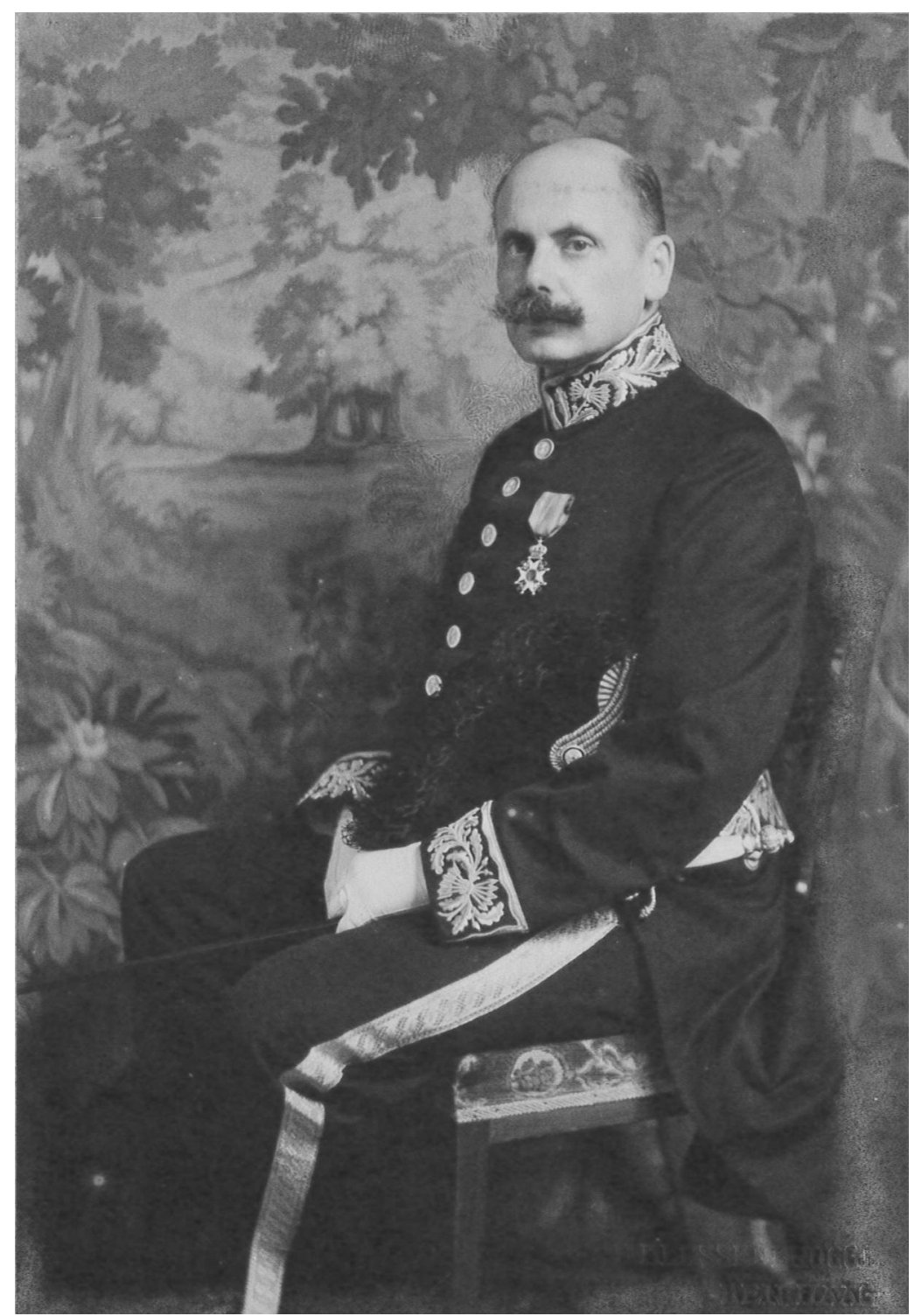

der Capellen op het korte en zakelijke preadvies van de secretaris. De Monté ver Loren was kennelijk onder de indruk geraakt van de hoeveelheid voorbeelden die de baron uit zijn adellijke netwerk naar voren had weten te brengen, want alle voorbeelden werden keurig uitgewerkt in het officiële advies overgenomen. We leren de secretaris hier kennen als een precieze wetenschapper, die meer puritein dan diplomaat was. Alle voorbeelden blijken namelijk op huwelijken uit de jaren negentig van de negentiende eeuw betrekking te hebben, op één na: een in 1936 afgegeven brief van wettiging door de gouverneur-generaal van Nederlands-Indië. ${ }^{308}$ Deze recente wettiging was dan ook de directe aanleiding voor de heftige discussie binnen de Raad. Het getuigde echter van weinig realiteitszin om de voorbeelden te beperken tot de laatste vijftig jaar, want wettiging door opvolgend huwelijk heeft -

\footnotetext{
${ }^{308}$ De huwelijken Van Heeckeren van Brandsenburg-Boucher (1892), Snouckaert van Schauburg-Van der Endt (1894) en Van Verschuer-Jung (1899). Het Indische voorbeeld betrof het concubinaat van baron Sloet van Oldruitenborgh met de Chinese vrouw Njo Bin Nio (1936).
} 


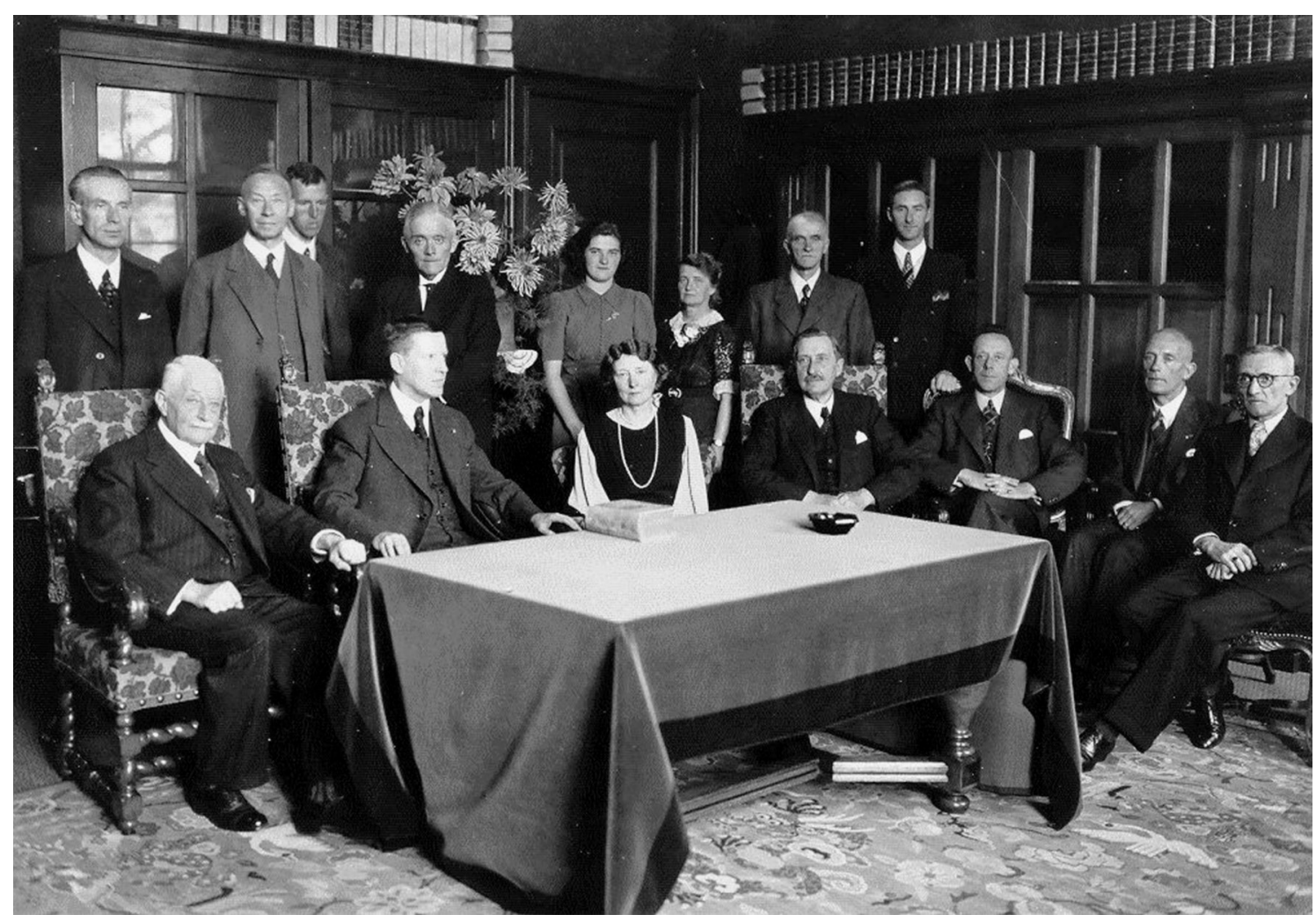

De (secretarie van de) Hoge Raad van Adel in het Departement van Justitie (Plein 2B, 'sGravenhage) vóór de overgang naar het Departement van Algemene Zaken in 1937. Zittend v.l.n.r. jonkheer A.F.O. van Sasse van Ysselt, voorzitter; J.Ph. de Monté ver Loren, secretaris; J.H.G. Meihuizen-Landré, eerste ambtenaar; J.P. de Meijere, secretaris-generaal Departement van Justitie; twee onbekenden; J.G. Meihuizen, ambtenaar. Staande v.l.n.r. twee onbekenden; jonkheer E.N. de Brauw, volontair; D.H. van Arkel, hoofd bureau adelszaken Departement van Justitie; C.M. Meihuizen, medewerkster; mej. Eldermans (Kanselarij der Nederlandse Orden); J.C. Faber, waarnemend hoofd kabinetszaken Departement van Justitie; onbekende.

Anonieme foto. Collectie en foto Zeister Historisch Genootschap, Van de Poll Stichting, Zeist.

nog afgezien van staande het huwelijk door overspel verwekte kinderen - door de eeuwen heen de verheven gedachte van erfelijke adeldom voortdurend ondergraven. Ons bepalend tot de Nederlandse adel, die in 1814 werd opgericht en waarbinnen vanaf de begintijd wettiging op deze wijze gestalte heeft gekregen, trad onder de afstammelingen kennelijk voldoende aanpassing en gewenning op, dat de Raad het niet nodig vond verder terug te grijpen. ${ }^{309}$

Het ondiplomatieke van het advies zat hierin, dat het aan de orde stellen van de zaak in een specifiek advies, waarop deze kwestie bovendien geen betrekking had, het de minister wel heel gemakkelijk maakte om daar niet op te hoeven reageren. Dat het advies niet ter harte is genomen, kan eenvoudigweg geconcludeerd worden uit het feit dat de redactie van koninklijk besluit en adelsdiploma niet werd gewijzigd. Daar had de Raad, op voorstel van het lid jonkheer F. Beelaerts, namelijk in hoofdzaak op ingezet om meningsverschil over discutabele voorwaarden als de

\footnotetext{
${ }^{309}$ Vergelijk bijv. het huwelijk Gevers-Bell (1876), waarbij kinderen werden gewettigd, waarvan de oudste zoon al 21 jaar was. Zie Ned. Adelsboek 83 (1993), 204.
} 
tweehonderddagenclausule te voorkomen. De woorden, dat adeldom wordt verleend aan de betrokkene 'en diens wettige nakomelingen' zou slechts vervangen behoeven te worden door 'en diens wettige staande huwelijk geboren nakomelingen' ${ }^{310}$ De argumentatie voor het advies was, dat verlaging van het aanzien van de Nederlandse adel voorkomen diende te worden, met de slotoverweging: 'dat een dergelijke opneming in den Nederlandschen Adel van kinderen van ongehuwde moeders voor het aanzien van den Adel hoogst ongewenscht is, behoeft geen nader betoog.' Dan volgde als juridische onderbouwing dat het grondwetsartikel geen enkele beperking aan de bevoegdheid van de Kroon zou opleggen, terwijl beperkingen in soevereine en koninklijke besluiten (erfelijke adeldom in wettige mannelijke lijn) andere beperkingen mogelijk zouden maken. De civielrechtelijke gevolgen van wettiging van natuurlijke kinderen zouden hierdoor niet worden aangetast, aangezien deze niet delen in een bijzondere koninklijke gunst 'in welker verleening de Kroon volkomen vrij is'. Hierbij werd een vergelijking getrokken met de adellijke titel bij eerstgeboorterecht, die zou kunnen worden uitgelegd als in strijd met het vigerende erfrecht, maar waartegen nooit enig bezwaar was gerezen.

\section{1937-1947: einde klassenmaatschappij}

\section{De Hoge Raad van Adel als adviseur van de minister van Algemene Zaken}

De oprichting in 1937 van een nieuw Departement met de naam Ministerie van Algemene Zaken betekende een herleving van de positie van de Hoge Raad van Adel. Met ingang van medio juli diende de Raad adviezen over adelszaken en wapens van publiekrechtelijke lichamen aan de minister van Algemene Zaken uit te brengen. ${ }^{311}$ De secretarie werd van een afdeling van het Departement van Justitie een meer zelfstandig opererend bureau, dat voorlopig nog wel in het Departement van Justitie aan het Plein in Den Haag bleef gehuisvest. ${ }^{312}$ Door de minister van Staat, minister van Algemene Zaken Colijn werd de Hoge Raad van Adel - meer dan vanaf 1850 het geval was geweest - gezien als een onafhankelijk college, dat ondersteund werd door een zelfstandig opererende secretarie. ${ }^{313}$

De verheffing van een lid van het Haarlemse regentengeslacht Van Valkenburg in 1939, een vorm van nobilitatie die sedert 1910 nog maar driemaal was voorgekomen - en deze vierde keer zou, zoals later bleek, tevens de laatste zijn - achtte de Raad reden voor een versoepeling van het beleid. Het criterium van voorouders in mannelijke lijn die vóór 1795 gedurende drie opeenvolgende generaties zitting

\footnotetext{
${ }^{310}$ De oorspronkelijke zinsnede in het adelsdiploma zou eerst na de inwerkingtreding van de Wet op de adeldom, d.d. 1 aug. 1994, worden aangepast door wijziging in 'al zijn afstammelingen, voorzover zij daarvoor volgens de wettelijke regelingen in aanmerking komen'.

${ }^{311}$ KB van 3 juli 1937 (Stb. 140); HRvA, RA, inv. nr. 205 (not. 1937-54); [Beelaerts van Blokland e.a.], De Hoge Raad van Adel, 183 (bijlage IIIb).

${ }^{312}$ Kort en Wolleswinkel, Het archief van de Hoge Raad van Adel, 6-7.

${ }^{313}$ HRvA, RA, inv. nr. 205 (not. 1937-54).
} 
hadden in de vroedschap van een stemhebbende stad, zou tot twee teruggebracht moeten worden, terwijl continuiteit in het bekleden van hoge ambten tot 1848 diende te worden doorgetrokken. Daarna zou slechts het op peil blijven van het maatschappelijk niveau vereist zijn. Aanleiding was een statistisch onderzoek van het lid baron De Smeth en secretaris De Monté ver Loren naar de stand van de Nederlandse adel over de jaren 1934-1937, die de Raad zorgen baarde. ${ }^{314}$ In 1937 was al een lijst van hoge ambten opgesteld waarvan men vond dat bekleders ervan voor adeldom in aanmerking zouden kunnen komen. ${ }^{315}$ In zijn vergadering van 14 december 1939 besloot de Raad unaniem bovengenoemd criterium als uitgangspunt voor toekomstige adviezen betreffende verheffing te zullen gaan hanteren. Door de inmiddels van regeringswege afgekondigde algehele mobilisatie zou deze beoordeling vanwege de verwachte oorlog voorlopig niet in de praktijk gebracht behoeven te worden. ${ }^{316}$

\section{Tweede Wereldoorlog}

De Hoge Raad van Adel is de Tweede Wereldoorlog als instituut tamelijk ongeschonden doorgekomen, al legde de bezetter wel een claim op de handschriftencollectie. ${ }^{317}$ De Raad moest per 1 januari 1941 het Departement van Justitie aan het Plein verlaten, maar het alternatief aan de Korte Vijverberg was overkomelijk. De Rijksgebouwendienst stelde daar een zestal kamers beschikbaar in het Kabinet der Koningin, waarvan de secretarie naar Londen was uitgeweken. Deze tijdelijke huisvesting duurde maar kort, aangezien de Duitse militaire autoriteit het pand per 10 september 1941 vorderde. De daaropvolgende locatie aan het Binnenhof, waar een viertal vertrekken van Eerste Kamer en Raad van State beschikbaar kwamen, zou na de oorlog tot 1957 worden gecontinueerd. ${ }^{318}$

Volgens de Grondwet van 1938 verleende de koning adeldom, maar de Kroon (koningin en regering) verbleef gedurende de oorlogsjaren in ballingschap te Londen. Adelsverleningen vonden in die periode niet plaats. De Raad meende zich in oktober 1940 nog wel te moeten uitspreken over het verzoek d.d. 6 mei 1940 van de Haagse generaal-majoor titulair Dirk Merens, die aanspraak op adeldom meende te kunnen maken. In zijn antwoord aan betrokkene gaf de Raad aan dat hij, als stammende uit een Hoorns regentengeslacht, zijn aanspraak op verheffing voldoende had bewezen en dat de Raad voornemens was op deze aangelegenheid terug te komen, 'zodra te zijner tijd adeldom wederom verleend mocht worden'. 319 Waarschijnlijk putte zijn zoon na de oorlog hieruit de moed en verwachting om verscheidene pogingen te ondernemen adeldom alsnog geëffectueerd te krijgen. Daarbij zou deze zich echter in de naoorlogse minister van Binnenlandse Zaken Beel vergissen, die daarover andere gedachten koesterde (zie hierna).

\footnotetext{
${ }^{314}$ HRvA, RA, inv. nrs. 205 (not. 1937-53) en 932.

${ }^{315}$ HRvA, RA, inv. nr. 205 (not. 1937-32).

${ }^{316}$ HRvA, RA, inv. nr. 206 (not. 1939-30).

${ }^{317}$ Wolleswinkel, 'Het "Niederländische Wappenbuch" uit Münster, 108-112.

${ }^{318}$ Kort en Wolleswinkel, Het archief van de Hoge Raad van Adel, 7.

${ }^{319}$ HRvA, RA, inv. nr. 206 (not. 1940-25).
} 
Een andere belangrijke taak, het adviseren op het gebied van overheidsheraldiek, werd tijdens de oorlogsjaren wel uitgeoefend. ${ }^{320}$ In het eerste oorlogsjaar stelde de Raad de overheidswapens zelf vast, maar daar stak de bezetter met ingang van 1941 een stokje voor. ${ }^{321}$ Deze bevoegdheid werd toevertrouwd aan de secretarisgeneraal van het Ministerie van Algemene Zaken, terwijl de Hoge Raad van Adel werd gehandhaafd als adviesorgaan. ${ }^{322}$ In de begintijd kwam de Raad nog wel sporadisch bijeen, maar al gauw lag de adviestaak grotendeels in handen van de toenmalige voorzitter, bijgestaan door een ambtelijke staf. Het personeelsbestand werd eind 1941 zelfs uitgebreid, maar dat had te maken met een bijkomende taak in opdracht van de secretaris-generaal van het Ministerie van Binnenlandse Zaken, namelijk de controle op het rechtmatig - dat wil zeggen op grond van een koninklijk besluit - voeren van samengestelde geslachtsnamen. Het Besluit Bevolkingsboekhouding 1936 noopte al tot een dergelijk onderzoek, maar zover was het onder $\mathrm{Ne}$ derlands bestuur nooit gekomen en na de oorlog zou deze nieuwe taak van de Raad in 1948 definitief stranden. ${ }^{323}$

\section{Zuivering van de Nederlandse adel}

De archiefvorming van de Hoge Raad van Adel was, met uitzondering van het zogenaamde dubbele namenarchief, tijdens de oorlogsjaren om bovenstaande redenen zeer gering. Inhoudelijk zijn tussen de minuutbrieven van de secretaris afschriften van de op 22 oktober 1940 ingezonden ariërverklaringen van de voorzitter, hemzelf en zijn medewerkster bewaard gebleven, ${ }^{324}$ terwijl daarnaast de overwegingen van de toenmalige voorzitter in zijn preadviezen over het al of niet honoreren van dubbele geslachtsnamen dikwijls discriminerend waren voor bepaalde bevolkingsgroepen. ${ }^{325}$ De Raad werd in oorlogstijd nauwelijks bijeengeroepen en de meeste zaken zijn door voorzitter en secretaris gezamenlijk afgehandeld. Dit kwam de Raad uiteindelijk goed uit, toen na de oorlog in de Tweede Kamer stemmen opgingen voor een zuivering van de Nederlandse ridderorden en in navolging daarvan van de Nederlandse adel: 'De personen, die een Koninklijke onderscheiding bezitten, hetzij in den vorm van een ridderorde, hetzij als erfelijk lid van den Nederlandschen adel, mogen in het algemeen geacht worden door ontwikkeling en afkomst in het bijzonder op de hoogte te zijn van wat eer en plicht tegenover Vorstin en vaderland van den Staatsburger vorderen; in geval van ontrouw aan de Koningin of aan de zaak van het Koninkrijk is er voor beide groepen gelijkelijk aanleiding tot het treffen van maatregelen. Met name ten aanzien van den erfelijken

\footnotetext{
${ }^{320}$ Opgedragen bij SB van 24 dec. 1814, nr. 32 (HRvA, RA, inv. nr. 2 (not. 1815-11)).

${ }^{321}$ Zie de gemeentewapens van Giessendam, Koudekerk aan de Rijn, Termunten en Vledder, die in 1940 bij besluit van de Hoge Raad van Adel werden vastgesteld.

${ }^{322}$ HRvA, RA, inv. nr. 206 (not. 1941-4). De wapens van een twintigtal thans veelal opgeheven gemeenten en een enkel waterschap (Beoosten de Eem, 1942) zijn tussen 1941-1944 vastgesteld bij besluit van de secretaris-generaal van het Ministerie van Algemene Zaken.

${ }^{323}$ Bruin, 'Wat heet dubbel', 102-111; Wolleswinkel, 'De boekstaving van distinctiedrang', 208-212.

${ }^{324}$ HRvA, Ra, inv. nr. 330 (1940-68).

${ }^{325}$ HRvA, RA, inv. nrs. 668-857 (naamsveranderingen).
} 
Nederlandschen adel is er wel geen krassere overtreding van het oude adagium "noblesse oblige" dan landverraad denkbaar., 326

Tijdens de behandeling van de rijksbegroting voor het dienstjaar 1947 gaf minister van Binnenlandse Zaken Witteman aan waarom van zuivering werd afgezien. Hij maakte daarbij onderscheid tussen het ontnemen aan personen die onttrouw aan het koninkrijk waren geweest, van de adellijke titel en het straffen van de adelstand als stand. In het eerste geval zou sprake zijn van een extra berechting (een bijzondere straf door een andere autoriteit) in vergelijking met andere politieke delinquenten, zodat geen sprake kon zijn van zuivering in de eigenlijke zin van het woord. Dubbele berechting zou slechts kunnen worden voorkomen in geval van bestraffing door ontneming van adeldom ter zuivering van de adel als groep. Hiertegen werden, volgens de minister, door de Eerste Kamer terecht bezwaren van constitutionele aard ingebracht. De grondwet voorzag immers niet in de mogelijkheid tot ontneming van adeldom, omdat dit in strijd was met het karakter van de adelsverlening. Ook hier schaarde hij zich achter de expliciete mening van de Eerste en de impliciete overtuiging van de Tweede Kamer, namelijk dat de betekenis van de adelstand te gering was om (nog) tot zuivering over te gaan en er belangrijker zaken om aandacht vroegen. ${ }^{327}$

Voorzitter en secretaris wilden na de oorlog onverdroten doorgaan met de hun op het lijf geschreven taak om het al of niet terecht voeren van dubbele geslachtsnamen te verifiëren, maar daar staken de leden van de Raad een stokje voor omdat men het een oneigenlijke en oeverloze taak vond. Toen onenigheid tussen de twee functionarissen ontstond, resulteerde een en ander in het vervroegd aftreden van de secretaris per 1 januari 1946 en van de voorzitter per 1 januari 1947. Jonkheer F. Beelaerts van Blokland, die naast vice-voorzitter van de Raad van State (19331956), tijdens de Tweede Wereldoorlog ook lid van de Hoge Raad van Adel was geweest, had in de ruzie bemiddeld en bekleedde vervolgens het voorzitterschap van de Raad van 1947 tot $1956 .{ }^{328}$

\section{1947-1983: geen creatie van adeldom}

In Londen werd al op het naoorlogse bestuur in Nederland vooruitgelopen door opheffing van het Departement van Algemene Zaken. Met ingang van 23 februari 1945 werden de taken daarvan overgenomen door het Departement van Binnen-

\footnotetext{
${ }^{326}$ Ontwerp van wet, d.d. 26 april 1946, van de Kamerleden Bach (G.), Ruijs de Beerenbrouck, Burger, Terpstra en Bajetto, waarin aan het ontnemen van een adellijke titel (bij KB) een bijzondere strafbepaling werd gekoppeld (max. zes maanden gevangenisstraf of 600 gulden boete), die verder ging dan het bestaande Wetboek van Strafrecht, art. 435, lid 1 (geldboete van max. 150 gulden). HRvA, RA, inv. nr. 935.

${ }^{327}$ Kamerstukken II en I, 1946-1947, Memorie van antwoord van de minister van Binnenlandse Zaken, Rijksbegroting 1947, hfdst. V, 300. De Jong, Het Koninkrijk der Nederlanden in de Tweede Wereldoorlog', vermeldt dit standpunt als het regeringsstandpunt in 1947 van het Kabinet Beel (p. 464).

${ }^{328}$ HRvA, RA, inv. nr. 935.
} 
landse Zaken. ${ }^{329}$ Bij de behandeling van de Rijksbegroting voor het dienstjaar 1946 werden in de Tweede Kamer kritische vragen gesteld over de posten die op de Hoge Raad van Adel betrekking hadden. ${ }^{330}$ Enkele leden zouden het bepaaldelijk onjuist vinden wanneer adelsverheffingen nog zouden plaatsvinden op grond van het feit dat voorouders in de zeventiende of achttiende eeuw gedurende een zekere periode tot de vroedschap van een stemhebbende stad hadden behoord. Zo kort na de afloop (in Europa) van de Tweede Wereldoorlog bestonden ook grote bezwaren tegen inlijvingen van adellijke geslachten van Duitse herkomst. Aan de regering werd gevraagd hoe deze zou staan tegenover verheffing van een aantal verdienstelijke Nederlanders (gerekend over de laatste vijftig jaar) ter gelegenheid van het aanstaande gouden regeringsjubileum. Minister Beel antwoordde op deze laatste vraag met de mededeling dat de Hoge Raad van Adel, die overigens meerdere taken dan alleen adelszaken behartigde, om advies zou worden gevraagd. ${ }^{331}$ Een schriftelijke adviesaanvraag is overigens niet bij de Raad binnengekomen, maar in de vergaderingen werd enige malen een agendapunt 'wijziging normen verlening adeldom' aangehouden. In 1947 besloot de Raad dat de voorzitter contact zou opnemen met de directeur van het Kabinet der Koningin over adelsverlening bij gelegenheid van het vijftigjarig regeringsjubileum van de koningin, de optie vanuit de Tweede Kamer. ${ }^{332}$ Van dit initiatief is in het Raadsarchief geen verslag en ook geen vervolg aangetroffen.

Op 8 september 1952 vroeg de minister van Staat Van Schaik als voorzitter van de staatscommissie tot herziening van de grondwet advies aan de Hoge Raad van Adel over wijziging van artikel 69 (over vreemde orden). In overleg met de (secretaris van de) Kanselarij der Nederlandse Orden, adviseerde de Raad om dit artikel ongewijzigd in stand te houden, maar nam hij de gelegenheid te baat een voorstel te doen tot aanvulling van artikel 67 ('De Koning verleent adeldom') met een derde lid, dat zou moeten luiden: 'Verlies van Nederlanderschap brengt mede verlies van adeldom'. De aanvulling zou geen terugwerkende kracht moeten hebben en het koninklijke prerogatief om aan vreemdelingen adeldom te verlenen niet moeten beknotten. Dit unanieme voorstel van de Raad was ingegeven door de in zijn ogen onwenselijke praktijk dat emigranten generaties later als genaturaliseerde buitenlanders nog adeldom zouden kunnen claimen zonder enige relatie met Nederland te hebben. De Raad achtte dit 'in strijd met aard en karakter van onze adel als zuiver Nederlands instituut.' Afgezien van deze historisch contraire zienswijze, is verlening van Nederlandse adeldom altijd voorbehouden geweest aan Nederlanders, met uitzondering van de prins van Waterloo en de markies van Heusden uit het eerste jaar van het koninkrijk. Er is dan ook geen reactie op deze opmerkelijke gedachtegang binnengekomen. ${ }^{333}$

\footnotetext{
${ }^{329} \mathrm{~KB}$ van 23 febr. 1945 (Stb. F11); [Beelaerts van Blokland e.a.], De Hoge Raad van Adel, 184 (bijlage IIIb).

${ }^{330}$ De Nerée tot Babberich, 'Nogmaals De Nederlandsche Adel', 179-182.

${ }^{331}$ Kamerstukken II, 1945-1946, Voorlopig verslag en Memorie van antwoord van de minister van Binnenlandse Zaken, Rijksbegroting 1946, hfdst. V, artt. 78, 79, 80 en 85.

${ }^{332}$ HRvA, RA, inv. nr. 209 (not. 1947-42).

${ }^{333}$ HRvA, RA, inv. nr. 213 (not. 1952-37).
} 


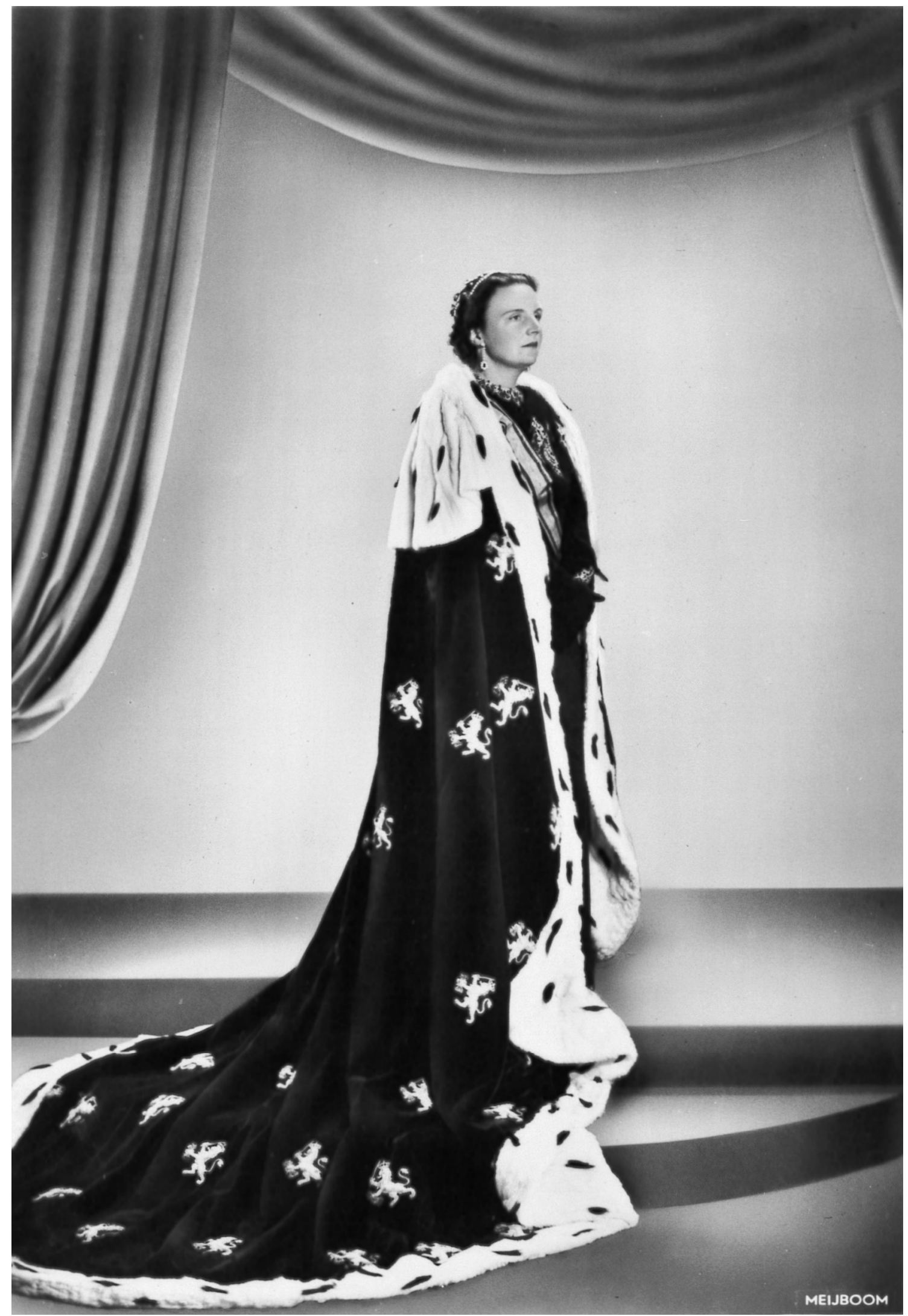

Juliana (1909-2004), koningin der Nederlanden 1948-1980. Inhuldiging, Amsterdam 6 september 1948.

Foto M. Meijboom. Collectie en foto HRvA, hs. coll. W.A. Beelaerts van Blokland, inv. nr. 21. 


\section{Adelsbeleid van de minister van Binnenlandse Zaken Beel}

In 1953 wendde minister van Binnenlandse Zaken Beel zich tot de ministerpresident om het beleid te bepalen ten aanzien van de verheffing van nazaten van zeventiende- en achttiende-eeuwse regentengeslachten, naar aanleiding van een concreet verzoek van twee leden van de Groningse familie Wichers. In zijn brief memoreerde hij een verzoek van de diplomaat Allard Merens, kort na de bevrijding, waarop in de Tweede Kamer afkeurend was gereageerd. Dit verzoek was toen afgewezen met de volgende argumenten: 1. het betrof geen geslacht, dat in de middeleeuwen deel uitmaakte van de ridderstand; 2. gezaghebbende historici oordeelden niet steeds gunstig over oligarchieën, waarvan gemakkelijk drie generaties deel van de vroedschap konden uitmaken; 3. de vóór 1848 voor verheffing aanvaarde redenen, waren na de grondwetsherziening van dat jaar door verlies van stemrecht vervallen; 4. de niettemin tot 1940 uit een oogpunt van billijkheid voortgezette gedragslijn kon bezwaarlijk blijven bestaan met het argument dat anderen op grond van reeds vervallen motieven in de adelstand zijn verheven. ${ }^{334}$

Het verzoek van de gebroeders Wichers was gebaseerd op de verheffing van andere takken op basis van afstamming van het oude Groningse patriciërsgeslacht in achtereenvolgens 1817, 1900, 1932 en 1938. De Hoge Raad van Adel had de aanvraag geverifieerd en was op grond van precedentwerking tot een positief advies aan de minister van Binnenlandse Zaken gekomen: 'de familie had zich van 1650 af tot heden, zonder onderbreking aan de publieke zaak gewijd, sommigen zelfs in zeer eervolle betrekkingen'. De minister zag echter geen aanleiding om af te wijken van het inzake Merens ingenomen standpunt, welke laatste kort daarvoor opnieuw verheffing had verzocht. ${ }^{335}$ Daarbij maakte het, volgens het standpunt van de minister, niet uit of andere takken van de familie in een eerder stadium op grond van de bestaande gedragslijn waren verheven. Andere gronden, als persoonlijke verdiensten voor het koningshuis en de Staat, waren zijn inziens evenmin nog redenen voor verheffing. Weliswaar had de Hoge Raad van Adel nog gewezen op de uitvinding van het snorkelapparaat door J.J. Wichers, belangrijk voor de onderzeebootdienst, maar ook hierin zag de minister geen genoegzame reden voor verheffing in de adelstand. Hij bracht zijn afwijzende standpunt door middel van een brief in de ministerraad, waarbij hij volledigheidshalve opmerkte dat ná de bevrijding één geval van erkenning in de Nederlandse adel (Ploos van Amstel, 1950) had plaatsgevonden, maar deze een feitelijk bestaande toestand bevestigde analoog aan een andere tak van dit geslacht, die wel tot de Nederlandse adel behoorde.

Een week later vergaderde de ministerraad, die - nadat twee ministers hun mening hadden gegeven - bij monde van de voorzitter, minister-president Drees, besloot 'het punt even aan te houden'. De minister van Oorlog en Marine, Staf, achtte een ruimere behandeling van dit onderwerp wenselijk, waartoe hij een grotere docu-

\footnotetext{
${ }^{334}$ Brief d.d. 4 aug. 1953, nr. 4653 Afd. Binnenl. Bestuur, Bureau Bestuurszaken ('ter behandeling in de Ministerraad'), documentnr. BZ-47-74. HRvA, RA, inv. nr. 225 (not. 1962-92).

${ }^{335}$ HRvA, RA, inv. nrs. 208 (not. 1946-4) en 355 (corr. 1957-98).
} 
mentatie nodig achtte, terwijl minister Suurhoff van Volksgezondheid van oordeel was dat de anachronistische wijze van verheffing beëindigd moest worden. ${ }^{336}$ Kennelijk resulteerde deze 'aanhouding' in een vertrouwelijk nota van de minister van Binnenlandse Zaken Beel inzake toepassing van artikel 74 van de Grondwet. De nota, die in stencilvorm is overgeleverd, beschrijft het ontstaan van de regentenadel in het begin van het Koninkrijk om evenwicht te realiseren tussen de grotere groep adel uit de Zuidelijke Nederlanden en de sterk uitgedunde ridderschappen in de Noordelijke Nederlanden. De historische paragraaf sluit af met de conclusie dat ook al werd de 'om utiliteitsredenen' gevolgde gedragslijn met betrekking tot verheffing na de grondwetsherziening van 1848 voortgezet 'uit overwegingen van billijkheid' ten opzichte van andere telgen uit regentengeslachten, dit geenszins met zich mee behoefde te brengen dat deze gedragslijn tot in lengte van dagen moest worden voortgezet. Daarna worden de overwegingen gegeven die aan eerdergenoemde vier redenen van afwijzing ten grondslag hadden gelegen. Zo worden gezaghebbende geschiedschrijvers geciteerd (Blok, Romein, Groen van Prinsterer, Kleintjes, Huybers, e.a.), die hadden gewezen op conventies en contracten waarbij regenten overeenkwamen de macht en de winstgevende ambten onder zich te houden. ${ }^{337}$ Daardoor waren regentengeslachten dikwijls niet door bekwaamheid, maar slechts door afspraken gedurende drie of meer generaties aan het roer gebleven. Bovendien deed dit criterium al meer dan anderhalve eeuw feitelijk geen dienst meer, waardoor het geen overtuigende grond meer was voor adelsverheffing. Daarbij maakte het geen verschil of takken van een patriciërgeslacht tot de Nederlandse adel behoorden of niet. Het als achterhaald beschouwde criterium bleef in beide gevallen immers hetzelfde, waardoor geen reden aanwezig was om met twee maten te meten. De nota wordt afgesloten met een opsomming van de drie vormen van adelsverlening, waarvan erkenning (formele bevestiging van een bestaande toestand) en inlijving (beoordeling van geval tot geval) in principe mogelijk bleven, maar verheffing achterwege diende te blijven. ${ }^{338}$

\section{Adelsbeleid van het Kabinet Drees}

Op 21 november 1953 nam de ministerraad een geheim besluit en bepaalde daarmee het adelsbeleid zonder dat de Hoge Raad van Adel daarvan formeel op de hoogte werd gesteld. ${ }^{339}$ Het kabinetsbesluit luidde: 'dat verheffingen in den vervolge achterwege dienen te blijven; dat inlijvingen zullen geschieden van geval tot geval te beoordelen aan de hand van bijzondere omstandigheden en erkenningen

\footnotetext{
${ }^{336}$ Notulen ministerraad, d.d. 12 aug. 1953, agendapunt 12, p. 8 (HRvA, RA, inv. nr. 225, not. 1962-92).

${ }^{337}$ Waarschijnlijk is de keuze van deze namen, die verschillende geledingen vertegenwoordigden, gedeeltelijk politiek bepaald: P.J. Blok (liberaal), J.M. Romein (socialist), G. Groen van Prinsterer (protestant), P.H. Kleintjes (voorm. Ned. Oost-Indië) en H.F.M. Huybers (katholiek).

${ }^{338}$ Nota van de minister van Binnenlandse Zaken Beel, stencilnr. BZ-49-900 (HRvA, RA, inv. nr. 225, not. 1962-92).

${ }^{339}$ De Rijk, 'De regentenadel in de ministerraad', 476-477, die vaststelde dat het besluit op zaterdagmiddag 21 nov. 1953 was genomen: '43. De (Minister)raad verklaart zich met deze nota accoord' (Nat. Archief, Ministerraad, doos 484).
} 
mits de betreffende personen behoren tot de Nederlandse adel van vóór 1795 en er geen bezwaren bestaan tegen hun persoon., 340

De Hoge Raad van Adel heeft tijdens het ministerschap van Beel geen poging ondernomen om diens in een notitie geformuleerde beleid van commentaar te voorzien. Kennelijk zag men in dat verandering van beleid tijdens deze door Drees geleide kabinetten weinig kans maakte. ${ }^{341}$ Een direct verband tussen de geringe belangstelling van de regering voor adelszaken en de verhuizing van de Raad in 1957 van het Binnenhof naar een pand aan de Zeestraat is niet aantoonbaar. De nieuwe huisvesting, tezamen met het Koninklijk Penningkabinet, was verder van het Binnenhof verwijderd dan ooit het geval was geweest. De gezamenlijke huisvesting met een museuminstelling, die later zou fuseren met het Museum van Oudheden in Leiden, deed het historisch gegroeide instituut mogelijk te nadrukkelijk eer aan, want de juridische strijd om de Nederlandse adeldom was nog lang niet gestreden. $^{342}$

\section{Een Nederlandse adellijke titel voeren zonder daartoe gerechtigd te zijn (435 Sr.)}

Of er een verband was met de naoorlogse bezwaren in de Tweede Kamer tegen inlijving van Duitse adellijke geslachten in de Nederlandse adel, is niet aantoonbaar, maar in 1954 begon het Openbaar Ministerie de vervolging van een in Nederland wonende schilderes, die volgens het telefoonboek als douairière van een Duitse Baron zijn in de Nederlandse taal vervoegde adellijke titel voerde. Op grond van artikel 435, lid 1, van het Wetboek van Strafrecht, werd zij door de kantonrechter veroordeeld tot een geldboete wegens het voeren van een Nederlandse adellijke titel, zonder daartoe gerechtigd te zijn. ${ }^{343}$ Dit mondelinge vonnis werd vervolgens door de Rechtbank Den Haag vernietigd, waartegen het Openbaar Ministerie in cassatie ging bij de Hoge Raad der Nederlanden. De rechtbank stelde vast dat in casu de Nederlandse adellijke titel 'baronesse' was gevoerd tezamen met een nietNederlandse familienaam - hetgeen uit de schrijfwijze van de naam zou zijn op te maken - en dat dus geen strafbaar feit was gepleegd. Hier zou dan geen sprake zijn geweest van een Nederlandse titel, maar deze zou opgevat kunnen worden als een vertaling van een buitenlandse titel. De nationaliteit van verdachte was niet nader vastgesteld omdat deze, volgens de rechtbank, niet van belang was. De rechtbank had nog wel de moeite genomen om secretaris van de Hoge Raad van Adel De Bruyn van Melis- en Mariekerke in hoger beroep als getuige-deskundige te laten verklaren, dat de geslachtsnaam van verdachtes overleden echtgenoot tot de Duitse oeradel van vóór 1400 behoorde. $^{344}$

Procureur-generaal jonkheer Van Asch van Wijck lichtte in zijn conclusie toe dat art. 435 Sr. de sanctie was op de artikelen 67 e.v. (1953: 74 e.v.) van de grondwet,

\footnotetext{
${ }^{340}$ Notulen ministerraad, d.d. 23 nov. 1953 (HRvA, RA, inv. nr. 355: corr. 1957-98); Van Lynden, 'Enkele notities over het adelsbeleid', 201.

${ }^{341}$ Slijkerman, In dienst van de kroon, 210-216.

${ }^{342}$ Kort en Wolleswinkel, Het archief van de Hoge Raad van Adel, 7.

${ }^{343}$ Kantongerecht 's -Gravenhage 19 nov. 1954 (Von Wedell).

${ }^{344}$ AR's-Gravenhage 23 sept. 1955.
} 
waarvan art. 67 luidde: 'De Koning verleent adeldom. Vreemde adeldom kan door geen Nederlander worden aangenomen', en liet weinig heel van de uitspraak van de rechtbank. Hij beargumenteerde dat de strekking van de strafrechtelijke bepaling geen andere kon zijn dan dat een Nederlandse adellijke titel in Nederland slechts gevoerd mag worden, indien zodanige titel door de koning is verleend door middel van erkenning, verheffing of inlijving. De enige uitzondering die hij kon bedenken zou een niet-Nederlander zijn, als deze titel hem rechtens competeerde. Dit hield noodzakelijkerwijs in dat een vreemde adellijke titel, een nietNederlander competerende, hier niet in zodanige Nederlandse vertaling mocht worden gevoerd, dat deze een Nederlandse adellijke titel opleverde. Het Nederlandse 'baronesse' was niet correct en had 'Baronin' moeten zijn, gesteld dat een zodanige titel rechtens zou bestaan. Het criterium van de nationaliteit leek hem belangrijker dan de al of niet Nederlandse geslachtsnaam, waarvan hij met voorbeelden aantoonde dat daar geen enkele lijn op te trekken was.

Tegen de verwachting in verklaarde de Hoge Raad der Nederlanden het Openbaar Ministerie niet ontvankelijk in zijn cassatieberoep omdat de rechtbank formeel als niet bewezen kon achten dat ten onrechte een Nederlandse adellijke titel was gevoerd. $^{345}$

Bovenstaande uitspraak van meer dan een halve eeuw geleden kent thans een revival en wordt dan positief en daardoor onjuist geciteerd. De Hoge Raad der Nederlanden zou volgens deze interpretatie aan Nederlanders in het algemeen toestemming geven om een buitenlandse adellijke titel in Nederland te voeren, mits vertaald naar het Nederlands en in samenhang met een niet-Nederlandse naam. ${ }^{346}$

Van vervolging op grond van het eerste lid van artikel $435 \mathrm{Sr}$. zijn niet veel voorbeelden te vinden. Laatstelijk werd in 2011 een drager van de adellijke geslachtsnaam van zijn moeder voorwaardelijk veroordeeld, omdat hij gedurende langere tijd ook de vervoegde adellijke titel van zijn moeder voerde zonder daar recht op te hebben. Adellijke titulatuur vererft immers alleen langs mannelijke lijn. ${ }^{347}$

Hanegraaff kwam in 1891 tot de conclusie, dat het tweede lid van art. 435 Sr., waarbij 'degene, die zonder 's Konings verlof, waar dit vereist wordt, een vreemd ordeteken, titel, rang of waardigheid aanneemt', strafbaar wordt gesteld, geen betrekking kan hebben op een adellijke titel omdat dit onvoorwaardelijk werd verboden in de grondwet. Artikel 67 (daarna 74) vermeldde immers in de tweede zinsnede: 'Vreemde adeldom kan door geen Nederlander worden aangenomen'. De oude formulering in de grondwet was dwingender: 'In geen geval mogen andere Nederlanders, of vreemdelingen, die in Nederlandsche staatsdienst zijn, vreemde ordeteekenen, titels, rang of waardigheden aannemen, zonder bijzonder verlof van den Koning. ${ }^{348}$ Dit verbod is al in de Grondwet van 1814 terug te vinden en heeft te maken met de soevereine (sinds 1815: koninklijke) waardigheid van het staats-

\footnotetext{
${ }^{345}$ HR (Strafkamer) 14 febr. 1956; NJ 1956, 208.

${ }^{346}$ De Neve, 'Buitenlandse adel(lijke titels) in Nederland', 129-141.

${ }^{347}$ Kantongerecht Maastricht, 8 juli 2011.

${ }^{348}$ Hanegraaff, Opmerkingen naar aanleiding van artikel 435 van het Wetboek van Strafrecht, 46-51.
} 
hoofd. Hij is immers bij uitsluiting gerechtigd zijn prerogatiefrecht uit te oefenen en behoefde zonder toestemming geen acties van andere soevereinen ten behoeve van zijn onderdanen toe te laten.

Ten aanzien van buitenlandse adellijke titulatuur voorzag het adelsrecht altijd al in de mogelijkheid om aan de koning inlijving in de Nederlandse adel te verzoeken, waarbij - na gunstige beslissing - een equivalent onder de Nederlandse titulatuur kon worden verleend.

Strikt genomen spreekt het strafrechtartikel over 'aannemen', en niet over 'voeren', zodat menigeen thans - nu artikel 74 uit de grondwet is verdwenen - de conclusie trekt, dat het voeren door een Nederlander van een buitenlandse adellijke titel, tenminste als het geen in Nederland voorkomende adellijke titel is, niet strafbaar is. ${ }^{349}$ Betrokkene moet dan wel kunnen aantonen dat hij deze buitenlandse titulatuur rechtens voert, omdat art. 435, lid 4, het tegenover het bevoegde gezag opgeven van een valse naam, althans anders dan in de gemeentelijke basisadministratie wordt vermeld, strafbaar stelt. Het voeren van een vreemde titel houdt overigens niet in dat deze voor opname in akten van de burgerlijke stand in aanmerking komt. De Groot nuanceert deze laatste conclusie door aan te geven dat er geen enkel bezwaar bestaat om buitenlandse adellijke getuigen bij huwelijken met hun titels in akten te vermelden, hetgeen bij koninklijke huwelijken in de praktijk ook gebeurt. Een probleem ontstaat eerst wanneer betrokkene (tevens) de Nederlandse nationaliteit heeft, waardoor verwarring zou kunnen ontstaan. ${ }^{350}$

Een inlijvingsverzoek - op grond van de overgangsbepaling in de Wet op de adeldom - van een Nederlander wiens grootvader in 1924 pauselijke adeldom en in 1926 de titel van palatijns graaf had verworven, werd ondermeer afgewezen omdat voor het aannemen destijds geen verlof aan de koning was gevraagd, zoals de grondwet voorschreef. De verleende adeldom achtte de minister bij overtreding van dit verbod, waarop geen sanctie stond, in de Nederlandse rechtstaat in ieder geval als non-existent. Ook het pauselijke adelsrecht van na 1870 (opname van de stadsstaat Rome in de eenheidsstaat Italië) verschilde in meerdere essentiële onderdelen van het Nederlandse adelsstatuut. ${ }^{351}$

\section{Voorstellen van de Hoge Raad van Adel voor een nieuw adelsbeleid}

Intern produceerde de Hoge Raad van Adel in oktober 1959 een beleidsstuk getiteld 'De Nederlandse adel', dat vooral tot doel had het vastgeroeste nobilitatiebeleid open te breken. In de daarop volgende vergaderingen leverden de voorzitter en

\footnotetext{
${ }^{349}$ Noyon, Langemeijer, Remmelink, Het Wetboek van Strafrecht verklaard (losbladige editie, bijgewerkt door supplement 122, juni 2003), aantekeningen op artikel 435.

${ }^{350}$ De Groot, 'Twee aantekeningen over het gebruik van adellijke titels', 100-102. Hij pleit er ook voor dat een minderjarige van buitenlandse adel die naast zijn buitenlandse nationaliteit het Nederlanderschap van rechtswege heeft verworven en die bij het bereiken van de meerjarigheid opteert voor de Nederlandse nationaliteit en inlijving in de Nederlandse adel verzoekt, gedurende zijn minderjarigheid net zoals zijn nietNederlandse adellijke vader met vreemde titulatuur in de Burgerlijke Stand mag worden vermeld (101).

${ }^{351}$ HRvA, RA, not. 1999-31. Vgl. Westerouen van Meeteren, 'Op zoek naar de pauselijke adel', 478-490, en 'Onverwacht gekregen en ook niet gekregen pauselijke adeldom', 407-419; Ten Houte de Lange en Van der Burg, Pauselijk eerbetoon, 34-40.
} 
de leden van de Raad commentaar op de wenselijkheid van uitbreiding en de eventuele maatstaven voor nobilitatie, ondersteund door een bijgewerkte statistiek uit 1937. ${ }^{352}$ Een jaar eerder had de secretaris-generaal van het ministerie de Raad verzocht eens zijn gedachten te laten gaan over een nieuwe instructie voor de Hoge Raad van Adel, waarvan de laatste uit de negentiende eeuw dateerde. Daarin zouden ook de adviestaken betreffende adellijk naamrecht (aan de minister van Justitie) en krijgsmachtemblemen (aan de minister van Defensie) genoemd moeten worden. Dit resulteerde voorjaar 1960 in een conceptinstructie, waarover met het ministerie overeenstemming werd bereikt maar die dit stadium nooit voorbij is gekomen. ${ }^{353}$ Waarschijnlijk is deze conceptinstructie in het verdere juridische circuit gestrand, want in het stuk werden alle SB's en KB's, die betrekking hadden op samenstelling, taak en bevoegdheden van de Raad, ingetrokken zonder dat daar kennelijk de gevolgen voldoende van waren voorzien. ${ }^{354}$ In de eerstvolgende vergaderingen van de Raad werd er niet meer over gerept, onder meer omdat andere zaken de aandacht vroegen. Vijf dagen na elkaar ontvielen de Raad in september 1960 zijn voorzitter, de rijksarchivaris jonkheer Graswinckel, en het lid baron Van Hardenbroek. In hetzelfde jaar gaf ook generaal baron Van Voorst tot Voorst te kennen als lid van de Raad te willen terugtreden. Zijn integraal in de notulen opgenomen afscheidsrede geeft een aardig overzicht van de naoorlogse geschiedenis van de Raad. Jonkheer M.A. Beelaerts van Blokland werd tot voorzitter benoemd. Met hem had de derde Beelaerts vanaf (1909) 1924, maar nu van een jongere generatie na het overlijden van zijn vader in 1956, zijn intrede in de Raad gedaan. Betrekkelijk snel werden drie nieuwe leden aangezocht: de latere vice-admiraal (en voorzitter) A.N. baron de Vos van Steenwijk, jonkheer Van Meeuwen en jonkheer Ruijs de Beerenbrouck, die nog hetzelfde jaar werden benoemd. ${ }^{355}$

Hare Majesteits ambassadeur Merens vond in de nieuwe voorzitter een oud-collega uit de diplomatieke dienst, aan wie hij zijn verheffingsverzoek nog eens informeel voorlegde. Hij deed daarbij een beroep op eerdere verzoeken van familieleden, die doorgaans positief waren beoordeeld maar om externe redenen (oorlog, gewijzigd adelsbeleid, etc.) nooit tot een koninklijke gunst hadden geleid. Dit herhaalde verzoek werd terloops aan de orde gesteld tijdens persoonlijke contacten tussen de minister van Binnenlandse Zaken Toxopeus en de voorzitter van de Raad. ${ }^{356}$ Deze resulteerden begin 1963 in een weloverwogen brief aan de minister, waarin de Raad een voorstel voor nieuw beleid deed. De Raad achtte het terugbrengen van adelsverleningen tot alleen inlijvingsverzoeken van genaturaliseerde Nederlanders in strijd met de grondwet: 'Het koninklijk prerogatief creëert een toch uiterlijk teken (erfelijke adeldom) van waardering voor verdiensten aan vorst, land en volk

\footnotetext{
${ }^{352}$ HRvA, RA, inv. nrs. 220 (not. 1959-44) en 221 (not. 1960-59).

${ }^{353}$ HRvA, RA, inv. nr. 220 (not. 1959-52).

${ }^{354}$ De uitvaardiging van de ministeriële circulaire van 22 juni 1961, nr. 291/161, betreffende ambtshalve toezenden van adellijke BS-akten, is hier een bewijs van aangezien artikel 10 van de concept-instructie daarin had moeten voorzien.

${ }^{355}$ HRvA, RA, inv. nr. 221 (not. 1960-53).

${ }^{356}$ HRvA, RA, inv. nr. 355 (corr. 1957-98).
} 
bewezen.' De Raad gaf toe dat het vasthouden aan het criterium van drie opeenvolgende generaties bestuurders van stemhebbende steden tijdens de Republiek op dat moment niet meer van werkelijkheidszin getuigde. Daar kwam bij dat deze vorm van nobilitatie de schijn van een recht had gekregen die strijdig was met de tekst van de grondwet, waarin immers sprake is van een koninklijke gunst. De Raad stelde een nieuw criterium voor, waarbij personen van uitzonderlijke verdiensten kans zouden maken, mits hun voorgeslacht in de twee voorafgaande generaties in de Nederlandse samenleving een gewaardeerde plaats innam. Naar de overtuiging van de Raad betekende een dergelijke gunst een stimulans voor het nageslacht van de genobiliteerde om op eigen wijze met eigen talenten zich als een goed lid van de Nederlandse gemeenschap te gedragen. Als reden hiervoor werd gegeven dat uitzonderlijke bekwaamheid meestal niet erfelijk is, maar verantwoordelijkheidszin en plichtsbetrachting wel. De brief werd afgesloten met een pleidooi voor afschaffing van leges en taxa, die bij nieuw beleid in strijd met de strekking van een eerbewijs werd geacht: "voor een belasting op de ijdelheid van betrokkenen is dan geen plaats meer. ${ }^{, 357}$ Er kwam echter geen antwoord op de brief en in het jubileumboek van de Raad (1966) werd nog eens een voorzichtige poging gewaagd het bevroren beleid te ontdooien. ${ }^{358}$

\section{Aanschrijf-en aanspreekvormen}

In 1964 blijkt er een voornemen van de minister-president te zijn geweest om het gebruik af te schaffen van aanschrijfvormen en predicaten in het onderlinge verkeer van overheidsinstanties. Het plan was mede gebaseerd op een Soeverein Besluit van 5 april 1814 betreffende de vorm van rapporten en voordrachten, waarin autoriteiten bij intern briefverkeer, met uitzondering van rekesten, werden vrijgesteld van gebruik van titulatuur. ${ }^{359}$ In de loop van 1965 werd een ontwerpbeschikking van de minister-president opgesteld, waaruit volgde dat ook adellijke titels en predikaten onder deze richtlijn zouden gaan vallen. In mei 1963 had de koningin (opnieuw) verzocht in aan haar gerichte brieven en rekesten geen termen meer te gebruiken als 'onderdanige dienaar' en 'gehoorzame onderdaan' en eraan herinnerd dat sinds twintig jaar in officiële stukken, als de koningin met 'zij/haar' wordt aangehaald, dit niet met een hoofdletter gebeurt. ${ }^{360}$ In een vertrouwelijk nota gaf de Hoge Raad van Adel aan dat adellijke titulatuur onder de bescherming valt van de KB's van 13 febr. 1815, nr. 60 (Stb. 15) en 26 jan. 1822 (Stb. 1), alsmede alle KB's waarbij adelslijsten zijn vastgesteld vanaf $1825 .^{361}$ Deze lijsten waren im-

\footnotetext{
${ }^{357}$ HRvA, RA, inv. nr. 225 (not. 1962-92).

${ }^{358}$ Van Valkenburg, 'Adelsbeleid sedert 1813', 71.

${ }^{359}$ Bij Kon. Disp. van 5 juni 1815, nr. 16, had koning Willem I hier nog aan toegevoegd, dat het opschrift alleen de tekst 'Aan den Koning' zou bevatten (HRvA, RA, inv. nr. 4, not. 1815-226).

${ }^{360}$ Kennisgeving van de minister-president, minister van Algemene Zaken, aan alle ministers over brieven aan de koningin, d.d. 12 mei 1965, nr. 162561 ('vooruitlopende op een nadere vaststelling van richtlijnen voor de titulatuur en vaste formules in ambtelijke brieven').

${ }^{361}$ De preambule van deze adelslijsten gaf steeds de hiërarchie van adellijke titulatuur aan met de daarbij behorende aanhef: prins, hertog, markies en (burg)graaf 'hooggeboren heer', tenzij hen een bijzonder predikaat bij hun diploma was verleend. Baron, ridder en jonkheer werden met 'hoogwelgeboren heer' aange-
} 
mers uitdrukkelijk bestemd voor overheidsdiensten om weet van de verleende titulatuur te hebben en deze op alle overheidsdocumenten te vermelden. ${ }^{362}$ Toen vervolgens bleek dat ook een recent koninklijk besluit over toe te passen titulatuur voor rechterlijke ambtenaren afschaffing in de weg stond, is de zaak in 1966 op de lange baan geschoven. ${ }^{363}$ Volgens de notulen van de Raad zou vanuit het Ministerie van Binnenlandse Zaken bezwaar zijn gerezen. ${ }^{364}$

Op 6 december 1972 nam de toenmalige minister van Binnenlandse Zaken Geertsema zelf het voortouw om de zozeer gewenste vereenvoudiging van het intern gebruik van titulatuur te bewerkstelligen. Hij stuitte op hetzelfde probleem, maar vroeg advies aan de Raad om gedetailleerd aan te geven hoe wijziging tot stand zou kunnen worden gebracht. In zijn advies van 5 januari 1973 gaf de Raad de beperkte mogelijkheden aan om tot wijziging van de betreffende KB's te kunnen komen. De voorzitter van de Raad lichtte zijn standpunt op 17 januari nog eens persoonlijk toe bij de minister, met als gevolg dat ook dit plan niet doorging. Volgens de Raadsnotulen was in 1974 vanuit het Kabinet der Koningin het bericht gekomen dat de koningin bezwaren had. ${ }^{365}$

In 1984 verzocht de Permanente commissie documentaire informatieverzorging, die ressorteerde onder het Ministerie van Binnenlandse Zaken, aan de Hoge Raad van Adel om richtlijnen voor de schrijfwijze van titels en predikaten ter beschikking te stellen. Deze zouden als bijlage opgenomen worden bij de herziene 'richtlijnen voor het typen van documenten' die in voorbereiding waren. Dit resulteerde in nieuwe door de Hoge Raad van Adel uitgebrachte richtlijnen voor het gebruik van adellijke titels en predikaten. Ze verschilden in zoverre van oudere stencils, dat vanaf die tijd principieel het gebruik van kleine (begin)letters voor adellijke titels en predikaten werd aanbevolen om op officiële documenten misverstanden met eigennamen te voorkomen. ${ }^{366}$ In 1989 vroeg de ceremoniemeester van de koningin informatie aan de Hoge Raad van Adel om tot een publicatie van gehanteerde titulatuur en aanspreekvormen te komen. ${ }^{367}$ De ceremoniemeester en de chef de bureau departement van de hofmaarschalk brachten kort daarna hun eerste gedrukte

\footnotetext{
schreven. De 'Prinsen van het Koninklijk Huis' en de 'Prinsen en Hertogen van het Heilige Roomsche Rijk' vielen er buiten en bleven hun predikaten voeren 'die aan hunne titels ten allen tijde zijn gehecht geweest.' (HRvA, RA, inv. nr. 878). De Statuten betrekkelijk den adel van het Koningrijk Holland (Amsterdam 1809) kenden identieke aanduidingen, maar somden die alleen op voor de 'edellieden van het koninkrijk' jonkheer, baron en graaf. De graven zouden bovendien de titel 'excellentie' voeren (art. 34). (HRvA, RA, inv. nr. 889).

${ }^{362}$ Ook de burgerlijke kamer van de Hoge Raad der Nederlanden had deze overheidsverplichting in zijn uitspraak van 19 okt. 1917 bevestigd inzake een weigering om de adellijke titel van baron Taets van Amerongen van Woudenberg tezamen met zijn naam op de kiezerslijst te plaatsen (uitspraak Kantonrechter Utrecht 12 mei 1917). Zie: NJ 1917, 1112; Prins, 'Nederlands namenrecht', 155-158.

${ }^{363}$ Marius Gerlings, 'Sine Titulis', 55-56.

${ }^{364}$ HRvA, RA, inv. nr. 878.

${ }^{365}$ HRvA, RA, inv. nr. 239 (not. 1972-65).

${ }^{366}$ HRvA, RA, inv. nr. 260 (not. 1984-37-I). Van der Wiel, ‘Adellijke titels', 60-64. Deze worden ook thans nog aanbevolen, zie: $w w w$.hogeraadvanadel.nl (adeldom>titel/predikaat>richtlijnen).

${ }^{367}$ HRvA, RA, inv. nr. 260 (not. 1984-37-II).
} 
titulatuurgids uit, die veel verder ging dan de beperkte richtlijnen van de Raad, omdat hun publicatie in het bijzonder betrekking had op het koninklijk huis. ${ }^{368}$ Adellijke en andere aanspreek- en aanschrijfvormen worden nog uitsluitend gebezigd binnen het koninklijk huis, de diplomatieke dienst en (soms) in familiecorrespondentie. De rechterlijke macht heeft al lange tijd afstand genomen van nog in 1960 voorgeschreven aanspreek- en aanschrijfvormen als 'edelhoogachtbare' en 'edelgrootachtbare' voor rechterlijke ambtenaren bij achtereenvolgens de Hoge Raad en de gerechtshoven. ${ }^{369}$ Nieuwe pogingen om tot vereenvoudiging of afschaffing te komen, zijn niet meer ondernomen, vermoedelijk omdat in het computertijdperk de wensen door de tijd zijn ingehaald.

\section{Bestuursrechtspraak voor afgewezen adelsverzoeken}

Betrof de jurisprudentie over adelszaken doorgaans het ten (on)rechte voeren van titulatuur, in 1964 trad de Wet Beroep Administratieve Beschikkingen (Wet BAB) in werking, die de in zijn belangen getroffen burger de mogelijkheid gaf het overheidsbesluit zelf aan te vechten. Schutte signaleerde dat verlening van adeldom van een aan regels gebonden gunst van de Kroon een recht van de aanvrager was geworden. ${ }^{370}$ Van der Burg noemde deze ontwikkeling de juridificering van de adeldom. $^{371}$

Administratief beroep kon ingesteld worden bij de Afdeling geschillen van bestuur van de Raad van State. De Afdeling kon de beschikkingen vervolgens aan de wet toetsen, maar ook aan het rechtszekerheids- en het gelijkheidsbeginsel en andere algemene rechtsbeginselen van behoorlijk bestuur, zoals zorgvuldigheid en voldoende motivering. Voorts kon de rechter onderzoeken of geen sprake was van misbruik van bevoegdheid of willekeur. Eén van de belangrijkste uitspraken op het gebied van het adelsrecht werd gedaan in het beroep van een lid van de Nederlandse adel betreffende twee door hem en zijn vrouw geadopteerde kinderen, die geen bewijs van adeldom konden krijgen omdat zij niet uit hun wettige huwelijk waren geboren. De Hoge Raad van Adel, die inschrijving van de kinderen in het filiatieregister had geweigerd, beriep zich onder meer op het KB van 13 februari 1815, nr. 60, waarin afstamming en wettigheid als twee afzonderlijke vereisten voor adeldom worden gesteld. De Afdeling stelde de Raad in het gelijk, aangezien de wetsgeschiedenis geen aanleiding gaf om aan het begrip afstammeling een ruimere betekenis toe te kennen dan afstamming door geboorte. ${ }^{372}$ Deze beslissing werd daarna door de Afdeling Bestuursrechtspraak van de Raad van State gevolgd in

\footnotetext{
${ }^{368}$ Monod de Froideville, Den Beer Poortugael en Van Eijk, Titulatuurgids. In de latere versies van 2005 en 2011 is ook de Wet op de adeldom (inclusief het commentaar van de HRvA) opgenomen, alsmede (internationale) onderwijstitulatuur, die bij de Wet op het hoger onderwijs en wetenschappelijk onderzoek van 1 september 2002 (Stb. 302) is vastgesteld.

${ }^{369} \mathrm{~KB}$ van 26 februari 1960 (Stb. 83), betreffende de titulatuur en het costuum der rechterlijke ambtenaren alsmede het costuum van de advocaten en procureurs (Reglement II).

${ }^{370}$ Schutte, 'Hoge Raad van Adel 1968-2003', 205-207.

${ }^{371}$ Van der Burg, 'Het Nederlandse adelsbeleid sedert 1980', 200-205.

372 RvS (BAB 1974), 8 juli 1975, nr. 124 (Boreel de Mauregnault). Vgl. Van Lynden, 'Enkele notities over het adelsbeleid', 202 (met literatuur).
} 
zijn uitspraken betreffende de afgewezen adeldom van een onwettige dochter van een ongehuwde adellijke moeder (1985) en van een door zijn adellijke vader geadopteerd voorkind (1990). ${ }^{373}$

In 1976 was namelijk de Wet Administratieve Rechtspraak Overheidsbeschikkingen (Wet AROB) van kracht geworden, waarmee een nieuwe Afdeling (Bestuurs)rechtspraak bij de Raad van State werd belast. ${ }^{374}$ Eén van de eerste adelszaken die werd beoordeeld, betrof een afwijzing door de minister van een verzoek om inlijving van een tot de voormalige Duitse adel behorende Nederlander, van wie de continuïteit van adeldom zou verjaard zijn wegens een geconcludeerd gebrek aan belangstelling. De Afdeling achtte deze onjuiste afwijzingsgrond als motivatie in strijd met het algemeen beginsel van behoorlijk bestuur en vernietigde het besluit. Zijdelings deed de Afdeling een interessante uitspraak over adeldom als gunst of als recht: 'de gebezigde kwalificatie van gunst-in-de-meest-zuiverezin-van-het-woord, brengt geenszins mee dat het besluit niet aan de wet zou mogen worden getoetst'. ${ }^{375}$ In de navolgende periode deed de Afdeling nog uitspraken in adelszaken betreffende bewijsvoering (bewijslast bij de verzoeker), vergelijkbare adelsstatuten (Europese vasteland) en inheemse adel (Nederlands-Indië). ${ }^{376}$

\section{Erfopvolging binnen het koninklijk huis}

Ook ten aanzien van het koninklijk huis noodzaakten de naoorlogse ontwikkelingen tot nadere regelgeving. In negentiende- en twintigste-eeuwse grondwetten werd er stilzwijgend van uitgegaan dat het recht op lidmaatschap van het koninklijk huis vererfde zoals adeldom overging op mannelijke en vrouwelijke nakomelingen in de mannelijke lijn. De Grondwet van 1815 sprak over 'het oir uit het Huis van Oranje-Nassau', dat als ruimer dan de nakomelingen van de koning moest worden opgevat. Een nooit ingevoerd familiestatuut uit 1829, dat het huisrecht nader had moeten regelen, betrok daarbij ook de gemalinnen en douairières gedurende hun weduwenstaat. In de praktijk behoorden deze aangetrouwde leden niet tot het huis, maar zij werden daarmee gelijkgesteld en genoten dezelfde rechten. De invoering van de ministeriële verantwoordelijkheid in 1848 werd nog niet in verband gebracht met de omvang van het koninklijk huis en de consequenties die dit voor de verantwoordelijke ministers zou kunnen hebben. Evenmin was er een koppeling tussen het lidmaatschap van het koninklijk huis en het recht van troonopvolging, dat tot 1922 aan alle nakomelingen (ook in vrouwelijke lijn) van stadhouder prins Willem IV toekwam. In genoemd jaar werd dit laatste recht be-

\footnotetext{
${ }^{373}$ ABRvS (Afdeling Bestuursrechtspraak Raad van State) 9 sept. 1985, R01.84.1081; ABRvS 3 juni 1990, R01.87.3997 (Van Andringa de Kempenaer).

${ }^{374}$ In het kader van de voltooiing eerste fase herziening rechterlijke organisatie werd de Wet AROB ingetrokken per 1 jan. 1994 (Stb. 1993, 650) en trad de Wet van 4 juni 1992, houdende algemene regels van bestuursrecht (AWB, laatstelijk gewijzigd bij: Stb. 2011, 190) in werking.

${ }^{375}$ ABRvS 18 april 1978, A-1.0666 (1977) (Von Hertzberg). Vgl. Van Lynden, 'Enkele notities over het adelsbeleid in de periode Van Valkenburg', 203 (met literatuur).

${ }^{376}$ ABRvS 28 okt. 1982, A-1.2024 (1981), Arpeau; ABRvS 15 febr. 1980, A-1.0465 (1979), Sewandono; ABRvS 18 aug. 1981, A-1.1949 (1980), Sewandono. Vgl. Van Lynden, 'Enkele notities over het adelsbeleid in de periode Van Valkenburg', 203-205 (met literatuur).
} 
perkt tot de nakomelingen van koningin Wilhelmina, die in de Grondwet van 1938 nader werden gespecificeerd als 'de dochter des Konings, die de vermoedelijke erfgenaam is van de kroon, en haar gemaal'. ${ }^{377}$ Daarmee waren tevens alle leden van het koninklijk huis, dat door natuurlijke omstandigheden was geminimaliseerd, opgesomd. ${ }^{378}$

De omstandigheid dat de kroon in 1948 voor de tweede keer in vrouwelijke lijn vererfde en de reële verwachting dat dit ook de daarop volgende keer zou plaatshebben, noopten tot een nadere invulling van het lidmaatschap van het koninklijk huis. Om die reden werd in de Grondwet van 1972 artikel 21a opgenomen, dat een regeling bij wet in het vooruitzicht stelde. Voorts was een discussie op gang gekomen over artikel 27 van dezelfde grondwet, met de bepaling dat 'de oudste van des Konings zonen of verdere nakomelingen, die de vermoedelijke erfgenaam is van de Kroon, des Konings eerste onderdaan [is] en den titel van Prins van Oranje [voert]', die vanaf 1815 onafgebroken in elke nieuwe grondwet was overgenomen. Als tussenstap was in de Grondwet van 1963 al expliciet opgenomen dat voor de erfopvolging ook dochters in aanmerking konden komen, maar met nog steeds voorrang voor de zonen. Vervolgens zou het oudste kind, met dezelfde plaatsvervulling, in aanmerking komen en niet de eventuele zuster, voornamelijk om te voorkomen dat onvoorbereide nakomelingen zouden opvolgen. ${ }^{379}$

Het grondbeginsel van de gelijkwaardigheid van de seksen vroeg om een aanpassing van de grondwet, waardoor de voorrang van zoons boven dochters zou vervallen. ${ }^{380}$ Deze werd in de Grondwet van 1983 gerealiseerd met de bepaling: 'Het koningschap gaat bij overlijden van de Koning krachtens erfopvolging over op zijn wettige nakomelingen, waarbij het oudste kind voorrang heeft, met plaatsvervulling volgens dezelfde regel. ${ }^{381}$ De consequentie hiervan voor de titel prins(es) van Oranje werd vooruitgeschoven - want niet urgent nu het oudste kind van de koningin een zoon was - door de bepaling betreffende de titel uit de grondwet te verwijderen. Van Dorp betreurde deze ontneming van een grondwettelijk grondslag aan de titel prins van Oranje en weet deze aan het zogenaamde deconstitutionaliseringsbeginsel. Volgens dit door de wetgever aangehangen beginsel werden bij deze grondwetsherziening zoveel mogelijk onderwerpen geweerd casu quo geëlimineerd welke niet van rechtstreeks staatsrechtelijk belang zouden zijn. ${ }^{382}$

In dezelfde grondwet werd de bepaling uit de Grondwet van 1972 (art. 21a) herhaald in artikel 39, dat 'de wet regelt wie lid is van het koninklijk huis'. Toen in 1985 de eerste Wet lidmaatschap koninklijk huis totstandkwam, was daar een periode van twintig jaar voorbereiding aan voorafgegaan. ${ }^{383}$ De aanleiding was destijds

\footnotetext{
${ }^{377}$ Van Valkenburg, 'Lidmaatschap van het Koninklijk Huis', 125-130.

${ }^{378}$ Grondwet van 1938, artt. 24 en 29.

${ }^{379}$ Grondwet van 1963, art. 11. Vgl. Van Valkenburg, 'De troonopvolging in Nederland', 143-144.

${ }^{380}$ Verdrag inzake de uitbanning van alle discriminatie van vrouwen van 19 dec. 1979, goedgekeurd bij Rijkswet van 3 juli 1991 (Stb. 355).

${ }^{381}$ Grondwet van 1983, art. 25a.

382 Van Dorp, 'De titel "Prins van Oranje", 272.

${ }^{383}$ Wet van 30 okt. 1985 (Stb. 578) tot regeling van het lidmaatschap koninklijk huis.
} 
het huwelijk in 1964 van prinses Irene geweest, waarvoor geen toestemming van het parlement was gevraagd. Het Kabinet Marijnen had daarop advies aan de ministers van staat Drees en Oud gevraagd, die als eersten een begrenzing van de relatie tussen ministeriële verantwoordelijkheid en lidmaatschap van het koninklijk huis voorstelden, waardoor verder van de troon verwijderde familieleden buiten verantwoordelijkheid van de regering zouden blijven. $\mathrm{Zij}$ introduceerden het nieuwe begrip 'indirecte ministeriële verantwoordelijkheid', waarmee een verantwoordelijkheid op basis van art. 68 van de grondwet aan het parlement werd gecreëerd voor familieleden van de koning die verder van de troon verwijderd zijn of daarop door het ontberen van toestemming voor hun huwelijk geen recht meer hebben. ${ }^{384}$ De eerdergenoemde Staatscommissie Cals-Donner zou voorstellen formuleren over de omvang van het koninklijk huis in samenhang met het recht van erfopvolging, zoals dit in de grondwet is omschreven. Het lidmaatschap van het koninklijk huis zou op dezelfde wijze worden beperkt als het recht op erfopvolging (tot en met de derde graad), met dit verschil dat zij, die dit laatste recht hadden verloren, wel lid van het koninklijk huis zouden blijven. Deze laatste uitzondering, de zogenaamde behoudbepaling (art. 2), lag politiek gevoelig en was de oorzaak van de vertraging. Na de troonsaanvaarding door koningin Beatrix kwam onder het eerste Kabinet Lubbers een oplossing tot stand, waarbij het lidmaatschap (tot en met de derde graad) afhankelijk werd gesteld van de afstand tot de op dat moment regerende vorst. ${ }^{385}$

Eerst bij de totstandkoming van de opvolgende Wet lidmaatschap koninklijk huis in 2002 werd het koninklijk huis verder beperkt tot erfopvolgers in de eerste en tweede graad van bloedverwantschap met de koning (alsmede hun echtgenoten). Hierdoor zijn niet alle grondwettelijke troonopvolgers, immers tot de derde graad, bij voorbaat meer lid van het koninklijk huis. ${ }^{386}$

\section{Adeldom uit de grondwet}

Bij de beperkte grondwetsherziening van 1972 werd artikel 74 ('De Koning verleent adeldom. Vreemde adeldom kan door geen Nederlander worden aangenomen') gehandhaafd ondanks het feit dat deze wetgeving niet meer overeenkwam met de praktijk. De Staatscommissie Cals-Donner had in haar eindrapport (1971) gepleit voor schrappen, maar met een additioneel grondwetartikel waarin uitzicht op een wettelijke regeling werd geboden.

Op 31 oktober 1979 diende de regering een ontwerp van Rijkswet ten aanzien van de grondwetsartikelen over adeldom en ridderorden in, maar betoonde zich geen voorstander van het schrappen van artikel 74. Daarbij werd gewezen op dit grondwetsartikel als basis voor titelverlening en naamgeving van leden van het koninklijk huis, die in de jaren 1965-1967 bij koninklijk besluit was gerealiseerd. Zij

\footnotetext{
${ }^{384}$ Van der Burg, 'De toestemming voor prinselijke huwelijken', 14-18.

${ }^{385}$ Van Poelgeest, "Een onderwerp van zoo teederen aard".

${ }^{386}$ Wet van 30 mei 2002 (Stb. 275), houdende regeling van het lidmaatschap koninklijk huis alsmede daaraan verbonden titels.
} 
wilde niet verder gaan dan een andere redactie van lid 1 ('Adeldom wordt verleend bij koninklijk besluit') en het schrappen van lid 2. In zijn advies aan de Staatscommissie Cals-Donner had de Hoge Raad van Adel in mei 1967 al gewezen op het ongewenste effect van vermindering van het koninklijke aanzien, dat schrapping uit de grondwet tot gevolg zou kunnen hebben. De bevoegdheid van de vorst om adeldom te verlenen, was vanouds immers 'een normaal aspect van de Koninklijke Waardigheden' ${ }^{387}$

De Raad van State wees echter op de noodzaak om het beleid, waartoe de ministerraad in 1953 had besloten, bij wet te regelen. Door dit besluit was de discrepantie tussen de in de grondwet neergelegde bevoegdheid en de gangbare praktijk te groot geworden. Tegen het ontwerp van de regering had de Raad van State materieel geen bezwaar, maar vond het instrument van erkennen en inlijven in de Nederlandse adel op grond van een niet gepubliceerd en daardoor niet algemeen bekend besluit een dermate ver strekkende beslissing, dat deze door de wetgever diende te gebeuren. $^{388}$

De Commissie voor de grondwetsherziening in de Tweede Kamer sloot zich in meerderheid aan bij de zienswijze van de Raad van State, zodat het parlement als wetgever invloed zou kunnen uitoefenen op het adelsbeleid. Naast het bezwaar tegen een exclusief verheffingenbeleid voor leden van het koninklijk huis en nog slechts een (titel)erkenning van takken van reeds bestaande adellijke geslachten, bleef de PvdA-fractie moeite houden met de inlijving van Nederlanders die een beroep konden doen op adelsstatuten, zoals het Russische, die al lang niet meer bestonden. De CDA-fractie sloot zich hierbij aan, maar toonde zich bewust van de rechterlijke uitspraak, die verjaring op dit punt uitsloot. ${ }^{389}$ De fractie had er begrip voor dat de adviezen van de Hoge Raad van Adel vanwege de bescherming van de persoonlijke levenssfeer niet altijd voor publicatie in aanmerking kwamen, hoezeer de Wet openbaarheid van bestuur onverkort van toepassing zou zijn. Het door de regering toegezegde jaarverslag van de werkzaamheden van de Raad, dat via de minister van Binnenlandse Zaken (met ingang van 1980) aan het parlement ter beschikking zou worden gesteld, werd met instemming begroet. ${ }^{390}$ Aangezien de regering niet voldoende aan de wensen van de Tweede Kamer tegemoet wilde komen, dienden de leden Van der Burg en Nijpels tijdens de mondelinge behandeling in de Tweede Kamer een amendement in om het grondwetsartikel te schrappen en een additioneel artikel toe te voegen. ${ }^{391}$ Dit werd aangenomen met de opdracht

\footnotetext{
${ }^{387}$ Stein, 'Wet op de adeldom en artikel 1 Grondwet', 714; HRvA, RA, inv. nr. 230 (not. 1966-44 en 196730/32), gepubliceerd in de Staatscourant van 23 nov. 1967, nr. 229.

${ }^{388}$ Van Lynden, 'Enkele notities over het adelsbeleid', 200-201.

${ }^{389}$ Expliciet werd hier verwezen naar de inlijving Von Hertzberg, ABRvS 18 april 1978, A-1.0666 (1977).

${ }^{390}$ Kamerstukken II, 1979-1980, 15883 (R 1129), nr. 9 (eindverslag, d.d. 5 aug. 1980).

${ }^{391}$ Van der Burg, 'Het Nederlandse adelsbeleid sedert 1980', 201 vermeldt dat dit het enige amendement is dat bij de grondwetsherziening van 1983 werd aanvaard. De bewering dat voor het eerst een (niet-adellijke) burger lid van de Hoge Raad van Adel kon worden, is echter historisch onjuist.
} 


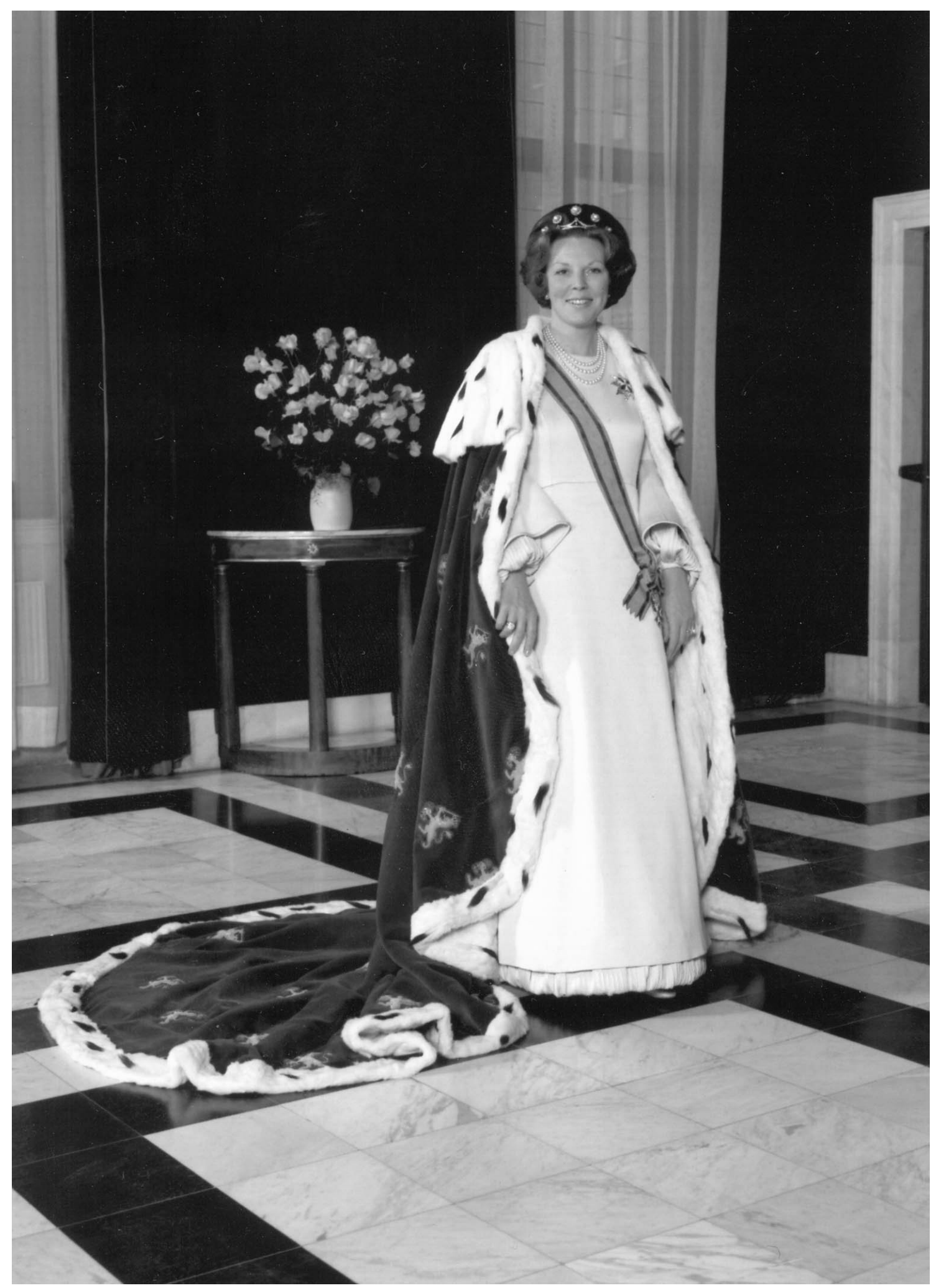

Beatrix (*1938), koningin der Nederlanden 1980-heden. Inhuldiging, Amsterdam 30 april 1980. Foto Rijksvoorlichtingsdienst, 's-Gravenhage. 
dat in een wet nauwkeurig zou worden vastgelegd in welke gevallen erkenning, verheffing en inlijving in de Nederlandse adel zou plaatsvinden. ${ }^{392}$ Hierdoor werden de voorstellen van de Staatscommissie Cals-Donner uit 1971 uiteindelijk toch overgenomen in de Rijkswet van 16 april 1981 (Stb. 219), die de algemene grondwetsherziening van 1983 voorbereidde. ${ }^{393}$ Zolang de aangekondigde adelswet niet was vastgesteld, gold overigens nog het grondwetsartikel van 1972. In de Grondwet van 1983 bepaalt artikel 111 dat ridderorden bij de wet worden ingesteld. ${ }^{394}$

\section{Royement uit de Nederlandse adel}

Uit de begintijd van het koninkrijk zijn gevallen bekend van royement bij koninklijk besluit uit de Nederlandse adel in geval van het aannemen van vreemde adeldom in Franse krijgsdienst (Van Dedem in 1816) ${ }^{395}$ of van rechtswege door een onterend vonnis (Changuion in 1825). ${ }^{396}$ Daarnaast zijn enkele persoonlijke verzoeken tot royement bekend, die bij koninklijke dispositie werden gehonoreerd en vervolgens zijn gepubliceerd in de zogenaamde adelslijsten (Van der Renne en Van Massow in 1843; Lampsins in 1845). ${ }^{397}$ In een enkel geval hadden verzoekers nakomelingen, maar deze behielden hun adeldom wanneer ze vóór de royementsdatum waren geboren. ${ }^{398}$

$\mathrm{Na}$ de invoering van de ministeriële verantwoordelijkheid komen gedurende ongeveer honderd jaar geen royementen voor. Koninklijke disposities werden kennelijk gemakkelijker afgegeven dan koninklijke besluiten, waarbij het contraseign van de minister vereist was. $\mathrm{Na}$ de Tweede Wereldoorlog zijn er verschillende verzoeken tot royement geweest, die echter niet konden worden gehonoreerd omdat de (grond)wet niet in die mogelijkheid voorzag. De redenen die werden opgegeven, varieerden van een minderwaardigheidscomplex, verlies van Nederlanderschap, godsdienstige redenen, zwaarwegende redenen van persoonlijke aard tot het slechts hebben van adoptiefkinderen. Een belangrijk argument tegen inwilliging is steeds geweest, dat het hier erfelijke adeldom betreft en eventuele nakomelingen niet benadeeld mogen worden. Betrokkene vormt als zoon van een edelman slechts een tussenschakel, die de erfelijke adeldom binnen zijn geslacht doorgeeft aan een volgende generatie. Daarbij werd het als oneervol ervaren om de koning in verlegenheid te brengen met een verzoek tot ontheffing van een aan het (voor)geslacht verleende gunst.

\footnotetext{
${ }^{392}$ Kamerstukken II, 1979-1980, 15883 (R 1129), nr. 14, deel 5d, 255; Handelingen II, 1980-1981, deel 5d, 268.

${ }^{393}$ Coenraad, 'Het Nederlandse adelsrecht', 142-143 (met bronvermelding).

${ }^{394}$ Rietkerk, De Herziene Grondwet, 32 en 79.

${ }^{395}$ HRvA, RA, inv. nrs. 10 (not. 1816-221), 281, p. 73vso., en 447, p. 774.

${ }^{396}$ HRvA, RA, inv. nr. 77 (not. 1824-481).

${ }^{397}$ KB van 25 juli 1825 (Stb. 61), p. 49; KB van 29 nov. 1843 (Stb. 59), p. 44-45 (mutaties eerste adelslijst); KB van 19 april 1846 (Stb. 20), p. 14-15 (mutatie eerste adelslijst); HRvA, RA, inv. nrs. 878 (extracten) en 449 (fotokopieën).

${ }^{398}$ De na het royement van Changuion geboren kleinkinderen waren eveneens uitgesloten (zie Nederland's Adelsboek 81 (1990-1991), 95-98), zodat het royement in feite gold voor de verzoeker en zijn afstammelingen.
} 
Prins formuleerde de onmogelijkheid nog bondiger: de koning kan niet bevoegd worden geacht zijn eenmaal onvoorwaardelijk verleende begunstigende beschikking eigenmachtig (voor het vervolg) in te trekken. Ook hij kwam tot de conclusie, dat alleen de wetgever een solide basis voor intrekking zou kunnen scheppen. Men wordt immers niet, met zijn afstammelingen, geadeld voor zolang als het de koning behaagt, doch in perpetuum. ${ }^{399}$

Onder invloed van eerdergenoemde juridisering van de adeldom, waardoor de koninklijke gunst in het maatschappelijk verkeer steeds meer als een (on)recht werd gezien, liet een verzoeker om royement wegens zwaarwichtige redenen van persoonlijke aard het niet zitten bij een beargumenteerd afhouden van de Hoge Raad van Adel. De Raad wees op het ontbreken van een (grond)wettelijke basis voor royement, in het bijzonder waar het erkende (oude) adel betrof, en stelde naamswijziging voor, die immers geen verlies van erfelijke adeldom tot gevolg zou hebben. Aangezien niemand gehouden is zijn titel of predikaat in het maatschappelijk verkeer te voeren, kon de Raad geen redelijk belang in het verzoek ontdekken en adviseerde de minister om de zaak aan te houden tot de in het vooruitzicht gestelde Wet op de adeldom van kracht zou zijn. ${ }^{400}$

Toen de verzoeker ten slotte zijn toevlucht nam tot een ombudsman van een omroepvereniging (VARA) en het verzoek politiek beladen werd, kon de verantwoordelijke minister van Binnenlandse Zaken Van Thijn, die tot dezelfde 'zuil' behoorde, niet achterblijven. Twee jaar later ondertekende de opvolgend minister Rietkerk een koninklijk besluit tot een persoonlijk royement uit de Nederlandse adel onder voorwaarde dat de adeldom niet aan diens kinderen zou worden ontnomen. Mochten er na de uitvaardiging van het koninklijke besluit nog kinderen van hem worden geboren, dan zouden deze niet tot de Nederlandse adel behoren, al zou voor hen een nieuw verzoek om erkenning altijd mogelijk blijven. ${ }^{401}$

$\mathrm{Na}$ de inwerkingtreding van de Wet op de adeldom voorzag artikel 5 in dergelijke situaties. Hierin werd voor bezwaarde edellieden de mogelijkheid gecreëerd om bij de gemeente, waar men in de Gemeentelijke Basisadministratie persoonsgegevens (GBA) staat ingeschreven, te verzoeken vermelding van adellijke titulatuur achterwege te laten of te verwijderen. De geboorteakte, die volgens art. BW 1:6 het dwingend bewijs levert voor de geslachtsnaam (en de eventuele adellijke titulatuur), blijft daarmee intact en brengt de erfelijke adeldom met het oog op afstammelingen niet in gevaar.

\footnotetext{
${ }^{399}$ Prins, 'De Hoge Raad van Adel', 101.

${ }^{400}$ HRvA, RA, inv. nr. 407 (not. 1981-27).

${ }^{401} \mathrm{~KB}$ van 21 febr. 1984, nr. 76 (Van Beijma). Als enige wettelijke basis werd de Grondwet van 1983, additioneel artikel XXV (dat een wet op de adeldom aankondigde), aangehaald.
} 


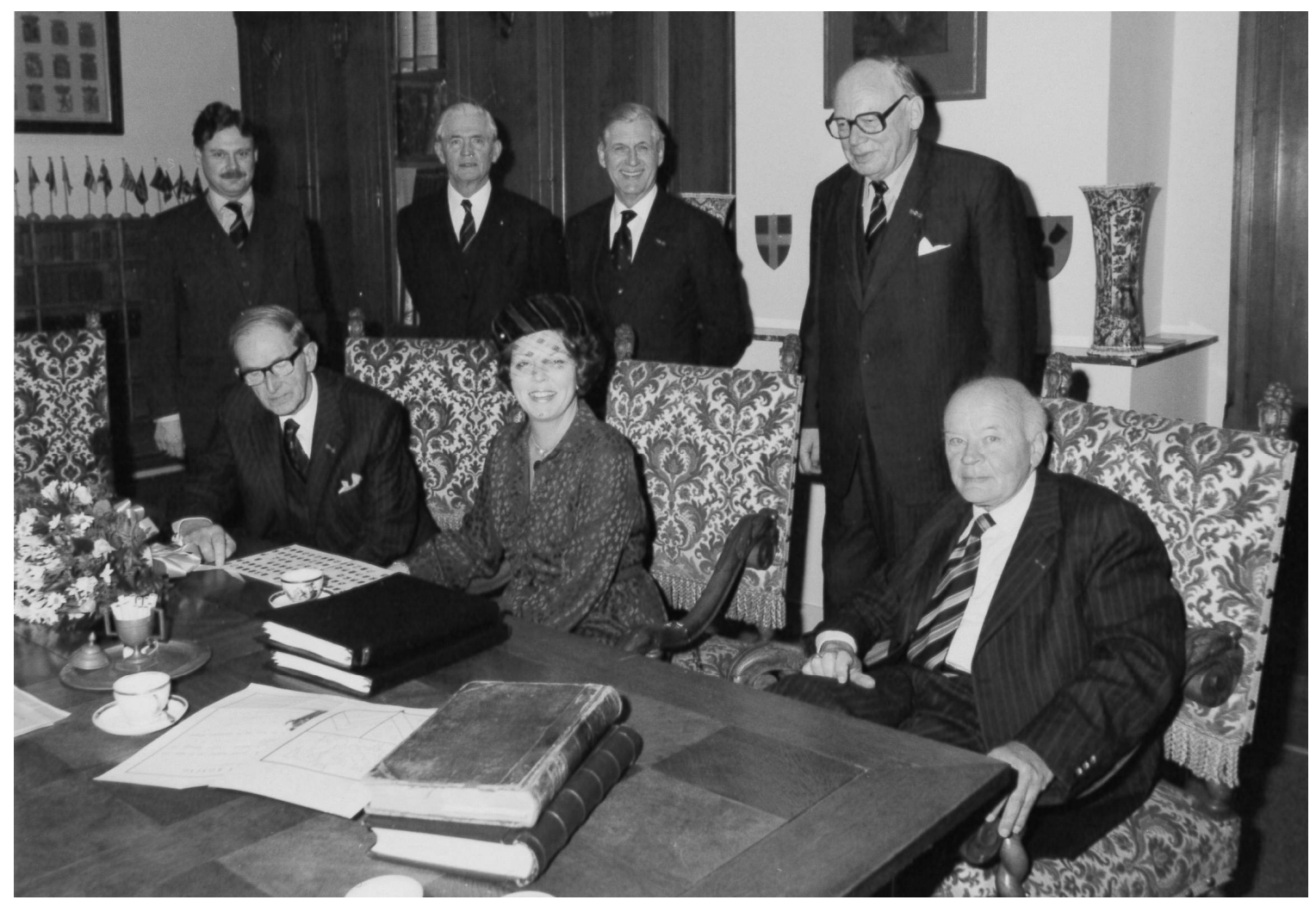

Kennismakingsbezoek van koningin Beatrix aan de Hoge Raad van Adel (Nassaulaan 18, 's-Gravenhage) d.d. 30 november 1982. De koningin wordt geflankeerd door drie achtereenvolgende voorzitters van de Raad: A.N. baron de Vos van Steenwijk (voorzitter, zittend links), jonkheer C.C. van Valkenburg (lid, staande rechts) en F.W.B. baron van Lynden (lid, staande tweede van rechts). Jonkheer T.K.M.J. van Sasse van Ysselt (zittend rechts) en A.M.J. baron van Hövell tot Westervlier en Wezeveld (staande tweede van links) waren lid van de Raad. Linksachter staat de secretaris van de Raad, O. Schutte.

Foto Ary Groeneveld, Rotterdam. Collectie en foto HRvA, 's-Gravenhage.

\section{1983-1994: Wet op de adeldom}

\section{Naamrecht}

In het door de Verenigde Naties uitgeroepen jaar van de vrouw (1975) ontwikkelde de Groningse jurist De Groot ideeën om de rechtsgelijkheid van man en vrouw in het (internationale) naamrecht vorm te geven, waarbij hij ook het Nederlandse adelsrecht betrok. Hij pleitte enerzijds voor handhaving van het anachronistische adelsrecht om uitbreiding van de adel als ongelijkwaardige groep in de samenleving te voorkomen, waarbij een verzachtende omstandigheid zou kunnen zijn dat aan adeldom geen privileges meer kunnen worden ontleend. Anderzijds gaf hij in overweging om het instituut, als men het wilde behouden, zoveel mogelijk in overeenstemming te brengen met het rechtsdenken van de tegenwoordige tijd. De wetgever zou een duidelijke keuze tussen deze twee standpunten moeten doen. ${ }^{402}$ De

\footnotetext{
${ }^{402}$ De Groot, 'Het recht van de geslachtsnaam in beweging', 1032-1033.
} 
Groot zag de wijziging van het naamrecht als een belangrijk instrument om onder de bevolking een mentaliteitverandering te bevorderen ten gunste van de emancipatie van de vrouw. ${ }^{403}$

Op initiatief van de Emancipatiecommissie werd eind jaren zeventig in opdracht van het Ministerie van Justitie een inventarisatie gedaan naar onvolkomenheden in het bestaande naamrecht. Samengevat bleek naast het gebrek aan keuze van de geslachtsnaam (achternaam) sprake te zijn van een voorkeursbehandeling van de man. Minister De Ruiter bracht het rapport in bij de dertiende conferentie van de Europese ministers van justitie in mei 1982 te Athene, waardoor het punt beargumenteerd op de agenda kwam te staan. ${ }^{404}$ De Amsterdamse hoogleraar privaatrecht aan de Vrije Universiteit, baron Van Wassenaer van Catwijck vond het rapport niet ver genoeg gaan en voegde nog het bezwaar toe van de vermindering van het namenbestand dat het bestaande naamrecht tot gevolg had. Deze verarming van het naamstelsel, waarbij hij adellijke familienamen als voorbeeld nam, zou door de voorgestelde emancipatoire aanpassing, een halt toegeroepen kunnen worden. Aan de twee in het rapport genoemde bezwaren tilde hij echter zwaarder omdat zij een inbreuk waren op fundamentele rechtsbeginselen als vrijheid van keuze en gelijkheid tussen man en vrouw. ${ }^{405}$

\section{'Adellijke geslachtsnamen'}

In de jaren tachtig kwam het geldende naamrecht werkelijk in beweging, waarbij ook de eventuele consequenties voor het adelsrecht officieel aandacht kregen. Om deze reden vroeg de minister van Justitie in oktober 1984 advies aan de Hoge Raad van Adel. De adviestaak in deze zaken was overigens niet nieuw, want al vanaf de begintijd, en opnieuw toen de Raad onder Justitie viel, werd van zijn expertise op dit gebied gebruik gemaakt. ${ }^{406}$ Het initiatief daartoe was op 12 oktober 1868 van de Raad zelf uitgegaan om te voorkomen dat 'adellijke voornamen en geslachtsnamen ten onrechte verworven of adellijke voorrechten door daartoe niet bevoegden verkregen zouden worden'. Op 30 oktober 1868 had de minister besloten dat bij verzoeken van adellijke personen om verandering of vermeerdering van geslachtsnamen het advies van de Raad zou worden ingeroepen alvorens een beschikking te nemen. ${ }^{407}$ Vijf jaar later was de minister dit alweer vergeten, maar be-

\footnotetext{
${ }^{403}$ De Groot, 'Kanttekeningen over de familienaam', 92.

${ }^{404}$ Rapport van de Nederlandse delegatie van de conferentie van Europese ministers van Justitie (Straatsburg 1982), grotendeels gebaseerd op het rapport van het Wetenschappelijk Onderzoek- en Documentatiecentrum van het Ministerie van Justitie (WODC-rapport), nr. 26 (Den Haag 1981).

${ }^{405}$ Van Wassenaer van Catwijck, 'Naamrecht op de helling', 411-415.

${ }^{406}$ In de Statuten betrekkelijk den adel van het Koningrijk Holland (Amsterdam 1809) verboden de artt. 12 (voor de edelman) en 13 (voor anderen) toevoeging van (adellijke) namen zonder toestemming. Voor de periode 1814-1852 (1878), zie HRvA, RA, inv. nr. 281. Vóór de invoering van het Burgerlijk Wetboek in 1838 was de Code Civil en de speciale Wet van 11 germinal an XI (= 1 april 1803) executoir verklaard. Deze zogenaamde Germinalwet gaf aan hoe toestemming verkregen kon worden voor naamsvermeerdering en naamsverandering. Vgl. Prins, 'Nederlands namenrecht', 100-104.

${ }^{407}$ HRvA, RA, inv. nr. 154 (not. 1868-16 en 18).
} 
loofde dit voortaan (weer) te zullen doen. ${ }^{408}$ In 1877 gaf de Raad de minister vervolgens nog in overweging om een toe te voegen naam altijd vóór en niet achter de reeds gevoerde geslachtsnaam te plaatsen om misbruik zoveel mogelijk te voorkomen. ${ }^{409}$ Onder het regime van minister van Justitie Regout (1910-1913) werden gedragslijnen ontwikkeld om het toevoegen van heerlijkheidsnamen tegen te gaan. Artikel 63 van het Burgerlijk Wetboek (1838) liet uitbreiding van een geslachtsnaam alleen toe na toestemming van de koning. Een ministeriële circulaire uit 1859 stelde vast dat de geslachtsnamen sinds 1838 zijn gefixeerd en slechts in bijzondere omstandigheden hiervan kon worden afgeweken. ${ }^{410}$ Een eeuw later werden door de minister van Justitie richtlijnen voor naamsverandering gepubliceerd, die het beleid op dit gebied in grote lijnen continueerden. ${ }^{411}$ In het Nederlands Juristenblad werd een heftige discussie over dit onderwerp gevoerd tussen Luiking en Maris, welke laatste de toevoeging 'van Sandelingenambacht', waaronder hij doorgaans publiceerde, hier wijselijk wegliet. ${ }^{412}$

De Raad liet zich in zijn advies van 12 februari 1985 buitengewoon kritisch uit over het Voorontwerp van wet, houdende herziening van het naamrecht, zonder zich tot het adelsrecht te beperken. Het keuzerecht van ouders voor de geslachtsnaam van hun kind werd daarin omschreven als een recht van willekeur, dat het geldende systeem, dat zijn gelding hield, zou ondergraven en daarin verwarring zou stichten. Het kiezen door de ouders voor de moederlijke geslachtsnaam, zou het kind uit het vaderlijke geslachtsverband lichten, waarmee het vanouds een emotionele band heeft die verder gaat dan de gezinsband. Naast een theoretische en praktische onderbouwing van deze algemene kritiek spitste het advies zich toe op het voorkomen van verwarring die bij de buitenwacht zou kunnen ontstaan als wettige kinderen van een adellijke vader geen adeldom zouden verwerven, wanneer voor de geslachtsnaam van de moeder zou worden gekozen. ${ }^{413}$ Hoewel deze kritiek uiteindelijk geen invloed op de realisatie van het nieuwe naamrecht heeft gehad - maar mogelijk wel op de vertraging ervan - gaf de conclusie de essentie aan waar naamrecht en adelsrecht kunnen conflicteren. Deze discrepantie was overigens al ontstaan onder het vigerende naamrecht, dat reeds uitzonderingen kende op de algemene regel dat een kind de geslachtsnaam van de wettige vader krijgt. $\mathrm{Na}$ de ontbinding van een huwelijk kon ten aanzien van de kinderen al voor de naam van de moeder of haar nieuwe echtgenoot worden gekozen, wanneer deze in het nieuwe gezin werden opgevoed. In 1969 was op grond van artikel BW 1:7, lid 1 , een algemene maatregel van bestuur vastgesteld, houdende regelingen betreffende verzoeken tot naamswijziging en tot naamsvaststelling, die overigens uitslui-

\footnotetext{
${ }^{408}$ HRvA, RA, inv. nr. 155 (not. 1873-5 en 7), betreffende de geslachtsnaam Van Panthaleon baron(es) van Eck.

${ }^{409}$ HRvA, RA, inv. nr. 156 (not. 1877-6).

${ }^{410}$ Ministeriële circulaire van 15 febr. 1859, nr. 100 (Staatscourant 1859, 158, bijvoegsel).

${ }^{411}$ Het Personeel Statuut (HPS), april 1959, Officiële mededeling 23; NJB 1959, 344-345.

${ }^{412}$ Onder de titel 'Heer van ....', NJB 1958, 654-655, 735-736, 866-870; 1959, 525-526.

${ }^{413}$ HRvA, RA, inv. nr. 259 (not. 1984-35).
} 
tend bij koninklijk besluit konden plaatsvinden. ${ }^{414}$ Als de wettige vader tot de $\mathrm{Ne}$ derlandse adel behoorde, ontstond na de naamswijziging een 'sluimerende adeldom', aangezien de kinderen bij meerderjarigheid hun oude situatie weer konden herstellen. ${ }^{415}$

Op 3 december 1976 vaardigde de staatssecretaris van Justitie, na ingewonnen advies van de Hoge Raad van Adel, ${ }^{416}$ nieuwe richtlijnen voor geslachtsnaamswijziging uit, waarin expliciet een verbod werd aangekondigd wanneer een lid van de Nederlandse adel naamstoevoeging zou vragen: 'wanneer de verzoeker tot de adel behoort of de drager van de naam waarvan de toevoeging wordt gevraagd tot een adellijk geslacht behoort, is geen toevoeging mogelijk.' De memorie van toelichting op deze richtlijnen gaf als reden dat bij een dergelijke samenvoeging onduidelijk zou worden of betrokkene nog tot de Nederlandse adel behoorde en tot welke titel of predikaat hij/zij dan gerechtigd zou zijn. De Raad was tot dit advies gekomen vanwege een verzoek, ruim tien jaar eerder, van een burger met een dubbele geslachtsnaam, die zonder overtuigende reden de naam van een nog bloeiend $\mathrm{Ne}-$ derlands adellijk geslacht aan de zijne wilde laten voorafgaan. Een negatief advies van de Raad aan de minister van Justitie resulteerde in 1963 in een afwijzing, waarna betrokkene administratief beroep aantekende bij de Raad van State. De Afdeling geschillen van bestuur van de Raad van State liet de afwijzing in stand. ${ }^{417}$

De Afdeling Bestuursrechtspraak van de Raad van State maakte in 1984 in een andere zaak uit, dat de argumentatie niet gold voor een tot de Nederlandse adel behorende moeder, die haar geslachtsnaam had doorgegeven aan haar zoon, die niet door zijn wettige vader werd opgevoed. Alle andere tot dit adellijke geslacht behorende familieleden hadden bezwaar aangetekend op grond van bovengenoemde richtlijnen, onder andere vanwege de schijn van adeldom, die zou ontstaan. De rechter stelde vast dat er geen opvallend verschil is tussen niet-adellijke en adellijke geslachtsnamen, waar in het laatste geval de titel slechts een element van accessoire aard is. ${ }^{418}$ Dit betekende tevens een verduidelijking van de definitie die het Gerechtshof 's-Hertogenbosch in 1899 had bedacht voor 'de titel als aanhangsel van den familienaam', expliciet om aan te geven dat deze in de geboorteakte 'één geheel met dien naam' vormt. ${ }^{419}$ Het gevolg van de uitspraak van de Afdeling was dat niet specifiek over adellijke geslachtsnamen kan worden gesproken, zelfs niet (meer) bij oude adellijke geslachten waarvan tot voor kort alleen maar adellijke

\footnotetext{
${ }^{414}$ KB van 9 dec. 1969 (Stb. 544).

${ }^{415}$ Van Sasse van Ysselt, 'Naamsverandering', 85.

${ }^{416}$ HRvA, RA, inv. nr. 244 (not. 1976-27).

${ }^{417}$ HRvA, RA, inv. nr. 226 (not. 1963-40).

418 ABRvS 12 nov. 1984, nr. R02.83.1504 (Taets van Amerongen). Administratiefrechtelijke Beslissingen $(A B) /$ Nederlandse Jurisprudentie (NJ) 1985, 616-619, nr. 242.

${ }^{419}$ Gerechtshof (GH) Den Bosch 17 juni 1899 (Clifford) op grond van KB 26 jan. 1822 (Stb. 1); Weekblad van het Recht $(W v h R)$ 1899/7298, 2-3 (zie ook voor de merkwaardige conclusie van de Rb. Breda later dat jaar: WvhR 1899/7475). De Hoge Raad deed op basis van hetzelfde KB en het KB van 13 febr. 1815, nr. 60 (Stb. 15), op 19 okt. 1917 de uitspraak dat de titel van baron Taets van Amerongen van Woudenberg op de kieslijst moest worden geplaatst; $N J$ 1917, 1112; Prins, 'Nederlands namenrecht', 155-158.
} 
naamdragers bekend waren. $\mathrm{Na}$ alle vernieuwingen die werden voorgesteld en ook grotendeels totstandkwamen, kon de conclusie worden getrokken dat naamrecht en adelsrecht naast elkaar bestaande grootheden zijn, waarvan het naamrecht domineert en het adelsrecht lijdzaam volgt. ${ }^{420}$

\section{Sluimerende adeldom}

$\mathrm{Na}$ een rechterlijke uitspraak in hoogste instantie dat het Nederlandse naamrecht vanwege het ontbreken van keuzemogelijkheid in strijd was met artikel 26 van het Internationaal Verdrag inzake burgerrechten en politieke rechten (IVBuPo), kwam de wetgever in 1988 in beweging. ${ }^{421}$ Het wetsontwerp tot herziening van de artikelen 5 en 9 van boek 1 van het Burgerlijk Wetboek ging minder ver dan het Voorontwerp van wet uit 1984. Toch had het wetsvoorstel tot herziening van het afstammingsrecht, zoals het werd omschreven, de afschaffing van begrippen als (on)wettig en wettiging tot gevolg, met opnieuw consequenties voor het adelsrecht. ${ }^{422}$ Volgens het vigerende adelsrecht was het onbestaanbaar dat adeldom via onwettige afstamming zou kunnen worden doorgegeven. Nog in 1985 had een ongehuwde adellijke moeder, aan wie de inschrijving van de geboorte van haar dochtertje in het filiatieregister van de Nederlandse adel door de Hoge Raad van Adel was geweigerd, tevergeefs een beroep gedaan op de beginselen van gelijkheid en non-discriminatie, die in artikel 1 van de grondwet en in door Nederland geratificeerde internationale verdragen inzake burgerrechten, politieke rechten en mensenrechten worden gewaarborgd. De Afdeling Bestuursrechtspraak van de Raad van State was niet gebleken dat het SB van 13 februari 1815, nr. 60, een discriminerend en daardoor ongeoorloofd onderscheid had gemaakt waar voor de overgang van adeldom naast afstamming ook wettigheid werd vereist. Voorts had het bestreden besluit geen rechten of vrijheden geschonden als vermeld in het Europese verdrag voor de rechten van de mens. ${ }^{423}$

Het wetsontwerp herziening naamrecht stelde vrijheid van geslachtsnaamskeuze in het vooruitzicht aan de ouders voor of bij de geboorteaangifte van het eerste kind en voor de echtgenoten het in het maatschappelijk verkeer voeren van elkaars geslachtsnamen, ook gecombineerd en in willekeurige volgorde. De keuze voor de echtgenoten zou bij het aangaan van het huwelijk moeten worden gedaan. ${ }^{424}$ Het kiezen van de moedersnaam voor het kind zou consequenties hebben voor de overgang van adeldom, wanneer het een door een adellijke vader erkend kind betrof. Het lid van de Hoge Raad van Adel, jonkheer Van Sasse van Ysselt, herkende daarin een situatie van 'sluimerende adeldom', een begrip dat hij in 1960 zelf had gelanceerd. Wanneer het kind meerderjarig zou worden, kon dit immers alsnog voor de naam van de vader kiezen en daarmee de adeldom doen herleven. Tezamen met de voorzitter van de Raad achtte hij vrijheid om de moeders naam te kie-

\footnotetext{
${ }^{420}$ Loeb, 'De relatie tussen het naamrecht en het adelsrecht', 262 e.v.

${ }^{421}$ HR 29 sept. 1988, NJ 1989, nr. 740.

${ }^{422}$ Loeb, 'De relatie tussen het naamrecht en het adelsrecht', 263-268.

${ }^{423}$ ABRvS 9 sept. 1985, R01.84.1081; De Groot, 'De adeldom en het gelijkheidsbeginsel', 522-534.

${ }^{424}$ Kamerstukken II, 1991-1996, 22408.
} 
zen voor echtparen waarvan de vader tot de adel behoorde, dan ook ongewenst. De andere leden van de Raad hadden daar minder moeite mee, onder meer omdat zij adellijke geslachtsnamen minder uniek achtten. ${ }^{425}$ In het gewijzigde voorstel van wet, d.d. 12 juli 1993, was nog een uitzonderingsbepaling opgenomen voor de naamskeuze van het kind wiens vader van adel is: 'dit kind ontvangt bij de geboorte de geslachtsnaam van de vader.' Hiertegen kwam verzet van verscheidene politieke partijen, die deze bepaling discriminerend vonden voor ouders waarvan de vader van adel was. De beperking van de vrijheid van naamskeuze zou hier op gespannen voet staan met de aan een ieder toekomende burgerlijke rechten en vrijheden. ${ }^{426}$ Deze exclusieve bepaling voor edellieden verdween dan ook uit het wetsontwerp en werd op 31 oktober 1995 gewijzigd in: 'indien een kind, wiens vader van adel is, niet zijn geslachtsnaam verkrijgt, gaat de adeldom niet over op dat kind. ${ }^{427}$

Het Tweede Kamerlid Dittrich, gesteund door vier vrouwelijke medeleden Van der Burg, Scheltema-De Nie, Soutendijk-Van Appeldoorn en Van der Stoel, vond deze knieval van de regering niet voldoende en diende op 30 mei 1996 een motie in om de regering te dwingen vóór 1 oktober 1996 een onderzoek in te stellen naar de mogelijkheid van wijziging van de inmiddels vastgestelde Wet op de adeldom van 10 mei 1994 (Stb. 360). Ook al kon volgens het wetsontwerp voor de geslachtsnaam van de moeder worden gekozen, onafhankelijk of zij tot de Nederlandse adel behoorde, de adeldom zou volgens de interpretatie van deze wet niet overgaan. De Kamerleden achtten een dergelijk systeem van overerving in strijd met artikel 1 van de grondwet en met diverse internationale verdragen. De regering werd gevraagd een onderzoek in te stellen naar de juridische houdbaarheid van dit systeem van overerfbaarheid van adellijke titels. Staatssecretaris van Justitie Schmitz zag de urgentie niet in van de motie omdat zowel de wetgever als de rechter meermalen hadden uitgesproken dat er geen strijd was en het voorts niet de bedoeling was door naamskeuze het historisch instituut adel uit te breiden. Niettemin beloofde zij deze zaak met haar ambtgenoot van Binnenlandse Zaken op te nemen, zonder overigens veel hoop op aanpassing van de nog maar kort geleden vastgestelde wet te kunnen geven. De motie werd echter aangenomen en de minister van Binnenlandse Zaken Dijkstal bracht op 30 september 1996 verslag uit van het onderzoek (zie hierna in de periode 1994-heden). ${ }^{428}$ Uiteindelijk zou de wijziging van het naamrecht met betrekking tot deze materie niet verder gaan dan de al voorgestelde bepaling, waarmee het adelsrecht ondergeschikt werd gemaakt aan het naamrecht. ${ }^{429}$

\footnotetext{
${ }^{425}$ HRvA, RA, notulen 1990-51 (vergadering 4 dec. 1990).

${ }^{426}$ Kamerstukken II, 1992-1993, 22 408, nr. 8; 1993-1994, 22 408, nr. 10 (eindverslag).

${ }^{427}$ Kamerstukken II, 1995-1996, 22 408, nr. 12 (tweede nota van wijziging).

${ }^{428}$ Kamerstukken II, 1995-1996, 22 408, nr. 23.

${ }^{429}$ Wet van 10 april 1997 (Stb. 161) tot wijziging van de artikelen 5 en 9 van Boek 1 van het Burgerlijk Wetboek, die op 1 januari 1998 in werking trad.
} 


\section{Opheffing externe adviescolleges}

Los van de constitutionele ontwikkeling bracht een door de minister van Binnenlandse Zaken Rietkerk gecoördineerde Projectgroep Externe Advisering (Projectgroep Van der Ploeg) ${ }^{430}$ in augustus 1984 haar eindrapport uit aan de Tweede Kamer inzake de efficiëntie van externe advisering. In deze derde rapportage werden ook de intersectorale adviescolleges, zoals de Hoge Raad van Adel onder de loep genomen. De conclusie was ten aanzien van dit college dat alleen de (sterk teruggelopen) advisering over adelsaangelegenheden in het oprichtingsbesluit van 1814 is opgenomen, maar alle andere werkzaamheden voortvloeien uit lagere regelgeving, die zonder bezwaar op ambtelijk niveau zou kunnen worden vastgesteld en uitgevoerd. De alinea sloot af met de beladen zinsnede: 'Opheffing van de raad moet daarbij naar de mening van de projectgroep niet worden uitgesloten. ${ }^{431} \mathrm{Ge}-$ steund door een interne notitie van de directeur-generaal binnenlands bestuur werd door de Hoge Raad van Adel een brandbrief aan minister Rietkerk gestuurd om de conclusies van de projectgroep ten aanzien van het voortbestaan van de Raad ten sterkste te ontraden. Daarin werd onder meer gewezen op het SB van 24 december 1814, nr. 32, waarin zijn adviestaak met betrekking tot de verlening van wapens van publiekrechtelijk lichamen is geregeld, en dat in het rapport Van der Ploeg geheel ontbrak. ${ }^{432}$ Ook de feitelijke behandeling van beroepszaken over afgewezen adelsverleningen behoorde tot de dagelijkse werkzaamheden van de secretaris. Verplaatsing van de taken naar een ministerie zou geen beperking van de (opgegeven) kosten met zich mee brengen, maar wel de onafhankelijkheid bedreigen die in verband met adviezen aan andere ministers (van Algemene Zaken voor titulatuur en naamgeving koninklijk huis; van Justitie voor naamgeving; van Defensie voor militaire emblemen) gewaarborgd diende te zijn. ${ }^{433}$ Het voorstel van de directeurgeneraal om de positie en het functioneren van de Raad bij de totstandkoming van de Wet op de adeldom fundamenteel aan de orde te stellen, nam de Raad niet in zijn brief op. De Raad zal zich ongetwijfeld gerealiseerd hebben dat hieraan niet te ontkomen viel. Een groot aantal adviezen van de projectgroep werden door de regering opgevolgd, maar de Hoge Raad van Adel werd daarbij gespaard. ${ }^{434}$

Het streven van de projectgroep om bij de uitvoering van art. 79 van de grondwet ('Vaste colleges van advies in zaken van wetgeving en bestuur van het Rijk worden ingesteld bij of krachtens de wet') een duidelijk onderscheid te maken tussen permanente (bij wet) en tijdelijke of ad hoc (bij KB of ministeriële beschikking in te stellen) adviesorganen, had een lange adem. Bij de opheffing van het adviesstelsel in zaken van algemeen verbindende voorschriften en beleid van het Rijk, ontsprong de Hoge Raad van Adel opnieuw de dans, en bleef buiten de nieuwe Ka-

\footnotetext{
${ }^{430}$ Genoemd naar haar voorzitter J.G. van der Ploeg, oud-wethouder van Rotterdam.

${ }^{431}$ Derde interimrapport van de PEA (samenvatting), 17 aug. 1984, nr. OA 84-2520/4666, § 7.2.7, 135-136.

${ }^{432}$ De opdracht in artikel 3 van dit SB luidt: 'Dat tot het bekomen van nieuwe wapens en de bevestiging van reeds gebruikelijke aan Ons door den Raad de noodige voordrachten zullen moeten worden gedaan'. De taken, hieruit voortvloeiende zijn uitvoerig beschreven in [J.H. Keuzenkamp] Gemeentewapens in Nederland, 9-20.

${ }^{433}$ HRvA, RA, inv. nr. 259 (1984-34).

${ }^{434}$ Stein, 'Wet op de adeldom en artikel 1 Grondwet', 714.
} 
derwet adviescolleges. ${ }^{435}$ Adviestaken inzake besluiten die niet van algemene strekking zijn, bleven onverlet. ${ }^{436}$

In 1987 diende een klacht bij de Nationale ombudsman van een burger over de minister van Binnenlandse Zaken, die ministeriële verantwoordelijkheid ontkende met betrekking tot het bijhouden van het filiatieregister door de Hoge Raad van Adel. De ombudsman deed uitgebreid onderzoek, waarin alle werkzaamheden van de Raad in zijn toen 173-jarig bestaan onder de loep werden genomen, en concludeerde tot een ministeriële verantwoordelijkheid op grond van het KB van 17 september 1852 (minister van Justitie). ${ }^{437}$ De in het jubileumboek van de Raad in 1966 gepubliceerde KB's van 3 juli 1937 (minister van Algemene Zaken) en 23 februari 1945 (minister van Binnenlandse Zaken) werden over het hoofd gezien, maar zouden niets hebben veranderd aan de eindverantwoordelijkheid van de desbetreffende minister. De uitspraak van de Nationale ombudsman, die in 2001 nog eens door de Afdeling Bestuursrechtspraak van de Raad van State werd herhaald, was mede aanleiding voor overleg op hoog niveau over de status van de Hoge Raad van Adel. ${ }^{438}$

Op 22 oktober 1987 werden voorzitter en secretaris van de Raad uitgenodigd voor een gesprek met minister-president Lubbers in aanwezigheid van de secretarisgeneraal van Algemene Zaken. Aanleiding van het onderhoud was een notitie van minister van Binnenlandse Zaken Van Dijk over de taak, werkzaamheden, samenstelling, administratie en omvang van de Hoge Raad van Adel, zijn verhouding tot andere hoge colleges van staat en zijn positie als adviescollege van verschillende ministers. Het gesprek, waarin gefilosofeerd werd over de wettelijke regelingen betreffende de hoge colleges van staat, was informatief van aard. ${ }^{439}$

De belangrijkste reden voor het gesprek bleek de motie van het Tweede Kamerlid Wiebenga te zijn om vóór 1 januari 1988 alle externe adviesorganen die gehandhaafd zouden worden, een wettelijke basis te geven. Deze motie had de wenselijkheid van een wet op de adeldom opnieuw aan de orde gesteld. Voorbereid door ambtelijke correspondentie tussen de directeur bestuurszaken van het Ministerie van Binnenlandse Zaken en de Hoge Raad van Adel waarin inhoudelijke informatie was uitgewisseld, stuurde de minister op 8 april 1988 een conceptwetsvoorstel met een voorziening inzake adeldom voor commentaar aan de voorzitter van de Raad. Uitgangspunt was daarin een Raad die adviseert over individuele gevallen van adelsverlening zonder dat de andere taken van de Raad, die buiten het terrein van de adeldom vallen, in deze wet geregeld zouden moeten worden. In zijn advies

\footnotetext{
${ }^{435}$ Wet van 3 juli 1996 (Stb. 378) houdende algemene regels over de advisering in zaken van algemeen verbindende voorschriften of te voeren beleid van het Rijk.

${ }^{436}$ Kamerstukken II, 1995-1996, 24 232, nr. 7 (toelichting).

${ }^{437}$ Nationale ombudsman (NO) 1 juni 1987, nr. 87/R522; AB/NJ 1987, 1433-1436, nr. 489.

438 ABRvS 27 juni 2001, nr. 200000061/1. Boddaert, 'De Zeeuwse adoptiezaak', 38; idem, 'De tweede Zeeuwse adoptiezaak', 227.

${ }^{439}$ HRvA, RA, not. 1986-30.
} 


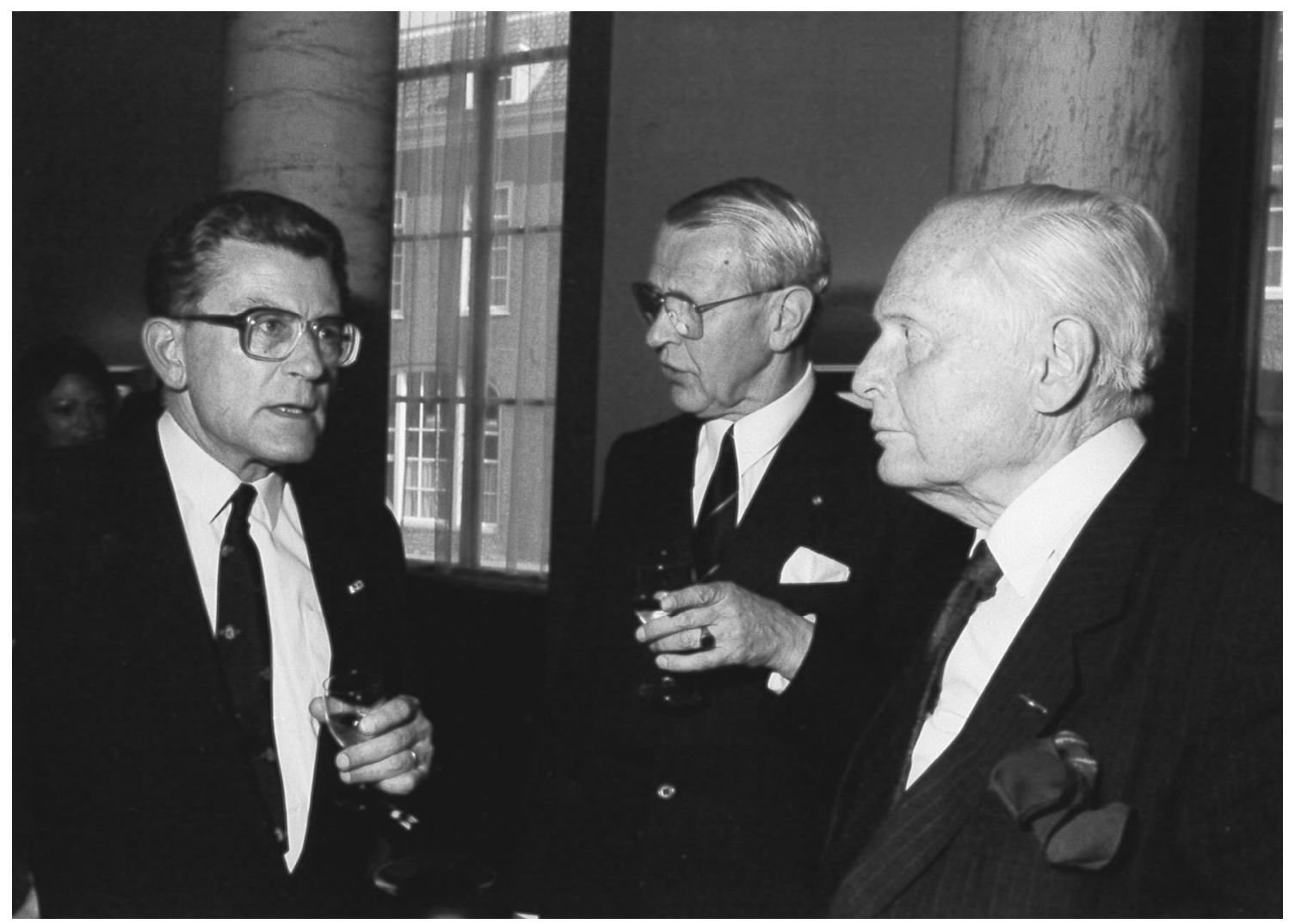

Viering van het 175-jarig jubileum van de Hoge Raad van Adel in de Gothische Zaal te 's-Gravenhage. C.P. van Dijk, minister van Binnenlandse Zaken 1986-1989, in gesprek met jonkheer M.A. Beelaerts van Blokland, voorzitter van de Raad. In het midden: jonkheer F.W.A. Beelaerts van Blokland, voorzitter van de Nederlandse Adelsvereniging.

Foto C. Bollier, 's-Gravenhage 1989. Collectie en foto HRvA, 's-Gravenhage.

aan de minister, betoonde de Raad op 6 mei 1988 zijn instemming op hoofdlijnen, maar bleef reserves houden inzake het afgezworen verheffingsbeleid en het verlies van de adviestaak in algemene zin. Dit laatste zou in strijd zijn met de in het soevereine besluit van 1814 aan de Raad opgedragen adviestaak. Artikelsgewijs werden ten slotte nog een aantal inhoudelijke en redactionele wijzigingen in het conceptwetsontwerp voorgesteld. Vanwege de uitspraak van de Nationale ombudsman achtte de Raad expliciete vermelding van zijn verantwoordelijkheid voor het filiatieregister in de wet gewenst. In zijn reactie van 28 juli 1988 legde de minister de bezwaren van de Hoge Raad van Adel naast zich neer door er nog eens op te wijzen dat van het vigerende adelsrecht werd uitgegaan. Het was niet de bedoeling het adelsbeleid, dat sinds 1953 werd gevoerd, uit te breiden maar slechts te handhaven. Ook ten aanzien van de (algemene) adviestaak was het niet gewenst om deze een groter gewicht te geven dan deze thans had. Externe adviescolleges dienden in de toekomst op grond van artikel 79 van de grondwet bij wet te worden geregeld, zodat ook de Tweede Kamer over initiatiefvoorstellen van wet inzake beleid advies zou moeten vragen, hetgeen volgens het vigerende adelsbeleid niet gebruikelijk was en dus voor de toekomst ongewenst zou zijn. Bij brief van 23 augustus 1988 
toonde de Raad zich niet overtuigd en persisteerde in de in eerdere correspondentie gegeven argumentatie. ${ }^{440}$

De minister kwam een jaar later zijn eerder gedane belofte na om het definitieve wetsvoorstel, zoals hij dat aan de ministerraad ging voorleggen, eerst nog aan de Hoge Raad van Adel te tonen. Hierin waren ook de redactionele aanwijzingen van de Raad voor een belangrijk deel overgenomen. Tijdens de behandeling van het wetsontwerp in het parlement (zie hierna), werden regelmatig vragen van kamerleden doorgespeeld aan de Hoge Raad van Adel wanneer de minister om specifieke beantwoording verlegen zat.

\section{Wet op de adeldom}

Eerst zes jaar na de grondwetsherziening van 1983 was minister van Binnenlandse Zaken Van Dijk met een voorstel van wet inzake adeldom gekomen. De ministerraad had zich hier in zijn vergadering van 22 mei 1989 achter geschaard.

Op 20 september van dat jaar bracht de Raad van State advies uit, waarin hij zich kritisch opstelde over de ruime delegatie van regelgeving betreffende adeldom, daar waar het additionele artikel XXV van de grondwet niet tot andere regelgeving dwong dan met betrekking tot adelsverlening. Om deze reden was de Raad van State voorstander van een aangepaste citeertitel als 'wet op de verlening van adeldom'. Voorts zou hij de adviestaak van de Hoge Raad van Adel, vanwege diens deskundigheid en ervaring, willen uitbreiden tot algemene aangelegenheden van wetgeving en bestuur ten aanzien van adeldom. Ten slotte diende aangegeven te worden in welke mate (vergelijkbare) adelsstatuten konden verschillen zonder dat inlijving uitgesloten is. In een nader rapport van 16 maart 1990 gaf de minister van Binnenlandse Zaken Dales aan dat de aangepaste citeertitel van de wet overbodig zou zijn, omdat slechts het bestaande adelsrecht wettelijk zou worden geregeld en geen grondslag aanwezig was om op andere terreinen van het burgerlijke recht te treden. Evenmin was uitbreiding van de adviestaak van de Hoge Raad van Adel aan de orde. Het niet handhaven als extern adviesorgaan in de zin van artikel 79 van de grondwet betekende overigens niet, dat de minister in voorkomende gevallen geen algemeen advies zou kunnen vragen. Als voorbeeld noemde zij naamrechtadviezen van organen welke niet de status van art. 79 hadden. De opmerking betreffende adelsstatuten kon zij niet in algemene zin beantwoorden. Hoewel het doorgaans Europese continentale adelsstatuten betrof, diende iedere aanvraag op eigen merites beoordeeld te worden. ${ }^{441}$

In de memorie van toelichting van 26 maart 1990 werden de uitgangspunten van de in het additionele artikel beoogde wettelijke voorziening opgesomd: vastlegging van het huidige adelsbeleid (door handhaving van de bestaande SB's en KB's), grondslag voor de taxaheffing (ingevolge art. $104 \mathrm{Gw}$.) en vastlegging van de ta-

\footnotetext{
${ }^{440}$ HRvA, RA, not. 1986-30.

${ }^{441}$ Kamerstukken II, 1989-1990, 21 485, B.
} 


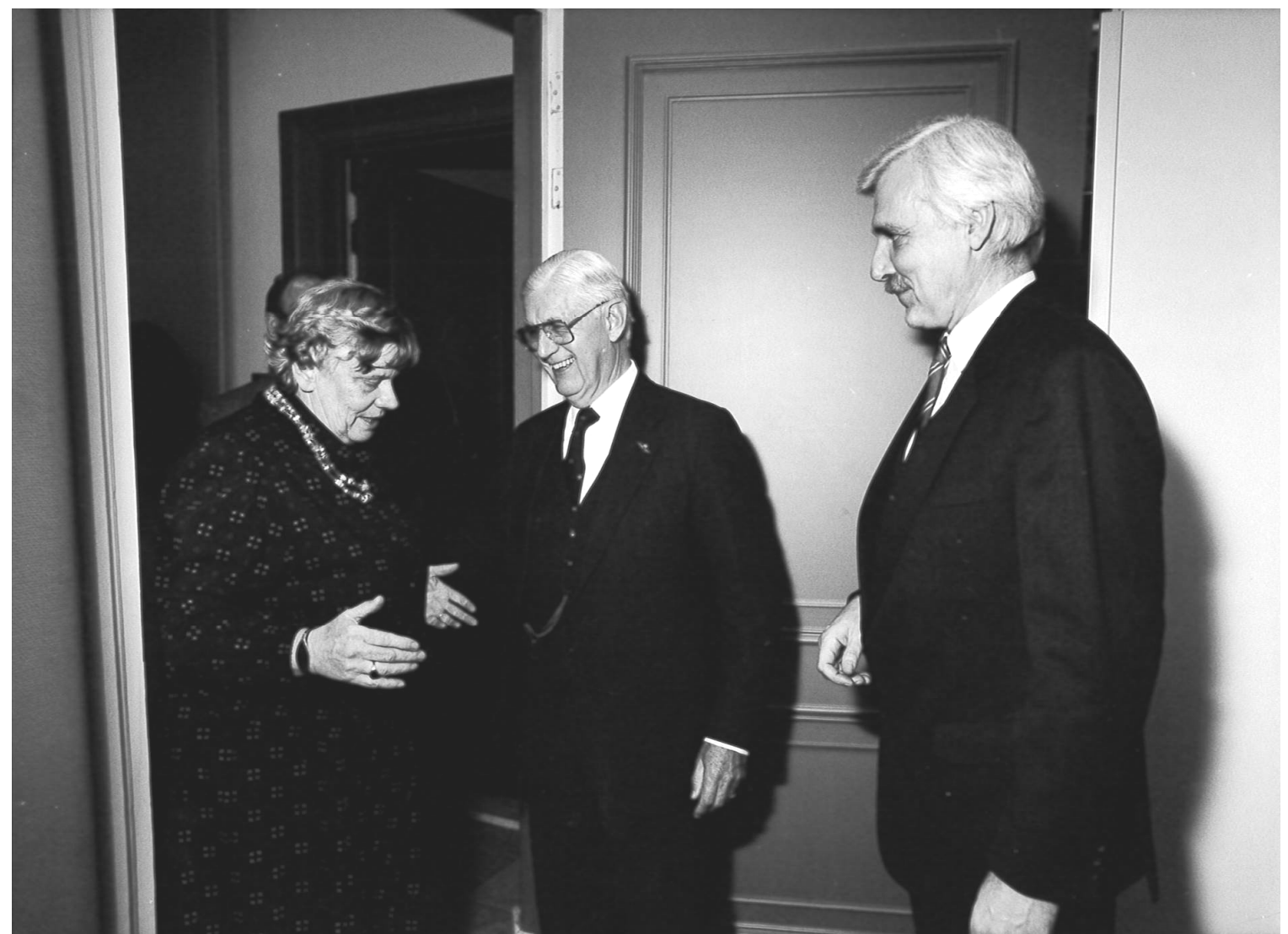

C.I. Dales, minister van Binnenlandse Zaken 1989-1994, in gesprek met de vertrekkend voorzitter van de Hoge Raad van Adel F.W.B. baron van Lynden en de aankomend voorzitter C.O.A. baron Schimmelpenninck van der Oije in het gebouw van de Raad, Nassaulaan 18, 's-Gravenhage. Foto Catrien Ariëns, Amsterdam 1991. Collectie en foto HRvA, 's-Gravenhage.

ken van de Hoge Raad van Adel (niet meer op basis van art. 79 Gw.). De minister zag af van het opnieuw codificeren van het adelsrecht als zodanig. Naar haar oordeel moest het adelsrecht gezien worden als een historisch gegroeid instituut, dat alleen kon worden gehandhaafd als historisch instituut, maar dat zijn grondslag zou verliezen als men zou trachten het naar eigentijdse denkbeelden te wijzigen of in te richten. Voor het huidige adelsbeleid verwees zij naar het besluit van de ministerraad van 21 november 1953, waardoor sinds 1945 geen verheffingen meer hadden plaatsgevonden. Tussen 1945 en 1990 hadden vijf erkenningen voor zeven personen en 15 inlijvingen voor 25 personen plaatsgevonden. Aangezien artikel 74 van de grondwet ook als basis had gediend bij de toekenning van titels aan (toekomstige) leden van het koninklijk huis, zou die in het vervolg op basis van de Wet op de adeldom en de Wet lidmaatschap koninklijk huis gebeuren. In het bijzonder had nog de toekenning van de titel prins van Oranje, die tussen 1815 en 1983 in de grondwet aan de vermoedelijke erfgenaam van de Kroon in het vooruitzicht werd gesteld, een wettelijke basis nodig. Deze was niet in de Wet lidmaatschap koninklijk huis (1985) expliciet vermeld, maar zou op den duur wel sekseneutraal (als prins(es) van Oranje) in de herziene wet (2002) worden opgeno- 
men. ${ }^{442}$ In haar verdediging van de adel als historisch instituut, waarbij vererving van adeldom langs mannelijke lijn (in het bijzonder ook de primogenituur) op grond van het KB van 13 febr. 1815, nr. 60, zou worden gehandhaafd, moest minister Dales aan de Tweede Kamer uitleggen waarom de erfopvolging van de koning in dit opzicht wel was aangepast. In de memorie van antwoord wees zij op de publieke en constitutionele aspecten van het koningschap, die de grondwetgever tot het oordeel had gebracht dat onderscheid naar geslacht bij de vervulling van dit publieke ambt ongewenst was. ${ }^{443}$

\section{Behandeling in de Tweede Kamer}

Het voorlopig verslag van de vaste Kamercommissie voor Binnenlandse Zaken van 27 juni 1990 sprak in het algemeen waardering uit voor het wetsontwerp, maar vooral de CDA-fractie stelde vele vragen over het adelsbeleid. ${ }^{44}$ De PvdA-fractie schaarde zich veelal achter de minister, die uit deze partij voortkwam, de VVDfractie stelde zich liberaalkritisch op en D66 wilde ook de consequenties van afschaffing weten. De kleine christelijke partijen toonden zich gouvernementeel, maar vroegen om nadere uitleg. In haar memorie van antwoord gaf de minister toe dat verlening van adeldom in de huidige tijd geen geschikt middel meer was voor het uiten van maatschappelijke waardering, maar zij achtte de beslissing van de Tweede Kamer bij de grondwetsherziening om tot een wettelijke regeling te komen, bepalend. Om deze reden toonde zij zich geen voorstander van de verlening van persoonlijke adeldom, zoals in België en Groot-Brittannië. Daarnaast was het niet de opdracht om het instituut te vernieuwen en uit te breiden. De legitimatie van het voortbestaan van het adelsrecht was alleen te vinden in het verleden en in een zeker respect voor dat verleden. Modernisering van de adel verdroeg zich in de visie van de regering niet met deze primair historische legitimatie. Van ongelijke behandeling en ongeoorloofde discriminatie, zoals die in de grondwet en in internationale verdragen worden verboden, zou in het Nederlandse adelsrecht geen sprake zijn, aangezien sinds 1848 geen gevolgen van staatsrechtelijke aard meer aan adeldom zijn verbonden maar slechts de bevoegdheid om een titel of predikaat te dragen. Het adelsrecht kan als lex specialis altijd door de rechter aan het burgerlijk recht inzake adoptie en naamrecht als lex generalis worden getoetst, waardoor thans al de nodige jurisprudentie was ontstaan. De minister verwees daarbij naar het wetsvoorstel herziening naamrecht, dat het verschijnsel van de 'adellijke namen' en de 'sluimerende adeldom' vanuit die optiek behandelde. ${ }^{445}$

Zoals aan de memorie van toelichting een bijlage was gehecht met een overzicht van relevante bestaande regelingen, was aan de memorie van antwoord een opsomming van het adelsbeleid in andere Europese landen toegevoegd. ${ }^{446}$

\footnotetext{
${ }^{442}$ Wet lidmaatschap koninklijk huis van 30 mei 2002 (Stb. 275), art. 7.

${ }^{443}$ Kamerstukken II, 1979-1980, 16 034, nr. 3, p. 4; 1991-1992, 21 485, nr. 3 en 5.

${ }^{444}$ Kamerstukken II, 1989-1990, 21 485, nr. 4.

${ }^{445}$ Kamerstukken II, 1991-1992, 22 408, nr. 3, p. 13 en B, p. 5-6.

${ }^{446}$ Kamerstukken II, 1991-1992, 22 485, nrs. 5 en 6 (memorie van antwoord en nota van wijziging, d.d. 5 maart 1992).
} 
Naar aanleiding van het eindverslag van de commissie uit de Tweede Kamer van 25 juni 1992 deed de minister in haar nota van 28 april 1993 een aantal toezeggingen. De argumenten uit diverse fracties voor beperking van de mogelijkheid van inlijving hadden haar aangesproken. Inlijving uitsluitend bij gelegenheid van verwerving van Nederlanderschap en afkomst uit een staat met een vergelijkbaar adelsstatuut werden als voorwaarden opgenomen in de tweede nota van wijziging, tezamen met een overgangsbepaling voor vijf jaren na de inwerkingtreding van de wet. $^{447}$

\section{Controversiële amendementen}

Voorafgaande aan de openbare behandeling van het wetsontwerp in september 1993 in de Tweede Kamer werd een aantal amendementen ingediend. ${ }^{448}$ In bloemrijke taal werd een debat gevoerd dat niet veel meer nieuwe gezichtspunten en tegenargumenten opleverde dan al in de schriftelijk behandeling waren opgenomen. De amendementen van het kamerlid Scheltema-De Nie, die overgang van adeldom op gelijke wijze via de mannelijke en vrouwelijke lijn en ontadeling op eigen verzoek mogelijk moesten maken, konden uiteindelijk niet op een meerderheid rekenen. ${ }^{449}$ De amendementen van de kamerleden Van der Burg en Jurgens betreffende overgang van adeldom op buiten het huwelijk geboren kinderen, de mogelijkheid om op verzoek titulatuur op officiële documenten weg te laten en om bestaande regelingen bij wet te wijzigen, werden door de minister in een brief aan de voorzitter van de Tweede Kamer ontraden. ${ }^{450}$ Bij de stemming een week later werden desalnietemin twee van de drie amendementen (wijziging bleef bij algemene maatregel van bestuur mogelijk) door een meerderheid aangenomen. ${ }^{451}$ Dit zijn de latere artikelen 3 en 5 van de Wet op de adeldom van 10 mei 1994 (Stb. 360). Maar voordat deze van kracht werd, moest de Eerste Kamer zich er nog over uitspreken.

\section{Behandeling in de Eerste Kamer}

Volgens het verslag van de vaste Commissie voor Binnenlandse Zaken en de Hoge Colleges van Staat van de Eerste Kamer van 26 oktober 1993 miste de GroenLinksfractie een motivering van de keuze om de adeldom (niet) af te schaffen en deed zij een voorstel tot privatisering, zodat de kosten niet op de overheid zouden drukken. De nota van de minister van 24 november daaraanvolgend wees nog eens op de opdracht uit 1983 om onder meer het taxabesluit, dat op grond van het profijtbeginsel was ingevoerd, een wettelijke basis te geven. Internationaal gezien bestond in Nederland een geringe noodzaak tot opheffing van het instituut als maatregel ter versterking van de democratie. In een relatief vroeg stadium had de adel in Nederland zijn staatsrechtelijke positie verloren, maar was als historisch gelegi-

\footnotetext{
${ }^{447}$ Kamerstukken II, 1992-1993, 21 485, nrs. 8 en 9.

${ }^{448}$ Handelingen II, 1992-1993, 6866-6884.

${ }^{449}$ Kamerstukken II, 1992-1993, 21 485, nrs. 10 en 11, d.d. 13 sept. 1993; Handelingen II, 1993-1994, 91.

${ }^{450}$ Kamerstukken II, 1992-1993, 21 485, nrs. 12, 13 en 14, d.d. 14 sept. 1993; nr. 15, d.d. 16 sept. 1993.

${ }^{451}$ Handelingen II, 1993-1994, 91.
} 
timeerd instituut blijven voortbestaan. De minister had becijferd dat de uitgaven in verband met de Hoge Raad van Adel, exclusief huisvestingskosten, 283.000 gulden per jaar bedroegen. ${ }^{452}$ Uit het schriftelijk overleg bleek voorts een misverstand te bestaan over de reikwijdte van artikel 3, waar men meende dat deze buiten het huwelijk om ook in vrouwelijke lijn kon overgaan. Voorts wenste men duidelijkheid van de minister over de consequenties van een besluit van de gouverneurgeneraal van Nederlands-Indië van 30 september 1936, waaruit overgang van adeldom langs mannelijke lijn viel op te maken. ${ }^{453}$ Daarmee zou dit adelsstatuut vergelijkbaar zijn met Europese adelsstatuten. Minister van Binnenlandse Zaken Van Thijn gaf in een brief van 10 februari 1994 aan dat adeldom buiten het huwelijk om alleen kon overgaan volgens de bestaande regelingen van adeldom en dus niet langs vrouwelijke lijn. Zijn inmiddels overleden ambtsvoorganger had eerder al aangegeven dat van discriminatie geen sprake was, omdat er geen staatsrechtelijke gevolgen of privileges aan adeldom waren verbonden. Ten aanzien van het besluit van de gouverneur-generaal deelde hij mee dat dit slechts betrekking had op het recht tot het voeren van een titel door de adel op Java en Madoera, als uitzondering op andere (Nederlands-)Indische adel, zoals op Nieuw-Guinea of de Molukken. ${ }^{454}$

Tijdens de openbare behandeling van het wetsontwerp in de Eerste Kamer toonden alle partijen zich buitengewoon kritisch over de twee door de Tweede Kamer aangenomen amendementen. Meerdere woordvoerders citeerden in het Nederlandse Juristenblad gepubliceerde commentaren, die opriepen tot verwerping van het wetsvoorstel. ${ }^{45}$ De vermeende discriminatie van de gehuwde ten opzichte van de ongehuwde vrouw en onvergelijkbare Indische adel bleef menigeen bezighouden. De reacties varieerden van afschaffing van de adel als publiekrechtelijk instituut en privatisering van de Hoge Raad van Adel (Groen-Links) tot spijt over de verwerping van het amendement Scheltema-De Nie betreffende overgang van adeldom zowel langs mannelijke als langs vrouwelijke lijn (SGP!). Ook het CDA brak een lans voor overgang langs vrouwelijke lijn, die de partij al meende te herkennen in de meermaals geciteerde koninklijke besluiten uit 1815. De PvdA bleef zich achter het door haar partij verdedigde wetsontwerp scharen, zich beroepende op de opdracht die voortkwam uit de grondwetsherziening. Wetgeving zou voorkomen dat een beleidsregel uit 1953 kon worden verlaten om alsnog nieuwe verheffingen te realiseren. Meerdere partijen, waaronder de VVD, vroegen om intrekking van het wetsvoorstel met onder meer als argumentatie dat additioneel artikel XXV van kracht zou blijven 'totdat bij wet een voorziening zal zijn (en niet: wordt) getroffen'. Er zou dus geen dwingende noodzaak zijn. ${ }^{456}$

\footnotetext{
${ }^{452}$ Kamerstukken I, 1993-1994, 21 485, nrs. 26, 26a, 26 b.

${ }^{453}$ Besluit van de Gouverneur-Generaal van Nederlandsch Indië betreffende inheemsche titulatuur van 30 sept. 1936, nr. 31 (Bijblad Indië, Stb. 13711).

${ }^{454}$ Kamerstukken I, 1993-1994, 21 485, nr. 26c.

${ }^{455}$ Elzinga en De Groot, 'Over adellijke namen en zo...', 124-127 en 478-480.

${ }^{456}$ Handelingen I, 1993-1994, 1440-1449, 1474-1478, 1559-1564, 1670-1674 en 1732-1733.
} 
In zijn antwoord wees minister van Binnenlandse Zaken Van Thijn op de 'intertemporaine' voorziening binnen de grondwet, die aan alle additionele artikelen eigen is, en vroeg of laat tot wetgeving verplicht. Omdat het kabinet, gesteund door de Tweede Kamer, consequent modernisering van het adelsrecht heeft afgewezen, speet het hem de ook bij de SGP levende wens tot vererving langs vrouwelijke lijn te moeten afwijzen. Hij ontkende niet dat door aanvaarding van het door zijn ambtsvoorganger sterk ontraden amendement Van der Burg inzake de positie van natuurlijke en adoptiefkinderen, het strikt codificerende karakter van het wetsontwerp was afgenomen. Door deze beperkte modernisering was het wezenlijke karakter echter niet aangetast, temeer daar het om een gering aantal gevallen zou gaan. Het verworpen amendement Scheltema-De Nie zou kwantitatief gezien een veel groter effect hebben gehad. Aan het slot van zijn betoog trachtte de minister de in het Nederlands Juristenblad opgeworpen vragen te beantwoorden. Zo ging hij uit van eerbiedigende werking van de wet, uitgaande van het afgesloten rechtsfeit van de geboorte van de desbetreffende kinderen. Andere varianten zouden de uitvoering van de wet uiterst complex maken en verder afstaan van de bestaande situatie, die een zo beperkt mogelijk kwantitatief effect voorstond. Ook uit het oogpunt van rechtmatigheid zou deze keuze goed te verdedigen zijn, omdat er onder deze laatste groep volstrekt geen verwachtingen waren gewekt omtrent een voortschrijdende rechtsontwikkeling op dit vlak. Op een interruptie van de VVDwoordvoerder of die wel gewekt waren bij kinderen die nog onwettig geboren moesten worden, moest de minister het antwoord schuldig blijven, omdat hij geen koffiedik kon kijken. De minister vervolgde zijn betoog met het voorbeeld van de primogenituur (titels bij eerstgeboorte), waarbij de keuze in het overgangsrecht voor eerbiedigende werking complicaties in de toepassing zou kunnen voorkomen. Ten slotte zouden er geen gevolgen uit het amendement voortvloeien voor natuurlijke kinderen van adellijke moeders, aangezien deze 'volgens bestaande regelingen' geen adeldom verwierven.

Ten aanzien van het Javaanse adelsstatuut kwam de minister tot de conclusie dat de verschillen weliswaar minder pregnant waren, maar nog steeds principieel afwijkend van het Nederlandse adelsstatuut. ${ }^{457}$

Een week later werd de beraadslaging hervat en riep de voorzitter van de Eerste Kamer op om het wetsvoorstel in een half uur, in ieder geval vóór 18.00 uur op die $19^{\text {de }}$ april 1994, af te handelen. De fractiewoordvoerder van D66 had zich inmiddels verdiept in de Indische adel en was op grond van recente literatuur tot de conclusie gekomen, dat Javaanse adel niet louter uit de vervulling van ambten was voortgekomen en ook op grond van andere kenmerken een vergelijkbaar adelsstatuut kon worden genoemd. ${ }^{458}$ Aangezien ook andere onderwerpen in dit verband zij noemde primogenituur, nationaliteit en mensenrechten - onvoldoende aan de orde bleken te zijn gekomen, pleitte zij voor intrekking van het wetsontwerp. Groen-Links sloot zich hierbij aan om verwerping van het ontwerp te voorkomen

\footnotetext{
${ }^{457}$ Handelingen I, 1993-1994, 1474-1477.

${ }^{458}$ Sewandono, 'Adeldom en de Indische neushoorn', 476-480.
} 
en om spoedig een nieuw voorstel, maar dan om afschaffing en privatisering van deze feodale restanten, te bereiken. Het argument van respect voor de historie zou, volgens deze fractie, immers ook voor de instandhouding van de slavernij met alle bijbehorende attributen hebben kunnen gelden. In navolging van het Nederlands Juristenblad maakte de woordvoerder zich bezorgd over de vele juridische procedures die het gevolg zouden kunnen zijn van de aangenomen amendementen, waardoor de ene discriminatie wel en de andere niet was opgeheven. De VVD vroeg de minister nadere uitleg over de eerbiedigende werking van artikel 3, want uit de nadere motivering werd begrepen dat hij onmiddellijke werking had bedoeld. Behalve met de kwestie van de Indische adel bleef de VVD moeite houden met de reikwijdte van artikel 5, aangezien het verzoek om weglating van de titulatuur op officiële documenten erfrechtelijke consequenties zou hebben. Het CDA had zich nog eens in de constitutionele achtergrond van de adelsverlening verdiept en vroeg zich af of adeldom bij gewone wet kon worden afgeschaft, als bij uitvaardiging van een nieuwe adelswet de werking van artikel 74 ('De Koning verleent adeldom') voorgoed was uitgewerkt. Overigens gaf een aantal voorbeelden in de grondwet van additionele artikelen, waarin de formulering 'is getroffen' was gebezigd, wel degelijk aan dat er 'geen noodzaak' voor nieuwe adelswetgeving was. Anders zou niet de ruimere formulering 'zal zijn getroffen' zijn gebruikt. Voorts pleitte de woordvoerder om de wijziging van bestaande regelingen, die volgens het ontwerp bij algemene maatregel van bestuur konden plaatsvinden, toch ook aan het parlement voor te leggen, omdat het grotendeels wetgeving in formele zin van vóór 1848 betrof. Ten slotte vroeg hij zich af of leden van de Nederlandse adel met een andere nationaliteit voor het filiatieregister in aanmerking (bleven) komen, nu in artikel 1 van het wetsontwerp over adeldom exclusief voor Nederlanders werd gesproken.

De SGP twijfelde aan het voortbestaan van art. 435, lid 1, Wetboek van Strafrecht (ten onrechte voeren adellijke titel), aangezien aan adeldom geen belangrijke rechtsgevolgen zijn verbonden. De woordvoerder constateerde dat adeldom daarin niet afweek van naamrecht, waar geen discriminatie kon worden gehandhaafd. Het amendement Scheltema-De Nie wees hij af omdat dit te algemeen was gesteld en vergaande consequenties zou hebben gehad, maar hij bleef voorstander van een ruime interpretatie van het KB's van 1815 , waarin 'wettelijke afstamming van geslacht en naam' stond en niet 'in mannelijke lijn'. 459

Het was de minister niet meer gelukt om het precisiewerk, dat de Eerste Kamer van hem verlangde, per omgaande te leveren, dus werd de behandeling op 26 april 1994 voorgezet met zijn antwoord in tweede termijn. Ten aanzien van het grondwettelijk overgangsrecht merkte hij op dat hieraan, in weerwil van de redactionele afwijkingen, geen materiële betekenis moest worden gehecht. De voorzieningen in de additionele artikelen zouden nadrukkelijk slechts voor beperkte tijd zijn gemakkt. Uit de geschiedenis van de grondwetsherziening kon worden afgeleid, dat

${ }^{459}$ Handelingen I, 1993-1994, 1559-1564. 
de grondwetgever met artikel XXV geen afschaffing, maar regeling had bedoeld. Met de nieuwe wet zou deze opdracht zijn uitgevoerd en was het vervolgens aan de wetgever voorbehouden wenselijke wijzigingen aan te brengen. Hierbij waarschuwde minister Van Thijn alvast voor de commotie die dit teweeg zou kunnen gaan brengen, gezien het onderhavige wetsontwerp. Voorts wees hij er op dat het adelsrecht ná 1848 steeds bij koninklijk besluit was gewijzigd, zodat onmogelijk kon worden volgehouden dat alle SB's en KB's van vóór 1848 wetten in formele zin zouden zijn geweest. Ten slotte kon de minister vaststellen dat weliswaar over de definitie van het overgangsrecht van artikel 3 meningsverschil bestond, maar niet over de reikwijdte ervan. De conclusie was dat dit artikel uitsluitend betrekking zou hebben op kinderen, die na de inwerkingtreding van de wet zouden worden geboren. Volgens de minister zou de rechter hier in voorkomende gevallen mee uit de voeten kunnen. De woordvoerder van de VVD was het niet eens met deze conclusie, maar wel over de wenselijkheid ervan, waarvan hij hoopte dat de rechter deze laatste dan zou honoreren. Ten aanzien van artikel 5 kon de minister zich geen andere uitleg voorstellen dan dat de verzoeker alleen voor zichzelf een verzoek tot weglating van titulatuur uit officiële documenten zou kunnen doen. Als hij daarbij optrad mede namens minderjarige kinderen, dan zouden zij bij meerderjarigheid daarop kunnen terugkomen. Ook buitenlandse afstammelingen van edellieden, die een andere nationaliteit hadden aangenomen, werden ingeschreven in het filiatieregister. De minister wees op blijvende adeldom bij verandering van nationaliteit, maar dat artikel 1 alleen op verlening van adeldom betrekking had, waarvoor Nederlanderschap een voorwaarde was.

De discussie over de Indische adel werd door de minister teruggebracht tot het probleem van inlijving van leden van de inlandse Indische adel, die destijds door de Nederlandse overheid als zodanig werd erkend. Sinds de soevereiniteitsoverdracht is deze Indische adel buitenlandse adel geworden, waarvan bij een verzoek tot inlijving in de Nederlandse adel het adelsstatuut vergelijkbaar moet zijn met het Nederlandse adelsstatuut. $\mathrm{Na} 1948$ was verwarring ontstaan over het al of niet vermelden van Indische adellijke titels en predikaten op officiële documenten. Op grond van een gezaghebbend artikel in Het Personeel Statuut van 1956 was geconcludeerd dat Indische adellijke titels en ambtstitels geen deel uitmaakten van de naam en dat vermelding in naturalisatiewetten, en nadien in de Nederlandse administratie, achterwege moest blijven. ${ }^{460}$ De minister kon zich achter de sindsdien gevoerde praktijk stellen, waarin adellijke Indische Nederlanders op gelijke wijze werden behandeld als andere adellijke buitenlanders die naturalisatie aanvroegen. Vervolgens somde hij nog eens de verschillen op tussen de twee adelsstatuten, om af te sluiten met de conclusie dat het voorbeeld van inlijving van Indische adel niets toevoegde of afdeed aan de letter van de wet, het criterium van vergelijkbare adelsstatuten, dat ter besluitvorming voorlag. Om het eindeloze debat, met steeds nieuwe woordvoerders, af te ronden, deed de minister een aantal opgeworpen suggesties kort af. Voor het naamrecht, waarmee adelsrecht door verscheidene woord-

${ }^{460}$ Prins, 'Titels en praedicaten', 13-21. 
voerders was vergeleken, verwees de minister door naar het desbetreffende wetsvoorstel over het nieuwe naamrecht, waarvoor de staatssecretaris van Justitie verantwoordelijk was. Onder diens competentie viel voorts ook artikel 435 Wetboek van Strafrecht, dat overigens niet aan de orde was. Met de verwerping van het amendement Scheltema-De Nie in de Tweede Kamer achtte de minister het onderwerp van vererving langs vrouwelijke lijn een gepasseerd station voor de Eerste Kamer. Hij hoopte dat het romantische onderwerp dat adeldom voor menigeen betekende en waarvan hij het belang niet wilde onderschatten, desalniettemin als staande aan de periferie van het Nederlandse rechtssysteem tot een snelle afronding zou komen. ${ }^{461}$

Op 10 mei 1994 kreeg de Eerste Kamer nog de gelegenheid om stemverklaringen af te leggen. Hiervan maakten de drie stromingen (D66, VVD en de kleine christelijke partijen) gebruik die voor verwerping van het wetsontwerp zouden stemmen, alsmede het CDA, dat zijn stem aan dit wetsontwerp niet zou onthouden. Alle partijen waren tevreden over de mogelijkheden ten aanzien van Indische adel en sekseneutrale interpretatie van de bestaande regelgeving, die de minister in zijn antwoord in twee termijnen impliciet zou hebben aangegeven, maar concludeerden verschillend. De woordvoerder van de SGP bleef voorts moeite houden met afschaffing van het prerogatief van de kroon en het rangschikken van het koninklijk huis onder de voorgestelde wet. Na hoofdelijke stemming bleek het wetsontwerp tot ieders verrassing aangenomen te zijn met 30 tegen 28 stemmen. ${ }^{462}$

Deze uitslag was ook tegen de zin van de Hoge Raad van Adel, die hoopte op intrekking of verwerping van het wetsvoorstel. In alle uitgebrachte adviezen toonde hij zich voorstander van handhaving van de bestaande situatie. Nu de wet met ingang van 1 augustus 1994 in werking trad, besloot de Raad tot een commentaar op en uitleg van de wet, die op aanvraag aan geïnteresseerden werd toegezonden. ${ }^{463}$ De becommentarieerde wet is, aan nieuwe regelgeving en jurisprudentie aangepast, thans nog op de website van de Hoge Raad van Adel te vinden. ${ }^{464}$

Nog in hetzelfde jaar publiceerde minister Van Thijn, die na meer dan tien jaar burgemeester van Amsterdam te zijn geweest, door zijn partij - naar later bleek slechts voor vijf maanden - naar Den Haag was geroepen, zijn memoires. Hierin komt ook de behandeling in de Eerste Kamer van de Wet op de adeldom voor. Hij was verheugd dat het onderwerp na een voorgeschiedenis van tientallen jaren eindelijk kon worden afgerond, maar moest concluderen, dat 'het bepaald geen walkover [is]. De senatoren, die het woord voeren, zijn zeer kritisch gestemd. Vooral de Wet op de Adeldom [naast de Herziening van het Decoratiestelsel] moet het ontgelden. De Tweede Kamer had de euvele moed gehad een amendement Van der Burg aan de nemen, waarin "natuurlijke" en adoptiefkinderen worden gelijkgesteld aan echte nazaten. Mede op grond van enkele doorwrochte beschouwingen in het

\footnotetext{
${ }^{461}$ Handelingen I, 1993-1994, 1670-1674.

${ }^{462}$ Handelingen I, 1993-1994, 1732-1733.

${ }^{463}$ HRvA, RA, notulen 1986-30.

${ }^{464}$ www.hogeraadvanadel.nl.
} 
Nederlands Juristenblad vreest men nu een explosieve groei van de adeldom in Nederland. Alsof losbandigheid in die kring troef is [dinsdag 12 april 1994]., 465 Vooral de laatste uitspraak was tekenend voor een tijd waarin het begrip 'wettig huwelijk' in het burgerlijk recht nog een lang leven leek te zijn beschoren. Zelfs de minister voorzag niet dat dit juridische begrip al voor de eeuwwisseling uit de $\mathrm{Ne}$ derlandse wetgeving zou verdwijnen. Hij vervolgde in zijn memoires op dinsdag 19 april 1994: 'Dan begint de tweede termijn over de Wet op de adeldom. De senatoren maken gehakt van mijn antwoord in eerste termijn. Het is duidelijk merkbaar dat ze zich verstaan hebben met de experts die over dit beperkte onderwerp een onbeperkte kennis hebben opgebouwd. Er ligt een goede spreektekst klaar en de voorzitter heeft haast, maar ik zie er, gehoord de discussie, toch maar vanaf onmiddellijk te antwoorden. ${ }^{466}$ Van zijn antwoord op 26 april maakte hij in zijn dagboek helemaal geen melding, terwijl hij bij de stemming over het wetsontwerp op 10 mei niet aanwezig was. Hij lunchte toen op Huis ten Bosch ter gelegenheid van het afscheid van de Chileense ambassadeur. Daar kwam het bericht binnen dat de wet nipt was aangenomen. 'Als ik erbij geweest was, zou hij misschien zijn verworpen, grap ik, maar ik had een goed excuus. Ik attendeer de Koningin op de fascinerende Formatiedagboeken van Beel. Haar reactie mag pas over 25 jaar gepubliceerd worden. ${ }^{467}$

\section{Aanpassing tekst koninklijke besluiten en adelsdiploma's}

De mededeling van de minister van Binnenlandse Zaken tijdens de behandeling van de Wet op de adeldom in de Eerste Kamer, dat artikel 3 (overgang van adeldom op buiten het huwelijk geboren kinderen) uitsluitend betrekking heeft op kinderen die na de inwerkingtreding van de wet zouden worden geboren, had gevolgen voor de formulering van de officiële teksten die de verleende erfelijke adeldom bepalen. Zowel de tekst van het koninklijk besluit als die van het adelsdiploma moest worden aangepast. De laatste inlijvingen volgens de oude regeling betroffen drie leden van het geslacht Von Balluseck, die hun verzoek kort voor de inwerkingtreding van de nieuwe wet hadden ingediend. Het koninklijk besluit en het adelsdiploma, die beide zijn ondertekend ná 1 augustus 1994, maar nog onder vigeur van het oude adelsrecht vallen, verlenen erfelijke adeldom aan de genobiliteerden 'en hun wettige afstammelingen in de mannelijke lijn, zowel mannelijke als vrouwelijke'. ${ }^{468}$ Deze tekst is gebaseerd op het bij KB van 18 december 1815 , nr. 46, vastgestelde formulier, dat in de loop van de tijd alleen in moderner Nederlands is omgezet.

\footnotetext{
${ }^{465}$ Van Thijn, Retour Den Haag, 199.

${ }^{466}$ Ibidem, 211.

${ }^{467}$ Ibidem, 251.

${ }^{468}$ KB van 3 okt. 1995, nr. 94.001769; adelsdiploma bij KB van 16 aug. 1996.
} 


\section{Staatsblad van het Koninkrijk der Nederlanden}

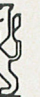

Jaargang 1994

\section{0 \\ Wet van 10 mei 1994, houdende regeling inzake de adeldom (Wet op de adeldom)}

Wij Beatrix, bij de gratie Gods, Koningin der Nederlanden, Prinses van Oranje-Nassau, enz. enz. enz.

Allen, die deze zullen zien of horen lezen, saluut! doen te weten:

Alzo $W i j$ in overweging genomen hebben, dat op grond van additioneel artikel XXV van de Grondwet een voorziening moet worden getroffen ter zake van de adeldom:

Zo is het, dat Wij, de Raad van State gehoord, en met gemeen overleg der Staten-Generaal, hebben goedgevonden en verstaan, gelijk Wij goedvinden en verstaan bij deze:

\section{Artikel 1}

Adeldom wordt verleend bij koninklijk besluit. De verlening kan uitsluitend geschieden aan Nederlanders.

\section{Artikel 2}

1. De verlening van adeldom geschiedt door verheffing, inlijving of erkenning.

2. Verheffing in de adel bij koninklijk besluit kan uitsluitend plaatsvinden ten aanzien van leden van het koninklijk huis.

3. Inlijving in de Nederlandse adel kan slechts plaatsvinden ten aanzien van personen wier geslacht behoort tot de wettelijk erkende adel van een staat met een vergelijkbaar adelsstatuut en die het verzoek tot inlijving hebben gedaan.

a. te zamen met het verzoek tot verlening van het Nederlanderschap;

b. te zamen met het afleggen van de verklaring ter verkrijging van het Nederlanderschap door optie;

c. te zamen met het bereiken van de meerderjarigheid bij de verkrijging van het Nederlanderschap van rechtswege indien de vader van de verzoeker het Nederlanderschap niet van rechtswege heeft verkregen.

4. Erkenning te behoren tot de Nederlandse adel kan uitsluitend plaatsvinden ten aanzien van personen die behoren tot een geslacht dat voor 1795 reeds tot de inheemse adel behoorde.

\section{Artikel 3}

Adeldom gaat ook volgens de bestaande regelingen met betrekking tot adeldom over op buiten het huwelijk geboren kinderen.

Krachtens de Bekendmakingswet trad de Wet op de adeldom in werking op de eerste dag van de tweede maand na publicatie in het Staatsblad (1994-360). Artikel 7, lid 1, bevat een foutief jaartal: in plaats van 1886 moet 1866 worden gelezen. 


\section{Artikel 4}

Bij de verlening van adeldom zijn taxa verschuldigd. Bij algemene maatregel van bestuur worden nadere regels omtrent de taxa gesteld.

\section{Artikel 5}

Adeldom wordt vermeld op officiële documenten waar dit vereist is, tenzij de betrokken persoon verzoekt, de vermelding achterwege te laten of te verwijderen.

\section{Artikel 6}

1. Er is een Hoge Raad van Adel.

2. De Raad heeft tot taak Onze Minister van Binnenlandse Zaken te adviseren over verzoeken tot verlening van adeldom.

3. De Raad is samengesteld uit vijf leden, die bij koninklijk besluit worden benoemd en ontslagen.

\section{Artikel 7}

1. De artikelen 2 en 3 van het koninklijk besluit van 12 mei 1886, nr. 48, vervallen.

2. De bestaande regelingen met betrekking tot adeldom en de Hoge Raad van Adel kunnen worden gewijzigd bij algemene maatregel van bestuur.

\section{Artikel 8}

Inlijving in de Nederlandse adel kan plaatsvinden ten aanzien van personen wier geslacht behoort tot de wettelijk erkende adel van een staat met een vergelijkbaar adelsstatuut en daartoe een verzoek om inlijving hebben gedaan binnen vijf jaar na de datum van inwerkingtreding van deze wet.

Zie voor de behandeling in de Kamerstukken II 1989/90, 1991/92, 1992/93, 21485

Handelingen II 1992/93, blz. 6866-6884; 1993/94, blz. 91

Kamerstukken I 1993/94, 21485 (26, 26a, 26b, 26c)

Handelingen I 1993/94, blz. 1440-1449; 1474-1477; 1559-1564: 1670-1674; zie vergadering d.d. 10 mei 1994

\section{Artikel 9}

Deze wet kan worden aangehaald als Wet op de adeldom.

Lasten en bevelen dat deze in het Staatsblad zal worden geplaatst en dat alle ministeries, autoriteiten, colleges en ambtenaren wie zulks aangaat, aan de nauwkeurige uitvoering de hand zullen houden.

Gegeven te 's-Gravenhage, 10 mei 1994

Beatrix

De Minister van Binnenlandse Zaken,

E. van Thijn

Uitgegeven de tweede juni 1994

De Minister van Justitie, E. M. H. Hirsch Ballin 
Alle koninklijke besluiten die op basis van de nieuwe wet zijn uitgevaardigd, om te beginnen die op grond van de overgangsbepaling van artikel 8 , verlenen erfelijke adeldom aan 'de genobiliteerde(n) en zijn/hun afstammelingen in mannelijke lijn, voor zover zij daarvoor volgens de bestaande wettelijke regelingen in aanmerking komen, zowel mannelijke als vrouwelijke'. Het eerste voorbeeld met de nieuwe formulering is de inlijving in de Nederlandse adel van vier leden van het geslacht De Bourbon de Parme. ${ }^{469}$

De verschillen in formulering komen eveneens tot uitdrukking in de gepubliceerde veertiende adelslijst, waarin alle verleningen tussen 1982 (dertiende adelslijst) en 2004 zijn gepubliceerd. ${ }^{470}$ De inwerkingtreding van de Wet op de adeldom valt midden in deze periode, zodat adelsverleningen volgens het oude en nieuwe adelsrecht elkaar in deze alfabetische lijst afwisselen.

\section{1994-2002: Wet lidmaatschap koninklijk huis}

\section{Overgang van adeldom}

Tijdens de parlementaire behandeling van de Wet op de adeldom was een tweetal juridische procedures over vererving langs vrouwelijke lijn en over Javaanse adel bij de rechter aanhangig, die in het parlement werden geciteerd en van invloed waren op het debat.

Op 21 februari 1995 deed de Afdeling Bestuursrechtspraak van de Raad van State uitspraak in beide zaken. Ten aanzien van de interpretatie van het geciteerde adelsrecht inzake vererving van adeldom stelde de Afdeling vast dat de bestaande regeling gezien moest worden in de tijd waarin deze was ontstaan. Zij nam daarbij in aanmerking dat het adelsrecht een historisch gegroeid instituut is, waaraan sedert 1848 geen rechten en vrijheden meer verbonden zijn. De conclusie was vervolgens dat de wetgever destijds vererving in mannelijke lijn had bedoeld en dat deze zienswijze overeenkwam met de zienswijze van de huidige wetgever, hetgeen was gebleken tijdens de parlementaire behandeling van de Wet op de adeldom. De Afdeling constateerde geen strijd met artikel 8 (in samenhang met art. 14) van het Europees Verdrag voor de Rechten van de Mens (EVRM), aangezien weigering van inschrijving in het filiatieregister niet als inmenging door de overheid in het privé-leven kan worden aangemerkt, hoewel het niet tot de adel behoren aspecten kan bevatten die tot iemands privé-leven behoren. Evenmin zag de Afdeling strijd met andere geciteerde internationale verdragen, alsmede artikel 1 van de grondwet. Het handhaven van onderscheid tussen afstamming via mannen of via vrouwen volgens een objectieve en redelijke grond, verantwoord binnen de regelgeving van het historisch instituut adel, die zich niet leende voor aanpassing aan moderne op-

\footnotetext{
${ }^{469} \mathrm{~KB}$ van 15 mei 1996, nr. 96.000163; adelsdiploma bij KB van 5 juli 1997.

${ }^{470} \mathrm{~KB}$ van 9 juni 2004 (Stb. 307), houdende goedkeuring van een veertiende lijst van personen of geslachten, wier titels en adeldom op de adelsregisters zijn ingeschreven, zomede van een vijfde lijst van veranderingen of vermeerderingen van adellijke geslachtsnamen.
} 
vattingen over gelijke behandeling, achtte de Afdeling niet strijdig met het gelijkheidsbeginsel of het beginsel van non-discriminatie. Van belang vond zij in dit verband dat de onmogelijkheid adeldom te verwerven altijd gelijkelijk heeft gegolden voor zowel mannen als vrouwen. ${ }^{471}$

In zijn commentaar wees De Groot, thans hoogleraar rechtsvergelijking en internationaal privaatrecht te Maastricht, op het meten met twee maten bij de totstandkoming van de Wet op de adeldom. Tijdens de behandeling van het wetsontwerp in de Eerste Kamer had de minister het door de Tweede Kamer aangenomen amendement Van der Burg (gelijkstelling kinderen die geboren zijn uit of buiten een huwelijk) verdedigd, maar de gedachte achter het verworpen amendement Scheltema-De Nie (vererving van adeldom langs zowel mannelijke als vrouwelijke lijn) om kwantitatieve redenen afgezworen. De Groot vond dat principes belangrijker behoren te zijn dan kwantiteiten en poneerde de stelling dat de Wet op de adeldom het adelsrecht wel degelijk heeft gemoderniseerd zonder ook de discriminatie van vrouwen af te schaffen. Als voorbeeld dat de laatste modernisering waarschijnlijk zelfs minder ingrijpend zou kunnen zijn dan de eerste, noemde hij de verleende (persoonlijke) adeldom van de kinderen van prinses Margriet. Hoewel De Groot de kans op adeldom voor verzoeker om overgangsrechtelijke redenen klein achtte, zag hij afwijzing van de motivering van de Afdeling door het Europese Hof voor de Rechten van de Mens (EHRM) in Straatsburg als een reële optie. De Groot sloot af met de stelling dat het adelsrecht met ingang van 1 augustus 1994 geen historisch instituut meer genoemd kon worden, waardoor de argumentatie van de Afdeling geen stand kon houden. ${ }^{472}$

\section{Javaanse adel}

In de andere rechterlijke uitspraak, betreffende Nederlandse en Javaanse adel als onderling vergelijkbare adelsstatuten, stelde de Afdeling Bestuursrechtspraak van de Raad van State verzoeker in het gelijk. Ook hierbij werd de parlementaire behandeling van de Wet op de adeldom in de argumentatie betrokken. Tijdens de behandeling van het wetsontwerp was de tegenstelling tussen de twee adelsstatuten minder groot gebleken dan waartoe de minister bij de behandeling van het verzoek had geconcludeerd. De Afdeling gaf aan dat het criterium niet 'gelijk' is, maar 'vergelijkbaar'. Aangezien het besluit tot afwijzing van de minister van Binnenlandse Zaken vanwege onvoldoende motivering in strijd was met het algemeen rechtsbeginsel van behoorlijk bestuur, werd het door de Afdeling vernietigd. ${ }^{473}$

\footnotetext{
${ }^{471}$ ABRvS 21 febr. 1995, nr. R01.92.0559 (Taets van Amerongen), met noot G.R. de Groot.

${ }^{472}$ AB/NJ 1996, nr. 222, 741-745.

${ }^{473}$ ABRvS 21 febr. 1995, nr. R01.93.0386 (Sewandono), met noot G.R. de Groot. Een nieuw verzoek om inlijving van 15 maart 1995 werd door de minister, na advies van de Hoge Raad van Adel, bij besluit van 15 januari 1996 afgewezen om inhoudelijke reden (onvoldoende bewijs van afstamming), HRvA, RA, not. 1992-14.
} 


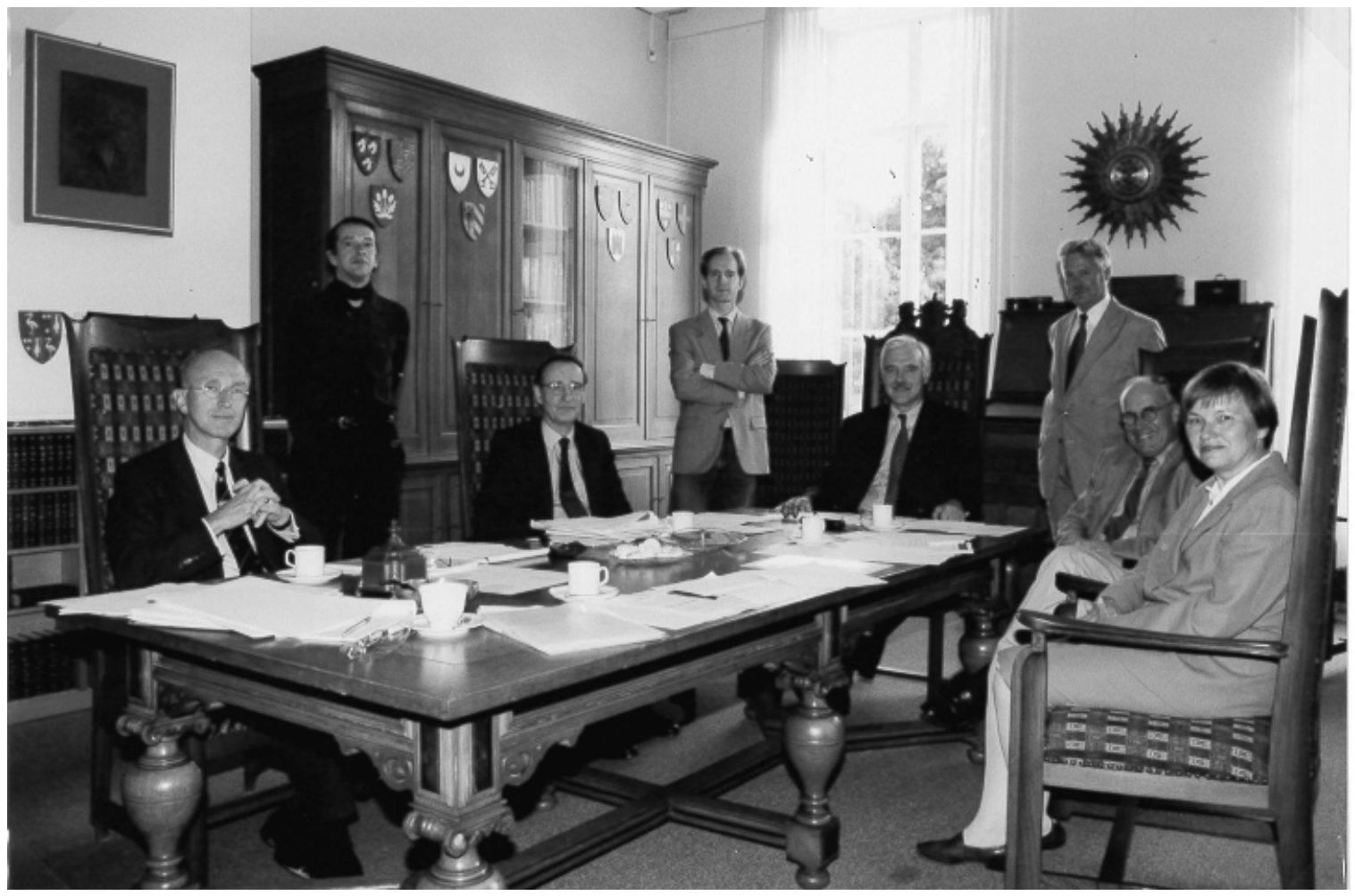

De Hoge Raad van Adel in zijn Raadzaal, Nassaulaan 18, 's-Gravenhage. Zittend v.l.n.r.: J.P. Eschauzier, jonkheer C.L. Reigersman, C.O.A. baron Schimmelpenninck van der Oije (voorzitter), C.W.J. baron de Weichs de Wenne en jonkvrouw M. van den Brandeler. Staande v.l.n.r.: G.P. Nijkamp en P. Husen, medewerkers, en O. Schutte, secretaris.

Foto Melchers, 's-Gravenhage 1996. Collectie en foto HRvA, 's-Gravenhage.

Ook hierop gaf De Groot commentaar, opzienbarend als hij de uitspraak vond. Uitvoerig besprak hij de kenmerken van de Indische (lees: Javaanse) adel, die ook tijdens het Kamerdebat aan de orde waren gekomen. Hij wees er nog eens op dat met 'vergelijkbaar' in feite 'soortgelijk' wordt bedoeld aangezien we niet met appels en peren te maken hebben, maar met adelsstatuten die niet te veel relevante verschillen mogen vertonen. De Groot wees ten slotte nog op het verschil tussen het oude en het nieuwe adelsrecht van na 1 augustus $1994 .{ }^{474}$ Ook de overgangsbepalingen gaan uit van de adeldom van een staat waar thans nog een vergelijkbaar adelsstatuut geldt en dat blijkt in de Republiek Indonesië niet meer het geval te zijn. Hiervan kon althans in een andere zaak het bewijs niet worden geleverd. ${ }^{475}$

\section{Overerfbaarheid van adellijke titels}

Tijdens de behandeling van enkele wijzigingen in het Burgerlijk Wetboek inzake het naamrecht nam de Tweede Kamer een motie Dittrich (D66) c.s. aan om een

\footnotetext{
${ }^{474}$ AB/NJ 1966, nr. 221, 737-741.

${ }^{475}$ ABRvS 19 mei 2000, 199901310/01 (Poerbodipoero; eveneens afgewezen wegens onvoldoende bewijs van afstamming).
} 
onderzoek in te stellen naar de overerfbaarheid van adellijke titels. ${ }^{476}$ Op 30 september 1996 bracht minister van Binnenlandse Zaken Dijkstal per brief aan de Tweede Kamer verslag uit van het onderzoek, dat het onderwerp vanuit drie gezichtspunten benaderde: volgens de wetgever, volgens de rechter en in verhouding tot het naamrecht. In het door hem gegeven verslag van de parlementaire behandeling van de Wet op de adeldom werd de vraag hoe het adelsrecht zich verhoudt tot het gelijkheidsbeginsel in grondwet en internationale verdragen niet expliciet beantwoord, omdat deze bij de totstandkoming van de wet aan de orde was geweest. $^{477}$

Het drietal rechterlijke uitspraken dat hij besprak, betrof afgewezen inschrijvingen in het filiatieregister van een onwettige dochter van een ongehuwde adellijke moeder en van de wettige zoon van een niet-adellijke vader, die door naamswijziging de naam van zijn adellijke moeder had verkregen. ${ }^{478}$ De Afdeling Bestuursrechtspraak van de Raad van State was in deze zaken van oordeel geweest dat deze weigering tot inschrijving terecht was, omdat deze berustte op het adelsrecht, dat niet in strijd was met relevante bepalingen in de grondwet, het IVBuPo en het EVRM. De minister vatte de argumentatie nog eens compact samen: (niet-) inschrijving is geen inmenging van de overheid in het privé-leven (art. 8 EVRM) en er zijn geen rechten aan verbonden; voorts is geen sprake van schending van artikel 14 van het EVRM, omdat het historische karakter van de adeldom een objectieve en redelijke grond vormt, terwijl de onmogelijkheid om adeldom via de vrouwelijke lijn te verwerven gelijkelijk geldt voor mannen en vrouwen. De derde rechterlijke uitspraak die de minister in zijn onderzoek had betrokken, betrof nogmaals de tweede zaak, waarin de afgewezen inschrijving in het filiatieregister een jaar later opnieuw werd verzocht op grond van nieuwe feiten en veranderde omstandigheden in de zin van artikel 4, lid 6, van de Algemene wet bestuursrecht (Awb). ${ }^{479}$ De Rechtbank Amsterdam had dit verzoek afgewezen omdat hiervan niet was gebleken. ${ }^{480}$

De minister had, zoals hem in de motie Dittrich was verzocht, het adelsrecht ook getoetst aan de normen zoals vastgelegd in de Algemene wet gelijke behandeling $(\mathrm{AWGB})^{481}$ en het Vrouwenverdrag. ${ }^{482}$ Hij was tot de conclusie gekomen dat er geen sprake was van een ongeoorloofd onderscheid en was met de wetgever en rechter van oordeel dat de overgang van adeldom in uitsluitend mannelijke lijn juridisch houdbaar was. De Nederlandse regering had bij de ondertekening van het

\footnotetext{
${ }^{476}$ Kamerstukken II, 1995-1996, 22 408, nr. 23.

${ }^{477}$ Kamerstukken II, 1996-1997, 25 039, nr. 1.

${ }^{478}$ ABRvS 9 sept. 1985, R01.84.1081; ABRvA 21 febr. 1995, R01.92.0559 (Taets van Amerongen).

${ }^{479}$ Wet van 4 juni 1992, houdende algemene regels van bestuursrecht (Algemene wet bestuursrecht) (inwerkingtreding 1 jan. 1994).

${ }^{480}$ AR 11 april 1996, 94/8061/19 (Taets van Amerongen).

${ }^{481}$ Wet van 2 maart 1994 (Stb. 230), houdende algemene regels ter bescherming tegen discriminatie op grond van godsdienst, levensovertuiging, politieke gezindheid, ras, geslacht, nationaliteit, hetero- of homoseksuele gerichtheid of burgerlijke staat (inwerkingtreding 1 sept. 1994).

${ }^{482} \mathrm{~V}$ (erenigde) N(aties)-verdrag inzake uitbanning van alle vormen van discriminatie van vrouwen (inwerkingtreding 22 aug. 1991).
} 
vrouwenverdrag geen voorbehoud met betrekking tot het adelsrecht gemaakt, omdat in tegenstelling tot bijvoorbeeld de Britse adel in Nederland geen staatsrechtelijke privileges aan adeldom zijn verbonden. ${ }^{483}$

In de vergelijking van adelsrecht met naamrecht deed de minister nog een poging om overtuigend uit te leggen, hoe de KB's van 30 sept. 1815, nr. 10, en 18 dec. 1815, nr. 46, moesten worden geïnterpreteerd en in het bijzonder de zinsnede 'en zijne wettige thans levende en toekomende kinderen zoo mannelijke als vrouwelijke, mitsgaders alle volgende afstammelingen van zijn geslagt en naam'. Naast het vereiste om een wettige afstammeling in mannelijke lijn van een adellijke stamvader te zijn, wordt als aanvullende eis gesteld het dragen van de geslachtsnaam van die stamvader. In de praktijk van het naamrecht kon dat intussen 'sluimerende adeldom' teweegbrengen, wanneer door de ouders van een kind voor de geslachtsnaam van de moeder was gekozen. Bij een latere wijziging van de geslachtsnaam in die van de adellijke vader, zou de adeldom van het kind herleven. ${ }^{484}$

De minister erkende in zijn conclusie weliswaar dat er een natuurlijke spanning is inzake de wijze van vererving van adeldom, maar dat deze juridisch houdbaar was en zonder bezwaar kon worden gehandhaafd. Het zou slechts gaan om een louter historisch instituut, waaraan geen wezenlijke voorrechten waren verbonden en dat slechts een geringe omvang had. De gevolgen van overgang van adeldom in de vrouwelijke lijn zouden de gevolgen van het amendement Van der Burg aanzienlijk overtreffen. ${ }^{485}$ Een dergelijke kwantitatieve toename achtte de regering in strijd met het historische karakter van het instituut. Dit strookte evenmin met het adelsbeleid sinds 1953, dat aan de Wet op de adeldom mede ten grondslag lag en dat door de Tweede Kamer nog eens was aangescherpt inzake inlijvingen. ${ }^{486}$

Samengevat zag de regering geen redenen om ten aanzien van de overgang van adeldom via de mannelijke lijn wijzigingen aan te brengen in de Wet op de adeldom en het bestaande adelsrecht. ${ }^{487}$

Niet alleen in de vaste Kamercommissie voor Binnenlandse Zaken - tijdens de behandeling van bovengenoemde ministeriële brief op 11 december 1996 - was er veel kritiek op de zienswijze van de regering. ${ }^{488}$ Met verwijzing naar het commentaar van De Groot adviseerde het Tweede Kamerlid Scheltema-De Nie (D66) de regering de eer aan zichzelf te houden, omdat het meten met twee maten (wel gelijke behandeling van wettige en onwettige kinderen, maar niet ten aanzien van vrouwen) hoogstwaarschijnlijk door het EHRM in Straatsburg wegens onvoldoende motivering om modernisering af te kunnen wijzen, ongedaan gemaakt zou worden. Zij wees in dit verband op een nieuw feit, namelijk de keuzevrijheid die sinds

\footnotetext{
${ }^{483}$ Tractatenblad 1991, nr. 134.

${ }^{484}$ Burgerlijk Wetboek (BW), art. 1:5, lid 11. In de tijd van behandeling van de motie Dittrich c.s. was deze bepaling (nog) in art. 5, lid 10, van het wetsontwerp inzake herziening van het naamrecht (22 408) ingebracht.

${ }^{485}$ Wet op de adeldom, art. 3, betreffende de overgang van adeldom op erkende en adoptiefkinderen.

${ }^{486}$ Ibidem, art. 2, lid 3, betreffende vergelijkbare adelsstatuten.

${ }^{487}$ Kamerstukken II, 1996-1997, 25 039, nr. 1, 4-5 (verslag, vastgesteld 29 jan. 1997).

${ }^{488}$ Sap, 'VVD-Ministers schenden democratie en persvrijheid', 565-568.
} 
1996 binnen het naamrecht ten aanzien van de naam in het algemeen werd voorgestaan, ook als het ging om adellijke namen. Van der Burg $(\operatorname{PvdA})^{489}$ sloot zich hierbij aan en wees er op dat het $\mathrm{KB}$ van 30 september 1815 sekseneutraal is en daardoor niet discriminerend, maar dat het ten onrechte mannelijk wordt geïnterpreteerd. Hierdoor zou bij een inschrijving in het filiatieregister het historische karakter van de adeldom een beoordeling volgens moderne maatstaven blokkeren. Ook zij wachtte met spanning op een uitspraak van het EHRM.

Bremmer (CDA) zag een parallel tussen de onderhavige tweespalt en het verschil in benadering van adellijke titulatuur als naamsbestanddeel of van adeldom als erfelijke onderscheiding. Hij wees in internationaal verband op het voorbehoud dat Engeland had gemaakt bij de ratificatie van het VN-vrouwenverdrag. Voor Nederland, dat dit voorbehoud niet had gemaakt, waren dus geen gronden aanwezig om een inbreuk op het beginsel van gelijke behandeling te rechtvaardigen. Het kwantitatieve argument om niet tot modernisering over te gaan vond hij evenals alle andere woordvoerders niet overtuigend.

Van der Stoel (VVD) moedigde de regering aan een duidelijke keuze te maken tussen instandhouding van het instituut of opheffing en zag de rechterlijke uitspraken in de context van het op dat moment vigerende naamrecht, dat uitging van naamgeving langs mannelijke lijn. $\mathrm{Nu}$ dit was gemoderniseerd, kon ook het $\mathrm{KB}$ van 30 september 1815 als zodanig worden uitgelegd.

Jonkheer Meijer (Groep Nijpels) was tegen het 'monumentenzorggevoel' en toonde zich een voorstander van uitbreiding aangezien de beperkingen in de wet geleidelijk tot het uitsterven van bepaalde geslachten zouden leiden. Hij achtte titel en naam onverbrekelijk met elkaar verbonden en pleitte voor overgang van adeldom tezamen met de keuze voor de naam van de adellijke moeder. Aan het slot van zijn betoog brak jonkheer Meijer nog een lans voor revitalisering van het verlenen van persoonsgebonden adellijke titulatuur aan mensen die zich bijzonder verdienstelijk hadden gemaakt voor de samenleving. ${ }^{490}$

In zijn antwoord herinnerde de minister de Kamer aan diens standpunt bij de behandeling van de Wet op de adeldom, toen gelijke behandeling en emancipatie al volop op de politieke agenda stonden en een amendement Scheltema-De Nie met deze strekking werd verworpen. ${ }^{491}$ Het zwaarste argument was toen de principiële keuze geweest voor instandhouding van het historische karakter van de adeldom, terwijl bewust niet voor totale afschaffing of fundamentele modernisering werd gekozen. De minister vreesde dat een beslissing om alsnog te moderniseren vervolgens niet los kon worden gezien van andere maatschappelijke ontwikkelingen als democratisering, individualisering, internationalisering, emancipatie en integratie van etnische en culturele minderheden, enz., enz. Van de adeldom als historisch

\footnotetext{
${ }^{489}$ Mevrouw M.M. van der Burg, ter onderscheiding van het CDA-Kamerlid mr. dr. V.A.M. van der Burg, indiener van het aangenomen amendement op het wetsontwerp 21485 (het latere art. 3 van de Wet op de adeldom).

${ }^{490}$ Kamerstukken II, 1996-1997, 25 039, nr. 3, 1-5.

${ }^{491}$ Kamerstukken II, 1993, 21 485, nr. 10.
} 
instituut zou dan niet veel meer over blijven. Artikel 3 van de Wet op de adeldom was tegen de wil van de toenmalige minister bij amendement toegevoegd en slechts een mineure wijziging gebleken. De vrees dat deze breuk met het historische adelsrecht (slechts overgang langs wettige mannelijke lijn) de weg naar volgende aanpassingen zou inluiden, was onterecht gebleken. De suggestie van jonkheer Meijer om het stelsel van adeldom te revitaliseren met persoonlijke adeldom wegens bijzondere verdienste nam de minister dan ook niet over, temeer daar de namen van deze personen - zo stelde hij - ook zonder adellijke titulatuur in de geschiedschrijving zouden blijven voortleven.

Het kabinetsstandpunt inzake overerfbaarheid van adellijke titels zou uit de aangehaalde rechterlijke uitspraken voldoende zijn bewezen en de hoop van verscheidene Kamerleden op een uitspraak van het EHRM in Straatsburg zou ijdel blijken te zijn. Het voeren van adellijke titulatuur hield geen recht in, aldus de minister, in de zin van het EVRM, waarbij hij verwees naar een recente niet-ontvankelijkheidsverklaring van een bij de Europese Commissie voor de Rechten van de Mens in Nederlandse zaken ingediende klacht, waarop het Hof dus geen uitspraak zou doen. ${ }^{492}$

De vier grootste partijen namen geen genoegen met het antwoord van de minister en zagen zich genoodzaakt het verslag van het algemeen overleg op de Kameragenda te plaatsen om een uitspraak van de Tweede Kamer te forceren. ${ }^{493}$

Tijdens het openbare debat in de Tweede Kamer op 18 december 1996 diende het lid Scheltema-De Nie een motie in, ondersteund door de andere woordvoerders en door de medeleden Dittrich en Soutendijk-Van Appeldoorn, waarin de regering werd gevraagd vóór 1 juli 1997 te komen met een voorstel tot wijziging van de Wet op de adeldom. In hun overwegingen noemden de Kamerleden achtereenvolgens de foutieve interpretatie van de bestaande regelingen betreffende de overgang van adeldom, een systeem dat op gespannen voet stond met de grondwet en verschillende internationale verdragen, het herziene naamrecht dat aan adellijke families de mogelijkheid gaf om de geslachtsnaam via de vrouwelijke lijn over te dragen en de principiële modernisering van de historische verervingsregels die al in de Wet op de adeldom had plaatsgevonden door de introductie van adelsvererving op natuurlijke kinderen en adoptiefkinderen.

In zijn reactie wees de minister nog eens op het verschil tussen overdracht van naam en overgang van adellijke titulatuur. Aan het voeren van een titel zijn geen rechtsgevolgen verbonden, laat staan dat er sprake zou zijn van een zogenaamd 'civil right' dat wordt beschermd door het EVRM. Het Kamerlid Scheltema-De Nie wierp vervolgens tegen, dat al was het EVRM mogelijk niet van toepassing, toch ook in de geest van het beginsel van gelijke behandeling moest worden gehandeld als er geen rechtsgevolgen aan verbonden waren. Deze koppeling werd in de grondwet immers niet gelegd. De minister vond dit een omgekeerde redenering,

\footnotetext{
${ }^{492}$ Vijghen, 'Adellijke titel is geen recht in de zin van het EVRM' (Taets van Amerongen, klachtnr. 28683/95), NJCM -Bulletin, d.d. 21 juli 1996, p. 970.

${ }^{493}$ Kamerstukken II, 1996-1997, 25 039, nr. 3, 5-6.
} 
die hij niet van plan was te volgen. Natuurlijk verzette de aangehaalde wetgeving zich niet tegen wijziging in de zin die de motie voorstelde, maar de minister zag daar het nut niet van in nu de huidige regelgeving niet strijdig was gebleken. Om praktische redenen was destijds uit drie mogelijkheden gekozen: afschaffing, modernisering of handhaving als historisch monument. Ondanks het zijns inziens ongelukkige amendement Van der Burg, dat door de Tweede Kamer was aangenomen, bleef de derde optie (adel als historisch gegroeid instituut) verdedigbaar en daar wilde de minister het bij laten.

Tijdens de hieropvolgende discussie over de praktische consequenties van overgang van adeldom tezamen met de adellijke geslachtsnaam van de moeder op haar kinderen - met hypotheses van toepassingspercentages - waarschuwde de minister nog voor de toename van het aantal adelsstatuten, die vervolgens vergelijkbaar zouden worden op grond van een gewijzigde Nederlandse Wet op de adeldom. Hierdoor zou het aantal inlijvingen navenant kunnen stijgen, waarvan de Kamer in eerdere samenstelling bepaald geen voorstander was. Aangezien hij niet overtuigd was van de argumenten, ontraadde hij de motie ten slotte dringend. ${ }^{494}$

Op 19 december 1996 werd de motie Scheltema-De Nie c.s. aangenomen, maar de minister was niet voornemens deze uit te voeren en schreef op 15 mei 1997 een brief aan de voorzitter van de Tweede Kamer, waarin hij het kabinetsstandpunt uiteenzette. Hierin somde hij nogmaals de belangrijkste bezwaren op tegen wijziging van de Wet op de adeldom, hoezeer het in de motie gedane verzoek in het licht van het beginsel van de gelijke behandeling op zichzelf redelijk klonk. Modernisering van het instituut adel stond op wezenlijke onderdelen op gespannen voet met het zeer recentelijk door de wetgever onderschreven standpunt om de adel louter als historisch instituut te handhaven. Vererving van adeldom langs vrouwelijke lijn zou niet in de historische legitimatie van het instituut passen, waarmee Nederland zich bovendien isoleerde van de continentale Europese lijn, die uitsluitend vererving langs mannelijke lijn voorstond. De te verwachten toename van verzoeken na aanpassing van de Wet op de adeldom stond in schril contrast met het adelsbeleid zoals dat sinds 1953 werd uitgedragen en op initiatief van de Tweede Kamer werd geconsolideerd ten aanzien van verheffingen en nu aanzienlijk beperkt werd ten aanzien van inlijvingen. Een praktische consequentie bij uitvoering van de motie zou nog zijn, dat het inmiddels herziene naamrecht opnieuw bij wet zou moeten worden aangepast door bepaalde geslachtsnamen aan bepaalde titels te koppelen.

Ten slotte wees de minister namens het kabinet op de tegenstrijdigheid om met een beroep op rechtsgelijkheid tussen mannen en vrouwen in feite uitbreiding te bevorderen van een groep personen die in de samenleving louter op grond van overerving een bepaalde status had, welke door sommigen als ongelijk werd ervaren. Naar het oordeel van het kabinet zou de adel als historisch instituut zijn grondslag verliezen wanneer hij werd aangepast aan hedendaagse inzichten. Na rijp beraad

\footnotetext{
${ }^{494}$ Handelingen II, 1996-1997, 3276-3281.
} 
hadden bovenstaande argumenten voor het kabinet zwaarder gewogen dan de argumenten uit de Tweede Kamer, waarmee het kabinet bij zijn eerdere standpunt bleef en het niet op zijn weg vond liggen om over te gaan tot de voorbereiding van een voorstel tot wijziging van de Wet op de adeldom. ${ }^{495}$

\section{Onrechtvaardigheden}

De Tweede Kamer liet het hierbij niet zitten bij monde van het lid jonkheer R.A. Meijer, die in het vergaderjaar 1997-1998 zeventig schriftelijke vragen op de minister van Binnenlandse Zaken afvuurde. ${ }^{496}$ Hoewel hierin doorgaans naar de bekende weg werd geïnformeerd, leverde de beantwoording meestal halsstarrige, maar soms heldere standpunten over het vigerende adelsrecht op. Eén van de vragen van jonkheer Meijer was hoe de juridische band die inmiddels in BW 1:5, lid 10 , tussen adellijke titel en geslachtsnaam volgens het herziene naamrecht werd gelegd, zich verhield tot de uit de memorie van antwoord bij de Wet op de adeldom geciteerde zinsnede 'Formeel bestaat er geen relatie tussen adeldom en geslachtsnaam. Naamswijziging brengt geen wijziging in adeldom. Adeldom gaat er niet door verloren en wordt er niet door verkregen.' Na een korte uitleg over de wetsgeschiedenis van beide bepalingen concludeerde minister Dijkstal dat artikel 5 , lid 10, ertoe strekte te voorkomen dat door de mogelijkheid van naamskeuze nieuwe combinaties van namen en adellijke titels zouden ontstaan. Hij wees er op dat het bestaan van een bepaalde door een adellijk geslacht gevoerde achternaam niet betekende dat dan ook alle dragers van de naam recht hebben op een adellijke titel of predikaat. Dit kunnen verschillende geslachten zijn, takken van éénzelfde geslacht, onwettige leden van dit geslacht (geboren vóór 1 augustus 1994) of afstammelingen van een kind van een adellijke moeder, die voor haar geslachtsnaam hebben gekozen. In Nederland was de situatie dus anders dan in Duitsland, waar na afschaffing van de adeldom in staatsrechtelijke zin de titel 'Namensbestandteil' was geworden. De minister legde uit dat het daar ging om een woord dat weliswaar ook taalkundig de aanduiding van een titel is maar als onderdeel van de naam juist geen titel is. ${ }^{497}$

Ontevreden over de beantwoording van zijn vragen diende jonkheer Meijer op 8 mei 1998 een initiatiefwetsvoorstel in 'tot wijziging van de Wet op de adeldom om enige onrechtvaardigheden in het overheidsbeleid ten aanzien van adellijke ouders en hun kinderen weg te nemen' ${ }^{498}$ Hij maakte zich bezorgd over het uitsterven van adellijke geslachten en over het verdwijnen van de eenheid binnen het het gezin, die de eerbiedigende werking van de Wet op de adeldom tot gevolg had. Het voorstel wilde in het bijzonder artikel 3 van de Wet op de adeldom ("Adeldom gaat ook volgens de bestaande regelingen met betrekking tot adeldom over op buiten het

\footnotetext{
${ }^{495}$ Kamerstukken II, 1996-1997, 25 039, nr. 4.

${ }^{496}$ Handelingen II, 1997-1998, aanhangsel, nrs. 473, 479, 1040, 1341-1343.

${ }^{497}$ Ibidem, nr. 1342, Aanhangsel van de Handelingen II, 2745-2746.

${ }^{498}$ Kamerstukken II, 1997-1998, 26 028, nrs. 1-5.
} 
huwelijk geboren kinderen') verruimen met het begrip 'adellijke ouder, die in familierechtelijke betrekking tot een kind staat', zodat ook vererving van adeldom langs vrouwelijke lijn mogelijk zou worden. Aangezien de redactie van het artikel sekseneutraal was, kon deze wijziging historisch verantwoord worden toegepast, zo betoogde jonkheer Meijer. In de memorie van toelichting bij zijn wetsvoorstel deed hij verslag van het adelsrecht vanaf de Middeleeuwen (volgens het Romeins recht) tot en met de aangenomen motie Scheltema-De Nie. Tijdens de behandeling van de motie Dittrich bleek al dat hij de intentie had om het instituut adeldom nieuw leven in te blazen. Ook in dit wetsvoorstel wilde hij verder gaan dan de koppeling tussen adeldom en naam, zoals in art. BW 1:5, lid 10, was verwoord en pleitte hij voor onmiddellijke werking. Hij verbaasde zich er althans over dat de wet zweeg over een situatie volgens welke de adeldom van de moeder los van haar geslachtsnaam kan overgaan, dan wel op analoge wijze als de adeldom van de vader. ${ }^{499}$ Eén van zijn argumenten hiervoor waren de bepalingen in de Grondwet van 1814 over de troonopvolging onder de wettige nakomelingen van de soevereine vorst, waarmee zowel afstammelingen in mannelijke als in vrouwelijke lijn werden bedoeld. De Salische wet had in het Koninkrijk der Nederlanden - en kennelijk ook al daarvóór - nooit ingang gevonden, dus zouden de KB's uit 1815, die sekseneutraal waren, onjuist door de overheid zijn geïnterpreteerd.

Een nieuw argument vond jonkheer Meijer in het verslag dat de Nederlandse Rapportagecommissie Internationaal Vrouwenverdrag op 18 maart 1997 had uitgebracht en waarin de directe discriminatie van vrouwen in de adelswetgeving werd gewraakt. Het rapport gaf een verslag van de behandeling van de herziening van de naamwetgeving in de Tweede Kamer, maar ging niet verder dan de overweging dat de kwestie maatschappelijk minder relevant was. ${ }^{500}$ Voorts koesterde hij hoop uit de artikelen 1 en 2 van het Vrouwenverdrag, die het Koninkrijk der Nederlanden de resultaatverplichting oplegden om ook bij historische instituten, zoals het koningschap, de adel en de ridderorden, alsmede de Staten-Generaal en de Raad van State, categorisch elke vorm van onderscheid, uitsluiting of beperking op grond van geslacht ongedaan te (doen) maken. ${ }^{501}$

De Tweede Kamerverkiezingen van 1998 staken een spaak in het wiel van jonkheer Meijer, want hij keerde niet terug in de Kamer en werd hem verzocht het wetsontwerp in te trekken.

\section{Onevenwichtigheden}

De CDA-Kamerleden P.C.E. van Wijmen en C.I.J.M. Ross-van Dorp namen op 7 april 2000 het gestrande initiatief van jonkheer Meijer onder een iets gewijzigde naam ('onevenwichtigheden' in plaats van 'onrechtvaardigheden') over, maar toonden zich hiermee ook de pleitbezorgers van zijn visie op het instituut adel. ${ }^{502}$

\footnotetext{
${ }^{499}$ Ibidem, nr. 3 (memorie van toelichting), p. 8.

${ }^{500}$ Rapport Het Vrouwenverdrag in Nederland anno 1997 (ISBN 90.5250.3699), 3.2.2, p. 53-54 en 144.

${ }^{501}$ Kamerstukken II, 1997-1998, 26 028, nr. 3, p. 6-7.

${ }^{502}$ Kamerstukken II, 1999-2000, 27 074, nr. 1-2.
} 
Dit zou eerst ten volle blijken tijdens de behandeling van het wetsvoorstel in de vaste Kamercommissie voor Binnenlandse Zaken en Koninkrijksrelaties (BZK). De argumentatie was meestal letterlijk, maar beknopter overgenomen uit de memorie van toelichting van het wetsontwerp-Meijer. In een enkel opzicht was het aangescherpt met nieuwe argumenten. Zo vonden de indieners dat de motivering bij de uitspraak van de Afdeling Bestuursrechtspraak van de Raad van State uit 1995 omkeerbaar was: het historisch karakter zou juist nimmer een argument zijn om ongelijkheid in stand te houden. Voorts werden de artikelen 1 en 2 van het Vrouwenverdrag letterlijk geciteerd, waarin ongelijke behandeling van vrouwen ten opzichte van mannen op het terrein van de burgerrechten als discriminatie van vrouwen wordt gedefinieerd, waarop aangesloten staten verplicht zijn om maatregelen te nemen. Ten slotte werd de rechtstreekse werking van artikelen 2 en 26 van het IVBuPo nog eens onderstreept, die bepalen dat verbonden staten geen onderscheid naar geslacht mogen maken in de uitoefening van hun rechtsmacht en discriminatie op grond van geslacht bij wet moeten verbieden. ${ }^{503}$

Het advies van de Raad van State naar aanleiding van het wetsontwerp, dat enige redactionele kanttekeningen maakte - zoals het vervangen van het onduidelijke begrip 'sexeneutraal' - was toegespitst op twee onderwerpen. Allereerst adviseerde hij de indieners om in het wijzigingsvoorstel het schrappen van artikel BW 1:5, lid 10, mee te nemen, en voorts af te zien van onmiddellijke werking. Aan de hand van een casus maakte de Raad van State duidelijk, dat het onverstandig zou zijn om bij de aanpassing van de wetgeving inzake overerving van adeldom aan hedendaagse opvattingen deze hedendaagse opvattingen met terugwerkende kracht op situaties in het verleden van toepassing te laten zijn (geen 'Hineininterpretierung' van hedendaagse normen in de adelsgeschiedenis).

Het advies werd in een reactie van de indieners ter harte genomen. Op eigen initiatief was inmiddels de expliciete vermelding als constitutief element van inschrijving in het filiatieregister van de Nederlandse adel uit de ontwerptekst teruggenomen, omdat deze eis nergens in de bestaande verervingsregels wordt gesteld. ${ }^{504}$ Voorafgaande aan de parlementaire behandeling was de redactie van het nieuwe artikel 3 van de Wet op de adeldom als volgt geformuleerd: 'Erfelijk verleende adeldom gaat volgens de bestaande verervingsregelingen over op alle kinderen die in familierechtelijke betrekking staan tot de adellijke ouder en de geslachtsnaam van die adellijke ouder hebben'. Aan het wetsontwerp, dat vasthield aan het beginsel van onmiddellijke werking, zou dan de volgende overgangsbepaling worden toegevoegd: 'Artikel 3 van de Wet op de adeldom, zoals dit artikel luidt na inwerkingtreding van deze wet, heeft geen gevolgen indien, op het tijdstip van inwerkingtreding van deze wet, het kind en degene aan wie het kind de adeldom ontleent, niet meer in leven zijn. ${ }^{505}$

\footnotetext{
${ }^{503}$ Kamerstukken II, 1999-2000, 27 074, nr. 3, p. 3.

${ }^{504}$ Kamerstukken II, 2000-2001, 27 074, A.

${ }^{505}$ Ibidem, 27 074, nr. 4.
} 
De gewijzigde memorie van toelichting bij het wetsvoorstel gaf de argumentatie bij de overgangsbepaling waar de Raad van State naar had gevraagd. Daarnaast werd het beroep op de artikelen uit de Grondwet van 1814 betreffende troonopvolging op alle wettige afstammelingen, enigszins genuanceerd door er op te wijzen dat de KB's van 1815 altijd 'beperkt' zijn uitgelegd in de zin van vererving van adeldom langs mannelijke lijn. Onder het hoofdstuk 'Internationale Verdragen' werd nog het EVRM bijgevoegd, waarvan de artikelen 8 en 14 verzekering eisen van het genot van rechten en vrijheden zonder enig onderscheid op welke grond ook, zoals bijvoorbeeld geslacht en geboorte. De indieners hadden ook commentaar op hun initiatiefvoorstel van de Commissie Gelijke Behandeling gevraagd, die afstand nam van de uitspraak van de Afdeling Bestuursrechtspraak van de Raad van State uit 1995. De Commissie miste in deze uitspraak de mindere acceptatie binnen de rechtspraak van het EHRM van het onderscheid op grond van geslacht, een ontwikkeling die de laatste jaren zou zijn waar te nemen. Zij concludeerde voorts dat het buiten twijfel was dat de huidige regel niet te verenigen was met de in de AWGB neergelegde normen. In de Wet op de adeldom is sprake van direct onderscheid, dat volgens de systematiek van de AWGB moet worden uitgebannen. Dit zou te meer klemmen na invoering van het nieuwe naamrecht, dat het nu mogelijk maakte wel de 'adellijke' naam van de moeder te verkrijgen, maar niet de titel. $^{506}$

Medio 2000 vroegen de indieners van het wetsvoorstel ontheffing aan minister van BZK K.G. de Vries om advies te mogen vragen aan de Hoge Raad van Adel, zijn adviescollege inzake verlening van adeldom. De minister kon dit verzoek op grond van artikel 6, lid 2, van de Wet op de adeldom niet honoreren, maar adviseerde hen deze Raad te vragen om enige bijstand te verlenen op grond van de aanwezige deskundigheid. Hij bood voorts ambtelijke ondersteuning aan bij de verdere afhandeling van het wetsontwerp. Vanwege de raakvlakken met Justitie zou hij bij zijn ambtgenoot bepleiten de ondersteuning vanuit de afdeling constitutionele zaken van BZK te coördineren. In de praktijk heeft de gevraagde ondersteuning op deze wijze plaatsgevonden, dat het ministerie dikwijls ruggespraak hield met de secretaris van de Hoge Raad van Adel, die in zijn hoedanigheid van ambtenaar in algemene dienst van BZK ambtshalve over de gevraagde deskundigheid kon beschikken. ${ }^{507}$

In dezelfde tijd werd ook contact gezocht met de Nederlandse Adelsvereniging, een belangenvereniging van (een deel van) de Nederlandse adel. Deze vereniging was bereid een enquête over dit onderwerp onder haar leden te organiseren. Ongeveer de helft van het aantal leden reageerde, waarvan weer de helft om zeer verschillende redenen tegen het wetsvoorstel bleek te zijn. De voorstemmers maakten,

\footnotetext{
${ }^{506}$ Kamerstukken II, 2000-2001, 27 074, nr. 5, p. 3-5.

507 Brief minister van Binnenlandse Zaken en Koninkrijksrelaties (BZK), d.d. 27 sept. 2000, kenmerk BK00/78286 (kopie in: HRvA, RA, not. 2000-11).
} 
eveneens met zeer diverse motiveringen, ongeveer $45 \%$ uit, terwijl $5 \%$ geen mening had. ${ }^{508}$

\section{Middel erger dan de kwaal?}

Het verslag van het voorbereidend onderzoek van het wetsvoorstel in de vaste Kamercommissie voor BZK, dat werd vastgesteld op 8 maart 2001, maakte een opzienbarende wending zichtbaar in de parlementaire discussie over het gelijkheidsbeginsel. ${ }^{509}$ Zowel de PvdA-, VVD- als D66-fractie wilden voorafgaand aan de bespreking van de ongelijkheid tussen vrouwen en mannen het fenomeen adeldom zelf nader beschouwd zien, omdat het bestaan ervan de ongelijkheid in zich herbergt tussen personen van adel en personen die niet van adel zijn. Ze verzochten de initiatiefnemers uiteen te zetten hoe de moderne gedachten over gelijkwaardigheid van man en vrouw zich verhouden tot het instituut van de adel. Verder werden er vragen gesteld over adeldom in verhouding tot naamrecht, dat tot het personen- en familierecht behoorde, en wat inschrijving in het filiatieregister te maken heeft met het geslacht van een bepaalde persoon. Ook was men benieuwd of advies was gevraagd aan de Hoge Raad van Adel, omdat deze Raad zich vooralsnog zeer terughoudend had opgesteld ten opzichte van vererving van de titel via de vrouwelijke lijn. De onduidelijkheid over kwantiteiten, die de minister destijds niet had kunnen ophelderen, was blijven voortbestaan. Wat zouden de maatschappelijke gevolgen zijn van het al of niet uitsterven van adellijke titels? Waarom grepen de initiatiefnemers terug op de Middeleeuwen en waar in Nederland was vererving via de vrouwelijke lijn van toepassing? Wat was de waarde van een specifiek middeleeuws adelsstatuut anno 2001? En hadden de initiatiefnemers mogelijk de regels voor het vorstenhuis verward met die voor de adel?

De leden van de D66-fractie hadden met verwondering kennis genomen van het wetsontwerp Van Wijmen/Ross-Van Dorp. Alles was toch vijf jaar geleden al de revue gepasseerd en de fractie kreeg steeds meer moeite met het feit dat adeldom op zichzelf reeds ongelijkheid tussen mensen inhield. De partij had destijds besloten niet mee te werken aan de gelijke behandeling van de vrouwelijke lijn, omdat de adel anders waarschijnlijk niet zou uitsterven, maar aanzienlijk in omvang zou toenemen. De D66-fractie was in haar huidige samenstelling van oordeel dat het uitgangspunt van de wetgever, handhaving van de adel als historisch instituut, conflicteerde met modernisering, zoals de initiatiefnemers voorstonden. Verder nam de fractie de indieners kwalijk dat zij selectief hadden geciteerd uit de rapportage van de Commissie Gelijke Behandeling. De commissie was namelijk om twee redenen niet tot een oordeel gekomen over de verenigbaarheid van de Wet op de adeldom met de AWGB. De eerste betrof de eerbiedigende werking van de AWGB: 'de wet laat onverlet onderscheid dat gemaakt wordt bij of krachtens enige andere wet, welke voorafgaande aan deze wet in werking is getreden'. De tweede reden was dat de AWGB niet van toepassing was op overgang van een

\footnotetext{
${ }^{508}$ Nieuwsbrief van de Nederlandse Adelsvereniging, december 2000.

${ }^{509}$ Kamerstukken II, 2000-2001, 27 074, nr. 6.
} 
adellijke titel, omdat inschrijving in het filiatieregister een eenzijdig publiekrechtelijk besluit is. In navolging van de Nederlandse Rapportagecommissie Internationaal Vrouwenverdrag onderstreepte de fractie het geringe maatschappelijk belang van het onderwerp. De leden van de D66-fractie vroegen ten slotte of de initiatiefnemers de ongelijkheid tussen mannen en vrouwen binnen de adeldom willen laten voortbestaan, waar het de aanduiding betrof van niet-adellijke aangehuwden van leden van de Nederlandse adel, met een verwijzing naar de toestemmingswet voor het huwelijk van prins Constantijn met Petra Laurentien Brinkhorst.

Aangezien de indieners van het voorstel tot de CDA-fractie behoorden, was deze fractie aanmerkelijk constructiever dan die van de andere grote partijen. Had de wetgever in 1994 op eigen initiatief de regelingen met betrekking tot adeldom op buiten het huwelijk geboren kinderen aangepast aan het personen- en familierecht, thans zou dit nogmaals gebeuren op het gebied van het naamrecht, waarmee de wet tevens in overeenstemming met de AWGB zou worden gebracht. De fractie vroeg nog wel om een statistisch onderzoek naar de gevolgen van het wetsontwerp, een kostenopgave en hoe de discrepantie tussen de uitspraak van de Afdeling Bestuursrechtspraak van de Raad van State en de kennelijk bijgestelde argumentatie van het EHRM met elkaar waren te verenigen. Tot slot wilde de fractie in verband met de op instigatie van de Raad van State toegevoegde overgangsbepaling weten, hoe de situatie zou zijn als de vader van wie het kind de adeldom erfde, kwam te overlijden voordat het kind was geboren? Hiermee gaf de fractie aan dat door de voorgestelde wijziging de bestaande erfelijke adeldom onverwacht kon eindigen op een wijze die niet was voorzien.

De Groen-Links-fractie juichte het initiatief toe maar had liever opheffing gezien van de gehele Wet op de adeldom, zodat aan het 'volstrekt achterhaalde instituut adeldom' een einde zou komen. De kleine christelijke fracties toonden zich ook nu meer gouvernementeel, al stelden zij wel vragen over de kwantitatieve consequenties van het wetsvoorstel. De SGP-fractie stelde ten slotte de vraag waarom het verschijnsel van de 'sluimerende' adeldom, die nog altijd kon ontstaan als niet de naam van de adellijke ouder zou worden gekozen, door de initiatiefnemers niet (meer) als een onevenwichtigheid werd ervaren?

Voor de beantwoording van de Kamervragen bleek een diepgaande studie naar het historische adelsrecht noodzakelijk, die de indieners niet zonder ambtelijke ondersteuning en deskundigheid hadden kunnen produceren. In dit stadium deden zij dan ook een indirect beroep op de Hoge Raad van Adel, wiens secretaris een notitie met commentaar op het wetsvoorstel uitbracht, die hen via het Ministerie van BZK bereikte.

Puntsgewijs werden in deze notitie de grotendeels op het ingetrokken wetsvoorstel van jonkheer Meijer teruggaande argumenten voor wijziging van de Wet op de adeldom afgeserveerd. Onjuiste formuleringen, bronnen en voorbeelden bleken schering en inslag en ook op de aantallen en percentages viel het nodige aan te merken. Naar aanleiding van de memorie van toelichting werd de bewering ontzenuwd dat van de 577 sinds 1814 in de Nederlandse adel opgenomen geslachten er 
inmiddels al 247 in mannelijke zouden zijn uitgestorven. De notitie van de Hoge Raad van Adel maakte duidelijk dat die 577 geslachten nooit op hetzelfde moment hadden geleefd en dat er sedert 1962 slechts negentien 'nieuwe' geslachten waren ingelijfd. Zonder dat het exacte aantal kon worden aangegeven, werd daarin aannemelijk gemaakt dat het grootste aantal adellijke geslachten dat ooit tegelijk leefde, eerder tussen de 300 en 350 heeft gelegen en dat het huidige aantal daar niet ver onder lag. Naar aanleiding hiervan werd in de notitie gewezen op de onjuiste opvatting in de memorie van toelichting als zou het aantal keuzes voor de moedersnaam gering zijn en toename van de Nederlandse adel, bij aanneming van het wetsvoorstel, eveneens gering zijn. Rekening zou gehouden moeten worden met extra keuzes voor de naam van de moeder - ook om sociale redenen, bijvoorbeeld wanneer de naam van de verzorgende ouder de biologische verdringt - indien hiermee overgang van adeldom zou kunnen worden bereikt. Daarnaast zou het wetsvoorstel indirect pleiten voor algehele openstelling van adeldom via vrouwelijke lijn, hetgeen een verdubbeling van de Nederlandse adel per generatie zou kunnen betekenen. De wetswijziging zou voorts geen einde maken aan de situatie van de 'sluimerende' adeldom, maar deze in het bijzonder voor het kind complexer maken door de toegenomen mogelijkheden van naamskeuze.

Aan het slot werd nog gewezen op de lichtvaardige meningsvorming over royement van adeldom, waarvan hoofdzakelijk vroeg negentiende-eeuwse voorbeelden bekend waren en dat slechts in uitzonderlijke gevallen door de Kroon zou kunnen worden geëffectueerd. ${ }^{510}$

Op 5 juli 2001 brachten Van Wijmen en Ross-Van Dorp hun nota naar aanleiding van het verslag van de vaste Kamercommissie van BZK uit met een lange inleiding, die refereerde aan de twee met grote meerderheid aangenomen moties Dittrich c.s. en Scheltema-De Nie c.s. naar aanleiding van de herziening van het naamrecht. ${ }^{511}$ Deze mochten niet zonder gevolg blijven vanwege de op deze wijze tot uitdrukking gebrachte wens van de Kamer. Aangezien het initiatiefontwerp Meijer moest worden ingetrokken, hadden zij het estafettestokje overgenomen. Daar het hier geen vrijblijvende handelingen waren geweest, maar standpunten van de volksvertegenwoordiging over gelijke behandeling van mannen en vrouwen waardoor bij betrokken burgers zekere verwachtingen waren gewekt, hadden zij besloten het onderhavige initiatiefwetsvoorstel voor te bereiden. De reactie van een aantal fracties had bij hen enige verwondering gewekt. Omdat de mening van de Tweede Kamer nogal contrasteerde met de opstelling van de Kamer in het recente verleden, namen de indieners uitgebreid de gelegenheid nog eens uit te leggen, waar bij de totstandkoming van de Wet op de adeldom voor was gekozen. In de eerste plaats om het instituut adeldom te laten voortbestaan en voorts door aanneming van het amendement Van der Burg om een eerste stap te zetten tot een wezenlijke modernisering. Door dit precedent was het onlogisch om te stoppen met moderniseren door de ongelijke behandeling van mannen en vrouwen te laten

\footnotetext{
${ }^{510}$ HRvA, RA, not. 2000-11.

${ }^{511}$ Kamerstukken II, 1995-1996, 22 408, nr. 23; 1996-1997, 25 039, nr. 2.
} 
voortbestaan. Het historische karakter van het instituut zou nimmer een argument mogen zijn om deze ongelijkheid in stand te houden. ${ }^{512}$

Als reactie op de Kamervragen van PvdA en D66 in hoeverre het een overheidstaak was om regels van adeldom vast te stellen, wezen de indieners op de verantwoordelijkheid van de overheid voor de inhoud en handhaving van alle wetten die van kracht zijn, dus niet alleen betreffende het naamrecht, maar ook de Wet op de adeldom. Voorts waren zij met de toenmalige fracties van mening dat overervingsregels van adeldom niet zonder meer kunnen worden losgekoppeld van de geslachtsnaam. Een visie op de adeldom als zodanig, die de VVD in het voorstel miste, achtten zij niet nodig omdat de evidente onevenwichtigheden in de overervingsregels reeds door de Kamer waren onderkend. Anders dan de VVD-fractie veronderstelde, was het wetsvoorstel niet ingegeven door een behoefte om mensen met behulp van adellijke titels in staat te stellen hun maatschappelijke aanzien te bevorderen. Vragen over kwantiteit werden wel beantwoord, maar vonden zij principieel beschouwd geen rechtvaardiging voor het instandhouden van ongelijke behandeling. De indieners verwezen voor prognoses naar een recent artikel van jonkheer Von Bönninghausen betreffende de berekening van het aantal bestaande en uitgestorven adellijke geslachten. ${ }^{513}$ Voor bewijzen van vererving van inheemse adeldom via de vrouwelijke lijn vóór 1815 verwezen zij naar de dissertatie van de Utrechtse hoogleraar geschiedenis jonkvrouw Van Winter, waarin werd aangetoond dat in de Middeleeuwen volgens het Romeinse recht standen erfelijk waren via de moeder, omdat alleen deze lijn bewijsbaar was. ${ }^{514}$

Twijfels van de VVD-fractie over de sekseneutrale interpretatie van de KB's van 1815 , waarbij mogelijke verwarring met de regels van vererving binnen het vorstenhuis werd verondersteld, werden tegengesproken op grond van de redactie van de KB's, waarin uitsluitend over de adel wordt gesproken. Een verwijzing naar de Salische wet werd verklaard met de mededeling dat deze slechts in bepaalde delen van Europa heeft gegolden waar vanouds de Franken regeerden, die hiermee specifiek wilden verhinderen dat vrouwen de troon konden bestijgen. Het KB van 26 maart 1868, dat de bijzondere verervingsregels vaststelde voor de circa veertig mannelijke adellijke titels die bij recht van eerstgeboorte (de primogenituur) uitsluitend aan wettige afstammelingen worden verleend, werd expliciet buiten het wetsvoorstel gehouden. ${ }^{515}$

De CDA-fractie liet de indieners nog eens uitleggen waarop minister Van Thijn destijds de eerbiedigende werking van artikel 3 van de Wet op de adeldom baseerde. Dit zouden drie motieven zijn geweest: 1. juridische eenvoud (het rechtsfeit van de geboorte is het meest eenduidig in vergelijking met eventuele andere

\footnotetext{
${ }^{512}$ Kamerstukken II, 2000-2001, 27 074, nr. 7, p. 1-5.

${ }^{513}$ Von Bönninghausen, 'Ruim 290 Nederlandse adellijke geslachten', 155-162.

${ }^{514}$ Van Winter, Ministerialiteit en ridderschap in Gelre en Zutphen, 234-235.

${ }^{515}$ Kamerstukken II, 2000-2001, 27 074, nr. 5, p. 5, art. III. Zie voor de geslachtsnamen: Schutte, 'Adellijke titels en predikaten in geboorteakten', 94-96.
} 
rechtsfeiten); 2. uitvoeringstechnisch gemak; 3 . kwantitatief zo beperkt mogelijke effecten. Hij somde deze toen op als reactie op de vrees van de vele juridische procedures die het gevolg zouden worden van toevoeging van dit artikel in de wet, hetgeen achteraf gezien was meegevallen.

Opmerkingen van deze fractie over de vele verschillende interpretaties en uitspraken aangaande het al of niet handhaven van het onderscheid tussen afstamming via adellijke mannen en vrouwen en de consequenties daarvan voor het wetvoorstel, werden door de indieners tegengesproken. Ze verwachtten juist dat door aanneming van het voorstel de wetgever duidelijkheid zou geven, waardoor de gang naar de bestuursrechter zou verminderen. De vraag over de vererving langs mannelijke lijn, wanneer de adellijke vader vóór de geboorte van het kind was overleden, pareerden zij met de geruststelling dat volgens art. BW 1:2 de ongeboren vrucht als reeds geboren wordt aangemerkt, zo dikwijls zijn belang dit vordert. Adeldom zou in een dergelijk geval dus gewoon overgaan. Financiële consequenties van aanneming van het wetsvoorstel konden de indieners niet aangeven, maar zouden volgens hen niet afwijken van andere ingevoerde wettelijke regelingen.

Het gegeven dat de Commissie Gelijke Behandeling in haar rapport om tweeërlei reden niet tot een oordeel had kunnen komen - hetgeen de D66-fractie in het advies had gemist - bracht de indieners niet van de wijs. Zij betoogden dat de commissie zonder een formeel oordeel te hebben kunnen uitspreken duidelijke taal had gesproken door expliciet te vermelden dat in de Wet op de adeldom ten onrechte een direct onderscheid werd gemaakt. Naar aanleiding van hun vraag of de indieners van zins waren om ook het verbod voor niet-adellijke echtgenoten om de titels van hun adellijke echtgenotes te mogen voeren, te doen opheffen, gaven zij aan dat dit buiten de reikwijdte van het voorstel viel. Niettemin zouden zij een voorstel van de zijde van D66 welwillend in overweging willen nemen. ${ }^{516}$

\section{Adeldom geen 'civil right' in de zin van het EVRM}

In het hierboven geciteerde verslag van de vaste Kamercommissie van BZK en de nota naar aanleiding van het verslag wordt nergens melding gemaakt van de uitspraak van het EHRM van 18 mei 1999. Hierop zat toch menig Kamerlid met smart te wachten, alsook de Commissie Gelijke Behandeling, die immers een aanscherping van het beleid meende te constateren. De Groot nam de uitspraak zonder noemenswaardig commentaar op in zijn beschrijving van het adelsrecht als drama in zes bedrijven. ${ }^{517}$ Het Hof liet de uitspraak van de Afdeling Bestuursrechtspraak van de Raad van State van 16 maart 1999, die eenzelfde afwijzing (geen overgang van adeldom op een kind dat had gekozen voor de adellijke geslachtsnaam van zijn moeder) als haar veelvuldig tijdens de Kamerdebatten geciteerde uitspraak van 21 februari 1995 inhield, intact. ${ }^{518}$ Het Hof bevestigde naar aanleiding van een klacht op grond van art. 6, lid 1, van het EVRM, dat het enkele bezit of niet-bezit van

\footnotetext{
${ }^{516}$ Kamerstukken II, 2000-2001, 27 074, nr. 7, p. 6-14.

${ }^{517}$ De Groot, 'Adelsrecht op de drempel van de $21^{\text {ste }}$ eeuw', 505-506.

${ }^{518}$ ABRvS 16 maart 1999, H01.98.0350/15.
} 
adeldom door de aard ervan buiten de rechten en vrijheden valt die door het verdrag en bijbehorende protocollen worden beschermd. En voorts overwoog het Hof dat de nationale wetgeving geen beleidsruimte geeft in de toepassing van de Wet op de adeldom, zodat niet gezegd kan worden dat onder de Nederlandse regelgeving een recht op het voeren van een adellijke titel bestaat. Verzoeken om adeldom kunnen slechts worden getoetst aan de drie criteria verheffing, erkenning en inlijving. ${ }^{519}$ Onder het hoofdstuk 'Relevant domestic law' heeft het Hof, alvorens uitspraak te doen, de bepalingen van de Wet op de adeldom genoemd en vervolgens uitgelegd dat adeldom in Nederland wordt verleend bij koninklijk besluit. Dan volgden twee zinnen, waaruit in de jurisprudentie van de daarop volgende jaren ten onrechte de conclusie werd getrokken dat het Hof hiermee de uitspraak zou hebben gedaan dat in Nederland adellijke titulatuur een onderdeel zou zijn van de geslachtsnaam: 'Under the relevant provisions of Dutch law governing names, noble titles and predicates form a part of a noble person's family name. The unlawful carrying of a noble title may attract consequences under Dutch criminal law.' In een recente uitspraak stelde de Rechtbank Haarlem vast, dat het EHRM hier slechts een opsomming gaf van de artikelen (BW 1:6 en WvSr. 435), die voor de onderhavige zaak van belang waren. ${ }^{520}$ De toelichting van het Hof werd afgesloten met een verwijzing naar de ABRvS van 21 februari 1995, waarmee de gewraakte ABRvS van 16 maart 1999 veel overeenkomst vertoonde en waar ook naar werd verwezen. $^{521}$

Niet alleen het Nederlandse adelsrecht ontkwam aan toetsing aan het gelijkheidsbeginsel zoals dat in het EVRM wordt beschermd, maar ook de primogenituur in het Spaanse adelsrecht. Later in hetzelfde jaar concludeerde het Hof in Straatsburg dat de aanspraak op een adellijke waardigheid of titel niet behoort tot de rechten en vrijheden die door het EVRM worden beschermd. Evenmin achtte het Hof door de achterstelling van de vrouw schending aanwezig van het recht op naam, noch op gelijk recht op het genot van een goed in de zin van artikel 1 van Protocol nummer 1 bij het Verdrag. ${ }^{522}$ Naar aanleiding van deze uitspraak achtte ook De Groot de kans geslonken dat het EHRM de Nederlandse jurisprudentie inzake het adelsrecht zou vernietigen als in strijd met het gelijkheidsbeginsel. Hij constateerde een soortgelijk terughoudend standpunt bij het Hof inzake de ongelijkheid tussen mannen en vrouwen in het naamrecht, waar - bij het uitblijven van een keuze voor de geslachtsnaam volgens artikel BW 1:5 - de naam van de vader blijft prevaleren. ${ }^{523}$ Hij achtte het Nederlandse adelsrecht en naamrecht in dit opzicht nog altijd discriminerend en voor wijziging vatbaar. Zijn hoop bleef nog in 2002 gevestigd op

\footnotetext{
${ }^{519}$ NJB 1999, 1324-1325, nr. 24 (Wolff Metternich contra Nederland).

${ }^{520}$ AR Haarlem 24 april 2012, nr. 184609 (BW 1:24); Jurisprudentie Personen- en Familierecht (JPF) 2012, 86 (met noot P. Vlaardingerbroek).

${ }^{521}$ EHRM 18 mei 1999, 45908/99.

${ }^{522}$ EHRM 28 oktober 1999 (Pilar de la Cierva y Osorio de Moscoso e.a.); Westerouen van Meeteren, 'De vrouw in het Nederlandse en Spaanse adelsrecht', 372-377.

${ }^{523}$ EHRM 27 april 2000, 42973/98 (Bijleveld).
} 
het initiatief-wetsontwerp Van Wijmen/Ross-Van Dorp en op de toegezegde evaluatie door de wetgever van het herziene naamrecht. ${ }^{524}$

Volgens de agenda van de Tweede Kamer zou de openbare beraadslaging van het wetsvoorstel in de vergadering van 29, 30 en 31 januari 2002, na uitstel in december daaraan voorafgaande, plaatsvinden, maar dit is uiteindelijk niet doorgegaan. ${ }^{525}$ Eén van de redenen was dat Van Wijmen inmiddels tot hoogleraar natuurbeschermingsrecht aan de Katholieke Universiteit Brabant te Tilburg was benoemd en de Kamer had verlaten. Toen na de Tweede Kamerverkiezingen ook mevrouw Ross niet als parlementariër terug zou komen, werd zij genoodzaakt het wetsvoorstel op 30 mei 2002 in te trekken, nog voor er überhaupt een openbaar debat had plaatsgevonden. ${ }^{526}$ Op 22 juli 2002 trad zij als staatssecretaris van Volksgezondheid, Welzijn en Sport toe tot het eerste Kabinet Balkenende, een positie die zij viereneenhalf jaar bekleedde tot in het derde Kabinet Balkenende, dat op 22 februari 2007 viel. $^{527}$

Gezien de overweldigende kritiek op het wetsvoorstel en de verruiming van de discussie is het uiterst onzeker of het wetsontwerp op een meerderheid had kunnen rekenen. Het leek eerder op een oeverloos debat te zullen uitlopen, dat nog eens herhaald kon worden in de Eerste Kamer. Door het voortdurend doorschuiven van de behandeling wijzigde ook regelmatig de samenstelling van de Kamers en het aantal woordvoerders, dat zich met nieuw enthousiasme in het onderwerp verdiepte. Net als destijds bij de behandeling van de Wet op de adeldom zou de afloop onvoorspelbaar zijn geweest.

\section{Wet lidmaatschap koninklijk huis}

De herziening van de Wet lidmaatschap koninklijk huis uit 1985, die door de toestemmingswet voor het huwelijk van de prins van Oranje (2001) enige urgentie had gekregen, bleek als een met het adelsrecht verwante regeling - achteraf gezien - een gelukkige samenloop van omstandigheden te zijn. Voor menigeen onverwacht maakte het tweede Kabinet Kok op 28 januari 2002, een dag voor de drie dagen die de Tweede Kamer had gereserveerd voor de openbare behandeling van het uitgestelde wetsvoorstel Van Wijmen/Ross-Van Dorp, het wetsontwerp 'Regeling van het lidmaatschap koninklijk huis alsmede daaraan verbonden titels' aanhangig. ${ }^{528}$ Het betrof een wijziging van de bestaande Wet lidmaatschap koninklijk huis (1985), in het bijzonder van de omvang van het huis, met het oog op de daaraan gekoppelde ministeriële verantwoordelijkheid en de daaraan verbonden titels. Het wijzigingsvoorstel bracht geen wijziging in de positie van het lidmaatschap van de bestaande leden - volgens de grondwet tot en met erfopvolgers in de derde

\footnotetext{
${ }^{524}$ De Groot, 'Adelsrecht op de drempel van de 21 ${ }^{\text {ste }}$ eeuw', 63-64 (als reactie op Westerouen van Meeteren, die 'rust in de tent' voorstond).

${ }^{525}$ Kamerstukken II, regeling van werkzaamheden d.d. 20 dec. 2001, 2911.

${ }^{526}$ Idem, 2000-2001, 27 074, nr. 8.

527 Staatsalmanak 2012, B 12 e.v.

${ }^{528}$ Kamerstukken II, 2001-2002, 28 223, nr. 3.
} 
graad - maar zou het toekomstige lidmaatschap beperken tot bloedverwanten met hun echtgenoten in de eerste en tweede graad. De grondslag hiervoor werd gevonden in de beschikbaarheid voor de verlening van bijstand bij de uitoefening van de koninklijke functie. De regering achtte het in het openbaar belang om zorg te dragen voor het handelen van de leden van het koninklijk huis, niet alleen beperkend, maar ook ondersteunend en ruimtebiedend. Daarnaast bleef de regering in de eerste plaats zijn op artikel 42, lid 2, van de grondwet gebaseerde ministeriële verantwoordelijkheid voor de onschendbare koning uitoefenen.

De titulatuur, die in het wijzigingsontwerp werd voorgesteld, betrof drie functionele erfelijke prinsentitels, waarvan de titel prins van Oranje voor de vermoedelijke opvolger van de koning in alle grondwetten van het koninkrijk tussen 1815 en 1972 was opgenomen. Bij de grondwetsherziening van 1983 was de erfopvolging volledig sekseneutraal verklaard, maar de specifieke titel uit de grondwet weggelaten. Deze ontbrak ook in de daaruit voortvloeiende Wet lidmaatschap koninklijk huis van 1985. Bij de behandeling van de toestemmingswet voor het huwelijk van de prins van Oranje in 2001 was deze lacune gesignaleerd en aangekondigd dat deze titel in de vernieuwde wet zou worden opgenomen. De titel prins(es) van Oranje valt van rechtswege toe aan de vermoedelijke opvolger van de koning (art. 7) op het moment dat deze unieke hoedanigheid wordt verkregen. De titel vervalt van rechtswege met het verlies van die hoedanigheid. ${ }^{529}$

De twee andere functionele prinsentitels waarover nadere regels werden voorgesteld, waren die van prins(es) der Nederlanden (art. 8) en prins(es) van OranjeNassau (art. 9). Het onderscheid daartussen hield verband met de positie van de potentiële erfopvolger binnen de derde graad (familietitel prins(es) van OranjeNassau) en de afstand in positie ten opzichte van de koning en de vermoedelijke troonopvolger.

Beide titels betroffen overigens geen familienaam, want deze zou eerst worden vastgesteld bij beëindiging van het lidmaatschap (art. 9, lid 3 en 4) en voor eventuele kinderen bij koninklijk besluit (BW 1:5, lid 12). ${ }^{530}$ Een recent voorbeeld van geslachtsnaamgeving betreft in 2001 de eventuele kinderen van prins Constantijn, van wie verwacht kon worden dat zij te eniger tijd buiten het koninklijk huis zouden vallen, namelijk wanneer de prins van Oranje koning zou zijn geworden. ${ }^{531}$ In de nieuwe wet werd tevens van de gelegenheid gebruik gemaakt om de artikelen BW 1: 5, leden 1-11, en 1:7 voor leden van het koninklijk huis buiten toepassing te verklaren (art. 9, lid 4). Hiermee werd de discussie tussen De Groot en Hofman Kolk beslecht over het al of niet van toepassing zijn van deze bepalingen over naamskeuze en naamswijziging voor leden van het koninklijk huis. Deze werd gevoerd naar aanleiding van de naamgeving van de eventuele kinderen van prins

\footnotetext{
${ }^{529}$ Rijkswet van 4 juli 2001 (Stb. 333), zie de memorie van toelichting.

${ }^{530}$ Kamerstukken II, 2001-2002, 28 223, nr. 3.

${ }^{531}$ Ibidem, nr. 5, p. 17. KB van 11 mei 2001, nr. 01.002382 (Stb. 227).
} 
Maurits in 1998, voor wie na overleg met de familie de samengestelde geslachtsnaam Van Lippe-Biesterfeld van Vollenhoven was bepaald. ${ }^{532}$

Geslachtsnaamgeving krachtens art. BW 1:5, lid 12, blijkt geen verplichting in te houden. De twee zonen van prinses Margriet die geen grondwettelijke toestemming voor hun huwelijken aan het parlement vroegen, hadden althans geen koninklijk besluit nodig om de naam van hun kinderen te bepalen. Door de persoonlijke adeldom van de kinderen van prinses Margriet voorzag het koninklijk besluit betreffende het huwelijk van prinses Margriet en de titulatuur en naamgeving van haar nazaten reeds in deze situatie. ${ }^{533}$

Vanwege de samenhang met de Wet op de adeldom en met het oog op de bepalingen in het wetsvoorstel die specifiek op titulatuur en naamgeving (artt. $7 \mathrm{t} / \mathrm{m} \mathrm{13}$ ) betrekking hebben, had de minister-president, minister van Algemene Zaken, mede namens zijn ambtgenoten van BZK en Justitie, al in een vroeg stadium advies van de Hoge Raad van Adel ingewonnen. Dit was binnen drie dagen na de aanvraag, op 21 januari 2002 uitgebracht en bevatte een tweetal aanbevelingen. ${ }^{534}$ De eerste betrof artikel 9, lid 3, dat de vraag openliet over de adellijke status gedurende de drie maanden na een eventueel verlies van het lidmaatschap waarbinnen nog geen koninklijk besluit over het al of niet behouden van de titel prins van Oranje-Nassau was uitgevaardigd. De Raad ging ervan uit dat betrokkene gedurende die tijd van adel bleef en alleen over een titel zou moeten worden beslist. Het tweede punt betrof de verheffing in de adel, die volgens artikel 13 in navolging van de Wet op de adeldom exclusief voor leden van het koninklijk huis was gereserveerd. De Raad adviseerde onder het begrip verheffing alle vormen van verlening te rangschikken die niet onder de begrippen inlijving en erkenning, zoals deze in de Wet op de adeldom zijn geregeld, vallen. Zonder met deze laatste aanbeveling creatie van geheel nieuwe titulatuur voor te staan, kon de regering met beide aanbevelingen meegaan, maar stelde bij deze gelegenheid nog eens vast dat geen wijziging zal worden gebracht in het uitgangspunt van de Wet op de adeldom, dat de adel als historisch instituut wordt gehandhaafd. ${ }^{535}$

Op 7 februari 2002 bracht de Raad van State advies uit. Aangezien het wetsvoorstel het lidmaatschap en de daaraan verbonden titels regelde, beval hij aan om betreffende het onderwerp naamgeving niet verder te gaan dan een toelichting op de uiteenzetting van het te voeren beleid met betrekking tot de geslachtsnaam Van Oranje-Nassau. Voorts zou met betrekking tot het lidmaatschap in de toelichting niet moeten worden gesproken over lidmaatschap 'al dan niet voor een in het besluit bepaalde duur', omdat de bepaling daarin niet voorzag. Ten slotte was in het artikel over de prins(es) van Oranje niet vermeld dat het een titel was, hetgeen

\footnotetext{
${ }^{532}$ De Groot, 'Pieter Prins der Nederlanden', 144; Hofman Kolk, 'Het koninklijk huis', 915.

${ }^{533} \mathrm{~KB}$ van 2 januari 1967 (Stb. 1). Zoals hierna zal blijken was het KB van naamsbepaling voor de kinderen van prins Bernhard overbodig.

${ }^{534}$ HRvA, RA, not. 2002-6.

${ }^{535}$ Kamerstukken II, 2001-2002, 28 223, nr. 3, p. 10.
} 
eveneens niet in overeenstemming met de toelichting was. Tezamen met enkele redactionele correcties zond de regering ontwerp, memorie van toelichting en adviezen, aangevuld met een nader rapport, op 15 februari naar de koningin. ${ }^{536}$

Het voorstel was goed voorbereid en kon betrekkelijk snel in de Tweede Kamer worden behandeld. Daar werd veel tijd en aandacht aan het wetsontwerp besteed, maar het voert in dit kader te ver om hiervan uitgebreid verslag te doen. Aangezien de Hoge Raad van Adel advies werd gevraagd specifiek met betrekking tot de artikelen over titulatuur en naamgeving, zal daar bij het vervolg van dit overzicht de nadruk op liggen.

In een nota van 27 maart 2002 naar aanleiding van het verslag van de behandeling in de Tweede Kamer ging de regering uitvoerig op deze zaken in. ${ }^{537}$ De regering begon de fracties van de verschillende partijen te complimenteren met de positieve opstelling die ze vanuit hun eigen politieke visie aan den dag hadden gelegd bij hun reacties. Op de vraag van de CDA-fractie wat de materiële verschillen en overeenkomsten waren tussen adellijke en functionele titels en waarom het nodig was deze in de wet te regelen, antwoordde de regering dat de materiële overeenkomst was dat het om de titel prins (prinses) ging. Het verschil was dat de functionele titels verbonden zijn aan het lidmaatschap van het koninklijk huis. Wettelijke regeling was nodig om de bij de verlening er van gevolgde praktijk van de afgelopen decennia te verduidelijken en te bestendigen. De regeling zou de historische relatie en verbondenheid van de titels prins(es) der Nederlanden en prins(es) van Oranje-Nassau met de koning en het koninklijk huis verzekeren door deze te verbinden aan het lidmaatschap van het koninklijk huis. Hiermee konden misverstanden over de reikwijdte worden voorkomen, die naar verwachting zouden kunnen ontstaan als de regeling zou ontbreken. ${ }^{538}$

Een vraag van de PvdA-fractie of het juist geconcludeerd was, dat de exclusieve titel prins(es) der Nederlanden in de toekomst niet meer gedragen zou kunnen worden door erfopvolgers, die geen lid zijn van het koninklijk huis, kon bevestigend worden beantwoord, behoudens de uitzondering van artikel 10. Deze bepaling verwijst naar de koninklijke besluiten van 26 oktober 1937 (Stb. 5) en 2 januari 1967 (Stb. 1) en betreft de titulatuur en naamgeving van de kinderen van prinses Juliana, respectievelijk prinses Margriet. Hoewel de in casu bedoelde uitzondering het KB van 1937 betrof, dat op zichzelf geen expliciete duidelijkheid geeft over de reikwijdte van het gebruik van de titel prinses der Nederlanden voor de dochters van de koningin, bood het spontane antwoord van de regering dit nu wel. Kennelijk konden alle dochters van koningin Juliana, ook diegenen die geen toestemming voor hun huwelijk vroegen, gedurende hun leven toch de titel blijven voeren. ${ }^{539}$

\footnotetext{
${ }^{536}$ Kamerstukken II, 2001-2002, 28 223, nrs. 1-2 en A.

${ }^{537}$ Ibidem, nr. 5.

${ }^{538}$ Ibidem, p. 15.

${ }^{539}$ Ibidem, p. 17. De nota van toelichting bij het KB van 19 maart 2004 (Stb. 126), houdende bepalingen inzake titels, predikaat en geslachtsnaam van ZKH Prins Johan Friso, zaaide onnodig opnieuw verwarring met de zinsnede: 'Ten overvloede wordt erop gewezen dat ook andere familieleden die geen lid (meer) zijn
} 
Alle partijen waren benieuwd of het wetsvoorstel de ongeschreven regel, gebaseerd op de Grondwet van 1972, gestand zou doen dat de echtgenote van de koning zich koningin mocht noemen en zo niet, of ook deze titel dan niet in het wetsvoorstel zou moeten worden bestendigd. De regering meldde dat sedert de algemene grondwetsherziening van 1983 buiten elke twijfel stond dat de grondwet slechts één koning (koningin) kende en dat die aanduiding in formele zin uitsluitend betrekking kon hebben op het staatshoofd. De aanspreektitel zou ruimer toegepast kunnen worden, maar over die aanduiding zou de regering eerst ter gelegenheid van de troonswisseling een besluit nemen, zo was tijdens de mondelinge behandeling van de toestemmingswet van het huwelijk van de prins van Oranje afgesproken. 540

Dit door de minister-president verkondigde standpunt is vanuit staatsrechtelijke hoek bestreden, omdat hij met deze voorwaarde van een nieuw beslissingsmoment een extra bevoegdheid voor het kabinet invoegde, die niet in de grondwet is voorzien. ${ }^{54}$ Van der Burg zag dit als een verdere verzwaring van het Nederlandse grondwettelijke systeem van parlementaire toestemming voor prinselijke huwelijken, dat in vergelijking met andere Europese koninkrijken opvallend gewichtig is. Hij weet de uitvoerige deliberaties in de verenigde vergadering van de StatenGeneraal aan de historische vormgeving van het koninkrijk als rechtsopvolger van de Republiek der Verenigde Nederlanden. Anders dan in België of Scandinavië kende Nederland betrekkelijk laat het stelsel van de ministeriële verantwoordelijkheid. Elders is voor prinselijke huwelijken doorgaans alleen toestemming van de Kroon noodzakelijk, maar de Staten-Generaal hebben zich niet tegen de verklaring van de minister-president verzet. ${ }^{542}$ Integendeel, tien jaar later was het ineens zover. Op 13 mei 2011 nam het Kabinet Rutte, daarin gesteund door de meerderheid van de Tweede Kamer, het principebesluit dat prinses Máxima (op dat moment tien jaar Nederlandse) volgens de bestaande traditie de aanspreektitel koningin mag voeren vanaf het moment dat haar echtgenoot koning wordt. ${ }^{543}$

De CDA-fractie vroeg waarom een regeling ontbrak met betrekking tot de historische titels van de koning, doorgaans schuilgaande achter het intitulé 'Enz. enz. enz.'. Waren deze met het overlijden van koningin Wilhelmina in 1962 uitgestorven en zo nee, waarom gold vererving van een adellijke titel via de vrouwelijke lijn niet voor de overige adel en waarom discrimineerde de wet in dat geval op dit punt?

\footnotetext{
van het koninklijk huis, zoals HKH Prinses Irene en HKH Prinses Christina, de familietitel en hun predikaat hebben behouden.'

${ }^{540}$ Ibidem, p. 18.

${ }^{541}$ Van der Burg en Koekkoek, 'Een dubbele proef voor Máxima', 1707.

${ }^{542}$ Van der Burg, 'De toestemming voor prinselijke huwelijken, een erfenis uit de tijd van de Republiek der Verenigde Nederlanden', 11-30.

${ }^{543}$ Bij KB van 17 mei 2001, nr. 01.002390, werd aan Máxima Zorreguieta het Nederlanderschap verleend. Minister U. Rosenthal deelde op vrijdag 13 mei 2011 na afloop van de ministerraad, die hij voorzat, mee dat het kabinet wil vasthouden aan het vaste gebruik dat de echtgenote van de koning de aanspreektitel koningin krijgt: 'Zij zal geen koningin zijn, maar de aanspreektitel is koningin' (Algemeen Nederlands Persbureau).
} 
Het antwoord van de regering begon met de opmerking dat geen uitputtende regeling is ontworpen. De noodzaak van verfijning, zoals gevraagd, ontbrak omdat buiten twijfel stond dat deze titels in het intitulé functioneel verbonden waren aan het koningschap en niet konden overgaan op personen die geen lid zijn van het koninklijk huis. De titels waren dus niet uitgestorven bij het overlijden van prinses Wilhelmina in 1962, maar reeds bij de troonwisseling in 1948 overgegaan op koningin Juliana. Gelet op de functionele verbondenheid van de genoemde titels met het koningschap ging de vergelijking met de overgang van adellijke titels niet op en kon van discriminatie derhalve geen sprake zijn. ${ }^{544}$

De VVD-fractie had twijfels of het besluit om de vermoedelijke troonopvolger de titel prins van Oranje te geven, gebaseerd was op een rechtmatig besluit, omdat het Tractaat van Partage uit 1732 zonder toestemming van de Franse koning, als rechthebbende op de titel, tot stand was gekomen. Ook een ouder besluit, volgens welk de titel in de Grondwet van 1815 was terechtgekomen, zou dan onrechtmatig zijn genomen. Deze twijfel trachtte de regering weg te nemen met de overweging, dat wat ook waar mocht zijn van de genoemde boedelscheiding tussen de erfgenamen van koning-stadhouder Willem III uit 1732, internationaal vaststond dat de rechtmatigheid van het voeren van de titel door de toenmalige stadhouders onbetwist was. Ditzelfde gold voor de bepaling in de Grondwet van 1815, die de titel had verbonden aan de hoedanigheid van de vermoedelijke opvolger van de koning. 545

Tijdens het laatste mondelinge debat in de Tweede Kamer op 11 april 2002 waren drie amendementen ingediend. Twee door het CDA-kamerlid Hillen opgestelde wijzigingsvoorstellen betroffen een toe te voegen artikel 'De echtgenote van de Koning draagt de titel Koningin' en een verruiming van het lidmaatschap tot en met de derde graad van bloedverwantschap. Het amendement Scheltema-De Nie (D66) wilde het lidmaatschap al bij de inwerkingtreding van de wet tot de tweede graad van bloedverwantschap inperken en daarmee de uitzonderingsbepaling voor de kinderen van prinses Margriet schrappen. ${ }^{546}$

Tijdens de stemming op 23 april werden de drie amendementen verworpen en werd het wetsontwerp aangenomen. ${ }^{547}$ Het voorstel van wet werd vervolgens naar de Eerste Kamer gezonden, die daar op 28 april zonder debat en stemming mee instemde. ${ }^{548}$

\footnotetext{
${ }^{544}$ Kamerstukken II, 2001-2002, 28 223, nr. 5, p. 20-21.

545 Ibidem, p. 23.

${ }^{546}$ Ibidem, nrs. 7, 8 en 9 ; Handelingen II, 2001-2002, 4469-4489 en 4493-4506.

${ }^{547}$ Handelingen II, 2001-2002, 4603.

${ }^{548}$ Kamerstukken I, 2001-2002, 28 223, nr. 315; Handelingen I, 2001-2002, 1418.
} 


\section{Staatsblad van het Koninkrijk der Nederlanden}

Jaargang 2002

\section{5}

Wet van 30 mei 2002, houdende regeling van

het lidmaatschap koninklijk huis alsmede

daaraan verbonden titels (Wet lidmaatschap koninklijk huis)

Wij Beatrix, bij de gratie Gods, Koningin der Nederlanden, Prinses van Oranje-Nassau, enz. enz. enz.

Allen, die deze zullen zien of horen lezen, saluut! doen te weten:

Alzo Wij in overweging genomen hebben, dat het wenselijk is een nieuwe regeling inzake het lidmaatschap van het koninklijk huis krachtens artikel 39 Grondwet vast te stellen alsmede enkele voorzieningen inzake de daaraan verbonden titels en namen te treffen;

Zo is het, dat Wij, de Raad van State gehoord, en met gemeen overleg der Staten-Generaal, hebben goedgevonden en verstaan, gelijk Wij goedvinden en verstaan bij deze:

\section{Artikel 1}

Met de Koning als hoofd van het koninklijk huis zijn daarvan lid:

a. zij die krachtens de Grondwet de Koning kunnen opvolgen en deze niet verder bestaan dan in de tweede graad van bloedverwantschap;

b. de vermoedelijke opvolger van de Koning;

c. de Koning die afstand van het koningschap heeft gedaan.

\section{Artikel 2}

1. Lid van het koninklijk huis zijn eveneens de echtgenoten van hen die ingevolge artikel 1 het lidmaatschap van het koninklijk huis bezitten.

2. Voor hen die het lidmaatschap van het koninklijk huis bezaten als echtgenote of echtgenoot, blijft dit lidmaatschap gedurende hun staat van weduwe of weduwnaar behouden, zolang de overleden echtgenote of echtgenoot bij leven ingevolge artikel 1 lid van het koninklijk huis zou zijn geweest.

\section{Artikel 3}

1. Lid van het koninklijk huis blijven zij die op het tijdstip van inwerkingtreding van deze wet meerderjarig lid zijn van het koninklijk huis en krachtens de Grondwet de Koning kunnen opvolgen. Zij behouden hun lidmaatschap zolang zij krachtens de Grondwet de Koning kunnen opvolgen.

2. Lid blijven voorts de echtgenoten van hen die ingevolge het eerste lid het lidmaatschap van het koninklijk huis bezitten.

Bij KB van 30 mei 2002 (Stb. 276) trad de Wet lidmaatschap koninklijk huis in werking. In artikel 13 was een aanvulling op artikel 2, lid 2, van de Wet op de adeldom (1994) opgenomen betreffende verleningstermijn en titulatuur voor leden van het koninklijk huis. 
3. Op hen die als echtgenoten het lidmaatschap van het koninklijk huis bezaten, is artikel 2, tweede lid, van toepassing.

\section{Artikel 4}

Het lidmaatschap van het koninklijk huis kan bij een koninklijk besluit waarover de Raad van State is gehoord worden verleend aan:

a. personen die krachtens de Grondwet de Koning kunnen opvolgen;

b. hun echtgenoten.

\section{Artikel 5}

Het lidmaatschap van het koninklijk huis eindigt door ontslag verleend bij een koninklijk besluit waarover de Raad van State is gehoord.

\section{Artikel 6}

Het lidmaatschap van het koninklijk huis wordt niet verkregen bij gemis van het Nederlanderschap en eindigt bij verlies van het Nederlanderschap.

\section{Artikel 7}

De vermoedelijke opvolger van de Koning draagt de titel van Prins (Prinses) van Oranje.

\section{Artikel 8}

1. De vermoedelijke opvolger van de Koning en de Koning die afstand van het koningschap heeft gedaan dragen de titel «Prins (Prinses) der Nederlanden".

2. De titel "Prins (Prinses) der Nederlanden» kan bij koninklijk besluit uitsluitend worden verleend aan de volgende leden van het koninklijk huis:

a. de echtgenoot of echtgenote van de Koning;

b. kinderen geboren uit een huwelijk van de Koning;

c. de echtgenoot of echtgenote van de vermoedelijke opvolger van de Koning;

d. kinderen geboren uit een huwelijk van de vermoedelijke opvolger van de Koning

e. zij die krachtens artikel 4 lid zijn van het koninklijk huis.

3. De titel "Prins (Prinses) der Nederlanden» vervalt met het verlies van het lidmaatschap van het koninklijk huis.

\section{Artikel 9}

1. De Koning, diens vermoedelijke opvolger en de Koning die afstand van het koningschap heeft gedaan dragen de titel «Prins (Prinses) van Oranje-Nassau».

2. De titel "Prins (Prinses) van Oranje-Nassau» kan bij koninklijk besluit uitsluitend worden verleend aan leden van het koninklijk huis.

3. Binnen drie maanden na verlies van het lidmaatschap van het koninklijk huis wordt bij koninklijk besluit beslist over het behoud van de titel "Prins (Prinses) van Oranje-Nassau» als persoonlijke titel voor degenen die het lidmaatschap hebben verloren.

4. Bij het koninklijk besluit genoemd in het derde lid kan tevens de geslachtsnaam worden bepaald. Artikel 5, eerste tot en met elfde lid, en artikel 7 van Boek 1 van het Burgerlijk Wetboek zijn niet van toepassing. 


\section{Artikel 10}

Degenen die titels en namen dragen krachtens de koninklijke besluiten van 26 oktober 1937 (Stb. 1937, nr. 5) en 2 januari 1967 (Stb. 1967, nr. 1), behouden deze.

\section{Artikel 11}

De koninklijke besluiten bedoeld in deze wet, worden genomen op voordracht van Onze Minister-President, Minister van Algemene Zaken Onze Minister van Binnenlandse Zaken en Koninkrijksrelaties en Onze Minister van Justitie en in het Staatsblad geplaatst.

\section{Artikel 12}

De Wet lidmaatschap koninklijk huis ${ }^{1}$ wordt ingetrokken.

\section{Artikel 13}

Artikel 2, tweede lid, van de Wet op de adeldom ${ }^{2}$ komt te luiden: 2. Verheffing in de adel bij koninklijk besluit kan uitsluitend plaatsvinden ten aanzien van leden van het koninklijk huis en van voormalige leden daarvan binnen drie maanden na verlies van het lidmaatschap van het koninklijk huis.

De verlening van de titels "Prins (Prinses) der Nederlanden» en «Prins (Prinses) van Oranje-Nassau» wordt bij of krachtens de Wet lidmaatschap koninklijk huis bepaald.

\section{Artikel 14}

Deze wet wordt aangehaald als: Wet lidmaatschap koninklijk huis.

Zie voor de behandeling in de StatenGeneraal:

Kamerstukken II 2001/2002, 28223 Handelingen II 2001/2002, blz. 4469-4489; 4493-4506; 4603

Kamerstukken I 2001/2002, $28223(315,315 a)$ Handelingen I 2001/2002, zie vergadering d.d. 28 mei 2002 .

1 Stb. 1985,578

Stb. 1994,360

\section{Artikel 15}

Deze wet treedt in werking op een bij koninklijk besluit te bepalen tijdstip.

Lasten en bevelen dat deze in het Staatsblad zal worden geplaatst en dat alle ministeries, autoriteiten, colleges en ambtenaren wie zulks aangaat, aan de nauwkeurige uitvoering de hand zullen houden.

Gegeven te 's-Gravenhage, 30 mei 2002

De Minister-President, Minister van Algemene Zaken,

W. Kok

De Minister van Binnenlandse Zaken en Koninkrijksrelaties,

K. G. de Vries

De Minister van Justitie,

A. H. Korthals

Uitgegeven de elfde juni 2002

De Minister van Justitie

A. H. Korthals 
Krachtens art. 13 van de aangenomen wet werd bij deze gelegenheid ook de Wet op de adeldom aangepast. ${ }^{549}$ Artikel 2, lid 2, betreffende de exclusieve verheffingsmogelijkheid van leden van het koninklijk huis, werd aangevuld met de zinsnede: 'en van voormalige leden daarvan binnen drie maanden na verlies van het lidmaatschap van het koninklijk huis. De verlening van de titels 'Prins (Prinses) der Nederlanden' en 'Prins (Prinses) van Oranje-Nassau' wordt bij of krachtens de Wet lidmaatschap koninklijk huis bepaald.'

\section{Vrouwen als 'decoratieve aanhangsels van hun echtgenoot'}

Tijdens de behandeling van de Wet lidmaatschap koninklijk huis kwam in een Kamervraag zijdelings de sinds 1998 gewijzigde naamwetgeving ter sprake. Gelijktijdig met de discussie over de wijziging van artikel BW 1:5 was door het parlement in meerderheid de noodzaak onderschreven om volledige keuzevrijheid te legaliseren voor echtgenoten tot het voeren in het maatschappelijk verkeer van één van beider geslachtsnamen afzonderlijk of tezamen in willekeurige volgorde. De sekseneutrale bepaling in art. BW 1:9, die per 1 januari 1998 van kracht werd, was hiervan het resultaat en gold ook voor geregistreerde partners. ${ }^{550}$ Sedertdien kon al bij de ondertrouw aan de ambtenaar van de burgerlijke stand worden opgegeven welke keuze de huwelijkspartners ieder voor zich hadden gemaakt. De consequentie hiervan voor 'adellijke geslachtsnamen' was onbekend, maar daar werd wel over gespeculeerd. De kwestie kreeg een zekere actualiteit bij de behandeling in de verenigde vergadering van het parlement van de toestemmingswet voor het aanstaande huwelijk van de eerste kleinzoon van koningin Juliana, Maurits prins van Oranje-Nassau, Van Vollenhoven met Marie-Hélène van den Broek. ${ }^{551}$

De Groot reageerde hierop door aan te geven dat het universele recht van gelijke behandeling van mannen en vrouwen tot geen andere conclusie kon leiden dan dat artikel BW 1:9 onbeperkt van toepassing was op partners die tot de Nederlandse adel behoorden en een geslachtsnaam met adellijke titulatuur droegen. Volgens het overgangsrecht zou mr. Pieter van Vollenhoven zijn aanschrijfnaam alsnog kunnen wijzigen in Pieter prins der Nederlanden en hij riep hem bij deze gelegenheid daartoe op zodat het koninklijk huis de emancipatie van de vrouw een grote dienst zou bewijzen. ${ }^{552}$ Hij uitte voorts kritiek op de memorie van toelichting bij de Rijkswet, die de keuzevrijheid van Marie-Hélène van den Broek zou beperken door de formulering 'zal voeren' en 'zal worden genoemd' in plaats van 'mag zich prinses van Oranje-Nassau noemen'. Hij vreesde dat het koninklijk huis hierin louter het negentiende-eeuwse gewoonterecht binnen de Nederlandse adel kopieerde, waardoor vrouwen in het maatschappelijk verkeer tot decoratieve aanhangsels van hun

\footnotetext{
${ }^{549}$ Wet van 30 mei 2002 (Stb. 275), houdende regeling van het lidmaatschap koninklijk huis alsmede daaraan verbonden titels (Wet lidmaatschap koninklijk huis).

${ }^{550}$ Het geregistreerd partnerschap werd in 1998 ingevoerd als juridische verbintenisconstructie voor paren van gelijk geslacht, die vanaf 1 april 2001 ook voor een huwelijk kunnen kiezen (Wet openstelling huwelijk van 21 dec. 2000, Stb. 2001, 9).

${ }^{551}$ Rijkswet van 31 maart 1998 (Stb. 212).

${ }^{552}$ De Groot, 'Pieter Prins der Nederlanden', 143-147.
} 
echtgenoot werden gebombardeerd. Volgens dit gewoonterecht mocht de echtgenote van de getitelde edelman diens geslachtsnaam met vervoegde titel voeren, maar omgekeerd de man niet als de vrouw van (hogere) adel was. De Groot citeerde echter even daarvóór uit dezelfde memorie van toelichting dat 'de regering met betrokkenen overleg heeft gevoerd', waaruit dan toch de keuze van de bruid voor de vervoegde titel van haar man gedestilleerd kon zijn?

Hij maakte van deze gelegenheid gebruik om nog eens de halfslachtigheid binnen het naamrecht inzake gelijke behandeling van man en vrouw bij de naamskeuze aan de kaak te stellen. Wanneer ouders geen keuze voor de naam van hun kind(eren) maken, dan prevaleert immers volgens art. BW 1:5a en 6 de naam van de vader. Zijn mening over art. BW 1:5, lid 11, is hierboven bij de herziening van het naamrecht en de totstandkoming van de Wet op de adeldom uitgebreid aan de orde gesteld.

Hoe het ook zij, van enige beweging aan het koninklijke front was twee jaar later, tot grote teleurstelling van De Groot, nog geen sprake. ${ }^{553}$ Toen werd namelijk de toestemmingswet voor het huwelijk van prins Bernhard in de verenigde vergadering van beide Kamers der Staten-Generaal behandeld. In de memorie van toelichting bij deze Rijkswet, waarin de regering opnieuw meldde overleg met het bruidspaar over de naam van de bruid en van hun eventuele kinderen te hebben gehad, werd een eerdere verklaring herhaald: 'het maatschappelijk gebruik brengt met zich mee dat de toekomstige echtgenote van de prins de titel van haar man zal voeren en derhalve prinses van Oranje-Nassau zal worden genoemd. ${ }^{554}$ Uit deze strenge formulering viel op te maken dat de vermeende keuzevrijheid inzake naamvoering voor potentiële troonopvolgers kennelijk minder vrij was dan voor gewone burgers. Voor een nadere verklaring daarvan zou echter nog gewacht moeten worden op de behandeling van de 'regeling van het lidmaatschap koninklijke huis alsmede daaraan verbonden titels', die aanstaande was. Maar eerst zouden ook nog de toestemmingswetten van de twee zonen van de koningin volgen, waarvan de memories van toelichting overeenkomstige zienswijzen zouden te zien geven.

\section{Toestemmingswet voor het huwelijk van prins Constantijn ${ }^{555}$}

De koninklijke boodschap waarbij het voorstel van Rijkswet inzake de verlening van toestemming aan prins Constantijn om een huwelijk aan te gaan met Petra Laurentien Brinkhorst, aan de verenigde vergadering der Staten-Generaal werd

\footnotetext{
${ }^{553}$ De Groot Schneider, 'De heer Bernhard Sekrève?', 1067-1068.

${ }^{554}$ Rijkswet van 31 mei 2000 (Stb. 245). De naamgeving van de kinderen kon overigens al uit het KB van 2 januari 1967 (Stb. 2) worden afgeleid, waardoor alleen bij een wijziging - zoals bij de kinderen van prins Maurits - een nieuw KB van naamgeving noodzakelijk zou zijn geweest. Toch kwam dit er in de vorm van het KB van 5 juli 2000, nr. 00.004137 (Stb. 288): Van Vollenhoven.

${ }^{555}$ M.R. Doortmont, 'De toestemmingswet voor het huwelijk van prins Constantijn en Petra Laurentien Brinkhorst', 439-452; P.H.M. Keesom, 'De titulatuur en geslachtsnamen van de kinderen van H.H.K.K.H.H. prins Constantijn en prinses Laurentien', 452-457, 661-662, 723-724. Het meervoud van de koninklijke predikaten is in het geciteerde artikel onjuist afgekort. Bedoeld zal zijn: HH.KK.HH.
} 
aangeboden, was gedateerd 'Lech, 15 februari 2001'. De memorie van toelichting gaf aan dat met de betrokkenen overeenstemming was bereikt over de geslachtsnaam van de kinderen die uit het huwelijk geboren mochten worden en dat deze zou luiden: 'Van Oranje-Nassau van Amsberg'. Tevens zou bepaald worden dat deze kinderen de erfelijke titel graaf (gravin) zouden krijgen, alsmede het predikaat jonkheer (jonkvrouw), zodat zij zouden zijn: 'Graaf (Gravin) van OranjeNassau, Jonkheer (Jonkvrouw) van Amsberg'. Op de overgang van naam, titel en predikaat op de nakomelingen zouden de regels van het naamrecht en het adelsrecht van toepassing zijn. De echtgenote van de prins zou door haar huwelijk geen adeldom verwerven. Het gebruik inzake de aanduiding van echtgenotes van leden van het koninklijk huis en van leden van de adel bracht met zich mee, dat zij de titels van haar echtgenoot zou voeren en dat zij derhalve zou worden genoemd: 'Prinses der Nederlanden, Prinses van Oranje-Nassau, mevrouw van Amsberg'. 556 Uit deze formulering betreffende de titulatuur viel op te maken, dat het adellijke gewoonterecht wel degelijk als voorbeeld had gediend en dat niet bij voorbaat een exclusieve rol aan leden van het koninklijk huis was toebedacht. Ten aanzien van de merkwaardige toevoeging, opnieuw achter een komma, als alternatief voor 'jonkvrouw van Amsberg' - volgens het adellijke gewoonterecht gebruikt de echtgenote nooit (de vrouwelijke vervoeging van) het adellijke predikaat van haar man - van 'mevrouw van Amsberg', kan de vraag gesteld worden of deze (hier) überhaupt had moeten worden vermeld.

De inhoud van het advies van de Raad van State is niet bekend, omdat het op enkele redactionele opmerkingen na zonder meer instemmend was en daardoor niet gepubliceerd behoefde te worden. Het advies van de Hoge Raad van Adel, dat op 2 februari was ingeroepen, werd als bijlage bij de memorie van toelichting gepubliceerd en bevatte een drietal aanbevelingen. Allereerst wees de Raad op de situatie dat weliswaar over kinderen werd gesproken, maar de bepaling ook voor hun nageslacht zou gelden, aangezien met deze wet erfelijke adeldom werd verleend. Voorts pleitte hij voor verwijdering van de komma's, die noch bij de naam noch bij de titel zouden behoren. Ten slotte bracht de Raad de principiële regel uit het adelsrecht onder ogen, dat een predikaat niet naast een titel noodzakelijk is om (hoge) adeldom aan te duiden. In het verleden, toen titels en namen steeds voor een persoon of generatie leden van het koninklijk huis werden vastgesteld, was er geen behoefte aan onderscheiding naar herkomst van de namen en naar titels. $\mathrm{Nu}$ beoogd werd een geslachtsnaam vast te stellen voor meer generaties en bovendien de herkomst der delen van de geslachtsnaam Van Oranje-Nassau van Amsberg duidelijk was, was het niet noodzakelijk de geslachtsnaam zowel met een titel als met een predikaat te voeren. Bovendien werd een predikaat gevoerd door adellijke personen die geen recht hadden op een adellijke titel.

De Hoge Raad van Adel adviseerde om te bepalen, dat 'zij zullen zijn graaf (gravin) van Oranje-Nassau van Amsberg, ${ }^{557}$

\footnotetext{
${ }^{556}$ Kamerstukken I/II, 2000-2001, 8 (R 1676), nrs. 1-3.

${ }^{557}$ Ibidem, nr. 4.
} 
Deze adviezen werden echter niet overgenomen, omdat er andere overwegingen waren voor een dergelijke combinatie van titels. Eertijds was bij het vaststellen van de geslachtnaam van prins Claus tevens bepaald dat hij 'Jonkheer van Amsberg' was. De beoogde combinatie van titel en predikaat voor zijn kinderen sloot hierbij aan en maakte duidelijk zichtbaar welk belang werd gehecht aan de zelfstandige en historische betekenis van de onderscheiden onderdelen van het geheel. $^{558}$

Tijdens het voorbereidend onderzoek van de commissie uit de verenigde vergadering werd de vraag gesteld waarom niet was gekozen voor de eensluidende titel 'graaf (gravin) van Nassau' voor alle betrokkenen? De regering vond deze titel echter te ver afstaan van die van de vader van de kinderen uit het huis OranjeNassau, waardoor de verbondenheid minder werd. ${ }^{559}$

De toestemmingswet werd op 11 april vastgesteld en het koninklijk besluit tot vaststelling van titel, predikaat en geslachtsnaam van de eventuele kinderen een maand later, op 11 mei. $^{560}$

\section{Toestemmingswet voor het huwelijk van de prins van Oranje $e^{561}$}

Op 21 mei 2001 werd bij koninklijke boodschap de toestemmingswet voor het huwelijk van prins Willem-Alexander en Máxima Zorreguieta aan de verenigde vergadering der Staten-Generaal voorgelegd. Er waren twee bijlagen toegevoegd aan de memorie van toelichting, die daarin ook besproken werden. ${ }^{562}$ De eerste bijlage was het koninklijke besluit van 17 mei 2001, waarbij aan Máxima Zorreguieta het Nederlandschap werd verleend. Zij behield de Argentijnse nationaliteit zonder aldaar staatkundige rechten te kunnen uitoefenen. Eventuele kinderen zouden van rechtswege de Nederlandse nationaliteit krijgen met naar Argentijns recht de mogelijkheid om te opteren voor de Argentijnse nationaliteit. De tweede bijlage betrof het advies van de Hoge Raad van Adel, dat op 8 mei door de minister-president was gevraagd en op 10 mei uitgebracht. De beoogde titulatuur voor de kinderen, die uit het huwelijk geboren mochten worden, kon de Raad onderschrijven. Dit waren de titels prins(es) der Nederlanden, prins(es) van Oranje-Nassau, en de predikaten Zijne (Hare) Koninklijke Hoogheid. De Raad maakte zich alleen bezorgd over verval of wijziging van titels voor de echtgenote van de prins van Oranje, indien zij om welke reden dan ook geen lid meer zou zijn van het koninklijk huis en de aangekondigde Wet lidmaatschap koninklijk huis nog niet van kracht zou zijn. Afstand van adeldom kon immers alleen geschieden in de vorm van een royement op eigen verzoek bij koninklijk besluit, maar daar waren nauwelijks voorbeelden van bekend. In de memorie van toelichting werd opnieuw de Wet lidmaatschap koninklijk huis aangekondigd, waarin dit geregeld zou kunnen worden. Ter gerust-

\footnotetext{
${ }^{558}$ Ibidem, nr. 3, p. 2. Vgl. Prins, 'Langs ongebaande wegen', 45-49.

${ }_{559}$ Ibidem, nr. 8; Kamerstukken I/II, 2000-2001, 9 (R 1684), nr. 9, p. 15 en 16.

${ }^{560}$ Rijkswet van 11 april 2001 (Stb. 202) en KB van 11 mei 2001, nr. 01.002382.

${ }^{561}$ Doortmont. 'De toestemmingswet voor het huwelijk van prins Willem-Alexander en Máxima Zorreguieta', 83-117.

${ }^{562}$ Kamerstukken I/II, 2000-2001, 9 (R 1684), nrs. 1-4.
} 
stelling wees de regering er voorts op dat bestaande wetten natuurlijk altijd gewijzigd konden worden.

De Hoge Raad van Adel waarschuwde in zijn advies voorts voor de officieuze titel 'prinses van Oranje', die zonder wettelijke bescherming, evenals de aanspreekvorm 'mevrouw van Amsberg', in het maatschappelijk verkeer als aanspreektitel voor de echtgenote van de prins van Oranje zou kunnen worden gebezigd. De regering wees ook hier op het voornemen tot vastlegging in een gewijzigde Wet lidmaatschap koninklijk huis, waartoe immers in 1983 de mogelijkheid was geschapen met het schrappen van de mannelijke vorm in art. 27 van de Grondwet van 1972. Een eventueel gebruik in het maatschappelijk verkeer van deze titel zou, volgens de regering, vermoedelijk vanzelf verdwijnen als het maatschappelijk gebruik zich zou gaan richten naar de wettelijke regeling. Ter gelegenheid van het huwelijk kreeg Máxima dezelfde twee titels verleend als haar eventuele kinderen met toevoeging van het eerder dat jaar voor prinses Laurentien bedachte 'mevrouw van Amsberg'. Voor de duidelijkheid werd nog eens bevestigd, dat zij zal zijn: 'Hare Koninklijke Hoogheid Prinses Máxima der Nederlanden, Prinses van Oranje-Nassau, mevrouw van Amsberg'. De plaats van haar voornaam na de titel, die in conflict lijkt met het adelsrecht, stoelde op een oude traditie binnen het koninklijk huis die verband houdt met aankondiging en ondertekening: 'De Prins van Oranje en Prinses Máxima der Nederlanden'. In feite staat de voornaam tussen delen van de titel in, omdat 'der Nederlanden' geen geslachtsnaam is. Over deze bijzondere aanspreekvorm werd noch in de memorie van toelichting noch in de bijgesloten 'notitie titels en namen leden koninklijk huis' een verklaring gegeven. ${ }^{563}$

Interessant was om te vernemen dat de eventuele kinderen in deze directe lijn van de grondwettelijke erfopvolging niet het predikaat en de naam 'Jonkheer van Amsberg' zullen dragen. ${ }^{564}$ Dit zou indruisen tegen de lijn die bij opeenvolgende generaties is gevolgd ten aanzien van handhaving van de geslachtsnaam Van Oranje-Nassau in de directe lijn van erfopvolging. Op het moment dat de prins van Oranje koning zal zijn, zal het predikaat 'Jonkheer van Amsberg' tot het 'enz. enz. enz.' gaan behoren en op die wijze overgaan op de volgende generaties. ${ }^{565}$

De commissie uit de verenigde vergadering, ingesteld op 22 mei 2001, die belast werd met het voorbereidend onderzoek van het wetsvoorstel, bracht op 12 juni voorlopig verslag uit van haar bevindingen. ${ }^{566}$ De regering reageerde hierop in een memorie van antwoord, die door de parlementsvoorzitter op 21 juni werd ontvangen. Met betrekking tot de titels en namen werd uitgebreid ingegaan op de al of niet aanwezige wenselijkheid om in het maatschappelijk verkeer de als strikt persoonlijk bedoelde titel prinses van Oranje (voor de vermoedelijke troonopvolgster)

\footnotetext{
${ }^{563}$ Ibidem, nr. 9, p. 14-18.

${ }^{564}$ Wolleswinkel, 'Wapen voor de kinderen uit het huwelijk van de Prins van Oranje en prinses Máxima', 330-332; Von Bönninghausen, 'Wapen voor prinses Amalia', 129-133.

${ }_{565}$ Kamerstukken I/II, 2000-2001, 9 (R 1684), nr. 3, p. 3.

566 Ibidem, nr. 5.
} 
ook voor de echtgenote van de prins van Oranje te bezigen. Hier lag de situatie in ieder geval anders dan voor de met andere prinsen getrouwde echtgenotes, die na overleg voor deze niet unieke aanspreektitels hadden gekozen. De regering besefte dat het maatschappelijk gebruik van prinselijke titels zich niet uitsluitend laat sturen door de wetgever. Zij ging er echter van uit dat de herziene Wet lidmaatschap koninklijk huis binnen korte tijd de vereiste duidelijkheid zou geven. De toevoeging te zijner tijd van het predikaat 'Jonkheer van Amsberg' aan de titels die behoren bij de voormalige bezittingen van de prinsen van Oranje tijdens de Republiek der Verenigde Nederlanden, stuitte op enig onbegrip omdat in het 'enz. enz. enz.' toch ook niet de titels hertogin van Mecklenburg en prinses van Lippe-Biesterfeld waren terechtgekomen. De regering stelde echter vast dat dit destijds niet aan de orde was en geenszins was uitgesloten. Een eigen titel voor Máxima Zorreguieta, zoals de ChristenUnie had voorgesteld - deze fractie dacht eerder aan adoptie dan aan toetreding krachtens het huwelijk - was volgens de regering in strijd met de Nederlandse traditie dat geen eigen titels worden verleend die andere leden van het koninklijk huis niet dragen. Bovendien sloot de gekozen oplossing aan bij het maatschappelijk gebruik in de adel dat echtgenotes de titulatuur van de adellijke man voeren. Een uitzondering hierop vormde de echtgenote van een jonkheer, die dan niet het predikaat jonkvrouw voert, maar als 'mevrouw' wordt aangeduid. Dit was dan tevens de achtergrond van de toevoeging 'mevrouw van Amsberg' achter de verleende titels, namelijk om meteen duidelijkheid te scheppen. ${ }^{567}$

\section{Titulatuur en geslachtsnaam voor prins Friso}

Eerder dan verwacht kon de herziene Wet lidmaatschap koninklijk huis, die bij koninklijk besluit inwerking was getreden, worden getoetst aan een concreet voorbeeld. ${ }^{568}$ Omdat door de regering geen toestemmingswetsvoorstel werd ingediend ten behoeve van het voorgenomen huwelijk van prins Friso, tweede zoon van de koningin, zou hij met ingang van het tijdstip van voltrekking van het huwelijk op grond van art. 28, lid 2, van de grondwet van rechtswege buiten de kring van troonopvolgers vallen. Krachtens de Wet lidmaatschap koninklijk huis zou hij voorts geen lid meer van het koninklijk huis zijn en de daaraan verbonden titel prins der Nederlanden verliezen. Ook zijn eventuele kinderen zouden vervolgens zijn uitgesloten van de erfopvolging. Naast deze puur functionele titel voerde hij vanaf zijn geboorte tevens de functionele titel die naar zijn historische aard en betekenis tevens een familietitel is, te weten prins van Oranje-Nassau. Op grond van dit bijzondere familiekarakter bepaalt art. 9, lid 3, van de Wet lidmaatschap koninklijk huis dat die titel om deze reden uitsluitend voor de betrokkene zelf als persoonlijke titel behouden kan blijven.

Binnen de termijn van drie maanden, die in deze wet wordt gesteld, werd deze wettelijke mogelijkheid door middel van het KB van 19 maart 2004 gerealiseerd,

\footnotetext{
${ }^{567}$ Ibidem, nr. 9, p. 8-11.

${ }^{568} \mathrm{~KB}$ van 30 mei 2002 (Stb. 276), houdende vaststelling van de het tijdstip van inwerkingtreding van de Wet lidmaatschap koninklijk huis.
} 
als mede de in lid 4 aangegeven bepaling van zijn geslachtsnaam: 'Van OranjeNassau van Amsberg'. ${ }^{56}$ Deze familienaam werd tezamen met de erfelijke adellijke titel graaf vastgesteld in navolging van die van de kinderen van zijn broer prins Constantijn, van wie verwacht kan worden dat deze te eniger tijd (als de prins van Oranje koning is) ook buiten het koninklijk huis zullen vallen. Met deze keuze werd recht gedaan aan het feit dat allen kleinkinderen zijn van koningin Beatrix en prins Claus.

In zijn op 2 maart aan de minister-president uitgebrachte advies had de Hoge Raad van Adel nog eens gewezen op de aanbevelingen ten aanzien van de titel en naamcombinatie 'graaf van Oranje-Nassau, jonkheer van Amsberg', die hij gedaan had ten behoeve van de toestemmingswet voor het huwelijk van prins Constantijn in 2001. Aangezien prins Friso en zijn eventuele kinderen geen lid meer zouden zijn van het koninklijk huis, maar tot de Nederlandse adel zouden behoren, kon de combinatie titel en predikaat in één samengestelde geslachtsnaam in conflict komen met het vigerende adelsrecht. ${ }^{570}$ De standaardregel uit het KB van 13 februari 1815, nr. 60, bepaalde immers dat iedereen die tot de Nederlandse adel behoorde het predikaat jonkheer/jonkvrouw voerde, tenzij hem of haar een titel was verleend. De regering reageerde hierop in de nota van toelichting op het koninklijk besluit door te vermelden, dat prins Friso en zijn eventuele kinderen in het maatschappelijk verkeer zullen worden aangeduid met de hoogste titel en het bijbehorende persoonlijke predikaat. ${ }^{571}$ Dit zou voor prins Friso Zijne Koninklijke Hoogheid Prins Johan Friso van Oranje-Nassau zijn en voor de kinderen, die uit zijn voorgenomen huwelijk geboren mochten worden: 'Hooggeboren Heer/Vrouwe Graaf/Gravin van Oranje-Nassau van Amsberg'. Zijn echtgenote, de moeder van zijn kinderen, zou door haar huwelijk geen adeldom verkrijgen, maar volgens het gebruik inzake de aanduiding van echtgenotes van leden van de adel met zijn verbogen hoogste titel aangeduid worden. ${ }^{572}$

Een consequentie van het terugtreden van prins Friso uit het koninklijk huis en de creatie van het grafelijke geslacht Van Oranje-Nassau van Amsberg was de vaststelling van het daaraan verbonden adellijke wapen. ${ }^{573}$ Het nieuwe wapen laat een subtiele wijziging zien ten opzichte van het wapen dat verleend werd aan de kinderen die uit het huwelijk van prinses Beatrix mochten geboren worden en dat prins Friso gedurende 35 jaar van zijn leven voerde. Door het wegvallen van de titel prins der Nederlanden raakte de Nederlandse leeuw in het wapen zijn zwaard en

\footnotetext{
${ }^{569} \mathrm{~KB}$ van 19 maart 2004 (Stb. 126), houdende bepalingen inzake titels, predikaat en geslachtsnaam van Z.K.H. Prins Johan Friso Bernhard Christiaan David der Nederlanden, Prins van Oranje-Nassau, Jonkheer van Amsberg, met ingang van zijn huwelijk.

${ }^{570}$ HRvA, RA, not. 2004-6.

${ }^{571} \mathrm{~KB}$ van 19 maart 2004 (Stb. 126), nota van toelichting, p. 4.

572 Ibidem, p. 4.

${ }^{573}$ Adelsdiploma, vastgesteld bij KB van 1 april 2005. Vgl. Wolswinkel, 'Nieuw wapen voor prins Friso', 11.
} 
pijlenbundel (symbool voor de macht) kwijt en werd daarmee weer de Nassause leeuw. ${ }^{574}$

\section{Inlijvingen volgens artikel 8 van de Wet op de adeldom}

Volgens artikel 2, lid 3, van de Wet op de adeldom is inlijving nog slechts tezamen met naturalisatie mogelijk, waarbij bovendien aan de (dubbele) voorwaarde moet worden voldaan dat verzoeker dient te behoren tot de wettelijk erkende adel van een staat met een vergelijkbaar adelsstatuut. Hoewel de wet geen overgangsregeling kende, bestond volgens artikel 8 nog gedurende vijf jaar de mogelijkheid om zonder gelijktijdige naturalisatie inlijving te verzoeken. In de praktijk kon een Nederlander wiens directe voorvader in mannelijke lijn ooit buitenlandse adeldom had verkregen, maar dan wel uit een land met een thans nog vergelijkbaar adelsstatuut, tot 1 augustus 1999 nog een verzoek bij de koningin indienen. ${ }^{575}$

Tijdens de parlementaire behandeling van de Wet op de adeldom zond de minister van Binnenlandse Zaken Dales, nadat het eindverslag van de vaste Kamercommissie was uitgebracht, haar conceptnota toe aan de directeur van het Kabinet der Koningin. Deze bracht de minister enkele vraagpunten onder ogen, die vooral betrekking hadden op de beperkte mogelijkheden die nog zouden bestaan met betrekking tot verzoeken om inlijving. Uit de schriftelijke reactie van de minister van $23 \mathrm{fe}-$ bruari 1993 aan de directeur bleken deze punten, na overleg met de Hoge Raad van Adel, aanleiding te hebben gegeven tot een wijziging van het wetsontwerp, namelijk tot aanpassing van artikel 2, lid 3, en toevoeging van een artikel 7a (overgangsregeling gedurende vijf jaar). ${ }^{576}$ De ministeriële brief bevatte een concrete alinea waaruit iets over de achtergronden van de bijzondere interesse naar de toekomstige mogelijkheden van inlijving zou kunnen worden opgemaakt: 'Het voorgaande houdt in dat de kinderen van prinses Irene, indien zij daartoe binnen de overgangstermijn een verzoek doen, ingelijfd kunnen worden in de Nederlandse adel.' Maar ook daaropvolgende uitspraken van de minister geven al bij voorbaat de interpretatieruimte van de wijzigingsartikelen aan: 'De inlijving van Belgen met een persoonlijke titel is uitgesloten, omdat het Nederlandse adelsstatuut in elk geval sinds 1953 geen verheffing in de adel wegens persoonlijke verdiensten meer kent (met uitzondering van leden van het koninklijk huis). Inlijving van personen die afkomstig zijn uit staten die in de toekomst de adel (opnieuw) wettelijk zullen erkennen, zal mogelijk zijn indien het adelsstatuut van deze staten vergelijkbaar is met het Nederlandse adelsstatuut.' De minister stelde ten slotte voor een nota van wijziging van deze strekking aan de Tweede Kamer te sturen, hetgeen nog voor de zomer van 1993 plaatsvond. ${ }^{577}$ In de officiële stukken werd ook in deze overgangs-

\footnotetext{
${ }^{574}$ KB van 24 mei 1966 (Stb. 438). Vgl. Wolleswinkel, 'Wapenverlening voor het grafelijke geslacht Van Oranje-Nassau van Amsberg', 183-185; Von Bönninghausen, 'Adelsdiploma voor prins Johan Friso', 4348.

${ }^{575}$ Kamerstukken II, vergaderjaar 1991-1992, 21 485, nr. 5, bijlage (hoofdlijnen adelsbeleid in andere Europese landen).

${ }^{576}$ HRvA, RA, not. 1986-37 (brief minister BiZa aan directeur KdK, d.d. 24 febr. 1993).

${ }^{577}$ Kamerstukken II, 1992-1993, 21 485, nr. 9 (tweede nota van wijziging Wet op de adeldom).
} 
bepaling steeds uitgegaan van het vereiste van wettelijk erkende adeldom van een staat met een ten tijde van het verzoekschrift vergelijkbaar adelsstatuut. Dat de Hoge Raad van Adel dit laatste vereiste niet had voorgesteld of bedoeld, is slechts gebaseerd op mondelinge overlevering. ${ }^{578}$

Een nota van de secretaris van de Hoge Raad van Adel over de titels die gevoerd worden door de nakomelingen van koningin Juliana, die volgens een aantekening was bestemd voor de directeur van het Kabinet der Koningin, dateerde van 11 maart 1993 en is dus opgesteld naar aanleiding van de brief van de minister. ${ }^{579} \mathrm{Ge}-$ zien het bovenstaande is niet verwonderlijk dat het meest uitgewerkte onderdeel van deze nota de nakomelingen De Bourbon de Parme betrof. De spelling en schrijfwijze van hun geslachtsnaam was rechtstreeks afgeleid uit hun geboorteakten - tussen 1970 en 1974 opgemaakt in de gemeente Nijmegen - die immers volgens art. BW 1:6 bepalend zijn. De naam van de vader werd daarin voorafgegaan door de titulatuur Zijne Koninklijke Hoogheid Prins Charles Hugues, waarmee hij zich als aangever kennelijk afdoende had kunnen identificeren. Uitgangspunt zou daarbij geweest zijn dat hij behoorde tot een geslacht dat na 1813 in Europa heeft geregeerd, zoals vermeld in de eerste afdeling van de Almanach de Gotha, die algemeen geldend is. De nota vervolgde: 'Zolang deze geslachten de facto regeerden, werden de hoofden (zij die zelf regeerden) en de leden van hun huis ook in het buitenland geaccepteerd met de hun aangeërfde of door het hoofd van hun huis verleende titels. Vanaf het moment dat zij niet meer regeerden, zijn zij echter aangewezen op de regels van het adelsrecht en het burgerlijk recht van het land waarvan zij onderdaan zijn. De mogelijkheid ontstaat dan dat de titulatuur volgens de regels uit de periode, toen deze nog wel regeerden - die in het maatschappelijk verkeer in het algemeen nog wel gevolgd worden - en de regels volgens het burgerlijk recht elkaar niet meer dekken.'

Aan de hand van twee voorbeelden werd in de nota deze situatie uitgelegd. Zo voerde het hoofd van het huis Reuss de titel Fürst en de overige leden de titel Prinz of Prinzessin. In de Duitse burgerlijke stand van na 1919 werd ook het hoofd van de familie als Prinz vermeld aangezien volgens het Duitse naamrecht geen titels bij eerstgeboorterecht meer (kunnen) bestaan. Het andere voorbeeld betrof leden van de huis Habsburg, die volgens de Oostenrijkse burgerlijke stand zowel de titulatuur als het voorvoegsel 'von' hadden verloren, maar in het maatschappelijk verkeer Prinz of Prinzessin von Habsburg-Lothringen waren. Mits geboren uit een ebenbürtig huwelijk zou in de adellijke hiërarchie destijds een maximale stijging tot Zijne Keizerlijke Hoogheid Erzherzog von Oesterreich in het verschiet hebben gelegen.

'De vraag of leden van (voormalig) regerende huizen zich moeten laten inlijven in de adel van het land waarvan zij de nationaliteit bezitten, hangt af van wat men zwaarder laat wegen: 1 . het behoren tot een (voormalig) regerend huis, waarbij inlijving door een andere vorst niet past met het risico dat ambtenaren van de burger-

\footnotetext{
${ }^{578}$ Versélewel de Witt Hamer, 'Drie maal is niet altijd scheepsrecht', 491; Lutter, 'De nieuwe wet op de adeldom, rechtsongelijkheid in het inlijvingsbeleid?', 315-318.

${ }^{579}$ HRvA, RA, not. 1986-30.
} 
lijke stand op grond van hun nationale regels weigeren titels op te nemen; dan wel 2. het zich wel laten inlijven om daardoor de zekerheid te hebben, dat ambtenaren van de burgerlijke stand in het betreffende land de plicht hebben de toekomstige titels te vermelden.' Ook hiervan was een voorbeeld voorhanden: In 1978 en 1983 waren twee zonen van een aartshertog van Oostenrijk uit diens huwelijk met een prinses De Ligne gelijktijdig met hun naturalisatie ingelijfd in de Belgische adel als prinsen de Habsbourg-Lorraine met het predikaat doorluchtige hoogheid.

\section{De Bourbon de Parme}

Nadat de Wet op de adeldom op 1 augustus 1994 in werking was getreden, zijn meerdere verzoeken om inlijving ingediend. Slechts vier verzoeken op grond van deze overgangsbepaling (artikel 7a was bij de hernummering 8 geworden) werden gehonoreerd omdat aan de gestelde voorwaarden voldaan kon worden. Eén verzoek werd gedaan op basis van Spaanse adeldom, te weten De Bourbon de Parme in 1996. ${ }^{580}$ Twee verzoeken zijn gedaan op grond van Scandinavische adeldom: De Lange (van Bergen) in 1996-1998 (Deense adel) en Ollongren in 2002 (Fins/Zweedse adel) ${ }^{581}$ Ten slotte werd één verzoek gedaan op grond van Belgische adeldom: Von Devivere in 1999 (voormalige Oostenrijkse Nederlanden). ${ }^{582}$ De jaren geven de effectuering aan; alle verzoeken waren vóór 1 augustus 1999, de einddatum van de overgangsbepaling, ingediend.

Van deze nobilitaties kregen vooral die van de prins(ess)en De Bourbon de Parme veel publiciteit, omdat er ten onrechte vanuit werd gegaan dat de adeldom te danken zou zijn aan de adeldom van de moeder van de vier genobiliteerden, prinses Irene als zuster van de koningin. De aanvragen, de taxabetalingen, de verklaringen van adeldom ten behoeve van de burgerlijke stand en de afgifte van het diploma liepen weliswaar via de directeur van het Kabinet der Koningin, maar de gehonoreerde adeldom was louter gebaseerd op de afstamming langs mannelijke lijn via hun vader Charles Hugues prins de Bourbon de Parme uit een tak van het regerende koningshuis van Spanje. ${ }^{583}$ Deze ambtelijke weg was ook om praktische redenen gekozen, omdat de verzoekers op verschillende adressen woonden, voor een deel in het buitenland.

De Leidse emeritus hoogleraar staats- en bestuursrecht Van der Burg uitte zijn twijfels over de mate van vergelijkbaarheid van het Spaanse met het Nederlandse adelsstatuut. Hij ging daarbij terug naar het Verdrag van Aranjuez, dat in 1801 werd gesloten tussen Napoleon en de koning van Spanje. Bij dit verdrag deed de regerende hertog van Parma uit het huis De Bourbon afstand van zijn hertogdom ten behoeve van Frankrijk, maar de zoon van de hertog werd als tegemoetkoming koning van Etrurië (Toscane). Aan deze overdracht werd de voorwaarde verbonden dat bij ontstentenis van een troonopvolger een prins (Infante) uit de Spaanse

\footnotetext{
${ }^{580} \mathrm{~KB}$ van 15 mei 1996, nr. 96.000163.

${ }^{581}$ KB's van 21 mei 1996, nr. 96.002723; 27 maart 1997, nr. 96.006137; 16 juni 1997, nrs. 96.003965 en 06.004595; 21 okt. 1998, nr. 98.000059 (De Lange). KB van 8 nov. 2002, nr. 99.003623 (Ollongren).

${ }^{582} \mathrm{~KB}$ van 17 juli 1999 , nr. 99.001530.

${ }^{583}$ HRvA, RA, not. 1986-37 (advies aan de minister van BiZa d.d. 12 maart 1996).
} 
koninklijke familie hem als koning zou opvolgen. Hiermee achtte Van der Burg de connectie bewezen, maar hij zette een vraagteken bij de continuïteit. Door de stichting midden negentiende eeuw van de Republiek Italië (met inbegrip van Parma en Toscane), die door Spanje werd erkend, en de strijd om de koninklijke kroon binnen het geslacht De Bourbon, zou de koninklijke familieband zijn doorgesneden. In 1967 werd bij Spaanse wet bepaald dat generaal Franco $(\dagger 1975)$ de persoon zou aanwijzen die na zijn dood koning van Spanje zou worden. Formeel heeft het soevereine Spaanse volk op basis van de Grondwet van 1978 het koningschap opgedragen aan koning Juan Carlos uit het huis De Bourbon, een verre neef van prins Charles Hugues. Door de aanwijzing van de huidige koning en zijn erfopvolgers, voor wie bij een apart besluit van 6 november 1987 titulatuur is vastgesteld, zou geen sprake meer kunnen zijn van een oudere zijtak van het regerende Spaanse koningshuis. ${ }^{584}$ De verlening van het Spaanse staatsburgerschap in 1979 aan de in Parijs geboren Don Carlos Hugo de Borbón-Parma y Borbón, die ook via zijn moeder verwant was aan de Spaanse koning, zou hierbij niet van belang zijn. Hij woonde immers niet in Spanje en in het besluit werd geen andere adellijke titulatuur vermeld dan het algemene 'don', dat vergelijkbaar zou zijn met 'jonkheer'. 585 De koning heeft volgens artikel 19 van de Codigo Civil in zeer bijzondere gevallen discretionaire bevoegdheid om de Spaanse nationaliteit te verlenen aan bijvoorbeeld sportlieden en andere voor het koninkrijk belangrijke buitenlanders. In de overwegingen van het koninklijk besluit wordt dan ook gememoreerd dat Don Carlos Hugo tot een familie behoort die zeer nauw verbonden is met de geschiedenis van Spanje, maar over verbondenheid met het regerende koningshuis wordt gezwegen. De titel had - nog steeds volgens Van der Burg - dan toch minstens Infante de España of Principe moeten zijn. Uit de familiewebsite is op te maken dat het besluit uit 1979 door de familie als een erkenning van Spaanse adeldom wordt gezien, hoewel daarin niets over rechten van nakomelingen is bepaald. ${ }^{586}$

\section{Meerdere koninklijke families?}

Het meest verwerpelijk achtte Van der Burg echter de inlijving in de Nederlandse adel met de titel prins(es) en de bijbehorende aanspreekvorm 'Zijne/Hare Koninklijke Hoogheid.' Hiermee zou binnen het Koninkrijk der Nederlanden een tweede koninklijke familie zijn binnengehaald, die nog altijd rechten op de Spaanse troon claimt. Door het ontbreken van toestemming voor het huwelijk van prinses Irene bestaan er voor haar en haar nakomelingen weliswaar geen rechten meer op troonopvolging in Nederland, maar de verleende status binnen de Nederlandse adel zou voor de leek veel verwarring scheppen. ${ }^{587}$

\footnotetext{
${ }^{584}$ Van der Burg, 'De toestemming voor prinselijke huwelijken', 14-16 en 20-21.

${ }^{585}$ Spaans KB van 5 jan. 1979, nr. 31 (Stb. 349).

${ }^{586} \mathrm{Vgl}$. Wolswinkel, 'Bourbon, een ruziënde familie', 40-44. Don Carlos Hugo en zijn kinderen worden op de website 'Infante van Spanje' genoemd en voeren diverse (voormalige) Italiaanse adellijke titels, die naar Nederlands recht niet worden erkend: www.borboneparma.it (geraadpleegd 6 april 2012).

${ }^{587}$ Van der Burg, 'Geen Parmezaanse Koninklijke Familie in Nederland', 1073-1074.
} 
Afgezien van het feit dat buitenlandse troonpretendenten in de Nederlandse geschiedenis altijd al een meer of minder gastvrij onthaal in ballingschap vonden, waarvan de bekendste voorbeelden wel Frederik V van de Paltz, (winter)koning van Bohemen (1619-1620) in de zeventiende eeuw en de Duitse keizer Wilhelm II in de twintigste eeuw waren, was Van der Burg kennelijk onwetend van een vergelijkbaar precedent in het prille begin van het koninkrijk. Eén van de eerste verheffingen in de Nederlandse adel, die op initiatief van koning Willem I tot stand kwam, betrof in 1815 de duke of Wellington als prins van Waterloo bij eerstgeboorte. Deze Engelse hertog, die nooit de Nederlandse of Belgische nationaliteit heeft gehad - een voorwaarde voor opname in de Nederlandse adel, waaraan vanaf die tijd strikt de hand is gehouden - koesterde weliswaar geen soevereine rechten, maar was de belangrijkste afgezant van de Engelse koning bij de herinrichting van Europa op grond van het Verdrag van Wenen. Bij zijn verlening werd aan 'Onzen zeer lieven en beminden Neef Arthur Wellesley hertog van Wellington enz., enz.' en zijn wettige nakomelingen in mannelijke lijn de aanspreektitel doorluchtige hoogheid toegekend. ${ }^{588}$ De huidige prins van Waterloo is de Britse militair attaché Zijne Doorluchtige Hoogheid Arthur-Valerian Wellesley prins van Waterloo, duke of Wellington, enz., enz., geboren te Rome in 1915, die zijn vader na diens overlijden in 1972 opvolgde. ${ }^{589}$ De verleende Nederlandse aanspreektitel was vergelijkbaar met de gangbare titulatuur binnen het Nederlandse vorstenhuis. Artikel 17 van de Grondwet van 1814 bepaalde immers dat de soevereine vorst en de erfprins de aanspreektitel koninklijke hoogheid zouden voeren en alle andere prinsen en prinsessen van het huis Oranje-Nassau de titel doorluchtige hoogheid. Hierop is kennelijk ook de in 1967 toegekende persoonlijke titulatuur van de vier zonen van prinses Margriet en Pieter van Vollenhoven gebaseerd, al is gemeend dat het sterk gedateerde 'doorluchtige' beter kon worden weggelaten ${ }^{590}$ Deze vier prinsen behoren tot het soevereine koninklijk huis gedurende de tijd dat koningin Beatrix regeert, maar voeren hun titulatuur voor het leven. Ten tijde van de verlening van deze bijzondere gunst voor de eventuele kinderen die uit dat huwelijk geboren mochten worden, was de discussie over de ministeriële verantwoordelijkheid en daarmee de omvang van het koninklijk huis in volle gang. Aangezien prinses Irene inmiddels zonder de grondwettelijk vereiste parlementaire toestemming was getrouwd en niet meer voor troonopvolging in anmerking kwam, was op dat moment de kring van potentiële troonopvolgers nog uiterst gering. Prinses Beatrix was overigens destijds al wel in verwachting van een ongeveer vier maanden later geboren troonopvolger van de volgende generatie. ${ }^{591}$

\footnotetext{
${ }^{588} \mathrm{~KB}$ van 8 juli 1815, nr. 13. Van Valkenburg, 'Adelsbeleid sedert 1813', 57-58.

${ }^{589}$ État présent de la noblesse Belge (Brussel 2001), 151-152.

${ }^{590} \mathrm{~KB}$ van 2 jan. 1967 (Stb. 1), houdende voorzieningen in verband met het huwelijk van HKH Prinses Margriet en Pieter van Vollenhoven.

${ }^{591}$ ZKH Prins Willem-Alexander werd te Utrecht op 27 april 1967 geboren.
} 


\section{Persoonlijke adeldom}

Op basis van artikel 74 van de grondwet ('De Koning verleent adeldom') verkregen de kinderen die geboren mochten worden uit het huwelijk van prinses Margriet en Pieter van Vollenhoven, adeldom. Deze gunst moet als een verheffing tezamen met titelverlening worden gezien, aangezien de adeldom niet via de moeder kon overgaan. Als motivatie staat in het koninklijk besluit omschreven: "verlangende, dat aan de kinderen die uit dit huwelijk mochten worden geboren de persoonlijke titel van Prins(es) van Oranje-Nassau wordt verleend en overwegende, dat dit verlangen door de aanstaande echtgenoten wordt gedeeld' ${ }^{592}$

Het bijzondere van deze titelverlening was dat deze voor hun persoon alleen was gecreëerd en hun kinderen weer zouden terugvallen op de niet-adellijke geslachtsnaam Van Vollenhoven, die zij ook zelf onderbroken door een komma ter onderscheiding van hun titel bleven dragen.

Gedurende hun hele leven, ook wanneer zij om bovenstaande reden buiten het koninklijk huis zouden gaan vallen, behielden zij de hoogste adellijke titel prins met de bijbehorende aanspreektitel hoogheid. ${ }^{593}$ In de geschiedenis van de Nederlandse adel was de verlening van persoonlijke titulatuur uniek. Het negentiende-eeuwse voorbeeld, dat doorgaans wordt aangehaald, betrof de verheffing met de titel barones van de grootmeesteres van wijlen koningin Sophie, die als vrouw adeldom niet kon doorgeven. Mede door het karakter van deze beloning wegens persoonlijke verdienste met vrijstelling van taxa is achteraf wel de conclusie getrokken dat het hier om persoonlijke adeldom zou gaan. ${ }^{594}$ Andere negentiende-eeuwse bijzondere adelsverleningen die een uitzondering op het wezen van de erfelijke adeldom waren, zijn op een hand te tellen. Een geval van uitsterven werd bij koninklijke gunst voorkomen door de zonen van een broer aan te wijzen; in een ander geval werd staande de verheffing de zoon van een dochter, met naamstoevoeging, als rechtsopvolger aangewezen. Een derde bijzondere verlening met het predikaat jonkvrouw betreft een stiefdochter van de genobiliteerde, eveneens na naamstoevoeging. 595

\section{Pieter van Vollenhoven}

Pieter van Vollenhoven, wiens familiewapen tezamen met dat van zijn nazaten bij koninklijk besluit werd vastgesteld, kreeg geen (functionele) adellijke titel verleend, omdat hij geen recht op troonopvolging had en als echtgenoot van prinses Margriet naar verwachting te ver af zou komen te staan van de potentiële kring van troonopvolgers. Als lid van het koninklijk huis was te verwachten dat hij represen-

\footnotetext{
592 Luiking, 'Het Koninklijk Besluit houdende "Voorzieningen in verband met het huwelijk van H.K.H. Prinses Margriet en Pieter van Vollenhoven"”, 182-185.

${ }^{593}$ Wet lidmaatschap koninklijk huis van 30 mei 2002 (Stb. 275), artt. 1a en 10.

594 [Nijkamp en Schutte], De Nederlandse Adel, 73: Van Wickevoort Crommelin (1877); Van Valkenburg, 'Adelsbeleid sedert 1813', 66.

595 [Nijkamp en Schutte], De Nederlandse Adel, 12-13: Vrijthoff (1841, geëffectueerd 1862), Pichot van Slijpe (1835) en Theunissen Reynst (1842).
} 
tatieve verplichtingen zou gaan vervullen en dit maakte de vaststelling (beter: bevestiging) van zijn familiewapen opportuun. ${ }^{596}$ Luiking keurde deze voordracht door twee ministers en met advies van de Hoge Raad van Adel af, omdat er geen wettelijke grondslag was, althans niet in het koninklijk besluit was aangegeven. Voor een niet-adellijk lid van het koninklijk huis was, zo betoogde hij, een koninklijke beschikking (zonder ministerieel contraseign) voldoende geweest, omdat het geen staatszaak zou zijn. ${ }^{597}$

Voor een lid van het koninklijk huis van de volgende generatie, prinses Laurentien, die als echtgenote van prins Constantijn representatieve verplichtingen zou gaan vervullen, werd de fase van een bij koninklijk besluit bevestigd familiewapen overgeslagen. Zij kreeg een bij koninklijk besluit vastgestelde onderscheidingsvlag, waarin een symbool (de ruit) uit het familiewapen Brinkhorst werd opgenomen. ${ }^{598}$

Voor zijn vele verdiensten aan het koninklijk huis en het koninkrijk bewezen, ontving Pieter van Vollenhoven hoge koninklijke onderscheidingen. Hij viel daarmee onder het regime van het herziene stelsel van beloning van burgers, die zich op bepaalde terreinen in het maatschappelijk verkeer op bijzondere wijze verdienstelijk hebben gemaakt. ${ }^{599}$ Speculaties vanaf zijn toetreding tot het koninklijk huis, over hoge adellijke titulatuur, waarop hij in zijn representatieve rol als echtgenoot van prinses Margriet recht zou hebben, waren in feite nergens op gebaseerd. In het kader van de voorbereidingen van hun huwelijk, blijkt het onderwerp wel op hoog niveau besproken te zijn, maar vooral in verband met de regeling voor de eventuele kinderen die uit het huwelijk geboren zouden worden. Verkeerd gelezen aantekeningen van premier Cals uit 1966 - die eerst in 1995 openbaar werden - waarin gerefereerd werd aan een gesprek met de toenmalige voorzitter van de Hoge Raad van Adel, jonkheer Van Valkenburg, veroorzaakten dertig jaar na dato een rel in de pers. De ophef bereikte een climax in 1998, toen de toestemmingswet voor het huwelijk van prins Maurits bij het parlement werd ingediend. ${ }^{600}$

Bij de hierboven aangegeven afweging zou in geval van een positieve beslissing zonder twijfel de adellijke hiërarchie zijn gevolgd van verheffing (met predikaat jonkheer) en in een bijzondere situatie (afhankelijk van de afstand binnen het koninklijk huis ten opzichte van de troonopvolger) titelverlening. Ook het naoorlogse overheidsbeleid om geen burgers meer te verheffen zal aan de beslissing debet zijn

\footnotetext{
${ }^{596} \mathrm{~KB}$ van 16 april 1968 (Stb. 225).

${ }^{597}$ Luiking, 'Het wapen van mr. P. van Vollenhoven en dat van zijn kind(eren)', 848-849. Eerder had hij zich al gebogen over de wettelijke grondslag van de Hoge Raad van Adel en de reikwijdte van diens taken ('De taakomschrijving van de Hoge Raad van Adel', 100-101).

${ }_{598} \mathrm{~KB}$ van 15 jan. 2003 (Stb. 36), houdende verlening van een onderscheidingsvlag aan H.K.H. Prinses Laurentien.

${ }^{599}$ Wolswinkel, 'Koninklijk eerbetoon voor mr. Pieter', 52-53. Nadat hij al in een eerder stadium het grootkruis in de Huisorde van Oranje had ontvangen, ontving hij aan de vooravond van zijn 65-ste verjaardag uit handen van de premier het grootkruis in de Orde van de Nederlandse Leeuw. Deze hoogste burgerlijke onderscheiding (ridder grootkruis) krijgen traditiegetrouw de kinderen van de regerend vorst op hun achttiende verjaardag en de partner van de vermoedelijke troonopvolger op de trouwdag.

${ }^{600}$ Hermans, Pieter van Vollenhoven, 92-106. Hierin komt de auteur tot de conclusie, dat de geslachtsnaam van de toenmalige voorzitter van de Hoge Raad van Adel, jonkheer Van Valkenburg, foutief gelezen moet zijn als Van Vollenhoven.
} 
geweest. Anders dan de Von Amsbergs behoorden de Van Vollenhovens immers niet tot de adel en het zou volgens de adellijke hiërarchie ondenkbaar zijn geweest om in geval van verheffing de familie van de gemaal van de (aankomende) koningin voorbij te streven. Prins Claus werd vanwege zijn bijzondere positie ter gelegenheid van zijn huwelijk de titel prins der Nederlanden verleend en de jure ingelijfd in de Nederlandse adel met het predikaat jonkheer, dat als het Nederlandse equivalent van het Duitse voorvoegsel 'von' werd gezien. ${ }^{601}$

\section{Supra-nationale vorstelijke titels}

Rijndorp maakte in zijn verhandeling over de herkomst en betekenis van de titel prins van Oranje onderscheid tussen inlands-adellijke titulatuur en supra-nationale vorstelijke titulatuur. In deze visie was de algemene huistitel Prince d'Orange voor (deze tak van) het vorstengeslacht Nassau onderdeel van het Nederlandse staatsrecht geworden sedert de opname in de Grondwet van 1815 als bijzondere titel voor de erfprins. In het KB van 25 juni 1825 (Stb. 61) stond in de aanhef voor de eerste adelslijst, na de opsomming van de rangorde binnen de adellijke titulatuur, dat 'de Prinsen van het Koninklijk Huis [en enige anderen] onder deze praedikaten niet begrepen [zijn], maar blijven voeren de praedikaten die aan hunne titels ten allen tijde zijn gehecht geweest'. Hieruit trok Rijndorp de conclusie, dat men de titulatuur van het koninklijk huis en andere vergelijkbare vorstenhuizen geheel los van de Nederlandse adellijke titels zag. ${ }^{602}$ Dit zou de reden zijn, dat over de titels hertog van Mecklenburg en prins van Lippe-Biesterfeld niet bij Nederlands koninklijk besluit was beslist. De gedachte er achter is dat vorstelijke titels internationaal worden erkend en gebruikt en niet beschouwd worden als te behoren tot de nationale adelsregelingen. Ze waren daardoor ook verheven boven het algehele verbod in de Nederlandse grondwet tot het aannemen van vreemde adeldom. Rijndorp toonde aan dat in de koninklijke besluiten betreffende titelverlening bij huwelijken binnen het koninklijk huis niet steeds consequent dezelfde grondwetsartikelen zijn geciteerd. Wel werd nauwkeurig de volgorde van de te bezigen titulatuur in acht genomen. $^{603}$

In 1901, toen de regerende koningin, als laatste telg van de Nederlandse Nassaus een huwelijk aanging met de hertog van Mecklenburg, moesten onder meer de namen en titels van eventuele kinderen worden geregeld. Alle hoop was nog gevestigd op de geboorte van een prins van Oranje, zodat voor nakomelingen (prinsen en prinsessen der Nederlanden) de algemene titel (naam) prins(es) van OranjeNassau werd vastgelegd: 'Aan de na(a)m(en), die zij aan het geslacht van hun vader ontlenen, zal de naam Oranje-Nassau vooraf gaan, zodat zij zullen zijn: Prins

\footnotetext{
${ }^{601} \mathrm{~KB}$ van 16 febr. 1966 (Stb. 70), gebaseerd op art. 74 van de grondwet; vgl. Rijndorp, 'Het wetsontwerp tot naturalisatie van de heer Claus von Amsberg', 773, en 'Nogmaals de Prins van Oranje', 959. Vgl. ook Prins, 'De wetgever en het huwelijk van Prinses Beatrix', 17-21 (met de huwelijksakte, 29-31), en 'Langs ongebaande wegen', 45-49.

${ }_{602}$ Rijndorp, 'Nogmaals de Prins van Oranje en andere titels der Koninklijke Familie', 955-959.

${ }^{603}$ Ibidem, 957-959.
} 
van Oranje-Nassau Hertog van Mecklenburg., ${ }^{604}$ Ten aanzien van de aan het groothertogelijk huis Mecklenburg ontleende titel werd dus alleen de plaats bepaald. Dit was noodzakelijk omdat volgens de adellijke hiërarchie de vorstelijke titel hertog boven een familietitel als prins van Oranje-Nassau ging. Ook in 1937 werd voor de nakomelingen van prins Bernhard dezelfde volgorde aangehouden, hoewel adelsrecht in Duitsland inmiddels niet meer bestond en alleen van naamrecht sprake was. ${ }^{605}$ Dit zal de reden zijn geweest, dat aan prinses Juliana op grond van art. 65 van de grondwet de titel van prinses van Lippe-Biesterfeld werd verleend. ${ }^{606}$ Adellijke titulatuur kan niet langs vrouwelijke lijn worden doorgegeven, waardoor de titel (naam) Van Lippe-Biesterfeld in de tak afstammende van de vader van prins Bernhard in mannelijke lijn dreigde te verdwijnen. Om deze naam aan het nageslacht door te geven, werd voor de kinderen van prins Maurits, oudste zoon van prinses Margriet, de geslachtsnaam Van Lippe-Biesterfeld van Vollenhoven vastgesteld. ${ }^{607} \mathrm{Bij}$ dit besluit, dat genomen kon worden op grond van art. BW 1:5, lid 12, werd voldaan aan het criterium uit het Besluit geslachtsnaamswijziging, dat "van de grootvader van vaderszijde van zijn moeder geen mannelijke afstammelingen in de mannelijke lijn meer in leven zijn van wie nog nakomelingenschap is te verwachten' (art. 2, lid 1b).

De afweging tussen het bestaan van supra-nationale titels en inlands-adellijke titels speelde ook een rol bij het inlijvingsverzoek De Bourbon de Parme in 1996, waarbij - zoals hiervoor onder de overgangsbepaling van de Wet op de adeldom vermeld - door verzoekers werd gekozen voor Nederlandse adeldom. Onzekerheid over de ontwikkelingen binnen het vigerende adellijke vorstenrecht zal daar mogelijk een rol bij hebben gespeeld.

\section{Koninklijke erfopvolging en adellijke afstamming}

Nadat in 1890 met het overlijden van koning Willem III het huis Oranje-Nassau in mannelijke lijn was uitgestorven, werd op basis van de Grondwet van 1887 het koningschap in vrouwelijke lijn voortgezet met de benoeming van koningin Emma tot regentes voor de tijd dat prinses Wilhelmina minderjarig was. ${ }^{608}$ Al veertig jaar voordat in 1962 het huis Oranje-Nassau - adelsrechtelijk beschouwd - ook in vrouwelijke lijn uitstierf, was bij de grondwetsherziening van 1922 al voorzien in de troonopvolging onder alleen nog de afstammelingen van koningin Wilhelmina. Op basis van deze grondwettelijke bepaling volgde koningin Juliana in 1948 haar moeder op en werd koningin Beatrix in 1980 troonopvolgster na het terugtreden van haar moeder. Anders dan in de negentiende eeuw, toen de supra-nationale rol

\footnotetext{
${ }^{604} \mathrm{~KB}$ van 8 febr. 1901 (Stb. 1908, 425).

${ }^{605}$ Vgl. Snethlage, 'De afkomst van Prins Bernhard, een mythe?', 201-203.

${ }^{606} \mathrm{~KB}$ van 6 jan. 1937 (Stb. 2).

${ }^{607} \mathrm{~KB}$ van 26 mei 1998, nr. 98.002723 (Stb. 310).

${ }^{608}$ De personele unie met Luxemburg werd echter op grond van een familiecontract verbroken omdat de staatsregeling van het groothertogdom vererving in mannelijke lijn voorschreef. Nog tot 1922 bleef in de grondwet staan, dat de koning geen vreemde kroon [kan] dragen, met uitzondering van die van Luxemburg (Grondwet van 1917, art. 23).
} 
van vorstengeslachten algemeen werd geaccepteerd, bevestigde de herziening van 1922 uitdrukkelijk het nationale koningschap, dat was geworteld in de verbondenheid met de Oranje-Nassaus. ${ }^{609}$

Toen aan de vooravond van het huwelijk van koningin Wilhelmina in 1901 een oplossing gezocht werd voor de vorm waarin de erfopvolging op haar eventuele nakomelingen moest overgaan, kon teruggegrepen worden op achttiende-eeuwse familieverdragen tussen de verschillende takken van het vorstengeslacht Nassau. Daar bleek de kiem te liggen van een erfopvolging, die bij uitsterven in mannelijke lijn van één der takken op de erfdochter zou overgaan, die haar naam, titel en wapen vervolgens op haar echtgenoot zou overbrengen. Sedert 1901 wordt behalve over erfelijke titulatuur in de desbetreffende koninklijke besluiten ook over de naam Oranje-Nassau gesproken. De groothertog van Luxemburg uit het huis Nassau had toestemming gegeven om de erfelijke titel als naam in combinatie met Oranje voort te zetten door de eventuele kinderen van koningin Wilhelmina. ${ }^{610}$

Deze afspraken waren ook de basis geweest voor de artikelen inzake erfopvolging in de grondwetten van 1814 (bij ontstentenis de nakomelingen van 's konings zuster en tante) en 1815 ('het oir uit het Huis van Oranje-Nassau', dat ruimer is dan de nakomelingen van de koning).

Aan de eerste grondwet lag de zogenaamde 'Schets' van Van Hogendorp ten grondslag, die zijn inspiratie had gevonden in het achttiende-eeuwse stadhouderlijke erfrecht. ${ }^{611}$ De invoering van het erfelijke stadhouderschap in 1747 was gebaseerd op een resolutie van de Staten van Holland waarin prins Willem IV en zijn mannelijke en vrouwelijke descendenten tevens de ambten van kapitein-generaal en admiraal-generaal werd opgedragen. ${ }^{612}$ Onder druk van buitenlandse (Franse) oorlogsdreiging en binnenlandse volksagitatie volgden een jaar later ook de andere gewesten en de Staten-Generaal, voor zover het om de generaliteit ging. ${ }^{613}$ De optie van vererving op vrouwelijke nakomelingen was reëel, omdat de stadhouder op dat moment alleen nog maar een dochter Carolina had. Op 8 maart 1748 werd de latere Willem V geboren, maar toen hun vader al in 1751 overleed, werd de hertog van Brunswijk als voogd namens hun moeder, prinses Anna van Hannover, aangesteld. ${ }^{614}$ De Staten-Generaal hadden hun handen vol aan het regelen van alle scenario's die zich zouden kunnen gaan voordoen. In 1814 is het stadhouderlijke erfrecht uit 1747 eenvoudigweg op het nieuwe vorstenhuis overgebracht. ${ }^{615}$

\footnotetext{
${ }^{609}$ Van Valkenburg, 'De troonopvolging in Nederland', 143-144.

${ }^{610}$ Van Valkenburg, 'Titulatuur, wapens en vlaggen van leden van het Koninklijk Huis', 99-103.

${ }^{611}$ Colenbrander, Ontstaan der Grondwet 1, 43-44.

${ }^{612}$ Gabriëls, De heren als dienaren en de dienaar als heer, 55-61. De auteur geeft aan dat het erfstadhouderschap nooit een geïntegreerd bestanddeel van de constitutie van de Republiek is geworden en dus niet van 'stadhouder van de Unie' kan worden gesproken (59).

${ }^{613}$ Groot placaatboek, inhoudende de placaten en ordonnantiën van de Hoogh Mog. Heeren StatenGeneraal der Vereenigde Nederlanden 7 (door I. Scheltus), p. 157.

${ }^{614}$ Van Ditzhuyzen, Oranje-Nassau, Een biografisch woordenboek, 236-239.

${ }^{615}$ Van der Burg, 'De toestemming voor prinselijke huwelijken, een erfenis uit de tijd van de Republiek der Verenigde Nederlanden', 24-30 (met literatuuropgave).
} 
De probleemstelling uit de inleiding, als zouden de regels betreffende erfopvolging binnen het koninklijk huis door de Grondwet van 1922 verwijderd zijn geraakt van de vanouds geldende standaardregel van vererving van adeldom louter via de mannelijke lijn, moet gezien het bovenstaande worden bijgesteld. In feite hebben de twee instituten een parallelle ontwikkeling doorgemaakt, die op het punt van de vererving langs vrouwelijke lijn van elkaar verschilde. De soevereine vorst heeft in 1814 een Nederlandse adel gecreëerd, die zich niet onderscheidde van vergelijkbare adeldom op het Europese continent, waar het vererving langs mannelijke lijn betreft. Aangetoond kon worden dat de grondwet en de statuten voor de adel van het Koninkrijk Holland tot voorbeeld hebben gediend voor de inrichting van de Nederlandse adel. Ook de constitutie van koning Lodewijk Napoleon sloot erfopvolging via de vrouwelijke lijn uit. Artikel 19 van de Constitutie van het Koningrijk Holland bepaalde dat de kroon alleen kon vererven 'op de natuurlijke, wettige en mannelijke afstammelingen, bij orde van eerstgeboorte, bij altoosdurende uitsluiting der vrouwen en van derzelver afstammelingen' ${ }^{616}$ De erfopvolging binnen het huis Oranje-Nassau, gebaseerd op een contract uit de Republiek der Verenigde Nederlanden, lijkt binnen de Europese adelsgeschiedenis dus eerder uitzondering dan regel te zijn geweest.

\section{2002-heden: eerbiedigende werking}

Sinds de uitwerking in 1999 van de overgangsbepaling (art. 8) in de Wet op de adeldom, die nog gedurende vijf jaar aan Nederlanders de mogelijkheid bood een verzoek om inlijving te doen, heeft nog maar één inlijving volgens het nieuwe regime plaatsgevonden. Dit betrof een lid van het Belgische adellijke geslacht Prisse in 2001. De directe voorvader van verzoeker was in 1844 door koning Leopold I verheven in de adel van het Koninkrijk België met de titel baron bij recht van eerstgeboorte. ${ }^{617}$ Inlijving in de Nederlandse adel werd in 2001 verleend tezamen met titelhomologatie, dus eveneens bij eerstgeboorte. ${ }^{618}$

$\mathrm{Na}$ lange tijd vonden ook weer verheffingen plaats. De laatste burger was jonkheer Van Valkenburg geweest in 1939 en de laatste leden van het koninklijk huis in 1967 de kinderen, die uit het huwelijk van prinses Margriet met Pieter van Vollenhoven mochten worden geboren. Deze verheffingen waren gedaan op grond van respectievelijk artikel 67 van de Grondwet van 1938 en artikel 74 van de Grondwet van 1963. Sinds de inwerkingtreding van de Wet op de adeldom in 1994 was verheffing volgens art. 2, lid 2, uitsluitend voorbehouden aan leden van het koninklijk huis en aan voormalige leden daarvan binnen drie maanden na verlies van het lidmaatschap. Van beide categorieën zijn inmiddels voorbeelden bekend. In de eerste categorie werd in 2001 de titel graaf/gravin verleend aan de kinderen die

\footnotetext{
${ }^{616}$ Van Hasselt, 'Verzameling van Nederlandsche Staatsregelingen en Grondwetten', 143.

${ }^{617}$ État présent de la noblesse de Belge (Brussel 1996), 366-372.

${ }^{618} \mathrm{~KB}$ van 13 nov. 2001, nr. 01.005385.
} 
mochten worden geboren uit het huwelijk van prins Constantijn. ${ }^{619}$ Eveneens in categorie één werd in 2002 de titel prins/prinses verleend aan Máxima Zorreguieta en de kinderen die uit haar huwelijk met de prins van Oranje mochten worden geboren. ${ }^{620}$ In de tweede categorie viel in 2004 de verlening van de erfelijke titel graaf aan prins Johan Friso. ${ }^{621}$

Daarnaast vond in 2009 nog een titelerkenning op grond van art. 2, lid 4, plaats voor drie jonkheren en twee jonkvrouwen Van Coeverden, die teruggreep op eerdere titelerkenningen binnen dit geslacht in de jaren 1991-1993. ${ }^{622}$

\section{Geen terugwerkende kracht}

Vanaf de datum van het besluit van de Hoge Raad van Adel (lees: de minister van BZK) van 13 augustus 2001 om inschrijving in het filiatieregister van de Nederlandse adel te weigeren van een door een jonkheer en zijn vrouw geadopteerd kind dat geboren was vóór de inwerkingtreding van de Wet op de adeldom, sleepte zich een juridisch proces voort dat om een beslissing in hoogste instantie vroeg. De jure ging het hierbij om de vraag of de Wet op de adeldom terugwerkende kracht had of niet, hetgeen niet uit overgangsbepalingen kon worden opgemaakt. Tijdens de behandeling van het wetsontwerp waren daarover al misverstanden ontstaan en de minister had deze maar gedeeltelijk kunnen wegnemen.

Behalve haar geboortedatum, viel ook haar adoptiedatum, waarbij nieuwe familierechtelijke betrekkingen met haar Zeeuwse adoptiefouders waren ontstaan, vóór 1 augustus 1994, de datum waarop de Wet op de adeldom in werking was getreden. Zij had haar verzoek bij de Hoge Raad van Adel ingediend vóór 15 augustus 2001, de dag waarop zij 23 jaar zou worden. Tussen haar $20^{\text {ste }}$ en $23^{\text {ste }}$ jaar had zij wettelijk nog de mogelijkheid gehad om de adoptie door een uitspraak van de rechter te laten herroepen en daarmee de door de adoptie opgehouden oorspronkelijke familierechtelijke betrekkingen te laten herleven (artt. BW 1:231 en 232).

De Arrondissementsrechtbank Middelburg deed op 20 april 2004 inhoudelijk uitspraak door haar in het gelijk te stellen. Zij overwoog, dat artikel 3 van de Wet op de adeldom onmiddellijke werking had en van toepassing was op hetgeen bij haar inwerkingtreding bestond. De parlementaire geschiedenis zou geen aanknopingspunten bieden voor een ander standpunt, aangezien tijdens de behandeling van het wetsontwerp in de Eerste Kamer uitsluitend was gesproken over overgangsrechtelijke consequenties voor de in artikel 3 genoemde natuurlijke kinderen. De rechtbank concludeerde daaruit dat het artikel na inwerkingtreding van de wet onmiddellijk gold voor op dat moment geadopteerde kinderen. ${ }^{623}$ De minister ging tegen

\footnotetext{
${ }^{619} \mathrm{~KB}$ van 11 mei 2001, nr. 01.002382 (Stb. 227).

${ }^{620} \mathrm{~KB}$ van 25 jan. 2002 (Stb. 41).

${ }^{621} \mathrm{~KB}$ van 19 maart 2004 (Stb. 126).

${ }^{622} \mathrm{~KB}$ van 24 febr. 2009, nr. 09.000560.

${ }^{623}$ AR (Middelburg) 20 april 2004, AWB 03/419 (Van Beijma). De Groot, 'Adelsrecht op de drempel van de 21ste eeuw', 506-508, en Boddaert, 'De Zeeuwse adoptiezaak', 36-42, concludeerden bij voorbaat ook tot deze zogenaamde 'ex nunc'-werking van de Wet op de adeldom.
} 
deze uitspraak in beroep bij de Afdeling Bestuursrechtspraak van de Raad van State, die hem in het gelijk stelde. Anders dan de rechtbank was de Afdeling van oordeel dat artikel 3, omdat er geen overgangsrecht was vastgesteld, eveneens niet mede van toepassing was op geadopteerde kinderen van mannelijke edellieden die waren geboren voordat de wet inwerking trad. De Afdeling voerde daarvoor drie argumenten aan: ten eerste verwijst de Wet op de adeldom in artikel 3 naar bestaande regelingen met betrekking tot adeldom, die bezwaarlijk anders kunnen worden opgevat dan als een verwijzing naar de geboorte en het tijdstip daarvan; in de regel wordt immers overgang van adeldom door geboorte bepaald. Het tweede argument was, dat de minister in de Eerste Kamer om uitvoeringstechnische redenen heeft verklaard, dat artikel 3 uitsluitend betrekking heeft op kinderen die geboren worden na de inwerkingtreding van de wet en dat het rechtsfeit van de geboorte daarbij bepalend is. Ten slotte voerde de Afdeling als argument aan, dat de rechtbank heeft miskend dat artikel 3 van de wet niet beoogd onderscheid te maken tussen natuurlijke en geadopteerde kinderen. De uitspraak van de rechtbank was dus in strijd met de bedoeling van artikel 3: adeldom zou wel overgaan op een vóór 1 augustus 1994 geboren kind als het door een adellijke man zou zijn geadopteerd, maar in de visie van de rechtbank niet overgaan als een vóór die datum geboren kind door de adellijke man zou zijn erkend. ${ }^{624}$

\section{Brieven van wettiging}

De uitspraak in deze zaak schiep na tien jaar duidelijkheid over de werking van de Wet op de adeldom, maar leverde kritiek op uit de juridische wereld. Boddaert constateerde dat deze beslissing in strijd zou zijn met artikel 85 van de Grondwet, waarin de rol van de Eerste Kamer wordt beperkt tot verwerping of aanneming van een door de Tweede Kamer aangenomen wetsontwerp. ${ }^{625}$ Zijn belangrijkste punt van kritiek was de gelijkschakeling van natuurlijke erkende en geadopteerde kinderen met betrekking tot het rechtsfeit van de geboorte. Voor de laatstgenoemde kinderen achtte Boddaert de adoptiedatum, waarop nieuwe familierechtelijke betrekkingen ontstonden en de oude vervielen, belangrijker dan de geboortedatum. Hij bestreed voorts dat adeldom in de regel overgaat door geboorte, waarbij hij wees op de verschillende wijzen van historische adelsverlening: benoeming in een ridderschap, verheffing, inlijving en erkenning. Verder bracht hij in herinnering het verlenen door de minister van Justitie van 'brieven van wettiging' aan overspelige kinderen die niet door de biologische vader konden worden erkend, laat staan gewettigd. In het belang van het kind kregen deze brieven na verlening onmiddellijke werking. In 1970 werd de mogelijkheid van erkenning alsnog geschapen, nadat het huwelijk van de vader was ontbonden. Met ingang van 1998 werden deze

\footnotetext{
${ }^{624}$ ABRvS 5 jan. 2005, 200404471/1 (Van Beijma); AB 2005, 62 (met noot I. Sewandono).

${ }^{625}$ Boddaert, 'De tweede Zeeuwse adoptiezaak', 227-232.
} 
bepalingen in het BW geschrapt, omdat het begrip wettiging uit het burgerlijk recht verdween. ${ }^{626}$

De Hoge Raad der Nederlanden adviseerde de minister in 1992 positief ten aanzien van de verlening van brieven van wettiging aan een onder de oude regeling geboren overspelig kind, waarvan de adellijke vader niet tot erkenning had kunnen komen door diens vooroverlijden. ${ }^{627}$ In zijn advies had de Hoge Raad zich laten leiden door het streven om ongelijkheid binnen het gezinsverband (art. 8 EVRM) zoveel mogelijk op te heffen. De vader was destijds gehuwd met de moeder en zij hadden acht jaar gezinsleven met hun zoontje gehad tot de vader overleed. De Hoge Raad volgde in zijn overweging het streven in internationaal verband om de achterstelling van overspelige, bloedschennige en natuurlijke kinderen waar mogelijk op te heffen. ${ }^{628}$

Boddaert moest tot zijn spijt vaststellen, dat noch de adoptiefouders, noch de adoptiefdochter voornemens waren zich tot het Hof in Straatsburg te wenden voor toetsing aan het EVRM. Hij maakte zich echter geen illusies, omdat niet elke uitspraak van de nationale rechter (meer) kan worden voorgelegd. Hiervoor moet minstens van een min of meer ernstige schending van het EVRM sprake zijn. ${ }^{629}$

\section{De mythe van het blauwe bloed $d^{630}$}

Inmiddels waren enkele vergelijkbare verzoeken om inschrijving in het filiatieregister bij de Hoge Raad van Adel aangehouden in afwachting van een onherroepelijke uitspraak van de Afdeling Bestuursrechtspraak van de Raad van State. Alle verzoeken werden ingetrokken, maar één schrijnend geval vroeg om clementie, waarvoor de Hoge Raad van Adel begrip toonde. Het betrof hier een anderhalve maand vóór de inwerkingtreding van de Wet op de adeldom geboren tweeling, die door de adellijke vader vanwege een ongeneeslijke ziekte van zijn vrouw, door middel van een medisch-technische ingreep was verwekt bij haar ongehuwde zuster. Laatstgenoemde had louter als draagmoeder gefungeerd en had, voorafgaande aan de adoptie van de tweeling door hun biologische vader en zijn vrouw, afstand gedaan van de voogdij over de kinderen. De discrepantie was dat als de kinderen een paar maanden later waren geboren, de adeldom ingevolge artikel 3 van de Wet op de adeldom wel op de kinderen zou zijn overgegaan. De kinderen hadden volgens hun geboorteakten de geslachtsnaam van hun biologische moeder gekregen,

\footnotetext{
${ }^{626}$ Voormalige artt. BW 1:214-220. Vgl. Evers en Vat, Afstamming en naam, 83-84. Het per 1 jan. 2012 ingevoerde boek 10 van het BW (internationaal privaatrecht) kent onder Titel 5 (afstamming) nog een afdeling (3) 'familierechtelijke betrekkingen door wettiging'. Het begrip 'wettige troonopvolgers' bleef bestaan en heeft in de grondwet betrekking op het vereiste van een bij Rijkswet verleende toestemming aan het huwelijk van een potentiële troonopvolger (artt. 24 en 28 van de Grondwet). Ook het primogenituurbesluit inzake vererving van adellijke titulatuur bij eerstgeboorte (KB van 26 maart 1868 (Stb. 37), dat geldend recht is, spreekt uitdrukkelijk van wettige afstamming.

${ }^{627}$ HR 8 okt. 1992, rekestnr. 5156 W.

${ }^{628}$ Drie jaar later adviseerde de Hoge Raad der Nederlanden eveneens positief in opnieuw een door overlijden van de adellijke vader onmogelijk geworden erkenning van een in 1993 geboren zoon, die daarmee brieven van wettiging en inschrijving in het filiatieregister bereikte (HR 30 juni 1995, rekestnr. $5180 \mathrm{~W}$ ).

${ }^{629}$ Myer, 'Een klacht indienen bij het EHRM', 18 febr. 2005.

${ }^{630}$ Dit opschrift is ontleend aan De Groot, 'Adelsrecht op de drempel van de $21^{\text {ste }}$ eeuw', 508.
} 
omdat erkenning door hun getrouwde vader toen niet mogelijk was, anders dan met speciale toestemming van de rechtbank. Om hun doel te bereiken was voor adoptie gekozen. De Raad had temeer begrip voor deze situatie, omdat hier geen sprake was van adoptie van een niet-verwant kind, maar van een eigen kind, zodat de biologische adellijke afstamming (de bloedband) bewijsbaar in orde was. De minister kon het advies van de Raad echter niet honoreren, omdat naar Nederlands recht alleen wettelijke adeldom bestaat en het criterium van het tijdstip van de geboorte door de rechter in hoogste instantie was vastgesteld. ${ }^{631}$

\section{Gerechtelijke vaststelling van het vaderschap}

Ook De Groot stelde vraagtekens bij het tijdstip van de verkrijging van adeldom door adoptiefkinderen volgens artikel 3 van de Wet op de adeldom. Hij kon zich in 2001 niet anders voorstellen dan dat de wet onmiddellijke werking ex nunc (dus direct van toepassing op alle op 1 augustus 1994 levende geadopteerde kinderen van ouders, van wie de vader tot de Nederlandse adel behoorde) zou hebben, aangezien de geboortedatum voor adoptiefkinderen juridisch minder belangrijk is dan de adoptiedatum. Toch moest ook hij zich bij de op zichzelf heldere uitspraak van de Afdeling Bestuursrechtspraak van de Raad van State inzake de Zeeuwse adoptiezaak neerleggen. Hij had zich destijds tevens afgevraagd hoe ten aanzien van gerechtelijke vaderschapsvaststellingen diende te worden gehandeld. ${ }^{632}$ Volgens art. BW 1:207, lid 5, heeft deze vaststelling terugwerkende kracht vanaf het moment van de geboorte van het kind. Vergelijkbaar met adoptie wordt ook hier de familierechtelijke betrekking geacht reeds aanwezig te zijn geweest. De Groot had dan ook tot onmiddellijke werking ex nunc geconcludeerd, in beide situaties mits conform art. BW 1:5, lid 11, als geslachtsnaam van het kind de naam van de adellijke vader zou worden gekozen.

Hoewel de uitspraak van de Afdeling in de Zeeuwse adoptiezaak gerechtelijke vaderschapsvaststellingen niet expliciet noemde, maar wel aangaf geen onderscheid te maken tussen erkende en adoptiefkinderen, kan er vanuit gegaan worden dat voor buiten het huwelijk geboren kinderen van wie het vaderschap gerechtelijk is vastgesteld, hetzelfde geldt. Wordt bijvoorbeeld door de rechtbank in het belang van het kind vastgesteld dat een adellijke man als levensgezel van de moeder van het kind heeft ingestemd met een daad die de verwekking van het kind tot gevolg heeft gehad (art. BW 1:207, lid 1), dan maakt het kind kans op adeldom. Hiervoor moet, de uitspraak van de Afdeling interpreterend, nog aan twee voorwaarden worden voldaan: in de eerste plaats geboorte na de inwerkingtreding van de Wet op de adeldom en in de tweede plaats naamswijziging in de adellijke naam van de vader, tot stand gekomen volgens de artt. BW 1:5, lid 2b en 11.

\footnotetext{
${ }^{631}$ HRvA, RA, not. 2002-23.

${ }^{632}$ De Groot, 'Adelsrecht op de drempel van de $21^{\text {ste }}$ eeuw', 506-507.
} 
Sewandono speculeerde al in 1997 op deze overgang van adeldom buiten het huwelijk aan de hand van een concreet geval. ${ }^{633}$ Deze vaderschapsvaststelling heeft op verzoek van de moeder bij beschikking van de rechtbank plaatsgevonden, maar aangezien de ouders van het kind bij gelegenheid van de vaststelling geen akte van naamskeuze hebben laten opmaken, ligt de beslissing om al of niet tot de Nederlandse adel te behoren bij het kind zelf. ${ }^{634}$ Deze kan zijn geslachtsnaam op verzoek laten wijzigen en daarmee adeldom verwerven, mits dit verzoek binnen drie jaren nadat de meerderjarigheid is bereikt, wordt ingediend. ${ }^{635}$

\section{Discriminatie ten aanzien van 'adellijke geslachtsnamen'}

In het kader van de herziening van het naamrecht, die op 1 januari 1998 gestalte kreeg, werden de ministeriële richtlijnen betreffende geslachtsnaamwijziging bij algemene maatregel van bestuur, krachtens artikel BW 1:7, lid 5, opnieuw vastgesteld. Net als in de oude richtlijnen werd ten aanzien van de toevoeging van een naam een uitzondering gemaakt voor een verzoeker die van adel is, of een drager van een naam waarvan de toevoeging wordt verzocht tot een adellijk geslacht behoort. In beide gevallen zou toevoeging niet gehonoreerd kunnen worden, ook niet als de toe te voegen naam een in haar tak uitgestorven of met uitsterving bedreigde geslachtsnaam van de moeder betreft (art. 2). ${ }^{636}$ Volgens de memorie van toelichting was het beleid er mede op gericht toeneming van dubbele geslachtsnamen zoveel mogelijk te voorkomen. Inzake adellijke geslachtsnamen zou in de praktijk een verband worden gelegd tussen bepaalde namen en adellijke titels of predikaten. Door toevoeging van een geslachtsnaam zou dan een niet gewenste verandering kunnen ontstaan. In de jurisprudentie zijn niettemin twee gevallen bekend waarbij een uitzondering werd gemaakt.

\section{Overgangsrecht inzake geslachtsnaamswijziging}

Het eerste geval betrof een verzoek uit 1996 van een lid van de Nederlandse adel, die de naam van zijn adellijke moeder met haar toestemming aan de zijne toegevoegd wenste te zien. Hij kon voorts aantonen, dat van de grootvader van vaderszijde van zijn moeder geen mannelijke afstammelingen in de mannelijke lijn meer in leven waren, van wie nog nakomelingschap te verwachten was (voorwaarde in art. 2, lid 1b). De staatssecretaris van Justitie vroeg advies aan de Hoge Raad van Adel omdat de verzoeker zich weliswaar realiseerde niet aan art. 3 van het Naamswijzigingsbesluit te voldoen, maar dat het omschreven bezwaar (verwarring omtrent adeldom en/of titulatuur) hier niet gold. Beide geslachten behoorden tot de Nederlandse adel, waren ongetiteld en kenden geen niet-adellijke takken. De Raad bracht op 13 januari 1997 positief advies uit. De algemene reden om naamstoe-

\footnotetext{
${ }^{633}$ Sewandono, 'Zijne doorluchtigheid de hertog van Parma', 725-726.

${ }^{634}$ AR (Zutphen) 1 april 1999, nr. 18503 FARK 981332.

${ }^{635}$ Nader bepaald in het op basis van het BW 1:7, lid 5, vastgestelde KB van 6 okt. 1997 (Stb. 463) houdende regels voor geslachtsnaamwijziging, art. 5 .

${ }^{636}$ KB van 6 okt. 1997 (Stb. 463), art. 2.
} 
voeging wettelijk toe te staan, namelijk om verarming van het namenbestand tegen te gaan, werd daarin onderschreven. De verwarring die in het maatschappelijk verkeer ten opzichte van adellijke namen en titels zou kunnen ontstaan, had destijds, op voorstel van de Raad naar aanleiding van een concreet voorbeeld, geleid tot de uitzonderingsbepaling. In casu zag hij echter geen bezwaren, zoals in de memorie van toelichting omschreven, en deed zelfs opties voor concrete toepassing: geen afgekorte (delen van) namen en bij uitzondering achter in plaats van vóór de bestaande naam, maar dan wel met een koppelwoord 'gezegd' of 'genaamd', zoals in omringende landen gebruikelijk was. ${ }^{637}$ Toch was de staatssecretaris niet onmiddellijk genegen het verzoek in te willigen, mede omdat precedentwerking werd gevreesd. In dit verband wilde hij van verzoeker weten in welke casus kortgeleden (ook) zou zijn afgeweken van de bepaling, zoals deze als argument had opgevoerd. Voorts zou verzoeker nog moeten aangeven of hij kinderen had, die de naam van hun vader zouden willen voortzetten, indien het verzoek zou worden ingewilligd. Kennelijk waren deze beide vraagpunten van tafel toen de staatssecretaris van Justitie op 7 september 1999 groen licht kon geven, louter op grond van het overgangsrecht. De Richtlijnen voor geslachtsnaamswijziging 1989, die aan die van 1997 waren voorafgegaan, kenden nog een uitzonderingsregel 'in het bijzondere geval', die in 1997 verviel. ${ }^{638}$ Het advies van de Raad werd gevolgd in de toepassing van een tussenvoegsel, zodat de toe te voegen naam achter de bestaande kon worden geplaatst. ${ }^{639}$

\section{Eerst naamswijziging, dan adeldom?}

Het tweede geval was van formele aard. Een inlijvingsverzoek volgens de overgangsbepaling in de Wet op de adeldom, gecombineerd met een verzoek om toevoeging van een naam, was op advies van de secretaris van de Hoge Raad van Adel ontkoppeld omdat het verschillende aanvragen betrof, die onder verschillende ministers vielen. Op dat moment kon de Hoge Raad van Adel zich wel buigen over het inlijvingsverzoek, maar had hij (nog) niet van doen met het naamswijzigingsverzoek omdat beide namen geen 'adellijke namen' betroffen en verzoeker niet tot de Nederlandse adel behoorde. ${ }^{640}$ Ten aanzien van het inlijvingsverzoek bracht de Raad positief advies uit aan de minister van Binnenlandse Zaken, waarna in de jaren 1996 tot en met 1998 bij koninklijk besluit adeldom werd verleend aan meer familieleden. Toen vervolgens door een van de familieleden alsnog naamsvermeerdering werd verzocht bij de staatssecretaris van Justitie kreeg deze nul op het rekest, omdat de verzoeker van adel was. Deze liet het er niet bij zitten en bracht de zaak voor de rechter. Deze nam de inmiddels adellijke burger in bescherming

\footnotetext{
${ }^{637}$ HRvA, RA, not. 1996-35.

${ }^{638}$ Op grond van deze uitzonderingsregel werd bij KB van 24 nov. 1992, nr. 92.010847, aan jonkheer József Béla Jankovitch en zijn vier kinderen naamswijzing toegestaan in Jankovitch de Jeszenice (HRvA, not. 1991-14.

${ }^{639}$ Besluit Staatssecretaris van Justitie d.d. 7 sept. 1999, nr. NM 963/170 (rapport nr. NMR 990/089). KB van 30 nov. 1999, nr. 99.005649 (Van Nispen tot Sevenaer genaamd Ruijs de Beerenbrouck).

${ }^{640}$ HRvA, RA, not. 1996-37.
} 
en was van mening dat de secretaris van de Hoge Raad van Adel hem hier expliciet van op de hoogte had moeten stellen. Van een burger kon niet verwacht worden dat deze tot in de finesses op de hoogte was van een verandering van omstandigheden na inlijving. Sterker nog, door de optie van splitsing van de twee zaken, was de verwachting gewekt, dat er na inlijving nog mogelijkheden voor hem zouden zijn. ${ }^{641}$ Naamswijziging, eveneens door de toe te voegen naam achter de bestaande naam te plaatsen, werd in 2000 alsnog verleend. ${ }^{642}$

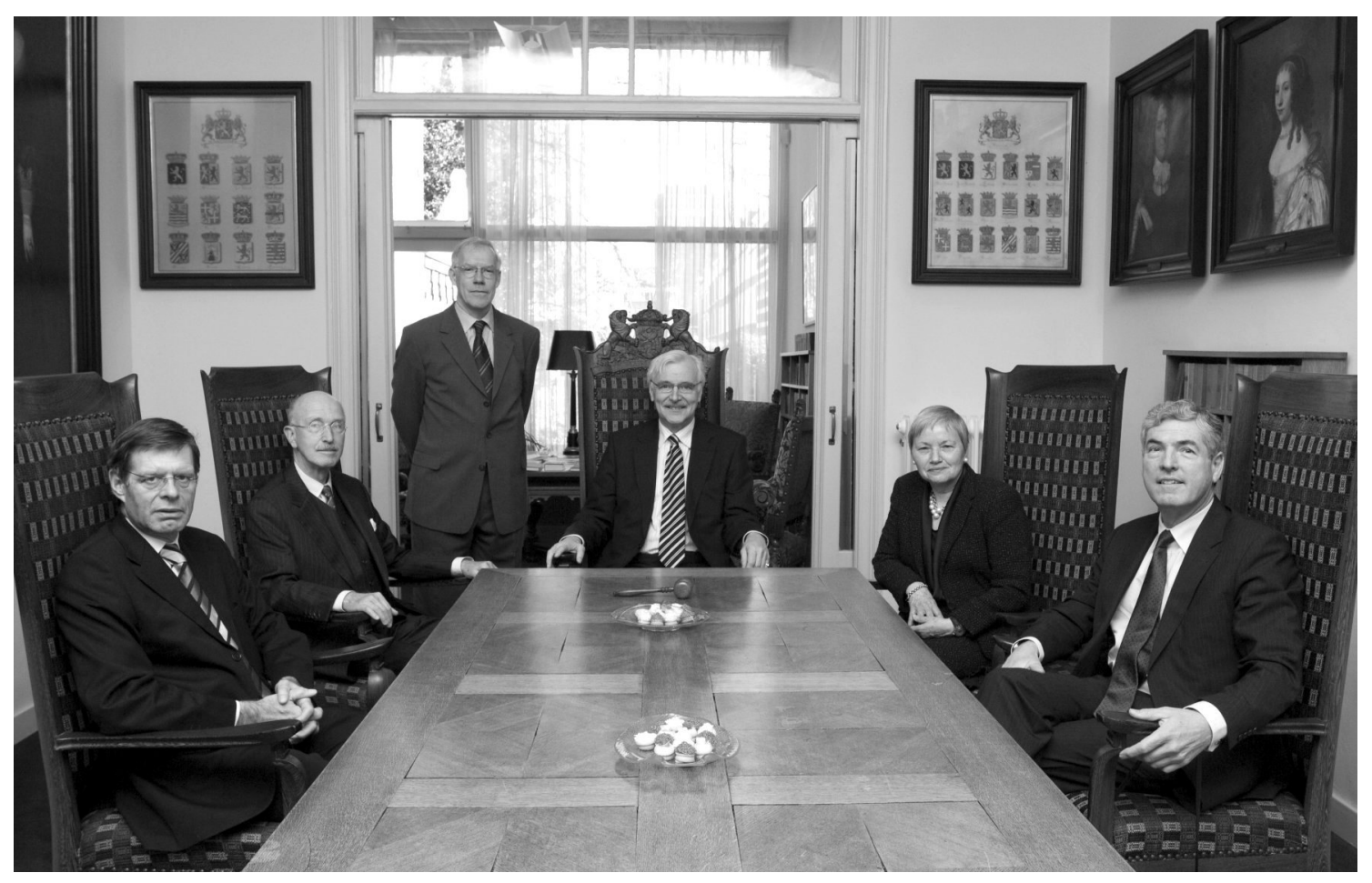

De Hoge Raad van Adel in zijn Raadzaal, Nassaulaan 2B, 's-Gravenhage. Zittend v.l.n.r.: jonkheer F.K.M. van Nispen tot Pannerden, J.P. Eschauzier, C.O.A. baron Schimmelpenninck van der Oije (voorzitter), jonkvrouw M. van den Brandeler en H.C.R.M. baron de Wijkerslooth de Weerdesteijn. Staande: E.J. Wolleswinkel, secretaris.

Foto Frank Krijger, Rijswijk Z.H. 2008. Collectie en foto HRvA, 's-Gravenhage.

Dit betekende overigens niet dat deze weg daardoor open stond voor alle familieleden, die hetzelfde wensten. De Afdeling Bestuursrechtspraak van de Raad van State wees in hoogste instantie een verzoek uit 2004 van een ander lid van hetzelfde adellijke geslacht af op grond van art. 2, lid 3, van het Naamswijzigingsbesluit van 1997, en concludeerde dat de uitspraak van de Rechtbank Den Haag niet in strijd was met art. 14 (non-discriminatie) van het EVRM. ${ }^{643}$

\footnotetext{
${ }^{641}$ AR ('s-Hertogenbosch) 15 mei 2000, AWB 99/3218 BESLU.

${ }^{642} \mathrm{~KB}$ van 5 aug. 2000, nr. 00.004396 (De Lange van Bergen).

${ }^{643}$ AR (Den Haag) 1 nov. 2004, nr. AWB 04/1308 BESLU; ABRvS 17 aug. 2005, 200410185/1 (De Lange).
} 


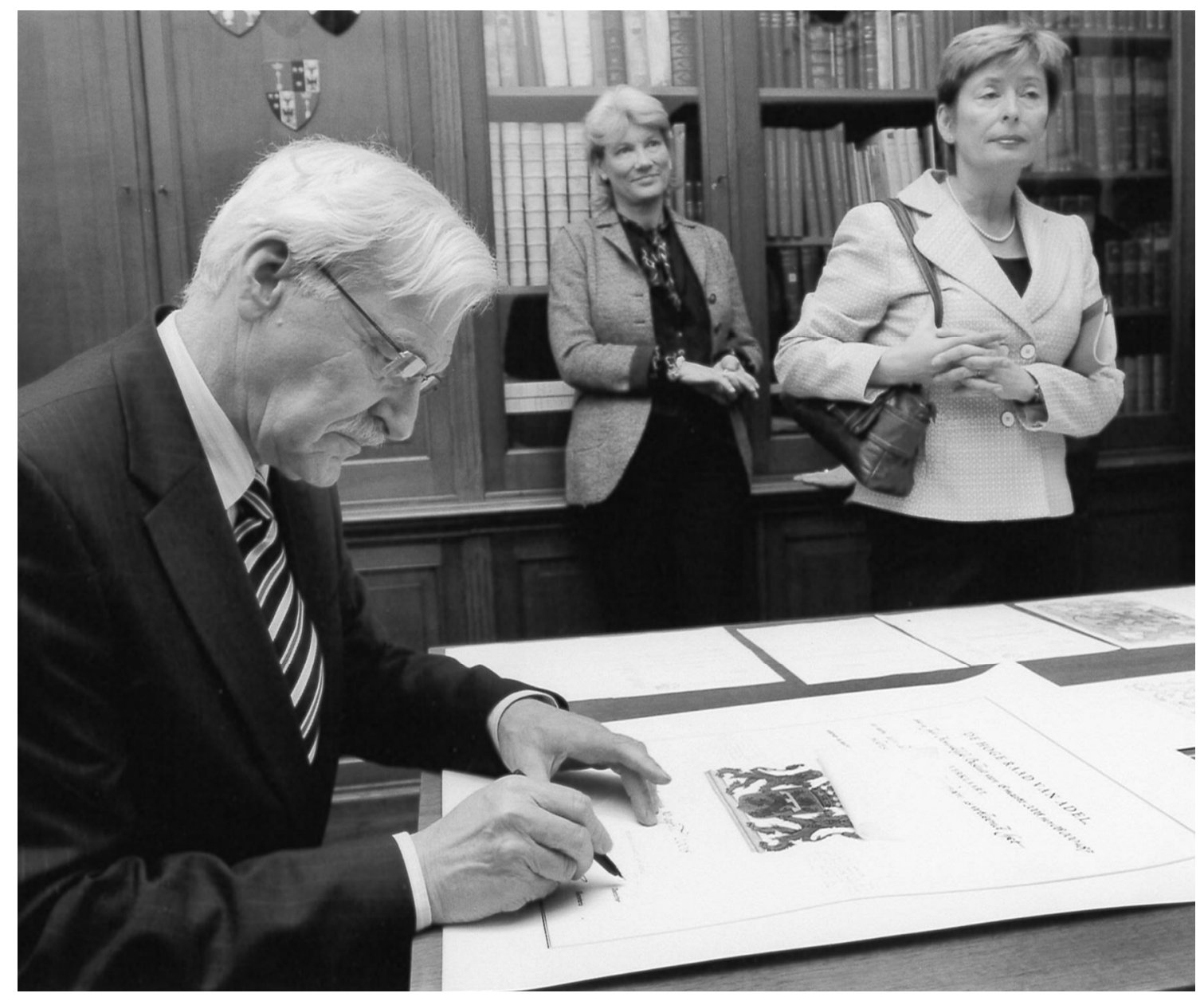

Tijdens het werkbezoek op 10 april 2008 van de minister van Binnenlandse Zaken en Koninkrijksrelaties, G. ter Horst, aan de Hoge Raad van Adel ondertekende voorzitter C.O.A. baron Schimmelpenninck van der Oije het wapendiploma voor de nieuwe gemeente Teylingen. Zij werd begeleid door A.C. van Es, directeur-generaal bestuur van het Ministerie.

Foto Frank Krijger, Rijswijk Z.H. Collectie en foto HRvA, 's-Gravenhage.

Met verwijzing naar twee uitspraken van het Hof te Straatsburg uit 1994 stelde de Afdeling vast dat de geslachtsnaam, als middel tot persoonlijke identificatie en als blijk van een familiebetrekking, tot het privé- en familieleven is te rekenen in de zin van artikel 8 van het EVRM. ${ }^{644}$ Dit recht op 'family life' wordt eerst geschonden als voor een verschil in behandeling in de zin van art. 14 van het EVRM geen objectieve en redelijke rechtvaardiging aanwezig is, dat wil zeggen als deze niet een legitiem doel dient en de ongelijke behandeling ten opzichte van het na te streven doel disproportioneel is. ${ }^{645}$ Volgens de Afdeling had de rechtbank - gezien 'a certain margin of appreciation', die de verdragsstaten volgens het arrest van 25 nov. 1994 toekomt - met juistheid overwogen dat voor het onderscheid tussen adellijke en niet-adellijke personen, zoals in artikel 2, derde lid, van het Besluit Naamswijziging bepaald, een objectieve en redelijke grond bestaat. Om deze reden

\footnotetext{
${ }^{644}$ EVRM van 22 febr. 1994, Series A, nr. 280-B (Burghartz contra Zwitserland).

${ }^{645}$ EVRM van 25 nov. 1994, Series A, nr. 299-B (Stjerna contra Finland).
} 
faalde ook het beroep van appellant op art. 26 van het IVBuPo, waarin wordt bepaald dat allen gelijk zijn voor de wet en zonder discriminatie aanspraak hebben op gelijke bescherming door de wet.

\section{Biologische en maatschappelijke werkelijkheid}

De laatste jaren is een tendens waarneembaar van meer begrip van de rechter voor de biologische en maatschappelijke werkelijkheid boven het belang van de strikte handhaving van wettelijke termijnen, mits niet de rechtszekerheid en de belangen van andere betrokkenen worden geschaad. Onlangs vernietigde het Gerechtshof Den Haag de uitspraak van de rechtbank, waarin geweigerd werd een erkenning ongedaan te maken omdat de gestelde termijn was overschreden: 'hoewel in beginsel het stellen van termijnen geen ongerechtvaardigde inmenging is in het familie- en gezinsleven van betrokkenen in de zin van artikel 8 EVRM, is het Hof van oordeel dat toepassing van de in art. BW 1:205, lid 4, gestelde termijn in de geschetste omstandigheden naar maatstaven van redelijkheid en billijkheid een ongerechtvaardigde inmenging in het familie- en gezinsleven van de dochter is' ${ }^{646}$

In een recent arrest van het EVRM over de naar Maltees recht onmogelijke verwerving van de nationaliteit van de vader door een buiten het huwelijk in GrootBrittannië geboren kind van een Maltese vader en een Britse moeder, maakte het Hof te Straatsburg onderscheid tussen 'family life' en 'private life'. Door de kortstondige relatie van de ouders kon het kind geen beroep doen op een 'family life', dat immers niet had bestaan, maar wel op discriminatie van zijn 'private life', dat het niet verwerven van de nationaliteit voor de sociale identiteit van hem persoonlijk betekende. De discriminatie zat in de onmogelijkheid om de nationaliteit op grond van de bloedband (iure sanguinis) te verwerven voor buiten het huwelijk geboren kinderen, er vanuit gaande dat nationaliteitsverwerving volgens het recht van de betreffende lidstaat door die staat wettelijk is geregeld. Tot dit laatste kan een land namelijk niet worden verplicht. ${ }^{647}$

\section{Volgorde primogenituur na geslachtsverandering}

Ook binnen de Nederlandse adel kunnen zich gevallen van geslachtsverandering voordoen. Naar aanleiding van een concrete zaak moest de Hoge Raad van Adel in samenwerking met de ambtenaar van de burgerlijke stand de vraag oplossen of het predikaat in de geboorteakte verbogen moest worden van jonkvrouw in jonkheer. De Raad kon in 2004 tot geen ander advies komen - cryptisch geformuleerd - dan dat het geslacht van een lid van de Nederlandse adel bepalend is voor de verbuigingsvorm van de verleende adellijke titulatuur. Uitgaande van de algemene verplichting dat de gekozen voornaam gerelateerd moet zijn aan het geslacht van het kind, dient dan bij wijziging van de voornamen in de geboorteakte op grond van

\footnotetext{
${ }^{646}$ GH (Den Haag) 19 jan. 2011, LJN: BP9615; Burgerzaken \& Recht 19 (2012), 22-24 (jurisprudentie).

${ }^{647}$ EHRM van 11 okt. 2011, nr. 53124/09; Europese Human Rights Cases (EHRC), 13 jan. 2012, afl. 1: Uitspraken EHRM, nr. 12, met noot G.R. de Groot.
} 
een medisch-psychologische verklaring van geslachtsverandering, gelijktijdig ook titel of predikaat op deze wijze te worden aangepast. De geboorteakte blijkt dus leidend te zijn voor de adelsrechtelijke gevolgen. ${ }^{648}$

In aansluiting daarop nam de Raad in 2008 een principebesluit over de aanwijzing van de rechthebbende op een adellijke titel bij eerstgeboorte overeenkomstig het KB van 26 maart 1868 (Stb. 37), de zogenaamde primogenituur. Deze aanwijzing, die de hiërarchie volgt binnen het betreffende adellijke geslacht en waarbij wettige eerstgeboren zonen naar anciënniteit voorrang hebben, wordt na het overlijden van de rechtsvoorganger op verzoek van de rechthebbende gedaan. Op dat moment wordt op grond van de dan rechtens bekende gegevens de aanwijzing gedaan. Wanneer in een later stadium door geslachtsverandering een andere volgorde of hiërarchie binnen de familie zou ontstaan, blijft het moment van aanwijzing bepalend. De Raad realiseerde zich vervolgens dat hij een kandidaat, die al voor de vererving van de titel geslachtsverandering had ondergaan en daardoor een wettige mannelijke afstammeling was geworden, als rechthebbende zal moeten aanwijzen. ${ }^{649}$ Daarentegen zal in de academische situatie, dat een drager van de titel bij eerstgeboorte van geslacht verandert, deze titel vervolgens moeten worden ingeleverd, waarna de opvolgende kandidaat kan worden aangewezen.

\footnotetext{
${ }^{648}$ Jaarverslag HRvA over 2004, 2.
}

${ }^{649}$ HRvA, RA, not. 2008-18. 


\section{Het vigerende adelsrecht belicht aan de hand van actuele vraagstukken}

\section{Inleiding}

Van de vier in 1815 beschreven rechten van de Nederlandse adel bleven er na 1850 , toen de staatsrechtelijke positie voor de ridderschappen als kiescollege voor het parlement (art. 1) ophield te bestaan, aanvankelijk drie en sedert 1923 nog twee over. ${ }^{650}$ De ene is de verplichting van de overheid om adellijke titulatuur op alle officiële documenten te vermelden (art. 2). De andere is de bevoegdheid tot het openlijk voeren en gebruiken van het bij koninklijk besluit vastgestelde adellijke familiewapen (art. 3). Het voeren van een familiewapen is nooit een exclusief recht voor edellieden geweest, maar wel het exclusief voeren van het bij koninklijk besluit vastgestelde eigen familiewapen. In geval van usurpatie geeft deze juridische basis in procedures een grotere bescherming dan voor niet-geregistreerde wapens bestaat. ${ }^{651}$ Het derde voorrecht, dat een edelman het jachtrecht heeft in de gehele provincie alwaar hij woonachtig is (art. 4), is sedert de afschaffing van het heerlijk jachtrecht in 1923 geen exclusief recht meer. ${ }^{652}$

Adellijke identiteit laat zich bij wettelijke adeldom moeilijk peilen, aangezien biologische afstamming niet van belang is en vererving alleen langs mannelijke lijn plaatsvindt. In het maatschappelijk verkeer ervaren adellijke verwanten die niet binnen de regelgeving vallen, soms een moeilijk te definiëren discrepantie tussen de wet en het bloed. Deze is aanleiding geweest voor menige juridische procedure waarbij de bestaande wetgeving werd aangevochten. Veel adellijk bloed, als daar al van gesproken kan worden, vloeit immers langs vrouwelijke lijn weg. Inmiddels kan door middel van DNA-onderzoek biologische adellijke afstamming worden bewezen die dan juridisch voor het adelsrecht niet bestaat, tenzij een gerechtelijke vaststelling van het vaderschap van een adellijke man heeft plaatsgevonden.

In de hierna volgende paragrafen zal het vigerende adelsrecht eerst institutioneel worden behandeld, waarbij ook de huidige positie en status van de Hoge Raad van Adel aan bod komen. Vervolgens zal de status quo van het adelsrecht na de inwerkingtreding van en de jurisprudentie op de Wet op de adeldom worden beschreven. Uitgebreid wordt ingegaan op de problemen die edellieden - dat wil zeggen personen die volgens hun geboorteakte tot de Nederlandse adel behoren - ondervinden bij de implementatie van hun belangrijkste privilege: het recht op vermelding van

\footnotetext{
${ }^{650}$ SB van 13 februari 1815 , nr. 60 (Stb. 15).

${ }^{651}$ Uitzonderingen worden beschreven door Van den Borne, 'Voorportaal van adeldom? De Hoge Raad van Adel en burgerwapens in Nederland', 277-312.

${ }^{652} \mathrm{Bij} \mathrm{KB}$ van 8 febr. 1815, nr. 42 (Stb. 11) definitief als heerlijk recht hersteld, bij Wet van 6 juli 1850 nader geregeld en bij Wet van 2 juli 1923 (Stb. 331) afgeschaft (art. 70: alle jachtrechten zijn opgeheven).
} 
de hun competerende adellijke titulatuur op overheidsdocumenten. De overheid kan niet volstaan met het louter vermelden van deze titulatuur, maar dient ook zogenaamde aanschrijfgegevens in acht te nemen. Deze vinden hun oorsprong in het traditionele gewoonterecht, dat in 1970 werd gecodificeerd en in 1998 sekseneutraal verklaard, maar lijkt te botsen met de adellijke gedragscode.

Ten slotte komt aan de hand van een aantal actuele vraagstukken het spanningsveld van het adelsrecht als constitutioneel recht van het Koninkrijk der Nederlanden aan de orde in verhouding tot het (internationaal) privaatrecht, in het bijzonder met betrekking tot het naamrecht.

\section{Institutionele consequenties}

\section{Een stand buiten de staat}

Uit het historisch overzicht blijkt dat de staatsrechtelijke rol van de adelstand, die op de Grondwet van 1814 was gefundeerd, weer verdween uit de Grondwet van 1848 (adelstand werd in artikel 63 gewijzigd in adeldom) en met de Provinciale wet van 1850 definitief uitgespeeld raakte. De situatie van na 1850 was in zekere zin vergelijkbaar met die in de periode 1795-1813, die door de eerste president van de Hoge Raad van Adel, W.A. baron van Spaen la Lecq, wel de 'annulatie' (annulering) van de (Nederlandse) adel werd genoemd. ${ }^{653}$ De adel had opgehouden een stand in de staat te zijn en verloor daarbij de daaraan verbonden voorrechten. Deze annulatie in de Bataafs-Franse tijd betekende volgens Van Spaen niet dat 'een persoon, bekend van adellijke geboorte en afkomst dezes Lands door het vernietigen van bestaan hebbende Ridderschappen en adelstand in den staat, zijn adeldom zoude hebben verloren gehad of dat zulk één om in den in te stellen adelstand der Vereenigde Nederlanden verheven te worden, eene nieuwe creatie van adeldom zoude benodigd hebben'. Onder verwijzing naar artikel 42 van de Grondwet van 1814 en naar artikel 21 van de instructie van de Hoge Raad van Adel bevestigde hij vervolgens 'dat niet de vanouds voor adellijk en riddermatig erkende geslachten en persoonen tot de voorregten van den in te stellen adelstand der Vereenigde Nederlanden in den staat bevoegd zijn, dan na alvoorens door den souvereinen vorst erkend te zijn daartoe te behoren'. ${ }^{654}$

Hoewel onder de staatsrechtsgeleerden de meningen over de verloren staatsrechtelijke positie van de adel na 1850, in samenhang met de handhaving van het koninklijke prerogatief in de grondwet, uiteenliepen, overheerste de gedachte dat het verlenen van eretitels en ridderorden als natuurlijk attribuut van het koningschap door schrapping uit de grondwet niet zou worden aangetast. ${ }^{655}$ Het meest vergaand toonden zich de samenstellers van de proeve voor een nieuwe grondwet in 1966 met hun conclusie: 'Aangezien het Nederlandse recht geen rechten en plichten

\footnotetext{
${ }^{653}$ HRvA, RA, inv. nr. 1 (not. 1814-3).

${ }^{654}$ HRvA, RA, inv. nr. 2 (not. 1814-49), advies namens de Raad aan de koning, d.d. 12 okt. 1814.

${ }^{655}$ Westerbeek, De Hoge Raad van Adel, 20-22.
} 
verbindt aan de adeldom, betekent het verlenen van adeldom positiefrechtelijk niet meer dan het toestaan van een bijzonder soort naamsverandering. Aan een grondwettelijke bepaling ter zake is reeds daarom geen behoefte. ${ }^{656}$ In zijn advies aan de minister van Binnenlandse Zaken wees de Hoge Raad van Adel op de koninklijke waardigheid, waarvan de bevoegdheid adeldom te verlenen een normaal aspect is. Het schrappen van deze bepaling uit de grondwet zou tot vermindering van koninklijk aanzien bijdragen; de grondwet diende er mede toe de (grenzen van) de bevoegdheden van het staatshoofd aan te geven. ${ }^{657}$ Luiking was van mening dat dit recht van de koning niets (meer) met de inrichting van het staatsbestel had te maken en dus zonder verlies van aanzien in een wet zou kunnen worden geregeld. ${ }^{658}$ Dit getuigde van een vooruitziende blik, al vond verwijdering uit de grondwet niet in 1972 plaats maar in 1983, en kwam de wet eerst in 1994 tot stand.

\section{Onbezoldigde ereambten}

Een niet expliciet genoemd voorrecht dat de adel als groep in 1814 ten deel viel, was het privilege van leden van de Nederlandse adel om zitting te nemen in een adviescollege van (aanvankelijk de koning en na 1850) de minister over verzoeken tot verlening van adeldom, te weten de Hoge Raad van Adel. Deze kreeg in 1994 wettelijke bescherming, voor zover de instructie van de Raad uit 1814 al niet als een wet in formele zin kan worden gezien. Het laatste lid van artikel 6 van de Wet op de adeldom luidt dat de Raad is samengesteld uit vijf leden, die bij koninklijk besluit worden benoemd en ontslagen. Hierin staat niet de voorwaarde vermeld dat een meerderheid (minimaal de president en twee leden) van de Raad tot de adel der Verenigde Nederlanden moet behoren. Deze is echter terug te vinden in het SB van 24 juni 1814, nr. 10, art. 2, de nog altijd geldende instructie voor de Raad, art. II. Dit privilege betreft dus geen recht van individuele leden van de Nederlandse adel om zitting te nemen - een lid van de Hoge Raad van Adel wordt bij KB benoemd na een voordracht vanuit de Raad - maar een recht van de groep om de minister over verzoeken tot verlening van adeldom te adviseren. ${ }^{659}$

In 1968 werd op verzoek van de Afdeling Financiële Zaken en Comptabiliteit van het Ministerie van Binnenlandse Zaken een literatuuronderzoek verricht naar de Hoge Raad van Adel en zijn plaats op de rijksbegroting. In een intern rapport stond de positie van de Raad als hoog college van staat centraal, een benaming die was bedacht voor colleges waarvan de financiën vanouds in een apart hoofdstuk van de rijksbegroting, te weten hoofdstuk II, waren ondergebracht. ${ }^{660}$ Onderzoeker en auteur Westerbeek onderkende zeven perioden, waarin de Raad gedurende twee daarvan op deze grond tot de hoge colleges van staat werd gerekend: 1814-1819 en 1844-1852. Tussen 1820 en 1843 voorzag de Raad door eigen inkomsten - uit het

\footnotetext{
${ }^{656}$ Proeve van een nieuwe Grondwet (Ministerie van Binnenlandse Zaken 1966), 229.

${ }^{657}$ HRvA, RA, inv. nr. 230 (not. 1966-44), d.d. 19 mei 1967, Scrt. 229, 3.

${ }^{658}$ Luiking, 'De "Proeve van een nieuwe Grondwet" en de adel', 408-411.

${ }^{659}$ Wet op de adeldom, art. 6, lid 2.

${ }^{660}$ Wet van 13 juli 2002 tot vaststelling van de Wet inzake het beheer van de financiën van het Rijk (Comptabiliteitswet 2001), art. 1.
} 
zogenaamde Adelsfonds, dat gevoed werd uit de op adelsdiploma's geheven taxa ruimschoots in zijn kosten. Van 1853-heden maakt de secretarie van de Raad financieel onderdeel uit van de Departementen van Binnenlandse Zaken, Jusititie, Algemene Zaken en vanaf 1945 opnieuw van het Ministerie van Binnenlandse Zaken. ${ }^{661}$ De voorzitter en de leden van de Raad bekleden vanaf 1853 een onbezoldigd ereambt en komen sindsdien op geen enkele begroting meer voor. Deze situatie is er mede oorzaak van geweest, dat twijfel is ontstaan over de positie van de Hoge Raad van Adel als hoog college van staat.

Toen in de woelige jaren na de wijziging van de Grondwet van 1848 door minister Thorbecke tot beperking van de taken en ontmanteling van de Raad werd besloten, zag de toenmalige voorzitter jonkheer De Witte van Citters dit als het einde van het instituut als onafhankelijk adviescollege en daarmee als hoog college van staat. Misschien gaf hij daarmee onbewust een acceptabele definitie van hoge colleges van staat als onafhankelijke adviescolleges van de regering zonder dat van een hiërarchisch verband sprake is. De Witte van Citters bood naar aanleiding daarvan op 30 december 1852 zijn ontslag aan en sloot zijn brief aan de koning af met de volgende alinea:

'Hoewel de bepalingen waarbij de werkzaamheden waarmede de Hooge Raad van Adel tot nu toe belast is geweest, hem ontnomen wierden, mij zeer griefden, zoo wenschte ik evenwel mijn leed daarover aan Uwer Majesteits verlangen op te offeren en besloot mij aan die bepalingen te onderwerpen. Maar daar op eergisteren de Raad bij Besluit van den Minister van Binnenl. Zaken van den $27^{\mathrm{e}}$ dezer (Kabinet No. 204) verwittigd is geworden, dat met $1^{\mathrm{e}}$ January 1853 over het lokaal tot dus ver bij dien Raad in gebruik anders zal worden beschikt en met dat tijdstip de meubelen, archieven, boeken, notulen of andere bezittingen namens dien Minister door den referendaris Baron d'Ablaing van Giessenburg overgenomen moeten worden - en ten volle uit dit Ministerieel besluit komt te blijken dat zelfs de schijnbare zelfstandigheid die de Hooge Raad van Adel nog na het Besluit van 20 July 1850 (No. 55) gehouden had, met January 1853 geheel zal komen te vervallen - zoo zal Uwe Majesteit het mij wel ten goede wille houden, dat ik na ruim zevenendertig jaren lid, voorzittend lid en laatslijk voorzitter van een op zich zelve gestaan hebbende en bij alle vroegere Rijksbegrootingen onder de Hooge Collegien gerangschikte Raad geweest te zijn, zwarigheid moet maken, mijn gevorderde jaren daarbij in aanmerkingen nemende, aan die Ministerieele beschikking, waardoor de Raad geheel afhankelijk wordt gemaakt van het Departement van Binnenl. Zaken of van eenen gedelegeerde Referendaris, mij te onderwerpen, zoodat mij niets anders overblijft dan aan Uwe Majesteit eerbiedig met den $1^{\text {ste }}$ January 1853 mijn ontslag als voorzitter van den Hoogen Raad van Adel, zooals ik bij deze de vrijheid neem te doen, aan te bieden. ${ }^{662}$

Tot zover de brief van jonkheer De Witte van Citters, die de koning op oudjaarsdag 1852 moet hebben bereikt.

\footnotetext{
${ }^{661}$ Westerbeek, De Hoge Raad van Adel, 13-19.

${ }^{662}$ HRvA, RA, inv. nr. 948, brief d.d. 30 dec. 1852.
} 


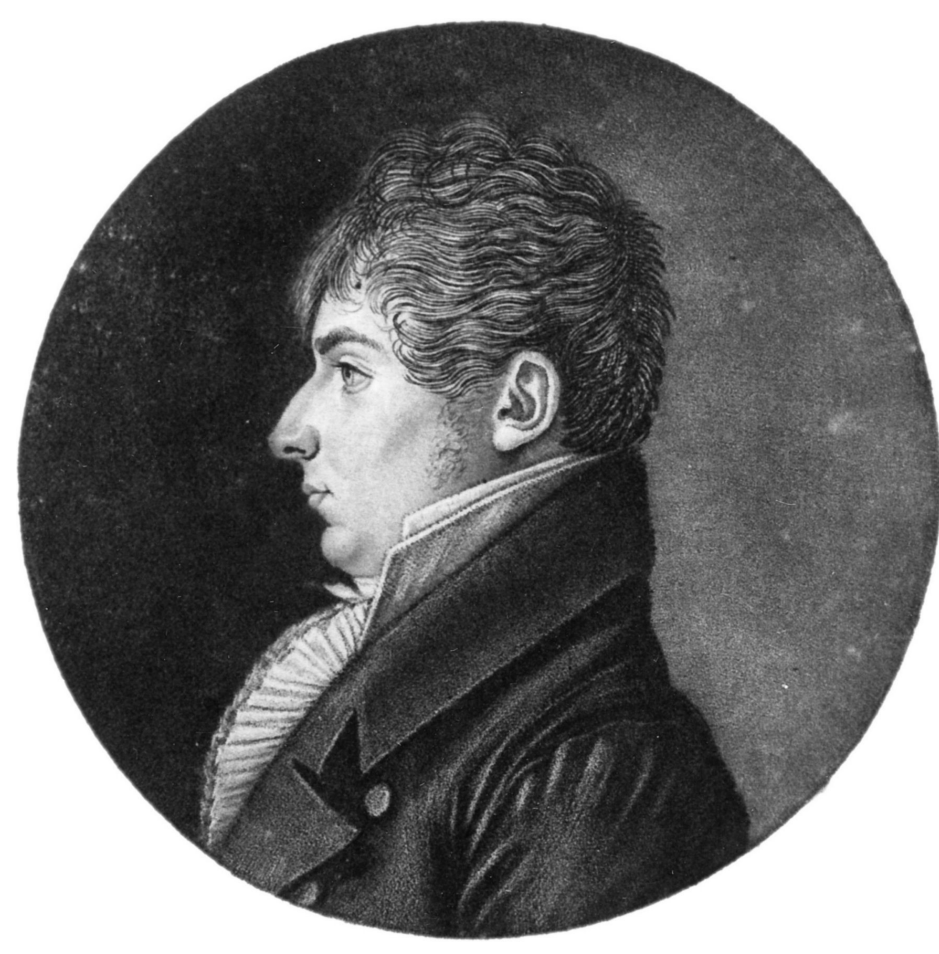

Jonkheer Laurens de Witte van Citters (1781-1862), lid (18151853), fungerend voorzitter (18451850) en voorzitter (1850-1853) van de Hoge Raad van Adel. Physionotrace (gravure).

Collectie en foto RKD/IB, 's-Gravenhage.

\section{Hoge colleges van staat}

De hoge colleges van staat die thans nog in een apart hoofdstuk van de rijksbegroting zijn opgenomen, zijn de Raad van State, de Staten-Generaal, de Algemene Rekenkamer, de Nationale ombudsman en de Kanselarij der Nederlandse Orden. ${ }^{663}$ Het Kabinet van de Koning werd ook altijd als zodanig beschouwd, maar staat thans op de begroting van het Ministerie van Algemene Zaken, terwijl de directeur op het niveau van secretaris-generaal onder directe verantwoordelijkheid van de minister-president valt. ${ }^{664}$

Ook andere criteria zijn soms ingeroepen om onderlinge verschillen aan te duiden en vervolgens te concluderen tot het al of niet behoren tot de hoge colleges van staat. Instelling door of op basis van de grondwet zou bepalend zijn. ${ }^{665}$ De Kapittels der Nederlandse Orden verkeerden in dit opzicht in een vergelijkbare positie als de Hoge Raad van Adel. Ze zijn direct of (thans) indirect bij wet ingesteld als vaste colleges van advies in zaken van bestuur volgens art. 79 van de grondwet, maar niet in zaken van wetgeving. ${ }^{666}$ In feite adviseren deze colleges de minister(s) inzake de uitvoering van beleid dat bij specifieke wet is vastgesteld. Zo ligt in de Wet op de adeldom in artikel 6, lid 2, vast, dat de Hoge Raad van Adel de minister van BZK adviseert over individuele verzoeken tot verlening van adeldom en niet

\footnotetext{
${ }^{663}$ Comptabiliteitswet 2001, art. 1, lid 1g. Aan deze categorie zijn later de Kabinetten van de gouverneurs van Caribisch Nederland toegevoegd.

${ }^{664}$ Ibidem, artt. 1, lid 1e, en 4; KB van 18 dec. 2003, houdende bepalingen over het Kabinet van de Koning (Stb. 2004-8).

${ }^{665}$ Tjeenk Willink, 'Het karakter van een Hoog College van Staat', 14-19.

${ }^{666}$ Grondwet, art. 111: Ridderorden worden bij de wet ingesteld. Bij Rijkswet van 15 april 1994 (Stb. 350) kreeg het vernieuwde decoratiestelsel een wettelijke basis. Vgl. Beks, Van Dam-Kooij en Swen, Adelsbeleid, adelsrecht en het decoratiestelsel ná 1945.
} 
over adelsbeleid. Deze beperking van zijn adviestaak werd ook geconstateerd door het EHRM in Straatsburg in een beroepszaak over gelijke behandeling: 'Aangezien de nationale wetgeving geen beleidsruimte geeft in de toepassing van de Wet op de adeldom, kan niet gezegd worden dat onder de Nederlandse regelgeving een recht op het voeren van een adellijke titel bestaat. Verzoeken om adeldom kunnen slechts worden getoetst aan de drie criteria verheffing, erkenning en inlijving. ${ }^{667}$ Ten slotte zou het uit kunnen maken of de colleges al of niet bestuursorgaan in de zin van de Algemene wet bestuursrecht (Awb) zijn. Met uitzondering van de Kapittels der Nederlandse Orden en de Hoge Raad van Adel worden geen van de hierboven genoemde colleges als zodanig aangemerkt. ${ }^{668}$ De Kapittels en de Hoge Raad van Adel adviseren de minister, die een voordracht of een verzoek al of niet honoreert. Tijdens de procedure die als de Zeeuwse adoptiezaak is bekend geworden, stelde de hoogste bestuursrechter vast dat de Hoge Raad van Adel het filiatieregister van de Nederlandse adel bijhoudt namens de minister van BZK, zodat een bezwaar tot laatstgenoemde moest worden gericht. ${ }^{669}$ Ook op de Kapittels der Nederlandse Orden is een dergelijke rechtsgang van toepassing, maar in een concreet geval was de appellant niet ontvankelijk omdat hij geen belanghebbende in de zin van de Awb was. De toekenning van ridderorden vindt immers zelden op verzoek van de belanghebbende (decorandus) zelf plaats, maar doorgaans op voordracht van derden. ${ }^{670}$

Deze colleges blijken wel bestuursorgaan in de zin van de Awb te zijn, waar het verzoeken om inzage in dossiers betreft op grond van de Wet openbaarheid van bestuur (Wob) en klachtprocedures bij de Nationale ombudsman. ${ }^{671}$ De Afdeling Bestuursrechtspraak van de Raad van State stelde enkele jaren geleden in twee beroepszaken op dezelfde dag vast, dat de Hoge Raad van Adel een bestuursorgaan in de zin van de Awb is en zelf besluiten (in tweede instantie op bezwaar) neemt volgens de Awb. Ook klachten op grond van deze wet moeten volgens de daarin geformuleerde regels door de Hoge Raad van Adel in behandeling worden genomen. ${ }^{672}$ Dat deze uitspraak van de hoogste bestuursrechter een betrekkelijk zware claim legt op de onbezoldigde erepositie van voorzitter en leden van de Hoge Raad van Adel lijdt geen twijfel.

Ook het Kapittel voor de civiele orden werd aangesproken op grond van de Wob, maar de verantwoordelijke minister voor de afgewezen voordracht kon de hoogste bestuursrechter in die zaak overtuigen, dat alle documenten zijn opgesteld ten be-

\footnotetext{
${ }^{667}$ EHRM 18 mei 1999, nr. 45908/99; NJB 1999, 1324-1325, nr. 24 (Wolff Metternich contra Nederland).

${ }^{668}$ Wet van 4 juni 1992, houdende algemene regels van bestuursrecht (Algemene wet bestuursrecht), art. 1, lid 1.

${ }^{669}$ ABRvS 27 juni 2001, 200000061/1.

${ }^{670}$ Van Ingen en De van der Schueren, Van herkenning tot erkenning, 149 (ABRvS 22 maart 2006, nr. 200508107/1). Een uitzondering was vanouds de Militaire Willemsorde, waarvoor men zichzelf kon voordragen, maar deze gang van zaken blijft uitzonderlijk en kwam in de laatste honderd jaar nauwelijks voor. Vgl. Vogelzang, Militaire Willems-Orde 1815-1990, 6.

${ }^{671}$ Wet van 31 oktober 1991, houdende regelen betreffende de openbaarheid van bestuur (inwerkingtreding 1 mei 1992), Wet van 4 februari 1981, houdende instelling van het ambt van Nationale ombudsman (inwerkingtreding 10 juni 1981) en Aanwijzingsbesluit bestuursorganen Wob en WNo (Stb. 1993, 535).

${ }^{672}$ ABRvS 13 aug. 2008, 200800076/1 (inzake De Bourbon de Parme) en 200800078/1 (inzake Von Devivere).
} 
hoeve van intern beraad (Wob, art. 11, lid 1). ${ }^{673}$ De status van het Kapittel voor de civiele orden als bestuursorgaan in de zin van de Awb werd nog eens bevestigd bij de vaststelling van zijn instructie. ${ }^{674}$

In 1994 werd het decoratiestelsel als beloningssysteem voor Nederlanders die zich maatschappelijk verdienstelijk hebben gemaakt, aanzienlijk gedemocratiseerd. Veel stukken betreffende de behandeling van deze (nog) betrekkelijk recente voordrachten vallen echter onder de werking van de Wet bescherming persoonsgegevens (Wbp). ${ }^{675}$ De archieven van de periode voor 1994, toen nog het oude regiem gold, zijn openbaar voor zover deze niet privacygevoelig van aard zijn (Wob, art. $10, \operatorname{lid} 1 \mathrm{~d}){ }^{676}$

Verzoeken om adeldom waarover de Hoge Raad van Adel advies aan de minister uitbrengt, vallen om dezelfde reden als bij de Kapittels onder de werking van de Wbp, maar de adviezen zelf zijn op grond van art. 80, lid 1, van de grondwet openbaar. Deze worden door de minister van BZK, aan wie ze zijn uitgebracht, verstrekt voor zover geen belangen die via de Wbp of andere wetten beschermd worden, in het geding zijn. Laatstelijk verplichtte de Afdeling Bestuursrechtspraak van de Raad van State de minister van BZK het door de Hoge Raad van Adel uitgebrachte advies, inzake een inlijvingsverzoek op grond van het overgangsartikel in de Wet op de adeldom, openbaar te maken naar aanleiding van een Wobverzoek. $^{677}$

\section{De Hoge Raad van Adel als hoog college van staat}

Concluderend lijkt de Hoge Raad van Adel zijn kwalificatie als hoog college van staat te hebben verloren toen zijn zelfstandige positie tussen 1853 en 1858 tot een minimum was teruggebracht en de secretarie onderdeel werd van het departement. Onder het Departement van Justitie bleef deze positie vervolgens constant minimaal, maar zij verbeterde opmerkelijk bij de totstandkoming van het vierde Kabinet Colijn. Onder dat bewind kreeg de Hoge Raad van Adel in 1937 zijn oude positie als hoog college van staat in zijn functie van adviseur van de minister van Algemene Zaken terug. Ik kan me niet aan de indruk onttrekken, dat de toetreding van de vice-president van de Raad van State, jonkheer F. Beelaerts van Blokland, in 1935 als lid van de Hoge Raad van Adel op de achtergrond een doorslaggevende rol heeft gespeeld. Fockema Andreae rekende de Hoge Raad van Adel (weer) tot

\footnotetext{
${ }^{673}$ Van Ingen en De van der Schueren, Van herkenning tot erkenning, 143-144 (ABRvS 14 maart 2000, nr. H01.99.0603).

${ }^{674} \mathrm{~KB}$ van 19 november 1994 (Stb. 831), houdende nadere regels inzake de samenstelling, de inrichting en de werkwijze van het Kapittel voor de civiele orden, nota van toelichting (algemeen, slotpassage).

${ }^{675}$ Wet van 6 juli 2000, houdende regels inzake de bescherming van persoonsgegevens (Wet bescherming persoonsgegevens) (inwerkingtreding 1 september 2001).

${ }^{676}$ Volgens de Archiefwet 1995, art. 13, lid 3, kan in bijzondere gevallen ontheffing worden verleend van de verplichte overbrenging van archiefbescheiden, die ouder zijn dan twintig jaar, naar een archiefbewaarplaats. Over deze ontheffing beschikt de Hoge Raad van Adel voor zijn archieven vanaf 1814-heden, steeds voor tien jaar verleend, onder voorwaarde van onderbrenging in een archiefruimte, die aan de wettelijke eisen voldoet.
}

${ }^{677}$ ABRvS 27 juli 2011, 2010011248/1/H3 (inzake Von Devivere). 
de hoge colleges van staat. ${ }^{678}$ Sedertdien is in de samenstelling en onafhankelijke positie van de Raad geen essentiële verandering gebracht, net zo min als in de bezetting van de secretarie, die nog altijd bestaat uit ambtenaren, zij het sinds 1945 in algemene dienst van het Ministerie van Binnenlandse Zaken. Adelszaken ressorteren bij het Ministerie van BZK onder het Directoraat-Generaal Bestuur en Koninkrijksrelaties, voorheen onder de chef kabinet, thans onder het hoofd van de Sector (Afdeling) Politieke Ambtsdragers. ${ }^{679}$ Onder deze sector valt tegenwoordig ook de overheidscontrole op de bewaking van topsalarissen, een combinatie die ten aanzien van de vervulling van de onbezoldigde ereambten door voorzitter en leden van de Hoge Raad van Adel een tere kant van hun aanstelling blootlegt. Dit temeer, daar zij ook presentiegeld ontberen en de leden geen reiskostenvergoeding ontvangen. ${ }^{680}$

Een verbouwing van de archiefruimte van de Raad, die aan de eisen van de Archiefwet en het Archiefbesluit moest voldoen, kon niet uit het jaarlijkse budget worden gefinancierd, maar uit de post huisvesting hoge colleges van staat. Deze gelden werden in 2009 door het Ministerie van Financiën beschikbaar gesteld aan de Rijksgebouwendienst. ${ }^{681}$

\section{Adelsrecht in beweging}

In de geschiedenis van het Nederlandse adelsrecht zijn enkele cruciale wendingen aanwijsbaar, die gevolgen hebben gehad voor het aantal tot de Nederlandse adel behorende personen. De belangrijkste hebben betrekking op de buitenlandse nationaliteit en op buiten het huwelijk geboren kinderen.

Een vroege bijstelling vond al in 1815 plaats door de soevereine vorst in de aanloop naar diens koningschap. Deze betrof de benoemingbesluiten van verscheidene prominente Nederlanders in de gewestelijke ridderschappen, waarvan het ledenbestand vanwege de herstelde functie van kiescolleges in 1814 op peil moest worden gebracht, die automatisch adeldom tot gevolg hadden. ${ }^{682}$ In de praktijk verwierven op deze wijze ook enkele Nederlanders adeldom die daarvoor volgens de opgestelde adelscriteria niet in aanmerking zouden zijn gekomen. Door middel van reparatiewetgeving corrigeerde de koning deze omissie in 1815 en 1823, waarna adelsen titelverlening alleen nog expliciet kon plaatsvinden en niet meer via benoeming in een ridderschap. ${ }^{683}$

Met betrekking tot de erkenning van oude adeldom werd sinds de nota Beel, die aan de basis stond van het (geheime) besluit van het Kabinet Drees in 1953, nog

\footnotetext{
${ }^{678}$ Fockema Andreae, Rechtsgeleerd handwoordenboek, 11 en 141.

${ }^{679}$ Organisatiebesluit Ministerie van BZK 2006, art. 3.22; Staatsalmanak 2008 e.v.

${ }^{680} \mathrm{~KB}$ van 20 juli 1850 , nr. 55, bepaalde dat de betrekkingen van voorzitter en lid van de Hoge Raad van Adel per 1 jan. 1851 onbezoldigde ereambten werden.

${ }^{681}$ Jaarverslag HRvA over 2009, 10.

${ }^{682}$ Ondermeer bij het verzamel-SB van 28 aug. 1814, nr. 14.

${ }^{683} \mathrm{SB}$ van 13 febr. 1815, nr. 61 (eerst adeldom, dan benoeming); KB van 21 maart 1823, nr. 95 (titel benoemden is persoonlijk).
} 
slechts gesproken over 'Nederlandse adel van vóór 1795', waarmee de verwijzing 'sedert het jaar 1579' leek te zijn losgelaten. Dit zou een versoepeling betekenen met betrekking tot het adelsbeleid volgens de instructie van de Hoge Raad van Adel (art. XVII) en het SB van 4 maart 1815, nr. 85, dat herhaald werd bij KB van 18 dec. 1815 , nr. $46 .{ }^{684}$ De formulering uit het kabinetsbesluit zou uiteindelijk, zonder enige discussie, ook in de Wet op de adeldom van 10 mei 1994 (Stb. 360) worden opgenomen. ${ }^{685}$ Een uitspraak van de Afdeling Bestuursrechtspraak van de Raad van State van 29 april 2003 maakte aan eventuele twijfel die hierover zou kunnen bestaan, een einde. De zaak betrof de afwijzing door de minister van een verzoek van een Nederlandse edelman van oorspronkelijk Duitse origine en zijn familie, die recht meenden te hebben op de inheemse titel van baron. De Afdeling oordeelde dat zij met de rechtbank van mening was dat de invulling die de minister aan het begrip inheemse adel had gegeven niet onredelijk of anderszins onjuist was. De minister rekende tot de inheemse adel 'personen van geslachten, die in de periode vanaf 1579 tot 1795 in een ridderschap zijn beschreven of om andere redenen werden geacht tot de inheemse adel te behoren. Deze inheemse adel kan als maatschappij-adel worden erkend, dat wil zeggen adel die in de maatschappij als zodanig bekend stond, en van wie niet bekend was dat ze ooit niet tot de adel had behoord.' Het beleid ten aanzien van de inheemse titel van baron hield in 'dat deze titel reeds gedurende meer dan een eeuw openlijk gevoerd' moest zijn om daarop aanspraak te kunnen maken. Aangezien appellanten niet in hun bewijs waren geslaagd, bevestigde de Afdeling de uitspraak in hoger beroep. ${ }^{686}$

Ingrijpender was de gewijzigde visie in de loop van de negentiende eeuw met betrekking tot de nationaliteit. Vanaf de eerste Grondwet van 1814 was het uitgangspunt exclusieve verlening van adeldom door de vorst aan Nederlanders geweest, wat nog eens werd onderstreept door de bepaling dat het geen Nederlander geoorloofd was vreemde adeldom aan te nemen. Ten tijde van de stichting van het koninkrijk waren slechts twee uitzonderingen gemaakt, te weten de prins van Waterloo en de markies van Heusden, die beiden de Britse nationaliteit hadden en met hun nageslacht tot op de dag van vandaag tot de Nederlandse adel behoren.

De kentering van het uitgangspunt ontstond na de afscheiding van België, waardoor de Zuid-Nederlandse edellieden, die voor het Koningrijk België opteerden en een andere nationaliteit kregen, niettemin tot de Nederlandse adel gerekend bleven, die de grondslag voor hun adeldom was. De probleemstelling openbaarde zich ten volle toen een nieuwe adelslijst gewenst was om duidelijkheid te krijgen wie wel en wie niet tot de Nederlandse adel behoorde. Na de afscheiding bleek het onmogelijk voor de Hoge Raad van Adel om zicht te krijgen op het aantal afstammelingen van Zuid-Nederlandse adellijke geslachten. Daar tussendoor speelde nog de

\footnotetext{
${ }^{684}$ HRvA, RA, inv. nrs. 3-154 en 7-581.

${ }^{685}$ Als art. 2, lid 4: 'Erkenning te behoren tot de Nederlandse adel kan uitsluitend plaatsvinden ten aanzien van personen die behoren tot een geslacht dat vóór 1795 reeds tot de inheemse adel behoorde.'

${ }^{686}$ ABRvS 29 april 2003, nr. 200204427/1 (HRvA, RA, not. 1999-17); $A B$ 2005, 63 (met noot I. Sewandono).
} 
kwestie van een Nederlandse edelman, die zonder toestemming van de koning in Oostenrijkse krijgsdienst was getreden en wiens Nederlandse adeldom daarmee vervallen leek te zijn. ${ }^{67}$ De minister van Justitie kwam echter tot de conclusie dat betrokkene zijn Nederlandse adeldom niet was kwijtgeraakt 'zolang hij geen onderdaan van een vreemd Rijk was geworden' ${ }^{688}$ Met deze uitspraak ging de minister al gedeeltelijk mee in een gewijzigde visie, die tussen 1871 en 1873 verder gestalte kreeg toen besloten werd om geen nieuwe adelslijsten meer uit te brengen, maar alleen nog aanvullingen op voorgaande. Dit had als praktisch voordeel dat alleen nog het adelsbeleid van de Noordelijke Nederlanden vanaf 1839 zou worden gepubliceerd. De minister deelde vervolgens op 5 juli 1873 aan de Hoge Raad van Adel de algemene regel mee, dat 'verlies van nationaliteit geen verlies van adeldom ten gevolge zal hebben'. ${ }^{689}$ Deze wending was de Hoge Raad van Adel kennelijk in 1952 alweer vergeten, toen hij voorstelde een bepaling in de te wijzigen grondwet op te nemen, die zou moeten luiden: 'Verlies van Nederlanderschap brengt mede verlies van adeldom. ${ }^{690}$ Dit advies is vanwege de ongetwijfeld onvoorziene consequenties voor de Nederlandse adel in het buitenland niet door de staatscommissie Van Schaik overgenomen. Was het aantal afstammelingen van de meer dan vijfhonderd Zuid-Nederlandse geslachten, die voor België opteerden, in 1870 al niet meer te tellen, thans is dit probleem vele malen groter. Dit is een van de redenen waarom het exacte aantal leden van de Nederlandse adel onbekend is. De gemeentelijke basisadministratie persoonsgegevens (GBA) kan bovendien slechts het aantal in Nederland wonende edellieden - personen, die recht hebben op een adellijke titel of een adellijke predikaat - geven maar niet het geëmigreerde deel van de Nederlandse adel met hun nakomelingen. ${ }^{691}$ Sommige geslachten bloeien al generatieslang rijker in het buitenland dan in Nederland en alleen Nederland's Adelsboek kan een aanwijzing over de omvang van het nageslacht geven, zij het gedateerd. ${ }^{692}$

Zonder enige twijfel is de belangrijkste vernieuwing in het Nederlandse adelsrecht tot stand gekomen door het amendement van de Tweede Kamer, dat als artikel 3 in de Wet op de adeldom is terecht gekomen: "Adeldom gaat ook volgens de bestaande regelingen met betrekking tot adeldom over op buiten het huwelijk geboren kinderen.' Deze bepaling betekent niet alleen een verruiming van het toelatingsbeleid, maar ook een handreiking naar de biologische adeldom in het geval het adellijke vaderschap gerechtelijk is vastgesteld. Bij erkenning van een kind door de adellijke vader is biologische afstamming geen voorwaarde, al zal deze doorgaans aanwezig zijn en niet worden betwijfeld.

\footnotetext{
${ }^{687}$ In de beginperiode van het verenigde koninkrijk was vreemde krijgsdienst in samenhang met zonder toestemming van de koning aanvaarde buitenlandse adellijke titulatuur reden tot royement uit de Nederlandse adel geweest (KB van 31 maart 1816, nr. 69: jonkheer A.B.G. van Dedem, heer van de Gelder).

${ }^{688}$ HRvA, RA, inv. nr. 155 (not. 1871-4).

${ }^{689}$ HRvA, RA, inv. nrs. 155 (not. 1873-7) en 878.

${ }^{690}$ HRvA, RA, inv. nr. 213 (not. 1952-37).

${ }^{691}$ De telling van de Hoge Raad van Adel, die geautoriseerde toegang heeft, was ultimo 2011: 8384 personen.

${ }^{692}$ Uitgave van het Centraal Bureau voor Genealogie, 's-Gravenhage.
} 
Uit voorgaande eeuwen zijn verscheidene voorbeelden bekend van buiten een adellijk huwelijk verwekte kinderen, die bij of tijdens dit huwelijk adeldom verwierven door wettiging, maar van wie de biologische vader niet van adel was. Tegen deze oude maas in de regelgeving, die geboorte uit een wettig huwelijk als ultieme voorwaarde stelde, kwam de Hoge Raad van Adel in 1936, overigens tevergeefs, in het geweer. ${ }^{693}$ In dit opzicht komt artikel 3 van de Wet op de adeldom enigszins tegemoet aan de onvrede van de Raad in zijn toenmalige samenstelling. Alleen het naamrecht zoals dat in 1998 is gewijzigd, kan echter nog roet in het eten gooien. Wanneer de ouders voor de geslachtsnaam van de moeder kiezen, is het kind immers niet van adel en gaat de adeldom 'sluimeren'. Het kind zelf heeft na het bereiken van de meerderjarigheid nog de mogelijkheid voor de vadersnaam te kiezen en daarmee de adeldom te laten herleven. ${ }^{694}$

\section{Het Europese Hof voor de Rechten van de Mens heeft gesproken}

Eén van de meest opvallende kenmerken van het vigerende adelsrecht betreft de exclusieve vererving van adeldom langs mannelijke lijn. Een direct gevolg hiervan is de ongelijke behandeling van mannen en vrouwen, die door menigeen als discriminerend wordt ervaren. Tijdens de behandeling van de Wet op de adeldom verdedigde de minister het wetsontwerp steeds met de zinsnede dat 'aanpassing van de regels betreffende de overgang van adeldom aan thans algemene opvattingen afbreuk zou doen aan het wezenlijke, historische karakter van de adeldom en zich niet zou verdragen met het uitgangspunt dat de adeldom uitsluitend als historisch instituut gehandhaafd wordt'. De argumentatie die ten aanzien van de erfopvolging binnen het koninklijk huis, waar geen onderscheid tussen mannen en vrouwen (meer) bestaat, werd gebezigd was spiegelbeeldig: 'in verband met de vele en belangrijke rechtsgevolgen die daaraan verbonden zijn, komt hieraan een ander, zwaarder gewicht toe; mede in verband met de publieke en constitutionele aspecten van het koningschap is de grondwetgever van oordeel geweest, dat een onderscheid naar geslacht bij de vervulling van dit publieke ambt ongewenst is. ${ }^{695}$

De afgelopen decennia is deze ongelijkheid in het Nederlandse adelsrecht op verschillende momenten door nationale en internationale rechters getoetst aan hogere regelingen waarmee deze in strijd zou kunnen zijn. In dit kader zijn een drietal uitspraken van de Afdeling Bestuursrechtspraak van de Raad van State uit de jaren 1985, 1995 en 1999 van cruciaal belang. In het laatstgenoemde jaar heeft het Europese Hof te Straatsburg de laatste twee uitspraken van de Afdeling getoetst aan het EHRM en geen reden gezien tot vernietiging. Hiermee lijkt voorlopig het laatste vonnis geveld te zijn, aangezien het Hof prioriteiten mag stellen en niet snel opnieuw een vergelijkbare zaak op dezelfde uitvoerige wijze zal behandelen. De uitspraak laat nauwelijks aan duidelijkheid te wensen over.

\footnotetext{
${ }^{693}$ HRvA, RA, inv. nr. 204 (not. 1936-17).

${ }^{694}$ Artt. BW 1:5, lid 2-5 en 11; 7, lid 5; KB van 6 okt. 1997 (Stb. 463), art. 5 (Besluit geslachtsnaamswijziging).

${ }^{695}$ Kamerstukken II, 1991-1992, 21 483, nr. 5, p. 4-5.
} 
Ten aanzien van de interpretatie van het geciteerde adelsrecht inzake vererving van adeldom stelde de Afdeling Bestuursrechtspraak van de Raad van State vast dat de bestaande regeling gezien moest worden in de tijd waarin deze was ontstaan. Zij nam daarbij in aanmerking dat het adelsrecht een historisch gegroeid instituut is waaraan sedert 1848 (1850) geen rechten en vrijheden meer verbonden zijn. Tijdens de parlementaire behandeling van de Wet op de adeldom was gebleken, dat de wetgever destijds vererving in mannelijke lijn had bedoeld en dat deze zienswijze overeenkwam met de zienswijze van de huidige wetgever. De Afdeling constateerde geen strijd met artikel 8 (in samenhang met art. 14) van het EVRM, aangezien weigering van inschrijving in het filiatieregister niet als inmenging door de overheid in het privé-leven kon worden aangemerkt, hoewel het niet tot de adel behoren aspecten kan bevatten die tot iemands privé-leven behoren. Evenmin zag de Afdeling strijd met andere geciteerde internationale verdragen, alsmede in artikel 1 van de grondwet beschermde grondrechten. Het handhaven van onderscheid tussen afstamming via mannen of via vrouwen volgens een objectieve en redelijke grond, verantwoord binnen de regelgeving van het historisch instituut adel, die zich niet leende voor aanpassing aan moderne opvattingen over gelijke behandeling, achtte de Afdeling niet strijdig met het gelijkheidsbeginsel of het beginsel van non-discriminatie. Van belang vond zij in dit verband dat de onmogelijkheid adeldom te verwerven altijd gelijkelijk heeft gegolden voor zowel mannen als vrouwen.

Al in 1985 deed de Afdeling Bestuursrechtspraak van de Raad van State inhoudelijk uitspraak over de weigering om een onwettige dochter van een ongehuwde adellijke moeder in te schrijven in het filiatieregister van de Nederlandse adel. De conclusie was dat deze weigering tot inschrijving niet in strijd was met relevante bepalingen in de grondwet, het IVBuPo en het EVRM. ${ }^{696}$ Deze uitspraak werd in 1995 en 1999, in beide gevallen inzake weigeringen om wettige zonen van adellijke moeders in te schrijven, met min of meer dezelfde argumentatie herhaald. ${ }^{697}$

Het EHRM te Straatsburg heeft in de laatste zaak bevestigd dat het enkele bezit of niet-bezit van adeldom door de aard ervan buiten de rechten en vrijheden valt die door het EVRM en bijbehorende protocollen worden beschermd. ${ }^{698}$ Aangezien de nationale wetgeving geen beleidsruimte geeft in de toepassing van de Wet op de adeldom, kan niet gezegd worden dat onder de Nederlandse regelgeving een recht op het voeren van een adellijke titel bestaat. Verzoeken om adeldom kunnen slechts worden getoetst aan de drie criteria verheffing, erkenning en inlijving. ${ }^{699}$

\footnotetext{
${ }^{696}$ ABRvS 9 sept. 1985, R01.84.1081).

${ }^{697}$ ABRvS 21 febr. 1995, R01.92.0559 (Taets van Amerongen) en ABRvS 16 maart 1999, H01.98.0350/15 (Wolff Metternich).

${ }^{698}$ EHRM 18 mei 1999, nr. 45908/99 (Wolff Metternich contra Nederland).

${ }^{699}$ NJB 1999, 1324-1325, nr. 24.
} 


\section{Adelsrecht en naamrecht}

\section{Afstamming als gemeenschappelijke noemer van adelsrecht en naamrecht}

De geschiedenis van het Nederlandse adelsrecht toont aan, dat dit recht vanouds tot het staats- en bestuursrecht wordt gerekend dat op de grondwet is gebaseerd en in 1994 in een afzonderlijke wet werd vastgelegd. Daarnaast vindt het adelsrecht aansluiting bij het privaatrecht, in het bijzonder het personen- en familierecht, dat in het burgerlijk wetboek is geregeld. In de grondwet komt het begrip adel(dom) sinds 1983 niet meer voor, maar in het BW wordt het vanaf 1998 expliciet vermeld, zonder dat een principiële karakterwijziging heeft plaatsgevonden. Adelsrecht en naamrecht hebben beide een uiterst nauwe relatie tot het afstammingsrecht, maar hanteren andere, eigen regels. Adelsrecht is dan ook als uitzonderingsbepaling op het naamrecht in het BW terechtgekomen.

Aan het einde van de twintigste eeuw ontstond het perspectief om te trachten het gedateerde adelsrecht door een herziening van het naamrecht te wijzigen. Na de inwerkingtreding van de Wet op de adeldom zijn in dat kader tussen 1996-2002 in de Tweede Kamer nog minstens drie pogingen ondernomen om door middel van wetswijziging overdraagbaarheid van adellijke titels in de vrouwelijke lijn mogelijk te maken. De eerste, bij motie, werd zelfs in meerderheid aangenomen, maar uiteindelijk door de toenmalige minister van Binnenlandse Zaken niet uitgevoerd, waarin de Tweede Kamer toen heeft berust.

De daarop volgende twee wetsontwerpen zijn teruggenomen aangezien de indieners niet voldoende medestanders in de Tweede Kamer vonden om deze te ondersteunen toen zij het parlement om politieke redenen of wegens benoeming elders moesten verlaten. Eén van deze indieners, jonkheer Meijer, vergeleek de totstandkoming van de wet met een vorm van monumentenzorg. Hoewel hij deze vergelijking in negatieve zin bedoelde, zou de kwalificatie ook in positieve zin kunnen worden opgevat. Wat is er op tegen om het adelsrecht binnen de eenentwintigsteeeuwse Nederlandse parlementaire democratie als cultureel erfgoed te koesteren en op deze wijze de historische identiteitsrechten van een bijzondere groep te respecteren? In feite heeft de uitvaardiging van de Wet op de adeldom, die anders dan verwacht tot betrekkelijk weinig juridische procedures aanleiding heeft gegeven, deze status quo van het instituut doen bereiken. ${ }^{700}$ Ook de modernisering die door een amendement vanuit de Tweede Kamer werd ingebracht en als artikel 3 (overgang buiten het huwelijk om) werd gehonoreerd, is vergelijkbaar met de algemeen aanvaarde visie binnen de monumentenzorg om cultureel erfgoed bij restauratie niet (meer) terug te brengen in de oorspronkelijke toestand, maar belangrijke al of niet geslaagde aanpassingen te markeren.

De aandacht voor het onderwerp verminderde na de laatste eeuwwisseling zienderogen, hetgeen bovenstaande conclusie onderschrijft. Dit behoeft overigens niet te betekenen dat de Wet op de adeldom in de toekomst een Wet van Meden en

\footnotetext{
${ }^{700}$ Vgl. ook: De Blocq van Scheltinga, 'Enkele opmerkingen over de positie van de adel in de huidige samenleving', 268-271.
} 
Perzen zal blijken te zijn. Afhankelijk als het adelsrecht van het naamrecht is, zou bij een volgende herziening van het naamrecht het adelsrecht wel degelijk kunnen worden beïnvloed.

\section{Discriminatie in het Nederlandse naamrecht}

Ten aanzien van de door De Groot geconstateerde discriminatie tussen mannen en vrouwen wanneer ouders geen keuze voor de geslachtsnaam van hun kind hebben gedaan en volgens art. BW 1:5, lid 5, onder a, de vadersnaam voorrang heeft boven die van de moeder, kwam in de nieuwe eeuw enige beweging. Kamervragen aan de minister van Justitie, naar aanleiding van de publicatie van een onderzoeksrapport waarin werd gesteld dat de Nederlandse procedure voor vaststelling van de naam van een kind in strijd was met het EVRM, leidden tot een toezegging van de minister om te bezien of het naamrecht zou kunnen worden gewijzigd. ${ }^{701}$ In deze overweging speelde een uitspraak van het Europese Hof van Justitie in Luxemburg mee, waarin werd bepaald dat kinderen die nationaliteiten van meerdere lidstaten van de Europese Unie bezitten, wijziging van hun geslachtsnaam kunnen vragen in de naam die zij volgens het recht van de andere lidstaat hebben. In casu weigerden de Belgische autoriteiten naamswijziging van de in België geboren kinderen van een Spaanse vader en een Belgische moeder, die naar Belgisch recht de (samengestelde) naam van de vader hadden gekregen, in die van naar Spaans recht de (samengestelde) naam van beide ouders. Het Hof van Justitie concludeerde dat het hier - anders dan in een zuiver nationale casus - om ongelijke gevallen ging, die op grond van het Europese burgerschap van de kinderen alsmede wegens artikel 12 van het EVRM verschillend moeten worden behandeld om ernstige ongemakken met betrekking tot een dergelijke verscheidenheid van namen in de verschillende rechtsordes te voorkomen en achtte wijziging van de geslachtsnaam gerechtvaardigd. ${ }^{702}$ Dit discriminatieverbod op grond van nationaliteit en burgerschap heeft tot gevolg, dat voor een Nederlands kind van een Spaanse of Portugese moeder wier nationaliteit het eveneens zou bezitten, de optie van een samengestelde naam volgens Spaans of Portugees recht in beeld komt. Naar aanleiding van bovengenoemde uitspraak is in Nederland het Besluit geslachtnaamswijziging (1997) aangepast. $^{703}$

Hoewel de Afdeling Bestuursrechtspraak van de Raad van State in hoogste instantie een verzoek om naamstoevoeging van een lid van een adellijke geslacht afwees op grond van art. 2, lid 3, van het Naamswijzigingsbesluit van 1997, en concludeerde dat de uitspraak van de Rechtbank Den Haag niet in strijd was met art. 14 (non-discriminatie) van het EVRM, is de situatie rond 'adellijke geslachtnamen'

\footnotetext{
${ }^{701}$ Kamerstukken II, 2004-2005, kamervraag 1499 (M. Braam, Vaders wil, geen wet meer?! Een onderzoek naar gelijke behandeling van man en vrouw bij de bepaling van de achternaam van hun kind, rapport Universiteit Utrecht 2005).

${ }^{702}$ Hof van Justitie van de Europese Unie (HvJEU) 2 okt. 2003, C-148/02, NIPR 2004/1, 2 (Garcia Avello).

${ }^{703} \mathrm{~KB}$ van 25 mei 2004 (Stb. 239), art. 3a, lid 1b.
} 
sinds 1984 aanmerkelijk gewijzigd. ${ }^{704}$ Binnen de Nederlandse adel werd de verbodsbepaling in het Besluit geslachtsnaamswijziging in toenemende mate als beklemmend en discriminerend ervaren. De gedachte achter deze bepaling (voorkomen van verwarring met betrekking tot adellijke geslachtsnamen) sprak de groep, op een enkele uitzondering na, vanaf het begin aan, maar door de ontwikkelingen binnen het naamrecht was de zingeving van de verbodsbepaling echter grotendeels verdwenen.

Al voor de herziening van het naamrecht had de rechter een zoon van een adellijke moeder met haar toestemming, maar onder unaniem protest van de rest van de adellijke familie - gesteund door de visie van de Hoge Raad van Adel - toestemming gegeven de geslachtsnaam van de moeder te voeren, overigens zonder overgang van adeldom. De andere familieleden hadden als belangrijkste motief aangevoerd, dat de naam uitsluitend bekend was in combinatie met zijn oeradellijke herkomst en dat op deze wijze de creatie plaatsvond van een burgerfamilie met diezelfde naam, waardoor een schijn van adeldom ontstond. De rechter was hier niet gevoelig voor en concludeerde dat er geen exclusieve adellijke geslachtsnamen bestonden en de titulatuur slechts een element van accessoire aard was. ${ }^{705}$

Aangezien de verbodsbepaling juist in de algemene maatregel van bestuur was opgenomen om deze verwarring te voorkomen, was er steeds minder reden om deze te handhaven. Na de herziening van het naamrecht in 1998 nam de keuze voor de naam van de moeder toe, waaronder die van adellijke moeders. Inmiddels bestaan van meerdere namen van oude adellijke geslachten, burgerlijke varianten. Dit was vervolgens de reden dat recentelijk in het Jaarverslag van de Hoge Raad van Adel, dat vanaf 1980 op verzoek van de Tweede Kamer aan de minister van Binnenlandse Zaken wordt uitgebracht, een passage aan deze discrepantie werd gewijd. ${ }^{706}$ Nadat de minister het jaarverslag naar de voorzitter van de Tweede Kamer had gezonden, reageerde de vaste commissie voor Binnenlandse Zaken en Koninkrijksrelaties met vragen, die op 27 juni 2009 door de minister van Justitie, verantwoordelijk voor de naamwetgeving, werden beantwoord met een concrete toezegging. Minister van Justitie Hirsch Ballin beloofde dit punt mee te nemen bij de herziening van het naamrecht, die de in 2008 ingestelde Werkgroep liberalisering naamrecht voorbereidde, en waarvan voorstellen werden ingewacht. ${ }^{707}$ Op 27 juli 2010 zond de inmiddels demissionaire minister het in het vooruitzicht gestelde rapport Bouwstenen voor een nieuw naamrecht, dat de werkgroep in 2009 had uitgebracht, toe aan de voorzitter van de Tweede Kamer. ${ }^{708}$ Vanwege de demissionaire status van het vierde Kabinet Balkenende leek het de minister minder opportuun het complete rapport te behandelen, maar hij maakte een uitzondering voor drie

\footnotetext{
${ }^{704}$ AR (Den Haag) 1 nov. 2004, nr. AWB 04/1308 BESLU; ABRvS 17 aug. 2005, 200410185/1 (De Lange).

${ }^{705}$ ABRvS 12 nov. 1984, R02.83.1504 (Taets van Amerongen).

${ }^{706}$ Jaarverslag van de Hoge Raad van Adel over 2008 (ten geleide van de voorzitter).

${ }^{707}$ Kamerstukken II, 2007-2008, 29 353, debat d.d. 6 febr. 2008; Ibidem, 2008-2009, 31 700-VII, nr. 96. De werkgroep bestaat uit W. Dronkers, G.R. de Groot, E.W.M. Gubbels, A.E. den Hartog, H. Lenters, R.S. Tenge en P. Vlaardingerbroek.

${ }^{708}$ Kamerstukken II, 2009-2010, 32123 VI, nr. 121.
} 
spoedeisende zaken. Deze betroffen een wijziging van de wijze waarop naamskeuze kan worden gedaan (ook bij eenvoudige schriftelijke verklaring), een verruimde mogelijkheid van wijziging van de geslachtsnaam gedurende een bepaalde periode na de geboorte (herstel voor spijtoptanten) en enkele wijzigingen van het Besluit geslachtsnaamswijziging. Onder deze laatste categorie vielen een lichte verruiming voor volwassen geadopteerden om hun geslachtsnaam te kunnen terugwijzigen in hun oorspronkelijk geslachtsnamen, vrijdom van leges bij verandering van geslachtsnaam na ernstige mishandeling of incest door een ouder, en ten slotte vervallenverklaring van artikel 2 , leden $3 \mathrm{a}$ en $3 \mathrm{~b}$, waarmee discriminatie op het gebied van adellijke naamswijziging wordt ongedaan gemaakt.

Naar aanleiding van de brief van de minister voerde de vaste commissie voor Justitie en Veiligheid schriftelijk overleg en stelde een groot aantal vragen aan de staatssecretaris. ${ }^{709}$ Deze hadden ook betrekking op minder urgente punten uit het rapport, zoals hoe de keuze voor deze spoedeisende zaken tot stand was gekomen en hoe de liberalisering van het naamrecht in internationaal verband kon worden gezien. ${ }^{710}$

Sluimerende adeldom als consequentie van het naamrecht en in vergelijking met adoptie

Adelsrecht volgt in toenemende mate het naamrecht. Sinds de wijziging in 1998 van de artt. BW 1:5 en 9 kunnen kinderen ook de (adellijke) naam van de moeder krijgen, maar niet de eventuele adeldom, die uitsluitend langs mannelijke lijn vererft (art. BW 1:5, lid 11). Tijdens de parlementaire behandeling wijzigde de toenmalige staatssecretaris van Justitie Schmitz de redactie van lid 11 (toen nog lid 10) zodanig dat discriminatie van edellieden werd voorkomen; in eerste opzet was naamskeuze uitgesloten, indien de vader van het kind tot de Nederlandse adel behoorde. ${ }^{711}$ Deze wijziging vond plaats kort nadat de Afdeling Bestuursrechtspraak van de Raad van State in 1995 uitspraak had gedaan in een beroepszaak van een zoon van een adellijke moeder die haar naam had mogen aannemen maar ook haar adellijke titel (in verbogen vorm) wilde gaan voeren. De Afdeling wees dit beroep af en motiveerde haar uitspraak enerzijds door uitgebreid op het historische afstammingsrecht in te gaan, maar anderzijds met de opzienbarende conclusie dat de onmogelijkheid adeldom te verwerven altijd gelijkelijk heeft gegolden voor zowel mannen als vrouwen. ${ }^{712}$ In concreto bedoelde de Afdeling hiermee te zeggen, dat kleinzoons van een edelman uit het huwelijk van zijn adellijke dochter met een niet-adellijke partner geen adeldom verwerven. Dit leidde dikwijls tot het uitsterven van een tak van een adellijk geslacht, wanneer de edelman geen zoon had of

\footnotetext{
709 Ibidem, 2010-2011, 2010D41820, d.d. 2 nov. 2010 (verslag van een schriftelijk overleg). Tijdens het Kabinet Rutte (2010-2012) had de liberalisering van het naamrecht geen prioriteit.

${ }^{710}$ Vgl. De Groot e.a., 'Naamrecht in vergelijkend perspectief: een quick scan', waarin de liberalisering van het naamrecht in een achttal Europese landen met elkaar en met het voorgestelde Nederlandse beleid wordt vergeleken (gepubliceerd als bijlage van het rapport Bouwstenen voor een nieuw naamrecht).

${ }^{711}$ Kamerstukken II, 1995-1996, 22 408, nr. 12 (tweede nota van wijziging).

${ }^{712}$ ABRvS 21 febr. 1995, nr. R01.92.0559 (Taets van Amerongen).
} 
wanneer de zoon slechts dochters voortbracht. Het historische adellijke afstammingssysteem was daardoor in opzet niet discriminatoir ten opzichte van vrouwen, hoe schrijnend de gevolgen voor een uitstervend adellijk geslacht ook konden zijn.

Als de adeldom volgens art. BW 1:5, lid 11, bij de keuze voor de geslachtsnaam van de adellijke moeder niet op het kind overgaat, wordt zolang de periode voortduurt waarin de naamgeving nog niet definitief is - bijvoorbeeld omdat het kind nog niet meerderjarig is en alsnog voor de geslachtsnaam van zijn adellijke vader kan kiezen - van 'sluimerende adeldom' gesproken. De Groot karakteriseerde deze ongemakkelijke juridische omstandigheid, die steeds optreedt wanneer het adelsrecht in de wacht staat van het dominerende naamrecht, als 'het toverstokje van de sluimerende adel', dat door de Hoge Raad van Adel in vergelijkbare gevallen te berde werd gebracht. De benaming is al in 1960 door de wetgevingsjurist bij het Ministerie van Justitie, jonkheer Van Sasse van Ysselt, gelanceerd, nog voor hij zitting nam in de Hoge Raad van Adel. Toen hij in 1972 als lid van de Raad aantrad, werd de term vanzelfsprekend nieuw leven ingeblazen. Inmiddels is het begrip geaccepteerd in de jurisprudentie en blijkt het minder uitzonderlijk en controversieel dan tien jaar geleden werd verondersteld. De Groot had vooral kritiek op de inconsequente wijze waarop in het verleden door de Hoge Raad van Adel sluimerende adeldom als excuus was gebruikt voor het al of niet inschrijven van adoptiefkinderen in het filiatieregister van de Nederlandse adel. Hij kon zich niet aan de indruk onttrekken dat hiermee kunstmatig een aureool van exclusiviteit werd beoogd. ${ }^{713}$ Het argument dat eerst zekerheid over de adeldom van een adoptiefkind zou bestaan als de adoptie definitief was geworden, was namelijk niet sterk ten opzichte van andere onzekerheden, zoals ook ten aanzien van erkende kinderen kunnen bestaan en zelfs bij staande het huwelijk geboren kinderen, waarvan het vaderschap wordt ontkend.

De rechtsgevolgen van een adoptie die nog lang een mogelijkheid tot herroeping geeft, blijken veel overeenkomst te vertonen met de juridische toestand van sluimerende adeldom. Als de adoptie op verzoek van de geadopteerde (na diens meerderjarigheid) door de rechtbank wordt herroepen (art. BW 1:231), houdt de familierechtelijke betrekking tussen de geadopteerde en zijn kinderen en de adoptiefouder(s) en zijn bloedverwanten op te bestaan en herleeft de familierechtelijke betrekking die door de adoptie opgehouden had te bestaan (art. BW 1:232). In genealogisch opzicht is de metamorfose dan vergelijkbaar met die van sluimerende adeldom, die al of niet ontwaakt. Ook de tijdsperiode waarna nog wijziging kan optreden, namelijk wanneer meerderjarigheid is bereikt, is overeenkomstig en kan even ingrijpend zijn. In geval van adoptie moet de verzoeker niet eerder dan twee jaar en niet later dan vijf jaar na de dag waarop de meerderjarigheid wordt bereikt, een verzoekschrift indienen. ${ }^{714}$ De termijn werd met twee jaar verschoven om meerderjarigen weloverwogen tot een voor hun identiteit ingrijpende keuze te laten

\footnotetext{
${ }^{713}$ De Groot, 'Adelsrecht op de drempel van de $21^{\text {ste }}$ eeuw', 508.

${ }^{714}$ Art. BW 1:231, lid twee; KB van 6 okt. 1997 (Stb. 463), art. 5 (gewijzigd in 2001, 2002 en 2004).
} 
komen. In geval van adoptie kan deze termijn in het belang van het kind bovendien opgerekt worden, waarmee ook het tijdstip van de uiteindelijke naamskeuze opschuift. ${ }^{715}$ Dit biedt mijns inziens perspectief voor de acceptatie van 'sluimerende adeldom' als overgangssituatie, in de wetenschap dat op enig moment de definitieve beslissing zal vallen. In vergelijking met adoptie zou het verlengen van de termijn waarop deze beslissing moet worden genomen, evenmin tot grote problemen leiden. Het al of niet inschrijven in het filiatieregister moet in dit kader slechts worden gezien als een aan de rechtshandeling ondergeschikte administratieve handeling, waaraan geen argument kan worden ontleend om adeldom al of niet aan een rechthebbende te onthouden. In beide situaties, adoptie en verkrijging van adeldom, zijn de consequenties voor de naamgeving ingrijpend. Ze hebben met persoonlijke identiteit te maken en vergen een zorgvuldige en daardoor soms langdurige behandeling.

\section{Traditioneel gewoonterecht?}

In 2005 gaf beleidsambtenaar burgerzaken van de Gemeente Den Haag Van der Velde een overzicht van de adellijke titels en predikaten die in de automatisering van de Gemeentelijke BasisAdministratie persoonsgegevens (GBA) een rol speelden en verplicht op alle officiële stukken vermeld dienden te worden. ${ }^{716}$ Hij tekende daarbij aan dat ten aanzien van de zogenaamde aanschrijfgegevens volgens de GBA-regelgeving, die na keuze op grond van art. BW 1:9 voor de adressering moesten worden nageleefd, in geval van adellijke titulatuur een traditioneel gewoonterecht gold. Dit zou onder meer inhouden dat gehuwden van gelijk geslacht, wanneer zij of één van hen tot de Nederlandse adel behoorden, niet van 'adellijke geslachtnaam' mochten wisselen en de bijbehorende titulatuur gebruiken.

Hierop reageerde De Groot door aan te tonen dat er weliswaar een traditioneel gewoonterecht had bestaan dat gehuwde vrouwen toestond in het maatschappelijk verkeer de geslachtsnaam van hun echtgenoot al dan niet in combinatie met de eigen geslachtsnaam te voeren, maar dat dit ongeschreven recht in 1970 was gecodificeerd in art. BW 1:9. Het gewoonterecht van echtgenotes van getitelde edellieden, die er voor kozen de geslachtsnaam van hun man te voeren, liep hiermee parallel en viel na 1970 onder hetzelfde artikel. Nadat in 1998 het artikel in sekseneutrale zin was gewijzigd, kon dit volgens De Groot niets anders betekenen, dan dat dit ook voor edellieden gold. De adellijke titel van de vrouw zou dan evenzeer voor verbuiging in aanmerking komen, zoals vanouds omgekeerd gold. Het kon toch niet zo zijn dat het gebruik van de geslachtsnaam was gecodificeerd, maar het gebruik van de adellijke titel in aangepaste vorm gewoonterecht was gebleven? ${ }^{717}$ Aan de hand van de Wet lidmaatschap koninklijk huis en de memories van toelichting bij de eerdergenoemde toestemmingswetten toonde De Groot vervolgens aan dat het gebruik van de adellijke titulatuur ten behoeve van de aangehuwde prinses-

\footnotetext{
${ }^{715}$ Folkert Jensma, 'Na 40 jaar terug in de echte familie', NRC Handelblad, donderdag 12 jan. 2012, 9.

${ }^{716}$ Van der Velde, 'Noblesse oblige', 18-21. Vgl. uitspraak AR (Arnhem) 1 nov. 2007 (kentekenbewijzen).

${ }^{717}$ De Groot, 'Twee aantekeningen over het gebruik van adellijke titels', 103-105.
} 
sen nauwkeurig werd omschreven. Hij constateerde dat daarbij een verschil werd gemaakt tussen 'dragen' (bij koninklijk besluit verleend) en 'voeren' in het maatschappelijk en juridisch verkeer. Hij bleef de mening toegedaan, zoals in eerdere publicaties verwoord, dat art. BW 1:9 universeel geldt en geen onderscheid maakt tussen mannen en vrouwen, huwelijken en partnerregistraties (ook van gelijk geslacht) en adel of geen adel. Beperking in naamskeuze zou immers discriminatie zijn.

\section{Gecodificeerde aanschrijf-en aanspreekvormen}

In Nederland bestaat niet de verplichting, zoals in veel andere West-Europese landen, om een huwelijk- of partnernaam te kiezen, wanneer een huwelijk of partnerschap wordt aangegaan. ${ }^{718}$ Op grond van art. BW 1:9 kent het naamrecht gebruiksrechten voor gehuwden en partners in het maatschappelijk verkeer. Ieder van de (huwelijks)partners kan aan de woongemeente kenbaar maken hoe hij of zij door deze wil worden aangeschreven. In de meeste gemeenten wordt dit bij de ondertrouw vastgelegd, maar op schriftelijk verzoek kan dit worden gewijzigd. ${ }^{719}$ De regeling in art. BW 1:9 is in 1998 non-discriminatoir gemaakt, maar in de praktijk doen zich toch problemen voor.

Om aan de hand van een voorbeeld aan te geven welke keuzes thans mogelijk zijn, voer ik hier een denkbeeldig geregistreerd partnerschap op van Jan Jansen en Nel Pieters. Beiden hebben de keuze zich door de gemeente te laten aanschrijven als Jansen of Pieters of als Jansen-Pieters of Pieters-Jansen. Omdat het hier om een partnerschap gaat en niet om een samengestelde geslachtsnaam, waar een vaststelling bij koninklijk besluit voor nodig is, werd traditioneel een koppelteken gebruikt, maar die verplichting bestaat thans niet meer. In 1998 is de zinsnede uit de oude bepaling van art. BW 1:9 weggelaten die de gehuwde of gehuwd geweest zijnde maar niet hertrouwde vrouw de bevoegdheid gaf de geslachtsnaam van haar man te voeren of 'op de in het verkeer gebruikelijke wijze aan de hare te doen voorafgaan'. ${ }^{720}$ Met deze laatste toevoeging werd op subtiele, maar decennia later kennelijk niet meer begrepen, wijze aangeduid dat bij de laatste optie een koppelteken wordt voorgeschreven. ${ }^{721}$ Deze leemte in de wet heeft als consequentie dat in

\footnotetext{
${ }^{718}$ Enigszins verwarrend in dit opzicht is dat in Nederlandse huwelijksakten zowel de geslachtsnaam van de echtgenoten vóór als ná het sluiten van het huwelijk moet worden vermeld (krachtens Besluit Burgerlijke Stand 1994, art. 57, lid 1). Dit voorschrift is in het bijzonder van belang voor echtgenoten op wie het eigen vreemde nationale naamrecht van toepassing is, dat anders kan zijn dan het Nederlandse naamrecht, dat doorgaans dwingend is (BW 10:20, maar ook 10:24 en 25). Vriendelijke mededeling van R.J. van der Velde, hoofd backoffice burgerzaken, Dienst Publiekszaken Gemeente Den Haag, bij brief van 20 april 2012.

${ }^{719}$ Loeb, Naam en recht, 127. Wet gemeentelijke basisadministratie persoonsgegevens (GBA) van 9 juni 1994 (Stb. 494), artt. 52, 80, lid 1, en 123, lid 8. Van der Velde constateerde, dat waar het BW 1:9 de term 'voeren' hanteert, de Wet GBA over 'gebruik' spreekt en voorts dat in de wet nergens over het gebruikelijke koppelstreepje tussen de partnernamen, ter onderscheiding van samengestelde namen, wordt gesproken (brief van 20 april 2012).

${ }^{720}$ De Groot, 'Het recht van de geslachtsnaam in beweging', 1022-1024.

${ }^{721}$ Vriendelijke mededeling van prof.mr. G.R. de Groot, die het op grond van de huidige regeling geoorloofd acht om zich op elk moment als hij dat wil De Groot Schneider (en wel zonder koppelteken) te noemen.
} 
het maatschappelijk verkeer verwarring kan ontstaan tussen bij koninklijk besluit vastgestelde samengestelde geslachtsnamen en partnernamen, die met de dag kunnen wisselen. Hoewel er grotere misstanden in de maatschappij denkbaar zijn, kan hier wel van een onevenwichtigheid worden gesproken, die voorkomen had kunnen worden.

Overigens treedt een opvallende gelijkenis op tussen de discriminerende werking van de artikelen BW 1:5 en 1:9. In het eerste geval heeft de wetgever bewust gekozen voor voorrang van de vadersnaam boven die van de moeder, mede op grond van gedragsenquêtes onder de bevolking. Daaruit kwam naar voren dat een grote meerderheid - zonder een keuze te maken - de vadersnaam als vanzelfsprekende naam voor de kinderen zag. De wetgever zou vervolgens niet vooruit hebben willen lopen op de volksopinie door een te radicale non-discriminatoire regelgeving vast te stellen. Uit het vergelijkend onderzoek onder West-Europese landen blijken, met uitzondering van Scandinavië, de landen met vergelijkbare naamwetgeving in geval van onenigheid tussen partners over de te kiezen naam voor het eerste kind, uiteindelijk prioriteit aan de naam van de vader te geven. ${ }^{722}$

Artikel BW 1:9, die volledige gelijkheid in naamgeving tussen partners voorschrijft, zwijgt over de toepassing in het maatschappelijk verkeer onder edellieden. Aan de vooravond van de codificatie in het BW van het gewoonterecht dat de gehuwde vrouw de naam van haar echtgenoot mag voeren, gaf Prins commentaar op het nieuwe artikel 6a van het BW (1970) met een moderne visie. Hij maakte daarin onderscheid tussen het recht van de gehuwde vrouw de naam van haar echtgenoot te mogen voeren (art. 6a, lid 1) en de uitzondering daarop: de mogelijkheid van de man om na echtscheiding wanneer het huwelijk kinderloos zou zijn de rechter te verzoeken aan dit gebruik een einde te maken (art. 6a, lid 2). Vervolgens bracht hij dit recht en die uitzondering in verband met 'een zeker maatschappelijk gebruik' van de vrouw om de titel of het predikaat van haar echtgenoot te voeren. Hij toonde een aanmerkelijk verschil aan tussen dit recht als wettelijke bevoegdheid en de uitzondering, met een daaraan gekoppeld gebruik in het maatschappelijk verkeer. Een belangrijk argument was voor hem dat adellijke titels en predikaten geen deel van de naam vormen. Ten slotte dacht hij dat bij de invoering van het artikel de tekst van de bepaling al niet meer in overeenstemming zou zijn met de, in snelle ontwikkeling begrepen, maatschappelijke werkelijkheid. Door de zelfstandige positie van de gehuwde vrouw - hij verwees naar de wijziging van de Wet op het Nederlanderschap en het ingezetenschap (Stb. 1892, 268) in 1963 - kwam aan het gebruik van de mansnaam nauwelijks meer rechtswaarde toe. ${ }^{723}$ Zij zou dit slechts doen om redenen van doelmatigheid: na echtscheiding alleen nog zolang zij een huishouding voerde met kinderen die de naam van de man droegen. Maar zelfs dan

\footnotetext{
${ }^{722}$ De Groot e.a., Naamrecht in vergelijkend perspectief, 35.

${ }^{723}$ Rijkswet van 14 nov. 1963 (Stb. 467), die bij Rijkswet van 21 dec. 2000 (gewijzigd in Stb. 2004, 335) werd ingetrokken.
} 
kon hij nauwelijks een geldig motief bedenken om aan die naam ook de titulatuur van haar gewezen echtgenoot toe te voegen. ${ }^{724}$

Een enquête onder de leden van de Nederlandse Adelsvereniging geeft een opmerkelijk laag percentage aan van edellieden die 'in het dagelijks leven hun adellijke titel voeren'. ${ }^{725}$ Waarschijnlijk zegt deze uitslag weinig over het percentage dat ook werkelijk aan de gemeente te kennen geeft van de mogelijkheid tot nietvermelding op overheidsdocumenten (volgens artikel 5 van de Wet op de adeldom) gebruik te willen maken.

De Wet GBA draagt het gemeentebestuur op, na een schriftelijk verzoek, het gewenste gebruik van de geslachtsnaam binnen vier weken op de persoonslijst aan te geven. ${ }^{726}$ Dit vindt plaats 'overeenkomstig de in de betreffende gemeente gebruikelijke wijze van aanschrijven van betrokkenen', waaruit een mate van vrijheid valt te concluderen. ${ }^{727}$ De gemeente is vervolgens verplicht de gemaakte keuze volgens art. BW 1:9 aan te houden bij haar adressering op officiële documenten. Van de wijze van optreden van gemeenten in dergelijke situaties is het geciteerde artikel van Van der Velde een treffend voorbeeld. Het is in zekere zin wachten op het bezwaar van een niet-adellijke partner, die de titulatuur van zijn/haar adellijke partner van gelijk geslacht wil gaan voeren, wegens discriminatoire behandeling door een gemeente die zich houdt aan het traditionele gewoonterecht...

\section{De jonkvrouw gezien als freule ${ }^{728}$}

Alvorens te trachten een praktische oplossing voor deze onbevredigende situatie aan te dragen, valt niet aan een terugblik te ontkomen op het ontstaan van dit traditionele gewoonterecht, zoals dat uit het archief van de Hoge Raad van Adel valt te construeren.

Algemeen wordt aangenomen dat de gewoonte van gehuwde vrouwen om zich met de naam van de echtgenoot te sieren, eventueel gevolgd door de eigen geslachtsnaam, verband houdt met de in het burgerlijk recht lang standgehouden handelingsonbekwaamheid van de gehuwde vrouw. In 1956 werd haar handelingsonbekwaamheid afgeschaft en eerst geleidelijk werd door (locale) overheden het ontslagrecht ten aanzien van vrouwelijke ambtenaren op de dag van hun huwelijk ongedaan gemaakt. ${ }^{729}$ Wel bleef tot 1970 volgens het burgerlijk recht de man 'hoofd van de echtvereniging' aan wie zijn vrouw 'gehoorzaamheid' verschuldigd was. ${ }^{730}$

\footnotetext{
${ }^{724}$ Prins, 'De Hoge Raad van Adel', 102.

${ }^{725}$ De Smeth van Alphen, 'Adel in Nederland', 23 en 42 (schema 25).

${ }^{726}$ Wet GBA, artt. 52 en 80, lid 1.

${ }^{727}$ Wet GBA, art. 123, lid 8 .

728 Ouderwetse aanspreekvormen, zoals 'jonker' en 'freule' (herkomst: Fräule, verkleinwoord van Frau) voor ongetrouwde edellieden en 'douairière', de weduwe van een edelman die zelf al dan niet van adel was, behoorden tot de omgangscodes van de adel, maar worden thans nauwelijks meer gebruikt. Vgl. Monod de Froideville en Den Beer Poortugael, Titulatuurgids, 40 en 90. Ze zijn al gedurende lange tijd een tweede leven gaan leiden als onderdeel van toneelstukken en kluchten.

${ }^{729}$ Bij Wet van 14 juni 1956 (Stb. 343), tot opheffing van de handelingsonbekwaamheid, die op 1 januari 1957 in werking trad.

${ }^{730}$ Het nieuwe personenrecht in boek 1 van het BW werd ingevoerd bij Wet van 3 april 1969 (Stb. 167) en trad op 1 januari 1970 in werking.
} 
De beëindiging van het huwelijk bracht in die achterstandssituatie vanouds een zekere verbetering, omdat de weduwe - zelfs als zij nog jonger was dan 21 jaar - wel handelingsbekwaam werd geacht. Binnen de adel werd laatstgenoemde vanouds douairière genoemd, die volgens het huwelijksvermogensrecht de houdster was van een douarie, haar deel van de nalatenschap van haar (edel)man. ${ }^{731} \mathrm{Zij}$ voerde dan ook de volledige naam, inclusief niet verbogen titulatuur en voorletter(s), van haar echtgenoot.

Een uitzonderlijk voorbeeld van vroeg-negentiende-eeuwse titelverlening proprio motu, dus louter als gunst van de koning en niet volgens de regels van het adelsrecht, betreft jonkvrouw Albertina Petronella Melvill van Carnbee. Zij werd bij KB van 20 dec. 1834, nr. 96, na het overlijden van haar moeder - die als niet adellijke echtgenote van haar vader, die baron bij eerstgeboorte was, zich in het maatschappelijk verkeer barones mocht noemen - de titel barones verleend 'in de plaats van haar moeder'. Dit gebeurde overigens, zoals te doen gebruikelijk, op haar eigen verzoek. De 'zin' van deze verlening was overigens van korte duur, want de gemeenschappelijke huishouding werd al in 1838 opgeheven toen zij in het huwelijk trad met jonkheer Van Hoogenhouck Tulleken en een gezin stichtte. ${ }^{732}$

In de loop van de negentiende eeuw is het traditionele gewoonterecht ontstaan om het adellijke predikaat 'jonkvrouw' als synoniem te gaan zien met de aanspreekvorm 'freule', die ongetrouwde adellijke dame betekende. ${ }^{733}$ Deze ingesleten gewoonte ging zelfs zover, dat een ongetrouwde getitelde vrouw in het maatschappelijk verkeer niet alleen deze titel voerde, maar tevens het predikaat jonkvrouw voor haar voornaam zette. Een aanduiding als 'jonkvrouw A. gravin van Limburg Stirum' werd algemeen begrepen en geaccepteerd. Deze hield hardnekkig stand, maar is formeel in strijd met het SB van 13 febr. 1815, nr. 60 (Stb. 15), lid 2.

Binnen die adellijke gedragscode was en is het ook thans nog altijd not-done voor een niet-getitelde adellijke vrouw die getrouwd is (geweest), om haar predikaat jonkvrouw te blijven voeren. Een groot bezwaar van deze traditie is dat vervolgens in het maatschappelijk verkeer uit niets blijkt dat zij tot de Nederlandse adel behoort, waarvan het voeren van een titel of predikaat nog het enige kenmerk en privilege is. Haar wordt door een sociale controle binnen de eigen groep haar wettelijke kenteken van adeldom zonder geldige reden ontnomen. Sterker nog, na echtscheiding zou haar, indien zij haar meisjesnaam weer met predikaat zou willen gaan voeren na een periode van keuze voor haar mansnaam, verweten worden zich ten onrechte voor te doen als nooit getrouwd geweest te zijn. Een situatie vergelijkbaar met de ouderwetse 'juffrouwen'-status, die in vorige eeuwen als symbool voor kuisheid en beschaving gold.

\footnotetext{
${ }^{731}$ Roes, Het naaste bloed erfde het goed, 95-99. Daar consequent als 'douarière' (96, noot 308) aangeduid.

${ }^{732}$ HRvA, FA Melvill van Carnbee, inv. nr. 49.

${ }^{733}$ De Statuten betrekkelijk den adel van het Koningrijk Holland (Amsterdam 1809) kenden de titel wel: 'De dochters van edellieden zijn voor haar persoon edel; ongetrouwd zijnde, zullen zij den titel van freule hebben' (art. 10). (HRvA, RA, inv. nr. 889).
} 
In deze kwestie gaat het overigens louter om het wettelijk gebruik van erfelijk verleende adellijke titulatuur en niet om de aanhef 'hoog(wel)geboren', die edellieden volgens de gepubliceerde adelslijsten (ook) toekomt. Deze is sedert de jaren zestig van de vorige eeuw in onbruik geraakt. ${ }^{734}$

Ter illustratie wordt hierbij een discussie over dit onderwerp van anderhalve eeuw geleden geciteerd, die gevoerd werd op ministerieel adviesniveau. In 1868 deed de Hoge Raad van Adel de toenmalige minister van Justitie Van Lilaar een voorstel om een nieuwe cumulatieve adelslijst te publiceren, waarmee deze akkoord ging mits de Raad nadere beschouwingen en voorstellen zou doen. Bij missive van 21 april 1870 volgde een lange lijst van aanbevelingen, waartoe het opmerkelijke voorstel behoorde om een declaratoire bepaling omtrent adellijke predikaten op te nemen, anders dan in de aanhef gebruikelijk was. In aanvulling op het S.B. van 13 febr. 1815, nr. 60 (Stb. 15) betreffende het gebruik van het predikaat jonkheer, zou ook een ter algemene kennis gebrachte regeling betreffende andere adellijke predikaten gewenst zijn: 'In het bijzonder is nu en dan twijfel geopperd of de benaming van jonkvrouw wel inderdaad zoude zijn een praedikaat, uitsluitend toekomend aan adellijke personen. Zooals duidelijk is uit de aanduiding voorkomende in de bestaande adelslijsten, wordt echter die twijfel ten onregte geopperd, en ten einde dien te doen ophouden, is in de laatste zinsnede van art. 2 [van het ontwerp] de bepaling opgenomen, dat de benaming van jonkvrouw uitsluitend een adellijk praedikaat is. Het schept echter voldoende de bevoegdheid tot het voeren van gemeld praedikaat uitdrukkelijk toe te kennen aan de ongehuwde dochters van al diegenen, die met of zonder titel tot den Nederlandschen adel behooren, en wel omdat het minder eigenaardig is dat eene gehuwde vrouw, welke uit hoofde van haar huwelijk den geslachtsnaam haars echtgenoots heeft aangenomen, zich jonkvrouw zoude noemen, al ware zij krachtens hare adellijke afkomst tot het voeren van dit praedikaat geregtigd. Trouwens de adellijke stand van de echtgenoote eens jonkheers wordt reeds genoegzaam aangeduid door de adellijke qualificatie van Hoog Welgeboren, haar in de voorlaatste zinsnede van art. 2 toegekend. ${ }^{735}$

'Verlies van het predikaat als straf verbonden aan het huwen met een niet-adellijk heer'

Het is interessant om te zien dat deze mystificatie van adellijke titulatuur, die in de loop van de negentiende eeuw in het maatschappelijk verkeer moet zijn ontstaan, bijna op voorstel van de Raad zou zijn gecodificeerd. Maar reeds de volgende dag zond de referendaris, tevens chef der Tweede Afdeling van het departement, A.A. de Pinto, een vernietigende nota aan de secretaris-generaal van Justitie.

In het algemeen bleek hij niet overtuigd van de noodzaak om het onbeschreven adelsrecht, zoals in het ontwerp omschreven, alsof het reeds onbetwist of rechtens geldend was, in een besluit om te zetten 'om met de werkelijkheid strijdend begrip

\footnotetext{
${ }^{734}$ KB van 25 juli 1825 (Stb. 61) e.v. Zie hiervóór bij het tot stand komen van door de Hoge Raad van Adel uitgebrachte richtlijnen voor het gebruik van adellijke titels en predikaten.

${ }^{735}$ HRvA, RA, inv. nrs 154 (not. 20 april 1870, nr. 5-4).
} 
te doen ophouden'. Inzake het praedikaat jonkvrouw achtte hij bovendien het bewijs zelfs niet geleverd, dat daar onbegrip over zou bestaan:

'Wel wist ik dat vele Nederlandsche 'mejufvrouwen' naar 't schijnt, zich niet wel kunnende vereenigen met dit wezenlijk nogal lelijke woord, zich tegenwoordig gaarne noemen 'mejonkvrouwen', maar ik vind dit eene vrij onschuldige liefhebberij, die wij door geen besluiten behoeven te beteugelen. En wat zal het baten? Of is de Raad van oordeel, dat dit besluit een brug zoude moeten zijn om de dames, die in deze liefhebberij mogten volharden, strafregterlijk te vervolgen ex art. 259 Code Pénal ${ }^{736}$ Dit ware toch wat al te dwaas.

Ik heb tegen dit art 2 [van het ontwerp] nog eene bedenking van meer gewigt:

a. Het praedikaat van Hooggeboren en Hoogwelgeboren Vrouwe wordt daarbij alleen toegekend aan de respectieve echtgenooten der Heeren leden van den Nederlandschen adel. Quaeritur, hoe is het gesteld met hunne weduwen?

b. Het praedikaat van jonkvrouw komt alleen toe aan de ongehuwde dochter van adellijke Heeren. Maar dan volgt uit a. en b. in onderling verband dat adellijke dames, die huwen met niet-adellijke Heeren, door dit huwelijk haar adeldom verbeuren. Waarom? "Het schijnt", zegt de Raad, "minder eigenaardig dat eene gehuwde vrouw, welke uit hoofde van haar huwelijk den geslachtsnaam van haar echtgenoot heeft aangenomen, zich jonkvrouw zoude noemen, als ware zij krachtens hare adellijke afkomst tot het voeren van dit praedikaat geregtigd".

Resp[once]:

a. Volgens ons burgerlijk regt neemt de vrouw den geslachtsnaam van haar man niet over, maar blijft zij haar eigen geslachtsnaam behouden.

b. Het is niet dwazer of minder dwaas dat een getrouwd heer zich jonkheer, dan dat eene gehuwde dame zich jonkvrouw noemt.

c. Aan dit belangrijke bezwaar is in elk geval tegemoet gekomen door te bepalen, dat de vrouwelijke afstammelingen van adellijke geslachten, na een huwelijk te hebben aangegaan, zullen hebben het praedikaat van Hooggeboren en Hoogwelgeboren Vrouwe naar mate van haren rang.

d. Wat er zij van 's Hoogen Raads argumenten van convenientie, daaraan mag niet worden opgeofferd het verkregen regt van vrouwelijke afstammelingen uit een adellijk geslacht tot het voeren van een adellijk praedikaat, omdat het verlies daarvan tot nu toe nimmer als straf is verbonden aan het huwelijk met een niet adellijk heer.'

De Pinto sloot zijn nota af met de overweging: 'Wij hebben den H.R.v.A. noch bij onze missive van 5 Aug. 1868, no. 104, noch vroeger noch later, het ontwerpen van zoodanig besluit opgedragen. Ik kan er mij om de bovenstaande redenen moeyelijk mede vereenigen. Ik geloof dus dat wij voor deze beleefdheid moeten bedanken. ${ }^{737}$

\footnotetext{
${ }^{736}$ Eerst bij Wet van 3 maart 1881 (Stb. 35) is het Wetboek van Strafrecht ingevoerd, dat met ingang van 1 jan. 1886 van kracht werd.

${ }^{737}$ HRvA, RA, inv. nr. 878 (betreffende adelslijsten).
} 
Bovenstaande discussie is nog altijd actueel en nog lang niet beslecht. ${ }^{738}$ De groepscode lijkt het te winnen van het juridische principe, maar daar zou van overheidswege niet langer aan meegewerkt moeten worden. Om een indruk te geven tot welke consequenties het uitvoeren van art. BW 1:9 voor overheidsinstanties in geval van adeldom van één of beide partners leidt, als al aan de wensen volgens de adellijke gedragscode voldaan kan worden, zal ik hieronder alle mogelijke opties aangeven. Dit traditionele gewoonterecht is aan de hand van de richtlijnen van de Hoge Raad van Adel beschreven door Van der Velde in zijn overzicht voor ambtenaren burgerzaken. ${ }^{739}$

De namen zijn in zoverre gefingeerd, dat hiervoor geslachtsnamen worden gebruikt van adellijke geslachten die kort of lang geleden zijn uitgestorven. In het hierna volgende rollenspel treden de volgende gefingeerde personen op die relaties met elkaar aangaan, zoals in art. BW 1:9 worden omschreven: A. baron van Boecop, die de eerste keer trouwde met een jonkvrouw Clifford en de tweede keer met een Van Aylva barones Rengers, en zijn zuster, B. barones van Boecop, die weduwe was van E. van Aylva baron Rengers, broer van haar schoonzuster bovengenoemd; ${ }^{740}$ baron (bij eerstgeboorte) Clifford, die getrouwd is met zijn verre nicht jonkvrouw D. Clifford, gescheiden echtgenote van zijn jongere broer jonkheer $\mathrm{C}$. Clifford. ${ }^{741}$ Laatstgenoemde hertrouwde met de douairière Van Aylva baron Rengers voornoemd. ${ }^{742}$ De broer en zuster Van Aylva baron en barones Rengers nemen een bijzondere plaats in, omdat zij een adellijke geboortetitel dragen die tussen de verschillende delen van de samengestelde geslachtsnaam in staat. Het bestaan van dergelijke samengestelde namen maakt nog weer eens duidelijk hoe een verleende titel bij een specifieke geslachtsnaam behoort en het vanouds hanteren van koppeltekens tussen partnernamen zin heeft om deze te onderscheiden van samengestelde, zogenaamde 'dubbele' namen. ${ }^{743}$ De wijze waarop adellijke titels binnen deze geslachtsnamen volgens het negentiende-eeuwse gewoonterecht worden gehanteerd, verschilt overigens niet ten opzichte van geslachtnamen, waarbij de titel aan het begin van de (soms ook samengestelde) naam staat.

\footnotetext{
${ }^{738}$ De Ranitz, 'Titulatuur', 14.

739 Zie: www.hogeraadvanadel.nl (adeldom>titel/predikaat>richtlijnen). Van der Velde, 'Noblesse oblige', 18-21; 'Adeldom verplicht nog steeds', 8-9.

${ }^{740}$ Van Boecop is oude Veluwse adel, bij KB van 30 nov. 1822, nr. 93 - en in 1824 met de titel baron op allen - erkend in de Nederlandse adel. Het adellijke geslacht stierf in 2004 uit.

${ }^{741}$ Amsterdamse regentengeslacht, bij KB van 16 sept. 1815 verheven in de Nederlandse adel; bij KB van 12 mei 1874, nr. 12, werd jonkheer H.M.C. Clifford de titel baron bij eerstgeboorte verleend; het adellijke geslacht stierf in 2000 uit.

${ }_{742}$ Bij KB van 28 maart 1815, nr. 65, werd Lamoraal Hans Willem van Aylva Rengers erkend als edele van Friesland; bij KB van 8 juli 1822, nr. 145, werd voor hem en zijn nakomelingen de titel baron op allen erkend. Met zijn kinderen stierf deze tak van het adellijke geslacht Rengers in het begin van de twintigste eeuw uit.

${ }^{743}$ Op dit moment bloeit nog een zevental adellijke geslachten met deze bijzondere titulatuur: Van Panthaleon baron(es) van Eck, Sixma baron(es) van Heemstra, Preud'homme d'Hailly de Nieuport burggraaf de Nieuport, Van Welderen baron(es) Rengers, Bosch ridder van Rosenthal, Van den Clooster baron(es) Sloet tot Everlo, Van Hangest baron(es) d'Yvoy. De titel burggraaf de Nieuport is een eerstgeboortetitel, terwijl de titel ridder alleen voor mannen geldt; bij beide voorbeelden zijn alle andere afstammelingen jonkheer/jonkvrouw.
} 
In onderstaand schema zijn de gefingeerde personen uit het voorbeeld in de gesuggereerde relaties aangegeven met hun geslachtsnaam en geboortetitel, zoals deze in de respectievelijke geboorteakten overeenkomstig artikel BW 1:6. zou zijn vermeld:
A. baron van Boecop $\mathrm{x}(1)$ jonkvrouw Clifford $\dagger$
$x$ (2) Van Aylva barones Rengers

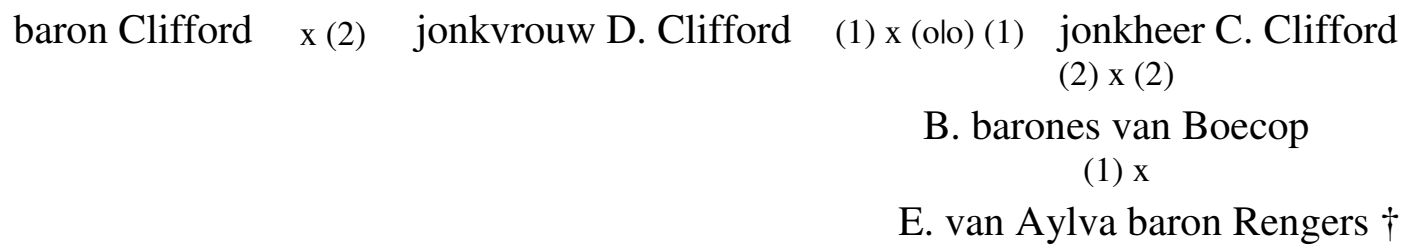

De richtlijnen voor gebruik van adellijke titels en predikaten zijn in 1984 op verzoek van het Ministerie van Binnenlandse Zaken door de Hoge Raad van Adel opnieuw vastgesteld. De belangrijkste aanpassing was een aanbeveling van het gebruik van kleine (begin)letters voor adellijke titels en predikaten om misverstanden met eigennamen op officiële documenten te voorkomen. ${ }^{744}$ De hoofdregels zijn:

1. De titels die verleend zijn bij of krachtens de Wet lidmaatschap koninklijk huis, vallen buiten toepassing van deze richtlijnen. ${ }^{745}$

2. Adellijke titels zijn onlosmakelijk verbonden met specifieke geslachtsnamen; alleen echtgenotes van getitelde edellieden mogen de verbogen titel van hun partner voeren, mits zij zijn naam gebruiken.

Het adellijke predikaat jonkheer wordt altijd vermeld voor de voorna(a)m(en) van een edelman, onafhankelijk van zijn burgerlijke staat; het adellijke predikaat jonkvrouw vervalt als de adellijke vrouw gehuwd, weduwe of gescheiden is, zelfs indien zij (weer) koos voor haar meisjesnaam.

Ad 1. Een reguliere combinatie als 'prins der Nederlanden, prins van OranjeNassau, jonkheer van Amsberg' is binnen het Nederlandse adelsrecht onbestaanbaar omdat een cumulatie van adellijke titulatuur vanaf het ontstaan van de Nederlandse adel, niet was toegestaan. In 1815 bepaalde de soevereine vorst al dat 'voor zoo verre door Ons aan dezelve geenen anderen of meerderen titel mogt zijn toegekend of verleend, zal worden gebezigd de titulature van Jonkheer en Hoog Welgeboren' ${ }^{746}$ Eerst bij het verlaten van het koninklijk huis dient binnen drie maanden een voorziening te worden getroffen omtrent de adellijke titulatuur, indien degene(n) waarom het gaat althans van adel is/zijn. ${ }^{747}$ Een recent voorbeeld betreft prins Friso, die in 2004 de titel van graaf voor zichzelf en zijn nakomelingen verleend kreeg, toen hij in het huwelijk trad zonder toestemming van het parlement te

\footnotetext{
${ }^{744}$ HRvA, RA, inv. nr. 260 (not. 1984-37-I). Schutte, ‘Adellijke titels en predikaten in geboorteakten', 9495; Van der Wiel, 'Adellijke titels', 60-64. Vgl. www.hogeraadvanadel.nl (adeldom $>$ titel/predikaat $<$ richtlijnen).

${ }_{745} \mathrm{~KB}$ van 25 juli 1825 (Stb. 61), preambule; Wet op de adeldom, art. 2, lid 2.

${ }^{746}$ SB van 13 febr. 1815 , nr. 60 (Stb. 15).

${ }^{747}$ Wet op de adeldom, art. 2, lid 2.
} 
vragen. Bij die gelegenheid werd als geslachtnaam vastgesteld Van Oranje-Nassau van Amsberg. ${ }^{748}$ In de memorie van toelichting bij het koninklijk besluit werd nog enigszins onduidelijk aangegeven, dat de genobiliteerde en zijn eventuele kinderen 'Graaf/Gravin Van Oranje-Nassau, Jonkheer/Jonkvrouw van Amsberg' zouden zijn. ${ }^{749}$ De titulatuur werd hier in kapitaalletters aangegeven, een vorm die binnen het koninklijk huis gangbaar is. De twee uit zijn huwelijk in Londen geboren dochters zijn inmiddels correct in de Nederlandse burgerlijke stand ingeschreven als gravin van Oranje-Nassau van Amsberg. ${ }^{750} \mathrm{Zij}$ hebben dezelfde geslachtsnaam gekregen als de kinderen van prins Constantijn, maar aangezien die nog tot het koninklijk huis behoren zolang hun grootmoeder vorstin is, gaan deze door het leven als Graaf/Gravin van Oranje-Nassau, Jonkheer/Jonkvrouw van Amsberg. ${ }^{751}$

Ad 2. Deze hoofdregel houdt, gebruikmakend van de voorbeeldnamen, meerdere keuzeopties in, waarbij iedere voorletter voor een en dezelfde persoon staat:

Man met adellijke titel en niet-adellijke óf predikaatvoerende, c.q. getitelde partner:

- [eigennaam man] A. baron van Boecop;

- [eigennaam man-partner; in strijd met gewoonterecht] A. baron van Boecop-Clifford, c.q. A. baron van Boecop-van Aylva Rengers;

- [eigennaam partner-man; i.s.m. gewoonterecht] ${ }^{752}$ A. Clifford-baron van Boecop, c.q. van Aylva Rengers-baron van Boecop;

- [eigennaam van partner] A. Clifford, c.q. A. van Aylva Rengers.

Vrouw met adellijke titel en getitelde, c.q. niet-adellijke óf predikaatvoerende partner:

- [eigennaam vrouw] B. barones van Boecop;

- [eigennaam vrouw-partner] B. barones van Boecop-van Aylva barones Rengers, c.q. B. barones van Boecop-Clifford;

- [eigennaam partner-vrouw] B. van Aylva barones Rengers-barones van Boecop, c.q. B. Clifford-barones van Boecop;

- [eigennaam partner] B. van Aylva barones Rengers, c.q. B. Clifford.

Man met adellijk predikaat en niet-adellijke óf predikaatvoerende, c.q. getitelde partner:

- [eigennaam man] jonkheer C. Clifford;

- [eigennaam man-partner; i.s.m. gewoonterecht] jonkheer C. Clifford-Clifford, c.q. jonkheer C. Clifford-van Boecop;

- [eigennaam partner-man; i.s.m. gewoonterecht] C. Clifford-Clifford, c.q. C. van Boecop-Clifford;

- [eigennaam partner] C. Clifford, c.q. C. van Boecop. ${ }^{753}$

\footnotetext{
${ }^{748}$ Wet lidmaatschap koninklijk huis, art. 9.

${ }^{749} \mathrm{~KB}$ van 19 maart 2004, nr. 04.001077 (Stb. 126).

${ }^{750}$ HRvA, Filiatieregister, nrs. B28 (geboorte d.d. Westminster 26 maart 2005 van gravin Luana) en B376 (geboorte d.d. Westminster 18 juni 2006 van gravin Zaria).

${ }^{751} \mathrm{~KB}$ van 11 mei 2001, nr. 01.002382 (Stb. 227).

752 Ook bij de niet-adellijke echtgenote van een getitelde edelman, die kiest voor haar eigen naam, gevolgd door die van haar man inclusief verbogen titel (bijv. F. Jansen-barones van Boecop), kan verwarring optreden, omdat - anders dan het lijkt - in casu geen sprake is van een geboren adellijke vrouw.

${ }^{753}$ Hier staat geen adellijke titel, aangezien deze volgens het gewoonterecht alleen door echtgenotes en niet door echtgenoten, laat staan geregistreerde partners, mag worden gevoerd.
} 
Vrouw met adellijke predikaat en niet-adellijke óf predikaatvoerende, c.q. getitelde partner:

- [eigennaam vrouw als freule] jonkvrouw D. Clifford;

- [eigennaam vrouw-partner] D. Clifford-Clifford, c.q. D. Clifford-barones Clifford;

- [eigennaam partner-vrouw] D. Clifford-Clifford, c.q. D. barones Clifford-Clifford;

- [eigennaam partner] D. barones Clifford.

In bovenstaande overzichten moet onder partner uitsluitend huwelijkspartner worden verstaan, aangezien de op negentiende-eeuws gewoonterecht gebaseerde richtlijnen voor het gebruik van adellijke titels en predikaten geen betrekking kunnen hebben op destijds onwettige relaties, zoals die tussen twee mensen van gelijk geslacht tot 1998 volgens de Nederlandse wet bestonden. De gekozen voorbeelden zijn volgens de richtlijnen zelfs ruim geïnterpreteerd, omdat vanwege de bescherming van 'adellijke geslachtsnamen', in het licht van de (nog) ongewijzigde richtlijnen geslachtsnaamswijziging uit 1997, het (nog steeds) ongewenst is dat een edelman de naam van zijn partner aan de zijne toevoegt. Voor vrouwen geldt dit niet; kennelijk gaf dit in het verleden geen aanleiding tot verwarring. Daarnaast is het gebruik van louter de naam van de al of niet adellijke partner in adellijke kringen hoogst ongebruikelijk. Toepassing van de richtlijnen voor het gebruik van adellijke titulatuur op het geregistreerde partnerschap (1998) of het homohuwelijk (2001) tonen het deficit aan van het traditionele gewoonterecht, dat zich niet leent voor projectie op eenentwintigste-eeuwse relaties.

\section{Constitutioneel recht}

\section{Nederlands naamrecht in Caribisch perspectief}

De enige keer dat adeldom in het Nederlandse Burgerlijk Wetboek wordt vermeld, is in lid 11 van het per 1 januari 1998 gewijzigde artikel 5 over de verkrijging van de geslachtsnaam. Het in het wijzigingsontwerp opgenomen voorstel om adellijke geslachtsnamen van naamskeuze uit te sluiten, zodat adellijke titulatuur zoveel mogelijk verbonden zou blijven met bepaalde geslachtsnamen, bleek om meerdere redenen niet houdbaar. Nadat tijdens het parlementaire debat was gebleken dat het voorstel een discriminatie van edellieden op het gebied van naamskeuze met zich mee zou brengen, kwam de staatssecretaris met een nieuw voorstel, dat de huidige formulering tot gevolg had: 'indien een kind, wiens vader van adel is, niet zijn geslachtsnaam verkrijgt, gaat adeldom niet over op dat kind. ${ }^{754}$

De Groot heeft in zijn bespreking van het gewijzigde naamrecht in Caribisch $\mathrm{Ne}$ derland, dat na de opheffing van de Nederlandse Antillen per 10 oktober 2010, bij landbesluit op Curaçao en op Sint Maarten van kracht werd, gesignaleerd dat daar geen uitzondering is gemaakt voor kinderen van adellijke vaders, die niet zijn ge-

\footnotetext{
${ }^{754}$ Kamerstukken II, 1995-1996, 22 408, nr. 12 (tweede nota van wijziging).
} 
slachtsnaam krijgen. Deze ruimere mogelijkheden voor naamskeuze voor kinderen binnen of buiten het huwelijk kan volgens De Groot hierdoor consequenties hebben. Hij gaat niet zover om te concluderen dat indien aldaar voor de adellijke naam van de moeder wordt gekozen, ook de adeldom zou overgaan, maar wel tot een soepeler (adellijk) naamrecht. ${ }^{755}$ De geslachtsnaam van het kind komt door naamskeuze tot stand, waarbij aldaar gekozen kan worden voor de naam van de vader, voor die van de moeder of voor een combinatie van beide geslachtsnamen, in een zelf gekozen volgorde. ${ }^{756}$ Wanneer bij de naamskeuze van het kind voor de beide geslachtsnamen van de ouders wordt gekozen, probeert het ingevoerde naamrecht extreem lange geslachtsnamen te voorkomen door slechts een deel van die samengestelde namen voor te schrijven. ${ }^{757}$ Een uitzondering wordt gemaakt voor 'dubbele namen van Nederlandse oorsprong (waaronder adellijke)'. Aan de ouders zelf wordt overgelaten te kiezen voor het behoud van de bestaande dubbele naam (met andere woorden om af te zien van een combinatie). ${ }^{758}$

De Groot gaat er ten onrechte van uit dat voor dubbele namen van Nederlandse oorsprong (waaronder adellijke) juist geen uitzondering zou zijn gemaakt. ${ }^{759}$ Ik kan de hierboven geciteerde artikelsgewijze toelichting van de memorie van toelichting bij de Landsverordening herziening namenrecht echter niet anders lezen, dan dat het verbod op het totstandkomen van te lange geslachtsnamen slechts één uitzondering kent.

Het Statuut voor het Koninkrijk zou - in de redenering van De Groot - bovendien voorschrijven dat het authentieke afschrift van de akte van de burgerlijke stand, dat in het gehele koninkrijk ten uitvoer kan worden gelegd, ingeschreven wordt in het filiatieregister van de Nederlandse adel. ${ }^{760}$ Overigens lijkt het nieuwe naamrecht op Curaçao en Sint Maarten nog niet in alle opzichten gelijkberechtiging van mannen en vrouwen voor te staan, want indien ouders voor een uit hun huwelijk geboren kind niet binnen de door de wet bepaalde termijn naamskeuze hebben gedaan, dan krijgt het kind (en alle volgende kinderen) de geslachtsnaam van de vader. ${ }^{761}$ Op het derde Caribische land binnen het Koninkrijk der Nederlanden, Aruba, is het naamrecht nog niet non-discriminatoir gemaakt en op de eilanden Bonaire, Sint

\footnotetext{
${ }^{755}$ De Groot Schneider, 'Haasje over springen: aantekeningen bij de Landsverordening herziening namenrecht', 1-6; De Groot, 'Autonomie und zwingende Bestimmungen im Namensrecht', 23-41.

${ }^{756}$ Landsverordening herziening namenrecht van 8 mei 2010 (Publicatieblad Ned. Antillen 2010, 29) en inwerkingtreding bij Landsbesluit van 9 okt. 2010 (Publicatieblad Ned. Antillen 2010, 85), BW, art. 1:5, lid 1 .

${ }^{757}$ BW(voor Curaçao en Sint Maarten), art. 1:5, lid 2.

${ }^{758}$ Landsverordening van 8 mei 2010, 3: memorie van toelichting, IV. Artikelsgewijze toelichting, art. 1:5, lid 2. De Werkgroep liberalisering naamrecht doet in haar rapport Bouwstenen voor een nieuw naamrecht (2009) een soortgelijk voorstel voor Nederland (42-43), waarin enkele voorbeelden van Nederlandse samengestelde namen worden genoemd, maar van 'adellijke namen' wordt geen melding gemaakt.

${ }_{759}$ De Groot Schneider, 'Haasje over springen', 34; zie echter de artikelsgewijze toelichting van de memorie van toelichting bij de Landsverordening herziening namenrecht (IV, art. I, art. 5, lid 2).

${ }^{760}$ Wet van 28 october 1954, houdende aanvaarding van een statuut voor het Koninkrijk der Nederlanden, art. 40.

${ }^{761}$ BW (voor Curaçao en Sint Maarten), art. 1:5a, lid 1, en 5i, lid 2 (overeenkomstig het Nederlandse BW, art. 1:5, lid 5a en 8).
} 
Eustatius en Saba (BES-eilanden), die als openbare lichamen gemeenten binnen het koninkrijk vormen, geldt nog de oude Nederlands-Antilliaanse wetgeving. ${ }^{762}$

\section{De (on)mogelijkheid van creatie van adeldom via de Caribische route}

De conclusie dat door het ontbreken van een bepaling als in het Nederlandse BW, art. 1:5, lid 11, in Caribisch Nederland overgang van adeldom langs vrouwelijke lijn tot gevolg kan hebben (als voor de adellijke naam van de moeder wordt gekozen) gaat te ver. Wanneer een bepaling als 'indien een kind, wiens vader van adel is, niet zijn geslachtsnaam verkrijgt, gaat adeldom niet over op dat kind', niet expliciet in het burgerlijke recht van een land is opgenomen, geldt mijns inziens niet onmiddellijk een ander adelsrecht dan dat van het Koninkrijk der Nederlanden. Het vigerende adelsrecht kent immers slechts vererving langs mannelijke lijn. Het ontbreken in het BW voor Curaçao en Sint Maarten van deze uitzonderingsbepaling op het naamrecht creëert nog geen adeldom in de landen binnen het koninkrijk, die langs vrouwelijke lijn vererft.

Hoewel adeldom in 1983 uit de grondwet verdween, betekent dit geenszins dat het geen aangelegenheid van het koninkrijk meer zou zijn. In de redenering van De Groot zou het Statuut voor het Koninkrijk bovendien voorschrijven, dat authentieke afschriften van de akten van de burgerlijke stand van de landen Curaçao en Sint Maarten, die in het gehele koninkrijk ten uitvoer kunnen worden gelegd, ingeschreven dienen te worden in het filiatieregister van de Nederlandse adel ${ }^{763}$ Ik kan me dit praktisch gezien echter niet voorstellen. Op grond van de Wet op de adeldom en zijn instructie van 1814 zal de Hoge Raad van Adel immers niet tot inschrijving in het filiatieregister van de Nederlandse adel kúnnen overgaan, aangezien vererving van adeldom langs vrouwelijke lijn in het koninkrijk niet bestaat en met deze wetgeving in strijd is. De weigering tot inschrijving zal ongetwijfeld een juridische procedure tot gevolg hebben, waarin de verbetering van de desbetreffende akte van de burgerlijke stand wordt gevraagd. Dit gebeurde eerder in enkele zaken die leidden tot het schrappen van ten onrechte in de burgerlijke stand opgenomen predikaten. Deze al sedert het midden van de negentiende eeuw tot stand gekomen foutieve inschrijvingen betroffen steeds afstammelingen van een niet geadelde oom, behorende tot een regentengeslacht waarvan een neef in 1814 adeldom was verleend. In zijn beschikkingen uit 1953 en 2006 concludeerde de Rechtbank Rotterdam tot schrapping van de adellijke predikaten in de geboorteakten van alle afstammelingen van deze oom. Het Gerechtshof Den Haag liet de beslissing in 1954 in stand; ook in 2006 kwam deze erop neer dat adeldom uitsluitend bij koninklijk besluit kan worden verleend en niet door een ambtenaar van de burgerlijke stand of rechter kan worden gecreëerd. ${ }^{764}$

\footnotetext{
${ }^{762}$ Aanpassingswet van 17 mei 2010 (Staatsblad 350); Bevestiging naamrecht 2009 bij Wet van 17 mei 2010 (Stb. 346), art. 2, lid 1 (met bijlage).

${ }^{763}$ Rijkswet van 28 okt. 1954, art. 40 ('grossen van authentieke akten'); De Groot, 'Autonomie und zwingende Bestimmungen im Namensrecht', 40.

${ }_{764}$ AR (Rotterdam) 14 sept. 1953, 270/51; GH ('s-Gravenhage) 14 jan. 1955, 2R/54; AR (Rotterdam) 19 mei 2006, 256363, en AR (Breda) 22 sept. 2006, 256379.
} 
In het Caribisch voorbeeld gaat het niet om schrappen, maar om toevoegen van adellijke titulatuur, hetgeen wanneer het akten van de burgerlijke stand betreft, zoveel betekent als verlening van adeldom. De argumentatie van de rechter, zoals laatstelijk in 2006 verwoord, heeft ook hierop direct betrekking. In een recente beschikking achtte de Rechtbank Haarlem zich niet bevoegd een adellijk predikaat aan de geboorteakte van verzoeker toe te voegen, aangezien dit een zaak van de Kroon is en de ambtenaar van de burgerlijke stand daarvoor een inschrijving van verzoeker in het filiatieregister van de Nederlandse adel nodig heeft. ${ }^{765}$

Ik concludeer hieruit dat een van oorsprong constitutioneel recht als het adelsrecht niet buiten werking kan worden gesteld door de al of niet dwingende bepalingen van in een burgerlijk wetboek geregeld naamrecht. Al is sinds 1994 het adelsrecht niet meer in de grondwet geregeld, het is vanouds een prerogatief van de vorst en vloeit mitsdien uit diens op de grondwet gebaseerde macht voort.

Asser-De Boer verbaast zich er over dat artikel BW 1:5, lid 11, onderdeel is geworden van het burgerlijk wetboek en niet een bepaling van de Wet op de adeldom. ${ }^{766}$ Laatstgenoemde wet was echter al ruim drie jaar van kracht, toen de wijziging van de artikelen 5 en 9 van het BW na veel discussie tot stand kwam. Voorts legt de Wet op de adeldom uitsluitend vast wat al in SB's en KB's vanaf het begin van het koninkrijk werd bepaald en waarin de inhoud van art. BW 1:5, lid 11, impliciet als een vanzelfsprekendheid is opgenomen. Het verplaatsen zou water-naarde-zee-dragen zijn, terwijl de subtiele herinnering aan geldend constitutioneel recht in het burgerlijk wetboek zijn nut zou kunnen hebben. Hiervan is overigens nauwelijks gebleken in de nieuwe wetgeving in de andere landen van het koninkrijk, hetgeen als een gemiste kans kan worden gezien. Het instituut adeldom moet echter bekend verondersteld worden, getuige het respect 'voor dubbele namen van Nederlandse oorsprong (waaronder adellijke)', dat in de memorie van toelichting wordt beschreven. Hiervoor wordt immers expliciet een uitzondering gemaakt, wanneer in geval van naamskeuze voor een combinatie van de geslachtsnamen van de ouders deze namen opgedeeld moeten worden als ze te lang dreigen te worden. ${ }^{767}$ Een belangrijk argument voor deze uitzonderingspositie wordt echter niet in de memorie van toelichting bij de Landsverordening herziening naamrecht voor Curaçao en Sint Maarten genoemd, namelijk dat het volgens Nederlands recht ongewenst wordt geacht 'adellijke geslachtsnamen' onderdeel te laten zijn van naamstoevoegingen. ${ }^{768}$ Weliswaar ligt er een wijzigingsvoorstel van juist deze regeling bij het parlement en is het Besluit geslachtsnaamswijziging niet in de andere landen binnen het koninkrijk van kracht, maar een verwijzing naar het Nederlandse recht zou een argumentatie voor invoering hebben kunnen geven.

\footnotetext{
${ }^{765}$ AR (Haarlem) 24 april 2012, 184609/FA RK 11-2853 (art. BW 1:24); JPF 2012, 86 (met noot P. Vlaardingerbroek).

766 Asser-De Boer, Personen- en Familierecht, nr. 42a, p. 59.

${ }^{767}$ Landsverordening van 8 mei 2010, 3: memorie van toelichting, III. Advies van de Raad van Advies, nr. RA/025-07'08.

${ }^{768}$ KB van 6 okt. 1997 (Stb, 463), houdende regels voor geslachtsnaamswijziging, art. 2, lid 3a en 3b.
} 
Hier duikt dus een tweede discrepantie op met het naamrecht op Curaçao en Sint Maarten, aangezien voor de toevoeging van adellijke titulatuur bij samengestelde geslachtsnamen nog geen oplossing is gevonden. Dit probleem is echter van ondergeschikt belang, aangezien er al eeuwenlang geslachtsnamen bestaan waarvan exact bekend is bij welke van de afzonderlijke delen de eventuele adellijke titulatuur behoort. ${ }^{769}$ De door De Groot opgeworpen vraag wat rechtens is indien in Caribisch Nederland door naamskeuze een gecombineerde geslachtsnaam van beide ouders, waarvan de vader van adel is, totstandkomt, kan daarmee gemakkelijk worden beantwoord. Adellijke titulatuur behoort immers altijd bij (een deel van) de adellijke geslachtsnaam van de vader en dit deel zal altijd relevant blijven voor de overgang van adeldom, die uitsluitend langs mannelijke lijn vererft. ${ }^{770}$

\section{Nederlands naamrecht in Europees perspectief}

Recentelijk heeft De Groot c.s. in het kader van een verdere liberalisering het naamrecht van een aantal West-Europese landen vergeleken met het Nederlandse naamrecht. Zo blijkt er tussen landen een verschil in verplichting te bestaan om doorgaans met het oog op de te kiezen geslachtsnaam voor de kinderen - een huwelijks- of partnersnaam te kiezen. Zwitserland is het meest conservatief: het kiezen van een huwelijksnaam is verplicht, waarbij die van de man prevaleert. Duitsland, Engeland en drie Scandinavische landen kennen een vrije keuze om een huwelijksnaam te kiezen. Maakt men geen keuze, dan kan in Scandinavië met behoud van de eigen naam voor de gelegenheid een tussennaam worden aangenomen. In Frankrijk, Spanje en Nederland heeft het huwelijk of partnerschap geen directe invloed op de geslachtsnaam. In Nederland bestaan slechts gebruiksrechten voor gehuwden en partners op grond van art. BW 1:9, die in het maatschappelijk verkeer van belang zijn. Frankrijk gaat zover dat ook kinderen in deze gebruiksrechten kunnen participeren, terwijl de gebruiksnamen niet tot die van de partners beperkt behoeven te blijven.

Aangezien Nederland geen huwelijksnaam kent, moet in tegenstelling tot andere landen de naam van het kind apart worden bepaald. In een toenemend aantal landen wordt het ouders toegestaan dat hun kind een dubbele geslachtsnaam draagt die van beide families is afgeleid. Spanje en Portugal kennen deze regeling traditioneel en daardoor dwingend, andere landen zoals Engeland, Frankrijk, Denemarken en Noorwegen hebben deze mogelijkheid inmiddels ook. Landen zoals Zweden met een zogenaamde tussennaam creëren hiermee een potentiële mogelijkheid. In Nederland is de optie nog in onderzoek. Als ouders het oneens zijn over naamsbepaling, heeft de naam van de vader in Frankrijk, Spanje, Nederland en Zwitserland voorrang, in de drie Scandinavische landen daarentegen de naam van de moeder. In Engeland bepaalt de rechter de naam, in Duitsland kiest de rechter de ouder uit die de naam bepaalt. In de meerderheid van de bestudeerde landen bestaat eenheid van naam, terwijl Engeland, Denemarken en Noorwegen keuzevrijheid heb-

\footnotetext{
${ }^{769}$ Bijv. Van Aylva baron(es) Rengers. Andere voorbeelden zijn onder noot 743 opgesomd.

${ }^{770}$ De Groot Schneider, 'Haasje over springen', 34-35.
} 
ben, zelfs onder volle broeders en zusters. Ook de verschillen met betrekking tot de vaststelling van de naam bij adoptie zijn soms groot tussen de afzonderlijke landen. Die betreffende geslachtsnaamswijziging zijn hier en daar tegengesteld. ${ }^{771}$ Het Nederlandse Besluit geslachtsnaamswijziging (1997) gaat nog uit van de gedachte van een ontmoediging van naamstoevoeging. Vanouds werd een toename van het aantal samengestelde geslachtsnamen om praktische redenen ongewenst geacht. In Europees perspectief gezien, komt Nederland daar niet meer mee weg en zal alleen al om die reden het besluit moeten worden aangepast. In dit kader past ook het voorstel om artikel 2, lid 3a en 3b, te schrappen, dat 'adellijke geslachtnamen' uitsluit als onderdeel van naamstoevoeging.

\section{Nederlands adelsrecht en Duits naamrecht}

Ook in Duitsland is het naamrecht non-discriminatoir gemaakt. Vanaf 1977 kunnen Duitse ouders een gezinsnaam kiezen anders dan de geslachtsnaam van de vader, terwijl de partner die de naam niet doorgeeft de eigen naam mag blijven voeren, zelfs zonder deze te combineren met de gezinsnaam. Deze keuzes gelden daar vanzelfsprekend ook ten aanzien van geslachtsnamen waarvan een (voormalige) adellijke titel deel uitmaakt. Ook in het maatschappelijk verkeer zijn in Duitsland vele vormen mogelijk, maar die worden niet geregistreerd in de registers van de burgerlijke stand. ${ }^{772}$ In geval van grensoverschrijdende situaties, zoals met Nederland, kan dit soms tot wonderlijke oplossingen leiden. ${ }^{773}$ De advocaat Van Rijn gaf in een liber amicorum van een adellijke collega die afscheid nam op het kantoor van de landsadvocaat, recentelijk een helder overzicht van het vigerende adelsrecht, gebiologeerd als hij altijd geweest was door haar Nederlandse adellijke afkomst en die van haar moeder, die tot de voormalige Duitse adel behoorde. ${ }^{774}$ Ten aanzien van het gecompliceerde Duitse naamrecht doen zich met betrekking tot voormalige adellijke titulatuur inconsequenties voor. De hoofdregel lijkt simpel; artikel 109, lid 3, van de Weimarer Reichsverfassung, die op 14 augustus 1919 in werking trad, luidde: 'Öffentlichrechtliche Vorrechte oder Nachteile der Geburt oder des Standes sind aufzuheben. Adelsbezeichnungen gelten nur als Teil des Namens und dürfen nicht mehr verliehen werden.' In het algemeen maken primogenituurtitels, zoals Fürst, sindsdien geen deel meer uit van de naam en hielden in de burgerlijke stand op te bestaan met het overlijden van degene die zo'n titel op

\footnotetext{
${ }^{771}$ De Groot e.a., Naamrecht in vergelijkend perspectief, 35-36.

${ }^{772}$ Palandt, Bürgerliches Gesetzbuch (BGB), 69 (München 2010), § 12 (Namensrecht), 6 (Adelsprädikate).

${ }^{773}$ Van der Velde, 'Het Nederlandse namenrecht blijft verbazen', 204-206.

${ }^{774}$ Van Rijn, 'What's in a name? - Adel in de $21^{\mathrm{e}}$ eeuw', 171-181. Beroepsmatig hadden beiden geen adelsrechtelijke zaken voor de landsadvocaat behartigd - zij troffen elkaar in 1995 op de sectie ruimtelijk bestuursrecht en milieurecht - maar zij raakten ook door hun beider Duitse achtergrond in elkaar geïnteresseerd. De auteur woonde negen jaar als journalist in Duitsland, trouwde een Duitse vrouw en zijn oudste twee kinderen waren daar geboren. De achtergrond van zijn collega had betrekking op haar moeder, een Reichsfreiin von Fürstenberg, die als negenjarig meisje met haar familie de wettelijke afschaffing van de Duitse adel had meegemaakt en overigens weer een Nederlandse adellijke moeder had, die in 1909 op Schloss Neuhauss te Paderborn (Westfalen) was geboren en twee wereldoorlogen binnen de kring van de Duitse adel had doorgemaakt.
} 
14 augustus 1919 droeg. ${ }^{775}$ De vermelding van de naam op deze datum is dus nog steeds bepalend in geval van twijfel over het naamsbestanddeel. Rijndorp nuanceerde deze grondwetsbepaling door uit te leggen dat de Duitse deelstaten zelf bij deelstaatwet de huisrechten van de vroeger in die deelstaten regerende vorstenhuizen moesten opheffen. De vrijstaat Lippe zou dat niet hebben gedaan, zodat het huisrecht daar bleef bestaan. ${ }^{776}$ Toch zal ook het deelstaatrecht zich hebben moeten conformeren aan de uitspraak van het Bundesverwaltungsgericht, dat besliste dat persoonlijke adellijke titulatuur, waaronder primogenituurtitels, met het overlijden van degenen, die deze in 1919 voerden, verdwenen waren. ${ }^{777}$ In de praktijk hadden in Duitsland adellijke geslachten nog de mogelijkheid hun primogenituurtitel om te zetten in een louter door het naamrecht geregeerde titel op allen. Een aantal families maakte van deze merkwaardige verruiming van het afgeschafte Duitse adelsrecht gebruik of voerde daarna procedures om de naamregistratie bij te stellen. ${ }^{778}$

Bij de naamswijziging van Ilonka Fürstin von Sayn-Wittgenstein, wier zaak aan het Europese Hof te Luxemburg werd voorgelegd, lijkt het juist niet om een door huisrecht bepaalde primogenituurtitel te gaan, aangezien deze volgens het Duitse naamrecht op allen was doorgegeven. De zaak ging over het al of niet terecht voeren door een in Oostenrijk geboren, maar in Duitsland geadopteerde volwassen vrouw door een man met een adellijke geslachtsnaam, inclusief verbogen voormalige adellijke titel. ${ }^{779}$ De makelaar in buitenplaatsen Ilonka Kerekes had haar omzet al vanaf 1991 zien stijgen, het jaar waarin zij door adoptie naamswijziging had verkregen in Ilonka Fürstin von Sayn-Wittgenstein. Haar adoptiefvader Lothar Fürst von Sayn-Wittgenstein voerde overigens, ter onderscheiding van andere takken van het voormalige hoogadellijke geslacht Zu Sayn-Wittgenstein, een gewijzigd voorvoegsel. ${ }^{780}$ Adopties binnen voormalige Duitse adellijke geslachten, die volwassen personen kunnen betreffen, worden in het Duitse Adelslexikon dikwijls apart vermeld. ${ }^{781}$ Als Oostenrijks onderdaan hadden de Oostenrijkse autoriteiten de vrouw op haar verzoek ingeschreven met titulatuur en voorvoegsel, maar in strijd met de Oostenrijkse grondwet uit 1919, die adeldom afschafte en het schrappen van titels en voorvoegsels voorschrijft. Een oplettende ambtenaar van de burgerlijke stand signaleerde de foutieve inschrijving en vroeg ambtshalve rectificatie bij de rechter. De Oostenrijkse rechter legde de kwestie in 2009 voor aan het Hof van

\footnotetext{
${ }^{775} B G B 69$ (2010), § 12, 6. Vgl. de nota van de secretaris van de Hoge Raad van Adel, d.d. 11 maart 1993 (HRvA-RA, not. 1986-30).

${ }^{776}$ Rijndorp, 'Nogmaals de Prins van Oranje en andere titels der Koninklijke Familie', 955.

${ }^{777}$ BGB 69 (2010), § 12, 6 (BVerwG 23, 345).

${ }^{778}$ Vriendelijke mededeling van mr. D. van Krugten, archief- en museumdirecteur van Fürst Carl Philip Prinz zu Salm Salm, Wasserburg Anholt, 11 april 2012.

${ }^{779}$ HvJEU 22 dec. 2010, C-208/09 (Ilonka Sayn-Wittgenstein contra Landeshauptmann von Wien); NJ 2011/119 (noot M.R. Mok); Kuipers, 'Sayn-Wittgenstein. Dokkumer Doctrine en Adellijke Aspiraties', nr. 56; Besselink, 'Respecting Constitutional Identity in the EU', 671-693.

${ }^{780}$ Adelslexikon 12 (Genealogisches Handbuch des Adels (GHA) 125, Limburg an der Lahn 2001), 281285.

${ }^{781}$ Genealogisches Handbuch der Fürstlichen Häuser 11 (GHA 75, Limburg an der Lahn 1980), 468-469. Deze Beierse tak Von Sayn-Wittgenstein was in 1959 in mannelijke lijn uitgestorven, zodat niet uitgesloten is, dat de adoptiefvader zelf ook al was geadopteerd.
} 
Justitie van de Europese Unie (HvJEU) te Luxemburg. De vrouw deed daarbij een beroep op artikel 21 van het Europese verdrag, dat het vrij verkeer van personen voor Europese burgers waarborgt (VWEU) ${ }^{782}$ in samenhang met artikel 8 van het EVRM (bescherming familieleven). Op grond van een uitspraak van het Europese Hof in 2008, waarin werd bepaald dat de lidstaten van de EU bij de uitoefening van de bevoegdheden inzake (in casu: dubbele) familienamen het gemeenschapsrecht van de EU in acht moeten nemen, koesterde de vrouw hoop. In deze zaak besliste het Hof, dat een in Denemarken wonend Duits ouderpaar hun in Denemarken geboren (eveneens Duitse) zoon, overeenkomstig Deens maar in strijd met Duits recht, de gecombineerde achternamen van beide ouders mag geven en dat een Duits burgerlijke-standkantoor dat moet accepteren. ${ }^{783}$ De in Nederland tot stand gekomen Wet conflictenrecht namen (WCN) geeft in soortgelijke situaties prioriteit aan het recht van het land van naamgeving. ${ }^{784}$

Het HvJEU stond de Oostenrijkse staat in zijn uitspraak toe zijn grondwettelijke opdracht uit te voeren en de voormalige adellijke titulatuur tezamen met het voorvoegsel te schrappen, zijnde van principiële aard. Daarin verschilde de zaak onder meer van die uit 2008. Het Hof stelde vast dat de vrijheid om te reizen en te verblijven in lidstaten zich niet verzet tegen een maatregel van één van de lidstaten tot aanpassing van de geslachtsnaam van een onderdaan - ook al is deze geadopteerd door een onderdaan van een andere lidstaat, wiens naam en (voormalige) adellijke titel worden gedragen - wanneer deze een voormalige adellijke titel bevat, die volgens het constitutionele recht van die staat niet is toegestaan. Als voorwaarde werd gesteld dat die maatregel moet zijn genomen op grond van redenen van openbare orde, hetgeen betekent dat ze noodzakelijk zijn ter bescherming van de belangen die zij beogen te waarborgen en dat zij evenredig zijn aan het rechtmatig nagestreefde doel.

Jonkheer Van Meeuwen gaf aan dat al in 1924 het Reichsgericht, de hoogste rechter in de Republiek van Weimar, had bepaald dat titulatuur geslachtsspecifiek verbogen mocht worden. ${ }^{785}$ Hij wees daarbij op de consequenties van het Duitse systeem, die tot gevolg konden hebben dat de naam van een adellijke moeder inclusief haar titel zowel door haar onwettige kind als door haar echtgenoot zou kunnen worden doorgegeven. In strijd met het vroegere landrecht zou de naam inclusief titel ook bij legitimatie en adoptie kunnen worden doorgegeven. Jonkheer Van Meeuwen concludeerde voorts, zich baserend op de uitspraak van de hoogste Nederlandse rechter in 1956, dat alleen vreemde titels die door vreemdelingen in $\mathrm{Ne}$ derland werden gevoerd, voor opname in officiële overheidsakten in aanmerking zouden komen, omdat dan geen verwarring kon ontstaan met Nederlandse titulatuur. De rechter had immers geen bezwaar gehad tegen in het Nederlandse maat-

\footnotetext{
${ }^{782}$ Verdrag betreffende de werking van de Europese Unie (inwerkingtreding 1 jan. 1958).

${ }^{783}$ HvJEU 14 okt. 2008, C 353/06 (Grunkin en Paul II), NJ 2009/64 (samenvatting in: NJ 2011/119, 1214).

${ }^{784}$ Wet conflictenrecht namen van 3 juli 1989, art. 1 en 5a; thans BW, boek 10 (Internationaal privaatrecht, ingevoerd per 1 jan. 2012), artt. 18-26.

${ }^{785}$ Entscheidungen des Reichsgerichts in Zivilsachen 108, 244, d.d. 27 nov. 1924.
} 
schappelijke verkeer gevoerde buitenlandse titulatuur, mits geen verwarring zou ontstaan. ${ }^{786}$ Toch sloot hij af met de overtuiging dat in een Nederlandse naturalisatiewet van een Duitser wiens adellijke titulatuur volgens Duits recht onderdeel van het Duitse naamrecht was geworden, deze titulatuur niet mocht worden vermeld als in strijd met de Nederlandse openbare orde. Wijziging van geslachtsnaam is bij naturalisatiewet geoorloofd, zodat de Duitse naam kon worden gewijzigd door de voormalige titulatuur daaruit te verwijderen. ${ }^{787} \mathrm{Hij}$ gaf daarbij de mogelijkheid aan om 'nog altijd inlijving in de Nederlandse adel te kunnen verzoeken'. Sindsdien zijn echter belangrijke wijzigingen in de regelgeving aangebracht, waarmee deze optie is vervallen: schrapping van art. 74 uit de grondwet (1983) en inwerkingtreding van art. 2, lid 3, van de Wet op de adeldom.

\footnotetext{
${ }^{786}$ HR (Strafkamer) 14 febr. 1956 (Von Wedell).

${ }^{787}$ Van Meeuwen, 'Een en ander over het Nederlandse adelsrecht', 85 (noten 30-32) en 87 (noot 41).
} 


\section{Conclusies en aanbevelingen}

\section{Conclusies}

Het fundamentele grondrecht van gelijkheid van een ieder voor de wet, dat eerst na de Tweede Wereldoorlog in de Nederlandse grondwet werd opgenomen en waarvoor de basis al in de Staatsregeling van 1798 werd gelegd, is in de tussentijd lang uit het zicht verdwenen. In de tien jaren die op de Bataafse vrijheid volgden heeft de rommelig verlopen democratische ontwikkeling uiteindelijk geresulteerd in een Franse machtsgreep bij volksreferendum met de vestiging in de Noordelijke Nederlanden van een centralistisch bewind onder koninklijk gezag. Hiermee kwam de weg vrij voor de creatie van een bijzondere status ten behoeve van de sympatisanten van de nieuwe koning. Met de instelling van een constitutionele adel in 1809 was de staatsrechtelijke ongelijkheid een feit.

Het Nederlandse adelsstatuut, dat op basis van de Grondwet van 1814 bij besluiten van de Soevereine Vorst der Verenigde Nederlanden werd vastgesteld, werd zowel institutioneel als adelsrechtelijk vergeleken met het adelsstatuut dat in het Koninkrijk Holland tussen 1809 en 1810 heeft gegolden. De auteur van beide adelsstatuten, W.A. baron van Spaen la Lecq, achtereenvolgens lid (als grootmeester van wapenen) van het Hoog Heraldiek Collegie en president van de Hoge Raad van Adel, was de belangrijkste adviseur van beide vorsten op het gebied van adelszaken. De regelgeving voor de in 1814 opgerichte nieuwe erfelijke Nederlandse adel, waarvoor iedere rechthebbende zich opnieuw moest aanmelden, blijkt op hoofdlijnen terug te gaan op het door koning Lodewijk Napoleon uitgevaardigde adelsstatuut. Het werd in 1810 in opdracht van keizer Napoleon vervallen verklaard alsof het nooit bestaan had, maar bleef op papier bewaard om in 1814 grotendeels te herleven.

De keuze voor dit Napoleontische adelsstatuut leidde tot een discrepantie tussen de afstammingsregels zoals die vanouds golden binnen het huis Oranje-Nassau, in het bijzonder met betrekking tot de troonopvolging, en die betreffende de vererving van de aan dit huis ontleende adeldom. De erfopvolging binnen het vorstenhuis is gebaseerd op een resolutie van de Staten-Generaal (1748), die in geval van uitsterven vererving langs vrouwelijke lijn mogelijk maakte. Het Nederlandse adelsstatuut, dat uitsluitend vererving langs mannelijke lijn kent, is via de grondwet en statuten van de adel van het Koninkrijk Holland uiteindelijk terug te voeren op de Constitutie van het Koningrijk Holland (1806). Artikel 19 van die constitutie laat er geen misverstand over bestaan dat de kroon alleen bij recht van eerstgeboorte kon vererven op wettige mannelijke afstammelingen, bij altijd durende uitsluiting van vrouwen en hun afstammelingen.

De gesignaleerde discrepantie leek te conflicteren met de theocratische staatsleer, volgens welke de bij de gratie Gods regerende soevereine vorst adeldom creëert 
naar de wetten en hiërarchie van zijn huis. Aangetoond kon echter worden dat de historische ontwikkeling van de erfopvolging binnen het koninklijk huis een andere is geweest dan die binnen de Nederlandse adel en deze kennelijk los van elkaar konden plaatsvinden. De vorstelijke afstammingsregels zijn binnen het huis (Oranje-)Nassau vanaf de achttiende eeuw steeds verder versoepeld, daar waar het adelsrecht vasthield aan vererving uitsluitend in de mannelijke lijn. De regelgeving betreffende de troonopvolging werd in de loop van de twintigste eeuw in etappes vrouwvriendelijk en vervolgens sekseneutraal gemaakt, overeenkomstig de wens van de volksvertegenwoordiging. In de tekst van de Grondwet van 1963 werd de troonopvolging expliciet opengesteld voor dochters en in die van 1983 ontdaan van de voorrang voor zonen.

Tijdens de parlementaire behandeling van de Wet op de adeldom heeft de minister van Binnenlandse Zaken Dales ter verdediging van die discrepantie meermaals gewezen op de publieke en constitutionele aspecten van het koningschap, die de grondwetgever tot het oordeel hadden gebracht dat onderscheid naar geslacht bij de vervulling van dit publieke ambt ongewenst is. Zij betoogde dat door de vele en belangrijke rechtsgevolgen die aan het koningschap verbonden zijn, de gelijkberechtiging van mannen en vrouwen een ander, zwaarder gewicht toekomt dan bij vererving van adeldom. Al een jaar na de inwerking van de Wet op de adeldom deed de Afdeling Bestuursrechtspraak van de Raad van State twee belangrijke uitspraken in adelszaken betreffende de aangevochten vererving langs mannelijke lijn. De motivering was dat het handhaven van onderscheid tussen afstamming via mannen of via vrouwen volgens een objectieve en redelijke grond, verantwoord binnen de regelgeving van het historisch instituut adel, die zich niet leende voor aanpassing aan moderne opvattingen over gelijke behandeling, niet strijdig is met het gelijkheidsbeginsel of het beginsel van non-discriminatie. Een extra argument was voor de Afdeling dat de onmogelijkheid adeldom te verwerven altijd gelijkelijk heeft gegolden voor zowel mannen als vrouwen.

In 1997 legde het eerste Kabinet Kok, bij monde van minister van Binnenlandse Zaken Dijkstal, een alsnog door de Tweede Kamer aangenomen motie, die vererving van adeldom langs vrouwelijke lijn mogelijk moest maken, naast zich neer. De liberale minister wees onder meer op de tegenstrijdigheid om met een beroep op rechtsgelijkheid tussen mannen en vrouwen in feite uitbreiding te bevorderen van een groep personen die in de samenleving louter op grond van overerving een bepaalde status had, die door sommigen als ongelijk werd ervaren. Naar het oordeel van dit 'paarse kabinet' zou de adel als historisch instituut zijn grondslag verliezen wanneer hij werd aangepast aan hedendaagse inzichten. Sindsdien heeft geen parlementaire meerderheid de beoogde vernieuwing van de Wet op de adeldom inzake vererving van adeldom langs vrouwelijke lijn kunnen realiseren.

De modernisering van het Nederlandse adelsrecht is daardoor beperkt gebleven tot de mogelijkheid van overgang van erfelijke adeldom op buiten het huwelijk gebo- 
ren kinderen, die geboren zijn op of ná 1 augustus $1994 .{ }^{788}$ Naar mijn mening had in het Nederlandse adelsstatuut de oude eis van wettige geboorte gehandhaafd moeten worden, in aanmerking genomen dat deze voorwaarde bij overgang van primogenituurtitels uitdrukkelijk is blijven bestaan. Deze inconsequente aanpassing bij amendement werd als artikel 3 in de wet opgenomen, waardoor het zo gekoesterde historisch instituut geweld is aangedaan. Een gevolg hiervan is dat thans via DNA-onderzoek gerechtelijke vaststelling van het vaderschap van een potentieel adellijk kind kan plaatsvinden op grond van biologische afstamming van een edelman. Daarmee komt bij uitzondering biologische afstamming in beeld, waar vanouds slechts wettelijke adeldom bestond. Dat de bloedband irrelevant was, blijkt niet alleen uit de verervingsregels - veel 'adellijk bloed' vloeit al eeuwenlang langs vrouwelijke lijn weg - maar ook uit gewettigde of staande het huwelijk geboren kinderen. Ook al waren deze niet door de wettige (adellijke) vader verwekt, dan nog kregen zij automatisch zijn geslachtsnaam inclusief titulatuur.

Achteraf bezien heeft de wetgever door deze beperkte modernisering niet alleen het uitsterven van adellijke geslachten voorkomen, maar tegelijkertijd een verdubbeling, althans aanzienlijke groei, van het aantal edellieden tegengehouden door het standpunt van de gewenste vererving langs vrouwelijke lijn los te laten.

$\mathrm{Nu}$ het EHRM heeft vastgesteld dat de privileges van de Nederlandse adel geen 'civil rights' zijn zoals deze door de Nederlandse grondwet en internationale verdragen worden beschermd, acht ik nieuwe acties van het parlement om de gelijkheid tussen mannen en vrouwen binnen het historisch gegroeide adelsrecht te verwezenlijken niet opportuun. ${ }^{789}$

Het enige relevante privilege is nog het recht van edellieden op vermelding van aan hen competerende adellijke titulatuur op overheidsdocumenten. De overheid is verplicht de adellijke titulatuur van een half promille burgers met een bijzondere historische achtergrond correct te vermelden op haar officiële stukken. Deze aan het naamrecht verwante taak van de overheid is dan ook belangrijker dan een eventuele zorg voor de bescherming van adeldom als cultureel erfgoed. Hieronder wordt een aantal aanbevelingen gedaan om door een geringe aanpassing van de wetgeving de in het voorgaande hoofdstuk gesignaleerde onvolkomenheden ongedaan te maken.

Schrijnend is ten slotte dat in de decennialange discussie over gelijkberechtiging een belangrijk aspect van het adelsrecht, namelijk zijn constitutionele grondslag als aangelegenheid van het koninkrijk, is verwaarloosd. Kennelijk vloeit dit gebrek aan juridische aandacht voort uit het hierboven toegekende lichtere gewicht dat aan vererving van adeldom wordt toegedicht tegenover het staatsrechtelijke belang van troonopvolging, maar deze zienswijze is niet expliciet uitgesproken. Het bij de grondwetsherziening van 1983 toegepaste deconstitutionaliseringprincipe heeft niet alleen de titel prins(es) van Oranje uit de grondwet verbannen, maar ook de

\footnotetext{
${ }^{788}$ Dit is de datum van inwerkingtreding van de wet die, zoals de Afdeling Bestuursrechtspraak van de Raad van State in 2005 vaststelde, geen terugwerkende kracht heeft.

${ }^{789}$ ABRvS 16 maart 1999, H01.98.0350/15; EHRM 18 mei 1999, nr. 45908/99.
} 
adeldom. Voor de gewenste regeling ontbreekt zelfs een verwijzing in de grondwet, die ridderorden wel ten deel is gevallen. Intussen dreigt niet alleen dubbelzinnige toepassing van het vigerende Nederlandse adelsrecht in de landen binnen het koninkrijk, maar ook overvleugeling door buitenlands naamrecht, dat elementen van afgeschaft adelsrecht bevat.

\section{Aanbevelingen}

Enkele actuele vraagstukken met betrekking tot het vigerende adelsrecht vragen om voorstellen tot aanpassing van wetgeving, zodat onevenwichtigheden in de regelgeving binnen het Koninkrijk der Nederlanden ongedaan kunnen worden gemaakt en problemen in de toekomst voorkomen. Allereerst zal worden ingegaan op de discrepantie tussen art. BW 1:9 en het vermeende (traditionele) gewoonterecht, die in het vorige hoofdstuk werd gesignaleerd. Vervolgens moet een oplossing worden gevonden inzake de uiteenlopende bepalingen in het burgerlijk wetboek van de verschillende landen binnen het koninkrijk, die consequenties kunnen hebben voor de toepassing van de Wet op de adeldom. Ten slotte dient een standpunt bepaald te worden ten aanzien van voormalige adellijke titulatuur, die als buitenlands naamrecht het Nederlands adelsrecht zou kunnen overvleugelen.

\section{Onderscheid tussen authentieke gegevens en aanschrijfgegevens}

Artikel BW 1:9 geeft sinds 1998 een universeel recht op naamskeuze (in het maatschappelijk verkeer) aan partners dat geen onderscheid tussen mannen en vrouwen, huwelijken en partnerregistraties, ook van gelijk geslacht, en tussen adel of nietadel toestaat. De Groot gaf aan dat vanaf de opname in 1970 van de gewoonterechtelijke regel dat echtgenotes de naam van hun man in het maatschappelijk verkeer mogen gebruiken al niet meer van traditioneel gewoonterecht kan worden gesproken, omdat dit gewoonterecht toen werd gecodificeerd. Beperking in naamskeuze door de overheid betekent sindsdien ongeoorloofde discriminatie, ook al zou de adellijke gedragscode op grond van negentiende-eeuws gewoonterecht zich daartegen verzetten. ${ }^{790}$

In deze discussie treedt dikwijls verwarring op tussen de verplichting voor bestuursorganen om adellijke titulatuur op officiële documenten te vermelden en de daaruit voortvloeiende toepassing binnen de voorgeschreven 'aanduiding van het naamgebruik' (in de aanschrijfgegevens naar aanleiding van de naamskeuze) na huwelijk of partnerschap.

De eerstgenoemde verplichting vloeit voort uit het SB van 13 febr. 1815, nr. 60 (Stb. 15) en het KB van 26 jan. 1822 (Stb. 1) en werd enkele malen door rechterlij-

\footnotetext{
${ }^{790}$ De Groot, 'Twee aantekeningen over het gebruik van adellijke titels', 103-105.
} 
ke uitspraken bevestigd. ${ }^{791}$ Hoewel adellijke titels en predikaten behoren tot de ultieme identiteitsgegevens van een persoon, zijn deze niet expliciet in het Besluit GBA onder de basisgegevens vermeld. ${ }^{792}$ Het gevolg van deze leemte in de wet is dat het Agentschap Basisadministratie Persoonsgegevens en Rijbewijzen (BPR) bestuursorganen niet kan verplichten adellijke titulatuur af te nemen en vervolgens te gebruiken. ${ }^{793}$

De Hoge Raad van Adel heeft regelmatig bij de minister van BZK aangedrongen op toevoeging van adellijke titulatuur aan de zogenoemde 'authentieke gegevens', maar de bewindspersoon wilde niet verder gaan dan het uitvaardigen van een ministeriële circulaire. ${ }^{794}$ Inmiddels is het Agentschap BPR wel overgegaan op automatische levering aan afnemers van de bij voor- of achternaam behorende adellijke predikaten en titels, maar het kan bestuursorganen noch andere afnemers verplichten tot werkelijk gebruik. Binnen het Agentschap BPR wordt adellijke titulatuur om deze reden louter behandeld als een door het naamrecht geregeerde accessoire van een familienaam, zoals bijvoorbeeld een tussenvoegsel. Deze zienswijze ontslaat het agentschap overigens niet van de verplichting tot correcte toepassing. Een klacht bij de Nationale ombudsman van een burger over het niet gebruiken van diakritische tekens in de schrijfwijze van zijn achternaam, leidde tot een circulaire van het agentschap aan alle afnemers, waarin op naleving van het voor de hele rijkdienst geldende ministeriële Besluit Standaardschrijfwijze Persoonsgegevens werd aangedrongen. ${ }^{795}$

Enkele afzonderlijke regelingen, zoals de Paspoortwet en het Reglement Rijbewijzen, vermelden wel het bestaan van adellijke titulatuur. ${ }^{796}$ De vermeldingstoepassing in laatstgenoemd reglement werd door een verkeerde interpretatie van artikel 5 van de Wet op de adeldom ten onrechte gewijzigd van een verplichting in een vermelding op verzoek. ${ }^{797}$ De Hoge Raad van Adel ervoer deze fout als schrijnend aangezien een rijbewijs zich van andere overheidsdocumenten onderscheidt door de bijzondere hoedanigheid van identiteitsbewijs, vergelijkbaar met een paspoort,

\footnotetext{
${ }^{791}$ HR 19 okt. 1917 (Taets van Amerongen van W.) en AR (Arnhem) 1 nov. 2007, AWB 07/1306 (Van Isselmuden); $A B$ 2007, 367 (met noot I. Sewandono).

${ }^{792}$ Besluit gemeentelijke basisadministratie persoonsgegevens (GBA) van 8 sept. 1994, art. 58a, bijlage 1d, lid 1 (Wetsontwerp basisregistratie personen (BPR) 2012, artt. 2.7 en 2.69). Met ingang van 2010 zijn bestuursorganen verplicht gebruik te maken van authentieke gegevens (naam, geboortegegevens, woonplaats, etc.) uit de GBA (BRP).

${ }^{793}$ Adellijke titulatuur is overeenkomstig de richtlijnen van de HRvA opgenomen in het op grond van art. 52 van de Wet GBA ingerichte Logisch Ontwerp, nr. 38. Vgl. http://www.bprbzk.nl/GBA/Informatiebank/ Procedures/Logisch_Ontwerp_LO(geraadpleegd 20 april 2012).

${ }^{794}$ Jaarverslag HRvA over 2009, 2; Ministerieel appèl van 15 februari 2010, BZK-DGBK kenmerk 20100000088703.

${ }^{795}$ NO, rapport 2007/161 met openbaar aanbevelingsrapport aan BZK van 3 aug. 2007. Circulaire Agentschap BPR van 12 okt. 2007, kenmerk U58280.

${ }^{796}$ Rijkswet van 26 sept. 1991, houdende het stellen van regelen betreffende de verstrekking van reisdocumenten (Paspoortwet), art. 4a (basisregister reisdocumenten), lid 5a (persoonsgegevens); KB van 30 mei 1996 (Stb. 277), houdende uitvoering van de Wegenverkeerswet 1994 (Reglement Rijbewijzen), art. 144 (rijbewijzenregister) en 145 (persoonsgegevens). Vgl. het wijzigingsbesluit van 23 juni 1998 (Stb. 422), art. I, K (wijziging art. 145b: toevoeging adellijke titulatuur van de partner).

${ }^{797} \mathrm{~KB}$ van 7 aug. 2006 (Stb. 377) tot wijziging van het Reglement Rijbewijzen, art. 145, lid 1b. Vgl. ook het wijzigingsbesluit van 27 jan. 2010 (Stb. 33), art. III, met betrekking tot art. 6, lid 1 onder a, van het Reglement Rijbewijzen (invoeging adellijke titulatuur).
} 
en vroeg de minister van Verkeer en Waterstaat in 2009 om lid 1b van art. 145 van het reglement te schrappen. ${ }^{798}$

Het ontbreken van het begrip 'adellijke titel/predikaat' in zowel de Wet GBA als in het Besluit GBA heeft als gevolg dat het aanhangige wetsontwerp BRP, dat beide regelingen moet gaan vervangen, daarin evenmin voorziet. ${ }^{799}$ Dit heeft als consequentie, dat - hoewel juridisch overbodig - in afzonderlijke regelingen uitdrukkelijk op de verplichting moet worden gewezen, met alle risico's van misvattingen van dien. In de praktijk moet de bijzondere toepassing, die vermelding van adellijke titulatuur nu eenmaal met zich meebrengt, dan steeds ad hoc worden afgedwongen. ${ }^{800}$ Om deze nodeloze acties, die de gemeenschap veel tijd en geld kosten, in de toekomst te voorkomen, pleit ik ervoor om adellijke titulatuur alsnog expliciet op te nemen onder de 'algemene gegevens' in het Wetsontwerp BRP en vervolgens bij algemene maatregel van bestuur als 'authentiek gegeven' aan te merken. ${ }^{801}$

\section{Aanschrijf-en aanspreeknamen vormen geen overheidsbelang}

De tweede verplichting, waarvan in het voorgaande hoofdstuk toepassingsproblemen met voorbeelden werden aangegeven, vloeit voort uit art. BW 1:9. Zowel deze bepaling, die gehuwde of geregistreerde partners de bevoegdheid geeft tot sekseneutraal gebruik - ook in combinatie - van hun beider geslachtsnaam, als die in de Wet GBA en in het Besluit GBA, die in relatie tot de overheid de praktische uitvoering ervan regelen ('aanduiding van het naamgebruik'), zouden voor herziening in aanmerking komen. ${ }^{802}$

Aangezien het blijven gebruiken van de meisjesnaam ook voor gehuwde vrouwen steeds meer gemeengoed is geworden en de eigen naam altijd het uitgangspunt voor een gemeente is als de aanschrijfnaam, kan zo langzamerhand de vraag worden gesteld of handhaving van art. BW 1:9 nog wel aansluit bij de wensen en gebruiken van deze tijd. ${ }^{803}$ De bepaling heeft in twee fases (1970 en 1998) haar emancipatoire werking gehad, maar lijkt thans uitgewerkt. De gelijkheid tussen mannen en vrouwen, waar het de benadering door de overheid betreft, blijkt inzake naamgeving alleen gerealiseerd te kunnen worden door de persoonlijke identiteits-

\footnotetext{
798 Jaarverslag HRvA 2009, 2. Minister Eurlings heeft naar aanleiding van deze brief de voorzitter van de HRvA bij brief van 15 maart 2010 (kenmerk CEND/HDJZ-2010/840 sector AWW) toegezegd bij de eerstvolgende wijziging van het Reglement Rijbewijzen lid 1b van art. 145 niet te zullen schrappen, maar aan te passen. Dit zou de jure een herhaling van art. 5 van de Wet op de adeldom betekenen. Medio 2012 had nog geen wijziging plaatsgevonden.

${ }^{799}$ De Wet GBA vervalt wanneer haar opvolger, de Wet basisregistratie personen (Wet BRP), waarvan het wetsontwerp door de minister van BZK naar de Tweede Kamer is gezonden (Kamerstukken II, 2011-2012, 33219 , nr. 2, d.d. 30 maart 2012), is vastgesteld.

800 Boddaert, 'Adellijke titulatuur in overheidsdocumenten. Zes jaar strijd tegen onkunde en automatiseringsproblemen', 86-87.

${ }^{801}$ Wet(sontwerp) BRP, krachtens art. 1.6 ( $\$ 2$. Verplicht gebruik).

${ }^{802}$ De uitwerking van de 'aanduiding van het naamgebruik' volgens art. 52 Wet GBA is vormgegeven in het Logisch Ontwerp § 3.2.8.

${ }^{803}$ In het Wetsontwerp BRP betreft het de uitvoeringsartt. 2.7, lid 1a, onder 9; 2.25 en 2.56.
} 
gegevens aan te houden los van de geslachtsnaam van eventuele partners. Die hebben immers hun eigen identiteitsgegevens en zullen deze ook hun hele leven behouden.

Aangezien het recht op naam geen eigendomsrecht is maar allereerst een door het EVRM beschermde exponent van het 'private life', is verdere individualisering van het naamrecht gewenst. Deze gedachte is ook de grondslag voor art. BW 1:8, dat onrechtmatig gedrag aan de kaak stelt bij het opwekken van de schijn iemand anders te zijn door zonder toestemming van diens naam gebruik te maken. ${ }^{804}$ Het gebruik van andermans naam houdt altijd risico's in, die in het uiterste geval tot overtreding van art. $435 \mathrm{Sr}$., lid 4, kunnen leiden, wanneer iemand bewust een valse naam aan het bevoegd gezag opgeeft.

In het kader van de verminderde regelgeving zou ik willen pleiten voor het schrappen van artikel 9 uit het eerste boek van het BW en als gevolg daarvan ook van de uitvoeringsartikelen 2.7, lid 1a, onder 9, 2.25 en 2.56 uit het Wetsontwerp BRP.

Samenvattend biedt dit de volgende voordelen:

1. aan ongeoorloofde discriminatie door de overheid bij het aanschrijven van edellieden of hun partners, door onvolledige toepassing van art. BW 1:9, komt een einde;

2. de overheid behoeft geen aanschrijfgegevens meer te registreren, maar schrijft burgers aan volgens de authentieke gegevens (inclusief adellijke titulatuur!), zoals deze zijn vermeld in de GBA (BRP), waarmee vele vergissingen (in het bijzonder bij adellijke namen) kunnen worden voorkomen;

3. in het maatschappelijk verkeer kan een ieder zich begeven onder de naam van welke partner dan ook tot op het moment dat de schijn van identiteitsverwisseling optreedt (art. BW 1:8), bijvoorbeeld bij identificatie (art. 435, lid $4 \mathrm{WvSr}$ );

4. de volledige gelijkheid tussen man en vrouw, die het naamrecht voorschrijft, kan door de overheid op efficiënte wijze en daardoor met aanzienlijk minder tijd en kosten worden geëffectueerd.

Met deze betrekkelijk eenvoudige aanpassing van de wetgeving zou tevens de ingeslopen gewoonterechtelijke onevenwichtigheid worden gecorrigeerd, volgens welke men het adellijke predikaat 'jonkvrouw' als synoniem voor 'freule' is gaan beschouwen. Een consequentie zou voorts zijn, dat de echtgenote van een getitelde edelman door de overheid niet meer met de (verbogen) titel van haar echtgenoot wordt aangeschreven. Aan een al meer dan anderhalve eeuw voortwoekerende juridische onvolkomenheid zou dan een einde komen. Eindelijk kan, althans in de adreslijst van de overheid - kort samengevat - de niet-adellijke vrouw van een getitelde edelman er niet meer met de adellijke eer van de gehuwde jonkvrouw vandoor gaan!

Als sluitstuk van deze juridische ingreep zullen dan ook de richtlijnen voor het gebruik van adellijke titulatuur, die de Hoge Raad van Adel destijds op verzoek van

${ }^{804}$ Loeb, Naam en recht, 119-130. 
het Ministerie van Binnenlandse Zaken opstelde en die (aangepast) op de website van de Raad zijn te vinden, hun officiële status verliezen. ${ }^{805}$ Dit betekent overigens niet dat ze bij particulier gebruik en in verenigingsverband niet nog hun functie kunnen behouden. Binnen de kring van personen die blijvend hechten aan hun opvallend vaak door moeders - doorgegeven al of niet adellijke gedragscode, kan cultivering immers blijven plaatsvinden. ${ }^{806}$

\section{Adelsrecht als aangelegenheid van het koninkrijk}

Aandacht vraagt verder een onvolkomenheid in het in 2010 gewijzigde naamrecht voor Curaçao en Sint Maarten, landen binnen het Koninkrijk der Nederlanden. ${ }^{807}$ Het ontbreken van een bepaling als in het Nederlandse BW, art. 1:5, lid 11, biedt weliswaar geen perspectieven voor overgang van adeldom via de keuze voor de naam van de adellijke moeder, maar zou wel (adellijke) naamsrechtelijke gevolgen kunnen hebben. ${ }^{808}$ Het op dit punt in overeenstemming brengen van het BW voor Curaçao en Sint Maarten met het burgerlijk recht dat in de andere landen van het koninkrijk geldt, lijkt gewenst.

Het Statuut voor het Koninkrijk der Nederlanden somt onder de aangelegenheden van het koninkrijk expliciet de regelingen op betreffende ridderorden, de Nederlandse vlag en het Rijkswapen. ${ }^{809}$ Merkwaardigerwijs ontbreekt in dit rijtje de regeling betreffende adeldom. ${ }^{810}$ Tijdens de Ronde Tafelconferentie 1952-1954, die het Statuut voor het Koninkrijk voorbereidde, is echter nauwelijks gesproken over ridderorden, vlag en wapen en al helemaal niet over adeldom. ${ }^{811}$ In de memorie van toelichting bij het statuut wordt slechts vermeld, dat deze bepaling uiteraard de mogelijkheid openlaat dat de landen ook een eigen vlag kunnen voeren. ${ }^{812}$ De reden hiervan was een brief van de delegatie van Suriname, d.d. 20 mei 1952, over de naam van het koninkrijk en een verschil van inzicht over de vlag. Van Helsdingen, die de conferenties bijwoonde, geeft als commentaar: 'Naar verluidt zou het wapen abusievelijk in de brief zijn vermeld. Over het wapen van het Koninkrijk is

\footnotetext{
${ }^{805}$ Van der Wiel, 'Adellijke titels', 60-64; www.hogeraadvanadel.nl (adeldom>titel/predikaat>richtlijnen).

${ }^{806}$ Dronkers, 'De maatschappelijke relevantie van hedendaagse Nederlandse adel', 233-268.

${ }^{807}$ Artikelen 5 t/m 5m van het eerste boek BW, vastgesteld bij Landsbesluit van 9 okt. 2010 (Publicatieblad van de Nederlandse Antillen 2010, 85).

${ }^{808}$ De Groot Schneider, 'Haasje over springen: aantekeningen bij de Landsverordening herziening namenrecht', 3; De Groot, 'Autonomie und zwingende Bestimmungen im Namensrecht', 34.

${ }^{809}$ Wet van 28 october 1954, houdende aanvaarding van een statuut voor het Koninkrijk der Nederlanden, art. 3, lid 1d.

${ }^{810}$ De geschiedenis van het adelsrecht laat zien, dat de Hoge Raad van Adel in het begin van zijn ontstaan de koning niet alleen adviseerde in adelszaken, maar ook betreffende de Militaire Willemsorde (ingesteld bij KB van 30 april 1815, nr. 5 (Stb. 33*) en de Orde van de Nederlandse Leeuw (ingesteld bij KB van 29 sept. 1815, nr. 49 (Stb. 47). De voorzitter en secretaris van de Raad zijn volgens de instructie van 1814 respectievelijk grootzegel- en kleinzegelbewaarder, hetgeen de facto het toezicht inhoudt op het correcte gebruik van het Rijkswapen (en als uitvloeisel daarvan de Nederlandse vlag) (SB van 24 juni 1814, nr. 10, art. 2 , art. XV).

${ }^{811}$ Juist in deze periode nam het Kabinet Drees het (geheime) besluit van 21 nov. 1953 om voortaan van verheffing in de adeldom af te zien (HRvA, RA, inv. nr. 225).

${ }^{812}$ Van Helsdingen, Het Statuut van het Koninkrijk, 262.
} 
namelijk niet gesproken (...). Wel werd uitgesproken dat ieder der landen gerechtigd was een eigen wapen, vlag en volkslied vast te stellen. ${ }^{, 813}$

Voor aangelegenheden van het koninkrijk waarin geen enkel land enige verandering wenste, zoals het koningschap en de troonopvolging, werd - voor zover het statuut daarin niet voorzag - volstaan met verwijzing naar de reeds bestaande bepalingen in de grondwet. ${ }^{814}$ Hoewel niet vermeld, mag ervan worden uitgegaan dat art. 74 van de Grondwet van 1953 ('De Koning verleent adeldom') begrepen is onder de koninklijke macht, die in art. 5, lid 1, van het Statuut voor het Koninkrijk wordt genoemd. Toen art. 74 in 1983 uit de grondwet werd geschrapt, is er niet aan gedacht om adeldom alsnog in het statuut op te nemen. Sterker nog, het bestaan van het Statuut voor het Koninkrijk zou een argument geweest zijn om adeldom niet uit de grondwet te schrappen of, zoals inzake ridderorden, een enkele bepaling in de grondwet te handhaven als: 'Adeldom wordt bij de wet ingesteld'.

Op basis van art. 111 ('Ridderorden worden bij de wet ingesteld') van de Grondwet van 1983 - juncto art. 3, lid 1 d, van het Statuut - werd de herziening van het decoratiestelsel in 1994 bij Rijkswet geregeld. ${ }^{815}$ De in hetzelfde jaar totstandgekomen Wet op de adeldom ontbeert deze 'rijksstatus'. Tijdens de behandeling van laatstgenoemde wet is over de noodzaak daarvan niet gesproken, kennelijk omdat het Statuut van het Koninkrijk adeldom niet noemde en in de tussenliggende veertig jaar geen onvolkomenheden waren gesignaleerd.

Aanvulling van art. 3, lid 1d, van het Statuut voor het Koninkrijk met 'adeldom' als aangelegenheid van het koninkrijk en als gevolg daarvan omzetting van de Wet op de adeldom in een Rijkswet op de adeldom, acht ik noodzakelijk om de hiërarchie tussen constitutioneel recht (adelsrecht) en privaatrecht (naamrecht) aan te geven en daarmee te herstellen. Onevenwichtigheden, zoals De Groot heeft beschreven, kunnen dan worden hersteld.

\section{Buitenlandse adellijke titulatuur in strijd met de Nederlandse openbare orde}

Een recente uitspraak van het Hof van Justitie van de Europese Unie te Luxemburg is van belang voor een lidstaat als Nederland, waar adelsrecht bestaat en adeldom bij koninklijk besluit wordt verleend. ${ }^{816}$ Adelsverlening behoorde vanouds tot het constitutionele recht en was tot 1983 (1994) gebaseerd op de grondwet. De verleende rechten bleven ook daarna beschermd door de Wet op de adeldom en gehandhaafd door de werking van artikel 435 van het Wetboek van Strafrecht. Overtreding van de strafbepaling leverde hoofdzakelijk strijd met de openbare orde op, wanneer het gebruik van niet-verleende adellijke titulatuur verwarring met rechtmatig gevoerde Nederlandse adellijke titulatuur veroorzaakte. Maar voormalige Duitse titulatuur, gevoerd als deel van de genaturaliseerde familienaam, zou vooral

\footnotetext{
${ }^{813}$ Ibidem, 282 (met verwijzing naar de wapenKB's van 1815, 1907, en 1909).

${ }^{814}$ Wet van 28 okt. 1954, houdende aanvaarding van een statuut voor het Koninkrijk der Nederlanden (inwerking getreden op 29 dec. 1954), art. 5.

${ }^{815}$ Rijkswet van 15 april 1994 (Stb. 350).

${ }^{816}$ HvJEU 22 dec. 2010, C 208/09 (Sayn-Wittgenstein); NJ 2011/119 (noot M.R. Mok).
} 
in de Nederlandse samenleving verwarring teweeg kunnen brengen in verhouding tot bestaande adeldom. Alleen aan de schrijfwijze zou dan immers te zien zijn dat de familie van betrokkene kennelijk tot de voormalige Duitse adel behoorde, met uitzondering van de 'universele' titel Baron. Het is vervolgens de vraag of de gemiddelde burger voldoende kennis heeft om deze conclusie te kunnen trekken. In een land waar adelsrecht bestaat, is de kans aanwezig dat de uitstraling van een dergelijke naam in het maatschappelijk verkeer meer impact zou kunnen hebben dan maatschappelijk en juridisch verantwoord is.

De stelling van jonkheer Van Meeuwen uit 1966 dat in een Nederlandse naturalisatiewet van een Duitser wiens adellijke titulatuur volgens Duits recht onderdeel van het Duitse naamrecht is geworden, deze titulatuur niet mag worden vermeld, blijkt actualiteitswaarde te hebben. ${ }^{817}$ De argumentatie dat anders strijd met de Nederlandse openbare orde zou ontstaan, komt dicht bij de uitspraak van het Luxemburgse Hof inzake Sayn-Wittgenstein. Als oplossing gaf jonkheer Van Meeuwen aan, dat wijziging van een geslachtsnaam bij een naturalisatiewet geoorloofd is, zodat de Duitse naam kan worden gewijzigd door de voormalige titulatuur daaruit te verwijderen. Hij baseerde zich overigens in belangrijke mate op het artikel van Prins, dat tien jaar eerder was verschenen. ${ }^{818}$

Kuipers zag in het arrest van het Luxemburgse Hof een bevestiging van de leer van de gevestigde rechten, de zogenaamde Dokkumer doctrine van de zeventiendeeeuwse Friese rechtsgeleerde Ulrik Huber, die in zijn tijd al wees op de noodzakelijkheid voor soevereine staten om elkaars recht te respecteren. ${ }^{819}$ Deze leer, die pleitte voor het respecteren van onder vreemd recht gecreëerde rechten, zolang geen strijd zou optreden met de openbare orde van het eigen land, vond navolging in Groot-Brittannië en in de Verenigde Staten van Noord-Amerika. Door de uitspraak van het Luxemburgse Hof werd het bezwaar over de afbakening van deze in onbruik geraakte leer opgeheven. De verplichting tot erkenning kreeg eindelijk de grondslag die door Huber slechts als 'een zekere volkenrechtelijke hoffelijkheid' werd gedefinieerd zonder het specifieke recht te noemen dat dan van toepassing zou zijn. ${ }^{820}$ Kuipers concludeerde dat de grondslag nu direct in het Unierecht, te weten het Europese burgerschap, kan worden gevonden zonder de onmogelijke vraag van het toepasselijke rechtsstelsel te hoeven beantwoorden. Door het eindresultaat van het conflictrechtelijke proces in andere lidstaten te erkennen, houdt de burger een optimale keuzemogelijkheid bij de vaststelling van een geslachtsnaam. De grens ligt bij de fundamentele rechtsbeginselen, die de constitutie van een lidstaat waarborgt. Inbreuk hierop kan strijd met de openbare orde tot gevolg hebben, zoals in casu Sayn-Wittgenstein het in Oostenrijk grondwettelijk afgeschafte adelsrecht. $^{821}$

\footnotetext{
${ }^{817}$ Van Meeuwen, “Een en ander over het Nederlandse adelsrecht', 85 (noten 30-32) en 87 (noot 41).

818 Prins, 'Titels en praedicaten', 13-21.

${ }^{819}$ Kuipers, 'Sayn-Wittgenstein. Dokkumer doctrine en adellijke aspiraties', 56.

${ }^{820}$ Huber, Heedendaegse Rechtsgeleertheyt 2, boek 1, kap. 3, p. 11 e.v. ('gebruik der Friesche rechten in andere landen en die van andere landen in Frieslandt').

${ }^{821}$ Kuipers, 'Sayn-Wittgenstein. Dokkumer doctrine en adellijke aspiraties', 56.
} 
Besselink achtte het arrest van het Luxemburgse Hof (te) beperkt en in sommige opzichten oneigenlijk onderbouwd. Hij had een 'zuivere' argumentatie op grond van art. F van het Europese Verdrag van Maastricht (eerbiediging van de nationale identiteit van lidstaten) logischer gevonden. ${ }^{822}$ Hoewel het Hof zichzelf als de hoogste Europese constitutionele rechter blijft zien, signaleerde Besselink een tendens naar een minder hiërarchische benadering van nationale constitutionele waarden ten opzichte van Europees recht. Hij concludeerde, dat deze tendens afwijkt van de oorspronkelijke visie van de verdragstaten, die autonome gelding van het Europese recht voorstond. ${ }^{823}$

Hoe anders is echter de praktijk in Nederland. Van der Velde heeft naar aanleiding van een concreet geval, maar met gefingeerde namen, beschreven hoe de geboorte van een zoon van een Duitse, tot een voormalige adellijke familie behorende, vader en een Nederlandse moeder in de Nederlandse GBA werd ingeschreven. Vanwege de verschillende rechtsstelsels die op deze casus van toepassing zijn, verwierf het kind van rechtswege zowel de Duitse als de Nederlandse nationaliteit en was op grond van de Wet conflictenrecht namen (WCN) het Nederlandse recht van toepassing voor de bepaling van zijn naam. ${ }^{824}$ Aangezien de voormalige adellijke titel naar Duits recht onderdeel was geworden van de geslachtsnaam van de vader, werd in de Nederlandse geboorteakte ook dit naamsbestanddeel onderdeel van de geslachtsnaam van de zoon. Naar Nederlands recht kan deze voormalige Duitse adellijke titel echter niet worden verbogen, hetgeen een probleem werd toen zich de geboorte van een dochter aandiende. De eenheid van naamskeuze binnen het gezin maakt verbuiging onmogelijk. ${ }^{825}$ Aangezien de kinderen twee nationaliteiten hebben, zou alleen een beroep op het Duitse recht soelaas kunnen bieden, omdat verbuiging van de voormalige titulatuur al door de hoogste rechter in de Republiek van Weimar werd toegestaan. ${ }^{826}$ Voorwaarde om dit recht te kunnen toepassen is echter dat de geboorte van de dochter in Duitsland zou moeten plaatsvinden. ${ }^{827}$ Van der Velde achtte deze actie te gekunsteld en bleef dus met een praktisch probleem zitten. Eigenhandige aanpassing van de geboorteakte van de intussen in Nederland geboren dochter durfde hij echter niet aan, omdat hij dan in strijd zou handelen met de wettelijke voorschriften van de ambtenaar van de burgerlijke stand. ${ }^{828}$ De Groot meende met een beroep op de uitspraak van het Europese Hof van Justitie in 2003 echter dat wel degelijk tot aanpassing van de geboorteakte kon worden overgaan, aangezien het ook in bovenstaande casus ging om iemand die zowel de

\footnotetext{
${ }^{822}$ Verdrag betreffende de Europese Unie, inwerking getreden op 1 nov. 1993 (wijziging bij het Verdrag van Lissabon, inwerking getreden op 1 dec. 2009), artt. 2 en 4.

${ }^{823}$ Besselink, 'Respecting Constitutional Identity in the EU', 671-693.

${ }^{824}$ Wet conflictenrecht namen van 3 juli 1989, art. 2; thans BW, boek 10 (Internationaal privaatrecht, ingevoerd per 1 jan. 2012), art. 20.

${ }^{825}$ Artikel BW 1:5, lid 8.

${ }^{826}$ BGB 69 (2010), § 12, 6 (Reichs Gericht 113, 110; Bayerisches Oberstes Landesgericht 55, 245; Düsseldorfs Fam. Recht 97, 1554): 'Weibl. Personen dürfen die Adelsbezeichnung in weibl. Form führen (Gräfin, Freifrau), männl. dürfen sie deklinieren'.

${ }^{827}$ Artikel BW 10:24.

${ }^{828}$ Van der Velde, 'Kronkels', 204-206.
} 
Nederlandse nationaliteit heeft als die van een andere lidstaat van de Europese Unie. $^{829}$

De uitspraak van hetzelfde Luxemburgse Hof in 2010, waarin het constitutionele recht van een lidstaat van overwegend belang wordt geacht inzake adelsrechtelijke consequenties, werpt een nieuw licht op bovenstaande casus. ${ }^{830}$ De unieke positie van Nederland als een van de weinige Europese landen waar nog een vigerend adelsstatuut bestaat, zou in voorkomende gevallen een overname van voormalige buitenlandse adellijke titulatuur als onderdeel van de geslachtsnaam kunnen voorkomen. ${ }^{831}$ Het overslaan naar Nederland van de jacht op mooie namen, een rage die in Duitsland onder meer door adoptie van volwassenen onder - maar ook door huwelijk met leden van - de voormalige adel plaatsheeft, lijkt in Nederland bedwongen te kunnen worden door een beroep op het van oorsprong constitutionele adelsrecht. $^{832}$

Het juridische gegeven dat er in Nederland een adelsstatuut bestaat, dat in voorkomende gevallen - namelijk indien een verzoek om inlijving in de Nederlandse adel tezamen met een verzoek om naturalisatie (Wet op de adeldom, art. 2, lid 3) wordt gedaan - consciëntieus moet worden vergeleken met andere adelsstatuten, conflicteert met de openbare orde als 'adellijke titulatuur' vanuit een land waar het adelsrecht al bijna een eeuw geleden werd afgeschaft, ongecensureerd via het naamrecht kan binnensluipen. Vanuit landen waar de adel nog wel staatsrechtelijk bestaat, is die mogelijkheid vanouds niet aanwezig als de adelsstatuten onvergelijkbaar zijn, zoals in Groot-Brittannië. Edellieden uit deze Europese koninkrijken zouden anders via het naamrecht gepasseerd worden door burgers uit voormalige monarchieën, thans republieken, waar überhaupt geen adelsrecht meer bestaat...

\footnotetext{
${ }^{829}$ HvJEU 2 okt. 2003, C 148/02, NIPR 2004, 2 (Garcia Avello). De Groot, 'Twee aantekeningen over het gebruik van adellijke titels', 101-102.

${ }^{830}$ HvJEU 22 dec. 2010, C 208/09 (Sayn-Wittgenstein); NJ 2011/119 (noot M.R. Mok).

${ }^{831}$ Besselink, 'Respecting Constitutional Identity in the EU', 671-672, telt onder de lidstaten van de Europese Unie nog zeven staatshoofden, die een erfelijk openbaar ambt bekleden.

${ }^{832}$ De Groot, 'Jacht op mooie namen', 13.
} 


\section{Bijlagen}

1. Briefwisseling tussen de minister van Binnenlandse Zaken, J.R. Thorbecke, en de directeur van het Kabinet des Konings, A.G.A. ridder van Rappard, over de positie van de Hoge Raad van Adel, 1852 [HRvA, RA, inv. nr. 948].

's-Gravenhage, den 5 January 1852 (Kabinet, N. 204)

Bij besluit van 20 July 1850, N. 55, behaagde het Uwe Majesteit, op de voordragt van Uwen Raad van Ministers, de betrekkingen van voorzitter en lid van den Hoogen Raad van Adel te verklaren tot onbezoldigde eere-ambten. De leden van dat Collegie, aan wie bij dat besluit een eervol ontslag was verleend, werden bij Uwer Majesteits besluit van 9 November 1850, N. 37, met de eere-ambten bekleed.

Hoewel nu sedert dien tijd de voor den Hoogen Raad van Adel vereischte uitgaven aanmerkelijk zijn verminderd, zoo vordert de tegenwoordige inrigting van dat Collegie toch nog steeds eene betrekkelijk aanmerkelijke uitgave, die door het nut van zijn werkkring niet schijnt geregtvaardigd te worden. Het daarvoor op de Staatsbegroting voor 1852 uitgetrokken bedrag van f. 7490,- heeft dan ook niet zonder tegenkanting de goedkeuring der Staten-Generaal kunnen verwerven. Uit die tegenkanting, in de laatste jaren steeds heviger geworden, is te voorzien dat die post in volgend jaar niet ligt door de StatenGeneraal zal worden goedgekeurd.

Inderdaad schijnt ook het doel van de instelling van dat Staatsligchaam, het onderzoeken en bewaren van geslachts-lijsten en bewijzen van adeldom enz, op eenvoudiger en min kostbare wijze even goed te kunnen worden bereikt. Vooral nu de veranderde stand van zaken reeds van zelve zoo veel heeft doen vervallen van hetgeen bij de instelling van dien Raad en zijne instructie, bij besluit van den Souvereinen Vorst van 24 Juny 1814, N. 10, aan dat Collegie was opgedragen.

Toen ik deze zaak, vele maanden geleden reeds, in den Ministersraad ter sprake bragt, werd dan ook met eenparigheid van stemmen geoordeeld, dat de Hooge Raad van Adel zelfs wel zou kunnen worden opgeheven en dat die opheffing zelfs hoogst wenschelijk te achten was uithoofde van de daardoor te verkrijgen bezuiniging. De werkzaamheden van de Raad van Adel, die ook eigenaardig tot den werkkring van het Departement van Binnenlandsche Zaken kunnen gezegd worden te behooren, zouden zeer wel aan een speciaal daarmede te belasten hoofdambtenaar bij dat Departement, des gevorderd met den noodigen bijstand, kunnen worden opgedragen.

$\mathrm{Nu}$ vereischen de tractementen van de Secretaris ad f. 2000,-, van den adjunct-Commies ad f. 1200,-, van den Klerk ad f. 800,-, van den Wapenteekenaar ad f. 800,-, van den Kamerbewaarder ad f. 800,-, van den bode ad f. 650,-, eene jaarlijksche uitgave van f. 6250,, terwijl voor bureau- en locaalbehoeften en drukwerk op de Staatsbegroting voor 1852, Hoofdstuk II, Afd. V, eene som van f. 1240,- is uitgetrokken.

Zoo nu de sedert hare eerste oprigting zoo zeer ingekrompen werkkring van den Hoogen Raad van Adel de taak wordt van een aan het Departement van Binnenlandsche Zaken toe te voegen hoofdambtenaar, die noode, zoo daartoe later de noodzakelijkheid mogt blijken, met toevoeging van een minder ambtenaar als wapenteekenaar enz, schijnen de tegenwoordig door dat Collegie verrigte werkzaamheden even goed te kunnen worden volbragt en zou vereenvoudiging en eene niet onaanzienlijke bezuiniging daarvan het gevolg zijn. 
Zoo het Uwe Majesteit mogt gelieven te behagen deze meening te deelen, zoude Uwe Majesteit ook, durf ik vertrouwen, kunnen goedvinden, bij hetzelfde besluit waarbij de opheffing van den Hoogen Raad van Adel zoude worden vastgesteld, het tegenwoordig lid van dien Raad, Mr. W.J. Baron d'Ablaing van Giessenburg, te benoemen tot Referendaris bij het Departement van Binnenlandsche Zaken. Het Departement zoude zich door die benoeming een ambtenaar toegevoegd zien, die door de in zijne tegenwoordige betrekking verkregen ondervinding mag geacht worden goed in staat te zijn den minister voor te lichten omtrent al datgene wat nu door den Raad van Adel met den minister wierd verrigt, en in het vervolg van den minister alleen zoude uitgaan. Tevens zoude daardoor het lot verzekerd worden van een verdienstelijk ambtenaar, die na het tot een onbezoldigde eere-ambt verklaren van het lidmaatschap van den Hoogen Raad van Adel, eene bezoldiging verloren heeft, die hij meende gedurende zijn geheele leven te zullen genieten en na het ophouden van het genot van het hem thans toegekende wachtgeld, geheel buiten tractement zoude zijn.

Zoo Uwe Majesteit zich met mijne inzigten mogt kunnen vereenigen, schijnt het tijdstip van 1 Mei 1852 geschikt om den voorgestelden maatregel in werking te doen treden. Op dat tijdstip zoude dan het nu door den heer d'Ablaing genoten wachtgeld, ten bedrage van f. 1333,- komen te vervallen en zouden de Secretaris en verdere beambten bij den Raad van Adel in het genot treden van pensioen of wachtgeld, waarop zij zouden blijken aanspraak te hebben.

In het eerbiedig vertrouwen dat Uwe Majesteit zich met mijne zienswijze zal kunnen vereenigen, veroorloof ik mij de vrijheid Uwe Majesteit een daartoe strekkend ontwerp van besluit ter bekrachtiging te onderwerpen.

De Minister van Binnenlandsche Zaken, [w.g.] Thorbecke.

Aan den Ministers van Binnenlandsche Zaken

's-Gravenhage, den 31 January 1852 en Financiën

De Koning kan niet verbergen, dat dit voorstel bij Hoogstdenzelve een onaangenamen indruk heeft teweeg gebragt. Naauwlijks een jaar geleden heeft men de betrekkingen van Voorzitter en lid van den Hoogen Raad van Adel tot onbezoldigde eerambten verklaard en nu stelt men voor het geheele Collegie af te schaffen!

Het heeft HoogstDenzelve getroffen in art. 1 van het concept-besluit herinnerd te zien, dat de Hooge Raad van Adel bij besluit van den Souvereinen Vorst van 24 Juny 1814 is ingesteld; omdat hierdoor te sterker uitkomt, welk eenen onaangename beslissing men van Zijne Majesteit verlangt.

Het voorstel grondt zich op den wensch naar bezuiniging en vereenvoudiging, op den tegenstand van de Staten-Generaal om de nu nog gevorderde uitgaven voor den Hoogen Raad van Adel toe te staan. Daar intusschen de leden reeds onbezoldigd zijn, kunnen de overige uitgaven niet worden aangevoerd als een grond om het Collegie zelf te supprimeren. Zijn zij te hoog en kan dan alleen de rede van zijn om ze te verminderen; ofschoon tegen het bedrag van deze uitgaven ruim overstaan de inkomsten van het Fonds ter administratie van den Hoogen Raad van Adel.

De nu voorgestelde bezuiniging zou bovendien betrekkelijk en op zich zelve slechts zeer gering zijn. Met een Referendaris ad f. 2500,-, een wapenteekenaar en de bureaukosten gaan ligtelijk f. 34 à 3500,- weg. Voegt men daarbij de wachtgelden en pensioenen der 
uitvallende ambtenaren, dan weet Zijne Majesteit werkelijk niet waarin de aangeprezen bezuiniging zou bestaan.

Wat den tegenstand der Staten-Generaal betreft, Zijne Majesteit heeft zich doen voorleggen hetgeen betrekking had tot het onderzoek en de discussie van het vragelijk punt in de beide Kamers. In het verslag van de Commissie van rapporteurs der Eerste en Tweede Kamer over Hoofdstuk II, heeft de Koning geene aanmerking omtrent de uitgaven voor den Hoogen Raad van Adel aangetroffen. Bij gelegenheid van de discussie in de Tweede Kamer heeft, zoo ver door den Koning is kunnen worden nagegaan, alléén de Heer van der Heyde tegen het bestaan van den Hoogen Raad van Adel gesproken. Zijne Majesteit zal van zijne argumenten slechts dit zeggen, dat zoo zij eenig gewigt hadden, zij met even veel grond zouden kunnen worden aangevoerd tegen het bezoldigen van ambtenaren bij het Departement van Binnenlandsche Zaken ter behandeling van onderwerpen den Adel betreffende.

Zijne Majesteit erkent dat de stemming in die Kamer over art. 22 geene gunstige aanwijzing geeft; maar het blijkt uit die stemming niet of de minderheid der Kamer de uitgaven te hoog vond of in het geheel niet wenschte toe te staan. Daarop kon dus het voorstel tot afschaffing van den Raad zelven althans niet worden gegrond. Bij de Eerste Kamer is er, voor zoo veel Zijne Majesteit weet, over dit punt niet eens gesproken.

Om alle deze redenen ziet HoogstDenzelve er geene noodzakelijkheid in om tot het voorstel, zoo als het daar ligt, toe te treden en herhaalt Zijne Majesteit dat het HoogstDenzelve leed gedaan heeft het te ontvangen.

De Staatsraad, Directeur van het Kabinet des Konings,

[w.g.] A.G.A. van Rappard.

$\mathrm{Nu}$ de tijd daar is de Staatsbegrooting voor het jaar 1853 op te maken, ben ik verpligt terug te komen op het voorstel betrekkelijk het uit die begrooting ligten van den post voor den H. Raad van Adel, waaromtrent ik de eer had U[w]e Maj. op den 5 january 1.l. een rapport aan te bieden en bij Kabinetsmissive op den 31 january antwoord te ontvangen.

Met leedwezen vernam ik, dat mijn voorstel op Uwe Maj. geen aangenamen indruk heeft gemaakt, maar U[w]e Maj. zal mij wel willen toestaan op de zaak terug te komen, wanneer ik de overtuiging koester dat het staatsbelang zulks vordert.

Ik moet U[w]e Maj. eerbiedig betuigen, dat het niet doenlijk zijn zal op de Staatsbegrooting andermaal een post voor den H. Raad van Adel te behouden. De Regering mag zich omtrent dit punt aan geene nederlaag bloot stellen bij de overtuiging, dat het aan goede gronden ontbreekt om den post te handhaven.

$\mathrm{U}[w]$ e Maj. doet mij opmerken dat bij de beraadslaging over de Staatsbegrooting in het vorig jaar slechts één lid der Tweede Kamer tegen het bestaan van den H. Raad van Adel heeft gesproken. Doch U[w]e Maj. voegt er de erkenning bij, dat de stemming dier Kamer over art. 22 van de begrooting geene gunstige aanwijzing geeft. U[w]e Maj. gelieve mij de opmerking te veroorloven, dat die enkele rede gevoegd bij die stemming en bij het omtrent deze zaak wel bekend gevoelen van zeer vele leden der Tweede Kamer, eene vrij deugdelijk sprekende aanwijzing is, dat naar het gevoelen dier Kamer de Hooge Raad van Adel op den tegenwoordigen zaak niet behoort te blijven bestaan. Het schijnt in allen deele raadzaam door nieuwe regeling te voorkomen, dat men door afstemming van het ar- 
tikel der begrooting, gedwongen wierd den H. Raad ten gevolge van een besluit der Tweede Kamer af te schaffen.

Aangezien echter door U[w]e Maj. belang wordt gesteld in het behoud van een Raad, ben ik op een middel bedacht geweest om het beginsel van het voorstel, dat ik gemeend heb eerbiedig aan $\mathrm{U}[\mathrm{w}] \mathrm{e}$ Maj[esteit]s goedkeuring te moeten onderwerpen, met $\mathrm{U}[\mathrm{w}] \mathrm{e}$ Maj[esteit]s wensch in overeenstemming te brengen. Ik meen mij te mogen vleijen daarin geslaagd te zijn op eene wijze, die - zoo ik eerbiedig vertrouw - aan U[w]e Maj. zal kunnen behagen.

Om de vroeger ontwikkelde gronden gelieve U[w]e Maj. mij te veroorloven te blijven hechten aan mijn voorstel dat de bureauwerkzaamheden van den Raad worden overgebragt bij het Departement van Binn. Zaken, waar het tegenwoordig lid van den H. Raad van Adel, mr. W.J. B[ar]on d'Ablaing van Giessenburg, een der zake zeer kundig en verdienstelijk ambtenaar, als Referendaris bepaald met die werkzaamheden zou kunnen worden belast. Tevens zou de Minister v. Binn. Z. omtrent zaken tot den tegenwoordigen werkkring van den H. Raad v. Adel behoorende, kunnen worden voorgelicht door een Collegie van mannen, geacht in de maatschappij en uitmuntende door hunne kennis van eene bijzondere zaak. Het lidmaatschap van dat Collegie zou evenals thans een onbezoldigd eereambt moeten zijn. Dit is ook eenigermate de wijze waarop deze zaak elders is geregeld, b.v. in België, waar sedert lang dergelijk adviserend Collegie aan een der hoofden van een departement van algemeen bestuur is toegevoegd. Aan dat Collegie zou de titel van Raad van Adel kunnen worden verleend. Zijne adviezen zouden door den Minister aan Uwe Maj. worden voorgelegd.

Omtrent de bezuiniging, die het gevolg van den voorgestelden maatregel zou kunnen zijn, meen ik mij aan mijn rapport van den 5 Jan. j.l. te mogen gedragen. In de Kabinetsmissive van 31 Jan. komt de aanmerking voor, dat U[w]e Maj. niet inziet waarin eigenlijk de door mij beoogde bezuiniging zal bestaan, aangezien U[w]e Maj. meent dat de meerdere kosten aan het Dep. v. B.Z. door de aanstelling van een nieuwe hoofdambtenaar met de wachtgelden en pensioenen voor de tegenwoordige ambtenaren bij den H. Raad v. Adel tegen de te erlangen bezuiniging bijna zullen opwegen. Het moge mij vergund zijn daartegen in het midden te brengen, dat die bezuiniging toch niet zoo gering is. Voor de $\mathrm{f}$. 7490 ,- toch, die op de Staatsbegrooting van 1852 voor den H. Raad van Adel zijn uitgetrokken, zal niets in de plaats komen dan de som van f. 2500,-, die ingevolge mijn voorstel de bezoldiging van den aan te stellen Referendaris zou uitmaken. De bureau- en locaalbehoeften zouden terstond geheel vervallen en gevonden worden uit de daarvoor onder het Hoofdstuk voor Binn. Z. gewoonlijk op de begrooting voorkomende gelden. Ik heb tevens de eer U[w]e Maj. voor te stellen den Referendaris bij het Dep. v. B.Z., aan wien de werkzaamheden van den H. Raad v. Adel zouden worden opgedragen met het Secretariaat van den nieuwen Raad v. Adel te belasten, zoodat dit ligchaam volstrekt geene kosten, zelfs niet van schrijfwerk zou vereischen. De pensioenen en wachtgelden der uitvallende ambtenaren, een noodzakelijk gevolg van iederen dergelijken maatregel, vormen toch ook slechts afloopende betalingen, waardoor de geldelijke voordeelen van de nieuwe regeling telken jare toenemen.

Indien U[w]e Maj. zich met mijn tegenwoordig voorstel mogt vereenigen, zou het H(oogst) D(enzelven) kunnen behagen den Hr. Mr. W.J. Baron d'Ablaing van Giessenburg tot Referendaris aan het Depart. van Binn. Z. en Secretaris van den nieuw in te stellen Raad van Adel te benoemen.

Tot leden van den nieuw op te rigten Raad van Adel zou U[w]e Maj. welligt goedvinden te benoemen den tegenwoordigen Voorz. van den H. Raad van Adel, Jhr. Mr. L. de Witte van Citters, den Secretaris van dat Collegie, Jhr. Mr. R.A. Baron van Hoëvell-Nijenhuis, die zeker door hunne tegenwoordige betrekking onder de meest bevoegden in den lande 
mogen worden geteld. Als derde lid van dat adviserend ligchaam zou in aanmerking kunnen komen Mr. L.N. baron van der Goes van Dirksland.

Aangezien op de Staatsbegrooting voor dit jaar een post voor kosten van den H. Raad van Adel is uitgetrokken en het jaar toch reeds half verstreken is, zou de tegenwoordige regeling nog tot het einde van dit jaar kunnen blijven bestaan. Maar op de Staatsbegrooting van het volgende jaar zou deze post niet meer behooren voor te komen en met $1^{\mathrm{e}}$ Jan. 1853 zouden de werkzaamheden van den $\mathrm{H}$. Raad van Adel, in voege voorschreven, op het Depart. v. Binn. Z. behooren over te gaan.

Ik neem eerbiedig de vrijheid een in dien zin opgemaakt ontwerp van besluit aan U[w]e Maj[esteit]s goedkeuring te onderwerpen.

\section{DMvBZ}

[w.g.] T[horbecke]

Aan Zijne Excellentie den Heer Minister van Binnenlandsche Zaken

[Geheim] 's-Gravenhage, den 10 Augustus 1852

Bij voordragt van den 12 July 1.1., Kabinet No. 204, is Uwe Excellentie teruggekomen op het voorstel om den Hoogen Raad van Adel op te heffen, hetgeen Uwe Excellentie bij rapport van den 5 January dezes jaars aan den Koning had gedaan, doch waarmede Zijne Majesteit zich niet had vereenigd om de redenen opgegeven in de Kabinetsbeschikking van den 31 January daaraanvolgende.

Uwer Excellenties voorstel is over het geheel aan het vroegere gelijk gebleven met uitzondering dat thans door Haar wordt voorgedragen het instellen van een Raad van Adel. Wanneer er een raadgevend Collegie voor de zaken van den Adel behouden wordt en wanneer er een post van f. 2500,-, plus de meerdere uitgaven voor Bureau- en lokaalbehoeften, op het Vde Hoofdstuk der Staatsbegrooting ten gevolge van Uwe Excellenties voorstel zou moeten uitgetrokken worden, dan ziet Zijne Majesteit niet in waarom niet de benaming van Hoogen Raad van Adel op Hoofdstuk II der Begroting zou kunnen behouden worden en onder die rubriek het traktement van den Secretaris ad f. 2500,- met een geringe som voor bureau- en lokaalbehoeften.

De bezuiniging is dan dezelfde als uit Uwer Excellenties voorstel zou voortvloeijen, ja zij is grooter omdat haar voorstel medebrengt een traktement te geven aan iemand, die thans geene jaarwedde trekt en bovendien een wachtgeld aan hem, die door dezen maatregel van zijne jaarwedde zou worden beroofd; hetgeen niet noodig zou wezen in het alternatief dat Zijne Majesteit op het oog heeft.Dat het Collegie alsdan de benaming zou blijven voeren, welke het thans draagt, kan naar Zijner Majesteits inzien geen aanstoot geven aan hen die billijk denken en op die wijze worden ook de moeijelijkheden vermeden, welke anders met opzigt tot het fonds van den Hoogen Raad van Adel welligt zouden kunnen ontstaan.

Zijne Majesteit kan niet denken, dat het der Tweede Kamer van de Staten-Generaal zou te doen zijn om ook den naam van het hier bedoeld Collegie uit de Staatsbegrooting te verdringen, ofschoon ook de uitgaven niet hooger zouden loopen. In allen gevallen zou Zijne Majesteit zich aan dergelijke bedoelingen niet kunnen aansluiten.

Ik heb de eer Uwe Excellentie van het bovenstaande op 's Konings last kennis te geven.

De Staatsraad, Directeur van het Kabinet des Konings, [w.g.] A.G.A. van Rappard. 
Bij Kabinetsmissive van 10 aug. 1852 (Geheim) zijn mij de redenen kenbaar gemaakt, die U[w]e Maj. bewegen alsnog Hare bekrachtiging te onthouden aan de voorstellen betreffende den H. Raad van Adel, waaromtrent ik de eer had laatstelijk bij rapport van 12 July j.l. eene voordragt te doen.U[w]e Maj. gelieve de betuiging aan te nemen, dat het mij leed deed uit die Kabinetsmissive te bespeuren, dat het mij niet mogt gelukken U[w]er Maj[esteit]s bezwaren tegen mijne voordragten betreffende dat Staatsligchaam uit den weg te ruimen.

Uwe Maj. vergunne mij op een paar punten terug te komen. Indien eene zaak voor eenvoudiger en zuiniger regeling vatbaar is, schijnt het pligt tot die nieuwe regeling over te gaan, zelfs al mogt het cijfer dier bezuinigingen geene groote som bedragen. Te eerder nog schijnt dit het geval te moeten zijn, wanneer gelijk hier, een Staatscollegie, welks werkkring men opnieuw wil regelen, reeds uit den aard der zaak en als een gevolg van veranderde Staatsinstellingen, zijn taak veel in omvang en belangrijkheid heeft zien verminderen. Het behoeft aan U[w]e Maj. naauwelijks te worden herinnerd, dat dit hier plaats heeft, nu o.a. de Ridderschappen hebben opgehouden als Staatscollegien te bestaan en in meer gevallen het belang dat iemand had om tot een adellijk geslacht te behooren, niet meer bestaat. Hierbij komt, dat de H. Raad van Adel volgens zijne instructie attributen van uitvoering had, die thans onder de ministeriële verantwoordelijkheid niet wel meer kunnen werken.

Zoo ik derhalve verpligt ben mijne voordragt eerbiedig aan Uwe Maj. nadere overweging te onderwerpen, voeg ik mij gaarne in $\mathrm{H}$ [oogst] $\mathrm{D}$ [eszelven] verlangen, dat de titel van Hoogen Raad v. Adel behouden blijve. Een aldus opgemaakt ontwerp van besluit moge Uwer Maj. goedkeuring kunnen verwerven.

In de Kabinetsmissive, waarop ik de eer heb te antwoorden, wordt ook weder gesproken van het min belangrijke der bezuiniging, die het gevolg van mijn voorstel zou zijn. U[w]e Maj. gelieve mij te veroorloven er nogmaals op te wijzen, dat die bezuiniging inderdaad zoo gering niet is. Voor eene vaste uitgave van f. 7490 ,- komt toch slechts eene som van f. 2500,- in de plaats. De pensioenen en wachtgelden aan de uitvallende ambtenaren te verleenen zijn van die afloopende betalingen, die iedere bezuiniging van dergelijken aard slechts na korter of langer tijd volledig doen werken. Maar is dat tijdstip eens daar, dan zal eene vaste uitgaaf van $\mathrm{f}$. 2500,- 's jaars die van $\mathrm{f}$. 7490,- vervangen.

Volgens Uwe Maj. denkbeeld zou de bezuiniging evenzeer te verkrijgen zijn, indien op de begrooting slechts het tractement van den Secretaris met eene geringe som voor bureau- en locaalbehoeften wierd uitgetrokken. Zoo echter de Raad van Adel in het bezit blijft van een eigen bureau en locaal, zal het niet wel doenlijk zijn daaraan klerken, boden en de tegenwoordige som voor bureau- en locaalbehoeften f. 1200,- à 1300,- te onthouden. Bij het Ministerie van Binnenl. Zaken kan het aanwezig personeel van klerken en boden het bureau van den Referendaris voor de zaken van den Adel zeer wel, zonder vermeerdering van kosten, bedienen. Ook de bureau- en locaalbehoeften kunnen aldaar uit de algemeene som worden gevonden. Mijns inziens zal de H. R. van Adel, op den door mij voorgestelden voet gebragt, dezelfde diensten als thans kunnen bewijzen zonder dat men verlegen zij een voldoend antwoord te geven op de vraag waartoe, zoo de bureauwerkzaamheden zeer wel in die van een Ministerie kunnen worden versmolten, een afzonderlijk bureau met al wat daaraan vast [zit], aan het Collegie [is] toegekend.

DMvBZ [w.g.] T[horbecke] 
Zijne Excellentie den Heer Minister van Binnenlandsche Zaken

[Geheim] 's-Gravenhage, den 11 Septbr. 1852

De Koning heeft overwogen Uwer Excellenties nadere voordragt van den 7 dezes (Kabinet geheim No. 204) betreffende den Hoogen Raad van Adel.

Zijne Majesteit heeft mij gelast, in antwoord daarop, aan Uwe Excellentie te kennen te geven, dat Zijne Majesteit zwarigheid blijft maken om te bewilligen in het voorstel tot opheffing van den Hoogen Raad van Adel, opgerigt bij besluit van den Souvereinen Vorst van den 24 Juny 1814, No. 10, en zijne vervanging door eenen anderen Hoogen Raad van Adel, maar dat Zijne Majesteit bereid is te bekrachtigen een besluit, waarbij uit overtuiging van de wenschelijkheid om ter bezuiniging en vereenvoudiging nader te regelen de zamenstelling en de werkzaamheden van den Hoogen Raad van Adel wordt bepaald dat de werkzaamheden van dien Raad worden beperkt tot het geven van advies over aangelegenheden den adelstand betreffende; terwijl de overige werkzaamheden zullen behooren tot den werkkring van het Departement van Binnenlandsche Zaken; in verband hiermede de Secretaris en de verdere beambten bij dat Collegie eervol worden ontslagen in den zin van art. 3 van het voorgelegde concept-besluit; de Baron d'Ablaing van Giessenburg, thans lid van den Raad, op den voet van art. 4 van hetzelfde concept, wordt benoemd tot Referendaris bij het Departement van Binnenlandsche Zaken en tot Secretaris; en aan den Raad als nieuwe, onbezoldigde leden worden toegevoegd de Heeren Van Hoëvell en Van der Goes van Dirksland.

Op deze wijze de zaak geregeld wordende, zou de Koning zich kunnen laten welgevallen de weglating van den Hoogen Raad van Adel van het Hoofdstuk II der Staatsbegrooting. Ik heb de eer mij door deze mededeeling van 's Konings bevelen te kwijten.

De Staatsraad, Directeur van het Kabinet des Konings, [w.g.] A.G.A. van Rappard.

Bij Kabinetsmissive van 11 Sept. 1852 (Geheim) zijn mij eenige punten medegedeeld, die werden zij bij de door mij voorgedragen nieuwe regeling van den werkkring van den Hoogen Raad van Adel in acht genomen, U[w]e Maj. zouden kunnen bewegen zich de weglating van den H. Raad van Adel van het Tweede Hoofdstuk der Staatsbegrooting voor 1853 te laten welgevallen.

Ik heb daartegen geene bedenking aan Uwe Maj. te onderwerpen en alzoo de eer een ontwerp van besluit $\mathrm{H}$ [oogst] $\mathrm{D}$ [enzelven] voor te leggen, houdende vaststelling der wijze waarop de tot nu toe door H. Raad van Adel verrigte werkzaamheden voortaan zal worden geregeld.

DMvBZ

[w.g.] T[horbecke] 


\section{Briefwisseling tussen de minister van Algemene Zaken, H. Colijn, en de Hoge Raad van Adel, 1937 [HRvA, RA, inv. nr. 205 (not. 1937-54)]}

den Hoogen Raad van Adel te 's-Gravenhage

's-Gravenhage, 16 November 1937

In verband met de omstandigheid, dat de behandeling van de adelszaken en van de zaken betreffende wapens van publiekrechtelijke lichamen thans ressorteert onder mijn Departement, overweeg ik verandering te brengen in de bestaande wijze van werken ten aanzien van de adelszaken en de werkzaamheden, die tot dusver ten departemente geschiedden, grootendeels over te dragen en te delegeeren aan den Hoogen Raad van Adel.

In verband daarmede heb ik de eer $\mathrm{U}$ mede te deelen, dat ik mij de volgende regeling dezer werkzaamheden als mogelijk heb gedacht.

De adelszaken komen rechtstreeks in bij mijn Departement en zoo zij bij den Hoogen Raad van Adel mochten inkomen, worden zij door dezen Raad aan mij toegezonden, waarna deze stukken, nadat zij dezerzijds zijn geagendeerd, ter verdere bewerking worden doorgezonden aan voornoemden Raad. Nadat de zaak door den Raad is behandeld, worden de stukken, vergezeld van een ontwerpbeschikking aan mij ter beslissing voorgelegd. Mocht onverhoopt mijn zienswijze niet strooken met het advies van den Raad, dan zou, aangezien de beschikkingen in adelszaken enz. niet met redenen plegen te worden omkleed en een weerlegging derhalve mij niet noodig voorkomt, dezerzijds een afwijkende beschikking kunnen worden opgemaakt.

De uitvoering der genomen beslissingen, zoomede het opmaken van adelsdiploma's en wapenbrieven voor publiekrechtelijke lichamen geschiedt in den vervolge door het Secretariaat van den Raad, daar dit tevens beschikt over deskundigen op het gebied van het vervaardigen van wapenafbeeldingen. Ook het bijhouden van filiatieregisters van den Nederlandschen Adel zou naar genoemd Secretariaat kunnen worden overgebracht, aangezien alleen dit beschikt over alle gegevens die ter contrôle noodig zijn.

In verband met de meerdere werkzaamheden van het Secretariaat heb ik er geen bezwaar tegen, dat de reeds daar werkzame losse werkkracht alle werkdagen beschikbaar wordt gesteld. Haar belooning kan naar billijkheid worden herzien.

Wat de huisvesting betreft, komt het mij voorshands gewenscht voor de tegenwoordige localiteiten in het Departement van Justitie te behouden, aangezien deze, behalve een uitnemende gelegenheid om te vergaderen, ruimte bieden voor 's-Raads omvangrijke archieven en boekerij. Mijn Ambtgenoot van Justitie stemt daarmede in.

Ik zal het zeer op prijs stellen van $U$ te mogen vernemen, dat $U$ zich met het bovenstaande kan vereenigen.

DE MINISTER VAN STAAT, MINISTER VAN ALGEMEENE ZAKEN, [w.g.] H. Colijn

Aan Zijne Excellentie den Minister van Staat,

's-Gravenhage, 23 November 1937. Minister van Algemeene Zaken.

In antwoord op bovenaangehaalde missive heeft de Hooge Raad van Adel de eer Uwe Excellentie te berichten, dat het college zich geheel kan vereenigen met Uwer Excellentie's voornemen om ten aanzien van de behandeling der adelszaken en van de zaken betreffende wapens van publiekrechtelijke lichamen de werkzaamheden, die tot dusver ten 
Departemente geschiedden, grootendeels over te dragen en te delegeeren aan den Hoogen Raad van Adel.

Ook met de regeling dezer werkzaamheden, zooals Uwe Excellentie zich die gedacht heeft, en welke in bovengenoemde missive werd uiteen gezet, gaat de Hooge Raad van Adel volkomen accoord.

de Hooge Raad van Adel

de Voorzitter, (w.g.) J. de Vos van Steenwijk.

de Secretaris, (w. g.) J.Ph. de Monté ver Loren.

den Hoogen Raad van Adel 's-Gravenhage, 16 November 1937. te 's-Gravenhage

Naar aanleiding van Uw brief van 13 November 1.1. heb ik de eer U mede te deelen, dat ik daaruit met genoegen heb mogen vernemen, dat de Hooge Raad van Adel zich bereid heeft verklaard de behandeling van Adelszaken en van de zaken betreffende de wapens van publiekrechtelijke lichamen, zooals aangegeven in mijn brief van 16 November 1.1. grootendeels over te nemen. Ik wil U gaarne de verzekering geven, dat ik dit zeer op prijs stel.

DE MINISTER VAN STAAT, MINISTER VAN ALGEMEENE ZAKEN, [w.g.] H. Colijn

3. Nota adelsbeleid van de minister van Binnenlandse Zaken, L.J.M. Beel, 1953 [HRvA, RA, inv. nr. 225 (not. 1962-92)]

\section{Nadere nota inzake toepassing van artikel 74 der Grondwet.}

Met betrekking tot de adelverlening en de daarbij in acht te nemen richtlijnen zij het volgende vermeld.

In de Middeleeuwen was de betekenis van de Edelen, die hun waardigheid voornamelijk ontleenden aan begiftiging met goederen door de souvereine vorst, minder gelegen in detitel, welke zij mochten voeren, dan in hun positie als grootgrondbezitters, welke medebracht, dat zij in het bezit kwamen van de aan het grondgebied verbonden prerogatieven der landsheerlijke macht, zoals rechtspraak, benoeming in ambten, tiendrecht, jacht- en visrecht, enz.

In deze positie kwam gedurende de tijd van de Republiek der Verenigde Nederlanden geen wijziging. Naast de adel, die zich hoofdzakelijk met het platteland verbonden achtte, was een nieuwe stand ontstaan: de patriciërs in de steden, die zich in genen dele de minderen voelden van de oude adel. Onder de Republiek der Verenigde Nederlanden kwam uiteraard, wegens ontstentenis van een souvereine vorst, het verlenen van adeldom niet voor. Het gevolg hiervan was, dat in sommige provinciën (bv. in Holland en Zeeland) de adel tenslotte, op enkele geslachten na, uitgestorven raakte. (In 1794 bedroeg het getal personen, in de Ridderschap van Holland beschreven, slechts 10). 
Vele landgoederen waren door aankoop in handen gekomen van stedelijke patriciërs. De bijzondere positie ten plattelande van de adel verviel uiteraard in 1795. Allen werden nu burgers. Wel herstelde Koning Lodewijk bij de wet van 22 April 1809 de adel als instelling "ter beloning van de oude adel, die hem over het algemeen met getrouwheid diende", echter zonder bijzondere voorrechten, doch op aandrang van keizer Napoleon werd deze wet reeds op 18 Februari 1810 ingetrokken.

Op het voetspoor van de 'Schets eener Grondwet' van Van Hogendorp werd in de Grondwet van 1814 (en 1815) de adel als afzonderlijke stand hersteld. Artikel 42 (63) bepaalde: 'De Souvereine Vorst (Koning) verheft in den adelstand. Al, wie door den Souvereinen Vorst (Koning) in den adelstand verheven wordt, brengt het bewijs daarvan (de brieven van adeldom) ter kennis van de Staten zijner provincie of Landschap en deelt aanstonds in alle de voorregten daaraan verbonden, bijzonderlijk in de bevoegdheid om beschreven te worden in de ridderschap, mits voldoende aan de vereischten voor dezelve bepaald.'

Tengevolge van de Grondwetswijziging van 1848 verviel de aan de adelstand toegekende staatsrechtelijke taak (benoeming leden Provinciale Staten) en kwam tevens aan de heerlijke rechten een einde. De adel had hierdoor zijn bevoorrechte positie en daarmede zijn betekenis als afzonderlijke stand verloren. Het enige thans aan de adel toekomende recht is dat op de titel of, wat de jonkheren aangaat, op het praedicaat.

Het verlenen van adeldom moet - evenals het toekennen van ridderorden - worden gezien als een Koninklijke gunst. De vraag is nu, wie voor een zodanige gunst in aanmerking kan worden gebracht.

Bij het verlenen van adeldom kan men drie gevallen onderscheiden: 1e. Erkenning; 2e. Inlijving; 3e. Verheffing.

ad. 1. Met betrekking tot erkenning als behorende tot de Nederlandse adel kan worden gesteld, dat hiermede een in feite bestaande toestand formeel wordt bevestigd. Zij kan geschieden op bewijs, dat men behoort tot een geslacht, hetwelk vóór 1795 reeds tot de adel behoorde. Verzoeken om erkenning kunnen mitsdien steeds in gunstige overweging worden genomen, indien deze op juiste gronden berusten en niet is gebleken van bezwaren tegen de persoon van de aanvragers, welke zich tegen de erkenning zouden kunnen verzetten.

ad. 2. Inlijving bij de Nederlandse adel kan geschieden ten aanzien van personen, die in mannelijke lijn afstammen van buitenlandse adellijke familiën en de Nederlandse nationaliteit verworven hebben. Van geval tot geval zal moeten worden beoordeeld, of een verzoek tot inlijving kan worden ingewilligd. Bepaalde algemene richtlijnen kunnen te dezen bezwaarlijk worden gegeven.

ad. 3. Voor verheffing in de adelstand zouden in de eerste plaats in aanmerking kunnen worden gebracht personen, die zich voor het land bijzonder verdienstelijk hebben gemaakt. Te dien aanzien heeft Koning Willem I van zijn bevoegdheid een ruim gebruik gemaakt door een aantal personen als beloning voor aan den lande bewezen diensten in de adelstand te verheffen (van Hogendorp, Falck, van den Bosch, e.a.).

Verlening van adeldom op grond van persoonlijke verdiensten heeft sedert lang niet meer plaatsgevonden. De vraag zou gesteld kunnen worden, of het wenselijk moet worden geacht, personen, die zich voor het land zeer verdienstelijk hebben gemaakt en die behoren tot een geslacht, hetwelk gedurende enkele generatiën (b.v. twee of drie) eveneens aan den lande bijzondere diensten heeft bewezen, bij wijze van beloning of erkentelijkheid adeldom te verlenen. Ik meen deze vraag ontkennend te moeten beantwoorden. Hieraan is geen behoefte. 
Naast verheffing in de adelstand op grond van persoonlijke verdiensten, werd aan tal van nazaten van vroegere regentenfamiliën adeldom verleend, met het oog op de volgende omstandigheid. Volgens artikel 85 (144) der Grondwet van 1814 (1815) werden de Provinciale Staten, aan wie was opgedragen het verkiezen van de leden van de Tweede Kamer, samengesteld uit leden, gekozen door de drie standen (n.l. Edelen of Ridderschappen, Steden en Landelijke Stand). Het bleek toen nodig vooral in de provinciën, waarin de oude adel zeer sterk was verminderd, door verheffing in de adelstand in het tekort te voorzien. Zulks was mede geboden door de omstandigheid, dat de adel in de Zuidelijke Nederlanden (België) uitgebreider was dan in de Noordelijke provinciën. Zodoende kon het noodzakelijke evenwicht worden verkregen.

Reeds van Hogendorp had zijn gedachten in die richting laten gaan, blijkens zijn toelichting ten aanzien van het voorstel, in de 'Schets ener Grondwet' opgenomen, tot herstel van de adel. Daaraan wordt het volgende ontleend: 'Het platteland heeft ook geleden door de Republikeinsche Regeering, doordat dezelve niet toeliet om den adel, die verhuisd, in den oorlog gebleven of anderszins uitgestorven was, wederom te vernieuwen en een behoorlijk aantal edellieden, in de provinciën Holland en Zeeland inzonderheid, op de been te houden. Het nadeel, hetwelk het platteland hierdoor geleden heeft, bestaat hierin, dat de Heerlijkheden, door koop, veelal geraakt zijn in de handen van stedelingen, die veraf woonden, zoodat de landsman zijn hoofd miste. De weinige familiën, in de ridderschappen zittende, konden de belangen van het platteland onmogelijk naar behoren voorstaan. $\mathrm{Nu}$ kan de Souvereine Vorst wederom, onder de aanzienlijkste ingezetenen, edellieden maken en de gestoorde evenredigheid herstellen. Deze edelen, willen zij in de Ridderschappen beschreven zijn, moeten een Heerlijkheid bezitten; zij zullen er een, die in hun familie is, op hun naam krijgen, of er een koopen, en zoodoende zal het platteland allengskens vanzelf wederom zijn natuurlijke hoofden krijgen, die het voor zullen staan in de Statenvergaderingen.' Als criterium voor de adelsverheffing van de hier bedoelde personen werd aangenomen, dat zij afstammelingen in mannelijke lijn moesten zijn uit een geslacht, hetwelk gedurende ten minste drie generatiën zitting had in de regering van een belangrijke stemhebbende stad.

Ofschoon de redenen, welke onder de werking van de Grondwet van 1814 (1815) en door de vereniging van de Zuidelijke- en Noordelijke Nederlanden tot uitbreiding van de adel noopten, door de Grondwetsherziening van 1848 en de afscheiding van België waren vervallen, bleef na 1848 verheffing in de adelstand van personen, afstammende van vroegere regentengeslachten, voortduren hoofdzakelijk uit overweging, dat het niet billijk zou zijn aan hen adeldom te onthouden, die, ware zulks onder vigueur van de Grondwet van 1814 (1815) aangevraagd, wel zou zijn verkregen. Na 1945 heeft adelsverheffing van afstammelingen van oude regentengeslachten niet meer plaatsgevonden.

De vraag is nu, of adelsverheffing van de hier bedoelde personen nog dient te worden bevorderd. Voor een ontkennende beantwoording van deze vraag zijn goede argumenten aan te voeren. Dat de om utiliteitsredenen na de Franse tijd tot aan de Grondwetsherziening van 1848 gevolgde gedragslijn uit overwegingen van billijkheid ook daarna in stand werd gehouden, behoeft geenszins mede te brengen, dat deze gedragslijn tot in lengte van dagen wordt gehandhaafd.

Te dezen mag niet uit het oog worden verloren, dat het oordeel omtrent de regentengeslachten niet bijster gunstig luidt. Gezaghebbende geschiedschrijvers als Blok, Romein, Groen van Prinsterer, Kleintjes, Huybers e.a. hebben voor hen maar weinig goede woorden over. Men denke slechts aan de beruchte 'conventiën' en 'contracten van correspondentie', waarbij de regenten overeenkwamen de macht en de winstgevende ambten onder zich te houden. Niet door bekwaamheid, maar slechts door afspraken konden vele regentengeslachten gedurende drie of meer generatiën aan het roer blijven. 
De afstamming van een oud regentengeslacht, hetwelk in ten minste drie generatiën in de regering ener stemhebbende stad zitting heeft gehad, moet, zeker thans, nu het reeds meer dan 50 jaar geleden is, dat aan de regenten (familie) regering een einde is gekomen, als een onbruikbaar criterium worden beschouwd. Afstamming van een oud regentengeslacht ware dan ook niet meer als voldoende grond voor adelsverheffing te aanvaarden.

In dit verband verdient nog de aandacht de groep personen, afstammende van een regentengeslacht, waarvan reeds een of meer takken in de adelstand zijn verheven. Gesteld zou kunnen worden, dat door de verheffing van deze takken in de adelstand redelijkerwijs het gehele geslacht als van adel moet worden beschouwd, en dat nog slechts formaliteiten (indienen van een verzoekschrift en betaling van een bepaalde som) zijn te vervullen voor daadwerkelijke opneming in de adelstand. Hiertegenover blijft echter staan, dat afstamming van een oud regentengeslacht thans niet langer als voldoende motief voor verheffing in de adelstand kan worden beschouwd. Men bedenke, dat, als men deze weg wel zou gaan, het niet redelijk zou zijn aan personen, behorende tot een geslacht, waarvan geen enkele tak in de adelstand is opgenomen, doch welk geslacht eveneens van een oud regentengeslacht afstamt, adelsverheffing te weigeren.

Dit alles overwegende, lijkt het de voorkeur te verdienen adelsverheffing op grond van afstamming van een regentengeslacht in het vervolg achterwege te laten. Resumerende moge de volgende richtlijn worden voorgesteld.

1e. Erkenning als behorende tot de Nederlandse adel kan geschieden, indien daarvoor gronden bestaan - als hiervoren aangegeven - en niet is gebleken van bezwaren tegen de persoon van de aanvragers, welke zich tegen de erkenning zouden verzetten.

2e. Inlijving bij de Nederlandse adel zal van geval tot geval worden beoordeeld aan de hand van de zich daarbij voordoende bijzondere omstandigheden.

3e. Verheffing in de adelstand dient achterwege te blijven.

DE MINISTER VAN BINNENLANDSE ZAKEN, [w.g.] Beel

\section{Lijst van voorzitters, leden en secretarissen van de Hoge Raad van Adel}

De Hoge Raad van Adel is volgens het Soeverein Besluit van 24 juni 1814, nr. 10, art. 1 (oprichting) en art. 2 (instructie) samengesteld uit een voorzitter, vier leden en een secretaris. Bij Koninklijk Besluit van 17 sept. 1852, nr. 44 werden een voorzitter, twee leden en een ambtelijk secretaris benoemd. De eedsaflegging van de leden is (opnieuw) bepaald bij K.B. van 22 maart 1856, nr. 60, en de samenstelling (opnieuw) bij de K.B.'s van 12 mei 1866, nr. 48, en van 25 dec. 1881, nr. 10 (secretaris ook bij K.B. benoemd). De Wet op de adeldom van 10 mei 1994 (Stb. 360) bepaalt in art. 6, lid 3, dat de Raad is samengesteld uit vijf leden, die bij koninklijk besluit worden benoemd en ontslagen. Benoemingen vinden in principe plaats voor het leven. De ambtelijk secretaris is tevens hoofd van het bureau.

\section{Voorzitters en leden van de Hoge Raad van Adel}

1. mr. W.A. baron van Spaen la Lecq (1750-1817), voorzitter 1814-1817.

2. M.L. van Hangest baron d'Yvoy van Mijdrecht (1753-1831), lid 1814-1831, fungerend voorzitter $1817-1818$.

3. A.C. baron Snouckaert van Schauburg (1763-1841), lid 1814-1841.

4. mr. R. Metelerkamp (1772-1836), lid 1814-1815.

5. mr. H. van Wijn (1740-1831), honorair lid 1814-1831. 
6. jonkheer E.F.H. O'Kelly de Galway (1765-1840), lid 1815-1830.

7. jonkheer mr. L. de Witte van Citters (1781-1862), lid 1815-1853, fungerend voorzitter 1845-1850, voorzitter 1851-1853.

8. F.G. baron van Lijnden van Hemmen (1761-1845), voorzitter 1818-1845.

9. W.H.J. baron van Westreenen van Tiellandt (1783-1848), lid 1831-1848, voordien thesaurier-chartermeester.

10. jonkheer mr. A.C. van der Goes (1791-1852), lid 1841-1852.

11. mr. W.J. baron d'Ablaing van Giessenburg (1812-1892), lid 1848-1852, daarna secretaris (zie onder Secretarissen, nr. 5).

12. mr. R.A. baron van Hoëvell van Nijenhuis (1810-1888), lid 1852, fungerend voorzitter 1853-1865, voordien secretaris (zie onder Secretarissen, nr. 4).

13. mr. L.N. baron van der Goes van Dirxland (1806-1885), lid 1852-1861.

14. jonkheer W.I.C. Rammelman Elsevier (1810-1885), lid 1856-1866.

15. dr. R.C. Bakhuizen van den Brink (1810-1865), lid 1861-1865.

16. mr. L.A.J.W. baron Sloet van de Beele (1806-1890), lid 1861, wederom benoemd 1875 (zie nr. 23).

17. mr. R.J. graaf Schimmelpenninck van Nijenhuis (1821-1893), lid 1861, voorzitter 1866-1893.

18. mr. A.C. baron Snouckaert van Schauburg (1803-1878), lid 1866-1878.

19. mr. W. baron van Goltstein (1831-1901), lid 1866-1874.

20. jonkheer C.A. van Sypesteijn (1823-1892), lid 1866-1873, wederom benoemd 1883 (zie nr. 25).

21. mr. L.Ph.C. van den Bergh (1805-1887), lid 1866-1887.

22. mr. M.Ch.H. ridder Pauw van Wieldrecht (1816-1895), lid 1873-1892.

23. mr. L.A.J.W. baron Sloet van de Beele, lid 1875-1890, eerder lid in 1861 (zie nr. 16).

24. mr. J.C.E. graaf van Lynden (1835-1878), lid 1878.

25. jonkheer C.A. van Sypesteijn (1823-1892), lid 1883-1892, voordien lid 1866-1873 (zie nr. 20).

26. mr. M.W. baron du Tour van Bellinchave (1835-1908), lid 1878-1883, wederom benoemd 1892 (zie nr. 29).

27. A. baron Schimmelpenninck van der Oye van de beide Pollen en Nijenbeek (18391918), lid 1887, voorzitter 1893-1907.

28. jonkheer mr. Th.H.F. van Riemsdijk (1848-1923), lid 1891-1923.

29. mr. M.W. baron du Tour van Bellinchave (1835-1908), lid 1892-1906, voordien lid 1878-1883 (zie nr. 26).

30. jonkheer M.P. Smissaert (1825-1900), lid 1893-1900.

31. A.C. baron Snouckaert van Schauburg (1841-1902), lid 1893-1902.

32. mr. C.J.E. graaf van Bijlandt (1840-1902), lid 1900-1902.

33. G.C. baron van Asbeck (1856-1934), lid 1902, voorzitter 1908-1934.

34. jonkheer mr. A.F.O. van Sasse van Ysselt (1852-1939), lid 1903, voorzitter 19341939.

35. mr. W.L. baron de Vos van Steenwijk (1859-1947), lid 1907-1935.

36. A.Z. graaf van Rechteren Limpurg (1863-1918), lid 1908-1918.

37. R.H.O. baron van der Capellen (1854-1937), lid 1919-1937.

38. jonkheer mr.dr. W.A. Beelaerts van Blokland (1883-1935), lid 1924-1935, voordien secretaris (zie onder Secretarissen, nr. 9).

39. mr. F.F. baron de Smeth (1887-1939), lid 1934-1939.

40. mr. J.A.G. baron de Vos van Steenwijk (1889-1972), lid 1935, voorzitter 1939-1947.

41. jonkheer mr. F. Beelaerts van Blokland (1872-1956), lid 1935, voorzitter 19471956.

42. mr. J.F. baron van Haersolte (1880-1957), lid 1937-1954. 
43. jonkheer dr. B. M. de Jonge van Ellemeet (1881-1962), 1939-1957.

44. mr. C.E.A. baron van Hövell van Westervlier en Weezeveld (1878-1956), lid 19391956.

45. J.J.G. baron van Voorst tot Voorst (1880-1963), lid 1947-1960.

46. jonkheer mr.dr. D.P.M. Graswinckel (1888-1960), lid 1954, voorzitter 1956-1960.

47. jonkheer mr. M.A. Beelaerts van Blokland (1910-1990), lid 1956, voorzitter 19601966.

48. mr. G.C.D. baron van Hardenbroek (1902-1960), lid 1956-1960.

49. jonkheer mr. C.C. van Valkenburg (1910-1984), lid 1957, voorzitter 1966-1984.

50. mr. A.N. baron de Vos van Steenwijk (1912-1996), lid 1960, voorzitter 1984-1986.

51. jonkheer mr. P.G.M. van Meeuwen (1899-1982), lid 1960-1972.

52. jonkheer mr. G.A.M.J. Ruijs de Beerenbrouck (1904-1983), lid 1960-1983.

53. jonkheer mr. A.J.M van Nispen tot Pannerden (1914-1972), lid 1966-1972.

54. jonkheer mr. T.K.M.J. van Sasse van Ysselt (1908-2004), lid 1972-1992.

55. mr. F.W.B. baron van Lynden (1918-2000), lid 1972, voorzitter 1986-1991.

56. mr. A.M.J. baron van Hövell tot Westervlier en Wezeveld (1911-1991), lid 19771987.

57. drs. C.O.A. baron Schimmelpenninck van der Oije (1943-), lid 1984, voorzitter 1991 tot heden.

58. jonkheer mr. C.L. Reigersman (1927- ), lid 1986-2001.

59. C.W.J. baron de Weichs de Wenne (1934- ), lid 1987-2005.

60. mr. J.P. Eschauzier (1941- ), lid 1991-2011.

61. jonkvrouw M. van den Brandeler (1941-2009), lid 1992-2009.

62. jonkheer dr. F.K.M. van Nispen tot Pannerden (1951- ), lid 2002 tot heden.

63. mr. H.C.R.M. baron de Wijkerslooth de Weerdesteijn (1950- ), lid 2005 tot heden.

64. drs. R.M. barones van Pallandt (1964- ), lid 2010 tot heden.

65. mr. C.J.A. barones Snouckaert van Schauburg-Buchwaldt (1965- ), lid 2012 - heden.

\section{Secretarissen van de Hoge Raad van Adel}

1. jonkheer mr. J. van der Lely van Oudewater (1769-1825), 1814-1815.

2. mr. P. de Wacker van Zon (1758-1818), 1815-1818.

3. mr. Ch.A. Chais (1762-1840), 1818-1841.

4. mr. R.A. baron van Hoëvell van Nijenhuis (1810-1888), 1841-1852, daarna lid en fungerend voorzitter (zie onder Voorzitters en leden, nr. 12).

5. mr. W.J. baron d'Ablaing van Giessenburg (1812-1892), 1852-1861, voordien lid (zie onder Voorzitters en leden, nr. 11).

6. jonkheer E.W. van Weede (1820-1897), 1861-1866.

7. jonkheer mr. P.A. van den Velden (1831-1892), waarnemend 1866-1881, 1881-1892.

8. jonkheer D. Rutgers van Rozenburg (1854-1929), 1892-1909.

9. jonkheer mr.dr. W.A. Beelaerts van Blokland (1883-1935), 1909-1924, daarna lid (zie onder Voorzitters en leden, nr. 38).

10. jonkheer mr. D.J.P. Hoeufft (1894-1977), 1924-1929.

11. mr.dr. J.Ph. de Monté ver Loren (1901-1974), 1930-1942.

12. mr.dr. J.P.J. Gewin (1880-1965), waarnemend 1942-1945.

13. mevrouw J.H.G. Meihuizen-Landré (1886-1970), waarnemend 1946.

14. mr. M.J.H. de Bruyn van Melis- en Mariekerke (1891-1964), 1946-1957.

15. jonkheer mr. H.E. van Weede (1918-1968), 1957-1968.

16. D. baron Mackay (1900-1969), waarnemend 1968.

17. mr. O. Schutte (1938- ), 1968-2003.

18. mr. E.J. Wolleswinkel (1950- ), 2003 tot heden. 


\section{Geraadpleegde literatuur}

Aalbers, J., 'Willem Anne van Spaen van Hardestein en de voormalige riddermatige adel (1806-1813)', De bloem der natie. Adel en patriciaat in de Noordelijke Nederlanden (Meppel/Amsterdam 1987), 104-128.

Aalbers, J., 'Van riddermatige naar koninklijke adel', De Eeuwwende 1800 (Utrecht 1992), Studium Generale Reeks 9201, 49-69.

Ablaing van Giessenburg, W.J. d', Over adelijke titels, erfelijk volgens regt van eerstgeboorte ('s-Gravenhage 1867).

Ablaing van Giessenburg, W.J. d', De Ridderschappen in het Koninkrijk der Nederlanden of de geschiedenis, regeling en zamenstelling van den stand der edelen van 1814-1850 ('s-Gravenhage 1875).

Ablaing van Giessenburg, W.J. d', 'Toestand van 's lands adel gedurende het bestaan van het Koninkrijk Holland', De Nederlandsche Heraut 1(1884), 5-44.

Asser, W.D.H., en J. de Boer, Personen- en Familierecht, Asser-serie 1 (18 ${ }^{\mathrm{de}}$ druk, Deventer 2010).

Beelaerts van Blokland, M.A., 'Adelsbeleid en adelsrecht vóór 1813', De Hoge Raad van Adel. Geschiedenis en werkzaamheden ('s-Gravenhage 1966), 1-54.

Beelaerts van Blokland, M.A., 'Titulatuur, standaarden en wapens van het Koninklijk Huis', De Hoge Raad van Adel. Geschiedenis en werkzaamheden ('s-Gravenhage 1966), 105-123.

Beks, G., Y. van Dam-Kooij en M. Swen, Adelsbeleid, adelsrecht en het decoratiestelsel na 1945. Een institutioneel onderzoek ('s-Gravenhage 2000), Rijksarchiefdienst, Pivotrapport 101.

[Berendse, Martin, en Paul Brood], In 21 stappen vrij onverveerd. Constitutionele topstukken van het Nationaal Archief (Den Haag 2009).

Berkvens, A.M.J.A., J. Hallebeek en A.J.B. Sirks (red.), Het Franse Nederland: de inlijving 1810-1813. De juridische en bestuurlijke gevolgen van de 'Réunion' met Frankrijk. Pro Memorie. Bijdragen tot de rechtsgeschiedenis der Nederlanden 13.2. (2011) (Hilversum 2012).

Besselink, L.F.M., 'Respecting Constitutional Identity in the EU', Common Market Law Review 49 (2012), 671-693.

Blocq van Scheltinga, D. de, 'Enkele opmerkingen over de positie van de adel in de huidige samenleving', De Nederlandsche Leeuw 109 (1992), 268-271.

Boddaert, A.R.Ph., 'De Zeeuwse adoptiezaak', De Nederlandsche Leeuw 119 (2002), 3647, 342-343 (met reacties van M.R. Doortmont en K. Kuiken); 'De tweede Zeeuwse adoptiezaak', idem 122 (2005), 227-232.

Boddaert, A.R.Ph., 'Ontneming van adellijke predikaten', De Nederlandsche Leeuw 125 (2008), 150-152.

Boddaert, A.R.Ph., 'Adellijke titulatuur in overheidsdocumenten. Zes jaar strijd tegen onkunde en automatiseringsproblemen', De Nederlandsche Leeuw 127 (2010), 86-87.

Boddaert, A.R.Ph., 'De Prins van Waterloo', Van Adel. Nieuwsbrief van de Nederlandse Adelsvereniging, Voorjaar 2012, 6-9.

Bönninghausen, T. von, 'Ruim 290 Nederlandse adellijke geslachten', De Nederlandsche Leeuw 117 (2000), 155-162.

Bönninghausen, T. von, 'Wapen voor prinses Amalia', De Nederlandsche Leeuw 122 (2005), 129-133. 
Bönninghausen, T. von, 'Adelsdiploma voor prins Johan Friso', De Nederlandsche Leeuw 123 (2006), 43-48.

Borne, Jos van den, 'Voorportaal van adeldom? De Hoge Raad van Adel en burgerwapens in Nederland', Adel en heraldiek in de Nederlanden. Adellijke identiteit en representatie. Opstellen aangeboden ter gelegenheid van het afscheid van jhr. Arnold Gevers als archivaris bij het Historisch Centrum Overijssel te Zwolle op 2 november 2012. Adelsgeschiedenis 10 / Werken Koninklijk Nederlandsch Genootschap voor Geslacht- en Wapenkunde (KNGGW) 18 (Hilversum, 2012), 277-312.

Breugel Douglas, R. van, Over het adelsregt in de Nederlanden ('s-Gravenhage 1867).

Brood, P., P. Nieuwland, L. Zoodsma (red.), Homines Novi. De eerste volksvertegenwoordigers van 1795 (Amsterdam 1993).

Bruin, Kees, 'Kwesties van stand. Over de opname in de adelstand van Amsterdamse patriciërs in de 19 eeuw', Sociologische Gids 28 (1981), 110-139.

Bruin, C.J.M., 'Een verloren zaak. Adel als beloning voor persoonlijke verdiensten in het Koninkrijk der Nederlanden', De Bloem der Natie. Adel en patriciaat in de Noordelijke Nederlanden (Meppel/Amsterdam 1987), 141-164.

Bruin, Kees, 'Notities bij recente ontwikkelingen in het Nederlandse adelsbeleid', De $\mathrm{Ne}$ derlandsche Leeuw 109 (1992), 227-237.

Bruin, Kees, 'Wat heet dubbel; de sanering van dubbele namen rond de Tweede Wereldoorlog', De Gids, februari 1999, 102-111.

Bruin, Renger E. de, Bedreigd door Napoleon. De Ridderlijke Duitsche Orde, Balije van Utrecht 1753-1838 (Hilversum 2012).

Bruyn van Melis- en Mariekerke, M.J.H. de, 'Hoge Raad van Adel', Jaarboek van het Centraal Bureau voor Genealogie 10 (1956), 15-26.

Burg, F.H. van der, en A.K. Koekkoek, 'Een dubbele proef voor Máxima', Nederlands Juristenblad 2001, 1707.

Burg, F.H. van der, 'Geen Parmezaanse Koninklijke Familie in Nederland', Nederlands Juristenblad 2003, 1073-1074.

Burg, F.H. van der, 'De toestemming voor prinselijke huwelijken, een erfenis uit de tijd van de Republiek der Verenigde Nederlanden', Getuigend Staatsrecht, Liber amicorum A.K. Koekkoek (Nijmegen 2005), 11-30.

Burg, V.A.M. van der, 'Pauselijke adel in Nederland na het herstel van de kerkelijke hiërarchie in 1853', De Nederlandsche Leeuw 105 (1988), 147-148; 108 (1991), 177-178 en 462-463; 111 (1994), 232-233.

Burg, V.A.M. van der, 'Het Nederlandse adelsbeleid sedert 1980 vanuit het perspectief van de wetgever en de rechter', Virtus. Jaarboek voor adelsgeschiedenis 10 (2003), 200-204.

Coenraad, R.P.N., 'Het Nederlandse adelsrecht. Een staatsrechtelijk overzicht van het vigerende adelsrecht', Virtus. Jaarboek voor adelsgeschiedenis 11 (2004) 118-171.

Colenbrander, H.T., Ontstaan der Grondwet. Bronnenverzameling; eerste deel (1814); tweede deel 1815. Rijks Geschiedkundige Publicatiën, kleine serie 1 ('s-Gravenhage 1908) en 2 ('s-Gravenhage 1909).

Colenbrander, H.T., De afscheiding van België. Nederlandsche Historische Bibliotheek 21 (Amsterdam 1936).

Damme, M. van, Adel. Algemene practische rechtsverzameling (Gent/Leuven 1982).

Ditzhuyzen, R.E. van, Oranje-Nassau. Een biografisch woordenboek (Haarlem 1992).

Doeleman, F., 'Johan Philip de Monté ver Loren', Biografisch Woordenboek van Nederland (red. I.Schöffer e.a.), 1 ('s-Gravenhage 1979), 404-405.

Doortmont, M.R., 'De toestemmingswet voor het huwelijk van prins Constantijn en Petra Laurentien Brinkhorst', De Nederlandsche Leeuw 118 (2001), 439-452. 
Doortmont, M.R., 'Bibliografie van artikelen over adeldom en adelsbeleid verschenen in De Nederlandsche Leeuw 1992-2000', De Nederlandsche Leeuw 118 (2001), 509-510.

Doortmont, M.R., 'De toestemmingswet voor het huwelijk van prins Willem-Alexander en Máxima Zorreguieta', De Nederlandsche Leeuw 119 (2002), 83-117.

Dorp, L. van, 'De titel "Prins van Oranje", De Nederlandsche Leeuw 105 (1988), 265273.

Dronkers, J., 'De maatschappelijke relevantie van hedendaagse Nederlandse adel', Amsterdams Sociologisch Tijdschrift 27 (2000), 233-268.

Dronkers, J., 'Verschillen tussen $20^{\text {ste }}$-eeuwse Nederlandse adel uit Amsterdam, 'sGravenhage, Rotterdam, Utrecht en Duitsland', De Nederlandsche Leeuw 118 (2001), 458-466.

Duerloo, L., en P. Janssens, Wapenboek van de Belgische adel van de $15^{\text {de }}$ tot $20^{\text {ste }}$ eeuw (Brussel 1992-1993), 4 delen.

Elias, A.M., en Paula C.M. Schölvinck, Volksrepresentanten en wetgevers. De politieke elite in de Bataafse Republiek 1796-1810 (Amsterdam 1991).

Elzinga, Wendelien, en Gerard-René de Groot, 'Over adellijke namen en zo...', Nederlands Juristenblad 1994, 124-127 en 478-480 (reactie van C.J.F. Taets van Amerongen).

État présent de la noblesse Belge (Brussel 1984-[2012]).

Ette, A.J.H. van, 'Onze Volksvertegenwoordigers', Jaarboek van het Centraal Bureau voor Genealogie 5 ('s-Gravenhage 1951), 81-118.

Evers, Léon, en Henk Vat, Afstamming en naam ('s-Gravenhage 2006).

Fasseur, Cees, De gekroonde republiek (Amsterdam 2011).

Feenstra, H., De bloeitijd en het verval van de Ommelandse adel (1600-1800) (diss. Groningen 1981).

Fockema Andreae, S.J., Rechtsgeleerd handwoordenboek (Groningen 1951).

Fox, J., 'Zuidnederlandse adel in betrekking tot Koning Willem I', Liber Amicorum Jhr.Mr. C.C. van Valkenburg ('s-Gravenhage 1985), 122-147.

Gabriëls, A.J.C.M., De heren als dienaren en de dienaar als heer. Het stadhouderlijk stelsel in de tweede helft van de achttiende eeuw. Hollandse Historische Reeks 14 (diss. Leiden / 's-Gravenhage 1990).

Gietman, Conrad, 'Genealogie, waarheid en statusangst in de late negentiende eeuw', Mensen van adel. Beelden, manifestaties, representaties. Opstellen aangeboden t.g.v. het afscheid van Albert Mensema als archivaris bij het Historisch Centrum Overijssel te Zwolle 14 september 2007. Adelsgeschiedenis 4 / Werken KNGGW 15 (Hilversum 2007), 178-208.

Gietman, Conrad, Republiek van adel. Eer in de Oost-Nederlandse adelscultuur. Adelsgeschiedenis 7 (diss. Utrecht / Westervoort 2010) [boekbespreking door Sebastiaan Roes in: Pro Memorie 13 (2011), 143-147].

Gou, L. de, De Staatsregeling van 1798. Bronnen van de totstandkoming. Rijks Geschiedkundige Publicatiën uitgegeven door het Instituut voor Nederlandse Geschiedenis, kleine serie 65 en 67 ('s-Gravenhage 1988 en 1990).

Gou, L. de, De Staatsregeling van 1801. Bronnen van de totstandkoming. Rijks Geschiedkundige Publicatiën uitgegeven door het Instituut voor Nederlandse Geschiedenis, kleine serie 85 ('s-Gravenhage 1995).

Gou, L. de, De Staatsregeling van 1805 en de Constitutie van 1806. Bronnen van de totstandkoming. Rijks Geschiedkundige Publicatiën uitgegeven door het Instituut voor Nederlandse Geschiedenis, kleine serie 89 ('s-Gravenhage 1997).

Groot, Gerard-René de, 'Einige Bemerkungen über das niederländische Adelsprädikat "Jonkheer"”, Das Standesamt 4 (1974), 103-104. 
Groot, G.-R. de, 'Het recht van de geslachtsnaam in beweging', Nederlands Juristenblad 50 (1975), 1022-1034.

Groot, G.-R. de, 'Kanttekeningen over de familienaam', Het Personeel Statuut 31 (1980), 78-80 en 86-92.

Groot, G.-R. de, 'De adeldom en het gelijkheidsbeginsel', Nederlands Tijdschrift voor de Mensenrechten (uitgave van het Nederlands Juristen Comité voor de Mensenrechten) [NJCM-bulletin] 11 (1986), 526-534.

Groot, Gerard-René de, 'Prins Pieter der Nederlanden. Aantekeningen over ongelijke behandeling van mannen en vrouwen in het Nederlandse naam en adelsrecht', Nemesis 15 (1998), 143-147.

Groot Schneider, Gerard-René de, 'De heer Bernhard Sekrève?', Nederlands Juristenblad 75 (2000), 1067-1068 [met reactie van P.A. Wackie Eysten en naschrift De Groot].

Groot, G.-R. de, 'Adelsrecht op de drempel van de $21^{\text {ste }}$ eeuw. Een drama in bedrijven; een korte beschrijving van de achtereenvolgende tonelen', De Nederlandsche Leeuw 118 (2001), 501-509 en 663-664; 119 (2002), 63-64 [met reactie van G.N. Westerouen van Meeteren].

Groot, Gerard-René de, 'Twee aantekeningen over het gebruik van adellijke titels; 1 . Buitenlandse adelstitels en buitenlandse naamsbestanddelen van adellijke origine; 2. Artikel 1:9 Burgerlijk Wetboek en het gebruik van adellijke titels en predikaten, Burgerzaken \& Recht 13 (2006), 100-105.

Groot, Gerard-René de, Viviënne Hautvast, Tes Gybels-van de Warenburg, Anna Berlee en Hans von Reden, 'Naamrecht in vergelijkend perspectief: een quick scan', Bouwstenen voor een nieuw naamrecht (Werkgroep liberalisering naamrecht, 's-Gravenhage 2009), 1-48.

Groot, Gerard-René de, 'Jacht op mooie namen', Minicongres Burgerzaken NoordNederland (Nederlandse Vereniging voor Burgerzaken, Assen 2009), 13.

Groot Schneider, Gerard-René de, 'Haasje over springen: aantekeningen bij de Landsverordening herziening namenrecht', Tijdschrift voor Antilliaans Recht / Justicia (TAR) 2010, 162-167.

Groot, Gerard-René de, 'Autonomie und zwingende Bestimmungen im Namensrecht: eine rechtsvergleichende Studie über die Rechtssysteme des Königreichs der Niederlande', Liber amicorum für Walter Pintens 1 (2012), 23-41.

Groot, Hugo de, Inleidinge tot de Hollandsche Regts-Geleertheyt ('s-Gravenhage 1631, herdruk Amsterdam 1667).

Haersolte, R.A.V. van, Inleiding tot het Nederlandse staatsrecht (vijfde druk, Zwolle 1972).

Hallebeek, J., en A.J.B. Sirks (red.), Nederland in Franse schaduw. Recht en bestuur in het Koninkrijk Holland (1806-1810) (Hilversum 2006).

Hanegraaff, J., Opmerkingen naar aanleiding van artikel 435 van het Wetboek van Strafrecht (diss. Leiden / Rotterdam 1891).

van Hasselt, W.J.C., Verzameling van Nederlandsche Staatsregelingen en Grondwetten (twaalfde druk, bewerkt door R. Kranenburg, Amsterdam 1938).

Helsdingen, W.H. van, (met medewerking van Th.J. van der Peyl), Het Statuut van het Koninkrijk der Nederlanden. Wordingsgeschiedenis, commentaar en praktijk ('sGravenhage 1957).

Heringa, A.W., en T. Zwart, Grondwet 1983 (tweede herziene druk, Zwolle 1987).

Hermans, Dorien, Pieter van Vollenhoven. Burger aan het hof (Amsterdam 2002).

Heijs, Eric, Van vreemdeling tot Nederlander. De verlening van het Nederlanderschap aan vreemdelingen 1813-1992 (diss. Amsterdam 1995).

Hirsch Ballin, Ernst, De Koning. Continuïteit en perspectief van het Nederlandse koningschap ('s-Gravenhage 2012). 
Hofman Kolk, Peter, 'Het symposium "Ontwikkelingen in het Nederlandse adelsrecht, van Koning Willem I tot een Wet op de Adeldom",, De Nederlandsche Leeuw 109 (1992), 225-227, 271-277 en 285-286.

Hofman Kolk, Peter, 'Beknopte bibliografie van het Nederlandse adelsrecht en de adelsgeschiedenis in de $19^{\mathrm{de}}$ en $20^{\text {ste }}$ eeuw', De Nederlandsche Leeuw 109 (1992), 225-227 en 277-284.

Hofman Kolk, Peter, 'Het koninklijk huis en de art. 5 en 7 boek 1 BW', Nederlands Juristenblad 73 (1998), 915.

Hogendorp, H. van, Brieven en gedenkschriften van Gijsbert Karel van Hogendorp (7 dln., 's-Gravenhage 1866-1903).

Hooykaas, G.J., en F.J.P. Santegoets, De briefwisseling van J.R. Thorbecke, V (18451853) Rijks Geschiedkundige Publicatiën uitgegeven door het Instituut voor Nederlandse Geschiedenis, kleine serie 78 ('s-Gravenhage 1996).

Houte de Lange, C.E.G. ten, V.A.M. van der Burg, Pauselijk eerbetoon. Een inleiding over Pauselijke onderscheidingen, ridderorden, Pauselijke adel en Nederlanders aan het Pauselijk Hof (Hilversum 2010).

Huber, U., Heedendaegse Rechtsgeleertheyt, soo elders als in Frieslandt gebruikelijk (2 dln., Leeuwarden 1686).

Huizinga, J., 'De beteekenis van 1813 voor Nederland's geestelijke beschaving', Verzamelde Werken 2 (Haarlem 1948), 528-542.

Ingen, Jan C. van, en Stefan de van der Schueren, Van herkenning tot erkenning. Een praktijkhandboek over het decoratiestelsel (Soesterberg 2012).

Janssens, Paul, De evolutie van de Belgische adel sinds de late Middeleeuwen (Brussel 1998).

Janssens, Paul, 'De Nederlandse en de Belgische adel door de eeuwen heen', De Nederlandsche Leeuw 123 (2006), 268-280.

Jong, L. de, Het Koninkrijk der Nederlanden in de Tweede Wereldoorlog 1939-1945, 12 (epiloog), eerste helft (Leiden 1988).

Karper, L.G., 'De geschiedenis van het Rijkswapen en het Koninklijk grootzegel', De Nederlandsche Leeuw 97 (1980), 114-125.

Keesom, P.H.M., 'Hoofdlijnen van het Nederlandse adelsrecht sedert het ontstaan van het Koninkrijk', De Nederlandsche Leeuw 109 (1992), 237-253.

Keesom, P.H.M., 'De titulatuur en geslachtsnamen van de kinderen van H.H.K.K.H.H. prins Constantijn en prinses Laurentien', De Nederlandsche Leeuw 118 (2001), 452457, 661-662, 723-724 [met reacties van B.M. Kamp en H.P.M. Cobben]

Keesom, P.H.M., 'Notities over Nederlands adelsrecht', Het Personeel Statuut 29 (1978), 89-94; 30 (1979), 14 (correctie).

Ketelaar, F.C.J., Oude zakelijke rechten, vroeger, nu en in de toekomst. Rechtshistorische studies 3 (diss. Leiden / Zwolle 1978).

Ketwich Verschuur, E. van, 'Verleening van adeldom', Vragen des Tijds 43 (1917), 297 316.

[Keuzenkamp, J.H.,] Gemeentewapens in Nederland ('s-Gravenhage 1989).

Kort, J.C., en E.J. Wolleswinkel, Het archief van de Hoge Raad van Adel (1809) 18141984 en de gedeponeerde familiearchieven. Inventarisreeks HRvA 9 ('s-Gravenhage 2006).

Kort, J.C., en E.J. Wolleswinkel, Het archief van de Chambre Héraldique, de handschriften-collectie van de Hoge Raad van Adel en enkele gedeponeerde familiearchieven. Inventarisreeks HRvA 10 ('s-Gravenhage 2009).

Kuiper, Y., Adel in Friesland 1780-1880 (diss. Groningen 1993). 
Kuipers, J.J., 'Sayn-Wittgenstein. Dokkumer Doctrine en Adellijke Aspiraties', Vrij verkeer van personen in 60 arresten. De zegeningen van het Europees burgerschap. PSspecial (Deventer 2012), 56.

Loeb, Ernée, Naam en recht. Praktische beschrijving van het naamrecht in Nederland ('s-Gravenhage 1990).

Loeb, Ernée, 'De relatie tussen het naamrecht en het adelsrecht', De Nederlandsche Leeuw 109 (1992), 254-268.

Luiking, H.F.W., "'Heer van ....."”, Nederlands Juristenblad 33 (1958), 654-655, 735736, 866-870; 34 (1959), 344-345, 525-526 [met reacties van J.C. Maris (van Sandelingenambacht)].

Luiking, H.F.W., 'De taakomschrijving van de Hoge Raad van Adel', Nederlands Juristenblad 36 (1961), 100-102.

Luiking, H.F.W., 'De Prins van Oranje', Nederlands Juristenblad 40 (1965), 705 e.v. [met een reactie van J.L. Rijndorp].

Luiking, H.F.W., 'Het Koninklijk Besluit houdende "Voorzieningen in verband met het huwelijk van H.K.H. Prinses Margriet en Pieter van Vollenhoven", Nederlands Juristenblad 42 (1967), 182-185.

Luiking, H.F.W., 'De "Proeve van een nieuwe Grondwet" en de adel', Nederlands Juristenblad 43 (1968), 408-411 [onder dezelfde titel gepubliceerd in: Tijdschrift voor Overheidsadministratie 24 (1968), nr. 1091, 163-165].

Luiking, H.F.W., 'Het wapen van mr. P. van Vollenhoven en dat van zijn kind(eren)', Nederlands Juristenblad 43 (1968), 848-849, 1047-1048 ['Nogmaals', reactie van A.J. Beenhakker] en 1076 [weerwoord].

Lutter, A.A., 'De nieuwe wet op de adeldom, rechtsongelijkheid in het inlijvingsbeleid?', De Nederlandsche Leeuw 116 (1999), 315-318.

Lynden, F.W.B. van, 'Enkele notities over het adelsbeleid in de periode Van Valkenburg', Liber Amicorum Jhr. Mr. C.C. van Valkenburg ('s-Gravenhage 1985), 200-206.

Maris van Sandelingenambacht, J.C., 'De Koning verleent adeldom', De Nederlandsche Leeuw 63 (1945-1946), 5-8.

Maris van Sandelingenambacht, J.C., 'Harmonische hantering van oud-vaderlands adelsrecht in deze tijd', De Nederlandsche Leeuw 72 (1955), 304-308; 75 (1958), 156-158; 78 (1961), 122-124 en 342-344 [met reactie van A. Haga].

Marius Gerlings, J.H., 'Sine Titulis', Tijdschrift voor Overheidsadministratie 24 (1968), nr. 1084, 55-56.

Meeuwen, P.G.M. van, 'Een en ander over het Nederlandse adelsrecht', De Hoge Raad van Adel. Geschiedenis en werkzaamheden ('s-Gravenhage 1966), 74-90.

Meuwissen, Daantje, Gekoesterde traditie. De portretreeks met de landscommandeurs van de Utrechtse Balije van de Ridderlijke Duitsche Orde. Bijdragen tot de geschiedenis van de Ridderlijke Duitsche Orde, Balije van Utrecht 4 (diss. Utrecht / Hilversum 2011).

Meij, J.M. de, 'Hoe belangrijk is de Bataafse Staatsregeling van 1798 geweest voor de Nederlandse constitutionele ontwikkelingsgeschiedenis?', Pro Memorie. Bijdragen tot de rechtsgeschiedenis der Nederlanden 5 (2003), 288-319.

Moes, Jaap, Onder aristocraten. Over hegemonie, welstand en aanzien van adel, patriciaat en andere notabelen in Nederland, 1848-1914. Adelsgeschiedenis 9 (diss. Groningen / Hilversum 2012).

Monod de Froideville, G.H.A., Sophie den Beer Poortugael, Inez van Eijk, Titulatuurgids ('s-Gravenhage 1991) [met een woord vooraf van de voorzitter van de Hoge Raad van Adel].

Monod de Froideville, G.H.A., en E.A.S. Crena de Iongh-den Beer Poortugael, Titels, graden, titulatuur ('s-Gravenhage 2005). 
Monod de Froideville, Gilbert, en Sophie den Beer Poortugael, Nederlandse titulatuur; in aanspreken en op schrift, in protocol en netwerken (Leiden 2011).

Monté ver Loren, J.Ph. de, Hoofdlijnen uit de ontwikkeling der rechterlijke organisatie in de Noordelijke Nederlanden tot de Bataafse omwenteling (zevende herziene druk, bewerkt door J.E. Spruit, Deventer 2000).

Moorman van Kappen, O., en E.C. Coppens (red.), De Staatsregeling voor het Bataafsche volk van 1798. Opstellen opgedragen aan de nagedachtenis van Dr. Mr. L. de Gou. Rechtshistorische reeks van het Gerard Noodt Instituut 46 (Nijmegen 2001).

Myer, E., c.s., 'Een klacht indienen bij het EHRM: elf veel voorkomende misverstanden', Advocatenblad 3 (2005), d.d. 18 februari 2005.

Nederland's Adelsboek 1-[96] ('s-Gravenhage 1903-[2011]).

Nerée tot Babberich, M.F.F.A. de, '(Nogmaals) De Nederlandsche Adel', De Nederlandsche Leeuw 63 (1945-1946), 83-87 en 179-182 [met een bijdrage van J.R.D. Zwahlen en de redactie]; 64 (1947) 80-83 [reacties van J.P.J. Gewin en J.C. Maris van Sandelingenambacht].

Neve, R.G. de, 'Genealogiebeoefening en adellijke pretenties. Noblesse d'obscurité tijdens de Republiek en het Koninkrijk', Jaarboek van het Centraal Bureau voor Genealogie 59 (2005), 117-15.

Neve, R.G. de, 'Hedendaagse adelspretenties in Nederland. "Freiherr von Quast-Juchter" en "Ritter von Lutter", De Nederlandsche Leeuw 124 (2007), 17-32.

Neve, Roel de, 'Buitenlandse adel(lijke titels) in Nederland', De Nederlandsche Leeuw 128 (2011), 129-141.

Nierop, H.F.K. van, Van ridders tot regenten. De Hollandse adel in de zestiende en de eerste helft van de zeventiende eeuw. Hollandse Historische Reeks 1 (diss. Leiden / Groningen 1984).

Nifterik, Gustaaf van, 'De vorst in evenwicht. Over de beste constitutie voor ons land volgens Gijsbert van Hogendorp', Pro Memorie. Bijdragen tot de rechtsgeschiedenis der Nederlanden 10 (2008), 182-202.

[Nijkamp, G.P., en O. Schutte], De Nederlandse Adel. Besluiten en Wapenbeschrijvingen ('s-Gravenhage 1989).

Oud, P.J., Honderd jaren; een eeuw van staatkundige vormgeving in Nederland 18401940 (Assen 1971).

Poelgeest, L. van, "'Een onderwerp van zoo teederen aard" (art. 39)', A.H. Heringa, C.H.A. Litjens en R.E. de Winter (red.), Verhalen over de Grondwet. Ter gelegenheid van het tienjarig jubileum van de Grondwet 1983-1993 (Den Haag 1993), 41-46.

Pot, C.W. van der, en A.M. Donner (laatstelijk bewerkt door D.J. Elzinga, R. de Lange en H.G. Hoogers), Handboek van het Nederlandse Staatsrecht (1940; vijftiende druk, Deventer 2006).

Prins, W.F., 'Nederlands namenrecht', Het Personeel Statuut 5 (1954), 97-107, 119-131 en 155-158.

Prins, W.F., 'Titels en praedicaten', Het Personeel Statuut 7 (1956), 13-21.

Prins, W.F., 'De wetgever en het huwelijk van Prinses Beatrix', Het Personeel Statuut 17 (1966), 17-21 en 29-31 (Redactie, 'De huwelijksakte van Prinses Beatrix en Claus von Amsberg).

Prins, W.F., 'Langs ongebaande paden', Het Personeel Statuut 17 (1966), 45-49.

Prins, W.F., 'De Hoge Raad van Adel. Geschiedenis en werkzaamheden', Het Personeel Statuut 17 (1966), 100-102 [boekbespreking].

Randwijck, A.J. van, 'De lijdensgeschiedenis van een Adelfonds. HistorischStaatsrechtelijke herinnering', De Nederlandsche Heraut 4 (1887), 18-36.

Ranitz, P.F. de, 'Titulatuur', Van Adel. Nieuwsbrief van de Nederlandse Adelsvereniging, 2007, 14. 
Rietkerk, J.G., De herziene Grondwet; tekst en toelichting ('s-Gravenhage 1983).

[Rietstap J.B.,], 'De adelsbrieven en de Hooge Raad van Adel, beoordeeld in de Staten Generaal', Heraldieke Bibliotheek 3 (1874), 268-273.

Roes, J.S.L.A.W.B., Het naaste bloed erfde het goed. De positie van de langstlevende echtgenoot in het Nederlandse erfrecht bij versterf, 1: de periode van het 'oudvaderlandse' recht (tot 1809) (diss. Nijmegen / Deventer 2006).

Rogge, C., Tafereel van de geschiedenis der jongste omwenteling in de Vereenigde Nederlanden (Amsterdam 1796).

Rosendaal, Joost, Bataven! Nederlandse vluchtelingen in Frankrijk 1787-1795 (Nijmegen 2003).

Ruijs de Beerenbrouck, G.A.M.J., 'Uit de geschiedenis van de Hoge Raad van Adel', De Hoge Raad van Adel. Geschiedenis en werkzaamheden ('s-Gravenhage 1966), 91-104.

Rijk, J.W.F.X. de, 'De regentenadel in de ministerraad', Gens Nostra 41 (1986), 476-477.

Rijn, A.B. van, 'What's in a name? - Adel in de $21^{\mathrm{e}}$ eeuw', Liber amicorum voor Jacoba den Drijver-van Rijckevorsel (Deventer 2009), 171-181.

Rijndorp, J.L., 'Het wetsontwerp tot naturalisatie van de heer Claus von Amsberg', Nederlands Juristenblad 40 (1965), 773 e.v.

Rijndorp, J.L., 'Nogmaals de Prins van Oranje en andere titels der Koninklijke Familie', Nederlands Juristenblad 40 (1965), 955-959.

Sap, J.W., 'VVD-Ministers schenden democratie en persvrijheid', Ars Aequi 46 (1997), 565-568.

Sasse van Ysselt, T.K.M.J. van, 'Naamsverandering', Het Personeel Statuut 11 (1960), 7/8, 77-87.

Schie, H.A.J. van, Inventaris van het archief van de Afdeling Adelszaken 1853-1937 (1938) van het Ministerie van Binnenlandse Zaken (1853-1859), het Ministerie van Justitie (1860-1937) en het Ministerie van Algemene Zaken (1937-1938) ('sGravenhage 1987).

Schie, H.A.J. van, Inventaris van het archief van Hendrik van Wijn ('s-Gravenhage, herzien 2011).

Schutte, O., 'Boekbespreking Nederland's Adelsboek 1971-1972, $64^{\mathrm{e}}$ jaargang', De Nederlandsche Leeuw 89 (1972), 284-286.

Schutte, O., 'Adellijke titels en predikaten in geboorteakten', Het Personeel Statuut 26 (1975), 94-96.

Schutte, O., 'La noblesse des Pays Bas', L'Ordre de la Noblesse, I (Parijs 1978), CDVCDXVI.

Schutte, Otto, 'Les Titres du Premier Empire Français en relation avec les Pays Bas', De Nederlandsche Leeuw 97 (1980), 323-358 [met literatuurverwijzing].

Schutte, O., De Orde van de Unie. Werken KNGGW 9 ('s-Gravenhage/Zutphen 1985).

Schutte, O., 'Het beleid tijdens het Koninkrijk der Nederlanden ten aanzien van de door Napoleon verleende titels', Liber Amicorum Jhr. Mr. C.C. van Valkenburg ('sGravenhage 1985), 310-322.

Schutte, O., 'Nederlandse adel met een vraagteken', Gens Nostra 41 (1986), 285-310.

Schutte, O., 'Hoge Raad van Adel 1968-2003', Virtus. Jaarboek voor adelsgeschiedenis 10 (2003), 205-207.

Schijf, Huibert, Jaap Dronkers en Jennifer R. van den Broeke-George, 'De overdracht van eliteposities binnen adellijke en patricische families in de twintigste eeuw', Nederlandse elites in de twintigste eeuw. Continuïteit en verandering (Amsterdam 2004), 57-84.

Sewandono, I., 'Adeldom en de Indische neushoorn', Nederlands Juristen Blad 69 (1994), 476-480.

Sewandono, I., 'Javaanse adel en de Wet op de adeldom', De Nederlandsche Leeuw 112 (1995), 65-70. 
Sewandono, I., 'Moet 'Zijne Doorluchtigheid de Hertog van Parma', het eerste achterkleinkind van H.K.H. Prinses Juliana, toch niet door zijn vader worden erkend?', Nederlands Juristen Blad 72 (1997), 725-726.

Slijkerman, Diederick, In dienst van de kroon. Vice-presidenten van de Raad van State (Zutphen 2001).

Sloet tot Everlo, A.L.H., Beschouwingen naar aanleiding van de artt. 63 en 65 der Grondwet (diss. Amsterdam 1887).

Smeth van Alphen, F.F. de, (e.a.), 'Adel in Nederland: 'niet meer zichtbaar, wel merkbaar'. Resultaten van de enquête onder leden van de Nederlandse adel, november 2005, Virtus. Jaarboek voor adelsgeschiedenis 13 (2006), 7-43 [met antropologische en sociologische kanttekeningen van Jaap Dronkers, Auke Huistra en Yme Kuiper: 'Hoe 'adellijk' is de adel in het huidige Nederland?', 44-61].

Smissaert, M.P., 'Acten van bewijs', De Nederlandsche Heraut 8 (1897), 61-68.

Snethlage, A., 'De afkomst van Prins Bernhard, een mythe?', De Nederlandsche Leeuw 127 (2010), 201-203, 128 (2011), 91-92 (reactie S.A.C. Dudok van Heel) en 129 (2012), 39-40 [boekbespreking n.a.v. Annejet van der Zijl, Bernhard. Een verborgen geschiedenis (diss. Amsterdam 2010)].

Staatsalmanak (voor het Koninkrijk der Nederlanden) 1815-heden ('s-Gravenhage 1815heden).

Stein, F.T.H., 'Wet op de adeldom en artikel 1 Grondwet', Nederlands Juristenblad 60 (1985), 714-715.

Thijn, Ed van, Retour Den Haag. Dagboek van een minister (Amsterdam 1994).

Tjeenk Willink, H.D., 'Het karakter van een Hoog College van Staat', Visie op constitutioneel partnerschap. Voordrachten tijdens het 25-jarig jubileum van de Nationale ombudsman ('s-Gravenhage 2007), 14-19.

[Udekem d'Acoz, H. d', Chr. Hoogstoel-Fabri en P. de Win], Le Droit nobilitaire et le Conseil héraldique/Het Adelsrecht en de Raad van Adel (1844-1994) (Brussel 1994).

Uitterhoeve, Wilfried, Koning, keizer, admiraal 1810. De ondergang van het Koninkrijk Holland (Nijmegen 2010).

Valkenburg, C.C. van, Nederlandse adel (AO-reeks, 8 mei 1964).

Valkenburg, C.C. van, 'Adelsbeleid sedert 1813', De Hoge Raad van Adel. Geschiedenis en werkzaamheden ('s-Gravenhage 1966), 55-73.

Valkenburg, C.C. van, 'Titulatuur, wapens en vlaggen van leden van het Koninklijk Huis', De Nederlandsche Leeuw 97 (1980), 99-107.

Valkenburg, C.C. van, 'Lidmaatschap van het Koninklijk Huis', De Nederlandsche Leeuw 97 (1980), 125-130.

Valkenburg, S.A. van, De Hoge Raad van Adel (ongepubliceerde doctoraalscriptie, Utrecht 1972).

Velde, Rob van der, 'Noblesse oblige', Burgerzaken \& Recht 12 (2005), 18-21.

Velde, Rob van der, 'Adel verplicht nog steeds', Burgerzaken \& Recht 13 (2006), 8-9.

Velde, Rob van der, 'Kronkels. Het Nederlandse namenrecht blijft verbazen', Burgerzaken \& Recht 15 (2008), 204-206.

Verburg, M.E., 'Twee nota's uit 1891 over de titel prinses van Oranje-Nassau', Verslagen en mededelingen Stichting tot uitgaaf der bronnen van het oud-vaderlandse recht. Nieuwe reeks 6 (1990), 121-139.

Versélewel de Witt Hamer, T.J., 'Drie maal is niet altijd scheepsrecht. Geen Nederlandse adeldom voor de familie Obolonski', De Nederlandsche Leeuw 118 (2001), 491-500.

Vermeulen, B.P., A.P. Krijnen en D.A. Roos (red.), De Koning in het Nederlandse staatsrecht. (Nijmegen 2005).

Vogelzang, H.P.G., Militaire Willems-Orde 1815-1990. Herdenkings-brochure ter gelegenheid van het 175-jarig bestaan der Militaire Willems-Orde (Rijswijk Z.H., 1990). 
Vorsterman van Oyen, A.A., De Hooge Raad van Adel beschouwd in verband met zijne boekerij en archief, benevens een woord over een nieuw soort van belasting (Leiden 1880).

Vijghen, M.J.T.M., 'Rapporten en ontvankelijkheidsbeslissingen van de Europese Commissie voor de Rechten van de Mens [ECRM] in Nederlandse zaken', Nederlands Tijdschrift voor de Mensenrechten (uitgave van het Nederlands Juristen Comité voor de Mensenrechten) [NJCM-bulletin] 21 (1996), 965-977.

Wassenaer van Catwijck, A.J.O. van, 'Naamrecht op de helling', Nederlands Juristenblad 58 (1983), 411-415.

Westerbeek, E., De Hoge Raad van Adel. Documentatierapport Ministerie van Binnenlandse Zaken 4 (BZ.68.4298) ('s-Gravenhage 1968)

Westerouen van Meeteren, G.N., en S.J.J. van Voorst tot Voorst, 'Pauselijke adel in Nederland na het herstel van de kerkelijke hiërarchie in 1853 (IV)', De Nederlandsche Leeuw 110 (1993), 75-76.

Westerouen van Meeteren, G.N., 'De vrouw in het Nederlandse en Spaanse adelsrecht', De Nederlandsche Leeuw 116 (1999), 372-377; 117 (2000), 87-88; 118 (2001), 663664; 119 (2002), 63-64 [met reactie van Gerard-René de Groot].

Westerouen van Meeteren, G.N., 'Op zoek naar de pauselijke adel', De Nederlandsche Leeuw 118 (2001), 467-490 en 662-663.

Westerouen van Meeteren ( $\dagger$ ), G.N., 'Onverwacht gekregen en ook niet verkregen pauselijke adeldom', De Nederlandsche Leeuw 119 (2002), 407-419.

Wichers, L., De regeering van koning Lodewijk Napoleon, 1806-1810: grootendeels naar oorspronkelijke en onuitgegeven bescheiden bewerkt (Utrecht 1892).

Wiel, Nanno S. van der, 'Adellijke titels', Burgerzaken \& Recht 6 (1999), 60-64.

Win, Paul de, 'De Raad van Adel van het Koninkrijk België', Heraldicum Disputationes 14 (2009), 77-81 [met bijlagen: adelbrieven verleend in 2008].

Winter, Johanna Maria van, Ministerialiteit en ridderschap in Gelre en Zutphen. Werken Gelre 32 (diss. Groningen 1962).

Wolleswinkel, E.J., 'Wapen voor de kinderen uit het huwelijk van de Prins van Oranje en Prinses Máxima', De Nederlandsche Leeuw 120 (2003), 330-332.

Wolleswinkel, E.J., 'Wapenverlening voor het grafelijke geslacht Van Oranje-Nassau van Amsberg', De Nederlandsche Leeuw 122 (2005), 183-185.

Wolleswinkel, E.J., 'Een wapenboek uit 1560 van Jan Jansz. Potter, notaris en landmeter te Delft', De Nederlandsche Leeuw 126 (2009) 23-27.

Wolleswinkel, Egbert, 'Willem Flessiers, wapenheraut in de Republiek', Jaarboek van het Centraal Bureau voor Genealogie 62 (2008), 45-68.

Wolleswinkel, Egbert, 'De boekstaving van distinctiedrang', Virtus. Jaarboek voor adelsgeschiedenis 16 (2009), 208-212.

Wolleswinkel, E.J. 'Het "Niederländische Wappenbuch" uit Münster, ruilobject uit de Tweede Wereldoorlog', De Nederlandsche Leeuw 126 (2009), 108-112.

Wolleswinkel, Egbert, 'Verheffing om verdiensten aan den staat bewezen. Het geslacht Gevers, zijn adeldom en heraldiek', Adel en heraldiek in de Nederlanden. Adellijke identiteit en representatie. Opstellen aangeboden ter gelegenheid van het afscheid van jhr. Arnold Gevers als archivaris bij het Historisch Centrum Overijssel te Zwolle op 2 november 2012. Adelsgeschiedenis 10 / Werken KNGGW 18 (Hilversum 2012), 252261.

Wolswinkel, Esther, 'Koninklijk eerbetoon voor mr. Pieter', Vorsten Royale 32 (2004), VI, 52-53.

Wolswinkel, Esther 'Bourbon, een ruziënde familie', Vorsten Royale 32 (2004), XI, 4044 [interview met prins Carlos Hugo door Han van Bree en Piet Lekkerkerk, XII, 815]. 
Wolswinkel, Esther, 'Nieuw wapen voor prins Friso', Vorsten Royale 33 (2005), V, 11.

Wijnaendts van Resandt, W., 'De laatste schakels in de afstamming Van der Feltz', Jaarboek van het Centraal Bureau voor Genealogie 21 (1967), 107-125.

Zanten Jut, Suze M. van, Inventaris van het familiearchief Van Spaen. Inventarisreeks HRvA 1 ('s-Gravenhage 1953).

Zelm van Eldik, J.A. van, Ons grondwetsartikel regelende de instelling van ridderorden en de ontwikkelingsgang van de Nederlandse orden in de negentiende en twintigste eeuw ('s-Gravenhage 1985).

Zelm van Eldik, J.A. van, Moed en Deugd. Ridderorden in Nederland (2 dln., Zutphen 2003).

Zwaag, Marianna van der, (red.), Koning Lodewijk Napoleon \& zijn Paleis op de Dam (Amsterdam 2012). 


\section{Summaries}

\section{Nederlandse samenvatting}

\section{Adelstand impliceert ongelijkheid}

In deze studie staat in de eerste plaats de vraag centraal hoe een fundamenteel grondrecht als de gelijkheid van een ieder voor de wet, waarvoor de basis in de Staatsregeling van 1798 werd gelegd, al binnen tien jaar door de instelling van een adelstand weer kon worden afgezworen? Vervolgens wordt ruime aandacht gegeven aan de vraag hoe na de afschaffing van deze adelstand in de Grondwet van 1848 de ongelijkheid die adeldom in essentie inhoudt, kon blijven voortbestaan, zij het sedertdien zonder staatsrechtelijke betekenis. Het Nederlandse adelsstatuut, dat op basis van de Grondwet van 1814 bij besluiten van de Soevereine Vorst der Verenigde Nederlanden werd vastgesteld, wordt vergeleken met het adelsstatuut dat in het Koninkrijk Holland heeft gegolden. De belangrijkste adviseur in adelszaken van zowel de koning van Holland als van de soevereine vorst, na 1815 koning der Nederlanden, was W.A. baron van Spaen la Lecq, lid van het Hoog Heraldiek Collegie (1809-1810) en president van de Hoge Raad van Adel (1814-1817), die voor beide vorsten de adelstand weer in ere herstelde. De regelgeving voor de in 1814 opgerichte nieuwe erfelijke Nederlandse adel, waarvoor iedere rechthebbende zich opnieuw moest aanmelden, blijkt op belangrijke punten terug te gaan op het door koning Lodewijk Napoleon in 1809 voor Holland uitgevaardigde, maar door keizer Napoleon in 1810 vervallen verklaarde, adelsstatuut.

\section{Koningshuis en adeldom}

De keuze voor dit Napoleontische adelsstatuut leidde tot een discrepantie tussen de afstammingsregels zoals die vanouds golden binnen het huis Oranje-Nassau, in het bijzonder met betrekking tot de troonopvolging, en die betreffende de vererving van de aan dit huis ontleende adeldom. Deze situatie leek in strijd met de theocratische staatsleer, volgens welke de bij de gratie Gods regerende soevereine vorst adeldom creëert naar de wetten en hiërarchie van zijn huis. Aangetoond kon worden dat de historische ontwikkeling van de erfopvolging binnen het koninklijk huis een andere is dan die binnen de Nederlandse adel. De vorstelijke afstammingsregels zijn binnen het huis (Oranje-)Nassau al in de achttiende eeuw versoepeld door bij uitsterven in mannelijke lijn vererving in de vrouwelijke lijn mogelijk te maken, daar waar het adelsrecht vasthield aan vererving uitsluitend in de mannelijke lijn. De regelgeving betreffende de troonopvolging werd in de loop van de twintigste eeuw in etappes vrouwvriendelijk en vervolgens sekseneutraal gemaakt, overeenkomstig de wens van de volksvertegenwoordiging. In de Grondwet van 1963 
werd de troonopvolging uitdrukkelijk opengesteld voor dochters en in die van 1983 ontdaan van de voorrang voor zonen.

\section{Wetgeving of afschaffing?}

De parlementaire behandeling van de Wet op de adeldom, die bij de grondwetsherziening van 1983 in het vooruitzicht was gesteld nadat artikel 74 ('De Koning verleent adeldom') was geschrapt, heeft heel wat voeten in de aarde gehad. De standpunten van het parlement varieerden van handhaving van de bestaande wetgeving tot modernisering of zelfs afschaffing van het instituut adeldom. De minister van Binnenlandse Zaken verdedigde in haar wetsontwerp het eerste standpunt. Zij verklaarde de gesignaleerde discrepantie tussen de regels voor het koningshuis en die betreffende adeldom uit de publieke en constitutionele aspecten van het koningschap, die de grondwetgever tot het oordeel hadden gebracht dat onderscheid naar geslacht bij de vervulling van dit publieke ambt ongewenst is. De minister wees er voorts op dat door de vele en belangrijke rechtsgevolgen die aan het koningschap verbonden zijn, aan de gelijkberechtiging van mannen en vrouwen een ander, zwaarder gewicht toekomt dan bij vererving van adeldom.

\section{Historisch gegroeid instituut}

In 1994 trad de Wet op de adeldom in werking en hadden voorstanders van vererving van adeldom langs vrouwelijke lijn, in het bijzonder kinderen van adellijke moeders die op grond van het naamrecht voor de geslachtsnaam van hun moeder hadden gekozen, nog steeds het nakijken. Zij lieten het er niet bij zitten en probeerden alsnog adeldom af te dwingen voor de rechter. Al een jaar na de inwerking van de wet deed de Afdeling Bestuursrechtspraak van de Raad van State in hoogste instantie uitspraak, maar stelde hen in het ongelijk. De motivering was dat 'het handhaven van onderscheid tussen afstamming via mannen of via vrouwen volgens een objectieve en redelijke grond, verantwoord binnen de regelgeving van het historisch instituut adel, die zich niet leende voor aanpassing aan moderne opvattingen over gelijke behandeling, niet strijdig is met het gelijkheidsbeginsel of het beginsel van non-discriminatie; de onmogelijkheid adeldom te verwerven heeft altijd gelijkelijk gegolden voor zowel mannen als vrouwen'.

\section{Adellijke privileges geen 'civil rights'}

In 1997 legde de toenmalige regering, bij monde van de minister van Binnenlandse Zaken, een alsnog door de Tweede Kamer aangenomen motie, die vererving van adeldom langs vrouwelijke lijn mogelijk moest maken, naast zich neer. De liberale minister wees onder meer op de tegenstrijdigheid om met een beroep op rechtsgelijkheid tussen mannen en vrouwen in feite uitbreiding te bevorderen van een groep personen die in de samenleving louter op grond van overerving een bepaalde status had, die door sommigen als ongelijk werd ervaren. Naar het oordeel van de regering zou de adel als historisch instituut zijn grondslag verliezen wanneer hij 
werd aangepast aan hedendaagse inzichten. Sindsdien heeft geen parlementaire meerderheid de beoogde vernieuwing van de Wet op de adeldom inzake vererving van adeldom langs vrouwelijke lijn kunnen realiseren. Rond de eeuwwisseling was er in het parlementaire debat een verschuiving waarneembaar van de vraag of adeldom in Nederland een wettelijke basis nodig heeft naar de vraag of erfelijke instituten als koningshuis en adeldom überhaupt nog wel thuishoren in een parlementaire democratie.

In 1999 is de Nederlandse uitspraak getoetst aan het Europees Verdrag voor de Rechten van de Mens. Het EHRM in Straatsburg heeft vastgesteld dat de privileges van de Nederlandse adel geen 'civil rights' zijn zoals deze door de Nederlandse grondwet en internationale verdragen worden beschermd. Nieuwe acties van het parlement om de gelijkheid tussen mannen en vrouwen binnen het historisch gegroeide adelsrecht te verwezenlijken zijn hierdoor sindsdien niet meer opportuun.

\section{Buiten het huwelijk geboren kinderen}

De modernisering van het Nederlandse adelsrecht is - door een in het parlement aangenomen amendement op het wetsontwerp - beperkt gebleven tot de mogelijkheid van overgang van erfelijke adeldom op buiten het huwelijk geboren kinderen die geboren zijn op of na 1 augustus 1994. Dit is de datum van inwerkingtreding van de wet die, zoals de Afdeling Bestuursrechtspraak van de Raad van State in 2005 vaststelde, geen terugwerkende kracht heeft. Deze ingrijpende vernieuwing, die in artikel 3 van de wet is terug te vinden, kan als een inconsequente aanpassing van het bestaande adelsrecht worden aangemerkt, waarmee dit tot in hoogste instantie verdedigde historisch instituut geweld is aangedaan. Het ware beter geweest als in het Nederlandse adelsstatuut de oude eis van wettige geboorte was gehandhaafd, zoals deze voorwaarde bij overgang van primogenituurtitels uitdrukkelijk is blijven bestaan.

Achteraf bezien heeft de wetgever met deze beperkte modernisering echter niet alleen het uitsterven van menig adellijk geslacht voorkomen, maar tegelijkertijd een verdubbeling, althans aanzienlijke groei, van het aantal edellieden tegengehouden door het standpunt van de gewenste vererving langs vrouwelijke lijn los te laten.

\section{Adellijke titulatuur op overheidsdocumenten}

Van de vier in 1815 beschreven rechten van de Nederlandse adel bleven er na 1848 , toen de staatsrechtelijke positie ophield te bestaan, aanvankelijk nog drie, maar sedert de inwerkingtreding van de Jachtwet van 1923 nog maar twee over. Naast een bij koninklijk besluit verleend familiewapen blijft als belangrijkste privilege over het recht van edellieden op expliciete vermelding van aan hen verleende erfelijke adellijke titulatuur op alle overheidsdocumenten. De overheid is verplicht de adellijke titulatuur van een half promille burgers met een bijzondere historische achtergrond correct te vermelden op haar officiële stukken. Deze aan het naamrecht verwante taak van de overheid is dan ook belangrijker dan een eventuele zorg voor de bescherming van adeldom als cultureel erfgoed. Concrete aanbeve- 
lingen worden gedaan om door een geringe aanpassing van de wetgeving een aantal gesignaleerde onvolkomenheden ongedaan te maken.

\section{Aangelegenheid van het koninkrijk}

De decennialange discussie over gelijkberechtiging ten slotte heeft een belangrijk aspect van het adelsrecht, namelijk zijn constitutionele grondslag als aangelegenheid van het koninkrijk, naar de achtergrond verdrongen. Kennelijk vloeit dit gebrek aan juridische aandacht voort uit het lichtere gewicht dat de overheid aan vererving van adeldom toekent in vergelijking met het staatsrechtelijke belang van troonopvolging binnen het koningshuis. Een gevolg hiervan is niet alleen de dreiging van dubbelzinnige toepassing van het vigerende Nederlandse adelsrecht in de landen binnen het koninkrijk, maar ook van mogelijke overvleugeling door buitenlands naamrecht, dat elementen van afgeschaft adelsrecht bevat. De conclusie wordt getrokken dat de constitutionele dimensie weer expliciet kan worden door adeldom alsnog onder de aangelegenheden van het koninkrijk te vermelden in het Statuut voor het Koninkrijk der Nederlanden. De consequentie hiervan is dat de structuur van de Wet op de adeldom omgevormd dient te worden van een gewone wet in een rijkswet.

\section{English summary}

\section{Inequality as an essential characteristic of any nobility}

This study primarily deals with the question how the fundamental constitutional right of every person's equality before the law, as guaranteed by the Constitution of 1798, could be renounced again after the Batavian Republic's relative freedom and equality (1795-1806) by the establishment of the nobility in the Napoleonic Kingdom of Holland (1806-1810)?

After that consideration is given to the question how this inequality, an essential characteristic of any nobility, could continue to exist even after the abolition of class society by the 1848 Constitution, although the nobility has been without constitutional significance ever since. A comparison is made between the nobiliary statute of the Kingdom of Holland of 1809 and the Dutch nobiliary statute, which was based on the Constitution of 1814 and on several Decrees by Willem prins van Oranje-Nassau, the sovereign ruler of the United Netherlands. Interestingly, the author of both nobiliary statutes and chief adviser in nobiliary matters of both Lodewijk Napoleon King of Holland and Willem I King of the Netherlands (since 1815) was Willem Anne baron van Spaen la Lecq, successively as a member of the Supreme College of Heraldry (1809-1810) and as president of the Supreme Council of Nobility (1814-1817). Hence it is no surprise that both statutes have much in common. 


\section{Royalty and nobility}

Another remarkable phenomenon discussed in this thesis is the increasing divergence between the legislation concerning the Royal House and that concerning the nobility during the two centuries of their existence. Assuming a common origin it could be expected that, from a hierarchical point of view, one of those Institutions originated from the other. It will be shown that the legislation concerning the House of Orange-Nassau, with its conspicuous basis in $18^{\text {th }}$ century Dutch Republic, has repeatedly been adapted according to several emancipatory and democratic preferences, resulting for instance in succession by women, whereas noble titles remained hereditary in the male line only, still following the Napoleonic statutory nobility.

\section{Historically grown institution}

In the parliamentary debate on the Act concerning the nobility the views ranged from maintenance of the existing legislation to modernization or even abolition of the entire institution of nobility. The reason for the legislature to study this subject was the fact that the article concerning nobility ('the king grants nobility') had been repealed in the Constitution of 1983, being reduced to the status of additional article pending the new Act.

On 1 august 1994 the Act concercing the nobility has become effective. Instead of accepting the explanation of the minister of the Interior that the nobiliary constitution must be viewed as a historically grown institution, which only can be maintained as a historical institution but would lose its basis if one would attempt to modify or rearrange it according to comtemporary ideas, some amendments were made by the House of Commons.

Proponents of inheritance in the female line, among them several descendants of noble mothers who had chosen to bear her family name, tried to enforce this in court but the judge rejected their claim. The justification of the judge was that "maintaining a distinction between descent through men or women according to an objective and reasonable rule, justified within the regulations of the historical institution of nobility, which are unfit for adaptation to modern notions of equality, is not inconsistent with equality or the principle of non-discrimination; the inability to acquire nobility has always been applied equally to both men and women".

\section{Noble privileges no civil rights}

In 1997 the Minister of the Interior ignored the majority decision by the House of Commons to enable inheritance of nobility in the female line. The minister pointed at the contradictory use of 'legal equality of men and women' as an argument to promote the actual increase of a group of persons whose purely hereditary social status is experienced by some as unequal. In the opinion of the Government, the nobility as a historically grown institution would lose its foundation if it would be adapted to contemporary insights. Since then no parliamentary majority could 
achieve renewal of the Act concerning the nobility with regard to inheritance in the female line.

In 1999 the compatibility of the Dutch verdict to the European Convention on Human Rights was tested. The ECtHR in Strasbourg found that the privileges of the Dutch nobility do not belong to the civil rights, which are guaranteed by the Dutch Constitution and international treaties. New attempts of the parliament to achieve equality between men and women within the historically grown institution, since this time are no longer appropriate.

\section{Extramarital children (children born out of wedlock)}

Therefore, modernization of the Dutch nobiliary legislation is restricted to the possibility of transfer of hereditary nobility on extramarital children born on 1 August 1994 or later. This radical innovation, which is codified in article 3 of the act, can be considered as an incon-sistent modification of the existing Act concerning the nobility, by which the notion of the historically grown institution has been afflicted. It would have been better if the old requirement of legitimate birth had been maintained, especially since it remains a condition for transition of titles of primogeniture. In retrospect this limited modernization of the legislature may have prevented the extinction of some Dutch noble families, but it also blocked the doubling, or at least substantial growth, of the number of members of the nobility by abandoning the previously desired inheritance in the female line.

\section{Noble titles on official documents}

Of the four privileges held by the Dutch nobility in 1815 initially three remained after 1848, when the constitutional position ceased to exist, but since the inception of the Hunting Act of 1923 only two are left. Besides a coat of arms granted by royal decree, there remains as an important privilege the explicit mention of their hereditary noble titles in all official documents. The public authorities has the duty to mention correctly the noble titles of a half permille of its citizens with a particular historical background in their official documents.

In this study specific recommendations are given in order to correct several observed imbalances by a minor amendment of the legislation.

\section{Matter of the Kingdom}

Finally an important aspect of nobiliary law, namely its constitutional foundation as a matter of the Kingdom, has been ignored during the debate of decades about equality. Apparently this lack of juridical consideration is a product of the lesser importance attributed to inheritance of nobility relative to the importance of succession within the Royal House as a matter of the Kingdom. Possible consequences of this neglect are not only the threat of ambiguous application of current Dutch nobiliary law in the Countries within the Kingdom (besides The Netherlands: Aruba, Curaçao and Sint-Maarten, formerly Dutch Antilles), but also intrusion of for- 
eign legislation concerning the surname that contains elements of abolished foreign nobiliary law (e.g. German law).

The constitutional dimension could be restored again by explicitly mentioning nobility among the matters of the Kingdom in the Charter ('Statuut') for the Kingdom of the Netherlands. The consequence is that the structure of the Act concerning the nobility should be transformed from a common statute for the European part of the Kingdom ('Wet') into a statute of the Kingdom ('Rijkswet') applicable for all Countries of the Kingdom.

\section{Deutsche Zusammenfassung}

\section{Adel impliziert Ungleichheit}

Diese Studie erklärt, aus welchen Gründen in der Niederlande man das in der Verfassung von 1798 festgeschriebene Recht der Gleichheit aller Menschen vor dem Gesetz schon binnen eines Zeitraums von nur zehn Jahren wieder aufgab, indem erneut ein Adelsstand kreiert wurde. Zudem wird dargelegt, wie diese Ungleichheit, die ja im Grunde das Wesen des Adels ist, auch nach der Abschaffung der Vorrechte des Adelsstandes in der Verfassung von 1848 grundsätzlich fortbestehen konnte, wenngleich sie seither ohne jegliche verfassungsrechtliche Bedeutung ist.

Die Studie vergleicht das niederländische Adelsrecht in der Verfassung von 1814 (nach 1815: im Königreich der Niederlande) mit dem Adelsrecht des napoleonischen Königreichs Holland (1809-1810). Wichtigster Berater in Adelssachen war in beiden Monarchien W.A. Baron van Spaen la Lecq, zuerst als Mitglied des Hoog Heraldiek Collegie (1809-1810); später als Präsident des Hoge Raad van Adel (1814-1817). So überrascht nicht, dass die Vorschriften von 1814/1815 auf den älteren Regeln aus 1809/1810 basieren.

\section{Königreich und Adelsstand}

Die Übernahme dieses napoleonischen Adelsrechts führte zu Abweichungen von den traditionellen Abstammungsregeln im Hause Oranien-Nassau, insbesondere im Hinblick auf die Thronfolge und auf die Vererbung des von diesem Hause verliehenen Adels. Die theokratische Staatsdoktrin, nach welcher der von Gottes Gnaden regierende souveräne Fürst den Adel gemäß den Gesetzen und der Hierarchie seines Hauses kreiert, wurde aufgegeben.

Es wird dargelegt, dass sich die Erbfolge innerhalb der königlichen Familie historisch ganz anders entwickelt hat als jene des niederländischen Adels. Die Abstammungsregeln im Hause (Oranien-) Nassau wurden bereits im achtzehnten Jahrhundert erweiternd verändert. Damals wurde bei einem Aussterben in männlicher Linie die weibliche Erbfolgeberechtigung manifestiert. Dagegen bestand im Adelsrecht ausschließlich eine Vererbung in männlicher Linie. Die Rechtsvorschriften bezüglich der Thronfolge wurden im Laufe des zwanzigsten Jahrhunderts den Wünschen des Parlaments folgend zunächst frauenfreundlich, später geschlechts- 
neutral formuliert: die Verfassung von 1963 erwähnte explizit die Möglichkeit der Thronfolge durch Töchter, und in der Verfassung von 1983 verzichtete man völlig auf den Vorrang der Söhne bei der Thronfolge.

\section{Rechtsvorschriften oder Abschaffung?}

Im Rahmen der Verfassungsrevision von 1983 wurde auch das Adelsrecht novelliert. Dabei wurde Artikel 74 ("Der König verleiht Adel") aufgehoben. Die Ansichten der Parlamentarier zum Thema Adel gingen weit auseinander: vom Festhalten an den existierenden Rechtsvorschriften über eine Modernisierung bis hin zu genereller Abschaffung.

Die Innenministerin verteidigte in ihrem Gesetzesentwurf die damals bestehenden Rechtsvorschriften. Sie erklärte die obengenannte Diskrepanz zwischen den Regeln für die königliche Familie bzw. für den Adel durch die öffentlichen und verfassungsrechtlichen Aspekte des Königtums, die der Gesetzgeber bis hin zu einer geschlechtsneutralen Regelung verändert hatte. Eine Unterscheidung zwischen Männern und Frauen sei hinsichtlich des öffentlichen Amtes des Monarchen unerwünscht. Die Ministerin wies auch auf die zahlreichen und bedeutsamen rechtlichen Konsequenzen hin. Die Gleichheit von Männern und Frauen sei zudem für die Monarchie im Rahmen der Thronfolgeregelung von größerem Gewicht als für die Feststellung von Regeln über die Vererbung des Adels.

\section{Historisch gewachsenes Institut}

Im Jahre 1994 erfolgte durch in Kraft treten des Adelsgesetzes eine Novellierung des Adelsrechts. Dem teilweise vorgetragenen Wunsch nach Vererbung des Adels auch in weiblicher Linie wurde nicht entsprochen. Vor allem Kinder adliger Mütter, die im Rahmen des allgemeinen Namensrechts den Familiennamen der Mutter gewählt hatten, waren enttäuscht und versuchten, die weibliche Rechtsfolge mittels eines Gerichtsurteils durchzusetzen. Ein Jahr nach dem Inkrafttreten des Gesetzes wies die Abteilung Verwaltungsrecht des Königlich niederländischen Staatsrates ihren Antrag mit der Begründung ab, die bestehende Rechtslage verletze weder das Prinzip der Gleichberechtigung noch stelle sie eine Diskriminierung dar. Damit wurde klargestellt, dass eine unterschiedliche Behandlung der Abstammung von Männern und Frauen gemäß den Vorschriften des historischen Instituts Adel vertretbar sei.

\section{Adelsprivilegien keine Bürgerrechte}

Im Jahre 1997 lehnte der niederländische Innenminister einen Parlamentsbeschluss zugunsten einer Einführung der Vererbung von Adel in weiblicher Linie ab. Der Minister wies auf den offensichtlichen Gegensatz hin, dass man mittels des Argumentes der Gleichberechtigung von Männern und Frauen die Ausdehnung gerade jener Gruppe von Personen in der Gesellschaft anstrebe, die nur auf Grund adliger 
Vererbung einen gewissen Status innehabe, der von manchen Personen gerade als ungleich empfunden werde.

Nach Ansicht der Regierung würde der Adel als historisches Institut durch Anpassung an zeitgenössische Prinzipien seine Grundlage verlieren. Seitdem haben sich keine weiteren parlamentarischen Mehrheiten für eine Novellierung im Sinne der weiblichen Erbfolge ergeben. Um die Jahrtausendwende gab es in der parlamentarischen Debatte eine offensichtliche gedankliche Verschiebung: von der Frage, ob der Adel in der Niederlande eine gesetzliche Grundlage brauche, hin zur Frage, ob Institutionen wie erbliche Monarchie und Adel überhaupt noch in den Rahmen einer parlamentarischen Demokratie passen.

Im Jahr 1999 wurde durch den Europäischen Gerichtshof für Menschenrechte in Straßburg geprüft, ob die niederländische Gerichtsentscheidung zur Gleichberechtigung im Adelsrecht der Europäischen Konvention zum Schutz der Menschenrechte und Grundfreiheiten entspricht. Der Gerichtshof stellte fest, dass die Privilegien des Adels in den Niederlanden keine Bürgerrechte im Sinne der niederländischen Verfassung und internationaler Verträge sind. Seither sind erneute Bemühungen des Parlaments zur Gleichstellung von Männern und Frauen innerhalb des historischen Adelsrechts ohne Aussicht auf Erfolg.

\section{Nichteheliche Kinder}

Die Novellierung des niederländischen Adelsrechts 1994 hat allerdings dazu geführt, dass durch einen vom Parlament angenommenen Änderungsantrag die Übertragung erblichen Adels auf nichteheliche Kinder ermöglicht wurde, soweit diese am oder nach dem 1. August 1994 geboren sind. Durch diese radikale Erneuerung, die in Artikel 3 des Gesetzes kodifiziert wurde, ist der Charakter des Adels als historisches Institut nachhaltig geschädigt worden.

Besser wäre gewesen, die alte Voraussetzung der ehelichen Geburt explizit aufrecht zu erhalten, so wie es beim Übergang von Primogeniturtiteln geschehen ist.

Im Nachhinein betrachtet hat der Gesetzgeber mit dieser beschränkten Novellierung 1994 einerseits zwar das Erlöschen mancher adligen Familie verhindert, andererseits aber eine Verdoppelung oder zumindest ein substanzielles Wachstum der Zahl der Adligen blockiert, weil er die gewünschte Vererbung in weiblicher Linie ablehnte.

\section{Adelstitel in behördlichen Dokumenten}

Von den vier im Jahre 1815 existierenden Privilegien des niederländischen Adels blieben nach dem Jahre 1848, als seine verfassungsrechtliche Stellung aufgehoben wurde, zunächst noch drei erhalten. Durch Inkrafttreten des Jagdgesetzes im Jahre 1923 wurden sie auf zwei reduziert. Neben einem durch königliches Dekret gewährtes Wappen bleibt den Mitgliedern des niederländischen Adels als wichtigstes Privileg die explizite Erwähnung der erblichen Adelstitel in allen behördlichen Dokumenten. Dies betrifft die besondere Identität einer kleinen Gruppe von Bürgern mit einem adligen Hintergrund. Weil die Regierung das Namensrecht seiner 
Bürger schützen muss, muss sie auf gleiche Weise auch die Adelstitel der Bürger wahren, die diesen besonderen historischen Hintergrund haben, auch wenn sie nur ein halbes Promille der Bevölkerung ausmachen.

In der vorliegenden Studie werden zudem konkrete Empfehlungen gegeben, mittels derer durch geringfügige Änderung von Rechtsvorschriften einige Unvollkommenheiten bei der Implementierung dieser Verpflichtung zu korrigieren sind.

\section{Adelsrecht als Angelegenheit des Königreiches}

Die jahrzehntelange Debatte im Parlament um die Gleichberechtigung drängte allerdings einen wichtigen Aspekt des Adelsrechts in den Hintergrund: seine verfassungsrechtliche Grundlage als eine Angelegenheit des Königreichs.

Dieser Mangel an juristischem Interesse ist wohl auf die geringere Bedeutung zurückzuführen, die die Vererbung des Adels in den Augen der Behörden im Vergleich zur verfassungsrechtlichen Bedeutung der Thronfolge innerhalb der Königlichen Familie hat.

Daraus folgt aber nicht nur die drohende inkonsequente Anwendung des derzeitigen niederländischen Adelsgesetzes in den verschiedenen Ländern des Königreiches (Nederland, Aruba, Curaçao und Sint-Maarten), sondern auch die mögliche Überwucherung durch ausländisches Namensrecht, das seinerseits Elemente des dort abgeschafften Adelsrechts enthält (wie z.B. im deutschen Recht). Es wird gefolgert, dass die verfassungsrechtliche Dimension erneut explizit erörtert werden müsste, wenn das Adelsrecht wieder als Angelegenheit des Königreiches im Statut für das Königreich der Niederlande (,Statuut voor het Koninkrijk der Nederlanden') kodifiziert würde. Die Folge davon wäre, dass das Adelsgesetz dann den Status eines für alle Länder des Königreiches geltenden Reichsgesetzes (,Rijkswet') statt eines nur für den europäischen Teils des Königreiches geltenden Gesetzes (,Wet') bekommen müsste. 


\section{Nawoord}

In de aanloop naar de viering van het tweehonderdjarig bestaan van de Hoge Raad van Adel in 2014 vroeg de voorzitter, drs. Coen O.A. baron Schimmelpenninck van der Oije, mij een overzicht samen te stellen van de recente jurisprudentie met betrekking tot het instituut Nederlandse adel. Bij het samenstellen hiervan kon ik sinds mijn aantreden per 1 februari 2003 als secretaris van de Raad - gebruik maken van een summiere lijst over de periode 1970-1999, die op verzoek van mr. drs. Arie-Jan Vos, hoofd van de afdeling kabinetszaken, directoraat-generaal koninkrijksrelaties en bestuur van het Ministerie van Binnenlandse Zaken en Koninkrijksrelaties, onder wie adelszaken ressorteert, was opgesteld.

Een interview over het vigerende adelsrecht in het zomernummer van 2011 van $M r$. magazine voor juristen, was de aanleiding voor prof. dr. Gerard-René de Groot, hoogleraar rechtsvergelijking en internationaal privaatrecht te Maastricht, Hasselt en Aruba, mij uit te nodigen tot het schrijven van een dissertatie over het Nederlandse adelsrecht. Ik kende René de Groot ambtshalve als lid van de Commissie van advies voor de zaken betreffende de burgerlijke staat en de nationaliteit, die de minister van Justitie op basis van artikel BW 1: 29 adviseert over de rechtstoepassing daarvan. Vanuit zijn specialisme, het nationaliteitsrecht, hoorden hij en de commissie mij een paar keer over het al of niet publiceren van een Officiële mededeling over (buitenlandse) adellijke titulatuur. Zijn eruditie was mij echter vooral bekend uit zijn kritische artikelen met betrekking tot de Wet op de adeldom. Overleg met mijn zuster dr. M.W. (Ria) Wolleswinkel, universitair hoofddocent vrouw en recht en onderwijsdirecteur aan de juridische faculteit van Maastricht, inspireerde mij ten slotte tot het afgebakende onderzoek en het daadwerkelijke schrijven van dit proefschrift.

Tijdens mijn juridische opleiding van 1969-1974 aan de Rijksuniversiteit Utrecht maakte ik voor het eerst kennis met de rechtsgeschiedenis en het adelsrecht. Mijn studiekeuze werd voor een belangrijk deel bepaald door het voor het kandidaatsexamen verplichte vak oud-vaderlands recht, dat op onnavolgbare wijze werd gedoceerd door prof. dr. J.Ph. de Monté ver Loren, die zijn carrière was begonnen als secretaris van de Hoge Raad van Adel. Na diens overlijden koos ik rechtsgeschiedenis als belangrijkste keuzevak, terwijl ik afstudeerde in het staats- en administratief recht bij prof. mr. W.F. Prins, specialist naamrecht, en prof. mr. R. Crince le Roy, bekend van 'de vierde macht'. Mijn afstudeerscriptie behandelde de Monumentenwet uit 1961, terwijl mijn keuzevakscriptie 'Het ontstaan van het gerecht Renswoude en Emmikhuizen' werd gepubliceerd in het Jaarboek Oud-Utrecht (1976).

$\mathrm{Na}$ een postdoctorale opleiding in de archiefwetenschappen onder leiding van prof. dr. F.C.J. (Eric) Ketelaar, destijds directeur van de Rijksarchiefschool en gepromoveerd op heerlijke rechten, begon mijn werkzame leven bij een kunsthistorisch 
documentatiecentrum. Vanwege mijn genealogische en heraldische belangstelling heb ik mij onder de bezielende leiding, aanvankelijk van jonkheer Frits G.L.O. van Kretschmar, directeur van de Stichting Iconographisch Bureau, en na de fusie met het Rijksbureau voor Kunsthistorische Documentatie, van prof. dr. Rudi E.O. Ekkart, kunnen bekwamen in de portreticonografie. In het Leids Kunsthistorisch Jaarboek (1989) publiceerde ik een methodologisch artikel, dat aan de hand van voorbeelden de wijze aangaf waarop identiteiten van anoniem geworden portretten achterhaald kunnen worden.

De inmiddels bijna tienjarige ervaring, die ik in mijn huidige functie opdeed in het centrum voor het levende Nederlandse adelsrecht, zoals de Hoge Raad van Adel omschreven zou kunnen worden, actualiseerde mijn juridische kennis en motiveerde mij voor de gekozen probleemstelling. Mijn kennis van de inhoud van het omvangrijke Raadsarchief, dat ik tezamen met wijlen dr. Jacob C. Kort in fasen heb geïnventariseerd, heeft de realisatie van het project versneld. Ten slotte ben ik door de Hoge Raad van Adel niet alleen aangemoedigd, maar ook in belangrijke mate praktisch gefaciliteerd. Dit betekent niet dat de Raad verantwoordelijk voor de inhoud van de dissertatie kan worden gesteld, in het bijzonder niet voor de door mij geformuleerde conclusies en aanbevelingen. Ik draag persoonlijk de verantwoordelijkheid voor de opties tot verbetering van de wetgeving.

Een woord van dank wil ik in de eerste plaats richten tot mijn promotor René de Groot, die al sinds 1974 door het adelsrecht wordt gegrepen en rond de eeuwwisseling moderniseringsideeën publiceerde, waarover niet alleen de Nederlandse Adelsvereniging zich bezorgd toonde. Zijn stimulans om het archaïsche adelsrecht nader te bestuderen en zijn oprechte poging om tot consequente $21^{\text {ste }}$-eeuwse toepassing te komen, hebben soms tot verschillende, maar verdedigbare conclusies geleid. Voorts dank ik de voorzitter en leden van de Hoge Raad van Adel, wier onvoorwaardelijk enthousiasme voor het plan de uitvoering heeft bevorderd. In het bijzonder roep ik wijlen jonkvrouw Marga van den Brandeler in herinnering, die de Raad in 2009 zo plotseling ontviel, maar destijds al het belang van een becommentarieerde jurisprudentielijst onderstreepte. Coen Schimmelpenninck voornoemd, voorzitter sinds 1991, en mr. Jean-Pierre Eschauzier, oud-advocaat en lid van de Raad van 1991-2011, waren bereid het manuscript kritisch door te lezen.

Een speciaal woord van erkentelijkheid richt ik tot mijn medewerkers ter secretarie van de Hoge Raad van Adel voor het kritisch lezen van het concept en de boeiende discussies, die daarvan het gevolg waren. Dr. Conrad A.M. Gietman, wetenschappelijk medewerker van de Raad, promoveerde in 2010 op de mentaliteitsgeschiedenis van de Oost-Nederlandse adel en was bereid om mijn zuster als paranimf terzijde te staan. Eerste medewerker drs. Jos C.C.F.M. van den Borne trad op als eindredacteur en vormgever van de publicatie en Aldert Gritter, tweede medewerker, heeft de samenvatting vertaald. De Duitse vertaling ten slotte is door Wolfgang Kramer gecorrigeerd.

Geboren (1950) en getogen in het Utrechtse Renswoude, sinds 1976 gevestigd in 's-Gravenhage, waan ik me tot slot in het voetspoor van mijn zeventiende-eeuwse 
voorvader Hendrik Pelt (ca. 1616-1681), die poorter van Maastricht was. Deze in de stad Utrecht, als buurman van de bekende heraldicus Arnold van Buchell, geboren notaris werd in 1648 door de Staten-Generaal benoemd tot griffier van de Staten van het Land van Valkenburg in het Overmaas. In 1669 komt hij in een notariële akte voor als ambtelijk secretaris van de Ridderschap van het Land van Valkenburg. Hij woonde aanvankelijk in 'Het Blauwe Schaap' te Maastricht, gelegen in de Platielstraat op de hoek van de Leliestraat, en aan het einde van zijn leven in de Nieuwstraat aldaar. ${ }^{833}$ Ik zie het als een voorrecht om als ambtelijk secretaris van de Hoge Raad van Adel in 's-Gravenhage mijn proefschrift te mogen verdedigen in Maastricht op ongeveer dezelfde locatie als waar mijn voorvader zich 350 jaar geleden als ridderschapsgriffier manifesteerde.

Egbert J. Wolleswinkel

Ter nagedachtenis van mijn ouders

Pieter Wolleswinkel (1909-1998) \&

Elizabeth van Ommering (1916-1988)

\footnotetext{
${ }^{833}$ Vgl. De Nederlandsche Leeuw 97 (1980), kk. 33-48, en 108 (1991), kk. 24-41 en 451-454 (afstamming Pelt $>\operatorname{Van} \operatorname{Ren}(\mathrm{n})$ es $(\mathrm{se})>$ (Fransen) van Eck $>$ Jochemsen $>$ Wolleswinkel).
} 
:

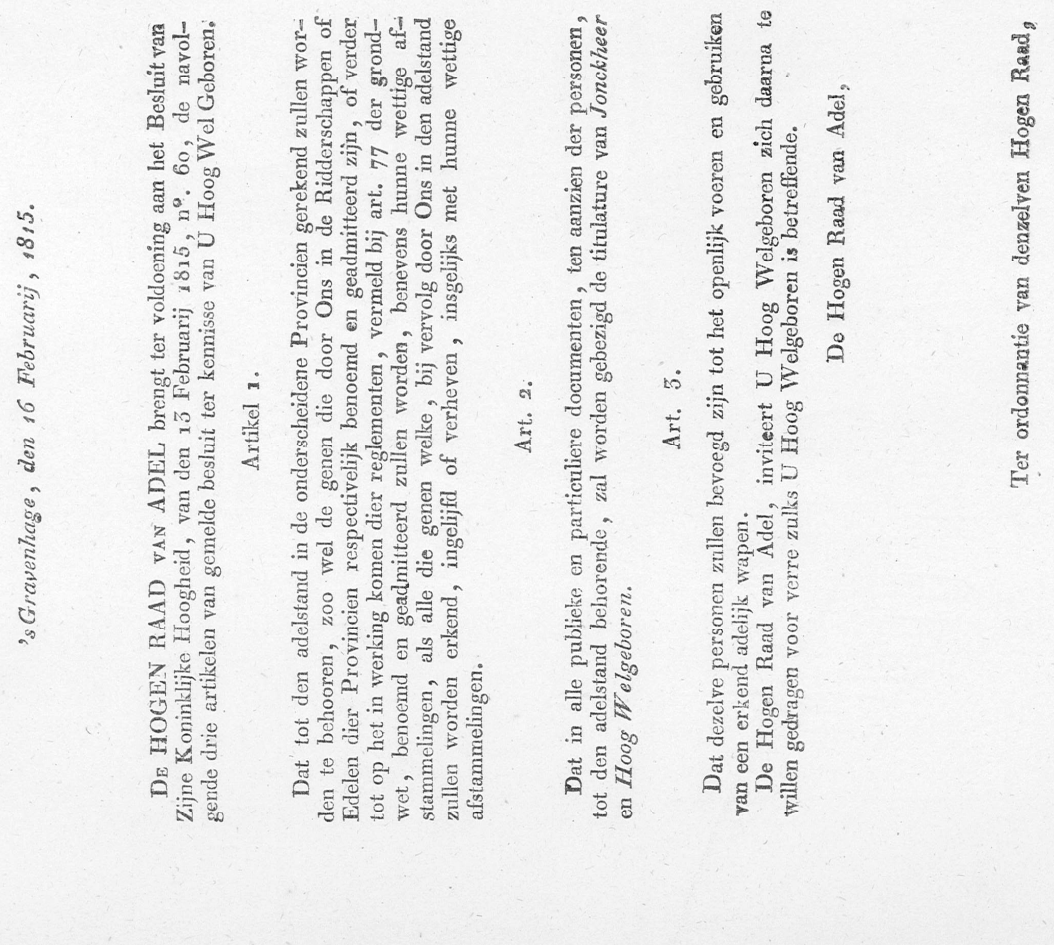

Aan

Den Hoog Welgeboren Heer

Circulaire van de Hoge Raad van Adel d.d. 16 februari 1815, waarin de voorrechten van de Nederlandse adel worden aangekondigd (met weglating van artikel 4 betreffende het jachtrecht).

HRvA, RA, inv.nr. 892. 


\section{Schema's}

\section{Geslachten in aantallen}

\begin{tabular}{|c|c|c|c|c|}
\hline NRD.-NED. GESLACHTEN & BENOEMD & ERKEND & INGELIJFD & VERHEVEN \\
\hline $1814 / 1815-1817$ & 181 & 3 & 21 & 88 \\
\hline $1818-1820$ & & 3 & 6 & 11 \\
\hline $1821-1830$ & & 12 & 18 & 40 \\
\hline $1831-1840$ & & 1 & 13 & 36 \\
\hline $1840-1849$ & 1 & 2 & 7 & 33 \\
\hline $1850-1860$ & & & 1 & 6 \\
\hline $1861-1870$ & & 1 & 6 & 1 \\
\hline $1871-1880$ & & & 1 & 8 \\
\hline $1881-1890$ & & & 3 & 8 \\
\hline $1890-1898$ & & 1 & 2 & 4 \\
\hline $1899-1910$ & & & 5 & 13 \\
\hline 1911-1920 & & & 2 & 2 \\
\hline 1921-1930 & & & & 1 \\
\hline 1931-1940 & & & 1 & 1 \\
\hline \multicolumn{5}{|l|}{ 1941-1960 } \\
\hline 1961-1964 & & & 2 & \\
\hline telling Van Valkenburg & 182 & 23 & 88 & 252 \\
\hline 1965-1995 & & & 15 & \\
\hline 1996-2002 Woa, art. 8 & & & 4 & \\
\hline 2001-heden & & & 1 & 1 \\
\hline telling 2012 & 182 & 23 & 108 & 253 \\
\hline
\end{tabular}

\section{Wetten, besluiten, circulaires, disposities en officiële mededelingen}

Koninkrijk Holland 1806-1810

\begin{tabular}{l|l|l}
\hline WETGEVING & KORTE INHOUD & VINDPLAATS \\
\hline $\begin{array}{l}\text { Constitutie 07.08.1806 (afschaffing in } \\
\text { 1810) }\end{array}$ & Koninkrijk Holland & $\begin{array}{l}\text { drukwerk; HRvA, RA, } \\
\text { inv.nr. 889 }\end{array}$ \\
\hline $\begin{array}{l}\text { Grondwet 22.04.1809, nr. 5 (afschaf- } \\
\text { fing in 1810) }\end{array}$ & constitutionele adel & $\begin{array}{l}\text { drukwerk; HRvA, RA, } \\
\text { inv.nr. 889 (afb. p. 297) }\end{array}$ \\
\hline $\begin{array}{l}\text { KB 01.10.1809, nr. 1 (afschaffing in } \\
1810)\end{array}$ & statuten constitutionele adel & $\begin{array}{l}\text { drukwerk; HRvA, RA, } \\
\text { inv.nr. 889 (afb. p.302) }\end{array}$ \\
\hline KB 01.10.1809, nr. 2 & instructie Hoog Heraldiek Collegie & HRvA, RA, inv.nr. 889 \\
\hline KB 01.10.1809, nr. 3 & benoem. grootmeester der wapenen & HRvA, RA, inv.nr. 889 \\
\hline KB 01.10.1809, nr. 4 & benoeming grootkanselier der titels & niet aanwezig \\
\hline KB 01.10.1809, nr. 5 & regl. v. orde Hoog Heraldiek Collegie & HRvA, RA, inv.nr. 889 \\
\hline KB 21.11.1809 (afschaffing in 1810) & $\begin{array}{l}\text { statuten constitutionele adel (wijzi- } \\
\text { ging art. 29) }\end{array}$ & $\begin{array}{l}\text { drukwerk; HRvA, RA, } \\
\text { inv.nr. 889 (afb. p.308) }\end{array}$ \\
\hline
\end{tabular}




\begin{tabular}{l|l|l}
\hline KB 18.02.1810 & opheffing constitutionele adel & $\begin{array}{l}\text { drukwerk; HRvA, RA, } \\
\text { inv.nr. 889 (afb. p.38) }\end{array}$ \\
\hline KB 01.03.1810 & idem, doch voortzetting HHC & HRvA, RA, inv.nr. 889 \\
\hline
\end{tabular}

\section{Soevereine Vorst der Verenigde Nederlanden}

\begin{tabular}{|c|c|c|}
\hline WETGEVING & KORTE INHOUD & VINDPLAATS \\
\hline SB 06.12.1813, nr. 7 & aanvaarding soevereiniteit & Stb. 1813,4 \\
\hline SB 11.12.1813 (wijziging 1886) & Code Pénal (art. 259: titulatuur) & Stb. 1814,10 \\
\hline SB 14.01.1814, nr. 133 (wijz. 1815) & wapen soevereine vorst & Stb. 9 \\
\hline SB 18.01.1814, nr. 6 & verdeling legesgelden & HRvA, RA, inv.nr. 858 \\
\hline SB 26.03.1814, nr. 20 (wijz. 1815) & herstel heerlijk jachtrecht (1) & Stb. 46 \\
\hline Grondwet 29.03.1814 (wijz. 1815) & artt. $6,7,17,42$ en 45 & Stb. 44 \\
\hline SB 05.04.1814 & afschaffing interne ambtel. titulatuur & \\
\hline SB 24.06.1814, nr. 10 & instructie HRvA & $\begin{array}{l}\text { drukwerk; HRvA, RA, inv.nr. } \\
\text { 1-1 (afb. p.309) }\end{array}$ \\
\hline SB 23.08.1814, nr. 40 (wijz. 1858) & reglement van orde HRvA & idem \\
\hline SB 28.08.1814, nr. 14 & collectieve benoeming adel & HRvA, RA, inv.nr. 1-36 \\
\hline SB 21.09.1814, nr. 25 (wijz. 1815) & herstel heerlijk jachtrecht (2) & Stb. 101 \\
\hline Kon. Disp. 15.11.1814, nr. 40 & opdracht aan HRvA etiq. v. h. paleis & HRvA, RA, inv.nr. 1-145 \\
\hline SB 06.12.1814, nr. 89 & opdracht aan HRvA etiq. v. h. paleis & HRvA, RA, inv.nr. 1-181 \\
\hline SB 24.12.1814, nr. 32 & voordracht overheidsheraldiek & $\begin{array}{l}\text { hogeraadvanadel.nl; HRvA, } \\
\text { RA, inv.nr. 1-200 }\end{array}$ \\
\hline Circulaire HRvA 05.01.1815, nr. 5 & oproep inzending gemeentewapens & $\begin{array}{l}\text { Stcr. 1815; HRvA, RA, inv.nr. } \\
2-11\end{array}$ \\
\hline SB 08.02.1815, nr. 42 & $\begin{array}{l}\text { definitief herstel heerlijk jachtrecht } \\
\text { (3) }\end{array}$ & $\begin{array}{l}\text { Stb. 11; HRvA, RA, inv.nr. 3- } \\
72\end{array}$ \\
\hline SB 13.02.1815, nr. 60 & voorrechten adel & $\begin{array}{l}\text { Stb. 15; overheid.nl; HRvA, } \\
\text { RA, inv.nrs. 3-63, } 877\end{array}$ \\
\hline SB 13.02.1815, nr. 61 & bevoegdheid ridderschappen & HRvA, RA, inv.nrs. 3-66, 447 \\
\hline Circulaire HRvA 16.02.1815 & voorrechten adel & $\begin{array}{l}\text { drukwerk; HRvA, RA, inv.nrs. } \\
\text { 449, } 892 \text { (afb. p.284) }\end{array}$ \\
\hline SB 22.02.1815, nr. 79 (wijz. 1852) & omschrijving heerlijk jachtrecht & Stb. 11 \\
\hline SB 04.03.1815, nr. 85 & $\begin{array}{l}\text { erkenning oude adel; diploma be- } \\
\text { noemden }\end{array}$ & $\begin{array}{l}\text { HRvA, RA, inv.nrs. 3-154, } \\
447\end{array}$ \\
\hline SB 04.03.1815, nr. La.T. & organisatie koningschap & $\begin{array}{l}\text { Jub.boek '66, 175; HRvA, RA, } \\
\text { inv.nr. 3-82 }\end{array}$ \\
\hline
\end{tabular}

Koninkrijk der Nederlanden

\begin{tabular}{l|l|l}
\hline WETGEVING & INHOUD & VINDPLAATS \\
\hline KB 16.03.1815, nr. 1 (aanv. 12 mei) & procl. titels koning en prins v. Oranje & Stb. 27, nr. 3-112 \\
\hline KB 16.03.1815, nr. 3 & instructie ceremoniemr. & HRvA, RA, inv.nr. 3-108 \\
\hline KB 17.03.1815, nr. 6 & eed ridderschappen & $\begin{array}{l}\text { HRvA, RA, inv.nrs. 3-109, } \\
447\end{array}$ \\
\hline KB 17.03.1815, nr. 20 & etiquette voor het paleis & $\begin{array}{l}\text { HRvA, RA, inv.nrs. 3-138, } \\
144-146\end{array}$ \\
\hline KB 26.03.1815, nr. 24 & advies instelling ridderorden & $\begin{array}{l}\text { HRvA, RA, inv.nrs. 3-122, } \\
128\end{array}$ \\
\hline Wet 23.03.1815 ( KB nr. 167) & wijziging grondwet noodzakelijk & Stb. 29, nr. 3-139 \\
\hline
\end{tabular}




\begin{tabular}{|c|c|c|}
\hline KB 30.04.1815, nr. 5 & instelling Miltaire Willemsorde & $\begin{array}{l}\text { Stb. 33*; HRvA, RA, inv. nr. } \\
3-135,4-198,141\end{array}$ \\
\hline $\begin{array}{l}\text { Kon. Disp. } 12.05 .1815, \text { nr. } 701 \text { (aanv. } \\
16 \text { maart) }\end{array}$ & $\begin{array}{l}\text { proclamatie titel groothertog van } \\
\text { Luxemburg }\end{array}$ & $\begin{array}{l}\text { drukwerk; HRvA, RA, inv.nr. } \\
\text { 4-201 (afb. p.53) }\end{array}$ \\
\hline Kon. Disp. 02.06. 1815, nr. 766 & advies kleding en regalia & HRvA, RA, inv.nr. 4-223 \\
\hline Kon. Disp. 05.06. 1815, nr. 16 & adres te richten: 'Aan den Koning' & HRvA, RA, inv.nr. 4-226 \\
\hline KB 07.07.1815, nr. 29 & Orde (Re)Unie vervallen & HRvA, RA, inv.nr. 4-195 \\
\hline Wet 08.08 .1815$, nr. 55 & herstel (Ridderlijke) Duitsche Orde & Stb. 43 \\
\hline KB 21.08.1815, nr. 79 & voorwaarden Britse adeldom & $\begin{array}{l}\text { overheid.nl; HRvA, RA, } \\
\text { inv.nrs. 447, } 740\end{array}$ \\
\hline Grondwet 24.08.1815 (wijz. 1840) & artt. $22,23,36,63$ en 66 & Stb. 45 \\
\hline KB 24.08.1815, nr. 71 (wijz. 1816) & vaststelling Rijkswapen & $\begin{array}{l}\text { Stb. 46; HRvA, RA, inv.nrs. 4- } \\
233,269,5-349\end{array}$ \\
\hline KB 16.09.1815, nr. 70 & geen Britse reciprociteit & $\begin{array}{l}\text { overheid.nl; ; HRvA, RA, } \\
\text { inv.nrs. 6-393, 447/9, 500 }\end{array}$ \\
\hline KB 29.09.1815, nr. 49 & $\begin{array}{l}\text { instelling Orde van de Nederlandsche } \\
\text { Leeuw }\end{array}$ & $\begin{array}{l}\text { Stb. 47; HRvA, RA, inv.nrs. 4- } \\
\text { 196, 6-411, 421, } 438\end{array}$ \\
\hline Wet 29.09.1815, nr. 50 (wijz. 1817) & dotatie prins van Waterloo & Stb. 48 \\
\hline KB 30.09.1815, nr. 10 (wijz. 1947) & formulieren, taxa, leges (1) & $\begin{array}{l}\text { Jub.boek'66, 186; HRvA, RA, } \\
\text { inv.nrs. 6-400, 449, } 877\end{array}$ \\
\hline KB 20.10.1815, nr. 107 & acte van bewijs voor benoemden & $\begin{array}{l}\text { Jub.boek'66, 187; HRvA, RA, } \\
\text { inv.nrs. } 447,877\end{array}$ \\
\hline KB 18.12.1815, nr. 46 & formulier acte van bewijs & $\begin{array}{l}\text { Jub.boek'66, 189; HRvA, RA, } \\
\text { inv.nrs. 447, 449, 7-581 }\end{array}$ \\
\hline Kon. Disp. 04.02.1816, nr. 272 & hiërarchie rangkronen & $\begin{array}{l}\text { Jub.boek'66, 190; HRvA, RA, } \\
\text { inv.nrs. 8-85, 449, } 947\end{array}$ \\
\hline KB 20.02.1816, nr. 69 (afsch. 1919) & HRvA bevestigt overheidsheraldiek & HRvA, RA, inv.nr. 9-135 \\
\hline KB 04.03.1816, nr. 169 (wijz. 1947) & taxa titel burggraaf & HRvA, RA, inv.nr. 449 \\
\hline KB 22.03.1816, nr. 31 & Adelsfonds uit opbrengst taxa & HRvA, RA, inv.nr. 915 \\
\hline $\begin{array}{l}\text { Kon. Disp. 05.06. 1816, nr. } 4 \text { (wijz. } \\
\text { 1907) }\end{array}$ & correctie Rijkswapen & HRvA, RA, inv.nr. 10-326 \\
\hline Kon. Disp. 24.06.1816, nr. 77 & goedkeuring kleurentek. Rijkswapen & HRvA, RA, inv.nr. 11-378 \\
\hline KB 25.06.1816, nr. 70 & oprichting Ridderschap Zeeland & HRvA, RA, inv.nrs. 447, 776 \\
\hline KB 01.07.1816, nr. 88 & bij acten van bewijs alleen leges & HRvA, RA, inv.nr. 915 \\
\hline Circulaire HRvA 02.07.1816 & correctie Rijkswapen & $\begin{array}{l}\text { drukwerk; HRvA, RA, inv.nr. } \\
11-378\end{array}$ \\
\hline KB 03.07.1816, nr. 106 & $\begin{array}{l}\text { goedkeuring reglementen Ridder- } \\
\text { schappen Noord-Nederland }\end{array}$ & $\begin{array}{l}\text { drukwerk; HRvA, RA, inv.nrs. } \\
447,449\end{array}$ \\
\hline KB 12.11.1816, nr. 63 & aanschrijving Riddersch. Zd-Ned. & HRvA, RA, inv.nrs. 447, 783 \\
\hline KB 28.12.1816, nr. 45 (wijz. 1842) & voorwaarden lichten diploma’s & $\begin{array}{l}\text { drukwerk (2-talig); HRvA, } \\
\text { RA, inv.nrs. } 447,449\end{array}$ \\
\hline Besluit HRvA 05.03.1817 & bij homologatie alleen leges & HRvA, RA, inv.nr. 15-94 \\
\hline KB 23.05.1817, nr. 2 & vrijstelling oude Zd-Ned. adel & HRvA, RA, inv.nrs. 447, 449 \\
\hline KB 03.06.1817, nr. 59 (wijz. 1989) & wijziging dotatie prins van Waterloo & NA, arch. KdK \\
\hline KB 03.01.1818, nr. 91 (afsch. 1919) & gemeentewapen niet verplicht & HRvA, RA, inv.nr. 915 \\
\hline KB 03.08.1818, nr. 19 & lichten diploma $<15.07 .1819$ & $\begin{array}{l}\text { Stcr. 1.5.1819; HRvA, RA, } \\
\text { inv.nr. 931A (afb. p. 63) }\end{array}$ \\
\hline Circulaire 30.09.1818, nr. 158 & inleveren genealogie + wapen & $\begin{array}{l}\text { drukwerk; HRvA, RA, inv.nr. } \\
877 \text { (afb. p. 66) }\end{array}$ \\
\hline KB 20.04.1819, nr. 2 (afsch. 1868) & visitatie Prov. Staten dorso diploma & HRvA, RA, inv.nrs. 447, 803 \\
\hline KB 28.07.1819, nr. 16 & ontlasting Rijksbegroting & HRvA, RA, inv.nr. 915 \\
\hline
\end{tabular}




\begin{tabular}{|c|c|c|}
\hline KB 30.04.1820, nr. 15 & traktementen uit rente Adelsfonds & HRvA, RA, inv.nr. 915 \\
\hline KB 22.02.1821, nr. 69 (wijz. 1947) & algemeen taxabesluit (2) & HRvA, RA, inv.nrs. 449, 915 \\
\hline KB 22.12.1821, nr. 19 (afsch. 1899) & versiers. overheidsheraldiek exclusief & HRvA, RA, inv.nr. 44-2 \\
\hline KB 26.01.1822 & $\begin{array}{l}\text { titulatuur verplicht op officiële docu- } \\
\text { menten }\end{array}$ & $\begin{array}{l}\text { Stb. 1; overheid.nl; HRvA, } \\
\text { RA, inv.nrs. 447, } 449\end{array}$ \\
\hline KB 08.09.1822, nr. 92 & exploitatie uit taxa & HRvA, RA, inv.nr. 57-1755 \\
\hline KB 24.09.1822, nr. 22 & erkenning baron nu diploma verplicht & HRvA, RA, inv nrs. 449, 915 \\
\hline KB 21.03.1823, nr. 95 & titel benoemden is persoonlijk & HRvA, RA, inv.nrs. 447,449 \\
\hline Wet 31.05.1824 (wijz. 1882) & Zegelwet (artt. 12 en 29) & Stb. 36 \\
\hline KB 25.07.1825 & 1e Adelslijst; rangorde titulatuur & Stb. 61 \\
\hline KB 23.12.1825, nr. 122 & oprichting Ridderschap Friesland & HRvA, RA, inv.nrs. 307, 447 \\
\hline Kon. Disp.02.12. 1826, nr. 112 & valse verklaring wapenheraut & HRvA, RA, inv.nr. 449 \\
\hline KB 02.01.1827 & 2e Adelslijst + naamscorrecties & $S t b .1$ \\
\hline KB 04.04.1827, nr. 169 & permissie eerstgeboortetitel & $\begin{array}{l}\text { Jub.boek '66, 194; overheid.nl; } \\
\text { HRvA, RA, inv.nrs. 449, 877, } \\
915\end{array}$ \\
\hline KB 24.05.1827 & completering adelslijsten & Stb. 28; overheid.nl \\
\hline KB 06.01.1828 & 3e Adelslijst + naamscorrecties & Stb. 1 \\
\hline KB 01.01.1829 & 4e Adelslijst + naamscorrecties & Stb. 1 \\
\hline KB 09.01.1830 & 5e Adelslijst + naamscorrecties & Stb. 1 \\
\hline Grondwet 04.09.1840 (wijz. 1848) & artt. $21,22,35,62$ en 65 & Stb. 47-59 \\
\hline KB 11.11.1840, nr. 69 & splitsing Riddersch. Nrd./Zd. Holland & HRvA, RA, inv.nr. 957 \\
\hline KB 01.05.1842, nr. 56 (wijz. 1868) & voorwaarden lichten diploma's & $\begin{array}{l}\text { drukwerk; HRvA, RA, inv.nrs. } \\
447,449\end{array}$ \\
\hline KB 08.05.1842, nr. 1 & oprichting Ridderschap Limburg & HRvA, RA, inv.nrs. 447, 876 \\
\hline KB 19.05.1842, nr. 3 & benoeming Riddersch. Limb., aanv. & HRvA, RA, inv.nrs. 447, 884 \\
\hline KB 29.11.1843 & 6e Adelslijst + naamscorrecties & Stb. 59 \\
\hline Wet 29.12 .1843 & Rijksbegroting, hfdst. II (HRvA) & $S t b .64$ \\
\hline Wet 26.06.1845 & Adelsfonds tot dekking uitgaven & $S t b .43$ \\
\hline KB 19.04.1846 & 7e Adelslijst + naamscorrecties & Stb. 20 \\
\hline Grondwet 14.10.1848 (wijz. 1887) & alg. herziening; artt. 21, 22, 32 en 63 & $S t b .71$ \\
\hline Wet 06.07.1850 & Provinciale wet: einde adelstand & $S t b .39$ \\
\hline KB 20.07.1850, nr. 55 & HRvA onbezoldigdigde ereambten & $\begin{array}{l}\text { Jub.boek '66, 177; HRvA, RA, } \\
\text { inv.nr. } 449\end{array}$ \\
\hline KB 09.11.1850, nr. 37 & benoeming nieuwe HRvA & $\begin{array}{l}\text { Jub.boek '66, 178; HRvA, RA, } \\
\text { inv.nr. } 876\end{array}$ \\
\hline Wet 06.07.1852 (afsch. 1923) & Jachtwet (artt. 4 en 31-36) & Stb. 47 \\
\hline KB 17.09.1852, nr. 44 & beperking adviestaak HRvA & $\begin{array}{l}\text { Jub.boek '66, 179; HRvA, RA, } \\
\text { inv.nr. } 449\end{array}$ \\
\hline KB 22.03.1856, nr. 60 & eed ten overstaan van minister BiZa & $\begin{array}{l}\text { Jub.boek '66, 180; HRvA, RA, } \\
\text { inv.nr. } 875\end{array}$ \\
\hline KB 20.06.1858, nr. 92 (wijz. 1867) & reglement van orde HRvA & $\begin{array}{l}\text { drukwerk; HRvA, RA, inv.nr. } \\
876\end{array}$ \\
\hline KB 06.02.1859 & 8e Adelslijst + naamscorrecties & $S t b .8$ \\
\hline Circulaire Justitie 15.02.1859 & $\begin{array}{l}\text { misbruik titulatuur + heerlijkheids- } \\
\text { namen }\end{array}$ & $\begin{array}{l}\text { drukwerk; HRvA, RA, inv.nr. } \\
449\end{array}$ \\
\hline KB 06.07.1859, nr. 46 & Rijksbegroting, hfdst. IV (Justitie ) & $\begin{array}{l}\text { Jub.boek '66, 181; HRvA, RA, } \\
\text { inv.nr. } 449\end{array}$ \\
\hline KB 25.11.1860, nr. 64 & vrijdom port dienstpost & HRvA, RA, inv.nr. 449 \\
\hline Circulaire Justitie 13.01.1866 & toezending BS-akten naar HRvA & Stcr. 1866, 14; HRvA, RA, \\
\hline
\end{tabular}




\begin{tabular}{|c|c|c|}
\hline & & inv.nr. 449 \\
\hline KB 12.05.1866, nr. 48 (wijz. 1994) & verruiming adviestaak HRvA & $\begin{array}{l}\text { Jub.boek '66, 181; HRvA, RA, } \\
\text { inv.nr. } 449\end{array}$ \\
\hline $\begin{array}{l}\text { Circulaire Justitie } 11.06 .1867 \text { (wijz. } \\
\text { 1883) }\end{array}$ & reglment van orde HRvA & $\begin{array}{l}\text { drukwerk; HRvA, RA, inv.nr. } \\
876\end{array}$ \\
\hline KB 26.03.1868 & overgang eerstgeboortetitel & Stb. 37; overheid.nl \\
\hline KB 18.10.1868 (wijz. 1927) & voorwaarden lichten diploma's & $\begin{array}{l}\text { Stb. 142; HRvA, RA, inv.nr. } \\
876\end{array}$ \\
\hline KB 15.02.1877 & 9e Adelslijst & Stb. 24 \\
\hline Wet 03.03.1881 (m. i. v. 1886) & Invoering Wetb. v. Strafr. (art. 435) & Stb. 35 \\
\hline KB 25.12.1881, nr. 10 & eed ten overstaan van minister Justitie & $\begin{array}{l}\text { Jub.boek ' } 66,182 \text {; HRvA, } \\
\text { RA, inv.nr. } 449\end{array}$ \\
\hline Wet 11.07.1882 (afsch. 1917) & registratierecht dipl. $50 \%$ verhoogd & Stb. 92 \\
\hline KB 28.02.1883 & 10e Adelslijst $+1 \mathrm{e}$ lijst wijzigingen. & Stb. 28 \\
\hline $\begin{array}{l}\text { Circulaire Justitie } 20.07 .1883 \text { (wijz. } \\
\text { 1893) }\end{array}$ & reglement van orde HRvA & $\begin{array}{l}\text { drukwerk; HRvA, RA, inv.nr. } \\
876\end{array}$ \\
\hline Grondwet 06.11.1887 (wijz. 1917) & artt. 15,29 en 65 & Stb. 183-193 \\
\hline KB 14.08.1891, nr. 43 (wijz. 1947) & leges op diploma t.b.v. Rijk & \\
\hline Circulaire Justitie 08.03.1893 & reglement van orde HRvA & $\begin{array}{l}\text { drukwerk; HRvA, RA, inv.nr. } \\
876\end{array}$ \\
\hline KB 30.08.1898 & 11e Adelslijst $+2 \mathrm{e}$ lijst wijzigingen & Stb. 204 \\
\hline KB 23.05.1899 & elke gemeente recht op kroon & $\begin{array}{l}\text { Jub.boek '66, 140; HRvA, RA, } \\
\text { inv.nr. 168-55 }\end{array}$ \\
\hline KB 10.07.1907 & wijziging Rijkswapen & Stb. 181 \\
\hline Wet 22.03.1917 & afschaffing registratierecht & Stb. 243 \\
\hline Wet 22.03.1917 (wijz. 1950) & Zegelwet (artt. 41 en 43) & Stb. 244 \\
\hline Grondwet 29.11.1917 (wijz. 1921) & artt. 15,29 en 65 & Stb. 660-633 \\
\hline KB 23.04.1919 (aanv. 1977) & procedure overheidsheraldiek & Stb. 181 \\
\hline Grondwet 27.12.1922 (wijz. 1938) & artt. 14,27 en 65 & Stb. 736 \\
\hline Wet 02.07 .1923 & Jachtwet (art. 69 e. v. ) & Stb. 331 \\
\hline KB 20.07.1927 & voorwaarden lichten diploma's & Stb. 255 \\
\hline KB 19.02.1937, nr. 93 & kleuren Nederlandse vlag & \\
\hline KB 03.07.1937 & Rijksbegroting, hfdst. II (Alg. Z. ) & Stb. 140 \\
\hline Grondwet 25.02.1938 (wijz. 1946) & artt. 14,27 en 67 & Stb. 300 \\
\hline KB 01.11.1938 & 12e Adelslijst $+3 \mathrm{e}$ lijst wijzigingen & Stb. 185 \\
\hline KB 23.02.1945 & Rijksbegroting, hfdst. V (BiZa) & Stb. F11 \\
\hline Grondwet 31.12.1946 (wijz. 1948) & artt. $14,27,67$ & Stb. G428 \\
\hline KB 16.08.1947, nr. 15 (wijz. 1982) & algemeen taxabesluit (3) & HRvA, RA, inv.nr. 449 \\
\hline Grondwet 03.09.1948 & artt. 14,27 en 67 & Stb. 410-414 \\
\hline Wet 21.12.1950 (afsch. 1972) & verhoging zegelrecht & Stb. K597 \\
\hline Grondwet 22.06.1953 (wijz. 1956) & artt. 14,27 en 74 & Stb. 295 \\
\hline Grondwet 11.09.1956 (wijz. 1964) & artt. 14,27 en 74 & Stb. 472 \\
\hline Off. meded. 1959, nr. 23 & richtlijn naamsverandering & HPS 1959, 41 \\
\hline Circulaire 22.06.1961 Justitie & toezending BS-akten nr. HRvA & HPS 1979, 38 \\
\hline Grondwet 14.11.1963 (wijz. 1972) & artt. $11,14,27$ en 74 & Stb. 462-465 \\
\hline Off. meded. 1964, nr. 24 & Ned. adell. titulat. op internat. akten & HPS 1964, 111 \\
\hline KB 09.12.1969 (wijz. 1997) & regeling naamswijzingen & $S t b .544$ \\
\hline Wet 24.12.1970 & afschaffing zegelrecht op KB's & Stb. 611 \\
\hline Grondwet 17.04.1972 (wijz. 1983) & artt. $11,14,27$ en 74 & Stb. 193 \\
\hline
\end{tabular}




\begin{tabular}{l|l|l}
\hline Off. meded. 1975, nr. 7 & adell. titulatuur in geboorteakten BS & HPS 1975, 94 \\
\hline Circulaire BiZa 18.10.1977 & richtlijnen overheidsheraldiek & hogeraadvanadel.nl \\
\hline KB 21.10.1977, nr. 15 & aanv. procedure overheidsheraldiek & Stb. 605; hogeraadvanadel.nl \\
\hline Circulaire BiZa 03.09.1979 & gebruik overheidswapens & hogeraadvanadel.nl \\
\hline Rijkswet 16.04.1981 (wijz. 1983) & wijziging grondwet noodzakelijk & Stb. 219 \\
\hline KB 26.03.1982 & algemeen taxabesluit (4) & Stb. 216; overheid.nl \\
\hline KB 04.05.1982 & 13e Adelslijst en 4e lijst wijzigingen & Stb. 410 \\
\hline Grondwet 17.02.1983 (Wet 1994) & alg. herzien.; art. 25 en add. art. XXV & Stb. 70 \\
\hline Circulaire BZK 22.12.1998 & gebruik adellijke titels en predikaten & $\begin{array}{l}\text { B\&R 1999, 64; hogeraadvana- } \\
\text { del.nl }\end{array}$ \\
\hline Wet 30.10.1985 (wijz. 2002) & lidmaatschap koninklijk huis & Stb. 578 \\
\hline Wet 10.05.1994 & adeldom & $\begin{array}{l}\text { Stb. 360; overheid.nl (afb. } \\
\text { p.140) }\end{array}$ \\
\hline Wet 10.04.1997 (m. i. v. 1998) & wijziging BW, artt. 1:5 en 9 & Stb. 161 \\
\hline KB 06.10.1997 & regel. naamswijzig. /toevoeging & Stb. 463; overheid.nl \\
\hline Wet 30.05.2002 & lidmaatschap koninklijk huis & $\begin{array}{l}\text { Stb. 275; overheid.nl (afb. } \\
\text { p.166) }\end{array}$ \\
\hline KB 09.06.2004 & & Stb. 307 \\
\hline Circulaire BZK 15.02.2010 & adell. titulat. op officiële documenten & hogeraadvanadel.nl \\
\hline & &
\end{tabular}

\section{Jurisprudentie}

Verzoeker / Appellant (Archiefbron HRvA, RA)

\begin{tabular}{l|l}
\hline Uitspraak / Vonnis & Onderwerp / Literatuur
\end{tabular}

Arrondissementsrechtbanken (AR); Gerechtshoven (GH); Hoge Raad der Nederlanden (HR); Afd. Bestuursrechtspraak Raad Van State (ABRvS), Europese Hof voor de Rechten van de Mens (EHRM); Nationale Ombudsman (NO)

Clifford (p.m.)

\begin{tabular}{l|l}
\hline AR (Breda) 25 maart 1899 (KB 26 jan. 1822) & $\begin{array}{l}\text { titel in geboorteakte } \\
\text { Weekblad van het Recht }[W v h R] 7298(1899), 2\end{array}$ \\
\hline GH (Den Bosch) 17 juni 1899 (KB 26 jan. 1822) & $\begin{array}{l}\text { titel in geboorteakte } \\
\text { WvhR 7298 (1899), 2-3; Het Personeel Statuut } \\
{[H P S] 5(1954), 155-158}\end{array}$ \\
\hline
\end{tabular}

Steengracht van Moyland (p.m.)

\begin{tabular}{l|l}
\hline AR (Den Haag) 14 febr. 1911 & recht wettelijkerfdeel niet bij geboorte \\
\hline GH (Den Haag) 24 juni 1912 & idem \\
\hline HR (Burgerlijke Kamer) 27 juni 1913 & recht wettelijk erfdeel eerst bij overlijden \\
& $\begin{array}{l}\text { Ned. Jurisprudentie }[N J] \text { 1913, 798-800; corr.op: } \\
\text { HPS 29, 92 }\end{array}$ \\
\hline
\end{tabular}

Van Lennep-Deutz van Assendelft (p.m.)

\begin{tabular}{l|l}
\hline AR (Amsterdam) 24 dec. 1912 & erkend (klein)kind erfgenaam \\
\hline GH (Amsterdam) 24 jan.1913 & erkend (klein)kind erfgenaam \\
& NJ 1913, 593-596; correctie op HPS 29 (1978), 92
\end{tabular}


De Vos van Steenwijk genaamd van Essen (p.m.)

\begin{tabular}{l|l}
\hline AR (Amsterdam) 30 juni 1913 & weigering verbetering geboorteakte \\
\hline GH (Amsterdam) 24 febr. 1914 & idem: betwiste biologische afstamming \\
& NJ 1914, 566-569; correctie op: HPS 29 (1978), 92 \\
\hline
\end{tabular}

Taets van Amerongen van Woudenberg (p.m.)

Kantonrechter (Utrecht) 12 mei 1917 (KB 26 jan. $\quad$ titel op kiezerslijst 1822)

HR (Burgerlijke Kamer) 19 okt. 1917 (KB 26 jan. $\quad$ titel op kiezerslijst 1822)

NJ 1917,1112; Het Personeel Statuut [HPS] 5 (1954), 155-158

Von Bönninghausen tot Heringhaven (p.m.)

\begin{tabular}{l|l}
\hline AR (Almelo) 6 maart 1929 & weigering aanvulling geboorteakte \\
\hline GH (Arnhem) 26 juni 1929 & adelsbrief bepaalt de naam \\
& NJ 1930, 408-409; HPS 29 (1978), 92 [foute datum] \\
\hline
\end{tabular}

Van Sasse van Ysselt (51/39)

\begin{tabular}{l|l}
\hline AR (Rotterdam) 14 sept. 1953 270/51 & schrappen predikaat \\
\hline GH (Den Haag) 14 jan. 1955 2R/54 & schrappen predikaat \\
\hline
\end{tabular}

Von Wedell (p.m.)

Kantonrechter (Den Haag) 19 nov. 1954 (WvSr. $\quad$ buitenlandse adellijke titel 435)

\begin{tabular}{l|l}
\hline AR (Den Haag) 23 sept. 1955 (WvSr. 435) & buitenlandse adellijke titel
\end{tabular}

\begin{tabular}{l|l}
\hline HR (Strafkamer) 14 febr. 1956 (WvSr. 435) & buitenlandse adellijke titel
\end{tabular}

NJ 1956/208

Calf de Noidans (p.m.)

\begin{tabular}{l|l}
\hline AR (Den Bosch) 19 okt. 1962 (BS) & adeldom blijft bij wijziging nationaliteit.
\end{tabular}

NJ 1963/190; Jubileumboek HRvA 1966, 89-90

Boreel de Mauregnault (70-45)

KB 9 aug. 1975, nr. 31; adv. RvS (KB 13 febr. geen adeldom bij adoptie

$1815,60)$

De Ned. Leeuw [DNL] 94 (1977), 421-423

8 juli 1975 nr. 124/BAB (1974)

geen adeldom bij adoptie

HPS 27 (1976).7-9,51-53,93-94; Liber Amicorum

C.C.v.Valkenburg [LA.CCvV] 1985, 202

Von Hertzberg (75-42)

\begin{tabular}{|c|c|}
\hline ABRvS 18 april 1978, A-1.0666 (1977) & $\begin{array}{l}\text { inlijving ook na wachtperiode } \\
\text { AB (Admin.Recht Besl.)1978, 377; DNL } 98 \text { (1981), } \\
\text { 251-258 }\end{array}$ \\
\hline ABRvS 27 jan. 1981, A-1.0889 (1980) & $\begin{array}{l}\text { geen homologatie titel } \\
\text { DNL } 98 \text { (1981), 258-263; LA. CCvV. 1985, 203; } \\
\text { Virtus } 11 \text { (2004), } 148\end{array}$ \\
\hline
\end{tabular}


Arpeau (78-42)

ABRvS 28 okt. 1982, A-1.2024 (1981)

geen inlijving Zwitserse adel

DNL 99 (1982), 463-466; DNL 103 (1986), 59-63

ABRvS 17 dec. 1985, R01.84.2502

geen inlijving Zwitserse adel

Sewandono (78-59)

\begin{tabular}{l|l}
\hline ABRvS 15 febr. 1980, A-1.0465 (1979) & $\begin{array}{l}\text { geen inlijving Indische adel } \\
\text { DNL 97 (1980), 188-194 }\end{array}$ \\
\hline ABRvS 18 aug. 1981, A-1.1949 (1980) & geen erkenning Indische adel \\
& DNL 98 (1981), 406-409; Virtus 11 (2004), 146 \\
\hline ABRvS 13 okt. 1981, A-1.1591 (1980) & inlichtingen \\
& LA.CCvV. 1985, 204-205 \\
\hline ABRvS 13 okt. 1981, A-1.1650 (1980) & inlichtingen \\
\hline
\end{tabular}

Veth (82-17)

\begin{tabular}{l|l}
\hline ABRvS 31 aug. 1981, A-2.1897 (1980) & $\begin{array}{l}\text { toevoeging naam Van Natewisch - zie: Taets van } \\
\text { Amerongen (91-13) }\end{array}$ \\
\hline ABRvS 12 nov. 1984, R02.83.1504 (AMvB 1976) & $\begin{array}{l}\text { naamswijziging in Taets v. Amerongen } \\
\text { AB 1984/242, 616-618 }\end{array}$ \\
\hline NO 1 juni 1987/R522; NO 27 okt. 1987/R922 & bevoegdheid HRvA; klacht over secretaris \\
& $A B$ 1987/489, 1433-1436 \\
\hline
\end{tabular}

Zwahlen (82-18)

\begin{tabular}{|c|c|}
\hline ABRvS 16 aug. 1984, R01.83.0427 & $\begin{array}{l}\text { vernietiging afwijzend besluit BiZa } \\
D N L 103 \text { (1986), 425-428 }\end{array}$ \\
\hline ABRvS 25 sept. 1986, R01.85.3166 & $\begin{array}{l}\text { geen inlijving Zwitserse adel } \\
\text { DNL } 103 \text { (1986), 428-431 }\end{array}$ \\
\hline
\end{tabular}

N.N. (84-6)

ABRvS 9 sept. 1985, R01.84.1081 (KB 13 febr. $\quad$ onwettig kind ongehuwde adellijke moeder $1815,60)$

DNL 102 (1985) 445-447; NJCM 1986, 522-534;

Virtus, 154

\section{C. te Schoorl (86-37)}

\begin{tabular}{l|l}
\hline [KB 15 mei 1996, nr. 96.000163] & [inlijving De Bourbon de Parme o.g.v. art. 8 Woa] \\
\hline AR (Alkmaar) 4 juni 2004, 03/1397 WOB & $\begin{array}{l}\text { openbaarheid } \\
\text { Ned.Juristenblad }[N J B] ~ 2003,1073-1074 ; \text { Liber } \\
\text { amicorum Koekkoek 2005, 11-30 }\end{array}$ \\
\hline ABRvS 20 april 2005, 200405981/1; LJN: AT4253 & $\begin{array}{l}\text { openbaarheid } \\
\text { NJB 2005, 170 }\end{array}$ \\
\hline AR (Alkmaar) 6 nov. 2007, 06/2772 WOB & openbaarheid \\
\hline ABRvS 13 aug. 2008, 200800076/1; LJN: BD9941 & openbaarheid \\
\hline AR (Alkmaar)14 okt. 2010, 09/274 WOB & openbaarheid - zie: Von Devivere (99-4) \\
\hline AR (Alkmaar) 17 nov. 2011, 10/2651 WOB & klacht over behandeling Wob door BZK
\end{tabular}


Van Andringa de Kempenaer (87-35)

ABRvS 3 juni 1990, R01.87.3997 (KB 26 jan. $1815,60)$

adoptie voorkind

DNL 107 (1990),147-150; Virtus 11 (2004), 156

Taets van Amerongen (91-13)

\begin{tabular}{l|l}
\hline ABRvS 21 febr. 1995, R01.92.0559 & geen vererving adeldom in vrouwelijke lijn \\
& AB 1996/222; DNL 112 (1995), 183-187; Virtus 11, \\
& 163
\end{tabular}

Sewandono (92-14)

\begin{tabular}{l|l}
\hline ABRvS 21 febr. 1995, R01.93.0368 & $\begin{array}{l}\text { vernietiging afwijzend besluit BiZa } \\
A B ~ 1996 / 221 ; D N L 113(1996), 341-344\end{array}$ \\
\hline $\begin{array}{l}\text { AR (Den Haag) 3 nov. 1998, AWB 95/10688 BE- } \\
\text { SLU }\end{array}$ & geen inlijving Indische adel \\
\hline ABRvS 28 juni 1999, H01.98.1959; LJN: AA3619 & $\begin{array}{l}\text { geen inlijving Indische adel } \\
N J B ~ 1999,219\end{array}$ \\
\hline
\end{tabular}

Van Drongelen (93-37)

AR (Den Haag) 3 april 1996, AWB 95/ 7462 WET afwijzing erkenning en titel

DNL 113 (1996), 221-223

Wolff Metternich (94-4)

\begin{tabular}{|c|c|}
\hline $\begin{array}{l}\text { AR (Amsterdam) } 21 \text { jan. 1998, AWB 96/11940 } \\
\text { WET }\end{array}$ & geen vererving adeldom in vrouwelijke lijn \\
\hline \multirow[t]{2}{*}{ ABRvS 16 maart 1999, H01.98.0350/15 } & geen vererving adeldom in vrouwelijke lijn \\
\hline & DNL 118 (2001), 505; NJB 1999, 1324-1325, 24 \\
\hline \multirow[t]{2}{*}{ EHRM 18 mei 1999, nr. 45908/99 } & geen vererving adeldom in vrouwelijke lijn \\
\hline & $\begin{array}{l}\text { DNL } 118 \text { (2001), 505-506; Virtus } 11 \text { (2004), 160, } \\
165\end{array}$ \\
\hline $\begin{array}{l}\text { AR (Amsterdam) } 4 \text { april 2001, AWB 99/9594 } \\
\text { WET (AWB 4:6) }\end{array}$ & geen nieuwe feiten/omstandighheden \\
\hline $\begin{array}{l}\text { GH (Den Bosch) } 4 \text { aug. 2009, K09/0065 (WvSv } \\
\text { 12) }\end{array}$ & klacht over OM niet ontvankelijk \\
\hline AR (Maastricht) 8 juli 2011 (WvSr 435) & onbev. gebruik titel graaf \\
\hline
\end{tabular}


N.N. $(95 / 80)$

AR (Den Haag) 26 sept. 1997, 96/12185 BESLU

ABRvS 14 jan. 1999, H01.97.1359

afwijzing titel graaf

ABRvS 30 dec. 1999, 199900192/Y40 (AWB 8) afwijzing titel graaf

geen nieuwe feiten/omstandigheden

Quast (96-16)

AR (Den Haag) 5 jan. 2000, AWB 98/650, 98/652, afwijzing inlijvingsverzoek en $98 / 655$ BESLU

ABRvS 17 april 2001, 200000753/1; LJN: AB3304 afwijzing inlijvingsverzoek

AB 2003,317; Virtus 11(2004),151; Jb.CBG 59

(2005),139-152

NO 17 sept. 2001/287; NO 30 mei 2006/193

klacht over BZK en secr.HRvA

Jvsl. HRvA 2006; DNL 124 (2007), 18-24

AR (Amsterdam) 24 nov. 2010,442376/HA ZA 09- weigering publicatie DNL

3536; LJN: BP7902

Meded. KNGGW 2011-2; DNL 128 (2011), 97

Lutter (96-17)

AR (Den Haag) 5 jan. 2000, AWB 98/88 BESLU afwijzing inlijvingsverzoek

ABRvS 17 april 2001, 200000823/1; LJN: AB1234 afwijzing inlijvingsverzoek

Jb.CBG 59 (2005),139,150; DNL 124 (2007), 24-32

De Lange (van Bergen) (96-37)

AR (Den Bosch) 15 mei 2000, AWB 99/3218 BE- naamstoevoeging vóór inlijving

SLU

Jb.CBG 59(2005),138-139,150; Ned. Adelsb. 95

(2010), 514

AR (Den Haag) 1 nov. 2004, AWB 04/1308 BE- $\quad$ naamstoevoeging ná inlijving

SLU

ABRvS 17 aug. 2005, 200410185/1; LJN: AU1108 naamstoevoeging ná inlijving

Poerbodipoero (97-31)

\begin{tabular}{l|l}
\hline AR (Den Haag) 11 juni 1999, 98/6700 BESLU & geen inlijving Indische adel
\end{tabular}

HPS 4 (1953), 80-82, 97-98 (WSr.435)

ABRvS 19 mei 2000, 199901310/01; LJN: $\quad$ geen inlijving Indische adel

AA6822

Van Beijma (97-33)

AR Middelburg) 24 nov. 1999, AWB 98/7+C2429 filiatieregister

DNL 118 (2001), 506-507

ABRvS 27 juni 2001, 200000061/1; LJN: AB3095 beperkte bevoegdheid HRvA

DNL 119 (2002), 36-47; NJB 2001, 206

AR (Middelburg) 20 april 2004, AWB 03/419; $\quad$ adoptie

LJN: AO8367

ABRvS 5 jan. 2005, 200404471/1; LJN: AR8732

adoptie; $A B$ 2005, 62; Jvsl. HRvA 2005;

DNL 122 (2005), 227-232

C. te Schoorl (99-4)

\begin{tabular}{l|l}
\hline [KB 17 juli 1999, nr. 99.001530] [inlijving Von Devivere o.g.v. art. 8 Woa] \\
\hline
\end{tabular}




\begin{tabular}{l|l}
\hline AR (Den Bosch) 15 jan. 2003, WOB & openbaarheid \\
\hline AR (Alkmaar) 6 nov. 2007, 06/3352 WOB & openbaarheid \\
\hline ABRvS 13 aug. 2008, 200800078/1 & openbaarheid \\
\hline AR (Alkmaar) 14 okt. 2010, 09/274 WOB & openbaarheid - zie: De Bourbon de Parme (86-37) \\
\hline ABRvS 27 juli 2011, 201011248/1/H3; LJN: & openbaarheid \\
BR3196 & De Gemeentestem (GST) 2011, 91 \\
\hline AR (Alkmaar) 2012,11/581 BESLU V05 & openbaarheid \\
WOB;11/1926 AWB & \\
\hline
\end{tabular}

N.N. (99-17)

AR (Amsterdam) 4 juli 2002, AWB 00/2163 WET afwijzing titel baron

ABRvS 29 april 2003, 200204427/1; LJN: AF7987 afwijzing titel baron

Jvsl.HRvA 2003; AB 2005, 63; Liber amic. J. v.

Rijckevorsel 2009

Tullingh (99-20)

\begin{tabular}{l|l}
\hline AR (Amsterdam) 13 maart 2002, AWB 00/4102 & afwijzing erkenning \\
WET & \\
\hline ABRvS 27 nov. 2002, 200202321/1; LJN: AF1128 & $\begin{array}{l}\text { afwijzing erkenning } \\
\text { Virtus } 11(2004), 145\end{array}$ \\
\hline
\end{tabular}

C. te Schoorl $(98 / 242)$

\begin{tabular}{l|l}
\hline NO 2 april 2004/113 & $\begin{array}{l}\text { klacht over AZ, BZK en HRvA } \\
\text { Jvsl. HRvA 2004 }\end{array}$
\end{tabular}

N.N. (03-17)

NO 9 juni en 18 aug. 2004, nr. 2004.02398 (Woa 8) geen inlijving (vermeende) Italiaanse adeldom Jvsl. HRvA 2003/2004

Nederlandse Adelsvereniging (05/263)

AR (Alkmaar) 31 okt. 2007, AWB 07/377 BESLU $\quad$ RDW-brief geen besluit DNL 127 (2010), 86-87

Van Isselmuden (05/263)

AR (Arnhem) 1 nov. 2007, AWB 07/1306 WET; $\quad$ titel op kentekenbewijs verplicht LJN: BB6978 AB 2007, 367; Jvsl. HRvA 2007; DNL 127 (2010), $86-87$

N.N. (06-16)

\begin{tabular}{l|l}
\hline AR (Rotterdam) 19 mei 2006, BESCH 256363 & $\begin{array}{l}\text { schrappen predikaat } \\
\text { Jvsl. HRvA 2004 en 2006 }\end{array}$ \\
\hline AR (Rotterdam) 22 sept. 2006, 256369/70 F2 RK & schrappen predikaat \\
06/447/8; LJN:BW4217 & DNL 125 (2008), 150-152 \\
\hline
\end{tabular}


N.N. (07-14)

AR (Utrecht) 13 juni 2007, BESCH 217483 schrappen predikaat

Jvsl. HRvA 2007

N.N. (07/388)

\begin{tabular}{l|l}
\hline AR (Den Haag) 19 mei 2008, 292615 BW 1:25 & ambtshalve toevoevoeging predikaat
\end{tabular}

Jvsl. HRvA 2008

N.N. (08-7)

AR (Haarlem) 25 okt. 2011/184609/FA RK 11-

HRvA belanghebbende

2853 (BW 1:24)

AR (Haarlem) 24 april 2012/184609/FA RK 11Jvsl. HRvA 2008

2853; LJN: BW5042 predikaat geen onderdeel naam

Jurisprudentie Personen- en Familierecht 2012, 86

'Van Wilderoden d'Aragon' (10/129)

AR (Zutphen) 1 juli 2011, 06/940305-10 en

verzonnen valse naam en titel

06/850746-10 (WvSr 226)

LJN: BQ9982; Ned. Jurisprudentie Feitenrecht-

spraak Strafzaken 2011, 229 


\section{Wetgeving in druk 1809 en 1814}

1. Grondwet constitutionele adel Koninkrijk Holland, 22 april 1809
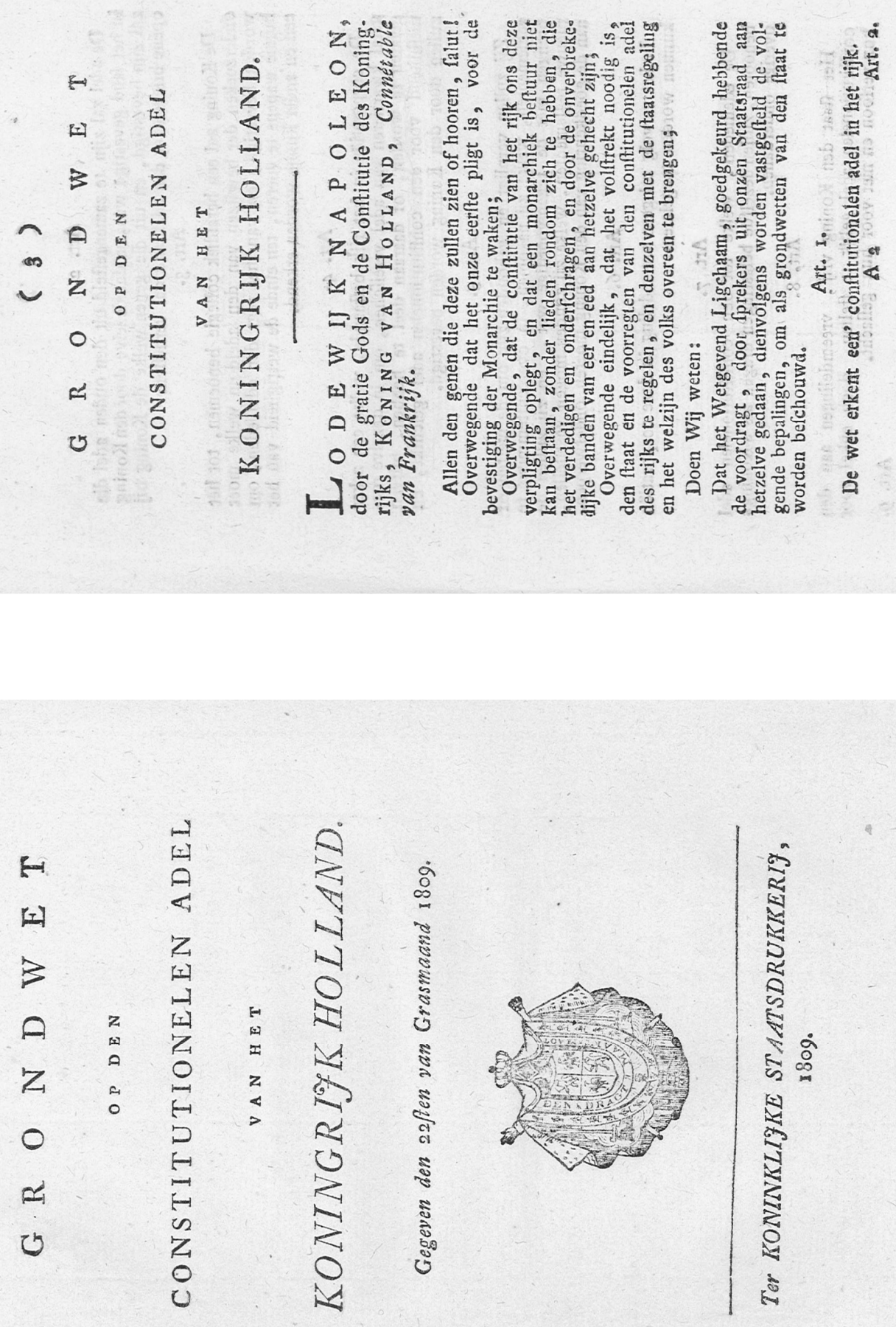

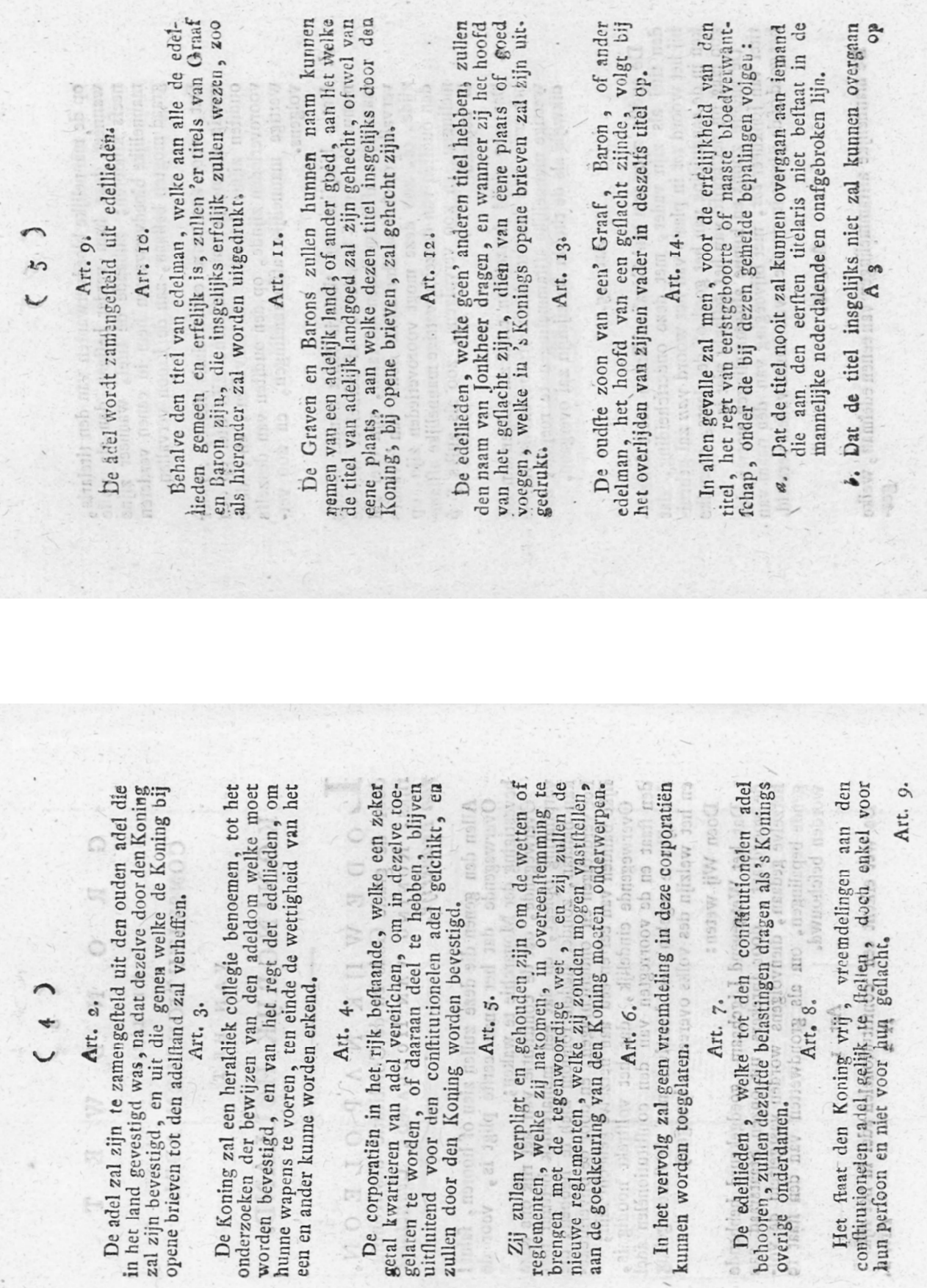

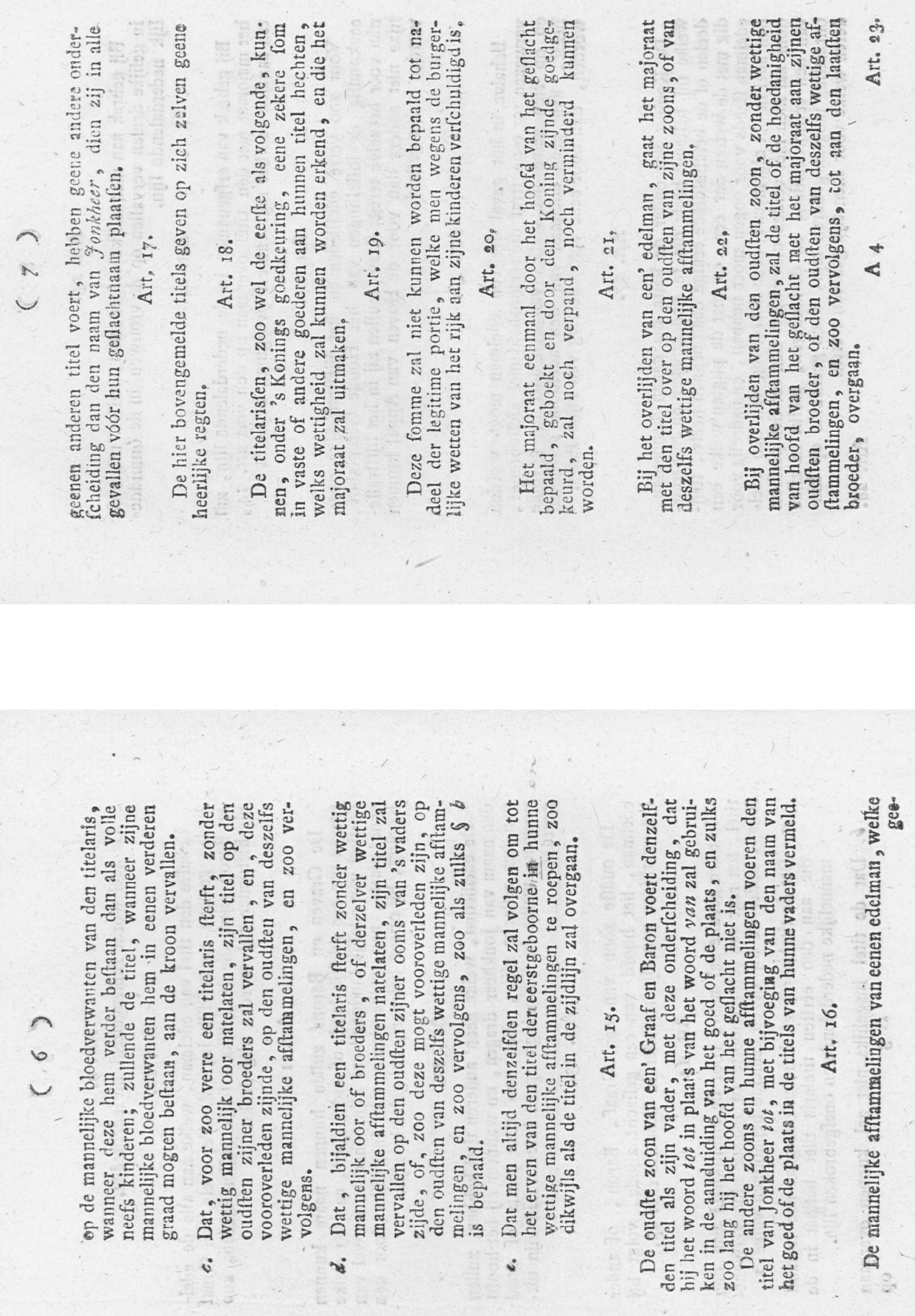


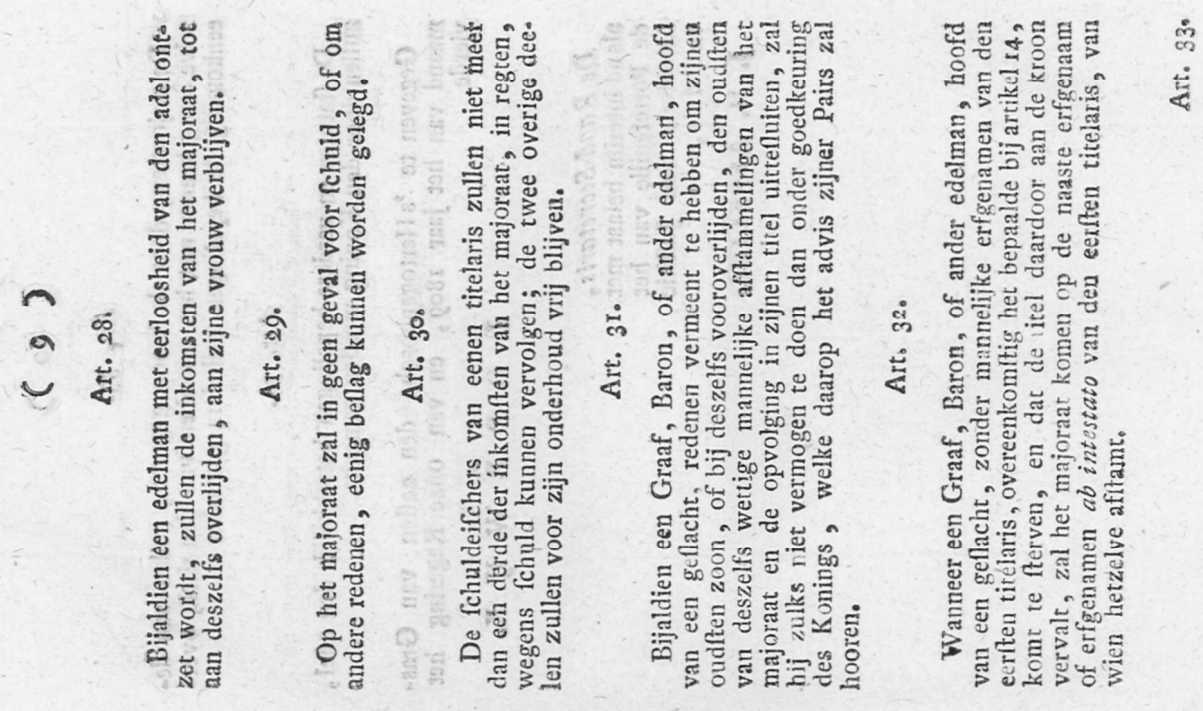

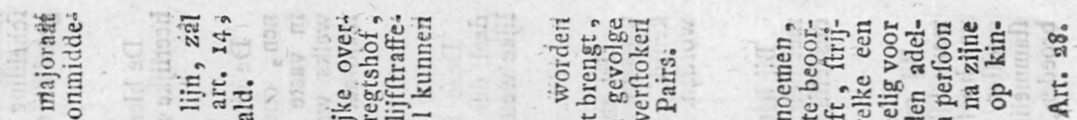

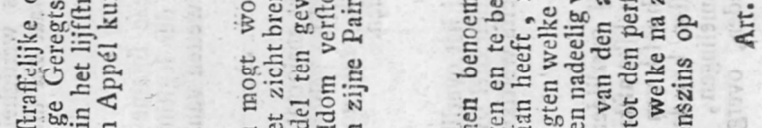

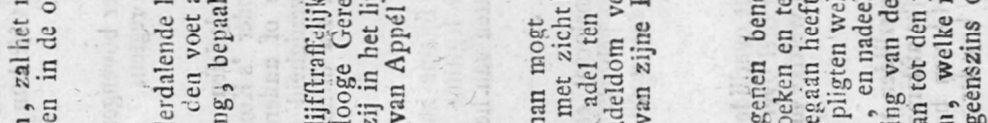

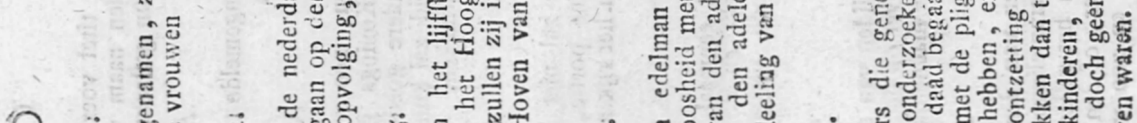

$$
\begin{aligned}
& \text { 们 }
\end{aligned}
$$

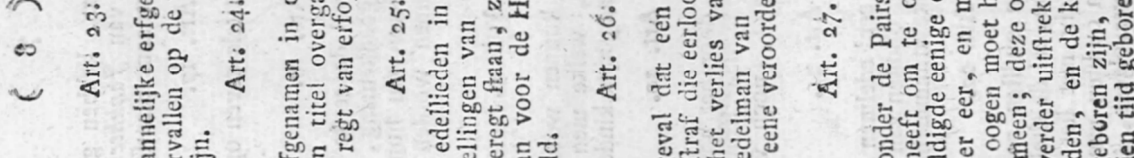

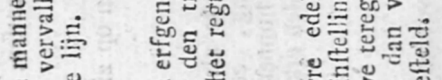

$$
\begin{aligned}
& \text { हี }
\end{aligned}
$$

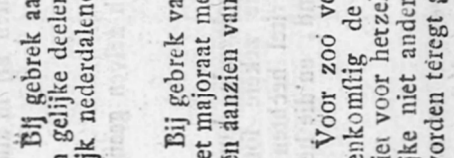

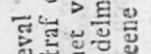

$$
\begin{aligned}
& \text { แू }
\end{aligned}
$$

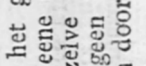

$$
\begin{aligned}
& \text { 政政 }
\end{aligned}
$$

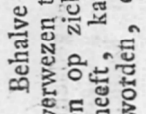

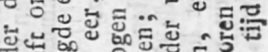

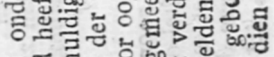

$$
\begin{aligned}
& \text { สำ } \\
& \text { br } \\
& \text { 船: } \\
& 4 \text { 월 }
\end{aligned}
$$

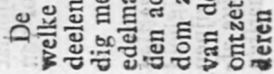




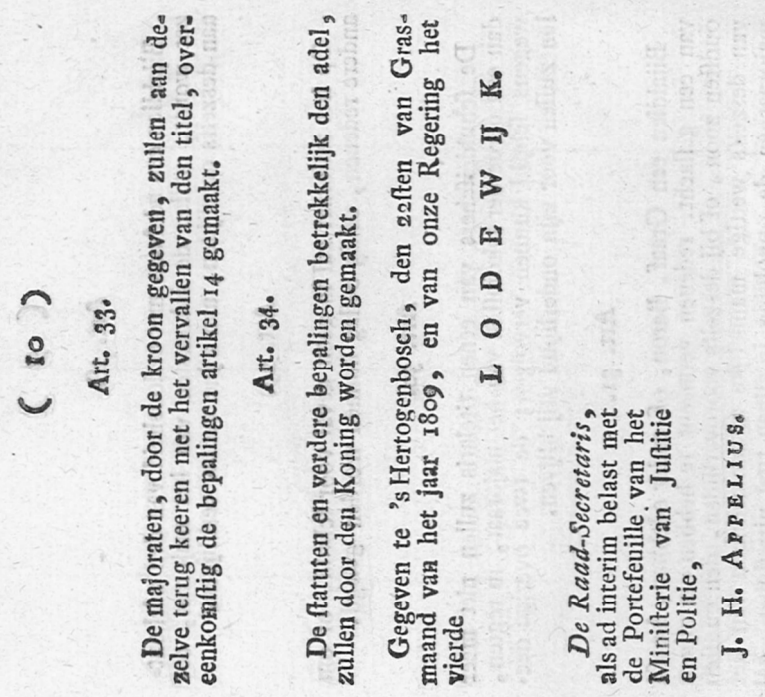


2. Statuten constitutionele adel Koninkrijk Holland, 1 oktober 1809
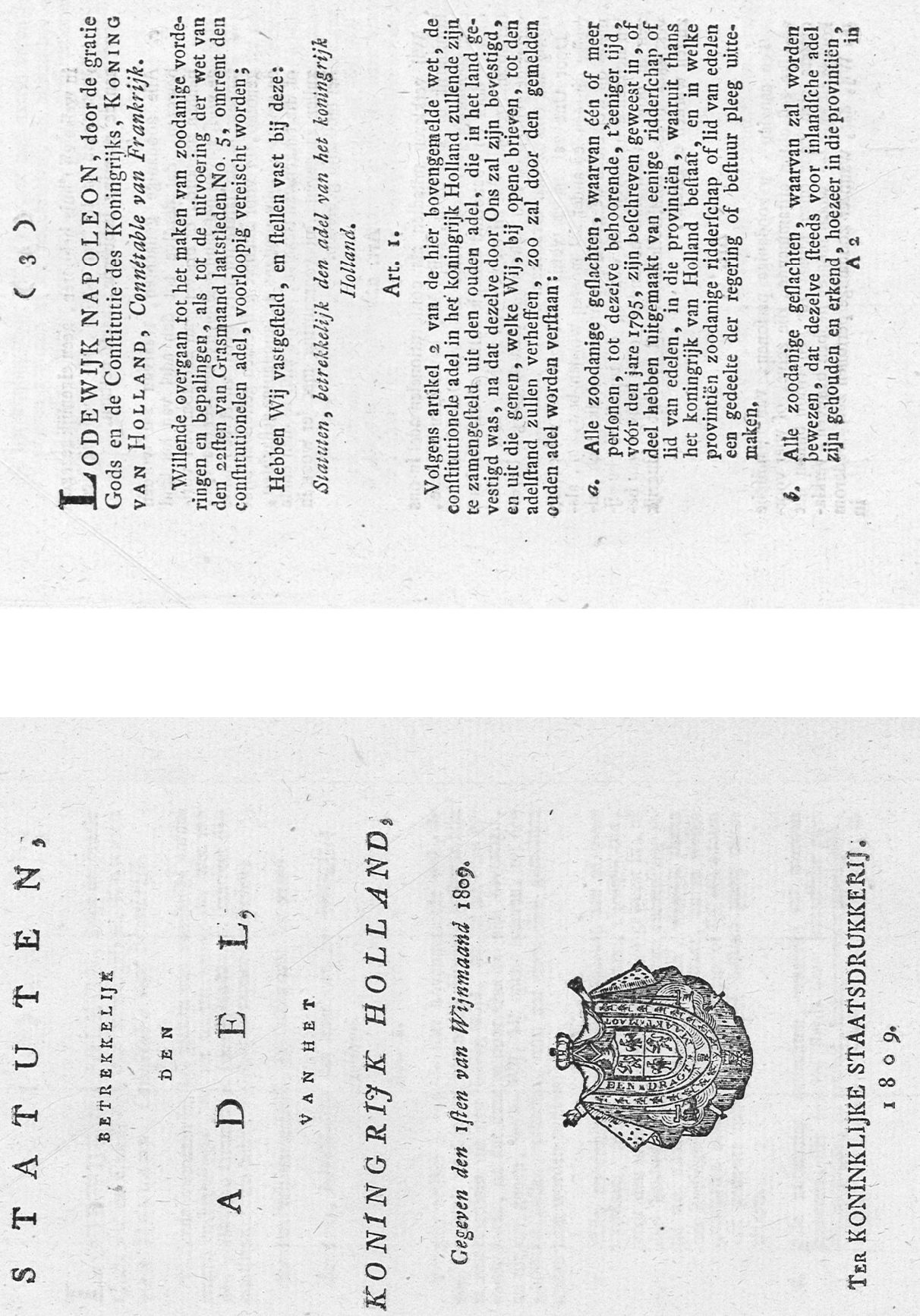


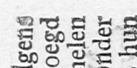

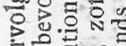

s.

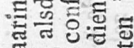

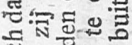

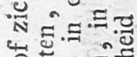

a

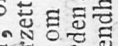

in

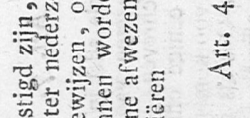

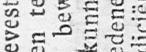

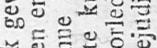

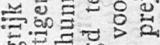

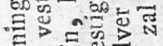

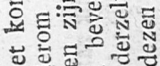

过苛, क्ष

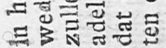

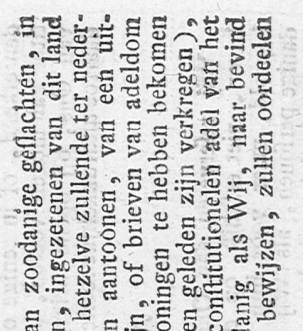

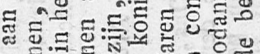

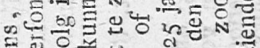

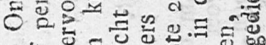
零

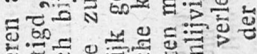

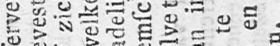

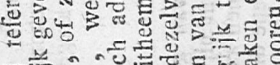

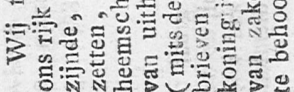

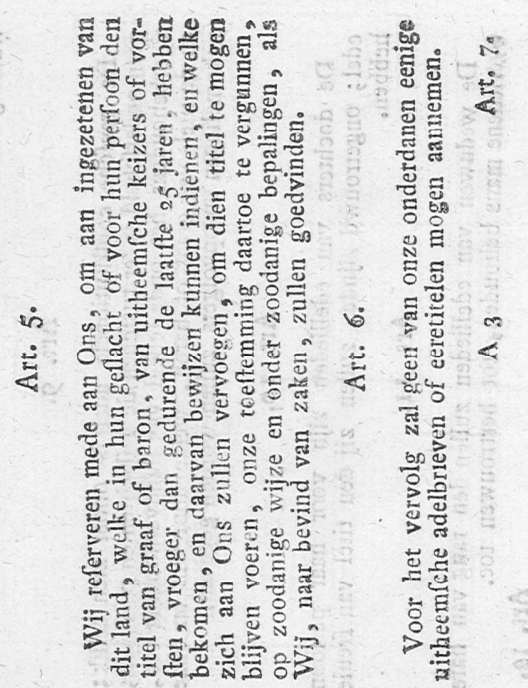

ญँّ

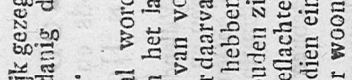

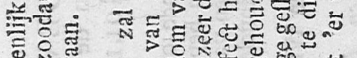

듕

等 D

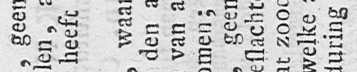

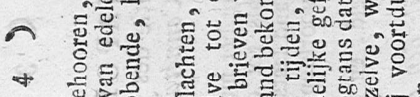

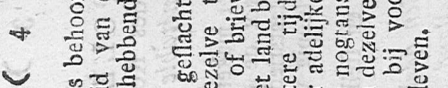
象胥

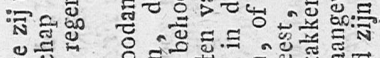

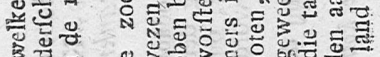

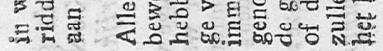
s)

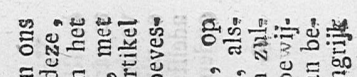

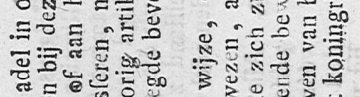
=

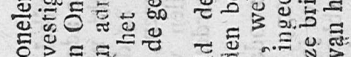

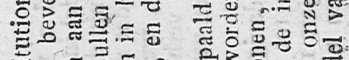
结:

a

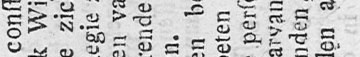

¿

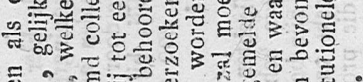

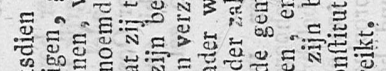

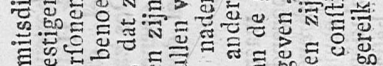

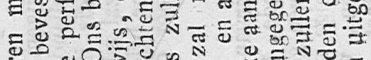

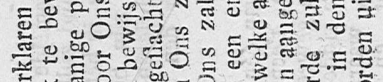

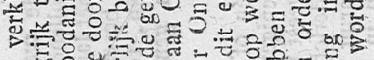
$=5$ 今.

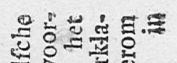

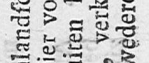

$\because \Xi_{0} \overline{0}$

क

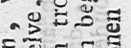

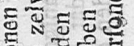

:

ल

党苛

䒕选造:

욜 요유

令

हते

동 $\frac{5}{2}$

둔 

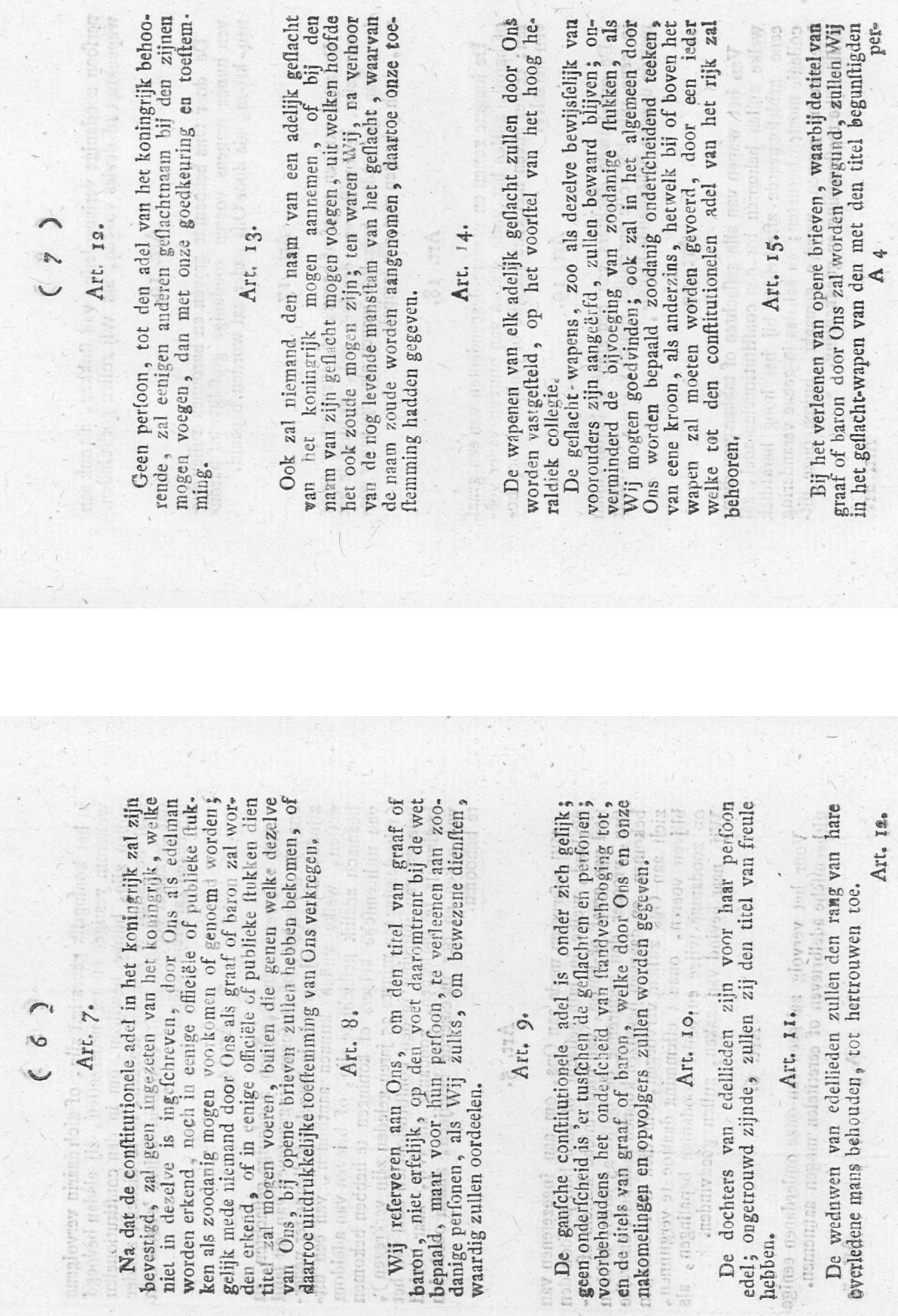

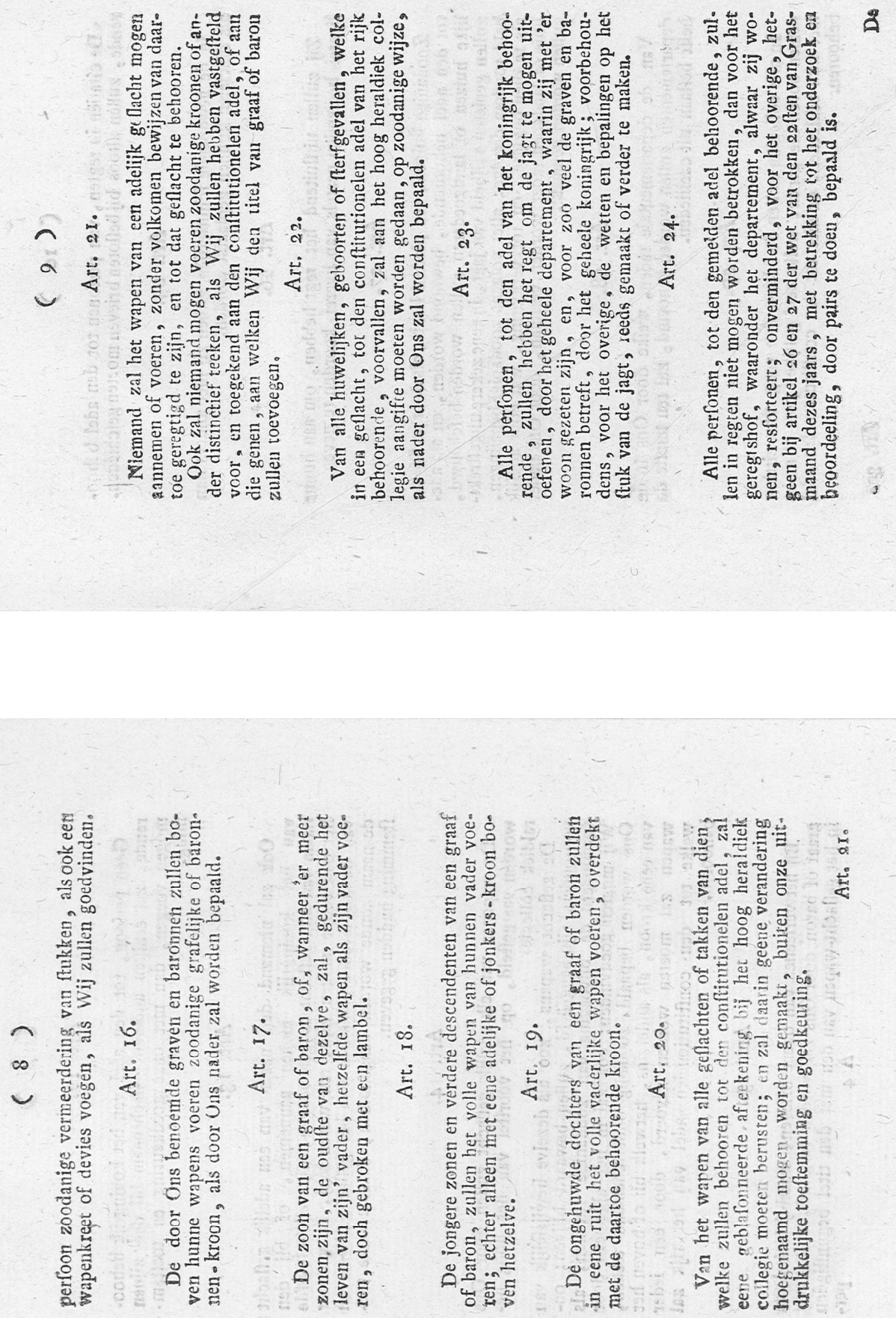

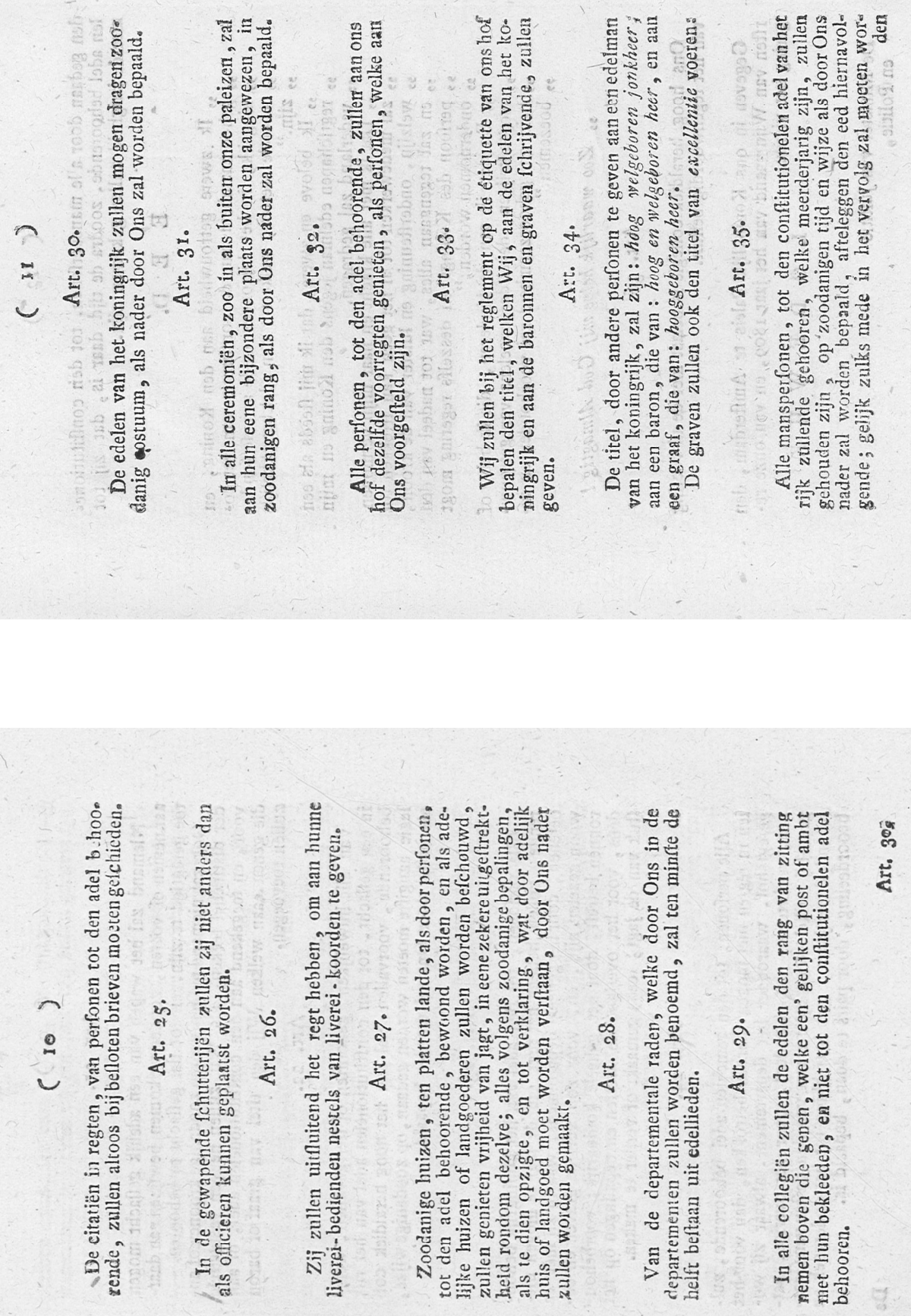


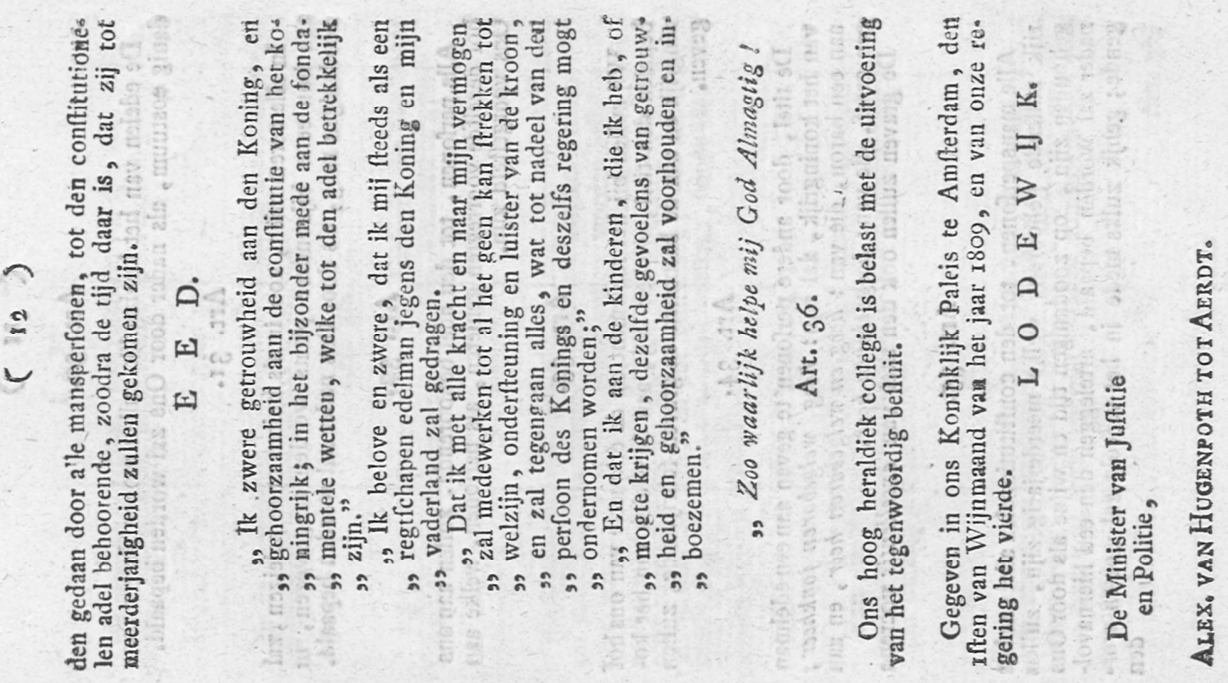


3. Besluit tot wijziging art. 29 van de Statuten, 21 november 1809
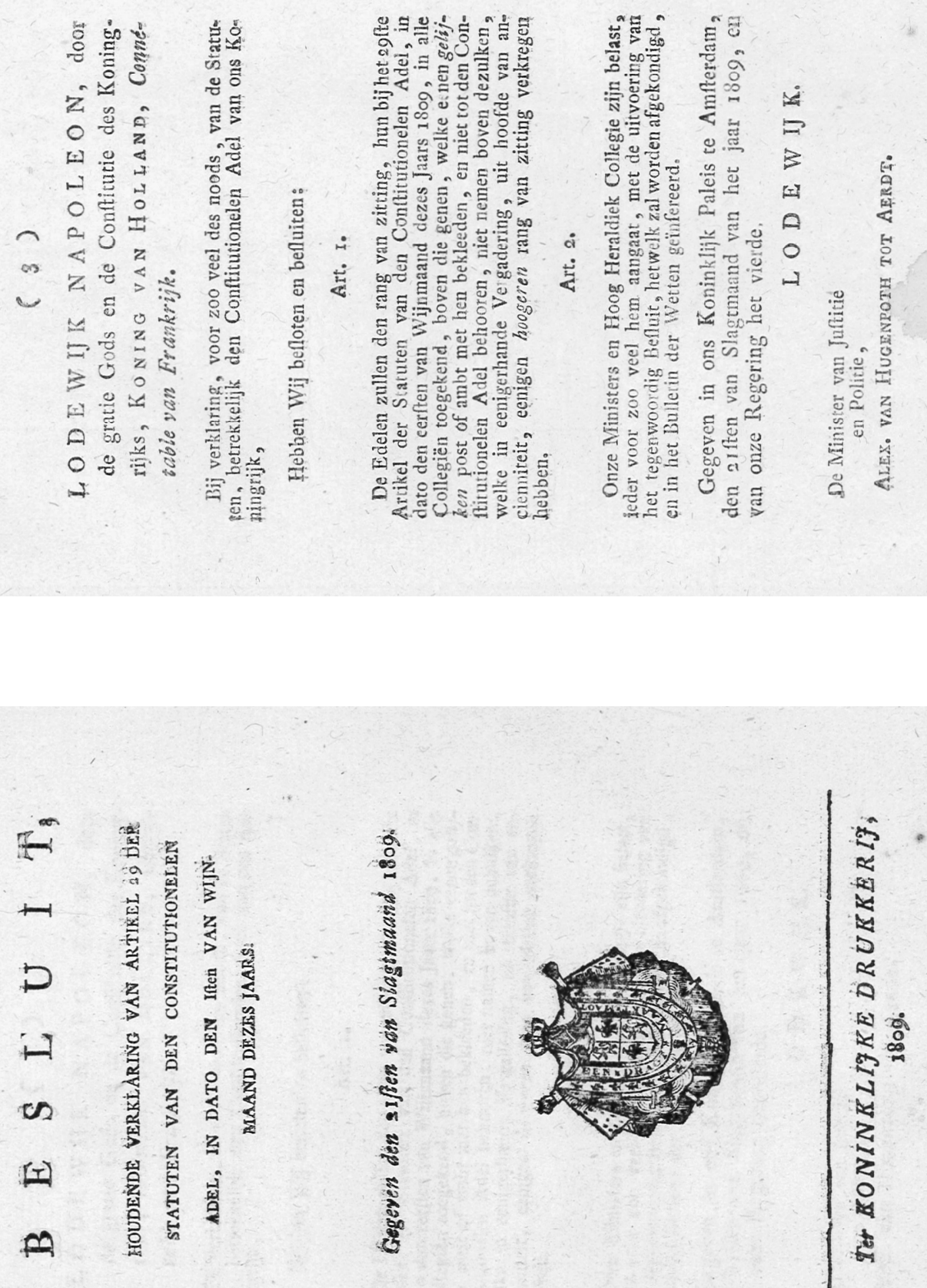
4. Instructie Hoge Raad van Adel, 24 juni 1814
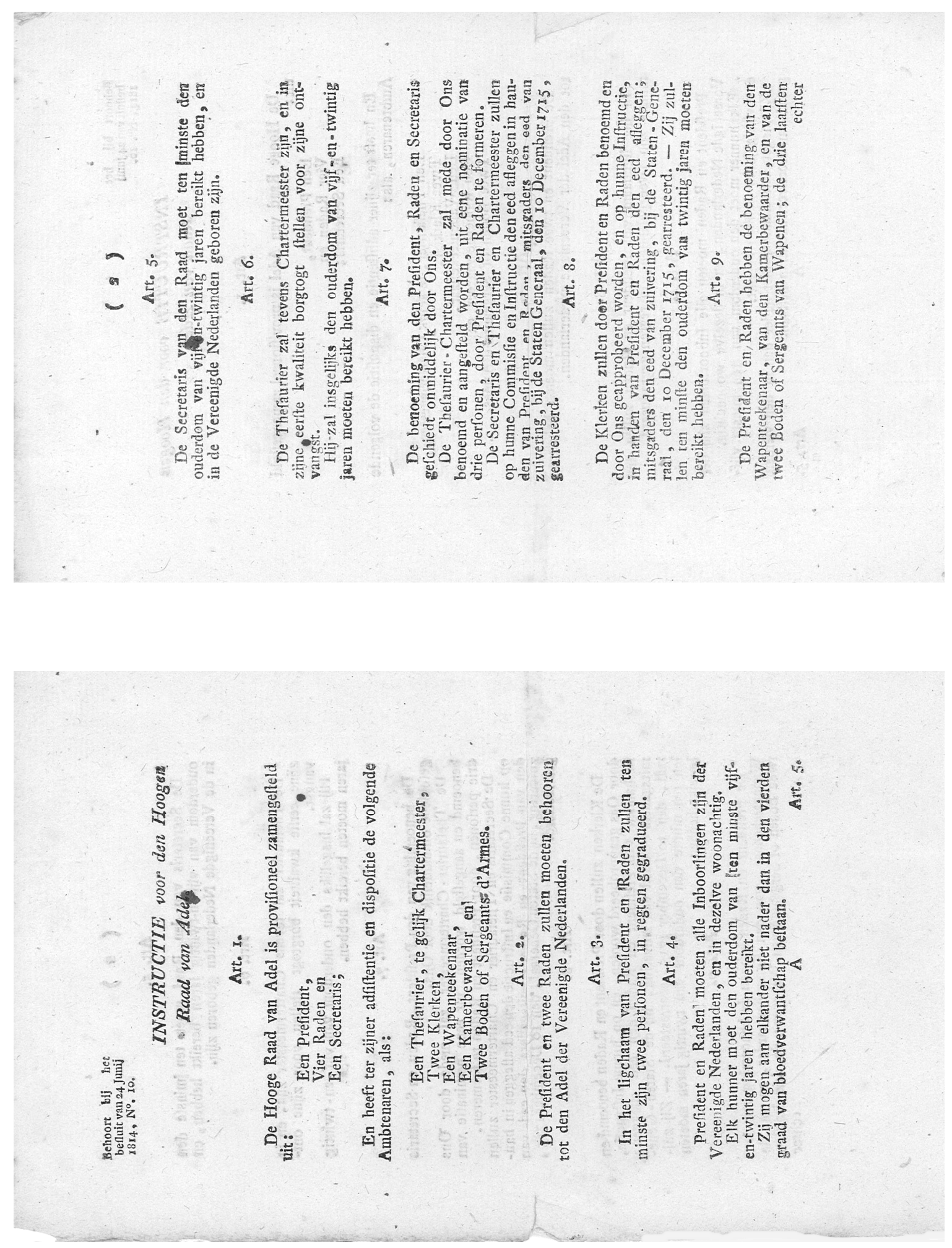

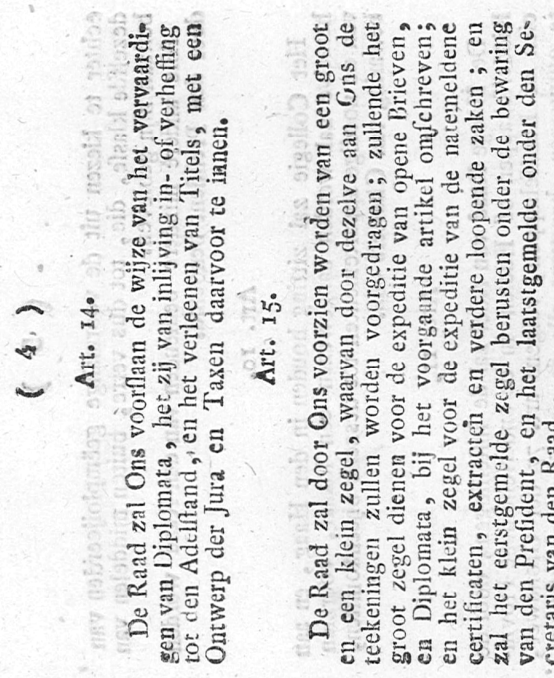

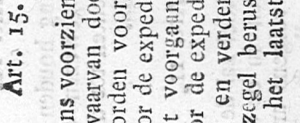

ô.

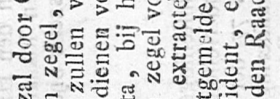

N. T)

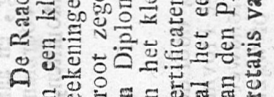

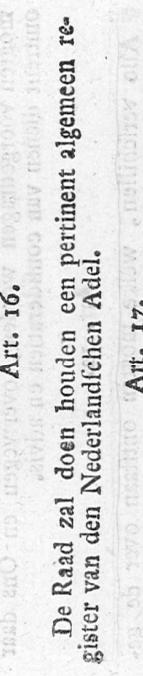

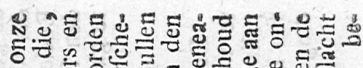

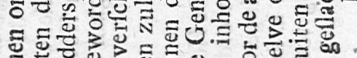

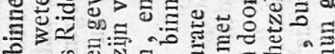

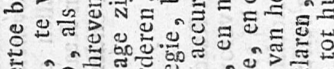

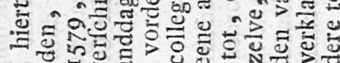

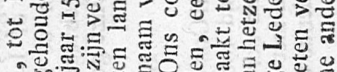
50.

혱

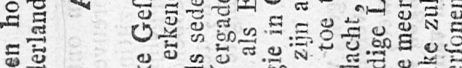

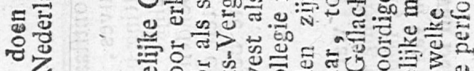

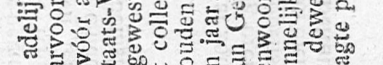

of

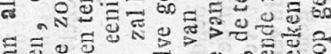

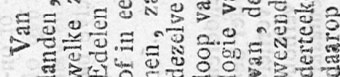
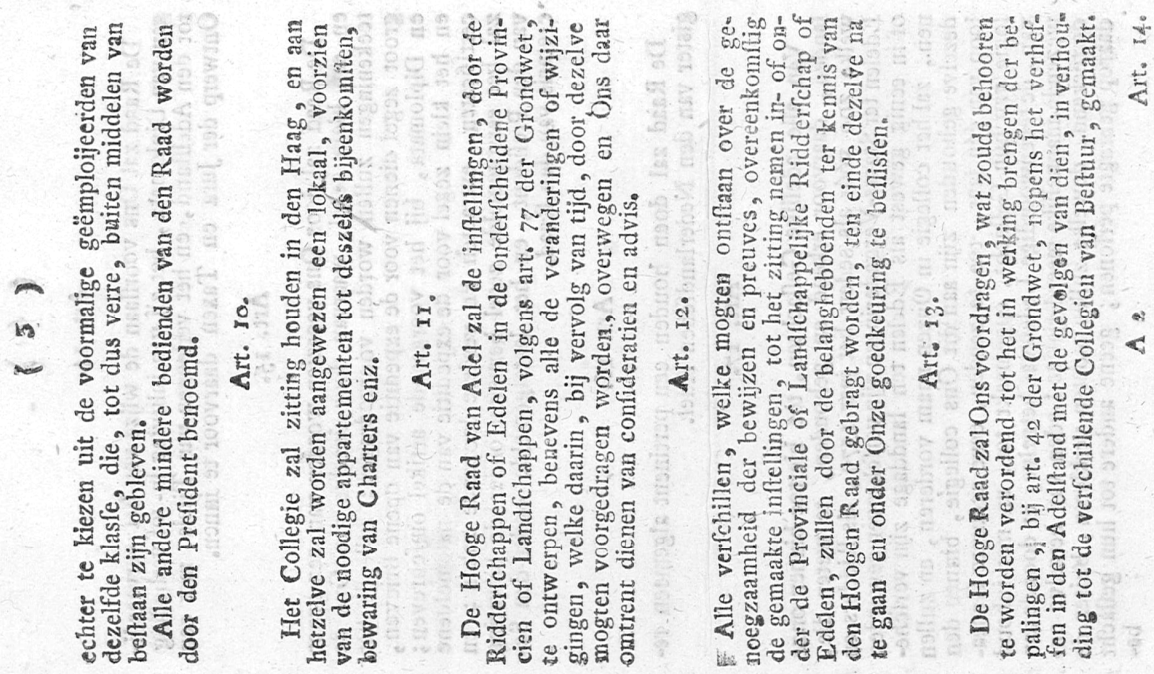

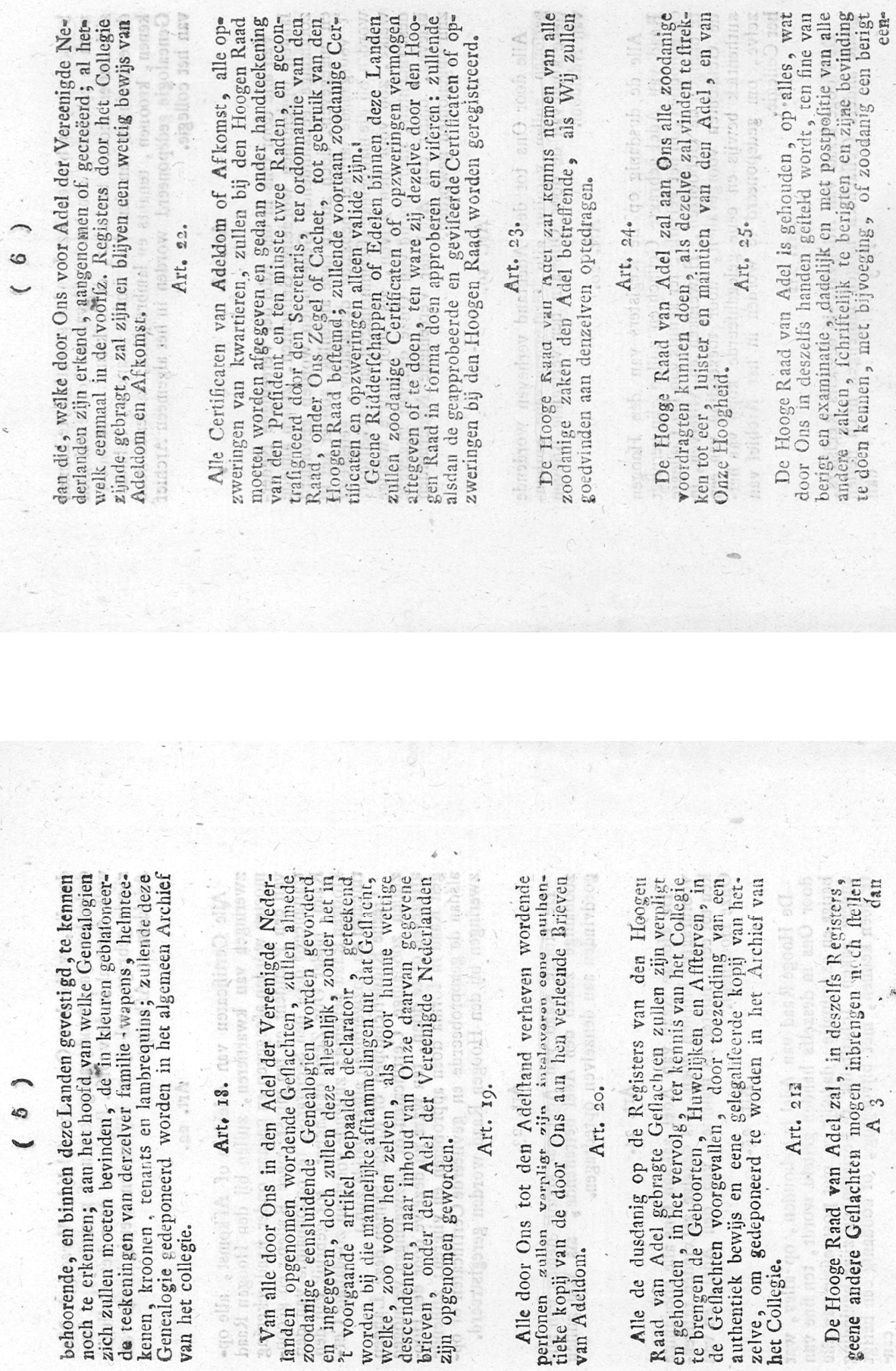

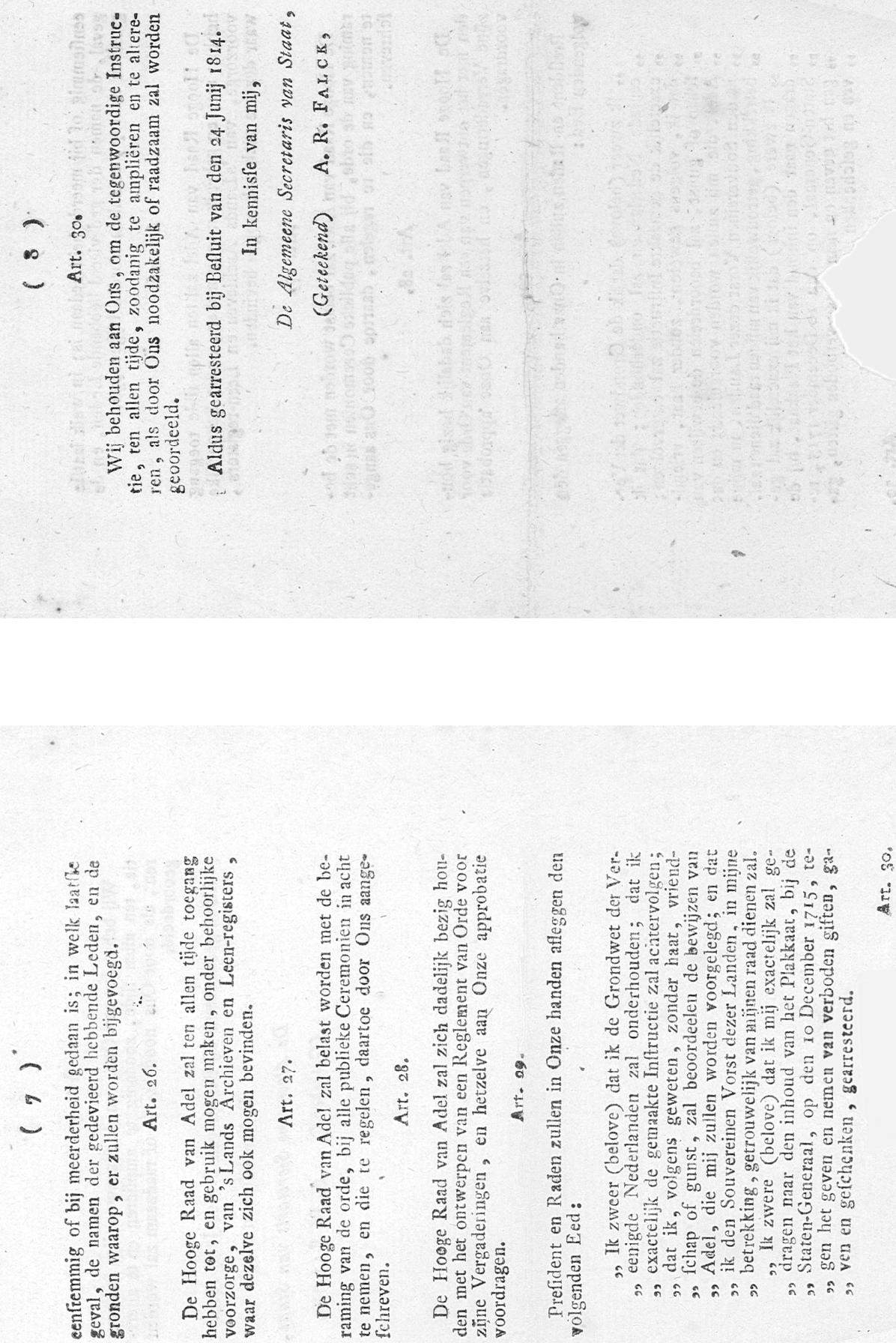


\section{Register}

Aalbers, J. - ...........................................24

Ablaing van Giessenburg, W.J. d' - ....13, $81,84,85,86,89,200,246,248,251$, 257, 258

Albrecht, aartshertog - ...................16, 51

Alvensleben, geslacht Von - ................59

Amsberg, geslacht Von -....................183

Amsterdam 24, 27, 31, 36, 41, 45, 46, 52, $55,57,63,86,90,104,118,122,131$, 138,145

Andreae, S.J. Fockema - ....................203

Anna, prinses - ....................................185

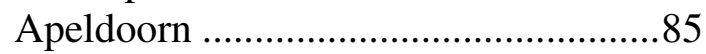

Appeldoorn, M.H.J. Soutendijk-van 126,148

Aranjuez.... 178

Ariëns, C. 131

Arkel, D.H. van -.................................. 98

Arnhem ..................................................34

Arpeau, M.D. - ..........................114, 292

Aruba..............................................2225

Asbeck, G.C. van -...............94, 96, 257

Asbeck, G.F. van - .............................62

Asbeck, geslacht Van - .......................62

Asser, W.D.H. -................................227

Athene ................................................122

Bach, G. ...........................................102

Bachasson comte de Montalivet, J.P. - 41

Bajetto, M.L.F. - ................................102

Balkenende, J.P. -...............160, 182, 211

Balluseck, geslacht Von - ..................139

Balveren, geslacht Van - .....................66

Barnaart, W.Ph. - ............................40, 41

Bas, F. de - .........................................91

Beatrix, koningin - ......55, 116, 118, 121, 139, 175, 180, 184

Beaufort, geslacht De - ......................96

Beauharnais, H.E. de - ...................30, 38

Beel, L.J.M. - 19, 25, 100, 102, 103, 105, 106, 107, 204, 253, 256

Beelaerts van Blokland, F. -..96, 98, 102, 203, 257

Beelaerts van Blokland, F.W.A. - ......129
Beelaerts van Blokland, M.A. - ....18, 24, 41, 110, 129, 258

Beelaerts van Blokland, W.A. - ....94, 96, 97, 257, 258

Beenhakker, A.J. -..............................264

Beijma, P.J. van - .................................. 84

Beijma, P.L. van - .....................120, 294

Beijma, S. van -.........................187, 188

Bell, C.J.J. -........................................... 98

Bergerduin ...........................................39

Bergh, L.Ph.C. van den - ...................257

Bernhard (jr.), prins - ................ 162, 170

Bernhard, prins - .................................. 184

Bernstorff, geslacht Von -....................59

Berssenbrugge, H. - ..............................97

Besselink, L.F.M. - .............................243

Beydaels de Zittaert, Ch. - ................... 71

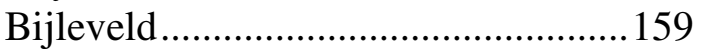

Bleiswijk, H.A. van - ............................ 35

Blok, P.J. -..................................106, 255

Boddaert, A.R.Ph. -....................188, 189

Bodelschwingh-Plettenberg, A.E.L.C. von - .............................................59

Bodelschwingh-Plettenberg, C.W.G.J. von - .............................................60

Boecop, geslacht Van - ......................221

Boer, J. de - .......................................222

Boetzelaer, geslacht Van - ..................67

Bollier, C. - ........................................ 129

Bonaire ................................................225

Bonaparte, keizer Napoleon - .18, 29, 32, $35,38,40,51,55,73,178,233,254$

Bonaparte, koning Lodewijk Napoleon $12,18,24,31,32,41,48,56,72,186$, 233, 254

Bonaparte, koning Napoleon Louis -..30, 38

Bönninghausen tot Heringhaven, L.E.M. von -..............................................291

Bönninghausen tot Herinkhave, T. von -

Borch, geslacht Van der - ............66, 67

Boreel de Mauregnault, geslacht - ....113, 291

Borssele, geslacht Van -.... .60 
Bosch, huis ten 139

Bosch, J. van den .254

Boucher, A.E. .97

Bourbon de Parme, geslacht De - .....142, 177, 178, 184, 202, 292

Bourbon, geslacht De $.75,179$

Bourbon, huis De 178,179

Brakell van den Eng, F.L.W. van - 59, 60 Brandeler, M. van den - .....144, 193, 258 Brauw, E.N. de .98

Breda 124

Bree, J.T.L.M. van .268

Bremmer, C. 147

Breugel Douglas, R. van -...................58

Brink, R.C. Bakhuizen van den - .......257

Brinkhorst, geslacht 182

Brinkhorst, P.L. - .......155, 170, 173, 182

Broek, M.H. van den - ........................169

Bruno, A. - ...........................................36

Brunswijk-Wolfenbüttel, L.E. van - ..185

Brussel...........27, 54, 55, 62, 68, 71, 72

Bruyn van Melis- en Mariekerke, M.J.H. de 107,258

Buchwaldt, C.J.A. Snouckaert van Schauburg.258

Burg, F.H. van der - ...164, 178, 179, 180

Burg, M.M. van der 126,147

Burg, V.A.M. van der - ....113, 117, 133, 135, 138, 143, 146, 147, 149, 156

Burger, J.A.W. 102

Burghartz. 194

Butkens, Chr. ...65

Bye, P.J. de 18,41

Bylandt (Bijlandt), C.J.E. van -..........257

Bylandt van Halt, F.S. van .35

Calf de Noidans, A.M.J. $.70,291$

Cals, J.M.L.T. $116,117,119,182$

Cannes. . .86

Capellen tot den Poll, J.D. van der - ....27

Capellen, R.H.O. van der -......94, 96, 97, 257

Carlos Hugo, prins -...177, 178, 179, 268

Carolina, prinses 185

Cels, C. .44

Chais, Ch.A. .258

Changuion, F.D. .119

Charlotte, prinses .51

Chassé, D.H. 41

Christina, prinses
Citters, L. de Witte van -.....83, 200, 201, 248, 257

Claus, prins $172,175,183$

Clifford, geslacht - ..............83, 124, 290

Clifford, H.M.C. - ................................2221

Cobben, H.P.M. - ...................................263

Coenraad, R.P.N. - .......................20, 22

Coeverden, geslacht Van -..........67, 187

Coeverden, J.W. van -..................67, 68

Colijn, H. - .................99, 203, 252, 253

Constantijn, prins -....155, 161, 170, 175, 182, 187, 223

Cremers, E.J.I. 35

Crommelin, A. van Wickevoort - 86, 181

Curaçao ......224, 225, 226, 227, 228, 240

Daendels, H.W. $27,29,37$

Dales, C.I. - ........130, 131, 132, 176, 234

Dedem, A.B.G. van - ..........70, 119, 206

Deutmann, $\mathrm{H}$. .95

Deutz van Assendelft, P.A. - ............2290

Devivere, geslacht Von - ..178, 202, 203, 294

Dijk, C.P. van $128,129,130$

Dijkstal, H.F. $126,145,150,234$

Dittrich, B.O. - .. 126, 144, 145, 146, 148, 151,156

Doggersbank 39

Dohmen, R. .68

Dokkum 242

Dönhoff, F.L.C.E.A. von - ....................59

Donker Curtius, D. - .............................. 77

Donker Curtius, W.B. -.......................69

Donner, A.M. -..................116, 117, 119

Donny, F.C.L. -..................................... 71

Doortmont, M.R. - ............................259

Dorp, C.I.J.M. Ross-van -..151, 154, 156, 160

Dorp, L. van -................................... 115

Dortmund ............................................47

Drees, W. - ....14, 19, 105, 107, 116, 204, 240

Drongelen, P. van - ............................2293

Dronkers, W.

Dumonceau, J.B. -..........................37, 39

Duyn van Maasdam, A.F.J.A. van der 45,55

Eck, geslacht Van Panthaleon van -..123, 221

Elba 
Eldermans .............................................98

Elsevier, W.I.C. Rammelman -..........257

Emma, koningin-regentes -.....14, 88, 89, 90, 91, 184

Endt, N. van der -................................97

Es, A.C. van - ...................................... 194

Eschauzier, J.P. -...............144, 193, 258

Eurlings, E.P.A. - ..............................238

Eysten, P.A. Wackie - ........................262

Faber, J.C. - ........................................ 98

Fagel, H. - ............................................ 45

Falck, A.R. -.......................................65

Falck, O.W.Ph. - ................................254

Feltz, geslacht Van der - .....................87

Ferwerda, A. - .....................................65

Finckenstein .........................................33

Franco y Bahamonde, F.P.H.T. - .......179

Frankfurt ............................................... 71

Frederik Hendrik, prins -......................51

Frederik Willem I, koning - ................92

Frederik Willem II, koning - ...............27

Frederik, prins -................................... 73

Friso, prins -.......163, 174, 175, 187, 222

Fruin, R.J. - ........................................91

Fürstenberg, M.L.A.C.H.F. von - ......229

Garcia Avello, C. - ...................210, 244

Geertsema, W.J. -................................112

Geldermalsen ......................................60

George III, koning - ..............................45

Gérard, F.P.S. - .................................... 30

Gevers, D.M. - .....................................98

Gewin, J.P.J. - ...........................258, 265

Giessendam ..........................................101

Gietman, C.A.M. - ................................ 17

Godefroi, M.H. - ....................................84

Goes van Dirxland, L.N. van der -....249, 251, 257

Goes, A.C. van der -.........................257

Goes, M. van der -.................................33

Goltstein, W. van -.............................257

Gotha........................................35, 177

Graswinckel, D.P.M. - ..............110, 258

Gratama, L. Oldenhuis -................86, 87

Groen van Prinsterer, G. - ..........106, 255

Groeneveld, A. -.................................121

Groningen .................................105, 121

Groot (Schneider), G.R. de - .......20, 109, 121, 122, 143, 144, 146, 158, 159, 161, 169, 170, 190, 195, 210, 211,
$213,214,215,224,225,226,228$, 236, 241, 243, 262, 268

Groot, Hugo de .5

Grunkin Paul, L.M. -...........................2231

Gubbels, E.W.M. - ..............................211

Haag, Den -.... 17, 21, 25, 28, 32, 45, 50, $52,55,66,68,71,73,74,85,89,92$, 95, 97, 98, 99, 107, 118, 121, 122, 129, 131, 138, 139, 144, 193, 195, $210,211,214,215,226,245,252$, $259,265,267$

Haarlem. $38,159,227$

Habsbourg-Lorraine, Ch. de - ............ 178

Habsburg-Lothringen, huis -............... 177

Haersolte, J.F. van - ............................257

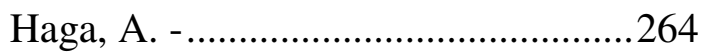

Hamburger, J.C. -..................................44

Hanegraaff, J. -.................................... 108

Hardenbroek, G.C.D. van - ........ 110, 258

Hartman .................................................. 84

Hartog, A.E. den -................................211

Heeckeren tot de Cloese, L van -..........36

Heeckeren van Brandsenburg, W.J.P. van - ............................................. 97

Heel, S.A.C. Dudok van - ...................267

Heemstra, geslacht Sixma van -.........221

Heijde, J.F. van der -..........................247

Helsdingen, W.H. van - .....................240

Hendrik, prins - ....................93, 94, 183

Heringa, A.W. -.....................................23

Hertogenbosch, 's- - ....................36, 124

Hertzberg, N.W.D.C. von -.20, 114, 117, 291

Hessen-Philippsthal, E.E.Ch.A.B.P. von

Heusden ............55, 57, 59, 73, 103, 205

Hillen, J.S.J. -.................................... 165

Hirsch Ballin, E.M.H. -......................211

Hodges, Ch.H. - ...........................31, 52

Hoeufft, D.J.P. - ..................................2258

Hoëvell van Nijenhuis, R.A. van -......72, 248, 251, 257, 258

Hoëvell, geslacht Van -........................66

Hogendorp, G.K. van -43, 44, 45, 46, 51, $55,57,58,64,72,73,185,254,255$

Hohenzollern, huis -.............................92

Hooff, J.F.R. van - .................................. 35

Hoorn ................................................... 100

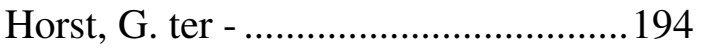

Houtain le Mont ......................................59 
Hövell tot Westervlier en Wezeveld,

A.M.J. van 121,258

Hövell van Westervlier en Weezeveld,

C.E.A. van .258

Huber, U. .242

Huissen. 39

Huizinga, J. 57,58

Husen, P. 144

Huybers, H.F.M. 106,255

Inn- und Knipphausen, E.M. von - ......35 Irene, prinses -...116, 164, 176, 178, 179, 180

Isabella, aartshertogin .16

Isselmuden, E.L.T. van 237,295

Jankovitch de Jeszenice, J.B. 192 Jansen van Afferden, G.A.N.T. - ..84, 86, 88,89

Java $134,135,142,143,144$

Jena .33

Jever ...39

Jolles, J.A. 70,84

Jonge van Ellemeet, B.M. de - ...........258

Jonge, W.C. de .94

Juan Carlos, koning 179

Juliana, koningin $14,104,163,165$, $169,177,184$

Jung, E.E. .97

Jurgens, E.C.M. 133

Juten, W.J.F. .94

Kamp, B.M. .263

Karel II, koning 16

Karel IV, koning - ................................ 178

Karel V, keizer .65

Keesom, P.H.M. .20

Kempenaer, geslacht Van Andringa de 114,293

Kemper, J.M. 45,46

Kerekes Zie Sayn-Wittgenstein

Keulen ...71

Kinsbergen, J.H. van $.37,39$

Kleerekooper, A.B. ...94

Kleintjes, P.H. 106,255

Koekkoek, A.K. 20

Kok, W. 160,234

Kolk, P.P.G. Hofman 161

Kort, J.C. .17

Koudekerk aan de Rijn 101

Krijger, F. 193,194
Krugten, D. van - ...............................2230

Kruseman, J.A. - .................................. 74

Künsberg, geslacht Von -....................59

Kuiken, K. - ......................................259

Kuipers, J.J. - ................................... 242

Laan, K. ter - .....................................94

Laken ................................................... 75

Lampsins, J.P.C.- .............................. 119

Landré, J.H.G. Meihuizen- ..........98, 258

Lange (van Bergen), geslacht De - ...178, 193, 211, 294

Lebrun duc de Plaisance, Ch.F. - .........39

Lech .................................................... 171

Leeuwen, J.E. van -.............................. 94

Leiden ........................................107, 178

Lekkerkerk, P.L. - .............................268

Lely van Oudewater, J. van der - .47, 258

Lennep, A.D. van -.............................290

Lenters, H. - ......................................211

Leopold I, koning - ..............68, 75, 186

Leyden, F.A. van - ................................35

Ligne, Y.M.J.Ch. de - ......................... 178

Lilaar, F.G.R.H. van - ........................219

Limburg Stirum, L. van - ...............45, 55

Lippe .............................................2230

Lippe-Biesterfeld, Van - .................... 184

Lissabon ..............................................243

Lodewijk I, koning - ......................... 178

Lodewijk XIII, koning -.......................51

Lodewijk XV, koning -...............92, 165

Lodewijk XVIII, koning -.................... 70

Loeb. E. - .............................................. 20

Loeff, J.A. -........................................... 91

Lohman, A.F. de Savornin - ................ 91

Londen ....................... 70, 100, 102, 223

Lubbers, R.F.M. -......................116, 128

Luiking, H.F.W. -...............123, 182, 199

Lutter, A.A. -....................................294

Lux, A.J.L.M. - ................................... 84

Luxemburg....14, 50, 53, 69, 72, 75, 184, $210,230,231,241,242,243,244$

Luzac, L.C. .69

Lynden (Lijnden) van Hemmen, F.G. van 84,257

Lynden van Blitterswijk, W.K.H. van -

Lynden van Sandenburg, C.Th. van -.84, 87

Lynden, F.W.B. van - .. 19, 121, 131, 258

Lynden, J.C.E. van 257 
Maanen, C.F. van .56

Maastricht $.72,83,243$

Mackay, A . .83

Mackay, D. .258

Mackay, geslacht 83,84

Madoera 134

Mainz .32

Malta 195

Margriet, prinses -.....143, 162, 163, 165, 180, 181, 182, 184, 186

Maria Theresia, keizerin - ..16, 51, 56, 57

Marijnen, Y.G.M. 116

Maris, J.C. $123,264,265$

Marmol, F.Ch.J. del .75

Massow, F. van 119

Maurits (jr.), prins $-. . .162,169,170,182$, 184

Maurits, prins

Máxima, prinses -......164, 172, 173, 174, 187

Mecklenburg, huis 93,184

Meerman, J. ..33

Meeuwen, P.G.M. van - .....19, 110, 231, 242, 258

Meihuizen, C.M. -...............................98

Meihuizen, J.G. -...................................98

Meijboom, M. 104

Meijer, R.A. -....147, 148, 150, 151, 152, 155, 156, 209

Meijere, J.P. de . .98

Melchers. 144

Melchers, R.R.J. . .96

Melvill van Carnbee, A.P. - ...............218

Melvill van Carnbee, geslacht - .....25, 83

Mentz Zie Mainz

Merens, A. $.105,110$

Merens, D. 100

Merens, geslacht 105

Metelerkamp, R. 47,256

Middelburg. 187

Modderman, A.E.J. .87

Moes, J.K.S. . .16

Mok, M.R. 230,241

Mollerus, E.J.R. ...38

Mollerus, J.H. $36,72,73$

Molukken 134

Monaco .30

Monté ver Loren, J.Ph. de -.....96, 97, 98, $100,253,258$

Münster-Langelage, A.U.G. zu 59

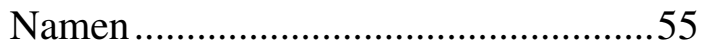

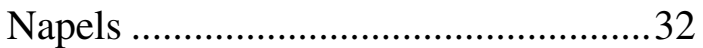

Nassau la Lecq, E.A.J. van - ................4 47

Nassau, A.W.K.A.F. van - .......... 91, 185

Nassau, geslacht Van -........91, 183, 185

Nassau, geslacht Van Oranje- -.....14, 50, $92,93,162,173,183,185$

Nassau, huis 91,185

Nassau, huis Oranje- -.....12, 14, 91, 114, $172,180,184,185,186,233,234$

Nassau, Ottoonse linie .........................93

Nassau, Walramse linie.........................93

Nassau-Dietz, tak -...............................91

Nassau-Dillenburg, tak -..................... 91

Nassau-Weilburg, tak - ..................50, 91

Neuhauss ..........................................229

Neuman, J.H. - ............................78, 85

Nie, O. Scheltema-de -.....126, 133, 134, 135, 136, 138, 143, 146, 147, 148, $149,151,156,165$

Nieuw-Guinea ................................... 134

Nijkamp, G.P. -................................. 144

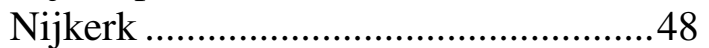

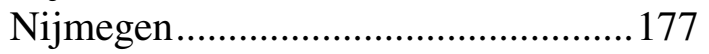

Nijpels, E.H.T.M. - ............................ 117

Nijpels, Groep -................................ 147

Nio, N.B. -...........................................97

Nispen tot Pannerden, A.J.M. van - ...258

Nispen tot Pannerden, F.K.M. van - ...17, 193, 258

Nispen tot Sevenaer genaamd Ruijs de

Beerenbrouck, C.C.C.M. van - ......192

Nivelles (Nijvel) ..................................55

O'Kelly de Galway, E.F.H. - -.............2257

Ollongren, A. - ..................................... 178

Oostenrijk, aartshertog van -.............. 178

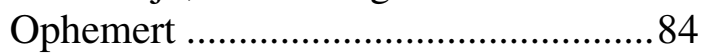

Orange..................................................92

Oranje, prins van - .41, 43, 45, 50, 73, 75

Oranje-Nassau van Amsberg, E.L.N.S. van - ...............................................2223

Oranje-Nassau van Amsberg, geslacht Van - ...........................171, 175, 223

Oranje-Nassau van Amsberg, J.Z.N.M.

van - ............................................... 223

Ort, B.- .......................................... 94

Oud, P.J. - ........................................... 116

Paderborn ...........................................229

Pallandt van Eerde, A. van - .................35 
Pallandt, R.M. van -

.258

Paltz, F. van de -

180

Parijs $18,27,35,37,38,40$

Parma, Ferdinand van 178

Pauw van Wieldrecht, M.Ch.H. - ... 257

Philips II, koning $16,51,65$

Pichot van Slijpe, K.G.S. 181

Pické, C.J. .84

Pieneman, N. .82

Piepers, H.A. .84

Pilar de la Cierva-Osorio de Moscoso, M. del 159

Pinto, A.A. de 219,220

Ploeg, J.G. van der 127

Plomp, N. .17

Plomp-Kamphuis, Z. .17

Ploos van Amstel, geslacht 105

Poerbodipoero, S. 144, 294

Preud'homme d'Hailly de Nieuport, geslacht De 221

Prins, W.F. $58,120,216,242$

Prisse, E.P.A. 186

Quarles, geslacht .83

Quast, geslacht .294

Quatre Bras $.55,75$

Quentin, St.

Rappard, A.G.A. van - .81, 247, 249, 251

Rechteren Limpurg, A.Z. van -..........257

Reenen, G.C.J. van - ............................ 83

Regout, E.R.H.

123

Reigersman, C.L. - ....................144, 258

Rengers, geslacht (Van Aylva) - 221, 228

Rengers, geslacht Van Welderen -.....221

Rengers, L.H.W. van Aylva - ............221

Rengers, L.J.J..35

Renne, O.P.H. van der 119

Reuss, huis 177

Reynst, L.J.B.Ch. Theunissen 181

Rhede van der Kloot, M.A. van -.........88

Riemsdijk, Th.H.F. van - .......91, 94, 257

Rietkerk, J.G. 120,127

Rijckevorsel, geslacht Van - ................96

Rijn, A.B. van - .................................229

Rijndorp, J.L. - ...................183, 230, 264

Rijswijk Z.H..............................193, 194

Röell, W.F. -..................................35, 45

Roes, J.S.L.A.W.B. -........................261

Roest van Alkemade, A.M.J.J. - ..........36

Romberg, G.L. von - ............................59
Rome $109,151,157,180$

Romein, J.M. 106,255

Rosenthal, geslacht Bosch van - .......221

Rosenthal, U. 164

Rotterdam. $43,71,121,226$

Roy van Zuydewijn, J. de -................. 17

Rozenburg ............................................39

Ruijs de Beerenbrouck, G.A.M.J. -.....19, 102, 110, 258

Ruijs de Beerenbrouck, G.L.M.H. -.....94

Ruiter, J. de -.................................. 122

Rutgers van Rozenburg, D. - ..86, 91, 92, 258

Rutte, M. 164,212

Ruyssenaers, L.H. -............................. 88

Saba...................................................226

Saksen-Coburg-Gotha, prins van -......Zie Leopold I, koning -

Salm Salm, C.Ph. Prinz zu.................230

Sannes, G.W. - ....................................94

Sasse van Ysselt, A.F.O. van -......94, 98, 257

Sasse van Ysselt, geslacht Van -..59, 291

Sasse van Ysselt, T.K.M.J. van - ......121, $125,213,258$

Sayn-Wittgenstein, geslacht Von - ...230

Sayn-Wittgenstein, geslacht $\mathrm{Zu}-.59,230$

Sayn-Wittgenstein, I. -......230, 241, 242

Sayn-Wittgenstein, L. Fürst von -......230

Schaik, J.R.H. van - ................... 103, 206

Schaper, J.H.A. -................................. 94

Scheveningen .........................15, 41, 45

Schie, H.A.J. van - ............................... 23

Schimmelpenninck van der Oije, C.O.A. $17,59,131,144,193,194,258$

Schimmelpenninck van der Oije, geslacht 56,66

Schimmelpenninck van der Oye, A. - 257

Schimmelpenninck van Nijenhuis, G.J.P. 91

Schimmelpenninck van Nijenhuis, R.J. -

Schimmelpenninck, G. - ...............56, 77

Schimmelpenninck, R.J. - ..29, 41, 56, 77

Schmitz, E.M.A. 126,212

Scholten, C.A. Fannius -................45, 46

Schutte, O. - ...... 18, 24, 41, 56, 113, 121, 144, 258

Schwerin-Wolfshagen, H.O.L.C. von -59 
Sewandono, I. - .114, 143, 188, 191, 205, 237, 292, 293

Sint Eustatius 226

Sint Maarten......224, 225, 226, 227, 228, 240

Sloet tot Everlo, geslacht Van den Clooster .221

Sloet van de Beele, L.A.J.W. .257

Sloet van Oldruitenborgh, E.. .97

Smeth, F.F. de -..................96, 100, 257

Smissaert, M.P. .257

Snouckaert van Schauburg (jr.), A.C. 91,257

Snouckaert van Schauburg (sr.), A.C. -

Snouckaert van Schauburg, A.C. - 35, 47, $62,84,256$

Snouckaert van Schauburg, G.Th.A. - .62

Snouckaert van Schauburg, W.F. - ......97

Sophie, koningin -......................86, 181

Spaen van Biljoen, J.F.W. van -....35, 48, 64,71

Spaen, G.C. van .71

Spaen, geslacht Van -..........................48

Spaen, W.A. van - .24, 33, 34, 35, 36, 37 , $41,42,47,48,56,57,61,198,233$, 256

Spinny, G.J.J. de .34

Staf, C. 105

Steengracht van Moyland, N.A. - .....290

Stjerna 194

Stoel, A.L.E.C. van der -............126, 147

Straatsburg 143, 146, 148, 159, 189, 194, 195, 202, 207, 208, 273

Styrum, J. van .33

Suurhoff, J.G. 106

Sypesteijn, C.A. van .257

Taets van Amerongen van Woudenberg, W.H. 112, 124, 237, 291

Taets van Amerongen, C.J.F. - .124, 143, 145, 148, 208, 211, 212, 261, 293

Taets van Amerongen, G.G. - ..............70

Taets van Amerongen, M. - ..................70

Teixeira de Mattos, A. - ........................84

Tempel, J. van den -..............................94

Tenge, R.S. - .......................................211

Termunten ...........................................101

Terpstra, J. - ........................................102

Tex, C.J.A. den - ..................................86

Thiennes, Ch.I.Ph. de -..........................51
Thijn, E. van - ...120, 134, 135, 137, 138, 157

Thorbecke, J.R. -...13, 19, 25, 77, 78, 79, $81,83,200,246,249,251$

Tiel 84

Tilburg .........................................21, 160

Tour van Bellinchave, M.W. du - 88, 257

Tour, geslacht $\mathrm{Du}-$......................66, 67

Toxopeus, E. - ...................................... 110

Trap, P.W.M. - .................................... 78

Travers, E.J. - ........................................39

Trench earl of Clancarty, R. le Poer - .55, 73, 205

Troelstra, P.J. -....................................94

Tulleken, C.G. van Hoogenhouck - ...218

Tullingh, J.F. -.....................................2295

Twent, A.P. -..............................35, 39

Ursel, Ch.J. van - .................................51

Utrecht ...11, 43, 57, 59, 65, 83, 157, 180

Valkenburg, C.C. van - .18, 19, 121, 182, 258, 285

Valkenburg, geslacht Van - .................99

Valkenburg, J.F.Th. van - ................... 186

Veere ..................................................55

Velde, R.J. van der - .214, 215, 217, 221, 243

Velden, P.A. van den -..........84, 86, 258

VerHuell, C.H. -............................37, 39

Verschuer, A.D. van - ..........................97

Verstolk van Soelen, J.G. - ...................71

Veth...Zie Taets van Amerongen, C.J.F. -

Vinkenbos \& Dewald.............................92 92

Vlaardingerbroek, P. -........159, 211, 227

Vledder

Vollenhoven, geslacht Van -.....170, 181, 182,183

Vollenhoven, geslacht Van Lippe-

Biesterfeld van 162,184

Vollenhoven, P. van -169, 180, 181, 182, 186

Voorst tot Voorst, geslacht Van - .......66

Voorst tot Voorst, J.J.G. van - ... 110, 258

Vos van Steenwijk genaamd van Essen, H.A.Z. de 291

Vos van Steenwijk, A.N. de - ...110, 121, 258

Vos van Steenwijk, J.A.G. de -...96, 253, 257

Vos van Steenwijk, W.L. de -......94, 257 
Vries, K.G. de 153

Vrijthoff, geslacht 181

Waldeck en Pyrmont, prinses van Zie Emma, koningin-regentes -

Wassenaer van Catwijck, A.J.O. van 122

Waterloo.51, 55, 57, 59, 73, 75, 103, 205

Wedel tot Gödens, C.A. von .35

Wedell, H.A. von $107,232,291$

Weede, E.W. van 86,258

Weede, H.E. van .258

Weert, E.A.H. Berckmans de - ............86

Wegner \& Mottu .90

Weichs de Wenne, C.W.J. de - ..144, 258

Weimar. 229, 231, 243

Wellesley duke of Wellington, A. - ....55, $75,180,205$

Wellesley duke of Wellington, A.V. -180

Wenen $50,71,180$

Wesel. .47

Westerbeek, E. 22,199

Westerholt, geslacht Van .66

Westerouen van Meeteren, G.N. - ......20, 160,262

Westreenen van Themaat, P.H. van -...35

Westreenen van Tiellandt, W.H.J. van -

71,257

Wichers, geslacht 105

Wichers, J.J. 105

Wiebenga, J.C. 128

Wijck, L.H.K.C. van Asch van 107

Wijkerslooth de Weerdesteijn, H.C.R.M. de 193,258

Wijmen, P.C.E. van - .151, 154, 156, 160 Wijn, H. van $33,36,47,256$
Wilhelm II, keizer 180

Wilhelmina, koningin -.....14, 88, 89, 91 , $92,93,95,115,164,165,183,184$, 185

Willem I, koning -.26, 46, 48, 50, 52, 56, $58,59,61,69,75,111,180,254$

Willem II, koning $74,75,77$

Willem III, koning - ....13, 14, 19, 50, 82, $83,89,91,184,245,246,247,249$, 251

Willem III, koning-stadhouder 165

Willem IV, prins $55,92,114,185$

Willem $\mathrm{V}$, prins $27,55,185$

Willem-Alexander, prins - 160, 161, 164, $172,173,180$

Win, P. de 77

Winter, J.M. van 157

Winter, J.W. de 37,39

Witteman, P.J. 102

Wolff Metternich, J.A.M. 159,202 208, 293

Wolleswinkel, E.J. -.......17, 21, 193, 258

Yvoy, geslacht Van Hangest d' 221

Yvoy, M.L. d' 47,256

Zeist 98

Zelm van Eldik, J.A. van 56

Zevenaar. .39

Zon, P. de Wacker van 258

Zorreguieta............Zie Máxima, prinses Zuylen van Nijevelt, Ph.J. van -....33, 36, 37

Zwahlen, J.R.D. 265,292

Zwart, T. 23 